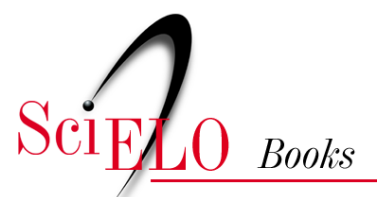

\title{
Cidades saudáveis? Alguns olhares sobre o tema
}

\author{
Carmen Beatriz Silveira \\ Tania Maria Fernandes \\ Bárbara Pellegrini \\ (orgs.)
}

\section{SciELO Books / SciELO Livros / SciELO Libros}

SILVEIRA, CB., FERNANDES, TM., and PELLEGRINI, B. comps. Cidades saudáveis? Alguns olhares sobre o tema [online]. Rio de Janeiro: Editora FIOCRUZ, 2014, 330 p. ISBN: 978-85-7541-529-0. https://doi.org/10.7476/9788575415290.

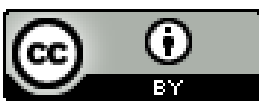

All the contents of this work, except where otherwise noted, is licensed under a Creative Commons Attribution 4.0 International license.

Todo o conteúdo deste trabalho, exceto quando houver ressalva, é publicado sob a licença Creative Commons Atribição 4.0. 


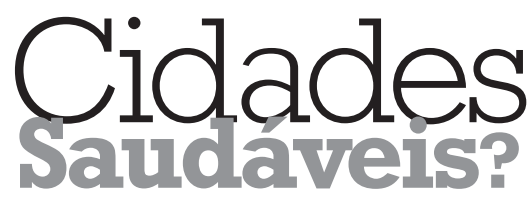

Alguns olhares sobre o tema 


\section{FUNDAÇÃO OSWALDO CRUZ}

Presidente

Paulo Gadelha

Vice-Presidente de Ensino, Informação e Comunicação

Nísia Trindade Lima

\section{EDITORA FIOCRUZ}

Diretora

Nísia Trindade Lima

Editor Executivo

João Carlos Canossa Mendes

Editores Científicos

Carlos Machado de Freitas

Gilberto Hochman

Conselho Editorial

Claudia Nunes Duarte dos Santos

Jane Russo

Ligia Maria Vieira da Silva

Maria Cecília de Souza Minayo

Marilia Santini de Oliveira

Moisés Goldbaum

Pedro Paulo Chieffi

Ricardo Lourenço de Oliveira

Ricardo Ventura Santos

Soraya Vargas Côrtes 


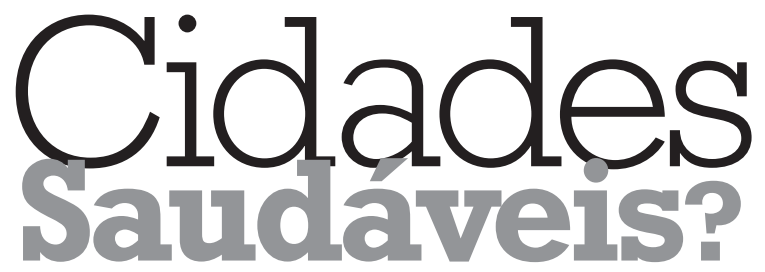

Alguns olhares sobre o tema

\author{
Carmen Beatriz Silveira \\ Tania Maria Fernandes \\ Bárbara Pellegrini \\ organizadoras
}

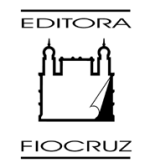


Copyright (C) 2014 dos autores

Todos os direitos desta edição reservados à

Fundação Oswaldo Cruz / Editora

Revisão e copidesque

Augusta Avalle, Marcionílio Cavalcanti de Paiva, Myllena Paiva

Normalização de referências

Clarissa Bravo

Capa, projeto gráfico e editoração eletrônica

Fernando Vasconcelos

Imagem da capa

Fotografia de Américo Vermelho, julho de 2013

Revisão técnica do capítulo 4

Sergio Lamarão e Carmen Beatriz Silveira

Catalogação na fonte

Instituto de Comunicação e Informação Científica e Tecnológica

Biblioteca de Saúde Pública

S587 Silveira, Carmen Beatriz (Org.)

Cidades saudáveis? Alguns olhares sobre o tema. / organizado por Carmen Beatriz Silveira, Tania Maria Fernandes e Bárbara Pellegrini. Rio de Janeiro : Editora Fiocruz, 2014.

332 p. : il. ; tab. ; graf.

ISBN: 978-85-7541-452-1

1. Cidade Saudável. 2. Áreas de Pobreza.

3. Indicadores de Desenvolvimento Sustentável. 4. Meio Ambiente. 5. Qualidade de Vida. 6. Ação Intersetorial.

7. Políticas Públicas. 8. Promoção da Saúde. I. Fernandes, Tania Maria (Org.). II. Pellegrini, Bárbara (Org.). III.

Título.

CDD - 22.ed. -613

2014

EDITORA FIOCRUZ

Av. Brasil, 4.036 - Térreo - sala 112 - Manguinhos

Editora filiada

21040-361 - Rio de Janeiro, RJ

Tels.: (21) 3882-9039/3882-9041

Fax: (21) 3882-9006

editora@fiocruz.br

www.fiocruz.br/editora 


\section{Autores}

Ana Beatriz Melo Oliveira - mestre em engenharia urbana pela Escola Politécnica da Universidade Federal do Rio de Janeiro (UFRJ), Pesquisadora/bolsista do campus Fiocruz da Mata Atlântica (CFMA/Fiocruz).

Ana Clara Torres Ribeiro (in memoriam) - doutora em ciências humanas pela Universidade de São Paulo (USP), professora do Instituto de Pesquisa e Planejamento Urbano e Regional da Universidade Federal do Rio de Janeiro (Ippur/UFRJ).

André Luiz Fischer - acadêmico de medicina da Faculdade de Medicina do ABC (FMABC); pesquisador do centro de estudos de saúde coletiva da FMABC.

Ângela Virgínia Coelho - mestre em saúde pública pela Escola Nacional de Saúde Pública Sergio Arouca da Fundação Oswaldo Cruz (Ensp/Fiocruz), assistente social da Secretaria Municipal de Assistência Social do Rio de Janeiro (SMAS-RJ).

Antonio Levino da Silva Neto - doutor em saúde pública pelo Centro de Pesquisas Aggeu Magalhães (CPqAM/Fiocruz-PE), pesquisador do Instituto Leônidas e Maria Deane (ILMD/ Fiocruz-AM), professor da Faculdade de Medicina da Universidade Federal do Amazonas (Ufam).

Bárbara Pellegrini (organizadora) - mestre em comunicação e cultura pela Escola de Comunicação da Universidade Federal do Rio de Janeiro (ECO/UFRJ); pesquisadora colaboradora do campus Fiocruz da Mata Atlântica (CFMA/Fiocruz).

Carla Moura Pereira Lima - doutora em ensino em biociências e saúde pela Fundação Oswaldo Cruz; assessora técnica/pesquisa-dora colaboradora na mesma instituição.
Carlos dos Santos Silva - doutor em saúde pública pela Escola Nacional de Saúde Pública Sergio Arouca da Fundação Oswaldo Cruz (Ensp/Fiocruz), secretário executivo da Associação Brasileira de Saúde Coletiva (Abrasco).

Carlos Machado de Freitas - doutor em saúde pública pela Escola Nacional de Saúde Pública Sergio Arouca da Fundação Oswaldo Cruz (Ensp/Fiocruz); pesquisador do Centro de Estudos e Pesquisas em Emergências e Desastres e do Centro de Estudos da Saúde do Trabalhador e Ecologia Humana (Ensp/Fiocruz).

Carmen Beatriz Silveira (organizadora) - doutora em planejamento urbano e regional pelo Instituto de Pesquisa e Planejamento Urbano e Regional da Universidade Federal do Rio de Janeiro (Ippur/UFRJ); pesquisadora/bolsista do campus Fiocruz da Mata Atlântica (CFMA/ Fiocruz).

Célia Leitão Ramos - mestre em antropologia social pela Universidade Estadual de Campinas (Unicamp); pesquisadora aposentada, uma das fundadoras do Departamento de Ciências Sociais da Escola Nacional de Saúde Pública Sergio Arouca da Fundação Oswaldo Cruz (Ensp/Fiocruz), o qual também coordenou. Ainda na Ensp, dentre várias atividades, respondeu pelo curso de Especialização em Saúde Pública e pela vice-direção de Ensino.

Cícero Dedice de Góes Junior - mestre em ecologia pela Universidade de Brasília (UNB); técnico especializado em saúde ambiental da Universidade de Brasília.

Eduardo Navarro Stotz - doutor em saúde pública pela Fundação Oswaldo Cruz; pesquisador titular da Escola Nacional de Saúde Pública Sergio Arouca da Fundação Oswaldo Cruz (Ensp/Fiocruz). 
Fábio Peres - doutor em saúde pública pela Escola Nacional de Saúde Pública Sergio Arouca da Fundação Oswaldo Cruz (Ensp/ Fiocruz), pesquisador visitante do Programa de Desenvolvimento e Inovação Tecnológica em Saúde Pública (PDTSP/Fiocruz).

Fatima Pivetta - mestre em química analítica inorgânica pela Pontifícia Universidade Católica do Rio de Janeiro (PUC-Rio), tecnologista do Centro de Estudos da Saúde do Trabalhador (Cesteh/Ensp/Fiocruz), coordenação do Laboratório Territorial de Manguinhos (LTM/ Ensp/Fiocruz).

Gil Sevalho - doutor em saúde pública pela Fundação Oswaldo Cruz; pesquisador da Escola Nacional de Saúde Pública Sergio Arouca da Fundação Oswaldo Cruz (Ensp/Fiocruz).

Guilherme Franco Netto - doutor em epidemiologia pela Tulane University of Louisiana (EUA), pós-doutorado pela Unicamp, médico da Fundação Nacional de Saúde (Funasa), assessor de saúde e ambiente da Vice-Presidência de Ambiente, Atenção e Promoção da Saúde da Fundação Oswaldo Cruz (Fiocruz).

Humberto Kzure-Cerquera - doutor em urbanismo pelo Prourb/FAU/UFRRJ, com doutorado sanduíche na Bauhaus Universität Weimar (Alemanha); professor adjunto do Departamento de Arquitetura e Urbanismo do Instituto de Tecnologia da Universidade Federal Rural do Rio de Janeiro (DAU/ IT/UFRRJ).

Jorge Azevedo de Castro - doutor em arquitetura e urbanismo pela Universidade de São Paulo (USP); tecnólogo sênior da Escola Nacional de Saúde Pública Sergio Arouca da Fundação Oswaldo Cruz (Ensp/Fiocruz).

Leandro Luiz Giatti - doutor em saúde pública pela Faculdade de Saúde Pública da Universidade de São Paulo (FSP/USP), professor do Departamento de Saúde Ambiental da mesma universidade.
Lenira Zancan - mestre em saúde pública pela Escola Nacional de Saúde Pública Sergio Arouca (Ensp/Fiocruz); pesquisadora adjunta do Departamento de Ciências Sociais da Ensp/ Fiocruz; coordenação do Laboratório Territorial de Manguinhos (LTM/Ensp/Fiocruz).

Letícia de Luna Freire - doutora em antropologia pela Universidade Federal Fluminense (UFF), onde também é pesquisadora colaboradora.

Lívia Cardoso Gomes - especialização em residência multiprofissional em saúde da família pela Escola Nacional de Saúde Pública Sergio Arouca da Fundação Oswaldo Cruz (Ensp/Fiocruz).

Luciene Burlandy - doutora em saúde pública pela Escola Nacional de Saúde Pública Sergio Arouca (Ensp/Fiocruz), professora da Faculdade de Nutrição da Universidade Federal Fluminense (UFF).

Marcelo Burgos - doutor em sociologia pelo Instituto Universitário de Pesquisas do Rio de Janeiro (Iuperj); professor do Departamento de Sociologia e Política da Pontifícia Universidade Católica do Rio de Janeiro (PUC-Rio).

Marcelo Firpo de Souza Porto - doutor em engenharia de produção pela Universidade Federal do Rio de Janeiro (UFRJ); pesquisador titular do Centro de Estudos da Saúde do Trabalhador (Cesteh/Ensp/Fiocruz); coordenação do Laboratório Territorial de Manguinhos (LTM/Ensp/Fiocruz).

Marcilio Sandro Medeiros - mestre em saúde pública pelo Centro de Pesquisas Aggeu Magalhães (CPqAM/Fiocruz-PE), pesquisador assistente do Instituto Leônidas e Maria Deane (ILMD/Fiocruz-AM).

Marco Akerman - doutor em epidemiologia e saúde pública pela Universidade de Londres (Inglaterra), professor titular do Departamento de Prática em Saúde Pública da Facul- 
dade de Saúde Pública da Universidade de São Paulo (USP).

Maria das Mercês Navarro - doutora em educação pela Universidade Federal Fluminense (UFF), professor I da Secretaria Municipal de Educação do Rio de Janeiro (SME-RJ).

Milena Nogueira Ferreira - mestre em saúde pública pela Escola Nacional de Saúde Pública Sergio Arouca (Ensp/Fiocruz), nutricionista na Secretaria Municipal de Saúde de Mangaratiba, Rio de Janeiro (SMS-Mangaratiba/RJ).

Mírcia Betânia Costa e Silva - doutora em saúde pública pelo Centro de Pesquisas Aggeu Magalhães (CPqAM/Fiocruz-PE), professora adjunta do Departamento de Medicina Social da Universidade Federal de Pernambuco (Ufpe).

Monica de Castro Maia Senna - doutora em saúde pública pela Escola Nacional de Saúde Pública Sergio Arouca (Ensp/Fiocruz), professora da Faculdade de Serviço Social da Universidade Federal Fluminense (UFF).

Monica Dias de Souza - doutora em antropologia social pela Universidade Federal do Rio de Janeiro (UFRJ), pesquisadora visitante da Fundação Oswaldo Cruz (Fiocruz).

Regina Bodstein - doutora em saúde pública pela Escola Nacional de Saúde Pública Sergio Arouca (Ensp/Fiocruz), onde é pesquisadora titular do Departamento de Ciências Sociais (DCS/Ensp/Fiocruz).

Renato Gama-Rosa Costa - doutor em urbanismo pela Faculdade de Arquitetura e Urbanismo da Universidade Federal do Rio de Janeiro (FAU/UFRJ), tecnologista sênior da Fundação Oswaldo Cruz (Fiocruz).
Rogério Fenner (in memoriam) - mestre em sciences de la terre pela Universidade de Genebra (Suíça). Atuou no OPA Topografia e Engenharia Ltda.

Rosana Magalhães - doutora em saúde coletiva pela Universidade Estadual do Rio de Janeiro (Uerj), pesquisadora titular do Departamento de Ciências Sociais da Escola Nacional de Saúde Pública Sergio Arouca (DCS/Ensp/Fiocruz).

Rosilda Mendes - doutora em saúde pública pela Faculdade de Saúde Pública da Universidade de São Paulo (USP), professora da Universidade Federal de São Paulo no campus Baixada Santista.

Rossana Silva Souza (in memoriam) - mestre em arquitetura e urbanismo pela Universidade Federal Fluminense (UFF); pesquisadora colaboradora da Fundação Oswaldo Cruz (Fiocruz).

Simone Cynamon Cohen - doutora em saúde pública pela Escola Nacional de Saúde Pública Sergio Arouca da Fundação Oswaldo Cruz (Ensp/Fiocruz), onde é professora titular.

Sylvain J. M. Desmoulière - doutor em etnobiologia pelo Museu Nacional de História Natural de Paris (França), pesquisador visitante do Instituto Leônidas e Maria Deane (ILMD/Fiocruz-AM).

Tania Maria Fernandes (organizadora) doutora em história social pela Universidade de São Paulo (USP), pesquisadora da Casa de Oswaldo Cruz da Fundação Oswaldo Cruz (COC/Fiocruz). 


\section{Sumário}

$\begin{array}{ll}\text { Prefácio } & 11\end{array}$

Apresentação 13

PARTE I - Cidades Saudáveis sob Diferentes Prismas

1. A Saúde da Cidade sob Suspeita 31

Humberto Kzure-Cerquera

2. Cidades Saudáveis: ainda um tema relevante?

Marco Akerman, Rosilda Mendes e André Luiz Fischer

3. Favela, Conjuntos Habitacionais, Bairros Populares e Outras

Formas Urbanas: por uma agenda comum de luta pela cidade

Marcelo Baumann Burgos

4. Cidades Saudáveis ou Cidades Justas?

Ana Clara Torres Ribeiro

\section{PARTE II - Seis Projetos para uma Cidade Saudável}

5. Manaus: uma análise ecossistêmica por meio de indicadores de sustentabilidade ambiental e de saúde

Leandro Luiz Giatti, Carlos Machado de Freitas, Sylvain J. M. Desmoulière, Marcilio Sandro Medeiros, Mírcia Betânia Costa e Silva e Antonio Levino da Silva Neto

6. Cidade Saudável e Direito à Cidade: outro mundo possível em Itaboraí

Carla Moura Pereira Lima, Eduardo Stotz, Gil Sevalho, Jorge Azevedo de Castro e Rossana Silva Souza

7. Em Busca da Qualidade de Vida: metodologia e indicadores para intervenções socioespaciais

Carmen Beatriz Silveira, Simone Cynamon Cohen, Bárbara Pellegrini, Monica Dias de Souza e Ana Beatriz Melo Oliveira

8. Análise da Implementação de Ações Intersetoriais: desafios e alternativas metodológicas

Rosana Magalhães, Célia Leitão Ramos, Regina Bodstein, Fábio Peres,

Luciene Burlandy, Ângela V. Coelho, Milena N. Ferreira, Monica de Castro M. Senna, Carlos dos Santos Silva e Lívia C. Gomes 
9. Políticas Públicas Urbanas para uma Cidade Saudável: 100 anos de história em Manguinhos

Renato Gama-Rosa Costa, Tania Maria Fernandes, Letícia de Luna Freire, Monica Dias de Souza e Maria das Mercês Navarro

10. Cidades Saudáveis e Promoção da Saúde Emancipatória: reinvenção cotidiana do (re)conhecimento nos territórios vulneráveis Marcelo Firpo de Souza Porto, Lenira Zancan e Fatima Pivetta

Guilherme Franco Netto, Rogério Fenner e Cícero Dedice de Góes Junior 


\section{Prefácio}

O processo de urbanização no Brasil se acentua a partir da segunda metade do século XX e nas últimas décadas observa-se a transformação do perfil do país, com mais de $80 \%$ da população habitando em áreas urbanas. Estudos socioeconômicos e demográficos apontam para a necessidade de compreender a dinâmica populacional, tanto em razão dos processos de migração rural-urbana, quanto pela premência de reflexões sobre a relação entre os arranjos socioespaciais e as condições de vida. Ou seja, para além da constatação dos significativos percentuais de urbanização, a complexidade das diferentes configurações de cidades impõe a investigação de suas implicações nas características da vida urbana e nas condições de saúde.

Esse quadro evidencia a necessidade de acumular conhecimento científico para que se possa subsidiar a tomada de decisões e as intervenções públicas relacionadas às cidades médias e grandes. De que modo nossas metrópoles podem se tornar cidades saudáveis? Nessa direção, o conteúdo desta obra apresenta contribuições significativas no que concerne à problematização e produção de estratégias de intervenções. Tem o propósito de aprofundar o conhecimento sobre questões e práticas que relacionam cidades, saúde e ambiente, mais especificamente as diferentes vertentes de políticas públicas que abordam essa temática, na perspectiva da promoção da saúde com seus múltiplos condicionantes.

Este livro resulta do investimento da Fundação Oswaldo Cruz (Fiocruz) em pesquisas sobre esse campo analítico para compreender a relevância da intersetorialidade preconizada pelo SUS e, assim, gerar conhecimento científico para o aprimoramento das políticas públicas sociais. Esse é um tipo de conhecimento transversal e multidisciplinar que requer metodologias, formulações estratégicas e construções de diferentes formas de funcionamento do setor saúde e de suas interfaces com os demais setores, as quais constituem desenvolvimento tecnológico e inovação em saúde.

Tal produção foi orientada por um dos programas de apoio à pesquisa da Fiocruz - o Programa de Desenvolvimento e Inovação Tecnológica em Saúde Pública (PDTSP). Originada de projetos concebidos com a finalidade de criação, aprimoramento e difusão de tecnologias e inovações em saúde, resultou de 
experiências cuja natureza é essencial para a formulação de políticas públicas intersetoriais.

O trabalho foi organizado mediante uma rede de pesquisa iniciada em 2007, numa parceria de duas Vice-Presidências da Fiocruz (a de Pesquisa e Laboratórios de Referência e a de Ambiente, Atenção e Promoção da Saúde) a Rede Cidades Saudáveis (Edital 1/2007 - Cidades Saudáveis: saúde, ambiente e desenvolvimento, promovido pelo PDTSP). Contou com a participação de pesquisadores visitantes, técnicos, tecnologistas e pesquisadores da Fiocruz que geraram inovação em saúde pública, nas dimensões coletiva e individual, sob a perspectiva de contribuir para melhorias do SUS e para a resolução dos problemas de saúde e da qualidade de vida da população brasileira.

Com vistas a enriquecer o debate, para os pesquisadores foi demandado o registro das pesquisas da Rede Cidades Saudáveis entre 2008 e 2010 - metodologias desenvolvidas e resultados obtidos -, de forma que propiciasse o diálogo entre a academia e os gestores públicos, tanto do sistema de saúde como dos demais serviços públicos. No encerramento da Rede, seus representantes institucionais apresentaram os resultados das pesquisas, que foram discutidos por convidados externos em seminário aberto à comunidade acadêmica e aos gestores e profissionais do SUS, em novembro de 2010. Os conteúdos desse seminário foram reelaborados para compor a coletânea de textos apresentados nesta publicação. Necessariamente a rede de pesquisa conformou produtos diversos nas abordagens, mas que, em seu conjunto, propiciam a orientação para diretrizes sobre o macrotema saúde, ambiente e espaço urbano.

O livro é composto de três partes relacionadas ao tema das cidades saudáveis por meio de abordagens conceituais, de levantamentos e referências a projetos específicos ou, ainda, mediante explicitação de estratégias públicas, o que o torna uma rica fonte de reflexão científica e contribui para a formulação de políticas sobre o tema.

\section{Claude Pirmez}

Pesquisadora titular da Fiocruz, Vice-Presidente de Pesquisa e Laboratórios de Referência da Fiocruz (2009-2013)

\section{Valcler Rangel Fernandes}

Vice-Presidente de Ambiente, Atenção e Promoção da Saúde da Fiocruz 


\section{Apresentação}

A iniciativa da Fundação Oswaldo Cruz (Fiocruz) de patrocinar estudos vinculados à saúde das cidades está relacionada ao conceito ampliado de saúde, ao entendimento do que, no campo da saúde pública, denomina-se saúde coletiva. Outro termo que evidencia essa concepção, determinantes sociais da saúde (DSS), assinala que, além das condições biológicas, as condições sociais em que vivem os seres humanos exercem influência sobre a sua saúde e qualidade de vida. A relevância dessa afirmativa deve ser repensada com base em investigações e debates recentes que procuram compreender a noção de determinantes sociais num sentido abrangente, reapropriando-se do "peso teórico e político" que essa noção expressava nos anos 1970 e 1980, período em que se buscava percebê-la "à luz da teoria marxista da sociedade" (Nogueira, 2010: 7).

No intuito de introduzir a temática abordada nesta publicação, pretende-se expor alguns aspectos das reflexões atuais que se aproximam ou abarcam as ideias de cidades saudáveis, identificados em dois eixos analíticos: o primeiro refere-se aos determinantes sociais da saúde e à relação entre qualidade de vida e saúde; o segundo engloba a promoção da saúde e os determinantes sociais da saúde, ambos essenciais para as visões recentes de cidades saudáveis. A despeito dessa divisão da temática em dois eixos, compreende-se que as noções e/ou concepções anteriormente discriminadas encontram-se nitidamente associadas e, no seu conjunto, constituem abordagens polissêmicas. Nessa perspectiva, pretende-se apenas expor algumas dimensões desses temas que, em razão de seu entrelaçamento, revelam a importância de interpretações qualitativas relacionadas às transformações tecnológicas no âmbito da saúde.

O primeiro eixo analítico - determinantes sociais da saúde e a relação entre qualidade de vida e saúde - pode ser examinado com base nos estudos de Ligia Maria Vieira da Silva (2010), Roberto Passos Nogueira (2009, 2010), Maria Cecília Minayo, Zulmira Hartz e Paulo Buss (2000) e Ana Clara Torres Ribeiro (2009).

Ligia Maria assinala que a reflexão sobre as conexões entre saúde e sociedade remonta ao século XIX e tem sido alargada nos séculos XX e XXI, sobretudo a partir da década de 1970. Malgrado as evidências que respaldam a "existência de relações entre a posição no espaço social e a saúde" na visão de diversos autores, a autora formula algumas indagações, referidas a diversos aspectos, como: 
o "sentido e significado" de tais relações; os "processos que medeiam as mesmas" e o "grau de autonomia relativa de cada componente da equação" (Vieira-daSilva, 2010: 180).

Por fim, questiona a existência dessas diferenças nas condições de saúde mesmo em países com distribuição mais equitativa da riqueza, combinada com ampla cobertura de saúde, assinalando situações paradigmáticas como as do Reino Unido e do Canadá (Vieira-da-Silva, 2010). Conforme sua concepção, tais indagações encontram-se ainda sem respostas suficientemente esclarecedoras, em razão da complexidade em se analisar problemas relacionados a diversos campos disciplinares, a exemplo da relação saúde e sociedade.

Acrescenta-se que essas dificuldades adquirem maior vulto se as análises se fundamentarem em concepções tradicionais, de cunho positivista. Nessa perspectiva, podem-se acionar alguns extratos sobre o "debate teórico entre saúde, sociedade, democracia e políticas públicas" (Nogueira, 2009: 398), que problematizam a noção de determinantes sociais na busca de uma visão dialética:

O que se pretende criticar aqui é o marco teórico positivista explicitado no relatório da OMS, que tende perigosamente para o determinismo social, na medida em que interpreta o que é social na saúde unicamente mediante o efeito de fatores causais, conforme o modelo das ciências naturais e da epidemiologia tradicional. O relatório faz tabula rasa do fato de que a saúde pública é um campo de políticas que deve ter em conta a contribuição não só da epidemiologia e das ciências médicas, mas também da sociologia, da antropologia e da filosofia. (Nogueira, 2009: 398, grifo do original)

Ao tratar do relatório da Organização Mundial da Saúde (OMS) sobre determinantes sociais, contudo, Nogueira compreende esse reconhecimento e origem no contexto internacional e afirma a abordagem ética desse relatório na "luta contra as desigualdades injustas, ou seja, as iniquidades" (Nogueira, 2009: 398). Ademais, ressalta aspectos de justiça social, ao considerar a viabilidade de solucionar "diferenças sistemáticas em saúde" se forem tomadas algumas medidas identificadas como necessárias. Nas palavras de Nogueira (2009: 398): "reduzir as desigualdades de saúde é, para a Comissão sobre Determinantes Sociais da Saúde (doravante, a Comissão), um imperativo ético. A injustiça social está matando as pessoas em grande escala".

A preocupação com os numerosos problemas decorrentes da injustiça social impõe o desenvolvimento de análises que contenham subsídios para a concepção e implementação de ações públicas inclusivas. Em busca de um pensamento que inclua a percepção das iniquidades em saúde, procurando recuperar a 
dialeticidade dos anos 1970/1980, Nogueira recomenda o abandono da expressão determinantes sociais, por ser calcada na ideia de que o "o conhecimento dos fenômenos da saúde deve estar sempre fundado na explicitação de causalidade em sentido estrito". Ressalta a necessidade de se reconhecer a saúde como "um fenômeno eminentemente humano e não um fator biológico-natural" (Nogueira, 2010: 8) e propõe, em lugar de determinantes, a adoção do termo determinação. Com essa abordagem o autor afirma que "os estudos de determinação social da saúde devem envolver a caracterização da saúde e da doença mediante fenômenos que são próprios dos modos de convivência do homem (...)". Portanto, valoriza a caracterização social da saúde e da doença, cuja compreensão passa pelo reconhecimento de diversos ângulos analíticos e afirma que "tal determinação pode ser de natureza inteiramente qualitativa" (Nogueira, 2010: 9).

Tais aspectos evidenciam a axiomática, conquanto não hegemônica, transdisciplinaridade do tema, sendo um grande desafio, tanto para a Academia quanto para os gestores públicos - não obstante o desafio da emancipação humana, de o ser humano reconhecer e organizar suas próprias forças "como forças sociais", conforme Karl Marx apontava, em 1844 (Marx, 2010: 54).

Trabalhar em conjunto - em colaboração - e considerar olhares diferentes sobre o mesmo objeto é complexo, porém indispensável. Nesse sentido, alude-se às ideias de Ribeiro (2009) ao enfatizar a carência de análises transdisciplinares que, no entanto, encontrar-se-iam em processo de construção lenta, desencadeada nas últimas décadas, no contexto político-econômico do neoliberalismo. Em suas palavras: "Esta construção sustenta-se no recurso à filosofia e em alterações na relação sujeito-objeto, como exemplificam as técnicas participativas de pesquisa; o resgate das narrativas e o respeito à fala do 'outro'" (Ribeiro, 2009: 148).

Verificam-se, nessa conjuntura, mudanças metodológicas significativas na análise social, que abrangem a "inclusão obrigatória do espaço e do território" (Ribeiro, 2009: 148) nas propostas que fundamentam tanto as investigações acadêmicas quanto as políticas públicas. Desse modo, reforça-se a percepção da complexidade que envolve as investigações que tratam do reconhecimento da relação espaço-sociedade nos estudos que almejam uma compreensão das determinações sociais sobre a saúde e a qualidade de vida nas cidades, de modo geral.

Retomando-se a reflexão sobre as conexões entre saúde e sociedade, acrescentase a abordagem de Minayo, Hartz e Buss (2000), que trata da relação entre saúde e qualidade de vida. Os autores reportam-se ao nascimento da medicina social, nos séculos XVIII e XIX, período em que estudos sistemáticos evidenciaram esta 
relação e ofereceram contribuições significativas para os movimentos sociais e as políticas públicas. Menciona o clássico estudo de Engels (1975), A Situação da Classe Trabalhadora na Inglaterra, entre outros. Cabe frisar que o trabalho de Engels tem sido acionado por distintos enfoques disciplinares, entre os quais se assinalam a geografia, o urbanismo e o planejamento urbano que, ao focalizar as cidades, sobretudo as grandes cidades, defrontam-se com a segregação espacial e as diferenças brutais na qualidade de vida e saúde, a depender da inserção dos grupos sociais na estrutura urbana.

Minayo, Hartz e Buss (2000: 3, grifo do original) expressam o elo indissociável entre condições e qualidade de vida e saúde que "aproxima os clássicos da medicina social da discussão que, nos últimos anos, vem-se revigorando na área e tem no conceito de promoção da saúde sua estratégia central".

Assim introduz-se a abordagem do segundo eixo analítico, referente à promoção da saúde e aos determinantes sociais da saúde, ambos constituindo fundamentos para a noção de cidades saudáveis. Fundamentam-se as considerações a seguir em Minayo, Hartz e Buss (2000), Lucíola Santos Rabello (2010), Ana Clara Ribeiro (2000) e Vieira-da-Silva (2010). Apresentada em diversos capítulos deste livro, a ideia de promoção da saúde será aqui exposta de maneira genérica, com ênfase em aspectos mais diretamente relacionados a esta publicação.

Minayo e outros autores explicitam o conceito de promoção da saúde que, desenvolvido pelo pensamento sanitarista canadense, respaldou-se na noção dos determinantes da saúde, abrangendo o estilo de vida, os avanços da biologia humana, o ambiente físico e social e os serviços de saúde. Debates recentes têm ampliado o sentido desse conceito, que passou a ser compreendido como "estratégia-chave da discussão da qualidade de vida" (Buss et al. apud Minayo, Hartz \& Buss, 2000).

A política pública de promoção da saúde, aprovada em Ottawa (Canadá), na Primeira Conferência Internacional sobre Promoção da Saúde (1986), estabeleceu um novo paradigma que questiona a concepção flexeneriana. ${ }^{1}$ Esta última expressa por meio de uma visão individualista, com foco na especialização, na tecnologização, bem como na atenção à saúde curativa, práticas hegemônicas na saúde (Rabello, 2010). Do ponto de vista de diversos autores, trata-se de um paradigma ainda em construção que, em síntese, preconiza a inserção de conteúdos sociais na sua abordagem, como a apropriação de uma proposta

\footnotetext{
${ }^{1}$ Ver Flexner Report, de Abraham Flexner (1910).
} 
transdisciplinar. Compreende a temática da saúde no seu escopo ampliado, portanto, intrinsecamente relacionado às formas de produção das sociedades.

A promoção da saúde, concepção que passou a ser incorporada nos países da América Latina a partir da década de 1990, alarga a potencialidade do atendimento às questões da saúde pública e inclui a adoção de propostas de cidades saudáveis. Na investigação de Rabello (2010), essa concepção é examinada mediante a perspectiva de Marcel Mauss e denominada "fenômeno social total" (Mauss apud Rabello, 2010: 46-47) - aquele que abrange as múltiplas dimensões da vida coletiva, incluindo-se as sociais, políticas, estéticas e o imaginário. Assim, a valorização de tais aspectos permitiria compreender a promoção da saúde como um fenômeno social total. Nas palavras de Rabello (2010: 47), "tudo se passa dentro da esfera da relação com a sociedade", por meio de representações coletivas. Desse modo, os fatos sociais constituiriam um amplo conjunto de representações que se relacionam entre si, no entrelaçamento das diversas esferas da vida coletiva. Nessa acepção, como compreender a saúde em seu sentido ampliado?

Cabe ainda mencionar, para o caso brasileiro, o foco da promoção da saúde na criação do Sistema Único de Saúde (SUS) e no desenvolvimento de propostas de cidades saudáveis ou municípios saudáveis, que, é possível afirmar, transcendem o escopo do SUS. Como as demais noções e/ou conceitos aqui expostos, a ideia de cidades saudáveis é suscetível a diversas interpretações, apropriações e implementações em termos de políticas públicas, a exemplo do conteúdo deste livro, que abarca a sistematização de um conjunto de projetos e iniciativas considerados significativos no contexto nacional.

Apenas no intuito de situar a temática, amplamente exposta em diversos capítulos, ressalta-se a noção genérica do Ministério da Saúde (MS), quando define cidades saudáveis (municípios ou comunidades) como uma filosofia e uma estratégia destinada a robustecer as ações públicas de promoção da saúde. Reiterando a definição da OMS, propugna uma ideia de cidade saudável mediante a prática contínua de aprimoramento do meio ambiente físico e social, contando com a utilização de todos os recursos de uma dada comunidade. Nessa direção, o MS assevera que uma cidade ou município saudável pressupõe que seus gestores priorizem "a saúde de seus cidadãos dentro de uma ótica ampliada de qualidade de vida", e destaca a participação social e a intersetorialidade como características indissociáveis. ${ }^{2}$

\footnotetext{
${ }^{2}$ Disponível em: <www.paho.org/bra/index2.php?option=com_content\&task=emailform\&id=388\&ltemid=1 $>$.
} 
A respeito das variadas apropriações da ideia de cidades saudáveis e hábitat saudável, deve-se aludir a uma concepção ideológica que incorpora a compreensão, ainda presente, de que a cidade vem historicamente sendo concebida como espaço que necessita ser cuidado tal qual um paciente adoecido. No caso brasileiro e, mais especificamente, na cidade do Rio de Janeiro, essa ideia remonta à visão higienista, nitidamente representada no Relatório da Comissão de Melhoramentos da Cidade do Rio de Janeiro:

A principal causa da insalubridade das casas em nosso país reside no péssimo sistema de sua distribuição interna. Construídas geralmente por homens práticos sem instrução alguma profissional e sem a menor ideia das condições de conforto e de higiene, que devem presidir à disposição dos aposentos, são as nossas habitações desprovidas dos meios de ventilação e de renovação de ar nos quartos de dormir e de muitos outros cômodos indispensáveis em uma residência... (Rio de Janeiro, 1977)

Tal descrição, que poderia ser comparada a situações recentes no Rio de Janeiro, expõe um pensamento que associa as condições de habitabilidade à desqualificação ou despreparo dos seus construtores e, assim, relaciona a qualidade de vida (e de saúde) a uma questão física da habitação. Os problemas nela explicitados revelam condições objetivas das moradias populares, analisados sob a visão das considerações estritamente técnicas, sanitárias e higiênicas abordadas no século XIX, sobretudo no contexto europeu, seja por arquitetos, médicos e outros profissionais envolvidos com as questões da casa e da cidade de modo geral. Assim, o tratamento de tais problemas foi proposto com base em mudanças de estilos de vida, por meio de projetos arquitetônicos que buscavam a introdução de novos hábitos ou formas de morar, em edificações que transformavam as práticas de construções populares. No caso brasileiro, muitas vezes, apropriaram-se desses pensamentos, que permaneceram nas políticas públicas e se exacerbaram com o crescimento do número de favelas em meados do século XX. Os moradores de favelas passavam a ser considerados como indivíduos socialmente desajustados, na visão de higienistas brasileiros.

A relevância do conceito de habitus, conforme Pierre Bourdieu (1998), pode ser evidenciada para auxiliar a compreensão das formas de tratamento dos problemas da moradia insalubre e suas consequências na saúde pública. Vieira-daSilva aciona esse conceito ao relacionar espaço social, habitus e saúde e ressalta a construção teórica de Bourdieu, afirmando que o "habitus corresponde a esquemas de percepção estruturados, à interiorização de estruturas sociais, sendo produzido 
pela história coletiva do grupo e transformado pela história individual, familiar, social e profissional" (Vieira-da-Silva, 2010: 187). Além disso, a autora acrescenta a reflexão de Bourdieau sobre as práticas sociais, as quais "não podem ser deduzidas nem da história passada que produziu o habitus, nem das condições presentes, e sim através da análise entre as condições de sua produção e as condições de sua utilização" (Vieira-da-Silva, 2010: 187).

Na procura de uma elucidação das ideias sobre cidades saudáveis e das propostas de equacionamento do seu contraponto - as cidades doentes -, a concepção de determinação social da saúde poderia destacar a relação entre saúde e espaço social, como preconiza Vieira-da-Silva:

Se os habitus orientam as diversas práticas sociais, por que razão não orientariam também as práticas do cuidado à saúde? Esse cuidado implica uma relação entre o paciente portador de um sofrer e o médico portador de um saber. O cuidado é, pois, o encontro entre esses dois habitus. Quanto mais próximos no espaço social estão o médico e o paciente, maior é a afinidade dos habitus, das práticas e dos gostos, o que torna também mais fácil a comunicação e maior a possibilidade do paciente reduzir a distância que a relação assimétrica, desde seu início, contém, fazendo melhor uso do cuidado recebido, realizando escolhas, recusando, decidindo, opinando. (Vieira-da-Silva, 2010: 193)

As observações anteriores também deveriam incluir o debate mais abrangente das reflexões sobre sociedade e território, com a incorporação da temática da cidadania, da democracia e da construção de sujeitos. Nas palavras de Ribeiro:

cidadania e democracia pressupõem a afirmação de sujeitos que, individual e coletivamente, lutem por direitos e por sua garantia. Sem sujeitos, que articulem sociedade e política, os direitos ou inexistem ou são letra morta, sendo reproduzido o afastamento entre lei e experiência social concreta. (Ribeiro, 2000: 83)

Nessa direção, pode-se enfatizar outra afirmação de Ribeiro (2002) sobre a evidente necessidade de se restaurar o tecido social, ${ }^{3}$ condicionante essencial do acesso à qualidade de vida e saúde, conforme a perspectiva aqui apropriada.

O Programa de Desenvolvimento Tecnológico em Saúde Pública (PDTSP) criado pela Fiocruz, em 2001, estimulou, entre outras, a pesquisa no campo da relação entre ambiente e saúde nas grandes cidades. Os textos desenvolvidos nesta

\footnotetext{
${ }^{3} \mathrm{~A}$ expressão "0 que deve ser restaurado é o tecido social" refere-se a uma afirmação da professora Ana Clara T. Ribeiro, mencionada em palestra proferida em Salvador em maio de 2002.
} 
publicação lidaram com a complexidade da abordagem transdisciplinar e buscaram propostas com potencialidades para tratar da problemática da saúde pública.

Os estudos promovidos pelo PDTSP e finalizados em 2010 são apresentados neste volume em seis capítulos, somados a outros quatro, de pesquisadores também voltados para os temas em questão. Essas contribuições derivam de participações no seminário realizado no fim do mesmo ano, para apresentação dos estudos então recém-concluídos. Têm o intuito de estimular o diálogo de pensadores de diferentes ramos do conhecimento com a prática vivenciada no decorrer dos projetos. O livro apresenta, também, um levantamento de experiências desenvolvidas no cotidiano das cidades, em diferentes regiões do país.

A publicação está dividida em três grupos: as reflexões de autores convidados, os seis estudos do PDTSP e o levantamento de redes e iniciativas empreendidas por gestores públicos ou por pesquisadores. O objetivo é incentivar o leitor a relacionar as considerações teóricas às experiências de projetos e àquelas realizadas na esfera executiva do SUS.

Intitulada "Cidades saudáveis sob diferentes prismas", a primeira parte é composta por contribuições de expoentes pensadores brasileiros voltados para o estudo da saúde das cidades. Humberto Kzure-Cerquera, no capítulo 1, revisita a história da construção das cidades desde o advento da industrialização e ressalta a distância entre a cidade ideal e a cidade real, dos "processos de urbanização excludentes e de disputas infindáveis pela apropriação do espaço territorial e, em associação, do domínio dos meios de produção". Chama atenção para a necessidade de se levar em conta a "questão da cultura" no planejamento da "urbe saudável" sob três diferentes aspectos: cultura-consciência, cultura-natureza e cultura-poder. Essa "cidade da acumulação do capital" "persegue e redefine seu 'desenho' com o artifício da mais-valia 'criativa' e, portanto, do lucro espetacular", que suplanta "a emergência por espaços urbanos sustentáveis, ou criam lógicas particulares de uma sustentabilidade a partir de simulacros expressos no desenho urbano ou urbanístico". Kzure sugere alternativas para o planejamento da cidade e destaca a necessidade de superação do isolamento entre os segmentos envolvidos por um trabalho intersetorial do qual provenham "reflexões espaciais sobre a relação entre objeto e sujeito, que sejam capazes de articular intervenções que vençam os desequilíbrios espaciais acumulados secularmente, na perspectiva de se vislumbrar uma cidade saudável e mais solidária".

No capítulo 2, Marco Akerman, Rosilda Mendes e André Fischer analisam publicações indexadas pela Biblioteca Virtual de Saúde (BVS) entre 1986-2010, no 
intuito de averiguar se as "contribuições teóricas expressam diferentes dimensões que podem possibilitar um interessante diálogo com o tema de cidades saudáveis". Em busca de "algum marco conceitual comum sobre cidade" e da pactuação de um quadro de desafios que tenha algum grau de consenso para que as 'armas' de cada corpo e conhecimento possam ser mutuamente potencializadas", os autores investigaram o caráter das respostas ao "enfrentamento da complexa realidade das cidades". Entre as observações resultantes da sondagem da utilização do termo - cidades saudáveis - em três idiomas (município saudável, na língua portuguesa; comunidades saludables, em espanhol e healthy cities, no inglês), constataram que os autores latinos relacionam o conceito à estratégia promoção da saúde, enquanto os de língua inglesa "inscrevem muito mais suas análises (...) no escopo de saúde urbana e planejamento urbano".

Marcelo Burgos busca construir "uma agenda mais universalista de luta pela cidade e pela cidadania". Chama atenção para a reconfiguração da urbe no período pós-aprovação da Constituição Federal de 1988, conquanto ainda hoje estejam (as cidades) "mergulhadas em um regime urbano construído em um contexto de modernização conservadora". No capítulo 3, Burgos traz ao debate o grau de acesso à cidade dos moradores das favelas e de outros espaços urbanos aquelas ainda apresentadas pela grande mídia como "espécie de inimiga da cidade"-, diz o autor, que salienta "a fragmentação da questão urbana em lutas particularizadas". Acrescenta que "ao menos no Rio de Janeiro, a favela (...) ocupa quase completamente o espaço da questão urbana, inibindo a formação de uma perspectiva mais universal de luta pelo direito à cidade".

Esta parte do livro não ficaria completa se fosse omitida a contribuição de Ana Clara Torres Ribeiro ao seminário "Cidades Saudáveis: desafios e perspectivas", no qual proferiu uma criativa e estimulante palestra sob um prisma deveras peculiar à professora. O seu falecimento, inesperado e prematuro, representa uma perda irreparável para o pensamento que busca uma visão transformadora das sociedades contemporâneas.

Esperávamos que Ana Clara encontrasse uma janela de tempo, como ela mesma havia mencionado, em meio aos seus numerosos compromissos acadêmicos, para dedicar-se à tessitura de mais uma das suas admiráveis reflexões sobre a cidade e a sociedade. Contudo, a janela de tempo não aconteceu. No intuito de fazer vir a público a sua contribuição e, ao mesmo tempo, conceder-lhe uma homenagem, optamos pela publicação, no capítulo 4, de dois textos complementares: um elaborado como um texto-guia para sua palestra e outro correspondente à transcrição editada da mesma palestra. 
O esforço realizado pretende revelar uma pequena parte do legado dessa professora, que deixou uma crítica aguda a respeito das ideias contidas na ementa proposta para a mesa "Equidade, participação social e sustentabilidade". Com a liberdade de pensamento que a caracterizava, afirmou a necessidade de uma abordagem verdadeiramente dialética e ousou desconstruir a temática, a começar pelo título da mesa, focalizando, no desenvolvimento da sua reflexão, as metas nela previstas. Apresentou, ainda, algumas ideias-síntese a respeito de uma cidade-justa, que seria contraposta à visão de cidade saudável. Indiscutivelmente, um pensamento que persegue a aventura do conhecimento, sem concessões.

No conjunto dos projetos do PDTSP que compõem a segunda parte deste livro "Seis projetos para uma cidade saudável", três aspectos se notabilizam e evidenciam a afinidade com os temas pontuados pelos autores convidados: de um lado, a busca por indicadores objetivos e plurais que contribuam para identificar problemas, orientar prioridades, monitorar investimentos e dimensionar a eficácia de ações realizadas. De outro, a procura por alternativas para a mobilização e o envolvimento social nas ações de Estado. Por fim, verifica-se a urdidura de alternativas para estímulo à integração de saberes e de ações (intersetorialidade e transdisciplinaridade) que contribuam para o aprimoramento da gestão pública.

O capítulo 5, de Leandro Giatti, Carlos Machado de Freitas e colaboradores, examina a problemática do reflexo do crescimento desordenado no coração da Amazônia Legal, em Manaus/AM, na degradação dos ecossistemas e no aumento da iniquidade social, inicialmente causados pela indução da industrialização da capital do estado, a partir da década de 1970. Destaca que o "processo econômico predominante nessa cidade globalizada" é um atrator cuja ação "consome espaço e recursos naturais de modo acelerado". Os autores partem do pressuposto de que as mudanças e impactos se apresentam "como forças motrizes e pressões e integram uma complexa cadeia de efeitos diretos e indiretos". Utilizam o modelo Forças Motrizes-Pressões-Situação-Exposição-Efeitos-Ações, proposto pela OMS. Considerando serem os sistemas socioambientais de grande complexidade, buscam "identificar os atratores e pontos críticos de instabilidade ou vulnerabilidade que podem resultar na emergência espontânea de novos padrões e estruturas de relações, bem como de novas formas de organização (social e ambiental)".

Também foi foco de pesquisa a região metropolitana do Rio de Janeiro. O trabalho de Carla Moura, Eduardo Stotz e demais autores apresentado no capítulo 6 focaliza o município de Itaboraí, em particular, onde elevados investimentos como o do Complexo Petroquímico do Estado do Rio de Janeiro (Comperj) e o 
Arco Metropolitano do Rio de Janeiro já fomentam a mobilidade da população, com crescimento exponencial previsto para esta mesma década e a consequente interferência nos ecossistemas locais. Destacam os autores que o município, de pouco mais de duzentos mil habitantes e PIB per capita de menos de R 7 mil/ ano, apresenta "forte dependência da transferência do governo federal e baixa participação do ICMS no conjunto das receitas correntes", além de pequena capacidade de "sustentar e impulsionar, mediante recursos fiscais, a economia local". O projeto também almejou "entender as consequências do Comperj sobre a vida, trabalho e saúde da população de Itaboraí e sua região". Assim, foi criada no distrito de Itambi, considerado de maior vulnerabilidade, uma ouvidoria coletiva "como um processo de educação e saúde, a saber, como uma prática social baseada no diálogo e no intercâmbio entre os saberes científico e popular ou do intercâmbio entre o saber científico e popular".

Outros quatro projetos se voltaram para duas áreas da capital fluminense que receberam significativos investimentos do Plano de Aceleração do Crescimento (PAC) destinados aos assentamentos urbanos irregulares, o PAC Favelas: Manguinhos, na Zona Norte do Rio de Janeiro, que abriga comunidades populares com uma população estimada em sessenta mil habitantes; e a área da antiga Colônia (psiquiátrica) Juliano Moreira (CJM), em Jacarepaguá, na Zona Oeste, com extensão original de mil hectares, onde hoje vivem cerca de trinta mil pessoas e onde parte da floresta atlântica brasileira ainda resiste.

Em Jacarepaguá, na tentativa de desenvolver uma metodologia de trabalho intersetorial e participativo para definição de indicadores de vulnerabilidade física e social das habitações em assentamentos urbanos irregulares, Simone Cohen, Carmen B. Silveira e colaboradores apresentam no capítulo 7 o estudo realizado numa pequena comunidade surgida há mais de 60 anos em espaço que abrigou os construtores (depois contratados como funcionários) do Hospital Rafael de Paula Souza - um dos equipamentos de saúde da antiga Colônia.

Com o pressuposto de que numa concepção ampla, as ações de saúde "devem se adequar às necessidades dos diferentes lugares, sem deixar de compreender as diferenças relativas às dimensões sociais, culturais e econômicas", a metodologia adotada conferiu "relevo ao estudo da habitação saudável como condição essencial à qualidade de vida compreendida no contexto do direito à cidade e, nesse sentido, identificada com o movimento nacional pela moradia digna". Por meio da formação de equipe de pesquisadores de distintas origens disciplinares, buscou-se aproximar saberes para realizar as pesquisas qualitativa e quantitativa pelas quais se fundamentou o desenvolvimento dos indicadores que, almejam 
os autores, possam servir de base para projetos a serem realizados por gestores públicos.

A intersetorialidade também é alvo do estudo relatado no capítulo 8 liderado por Rosana Magalhães, o qual buscou construir uma metodologia que viesse ajudar a avaliar a eficácia de ações levadas a cabo conjuntamente por gestores públicos de diferentes pastas, com o pressuposto de que o necessário trabalho associativo é custoso, em vista da "complexa cadeia de negociações e compromissos" e das "complexas redes de parcerias (...) imersas em contextos marcados pela diversidade de interesses e demandas". Para desenvolver tal ferramenta metodológica e constituir critérios que pudessem testar a capacidade de contribuir para a avaliação desejada, o projeto elegeu duas ações governamentais: o Programa Bolsa Família e a Estratégia Saúde da Família. O estudo articulou duas dimensões que, segundo os autores, "interagem permanentemente": "uma associada aos modelos lógicos e componentes estruturais das intervenções e outra ligada aos sentidos e significados atribuídos pelos atores no cotidiano das ações".

O projeto executado sob a orientação de Renato Gama-Rosa Costa e de Tania Maria Fernandes recupera, no capítulo 9, a história das diversas tentativas malogradas de urbanização da área conhecida como Complexo de Manguinhos, até a atual intervenção promovida com recursos do PAC em associação com os governos municipal e estadual. Iniciado simultaneamente ao estabelecimento do projeto intergovernamental, o estudo concentrou-se em duas comunidades do complexo - CHP2 (referência a Centro de Habitação Provisória) e Embratel-, na localidade que agrega uma população que vive em diferentes comunidades construídas às margens dos rios Faria-Timbó e Jacaré e nos terrenos que ladeiam a linha férrea. Seu objetivo foi "apreender a implantação do PAC pela ótica dos moradores" e "produzir uma reflexão sobre as características necessárias para políticas públicas urbanas, na perspectiva de que estas não considerem as favelas como tumores a serem extirpados do corpo da cidade", considerando que as opções apresentadas pelos gestores públicos variavam entre "melhorar as condições de vida da população no próprio local de moradia" e "abolir a própria existência da favela".

O projeto do Laboratório Territorial de Manguinhos (LTM) - relatado no capítulo 10 por Marcelo Firpo, Lenira Zancan e Fatima Pivetta teve o propósito de "contribuir com as bases conceituais e metodológicas para a constituição" do que os autores denominaram "uma promoção da saúde (PS) emancipatória no âmbito territorial". Por meio de pesquisa realizada em conjunto com moradores das comunidades vizinhas à sede da Fiocruz que já participam da comunidade 
ampliada de pesquisa-ação (CAP) fomentada pelo LTM há quase uma década, o trabalho baseou-se na troca de experiências - uma "produção compartilhada de conhecimento, entendida como dinâmicas de mediação entre os conhecimentos científicos e o saberes populares e contextualizados presentes no cotidiano das populações em seus lugares de vida".

Adotando como estratégia a "incorporação de linguagens audiovisuais, artísticas e lúdicas como forma de abordar temáticas mais complexas" e a superação dos "discursos argumentativos distanciados das pessoas do lugar", o projeto explora situações-problema que possam favorecer o diálogo entre os diferentes saberes até a almejada apropriação e produção de sentidos.

Também compõe este livro um apêndice que apresenta um levantamento das redes e iniciativas ou projetos identificados no território brasileiro, voltados para a melhoria da saúde das cidades. Tal levantamento foi realizado por Rogério Fenner, Guilherme Franco Netto e Cícero Góes Junior e contou com a participação de equipes de 14 municípios em diferentes pontos do país. Consideradas por eles como ações de "Promoção da Saúde relacionadas ao eixo 'Desenvolvimento Sustentável' da Política Nacional de Promoção da Saúde (PNPS)" que podem inspirar outras práticas, as iniciativas compõem um acervo de experiências ora "mais sociais que ambientais", ora o inverso, por vezes com "atuação mais comunitária" e outras "mais atuantes na gestão".

A criatividade dos empreendimentos e a tentativa de adequação às identidades locais, reunidas nesse Apêndice, evidenciam o grau de assertividade da luta empreendida pelos movimentos municipalista e sanitário - que, no campo da saúde, levou à criação do SUS. Consolidada na Constituição Brasileira de 1988, a organização ascendente do sistema federativo reconhece que a participação civica, ainda frágil após quase três décadas de aprovação da Carta Magna, será tão mais fortalecida quanto mais perto as decisões e as ações estiverem do cidadão.

Para finalizar, agradecemos à Maria del Carmen Rojas pela gentileza de vincular sua história profissional a este livro. Maria del Carmen é arquiteta, doutora em demografia pela Universidade Nacional de Córdoba, Argentina; subsecretária executiva da Rede Interamericana de Habitação Saudável sancionada pela Organização Pan-Americana da Saúde (Opas) e pela Organização Mundial da Saúde (OMS); coordena a linha de trabalho Gestão do Risco e Investigação Científico-Tecnológica da Rede; membro do Grupo de Desarrollo de la Guía para la Vivienda y las Directrices de la Salud da OMS; é pesquisadora independente no Consejo Nacional de Investigaciones Científicas y Técnicas (Conicet) de seu 
país, onde coordena outra linha de pesquisa: Vivienda Saludable: riesgo, vivienda, ambiente y salud - em associação com a Universidade Nacional do Nordeste, Argentina. É, também, sócia-fundadora da Associação Latino-Americana de População (Alap).

As organizadoras 


\section{Referências}

BOURDIEU, P. O Poder Simbólico. Rio de Janeiro: Bertrand Brasil, 1998.

ENGELS, F. A Situação da Classe Trabalhadora na Inglaterra. Porto: Afrontamento, 1975.

FLEXNER, A. Medical Education in the United States and Canada: a report to The Carnegie Foundation for the Advancement of Teaching. Nova York: The Carnegie Foundation for the Advancement of Teaching, 1910.

MARX, K. Sobre a Questão Judaica [1844]. Trad. Nélio Schneider. São Paulo: Boitempo. Apres. e posf. Daniel Bensaïd, 2010.

MINAYO. M. C. S.; HARTZ, Z. M. \&BUSS, P.M. Qualidade de vida e saúde: um debate necessário. Ciência \& Saúde Coletiva, 5(1): 7-18, 2000.

NOGUEIRA, R. P. Determinantes, determinação e determinismo sociais. Saúde em Debate, 33(83): 397- 406, 2009.

NOGUEIRA. R. P. (Org.). Determinação Social da Saúde e Reforma Sanitária. Rio de Janeiro: Cebes, 2010.

RABELLO, L. S. Promoção da Saúde: a construção social de um conceito em perspectiva comparada. Rio de Janeiro: Editora Fiocruz, 2010.

RIBEIRO, A. C. Sujeito corporificado e bioética: caminhos da democracia. Revista Brasileira de Educação Médica, 24(1): 83, 2000.

RIBEIRO, A. C. Palestra proferida em mesa-redonda. In: III SEMINÁRIO INTERNACIONAL PATRIMÔNIO E CIDADE CONTEMPORÂNEA: POLITICAS, PRÁTICAS E NOVOS ATORES, maio 2002, Salvador.

RIBEIRO, A. C. Cartografia da ação social: região latino-americana e novo desenvolvimento urbano. In:POGGIESE, H. \& EGLER, T. T. C. (Orgs.). Otro Desarrollo Urbano: ciudad incluyente, justicia social y gestión democratica. Buenos Aires: Clacso, 2009.

RIO DE JANEIRO. Prefeitura. Relatório da Comissão de Melhoramentos da Cidade do Rio de Janeiro, 1875. In: OLIVEIRA REIS, J. O Rio de Janeiro e Seus Prefeitos: evolução urbanística da cidade. Rio de Janeiro: Lidador, 1977.

VIEIRA-DA-SILVA, L. M. Saúde e Espaço Social. In: NOGUEIRA, R. P. (Org.).Determinação Social da Saúde e Reforma Sanitária. Rio de Janeiro: Cebes, 2010. 


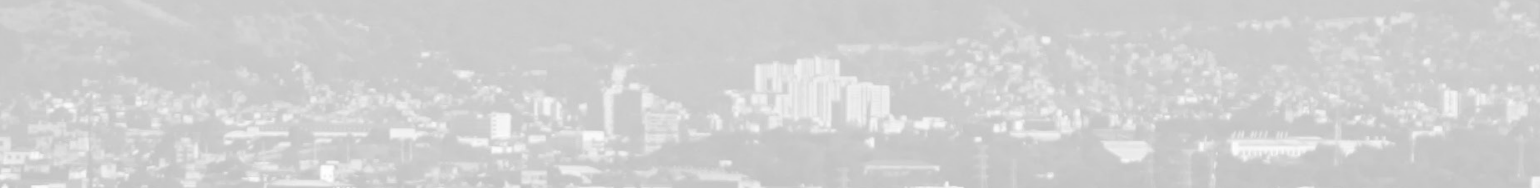

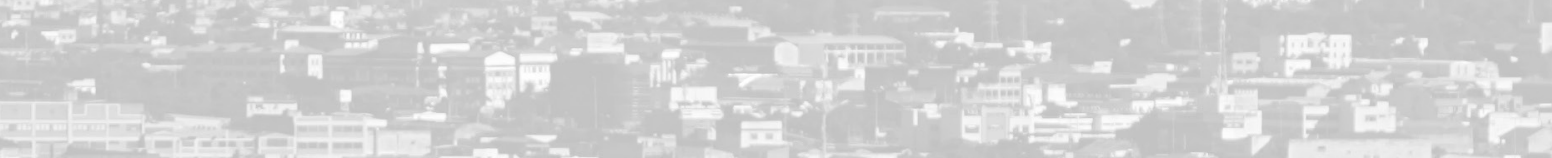

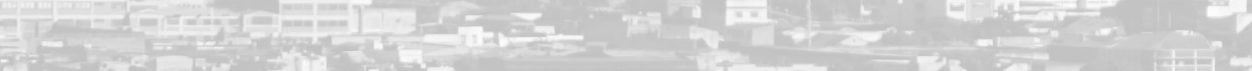

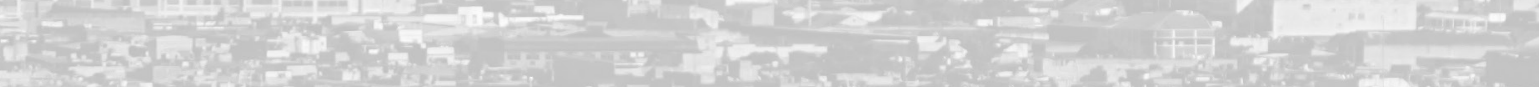

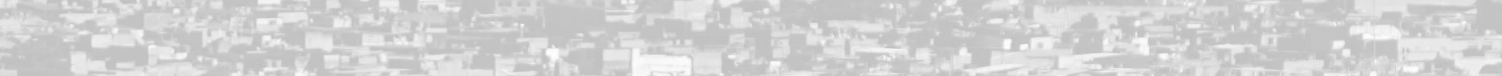

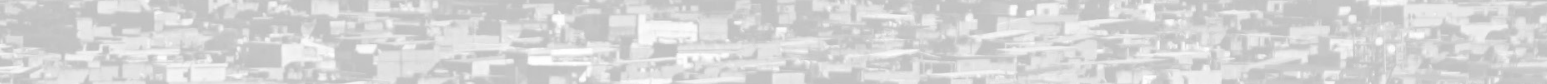

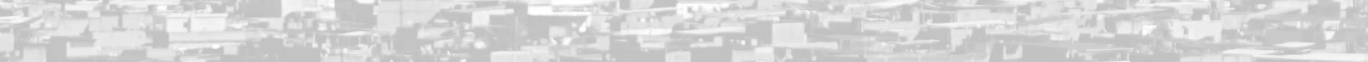

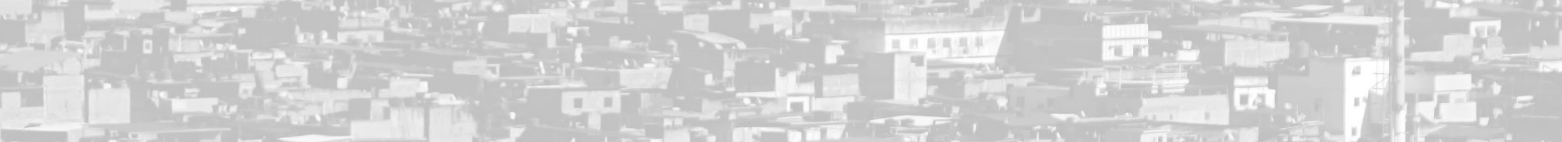

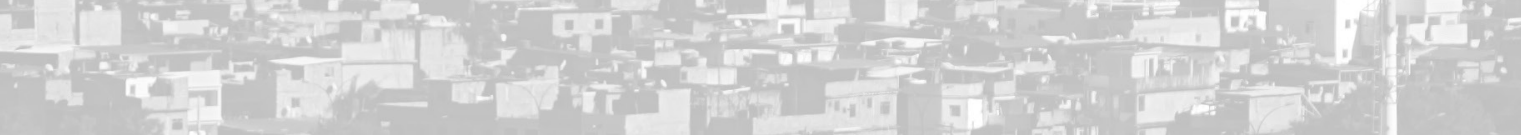

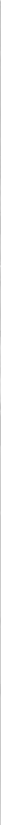




\section{PARTE I CIDADES SAUUAÁVEIS SOB DIFERENTES PRISIMAS}




\section{1 \\ A Saúde da Cidade sob Suspeita}

Humberto Kzure-Cerquera

Mas que coisa é o homem, que há sob o nome: uma geografia? um ser metafísico? uma fábula sem signo que a desmonte? Como pode o homem sentir-se a si mesmo, quando o mundo some?... Carlos Drummond de Andrade

Tnúmeros estudos acadêmicos buscam incessantemente conceituar a cidade na 1 perspectiva material, relacional e representacional, amparados em atributos conferidos ao tempo e ao espaço. Nesse sentido, versa o discurso corrente das ciências sociais, por exemplo, de que a urbe é uma construção humana, inacabada e de caráter heterogêneo e contraditório. Sabe-se, porém, que na cidade se configuram e se definem as relações socioespaciais materializadas por intermédio de um tempo histórico-político e cultural.

Contudo, é na experiência cotidiana do ser urbano, a despeito de toda carga subjetiva intrínseca à sua própria existência, que as múltiplas contradições citadinas expõem e revelam as fragmentações e as colisões espaciais provocadas 
pelos interesses individuais e coletivos, particularmente relacionados à apropriação seletiva da terra. Essa dinâmica espacial, fruto da histórica produção socioeconômica que estabelece hierarquias e controle de indivíduos e territórios, no entanto, tem orientado e definido os padrões diferenciados de consumo e habitabilidade urbana. Quanto a isso, ainda se observam nas cidades brasileiras a persistência do acentuado abismo social e a criticidade físico-espacial. Tais aspectos, seus desdobramentos e consequências para a vida urbana, indicam o quão inadequadas são as cidades desde a sua origem, com expressivo acúmulo do déficit de infraestrutura.

Os elementos da forma material da cidade, tal qual se apresentam, vistos frequentemente nas distintas paisagens urbanas, não eximem a urbe de "produzir identificações, alianças e conflitos, que se transformam e expõem partes de si mesma" (Kzure-Cerquera, 2008: 95). Não se encerram, com isso, em um corpo totalitário. Afinal, os significados e significantes contidos nos modos de vida urbana estão inscritos nos valores identitários e suas particulares representações culturais, como bem destacaram os escritos de Henri Lefebvre, Milton Santos e outros.

Vale lembrar que do fim do século XIX aos dias atuais, a compreensão sobre a cidade se tornou cada vez mais complexa. A paisagem urbana adquiriu novos contornos e se intensificou seu sistema de representações - políticas, econômicas, socioculturais, ambientais. Christine Boyer (1994) descreve uma série de modelos visuais e mentais pela qual o ambiente urbano foi identificado, figurado e planejado. Segundo ela, podem ser distinguidos três mapas principais: a cidade como obra de arte (cidade tradicional); a cidade como panorama (cidade moderna); e a cidade como espetáculo (cidade contemporânea e global), para a qual Guy Debord, ao escrever em 1968 A Sociedade do Espetáculo, antecipou:

A sociedade modernizada até o estágio do espetacular integrado se caracteriza pela combinação de cinco aspectos principais: a incessante renovação tecnológica, a fusão econômico-estatal, o segredo generalizado, a mentira sem contestação e o presente perpétuo. (Debord, 1997: 175)

A cidade contemporânea, por sua vez, molda e concentra fenômenos socioespaciais investidos de imponderabilidades, mutações que operam territorialmente e incertezas que instigam o pensamento científico. Para muitos analistas do mundo global, a cidade tornou-se a base fértil para o espetáculo do consumo, em que a admissão de um estágio de inadequação espacial obriga a otimizá-la em uma perspectiva de futuro que nega suas matrizes do passado. E torna também espetáculo a qualidade ambiental urbana, contrariando, segundo Françoise Choay (1979), as preocupações propaladas pelos sanitaristas (ou pré-urbanistas) das 
últimas décadas do século XIX, quando já se expressava uma concepção de cidade saudável.

Nesse período, os estudos de Choay (1979) destacam o crescimento da industrialização e a eclosão de elevadas densidades populacionais de grandes centros urbanos capitalistas como Paris, Londres e Berlim, por exemplo. Nesses casos, foi possível observar o surgimento de uma paisagem citadina marcada, entre outros aspectos, pela presença de chaminés de fábricas, novas construções edilícias e pelos meios de transporte de massa. A cidade priorizava, dessa maneira, a política de desenvolvimento fabril. Não tardou, e essa cidade da acumulação do capital assistiu ao surgimento de inúmeros problemas de saúde pública decorrentes da emissão de poluentes no meio urbano construído, da precariedade da infraestrutura sanitária e, também, dos conflitos relacionados ao sistema de transportes e moradia para as classes sociais de menor renda. No entanto, a preocupação dos sanitaristas em tornar a cidade saudável se restringiu à implantação e expansão da infraestrutura urbana e ao combate às epidemias.

Posteriormente, já no século XX, Choay revela que vigorou por muitas décadas, ainda, a tônica da construção de modelos utópicos que objetivavam fazer intervenções no espaço da cidade de caráter meramente formal - expansão do sistema viário, novos padrões de habitação, espaços públicos de convívio e lazer etc. Nesse caso, pode-se constatar que a implantação de intervenções físicoespaciais esteve mais ao alcance do desenvolvimento econômico e menos da relação equilibrada entre a cidade e o meio ambiente.

Cabe salientar que o surgimento do urbanismo como disciplina preocupada em estabelecer correções para a estrutura socioeconômica, ambiental e formal da cidade, que havia adquirido novos contornos com o advento da Revolução Industrial, possibilitou também debates e análises sobre as novas bases de acumulação patrimonial. Contudo, desde a sua criação até os dias atuais, a cidade busca uma forma definitiva que já não mais se inscreve entre muros, mas persegue e redefine seu desenho com o artifício da mais-valia criativa e, portanto, do lucro espetacular para os detentores da hegemonia política e econômica.

Paradoxalmente, a ideia de cidade ideal - do desenho urbano da pretensa perfeição que buscavam os utopistas do modernismo - à luz do capital, colide com os rizomas ${ }^{1}$ - diferentes conexões e heterogeneidades - resultantes das próprias

\footnotetext{
${ }^{1}$ Rizoma, segundo a perspectiva filosófica de Deleuze e Guattari, trata-se de uma metáfora biológica que se refere à transformação da imagem do mundo como cosmo-raiz em cosmo-radícula. Entre várias características, compreende-se 0 uso da metáfora rizoma para o espaço urbano como a existência de diferentes conexões e heterogeneidades. Para esses filósofos, também é comum em estudos acadêmicos relacionar rizoma à ideia de multiplicidade - não tem sujeito nem objeto. E, ainda, rizoma pressupõe a ideia de cartografia - faz mapas, não decalques.
} 
disfunções urbanas secularmente construídas e que hoje obriga aos planejadores tecerem reflexões sobre a cidade real. Um caso exemplar são as aglomerações de assentamentos pauperizados excluídos dos bens essenciais para a reprodução da vida e dos valores contíguos à própria existência humana, que clamam pela provisão de oportunidades mais igualitárias em sociedade.

A cidade real, a mesma que se contrapõe aos ensejos pretéritos de uma construção ideal, impõe aos estudos urbanos contemporâneos a emergência da criação de uma agenda de mudanças de ordem política, econômica, social, cultural e, também, ambiental. Contudo, a cidade do passado - da tradicional à moderna -, vitimada por hordas que a levou, por um lado, a erguer muros e, por outro, a compor uma paisagem de chaminés própria da infraestrutura industrial não paralisou os processos de urbanização excludentes e de disputas infindáveis pela apropriação do espaço territorial e, em associação, do domínio dos meios de produção. Assim, mesmo com as grandes intervenções urbanas ou reformas sociais e econômicas do século passado, além do surgimento de novas tecnologias de comunicação, que impactaram a vida na cidade, só reforçaram embates - em diversos estratos e diferentes escalas da sociedade - e conformaram verdadeiras trincheiras.

Entretanto, os processos atuais de urbanização, na perspectiva da cidade real, admitem fragmentações e articulações socioespaciais acumuladas no tempo que representam a tônica contemporânea, em que são definidas as novas redes de produção e comunicação. Igualmente, identificam-se novos modos de vida urbana que abrangem contradições entre o maior equilíbrio ambiental e a equidade social. Significa indagar, no entanto, que há uma emergência quanto à implementação de políticas urbanas sustentáveis? E que essa nova postura do planejamento urbano e do urbanismo busca incessantemente tornar a cidade um lugar saudável?

A concepção de cidade saudável, que hoje é pauta de debates em diferentes fóruns político-institucionais, representa inúmeras tentativas para diminuir os abismos sociais provocados, historicamente, pelos setores públicos e privados que detêm os meios de produção socioeconômica e a governabilidade dos territórios. Porém, na busca pela equidade e justiça social, a Carta de Ottawa, datada de 21 de novembro de 1986, destaca os requisitos e as condições fundamentais para a promoção da saúde, contemplando o direito à moradia, à educação, à renda, à alimentação, ao meio ambiente equilibrado e à paz, na perspectiva de garantir o bem-estar físico, mental e social. As questões sublinhadas nesse documento orientam novas possibilidades para se pensar o planejamento da cidade, incluindo 
a modernização dos instrumentos normativos, a gestão democrática de bens e serviços e a melhor qualidade do ambiente construído.

No cerne dessas reflexões, faz-se necessário ressaltar que "da cidade tradicional à chamada cidade global, alteraram-se os padrões de consumo, as relações de trabalho, mas, também, as ações humanas sobre o meio ambiente" (KzureCerquera, 2010: 316), com o registro de impactos irreversíveis sobre a ocupação massificada, e em muitos casos desordenada, do solo urbano e suas redes socioespaciais e físicas.

As cidades, desde a origem aos dias atuais, materializam mudanças dos sistemas político-econômicos, dos meios de produção em face das novas tecnologias, das altas densidades, provocadas em grande medida pelo êxodo rural acentuado entre os séculos XIX e XX, entre outras. Sob esse aspecto, sublinham-se aqui os estudos de Ana Fernandes (2003) quando chama a atenção para o fato de que:

Está sendo reconfigurado o conjunto de elementos que impulsionam e caracterizam a rede urbana mundial e sua hierarquia. Nesse sentido, as profundas transformações da economia, das relações sociais e do aparelho do Estado têm dado lugar, em termos urbanos e urbanísticos, à produção de novas centralidades, ao aumento gigantesco de mobilidade das pessoas, à competição acirrada entre cidades e à readequação dos seus espaços a esses novos processos. (Fernandes apud Kzure-Cerquera, 2010: 316)

Assim, a cidade capitalista, berço da especulação, como destaca a autora, torna-se cada vez mais o espaço da financeirização e espetacularização dos modos e condições de vida urbana, com a cumplicidade nefasta dos meios de comunicação conservadora e hegemônica. No mundo atual, não há dúvidas de que "a comercialização dos modos de vida não mais encontra resistências estruturais, culturais nem ideológicas" (Lipovetsky, 2004: 31). Em linhas gerais, observa-se que as reflexões condutoras das análises acerca dessas questões atuais reforçam, também, a ideia de "que as esferas da vida social e individual se reorganizam em função da lógica de consumo" (Lipovetsky, 2004: 31) e provocam, sobretudo, a exacerbação de excluídos das benesses do mundo moderno e globalizado, mesmo nas áreas pobres urbanizadas. Nesse caso, destacam-se a manutenção de elevados índices de baixos salários e acesso limitado aos meios de informação e comunicação.

Do urbanismo utópico ao urbanismo de negócio, Fernandes é enfática ao afirmar que o "campo de tensão da ação corporativa é urbano e urbanístico" (Fernandes apud Kzure-Cerquera, 2010: 316). Assim:

Esse urbanismo de negócio reestrutura os centros de nossas cidades, normatiza novos espaços de moradia, cria espaços de valorização e desvalorização, 
captura a paisagem, define eixos de expansão das cidades.Esse urbanismo é ainda avesso a qualquer forma de explicitação de conflitos sociais e urbanos. (Fernandes apud Kzure-Cerquera, 2010: 316)

O ambiente urbano construído e a lógica de mercado impetrada pelos seguimentos mais conservadores das esferas políticas e econômicas, da lucratividade e a negociação, "suplantam a emergência por espaços urbanos sustentáveis, ou criam lógicas particulares de uma sustentabilidade a partir simulacros expressos no desenho urbano ou urbanístico" (Kzure-Cerquera, 2010: 317). Com isso:

Fala-se em urbanização sustentável como uma ação corporativa, que cria simulacros e novas divisas de capitais sem, de fato, ater-se na função social da propriedade e o direito à cidade, principalmente para os mais pobres. O urbanismo contemporâneo enseja a mais-valia e, para tanto, constrói o discurso da sustentabilidade como marketing da (re)produção de novos capitais dos principais setores da economia. (Kzure-Cerquera, 2010: 316)

As questões que envolvem políticas de urbanização e infraestrutura no Brasil, em vista dos fenômenos espaciais e históricos, contribuem para a configuração da cidade contemporânea. No entanto, as metrópoles do Rio de Janeiro e de São Paulo, como exemplos latino-americanos, permitem compreender o arranjo espacial valendo-se da apropriação desigual dos bens produzidos, originados no âmago da esfera socioindustrial e cujas disfunções, como lembram os estudos de Roberto Lobato Corrêa (1995) e de outros autores, moldam a sociedade por meio de estratificações, ambiguidades e colisões em diferentes esferas de domínio territorial. Com isso, chamam atenção as áreas urbanas segregadas, como as inúmeras favelas cariocas, que representam parte desse fenômeno e que compõem expressiva parcela da população do Rio de Janeiro alijada das principais necessidades básicas.

Nesse contexto, destacam-se o papel de diferentes técnicos e múltiplas disciplinas ante os desafios que lhe são impostos para traçar medidas mitigadoras e compensatórias para os problemas urbanos que têm revelado, com frequência, as faces da exclusão social, da pobreza e, também, da insegurança e violência nas grandes cidades. De tal ponto de vista, os desafios para a elaboração de planos e projetos urbanos tornam mais frequente a necessidade do diálogo interdisciplinar como uma das alternativas para a compreensão da dinâmica sociocultural heterogênea, complexa e estratificada das aglomerações urbanas. Nesse caso, aos planejadores urbanos cabe um novo olhar sobre a cidade, que os possibilite reconhecê-la valendo-se das fronteiras materiais e imateriais como 
produto intrínseco à cultura urbana - identidade, lugar e memória, como aportes significativos para a constituição de uma cidade saudável.

Ademais, o atendimento das demandas por infraestrutura e desenvolvimento social localizado, nessa árdua tarefa de formulação das políticas urbanas, ressalta a ótica da intersetorialidade. Abordar a intersetorialidade, contudo, requer a predisposição de várias áreas do conhecimento para a busca de alternativas que assegurem a melhor qualidade do espaço urbano. Para tanto, é necessário compreender a cidade desde a sua constituição e admitir as diversas trincheiras insurgentes no cotidiano urbano. A intersetorialidade, no entanto, pressupõe que as diferentes áreas do saber científico e seus analistas superem a condição de isolamento e arbitrariedade conceitual, com vistas à compreensão dos fenômenos socioespaciais da cidade, materializados em paisagens urbanas díspares e ambíguas.

Dificilmente, contudo, se pode compreender os fenômenos que insurgem no espaço urbano sem reconhecer os meios e as condições territoriais resultantes das práticas socioculturais, econômicas, políticas e ambientais impetradas pelas ações humanas. O desafio de trabalhar a intersetorialidade, por sua vez, está em promover reflexões espaciais sobre a relação entre objeto e sujeito, que sejam capazes de articular intervenções que vençam os desequilíbrios espaciais acumulados secularmente, na perspectiva de se vislumbrar uma cidade saudável e mais solidária.

Recortes Espaciais da Desigualdade Brasileira: construção de paisagens urbanas fragmentadas e heterogêneas

Convém lembrar que até o século XIX o Brasil, segundo a literatura acadêmica, era constituído por uma economia predominantemente agropastoril, utilizando-se, ainda, do trabalho escravo. Já no início do século XX, as atenções se voltaram para a constituição de uma sociedade agroindustrial, que fortalecia e centralizava o capital nas cidades. Os meios de produção rural foram alterados com a substituição de mão de obra escrava - abolida em 1888 - pelos imigrantes assalariados, em sua maioria de origem europeia, que, embora livres, também eram submetidos aos rigorosos padrões de trabalho e comportamento impostos, principalmente, pelos conhecidos barões do café.

A configuração socioeconômica forçou a população liberta das atividades hostis do campo migrar para as cidades. Com isso, esse contingente populacional irá se deparar com as dificuldades de se estabelecer no meio urbano, em vista 
da inexistência de recursos financeiros, da falta de qualificação profissional e da indisponibilidade de terras, entre outros fatores. Como alternativa para a sobrevivência ante a nova realidade, como expressam as análises de Maurício Abreu (1987) e Lilian Fessler Vaz (2002), essa população irá se aglomerar em áreas inóspitas, de difícil acesso e de topografia acidentada, como ocorreu no Rio de Janeiro. Em tais áreas, edificará moradias rudimentares e irá submeter-se a trabalhos que não exijam qualificação profissional, tais como: emprego doméstico, engraxates, pedreiros, entre outros.

A omissão ou inoperância do Estado quanto às políticas sociais voltadas para a distribuição de renda e democratização de terras urbanas e rurais resultará no acúmulo do déficit habitacional que permeará todo o século XX. Notadamente, algumas iniciativas governamentais, como a criação do Banco Nacional da Habitação (BNH) em meados dos anos 1960, extinto duas décadas depois, constituíram-se em alternativas para o acesso à moradia em um país cada vez mais urbano, como atesta a literatura acadêmica sobre o assunto. Sublinha-se, porém, que, embora tenha existido um esforço da esfera político-governamental em solucionar problemas dessa envergadura, não houve um equilíbrio entre trabalho qualificado, salário justo e crescimento populacional.

Esse panorama evidencia que as grandes cidades brasileiras, e também as de menor porte, configuram abismos espaciais em que se verificam práticas de segregação sociocultural, econômica e política historicamente impostas por grupos que detêm a hegemonia do país. Metrópoles como São Paulo, Rio de Janeiro, Salvador, Recife, Fortaleza, Porto Alegre, Belo Horizonte e Brasília, por exemplo, não apenas assistirão ao aumento significativo da sua população urbana, como passarão a conviver com o crescimento expressivo da classe baixa. Elevados índices de pobreza urbana, como ocorre nas favelas, consolidaram-se em "uma época de crise e de transformações, marcada, na década de 1980, pela recessão, pelo desemprego e pela inflação, e, na de 1990, pelos efeitos da globalização da economia" (Vaz \& Kzure-Cerquera, 2000: 67).

O Brasil, e muitos países latino-americanos, "viram seus poucos recursos serem drenados para o pagamento de dívidas externas; com o Estado falido, reduziram-se os investimentos sociais, as já insuficientes redes de serviços e infraestrutura existente se deterioraram" (Vaz \& Kzure-Cerquera, 2000: 67). Assim, como falar em cidade saudável como prerrogativa do planejamento urbano atual sem se ater às questões estruturantes da vida social urbana, como o direito à moradia regularizada de qualidade para os cidadãos? 
Parte-se do pressuposto de que a informalidade que caracteriza o espaço-favela, em diferentes marcos temporais pela disputa e a apropriação territorial, tem em sua origem a má distribuição de terras e de renda, fruto de séculos de domínio oligárquico. Por um lado, essas mesmas elites brasileiras, detentoras dos meios de produção socioeconômicos, sempre privaram parte expressiva da população dos benefícios dos bens de consumo essenciais. Por outro, fixaram instrumentos de exploração da força de trabalho, desde a mão de obra escrava à de baixos salários. Não obstante, o país de economia agropastoril transformar-se-á, durante todo o século XX, em agroindustrial e industrial. Se, de certo modo, a mecanização da agricultura retrai a força de trabalho no campo, de outro, o avanço das atividades da indústria estimulará um fluxo migratório do campo para as cidades.

Tais aspectos, em verdade, tratam dos desequilíbrios territoriais que até os dias de hoje mantêm extensos latifúndios rurais e grandes propriedades de terra urbana sob o domínio da União, estados e municípios, da Igreja católica e da iniciativa privada. Sublinha-se o caso da cidade do Rio de Janeiro, onde esses aspectos históricos fundiários, que compõem a obra acadêmica Donos do Rio em Nome do Rei, são analisados cuidadosamente por Fania Fridman (1999). Nesse contexto, as cidades brasileiras, sobretudo na Região Sudeste do país, nas últimas três décadas do século XX, apresentaram crescimento populacional expressivo e inversamente proporcional à provisão de moradias. Paralelamente, as ocupações clandestinas e irregulares, por meio da prática de invasões de terras livres, em geral destinadas à especulação por parte de seus proprietários, expandiram-se no limiar da informalidade. Destaca-se, também, a progressão do trabalho informal como a maneira encontrada pelos mais pobres para garantir a própria sobrevivência urbana.

Ressalte-se, porém, que as metrópoles latino-americanas enfrentam problemas de ordem econômica, social e institucional que remontam às políticas dominantes extrativistas do domínio português ou espanhol e, também, aos conflitos entre grupos políticos durante os regimes ditatoriais do século XX, como tratam, unanimemente, vários analistas desse assunto. Se, por um lado, a produção interna foi desaparelhada, principalmente com os desequilíbrios da produtividade econômica, por outro, os problemas sociais se agravaram com o aumento da pobreza e a consequente elevação dos índices de desemprego e subemprego. Nesse contexto, entre disputas político-territoriais fomentadas por diversos interesses de agentes internos e externos como a história revela, definiram-se no espaço urbano de metrópoles como Rio de Janeiro e São Paulo uma nova geopolítica e novas tendências geoeconômicas. Quanto a isso, um caso exemplar 
dessa desarticulação macroeconômica é o impacto sobre as populações que foram reduzidas e subjugadas à condição de apartadas, cujo reflexo imprimiu o expressivo número de pobres em áreas periféricas, mas também em áreas centrais.

O problema econômico que se observa nessas megacidades alia-se à insuficiência da aplicação de capitais em infraestrutura, serviços e equipamentos em áreas urbanas, assim como à falta de dinamismo no setor industrial e à exploração equilibrada das potencialidades dos recursos naturais. Por sua vez, o agravamento dos problemas está relacionado à inoperância e às limitações político-institucionais na formulação e aplicação de instrumentos reguladores de planejamento e gestão territorial e ambiental. Acrescente-se a isso a proliferação de áreas urbanas informais, que culminou com o surgimento de periferias pauperizadas nas principais cidades brasileiras, onde tal situação tem provocado deseconomias observadas no déficit de saneamento, transportes, equipamentos sociais e urbanos e habitação. Questões dessa natureza impõem grandes desafios para as administrações públicas e planejadores de diferentes campos disciplinares.

Porém, os efeitos da reestruturação produtiva em relação às ocorrências recentes do passado, que passam pela desconcentração de atividades e o surgimento de novos espaços econômicos como os da produção energética e a expansão dos meios de comunicação, intensificam os processos de formação de redes complexas de distribuição territorial da população. Estas redesenham, grosso modo, os níveis de desenvolvimento humano, maneira pela qual a informalidade, tanto no mercado econômico quanto na estruturação físico-espacial, constitui um dos principais temas que merece reflexões e ações para o enfrentamento de diferentes impactos nas cidades, inclusive sobre a saúde urbana.

\section{Planejamento Urbano Contemporâneo e Incorporação de} Conceitos Relacionados à Paisagem: contribuições à experiência do indivíduo na cidade

O debate sobre cidades saudáveis também exige a compreensão do espaço urbano além da forma e da aparência das múltiplas e fragmentadas paisagens, reveladas com base no olhar e na experiência de cada um. Nesse caso, não se trata apenas da maneira de ver, individual ou coletivamente, para compor o mundo externo em uma cena, em uma unidade visual dissociada das práticas sociais vigentes. Ao contrário, a observação da paisagem urbana pressupõe admitir as mudanças morfológicas que operam sobre ela e que não resultam de uma ação ingênua de seus atores sociais, como tratam inúmeros estudos da antropologia, 
da economia, da sociologia e da geografia contemporânea, entre outros. Embora uma paisagem seja apenas um fragmento de uma dada configuração territorial, "o que se encontra na forma-objeto como significante, encontra-se na totalidade como significado" (Santos, 1986: 24). Assim, os conteúdos da paisagem remetem à lembrança de que estes não se revelam totalmente a um olhar pouco reflexivo. Trata-se, à luz da geografia humana, de um objeto da cultura que se materializa com base nas ideias e composições de formas visíveis, complexas e contraditórias sobre a superfície da Terra.

\section{Paisagem, espaço e tempo: uma compreensão conceitual}

Todavia, se paisagens são em princípio materialidades, são elas mesmas que permitem às sociedades a efetivação de seus simbolismos representados no espaço por objetos visíveis - uma favela, um condomínio de luxo, um centro urbano financeiro ou um shopping center, por exemplo. Com isso, a compreensão conceitual acerca da paisagem urbana é complexa e implica, pelo menos, três aspectos, de acordo com Denis Cosgrove (1998b): o que faz referência a um foco nas formas visíveis do mundo, sua composição e estrutura espacial; o que se relaciona com a unidade, coerência ou concepção racional do meio ambiente; e aquele que traz a ideia de intervenção humana e controle das forças que (re) modelam o mundo. Nesse sentido, qualquer paisagem pode ser analisada de forma absoluta, tais quais os objetos visualizados se encontram sobre a superfície terrestre, ou de forma relativa, a depender das experiências e valores individuais inerentes ao momento da observação. Trata-se aqui, portanto, das noções de espaço absoluto e de espaço relativo como questão epistemológica das diversas ciências sociais.

Durante muito tempo, a primeira noção predominou na construção do conhecimento. Com algumas variações, tal ideia está presente, por exemplo, na filosofia de Descartes, na de Kant e na física de Newton. O espaço é, portanto, uma extensão absoluta que contém todas as coisas do universo. Constitui uma categoria preexistente a todas as coisas, na medida em que os elementos da natureza e os objetos humanos ocupam o espaço, estão no espaço. Em tal perspectiva, ele é apenas palco dos acontecimentos e das intervenções humanas, algo externo às sociedades e às experiências individuais.

Segundo a noção de espaço relativo, que encontra respaldo, por exemplo, tanto na filosofia de Leibniz quanto na física de Einstein, ${ }^{2}$ o espaço não é uma

\footnotetext{
${ }^{2}$ A teoria einsteiniana da relatividade do tempo e do espaço se baseia no seguinte fenômeno: para dois observadores em movimento e em relação entre si, a sucessão do tempo não é a mesma. Enquanto na física clássica se considerava o tempo inteiramente independente do espaço e do movimento, "fluindo sem relação com algo de externo" (Newton), na nova física o espaço e o tempo dispõem de relação de interdependência, fato este decisivo para uma variedade de ciências, inclusive as sociais.
} 
extensão preexistente, mas algo constituído pelas coisas, no qual o valor de cada elemento dá-se na relação com os demais. Tendo como base esse entendimento, é possível pensar em um espaço produzido pelas sociedades ou em um espaço humano, vivido, sentido e representado pelas experiências individuais: um espaço social. Dessa forma, apreende-se que, no processo de construção da paisagem pelo imaginário social, ela não se revela apenas como um quadro em que se desenvolve a trama das práticas sociais: configura-se na própria representação de práticas que lhe dão novo conteúdo, transformando-se em espaço geográfico como sublinha Maria Tereza Luchiari (2001).

Como ensinam vários autores contemporâneos, a compreensão do espaço geográfico, o mesmo que abriga a urbe e possibilita analisá-la, inicialmente assumiu uma concepção de tempo à maneira de Kant, concebendo-o de forma sequencial como sucessão de fatos no espaço. Construiu suas análises em uma perspectiva histórica linear, buscando explicar as relações dos grupos particularizados com a natureza baseando-se em uma visão de tempo como seta-evolução. Sob outra ótica, o espaço geográfico foi analisado em uma visão cíclica de tempo, em que fatos sucessivos voltavam ao ponto inicial. O tempo, nessa perspectiva, evocava a ideia de uma dinâmica estável, de um movimento que se repete.

A visão crítica da geografia, ao romper com a perspectiva de estabilidade, passou a conceber o tempo como espiral. ${ }^{3}$ Nessa concepção, o tempo é entendido como seta e ciclo, ou seja, o espaço geográfico se forma (no sentido de formação, origem) e se organiza (no sentido de funcionalidade), projetando-se como determinação ou como possibilidade. Tal projeção se faz por avanços (seta) e retornos (ciclo). Nesse contexto, o espaço geográfico é a coexistência das formas herdadas (de outra funcionalidade), reconstruídas sob uma nova organização com formas novas em construção, ou seja, é a coexistência do passado e do presente ou de um passado reconstituído no presente.

Milton Santos, estabelecendo a diferenciação entre paisagem e espaço, afirma que "a paisagem é o conjunto de formas que, num dado momento, exprime as heranças que representam as sucessivas relações localizadas entre homem e natureza. (...) a paisagem é transtemporal, juntando objetos passados e presentes, uma construção transversal" (Santos, 1996: 83). Assim, a paisagem fala sobre as sucessivas relações entre homem e natureza de forma localizada, apontando

\footnotetext{
${ }^{3}$ Sob o movimento de renovação da geografia da década de 1970, encontravam-se propostas filosóficas e práticas que, apesar de não constituírem um bloco monolítico, tinham por objetivo comum questionar a forma de conhecimento geográfico (teorias, métodos e conceitos) produzido sob o domínio do neopositivismo.
} 
para a importância do momento e da temporalidade: o momento diz respeito à observação, ao contexto em que se olha e busca entendê-la, ressaltando a construção da paisagem no presente, enquanto a temporalidade transversal permite compreender a história das relações espaciais. Desse modo, o autor propõe uma concepção de espaço-tempo indissociável.

Para pensar a paisagem considerando a articulação espaço-tempo na concepção de Santos (1994), a dimensão temporal na geografia pode ser trabalhada em dois eixos: o das sucessões ${ }^{4}$ e o das coexistências. ${ }^{5}$ Conforme o autor, o tempo como sucessão, chamado de tempo histórico, foi o que dominou os estudos geográficos. Todavia, embora seja necessário conhecer o tempo histórico para poder periodizar o fenômeno estudado e saber o que distingue uma periodização de outra, é fundamental atentar para o tempo da simultaneidade, da coexistência. É a simultaneidade dos diversos tempos sobre uma dada área, e não o tempo como sucessão, que é concreto, tendo o espaço a capacidade de reuni-los. Independentemente do recorte espacial, observa-se o uso não hegemônico do tempo, a variedade temporal das ações e, da mesma forma, a sincronia entre elas.

De fato, cada ação se dá em seu tempo, mas as diversas ações se dão conjuntamente, e isso é próprio da vida em sociedade. Portanto, a investigação da territorialidade humana em geografia, ainda que não constitua uma tarefa fácil, requer atenção às diferenças, desigualdades e hierarquias que se dão na vida social segundo tempos diversos que se casam, unem-se e se entrelaçam no chamado viver comum. Esse viver se realiza no espaço, seja qual for a escala do lugarejo, da grande cidade, da região, do país inteiro, do mundo, valendo-se de uma ordem temporal maior, a do tempo histórico. Um tempo, em geral, que coordena e regula as ordens exclusivas de cada tempo particular concreto.

Na perspectiva crítica, o espaço se constituirá como categoria central para a geografia, tendo sido, por vezes, confundido como o objeto próprio da geografia. Da mesma forma que as demais categorias analisadas, a concepção de espaço para os geógrafos foi e é concebida diferentemente. Inicialmente, assim como o tempo, o espaço foi concebido à maneira de Kant, como espaço absoluto, espaço receptáculo, espaço continente, lugar de ocorrência do fenômeno geográfico.

\footnotetext{
${ }^{4}$ Sucessões: um fenômeno vem depois de outro fenômeno; há uma sucessão de fenômenos ao longo do tempo, uma sequência; esta é a dimensão em que se pode trabalhar a geografia e que conduz à ideia de pedaços do tempo, da sequência do acontecer, uma ordem temporal.

${ }^{5}$ Coexistências: simultaneidade; um lugar, uma área, o tempo das diversas ações e dos diversos agentes, a maneira como utilizam 0 tempo não é a mesma; os fenômenos não são apenas sucessivos, mas concomitantes; temos que considerar a simultaneidade das temporalidades diversas.
} 
Adquiriu dimensões específicas, tornou-se demarcável, passível de delimitação, de localização, de forma absoluta. A cartografia de base e a localização absoluta coordenadas geográficas - foram, em parte, suportes dessa concepção.

As transformações do mundo após a Segunda Guerra, associadas à difusão de novas concepções científicas, como a física de Einstein, permitiram à geografia, após os anos 1950, falar de outro espaço: o espaço relativo. Nesse contexto, os geógrafos passaram a conceber o espaço como algo definível tendo como base as variáveis preestabelecidas, definidas a priori, valendo-se dos objetivos de delimitação. O espaço existiria, então, como representação, podendo ser objetivamente delimitado em cartas e mapas. O clássico trabalho de David Grigg (1974), Regiões Modelos e Classes, segundo o qual o processo de regionalização e a região nada mais são do que classificações e representações com base em determinados critérios, é um bom exemplo.

Por sua vez, David Harvey (1980) enuncia a compreensão do espaço em novas reflexões e perspectivas. Num contexto dialético, concebe o espaço como sendo ao mesmo tempo absoluto (com existência material), relativo (como relação entre objetos) e relacional (espaço que contém e que está contido nos objetos). Em $A$ Justiça Social e a Cidade, ele afirma que "o objeto existe somente na medida em que contém e representa dentro de si próprio as relações com outros objetos" (Harvey, 1980: 5). Para o autor, o espaço não é nem um nem outro em si mesmo, podendo transformar-se em um ou outro, dependendo das circunstâncias.

Mais recentemente, outras interpretações fazem parte da concepção de espaço geográfico e urbano, como a de Milton Santos (1994), que vai se referir a essa categoria a partir da correlação do espaço às formas pretéritas e aos tempos acumulados de maneira desigual, o que significa conceber espaço como heranças. O mesmo Milton Santos (1996) vai se reportar à relação espaço-tempo como categorias indissociáveis, o que permite uma reflexão sobre espaço como coexistência de tempos. Dessa forma, num mesmo espaço coabitam tempos diferentes, tempos tecnológicos diferentes, resultando daí inserções diferentes do lugar no sistema ou na rede mundial (mundo globalizado), bem como resultando diferentes ritmos e coexistências nos lugares, o que constitui essas diferentes formas de coexistir, materializações diversas e, por consequência, espaço(s) geográfico(s) complexo(s) e carregado(s) de heranças e de novas possibilidades. Isso só reforça a ideia de planejar a cidade como objeto real repleto de heranças e contradições.

Fundamentando-se na formulação do espaço geográfico baseado no princípio da relatividade, a geografia melhor instrumentalizou suas bases teórico- 
conceituais para trabalhar com conceitos mais operacionais como, por exemplo, o de paisagem. Este tem sido historicamente considerado como a própria essência do conhecimento geográfico, uma vez que paisagem é um dos seus conceitos mais antigos a ponto de ela ser, em seu início, reconhecida como ciência da paisagem, aquela preocupada com o entendimento do espaço natural e as práticas sociais nele observadas. No entanto, na própria geografia, o conceito de paisagem é acompanhado por uma variedade de acepções. Ele é múltiplo e, por vezes, ambíguo. A construção de um conceito científico de paisagem, dessa forma, não tem sido uma das tarefas mais retilíneas para a geografia, pois, além da questão da percepção, a sua materialidade não é una, constituindo-se de fragmentos em que se identificam distintas lógicas e também referências a distintos marcos temporais.

Uma paisagem constitui-se de um todo percebido por meio da investigação de suas múltiplas relações causais, fragmentando-se de acordo com as variadas interações do complexo vivo, mas constituído em diferentes tempos. De tal sorte, os geógrafos relegaram um pouco o conceito de paisagem a um plano secundário, em seus estudos, pelo fato de ele ser dotado de uma carga subjetiva de apreensão que é definida com base no olhar do sujeito, por meio dos seus valores e dos seus filtros de experiência de vida. Portanto, não sendo mensurados e/ou classificados, não poderiam fazer parte do contexto das ciências. Apenas recentemente tal conceito foi revalorizado pela geografia humanista, voltando ao cerne dos debates atuais.

\section{Paisagem, espaço e tempo: uma perspectiva cultural}

Como materialidade, as paisagens são fragmentadas ao lance do olhar. Decorre desse fato a observação de que elas também podem ser fragmentadas em relação aos espaços de vivência por parte de cada um, e fragmentadas ainda em suas interpretações/acepções. Afinal, o traço cultural é reflexo e condicionante das paisagens. Se na década de 1920 o americano Carl Sauer, da Escola de Berkeley, ${ }^{6}$ já iniciava as discussões sobre o entendimento das paisagens por uma perspectiva cultural, ${ }^{7}$ tais estudos ainda estavam atentos apenas às dimensões materiais da cultura ao privilegiar a análise morfológica da paisagem. No entanto, por seus

\footnotetext{
${ }^{6} \mathrm{~A}$ Escola de Berkeley surgiu nos Estados Unidos no início do século XX, em contraposição ao pensamento científico europeu, como 0 determinismo alemão. Essa Escola se aproximou dos estudos antropológicos, tendo como prerrogativa a criação de reflexões acerca da paisagem cultural, valendo-se da análise dos aspectos culturais de um povo e sua relação com seu próprio meio, destacando-se, desde então, pelos escritos de Sauer, em 1925.
}

${ }^{7} 0$ clássico estudo de Sauer, de 1925 - The Morphology of Landscape -, traduzido para o português na década de 1990, representou uma contestação ao determinismo geográfico da época, incentivando pesquisas a não mais se restringirem aos limites do racionalismo. 
pioneiros estudos sobre a importância do homem na modificação das paisagens, Sauer definiu a paisagem geográfica como "o resultado da ação da cultura, ao longo do tempo, sobre a paisagem natural"8 (Corrêa \& Rosendhal, 1998: 7).

Os estudos sobre paisagem geográfica ainda tardariam algumas décadas para serem requalificados tendo como base a adoção de outras dimensões além da análise saueriana, que versa sobre a morfologia das paisagens e os aspectos materiais da cultura. Valendo-se de novas matrizes epistemológicas, a paisagem poderia, após 1970, ser pesquisada mediante suas dimensões morfológica, funcional, histórica e simbólica. Com isso, a compreensão das dimensões do conceito paisagem permite leituras capazes de facilitar a elaboração de diretrizes físico-espaciais para intervenções no meio urbano e, também, regional. Afinal,

Ela tem uma dimensão morfológica, ou seja, é um conjunto de formas criadas pela natureza e pela ação humana, e uma dimensão funcional, isto é, apresenta relações entre as suas diversas partes. Produto da ação humana ao longo do tempo, a paisagem apresenta uma dimensão histórica. Na medida em que a mesma paisagem ocorre em certa área da superfície terrestre, apresenta uma dimensão espacial. Mas, convém ressaltar que a paisagem é portadora de significados, expressando valores, crenças, mitos e utopias: tem assim uma dimensão simbólica. (Corrêa \& Rosendhal, 1998: 8)

As novas abordagens sobre a paisagem permeariam os debates nas ciências sociais, incorporando seus aspectos subjetivos (o significado). Assim, uma visão humanista, baseada na fenomenologia e no existencialismo, nutre uma nova perspectiva cultural, a qual se desenvolve a partir dos anos 1980 e da qual se destacam autores como Denis Cosgrove (1998a), Augustin Berque (1994, 1995) e Paul Claval (1999).

A respeito do debate em torno da paisagem como representação simbólica e da sua interpretação como meio ambiente na sociedade contemporânea, Luchiari (2001: 22-23) afirma que "se a paisagem é representação, não se esgota: reproduz-se, renova-se, regenera-se, tal qual as sociedades", e "se a morte da paisagem tradicional nos confunde, por outro lado prenuncia o nascimento de uma nova forma de representação do mundo". ${ }^{9}$ A paisagem contemporânea deverá ser, cada vez mais, a paisagem híbrida, construída como um palimpsesto, "uma paisagem de mil folhas" que exige a convivência de várias paisagens, ritmos, percepções, escalas e perspectivas (Luchiari apud Berque, 1991: 26-27).

\footnotetext{
8"A paisagem cultural é modelada a partir de uma paisagem natural por um grupo cultural. A cultura é 0 agente, a área natural é 0 meio e a paisagem cultural é o resultado" (Sauer, 1998: 59).

${ }^{9}$ Estudos também realizados por Jorge Luiz Barbosa sobre o conceito de representação e suas relações com a (re)produção do espaço (Barbosa, 2002).
} 
Nas abordagens culturais a paisagem se reveste, portanto, de um caráter de espaço percebido, relacionando-se à esfera das sensações. ${ }^{10}$ Berque (1998), que conceitua a paisagem plurimodal na qual sujeito e meio são cointegrados, autoproduzindo-se e se autorreproduzindo, sentencia, em uma visão abrangente, que:

De fato, o que está em causa não é somente a visão, mas todos os sentidos; não somente a percepção, mas todos os modos de relação do indivíduo com o mundo; enfim, não é somente o indivíduo, mas tudo aquilo pelo qual a sociedade o condiciona e o supera, isto é, ela situa os indivíduos no seio de uma cultura, dando com isso um sentido à sua relação com o mundo [sentido que, naturalmente, nunca é o mesmo para cada indivíduo]. (Berque, 1998: 87)

Para que se compreendam os vínculos emocionais que ligam as pessoas ao lugar onde vivem, é necessária a consideração dos fatos sociais em uma perspectiva pessoal, individual. A esfera do sentimento, profundamente comprometida com as formas de dar valor aos espaços vividos, pressupõe o ponto de vista do indivíduo. Tal abordagem não prescinde do entendimento das estruturas sociais em uma escala mais ampla, mas privilegia o indivíduo como sujeito da análise. Desde que o observador é o sujeito, o conceito de paisagem deve ser visto como impregnado de conotações culturais e ideológicas. Nessa perspectiva, as discussões sobre paisagem apontam um caminho de pesquisa que considere a relação de interação entre o homem e o meio, ressaltando o componente afetivo do espaço para a sociedade.

A paisagem, considerada como um espaço percebido, segundo Michel Collot (1990), permite entender o espaço como construção da cultura de um grupo, sem, no entanto, deixar de perceber a relevância das experiências individuais, do olhar pessoal. De maneira mais abrangente, Berque (1998) reafirma a importância da paisagem para os estudos de planejamento da cidade, por exemplo, como um elemento que situa o sentido da relação dos sujeitos com o mundo.

As sucessivas relações entre homem e natureza, de forma localizada, apontam para a importância do momento e da temporalidade. O momento diz respeito à observação, ao contexto em que se olha e se busca entendê-la, ressaltando a construção da paisagem no presente. A temporalidade (transversal) permite compreender a história das relações espaciais. Nesses termos, a paisagem é vista de maneira interdisciplinar, na qual se permite reconhecer que suas formas e seus conteúdos se inscrevem no âmbito da cultura, de acordo com Conan (1995).

${ }^{10}$ Considerando que cada pessoa ou grupo social experiencia determinada visão do mundo, e que as decisões são tomadas em virtude do conhecimento teórico e conceitual que o indivíduo dispõe. 
Contudo, a história, como disciplina, trata a paisagem como um texto produzido pela ação humana a ser interpretado conforme uma dada matriz filosófica de valores, portanto. Com efeito,

Os historiadores do ambiente também têm lamentado a anexação da natureza pela cultura. Conquanto não neguem que a paisagem possa, realmente, ser um texto em que as gerações escrevem suas obsessões recorrentes, eles não exultam com isso. A idílica paisagem arcádica, por exemplo, parece ser só mais uma bela mentira contada pelas aristocracias proprietárias dos senhores de escravos atenienses aos senhores de escravos virginianos a fim de disfarçar as consequências ecológicas de sua cobiça. Para elas, era uma questão de honra restabelecer uma distinção entre paisagem natural e paisagem criada pelo homem e estudar a possibilidade de escrever-se uma história que não apresentasse a Terra e suas diversas espécies como criações concebidas para o expresso e exclusivo prazer do senhor homem. (Muir apud Schama, 1996: 23, grifos do original)

Discorrendo ainda sobre a natureza das paisagens, enfatiza ele:

Toda a nossa tradição da paisagem é produto de uma cultura comum (...) trata-se, ademais, 'de uma tradição construída a partir de um rico depósito de mitos, lembranças e obsessões' (Schama, 1996: 24) e que 'paisagem é cultura antes de ser natureza; um constructo da imaginação projetado sobre a mata, água, rocha'. (...) Cabe também reconhecer que, quando uma determinada ideia de paisagem, um mito, uma visão, se forma num lugar concreto, ela mistura categorias, torna as metáforas mais reais que seus referentes, torna-se de fato parte do cenário. (Schama, 1996: 70)

\section{Planejar a Urbe Saudável: uma questão da cultura}

Para a discussão aqui pretendida, é essencial lembrar, com base em Cosgrove (1998b), do fato de que reflexões sobre o espaço na vertente cultural moderna movem-se, teoricamente, segundo três abordagens distintas e complementares: cultura-consciência, cultura-natureza e cultura-poder. Para ele, a cultura não é algo que funciona por meio dos seres humanos, mas que tem que ser constantemente reproduzida por eles em suas ações (muitas delas não reflexivas). Nesses termos, transformações culturais vêm de mudanças rápidas ou lentas em sua prática no ato da reprodução cultural. Tal afirmativa equivale a dizer que a cultura tanto é determinada quanto é determinante da consciência e das práticas humanas.

A essa questão associa-se o fato de que qualquer intervenção humana na natureza envolve sua transformação em cultura, na medida em que os objetos 
naturais tornam-se objetos culturais ao receberem um determinado significado no contexto de uma dada sociedade. Por sua vez, as sociedades são, em sua totalidade, divididas em classe, casta, sexo, idade ou etnicidade, em que tais divisões geralmente correspondem à divisão do trabalho. Assim, o estudo da cultura está diretamente ligado ao estudo do poder, pois há culturas dominantes, subordinadas ou alternativas e há a necessidade de se entender seus mecanismos próprios de luta, produção e constante reprodução.

A própria palavra cultura é aberta a várias acepções, de acordo com a disciplina que se leva em consideração. No entanto, nas ciências sociais, de forma geral, ela é tida como a visão de que as características que determinam as ações dos indivíduos em sociedade não lhes são natas e se preservam ou se aprimoram por intermédio das comunicações nela existentes. Da antropologia, em específico, vem a definição de cultura, tendo por base a premissa de que as regras e padrões reguladores da vida coletiva e individual se manifestam em todos os aspectos da vida. Por sua vez, na filosofia o termo cultura se reveste da noção de que ela é uma categoria de análise do processo pelo qual o homem, por meio de suas atividades concretas, modifica a si e a sociedade na qual está inserido. Uma vez que considerado o conceito de cultura, deve-se entendê-lo melhor como construção antropológico-filosófica que é. Desse modo, a relação entre cultura e natureza e a discussão dessa interação passa a ser uma questão central. ${ }^{11}$

Os grandes paradigmas surgidos ao longo da história de tais disciplinas se viram influenciados diretamente ora pela preponderância de uma dessas forças, ora pela outra. Por vezes, a natureza foi a matriz e emergiram paradigmas como o evolucionismo, o funcionalismo malinowskiano e a antropologia ecológica. Em outras oportunidades, pensadores que encaravam o homem como um ser que havia conseguido transcender o natural, colocando a cultura como fonte dessa transcendência, tomavam a dianteira, e se viu surgir os diversos modos de relativismos culturais, o estruturalismo levistraussiano, a antropologia simbólica. ${ }^{12}$

Marcelo Simão Mercante (2006) sublinha que o perspectivismo proposto por Viveiros-de-Castro (1996) seria um dos pontos no qual natureza e cultura se encontram sem uma hierarquia dicotômica de influência entre ambas. Embasada em uma visão um tanto geral dos índios que habitam as terras baixas sul-americanas, tal teoria, descrita de uma forma geral, não coloca nem o homem

\footnotetext{
11 "Na sociedade ocidental, a concepção de paisagem emergiu no mesmo período em que a ciência arquitetava a dicotomia entre a sociedade e a natureza" (Luchiari, 2001: 12).

12 Uma discussão mais aprofundada entre essas duas vertentes do pensamento antropológico encontra-se em Sahlins (1979).
} 
dentro da natureza nem os animais dentro da sociedade. Cada ser teria sua cultura, sua sociedade, independentemente de ser humano, animal ou planta e esta seria uma característica geral, a de dispor de uma forma de organização e um código organizador. Nesse sentido, Mercante (2006) se propõe a analisar não exatamente o perspectivismo, mas uma das consequências dele, que é a colocação do universo simbólico como o ponto central do relacionamento do homem com o meio ambiente em que está inserido.

Algumas questões relevantes podem aqui ser indicadas como, por exemplo, as vertentes teóricas que para Mercante coabitam a antropologia desde seu início.

O Evolucionismo foi uma das linhas de pensamento das ciências humanas a lançar mão não só da linguagem das ciências naturais, mas exatamente da Teoria da Evolução proposta por Charles Darwin, mas da teoria em si, aplicando-a ao homem. A ideia de que a natureza como um todo partiu de um estado mais simples e tendia a se complexificar, existindo um gradiente evolutivo, seduzia o mundo científico do final do século XIX. (Mercante, 2006)

Foi bastante difícil, no entanto, deixar de fora o caráter hierárquico que estava subliminar em toda teoria, principalmente quando ela foi apreendida por uma ciência social que surgia. Uma Europa que retomava o movimento colonialista abraçou com entusiasmo tal justificativa, para levar o progresso aos irmãos considerados menos desenvolvidos.

O funcionalismo também coloca o pensamento humano como parte da natureza. Com isso, Mercante (2006) salienta que tal modelo teórico lança mão da cultura como um meio proposto para atingir um fim almejado, ou seja, manipular o ambiente de alguma forma. Criada com a intenção de codificar atitudes baseadas na observação do próprio ecossistema e nos melhores caminhos para se lidar com problemas impostos pela natureza, a cultura, nesse contexto, é um meio pelo qual o ser humano satisfaz suas necessidades básicas, naturais, segundo Malinowski (1962). Seguindo tal raciocínio, Mercante enfatiza:

O passo seguinte foi o surgimento da antropologia ecológica, que toma emprestado vários termos da própria Ecologia para explicar o fenômeno cultural. Todos os processos 'terminam num misto de feedback, homeostase, fitness etc.' e, seguindo a análise de Sahlins (1979), um dos resultados é a diluição do próprio conceito de cultura dentro desses parâmetros naturais. Dentro dessa visão, muitos autores levaram ao extremo a consideração malinowskiana de 'satisfação das necessidades vitais' e renunciaram aos conceitos de cultura e de sistema social, que, para estes, se limitam a 
acontecer por interesses pessoais, [segundo] Sahlins (1979). ${ }^{13}$ (Mercante, 2006, grifos do original)

A despeito dessa abordagem, outra linha de pesquisa que segue os preceitos ecológicos dentro da antropologia é a exemplificada por Thomas (apud Werner, 1995). Em seu estudo com populações andinas, em que media as quantidades de calorias gastas por diferentes pessoas dentro de distintas categorias de idade, sexo e funções, os resultados obtidos tendiam a valorizar a produção energética e as questões a respeito, por exemplo, da qualidade da dieta sob observação muito mais que os fatores culturais nas explicações sobre os modos e meios de vida das populações analisadas, como considera Mercante (2006). Deve-se observar, no entanto, que o mote dessa linha teórica era colocar o modo de produção na base do comportamento humano. Nela, eram ressaltadas as interações diretas do homem com seu meio ambiente, na medida em que ele é considerado parte dele. Sobreviver seria a meta última do homem. Aumentar ao máximo seu fitness, ou seja, deixar a maior prole possível dentro dos limites de suporte do ecossistema. E isso não é de forma alguma consciente, pois o ser humano está sujeito a uma série de forças que regulam toda a natureza (Mercante, 2006).

A tendência natural na disciplina foi o surgimento de teorias que privilegiassem essencialmente a cultura na base do comportamento. A outra face dessa moeda passa a considerar o Homem não mais somente por seu material genético, mas principalmente por sua capacidade de produzir cultura e de se sociabilizar, sendo isso o alicerce de seu relacionamento com o meio ambiente onde se insere. Deixa-se de lado o modo de produção e parte para a capacidade de dar e obter significado de uma determinada atitude ou intenção.

Principiando em Franz Boas (2004), que ao sair da física termina como fundador de toda uma escola antropológica, como escreve Mercante (2006), tem-se nele a separação do homem do ambiente natural, e a partir daí tem-se a cultura como o molde no qual se inserem todos os processos de percepção do mundo, por onde passa o conhecimento e de onde as práticas são orientadas. Para ele a cultura não tinha decididamente sua origem na natureza. Era um corpo de significados e uma tradição, que orientava todo o resto.

É essa a abordagem que Claude Lévi-Strauss (1976) expõe em seu capítulo "Natureza e cultura" de As Estruturas Elementares do Parentesco, quando categoricamente afirma:

${ }^{13}$ Para discutir a cultura como projeto de poder, interesses pessoais ou representativos de grupos tomando por base a manipulação do coletivo. 
Um ser humano destituído de seu ambiente cultural não agiria como um animal doméstico que retorna ao seu comportamento selvagem ao ser deixado em liberdade total (...) Não há estado selvagem humano, e o que quer que se consiga numa situação dessas seria uma anormalidade, não um retorno! (Lévi-Strauss, 1976: 40)

Assim, a cultura seria fundamental para que o homem sobrevivesse no meio ambiente. Não obstante, o homem é colocado distante dos animais por um salto qualitativo: "é que a cultura não pode ser considerada nem simplesmente justaposta nem simplesmente superposta à vida. Em certo sentido substitui-se à vida, e em outro sentido utiliza-a e a transforma para realizar uma síntese de nova ordem" (Lévi-Strauss, 1976: 42).

Sua noção de estrutura daria a continuidade entre natureza e cultura, mas uma continuidade que diferenciaria o homem dos animais, pois estes não produzem cultura. Na verdade, boa parte da discussão levistraussiana acerca dessa dicotomia se insere em suas críticas ao totemismo e à visão naturalista desenvolvida anteriormente, na qual o nativo estaria muito mais perto do mundo natural, estando suas categorias sociais orientadas em virtude de sua relação prática com a natureza, em que as elaborações culturais estariam colocadas a posteriori. LéviStrauss (1985) conduz suas análises exatamente para o outro lado, para a percepção do mundo natural como um símbolo para o social, fruto de elaborações culturais. O termo final dessa discussão é argumentar contra a distinção dos primitivos como uma categoria inferior de ser humano.

$\mathrm{Na}$ década de 1960 surge a antropologia cognitiva, da qual emergem as categorias atuais de etnociência (etno: botânica, zoologia, ecologia etc.). Como Lévi-Strauss, seus autores se interessavam em descobrir a lógica interna da cultura estudada, sendo a diferença básica entre ambos a originalidade do material utilizado, uma vez que os cognitivistas lançam mão de dados de trabalhos de campo coletados por eles mesmos. Ambas as linhas partem da linguagem como fonte de pesquisa, mas tal semelhança se dilui à medida que o método levistraussiano impõe uma ordem ou, ainda, encaixa o que é observado numa regra externa.

A resultante desses dois vetores teóricos foi uma linha de pesquisa que lida com ambos os lados da moeda. Ainda que sua origem tenha sido o culturalismo, com doses de estruturalismo, relativismo, produziram-se trabalhos em que se misturam alguns procedimentos da linhagem que parte do evolucionismo como a própria percepção de um ecossistema e a integração do homem neste. Os fatores físicos do meio ambiente são levados em conta nos estudos, e tenta-se captar 
a visão adaptativa de determinado grupo, suas táticas e estratégias para se lidar com problemas diários e práticos, suas interações bióticas.

Essas táticas e estratégias, entretanto, não são levadas em conta apenas pelo lado da razão prática da existência. Além disso, entende-se que o cientista não é o único que pode explicar o relacionamento homem-natureza. Busca-se também o discurso nativo como forma de entendimento a respeito de como determinado grupo se mantém em seu ambiente e, mais que isso, buscam-se os preceitos culturais e simbólicos que intermedeiam o contato humano com o natural. Os significados tomam seu lugar ao lado das práticas.

\section{Caminhos para o Planejamento da Cidade Contemporânea: representações culturais, símbolos e significados como construção humana}

Ao se referir a símbolos e significados, abordam-se também as representações. Ressalte-se, no entanto, que o ato de representar é parte da cultura, revelado por intermédio das diferentes experiências que cada indivíduo adquire ao longo de sua existência. Essa percepção de mundo, particular ou coletiva, exige, necessariamente, algumas considerações sobre conceituação e apropriação do termo cultura. Assim, relembrando as visões de cultura provenientes da sociologia e da filosofia, além de algumas reflexões sobre a construção e vertentes da acepção mais antropológica do termo, cabe tecer alguns elos entre diferentes noções e concepções.

Primeiramente, assinala-se que, no conjunto das ciências ou em disciplinas específicas, não existe um consenso sobre o conceito de cultura. Desde a Antiguidade, tem-se tentado explicar as diferenças de comportamento entre os homens, valendo-se das diversidades genéticas ou geográficas sem, no entanto, considerar que o comportamento dos indivíduos depende de um aprendizado, de um processo chamado endoculturação/socialização. Ao aludir-se ao pensamento do século XIX, evidencia-se a corrente durkheimiana, segundo a qual o homem age de acordo com seus padrões culturais, sendo resultado do meio em que foi socializado.

De modo geral, cultura é um conceito complexo que inclui conhecimentos, crenças, arte, moral, leis, costumes ou qualquer outra capacidade ou hábitos adquiridos pelo homem na condição de membro de uma sociedade. Para muitos autores, a cultura é concebida como o meio pelo qual o homem se adapta aos diferentes ambientes. Trata-se de um processo acumulativo. O homem recebe 
conhecimentos e experiências acumulados ao longo das gerações que o antecederam, e se essas informações forem adequada e criativamente manipuladas permitirão a construção de inovações e invenções que constituirão parte do complexo de conhecimentos adquiridos culturalmente.

A cultura é uma lente através da qual o homem vê o mundo, o que explica o fato de haver pessoas de diferentes culturas com distintas visões da realidade, valores específicos, de díspares lentes para enxergá-lo. A realidade de o homem ver o mundo por intermédio de uma cultura específica a determinados grupos sociais tem como consequência a propensão de diversificados grupos considerarem o seu modo de vida como o mais correto e o mais natural.

Qualquer sistema cultural está sempre em um contínuo processo de mudança (transformações, rupturas e/ou continuidades). Daí a consideração de que o tempo é um importante elemento na análise de uma cultura. Nessa direção, identificam-se dois tipos de mudança cultural: interna e externa. A primeira resulta da dinâmica do próprio sistema cultural e, em regra, é lenta em relação à segunda. ${ }^{14}$ Esta, por sua vez, é resultado do contato de um sistema cultural com outro, sendo mais rápida e brusca se comparada à primeira.

Da conjunção dessas considerações sobre cultura, lembra-se ainda do pensamento do antropólogo Roger Keesing, em seu artigo "Theories of culture" (1974), ao assinalar que muitos autores a definem por meio de duas correntes: as teorias que a consideram como um sistema adaptativo e as teorias idealistas da cultura. No primeiro caso, a premissa adotada é a de que os padrões de comportamento socialmente transmitidos servem para adaptar as comunidades humanas ao seu modo de vida, que inclui aspectos como tecnologias conhecidas, modo de organização econômica, padrões de agrupamento social, organização política, crenças, práticas religiosas etc.

No segundo caso, baseado em Keesing (1974), as teorias idealistas da cultura são divididas em três abordagens: a primeira considera cultura como um sistema cognitivo - um sistema de conhecimento que o indivíduo adquire e apreende para atuar dentro da sociedade de maneira aceitável. A segunda considera cultura como sistemas estruturais - como um sistema de representações que é apreendido na mente de cada indivíduo, e que permite a definição dos domínios culturais e a estruturação das relações de parentesco, crenças, significados e significantes. Por fim, a terceira abordagem considera cultura como sistemas simbólicos - como

\footnotetext{
${ }^{14}$ NNo entanto, o ritmo de tais mudanças pode ser alterado por eventos históricos como, por exemplo, uma significativa inovação tecnológica.
} 
um sistema de símbolos e significados partilhados pelos membros de uma sociedadee envolve regras sobre relações e modos de comportamento.

Após essas considerações, deve-se ressaltar a importância de enquadrar tais questões no tempo da contemporaneidade, observando seus pontos mais fundamentais e, sobretudo, a relação cultura-poder. Dessa forma, pode-se dizer que atualmente, quando se verifica um avanço do processo de globalização, a vida tem sido marcada por mudanças que atingem todos os âmbitos da sociedade. Nesse movimento de interação intensa e contínua entre diferentes culturas, os indivíduos se deparam com novos modos de ver o mundo e agir nele e/ou sobre ele. Sob a égide dos novos mecanismos de comunicação, informação e transporte, uma poderosa esfera global ${ }^{15}$ se sobrepõe aos ditames da vida nacional, padronizando valores e comportamentos.

Para compreender o processo de globalização que se efetiva, é necessário visualizar os fatos históricos que nortearam essa trajetória e, dentre os mais recentes, destaca-se o fim da Guerra Fria. A dicotomia capitalismo/socialismo orientou durante décadas as ações estratégicas dos países, fomentou discussões teóricas e serviu de alicerce para a formação ideológica de indivíduos das mais diversas partes do mundo. Seu fim, além de representar a perda de uma referência de antagonismo, também permitiu que as contradições do capitalismo aflorassem. Vale lembrar ainda que as duas Grandes Guerras e a Crise de 1929 revelaram a crescente interdependência entre os países e que, no pós-1945, a disputa dos Estados-nação pela hegemonia mundial foi gradualmente sendo substituída pela disputa entre as grandes organizações, independentemente, inclusive, do seu território de origem.

Enquanto a internacionalização (verificada desde as grandes navegações até as últimas décadas) marcava as relações de importação e exportação entre países, nas quais a origem dos produtos tinha importância considerável, a globalização é caracterizada pelo desenraizamento das ideias, das coisas e das pessoas. Ao mesmo tempo em que se consomem produtos ou se utilizam serviços de outras sociedades, os indivíduos experimentam culturas distintas e conhecem novos códigos de significados. Nessa interação, percebe-se o predomínio de algumas culturas e a eliminação de outras, além da recriação de cada uma delas. Pode-se, inclusive, salientar que atualmente as culturas locais (consideradas na escala do nacional) influenciam e são influenciadas mutuamente em uma rapidez tanta

${ }^{15}$ Aqui, a expressão esfera global é compreendida e utilizada como um conjunto de interações políticas, socioeconômicas e culturais. 
que o completo isolamento cultural já não é mais possível no estágio em que se encontra a humanidade, principalmente os indivíduos que são partícipes das redes urbanas.

As referências territoriais enfraqueceram, provocando um deslocamento do senso de pertencer a espaços geográficos ou pertencer a grupos socioculturais. A fim de contemplar essa nova realidade, muitos autores defendem a ampliação da definição socioespacial de identidade para uma definição sociocomunicacional de identidade, que está ligada às novas formas de interação entre os indivíduos que compartilham interesses comuns. Observa-se tal fato, por exemplo, na relação de proximidade que se cria entre indivíduos que trabalham em uma mesma empresa multinacional, cada qual em uma parte do mundo, assim como nas comunidades virtuais. Nesses dois casos, o que une os indivíduos não são os vínculos territoriais, mas os laços culturais e simbólicos do novo "meio técnicocientífico-informacional", conforme Milton Santos (1994).

Diante dos novos paradigmas e das novas formas de racionalidade que emergem, um deles consiste na ideia de sociedade em redes apresentada por Manuel Castells (1999). Sua análise se preocupa com a importância da informação em um mundo no qual a tecnologia deixou de ser auxiliar no sistema produtivo capitalista para ser o próprio veículo do processo, centrando a atenção nas novas economias de rede, seus impactos territoriais, seus fluxos e sua relação com os indivíduos. Em outras palavras, o autor parte da premissa de que a revolução tecnológica no sistema de comunicações é o que estabelece as novas economias de rede, sendo esta imaterial (pois se constitui de fluxos), mas que precisa de cada indivíduo (pontos físicos) para a sua dinâmica. E ainda mais: a individualização do trabalho (por conta da substituição do trabalho abstrato pelo concreto, segundo suas explicações) e os processos de dualização (mais superficial) e o de fragmentação (mais profundo) da sociedade emergem, para ele, como pontos centrais em meio à revolução tecnológica em andamento.

Castells também se preocupa em demonstrar que as mudanças na sociedade, e seus efeitos fragmentadores, não resultam apenas dos processos gerais de mudança no mundo da produção, mas de outras no nível da cultura e da vida como um todo. Sobre o tempo e o espaço, o autor dedica significativa discussão tentando entender a existência (ou não) do segundo em razão das mudanças nos parâmetros de localização das atividades e a questão da importância dos lugares. Acerca do tempo, adjetivado por Castells (1999) de "intemporal", é requalificado pela simultaneidade dos fatos na atualidade, diferentemente de quando apenas se empilhavam. Para o autor, o tempo perde seu poder de referência 
para marcar o social enquanto o espaço ganha essa relevância, uma vez que continua a estabelecer as escalas e a natureza das novas centralidades do mundo contemporâneo. Como exemplo, têm-se as cidades globais.

Nesse sentido, não se pode se esquecer de fazer alguns comentários sobre as novas tendências da atualidade em relação à economia, consumo e mercado de trabalho visto por Sassen (1998), que as identificam como fenômenos observados, sobretudo, nas grandes cidades com funções especificamente globais. Após uma vasta caracterização da dinâmica das mudanças expressas a partir dos anos 1960, a autora identifica quatro grandes processos para o trabalho na formação de cidades globais: a dispersão geográfica de indústrias; o crescimento da indústria financeira; as transformações nas conexões econômicas entre as referidas cidades globais (consideradas por ela como Estados-nações), onde se localiza a economia mundial; e as novas condições de crescimento, que contribuíram para a criação de elementos de uma nova classe alinhada às cidades globais.

A autora, ao considerar o princípio de que os sistemas econômicos exercem influências determinantes nas cidades, destaca o novo papel que estas (algumas privilegiadas) têm a desempenhar diante de novos fluxos, novas trocas e novas formas espaciais. Suas preocupações elencadas centram-se na sobrevivência das classes médias, na crescente participação do setor de serviços nas cidades e na perspectiva do aumento das desigualdades socioespaciais no ambiente urbano.

No caso específico da análise sobre o urbano na nova ordem espaço-tempo da contemporaneidade, algumas considerações devem precedê-la. A cidade tal qual vista pelo pensamento crítico dos anos 1970 apresentava-se como um espaço de (re)produção das relações capitalistas que paradoxal e interdependentemente se mantinha como ambiente de reprodução da força de trabalho por meio da oferta de equipamentos coletivos. O urbano era também visto como um elemento positivo, uma vez que podia ser entendido como um espaço propício para transformações sociais valendo-se dos movimentos populares questionadores. A crise das cidades, proclamada com o pós-fordismo, por conta da dispersão econômica e espacial dos núcleos urbanos e de certo ocultamento dos movimentos sociais, fez com que se mudassem, no debate teórico, as percepções sobre o urbano, desde então sob o signo do pessimismo. Apenas gradativamente, com o crescimento de algumas cidades, a crise foi relativizada. Na atual década, a globalização, a questão tecnológica, a reestruturação produtiva, a remercantilização da força de trabalho e os novos territórios do capitalismo fizeram emergir uma revalorização das cidades. 
Sobre as tentativas de entendimento do urbano atual, observa-se uma bifurcação de análises com base em dois paradigmas para a própria sociedade: aquele do pós-industrialismo que defende o predomínio do setor financeiro sobre o produtivo, dos serviços sobre a indústria; e aquele industrialista/regulacionista que acredita no capitalismo sob novas formas de extração da mais-valia e na emergência dos serviços como evidência dessas novas formas. Debates à parte, é preciso observar que ambos mantêm a consideração do urbano como local privilegiado para a acumulação capitalista, manifestações e massificação culturais.

Alguns impactos sociais e territoriais podem ser apontados, de acordo com cada um dos paradigmas citados. Para os industrialistas, a emergência dos serviços apenas evidencia novas funções produtivas materiais. No entanto, para os pós-industrialistas, verifica-se nessa nova fase uma economia desterritorializada, com a marginalização de muitas cidades em detrimento de outras com funções globais e, especificamente na economia de serviços, uma inexorável dualização da estrutura social, com enorme crescimento do setor informal. É nesse urbano que se manifestam as mais diversas formas de representação do mundo atual.

Nesse mundo global se confundem esferas da economia, da política, da vida social e cultural em uma ambígua e confusa representação. Confundem-se esferas da produção e do consumo em um conceito de múltiplos adjetivos. Aqui, vale lembrar-se de Santos (1994: 22) quando usa a expressão "terrorismo da linguagem" para caracterizar o papel da mídia, da mais local àquelas de alcance internacional, como determinante para o novo modelo em que se está vivendo, "baseado no medo e na fantasia" e elaborado valendo-se de um tempo no qual "os símbolos baralham porque tomam lugar das coisas verdadeiras" (Santos, 1994: 29).

Ressalte-se aqui a função do pensamento crítico no que diz respeito à compreensão abrangente sobre os processos em voga, seus discursos, seus mecanismos de legitimidade e as mudanças que impõem. Essas mudanças de referências e de construção de identidade geram ansiedade e incerteza nos indivíduos, que convivem com uma multiplicidade de modos de ver o mundo e nele agir, mas, muitas vezes, não encontram segurança em nenhum dos caminhos possíveis. Nessa relativa perda de referência, as representações, tomando por base as reflexões de Milton Santos já citadas, estão ampliando seu papel, penetrando em todos os âmbitos da vida do indivíduo. Por intermédio da cultura, os indivíduos assimilam valores, códigos e significados preestabelecidos de acordo com uma intencionalidade pretendida externamente a eles. Tais fenômenos podem ser observados no mundo do consumo padronizado, inclusive no que tange aos produtos culturais. 


\section{Alternativas para a Urbanização Atual: breves tópicos}

Um dos desafios para os planejadores urbanos em pensar e propor projetos de intervenção urbana nos dias de hoje exige ater-se ao conjunto de proposições conectadas à dinâmica plural da cidade contemporânea. A sociedade torna-se cada vez mais heterogênea e, por isso mesmo, cabe destacar as redes de produção que incorporam as novas tecnologias e pressupõem a definição de metas que garantam a tão sonhada sustentabilidade - socioeconômica ambiental e cultural nas intervenções físico-espacial e sociocultural. Isso requer afirmar a necessidade de os projetos urbanos contemplarem mecanismos capazes de possibilitar a ampliação das redes de produção e infraestrutura, como pressuposto para a modernização estrutural e, consequentemente, a inclusão social. Nesse sentido, várias obras acadêmicas comumente discorrem sobre o papel do planejamento na estruturação de políticas econômicas e urbanas, enumerando-o em três níveis: o estratégico, o táctico e o operacional.

Ao longo das últimas décadas, cidades como o Rio de Janeiro e São Paulo têm sido configuradas por uma paisagem urbana repleta de acentuados contrastes socioespaciais. Resultam numa construção simultânea de paisagens fragmentadas e articuladas, que expressam contornos de relevante heterogeneidade espacial. Ao mesmo tempo que se formou uma rede de investimentos de caráter econômico e de sociabilidade, as disfunções urbanas se agravaram, principalmente por meio da degradação ambiental, das condições precárias de habitação e segurança, dos quais as favelas são grandes expoentes.

Notadamente, ao vetor de crescimento econômico somam-se os impactos provocados pelo crescimento urbano desordenado que assola muitas áreas dessas megacidades. Questões de tal natureza apontam para a necessidade da elaboração de planos de intervenção seguida de procedimentos metodológicos que favoreçam as articulações entre as diversas esferas de governo, da sociedade civil e dos distintos saberes, de modo que a formulação de programas e parcerias objetive um alcance urbanístico, social, econômico e cultural.

Com o propósito de desenvolver práticas de urbanização em que o indivíduo e a urbe interajam - para a construção de uma melhor qualidade das relações sociais, do meio ambiente e garantia da identidade e da memória do lugar - tornase urgente para o planejamento urbano reconhecer as diferentes conexões entre os fragmentos da cidade associando, também, procedimentos de mobilização social aos instrumentos e parâmetros urbanísticos dispostos em legislações flexíveis e modernas. 
Sob tal perspectiva, os cenários a serem esboçados numa intervenção em áreas urbanas têm como finalidade minimizar ou eliminar as barreiras sociais que estigmatizam, segregam e confinam principalmente as populações de baixa renda, destacando, prioritariamente, o enfoque temporal e espacial, em que se situam as relações humanas nos contextos selecionados. Assim, as diversas ações urbanas devem ser precedidas de uma avaliação baseada na percepção e apreensão dos espaços da área foco, para depois se aliar os critérios quantitativos aos qualitativos. Importa lembrar que as transformações pretendidas em áreas periféricas pressupõem conferir abrangência, qualidade ambiental e sentido social para a população direta e indiretamente envolvida.

Em um projeto de urbanização, de contexto complexo e contraditório, têm-se, por um lado, a necessidade da compreensão físico-espacial, que implica o atendimento às demandas por serviços e infraestrutura; e, por outro, a identificação dos diferentes interesses individuais e coletivos internos e externos a uma determinada parte da cidade. Significa afirmar que o trabalho dos técnicos de planejamento urbano não se resume apenas em solucionar os problemas previamente diagnosticados, mas fazer a mediação entre a esfera pública e a população envolvida. Sob tal aspecto, é preciso incorporar as dimensões socioculturais, política, econômica, jurídica e ambiental postas no ambiente construído, como parte integrante das bases do projeto.

Por fim, o debate e a evidência derivados da relação entre a natureza e a experiência da humanidade, no que tange às distintas práticas de ocupação socioespacial, parece ser a compreensão mais linear que se tem da sociedade, $o$ que constitui um problema para o planejamento urbano e para o urbanismo. Contudo, o conhecimento relacionado com a mudança, quer seja a tecnológica quer seja a social, geralmente tem sido configurado tanto pela natureza dos dados quanto pela disposição dos pesquisadores para análise. Aí, a construção intelectual voltada para a explicação dos fenômenos socioespaciais, numa dimensão temporal, associada a um lastro ideológico, implica a sistematização do conhecimento acerca do espaço e suas explicações. Para traçar novos caminhos é preciso reconhecer que:

Todos nós sabemos que a história avançou de modo muito diferente para os povos de cada parte do globo. Nos 13.000 anos que se passaram desde o fim da última Era Glacial, algumas partes do mundo desenvolveram sociedades industriais e letradas, que usavam utensílios de metal, enquanto outras produziram apenas sociedades agrícolas analfabetas e ainda outras se mantiveram caçadoras-coletoras de alimentos, usando artefatos feitos com 
pedras. Essas desigualdades projetaram grandes sombras sobre o mundo moderno, uma vez que as sociedades letradas que possuíam utensílios de metal conquistaram ou exterminaram as outras sociedades. Embora essas diferenças representem os fatos mais elementares da história mundial, suas causas continuam incertas e controvertidas. (Diamond, 2003: 13)

Entre inúmeras esferas de domínio que vêm, secularmente, moldando a paisagem urbana tendo como base os contrastes físico-geográficos e socioculturais, o homem pouco tem contribuído para diminuir as fronteiras das desigualdades. Ao contrário, a cidade contemporânea informacional, espetacular e global, principalmente em países hoje denominados de emergentes como o Brasil, tem ampliado as divisas econômicas daqueles que já detinham o poder hegemônico, ampliando, inclusive, suas redes de agregados e cúmplices da apropriação desigual de bens, como a nova classe média brasileira.

A saúde da cidade sob suspeita parece apresentar caminhos ambíguos e controversos. Por um lado, analistas e parcela da sociedade civil engajada em movimentos reivindicatórios relativos à melhor qualidade do meio ambiente construído buscam práticas voltadas para o desenvolvimento urbano sustentado e, portanto, saudável. Por outro, as organizações político-governamentais e os setores econômicos utilizam-se do marketing da sustentabilidade para viabilizar interesses particulares em detrimento do bem-estar coletivo. A urbe pretendida como saudável, ao que parece, é aquela que democratiza os bens e serviços, que elimina obstáculos relacionados à provisão da infraestrutura, que gera melhores condições de qualificação e trabalho para os indivíduos, que conserva os recursos naturais, que elimina barreiras sociais. É, por fim, a cidade que constrói e preserva uma paisagem constituída pela memória e identidade social coletivamente articulada e solidária.

As reflexões aqui desenvolvidas se inscrevem no campo dos estudos urbanos contemporâneos, o qual reconhece na interdisciplinaridade o suporte e os meios para a compreensão plural da cidade, que exige a incorporação de diferentes conexões entre os saberes científicos em vista da experiência da vida individual e coletiva cotidiana. A saúde da cidade está mesmo sob suspeita. Destaca-se, com frequência, a necessidade da definição de ações que garantam uma gestão territorial democrática e promotora de políticas urbanas sustentáveis fundamentadas, em grande medida, em atos que remetem a uma perspectiva de cura das enfermidades urbanas.

A gestão da cidade brasileira, controlada por administradores públicos e setores econômicos conservadores e reacionários, está longe de contemplar o 
planejamento urbano como instrumento de prevenção e inibição, por exemplo, de ocupações desordenadas cada vez mais vulneráveis a catástrofes que têm ocorrido, por diferentes razões, no meio ambiente. A noção de cidade saudável pressupõe muito mais que o acesso a bens materiais, infraestrutura e serviços urbanos, como os de saúde. Ao contrário, uma cidade saudável é aquela que incorpora ao desenvolvimento socioeconômico a inclusão sociocultural e a proteção à vida como requisito de manutenção dos aspectos valóricos intrínsecos à condição humana e ao meio ambiente. Se a cidade está doente desde sempre, é algo que requer aprofundamentos científicos para elucidar questões sobre sua própria constituição territorial. Não se trata, porém, de curar a cidade, mas de torná-la um espaço coletivo movido pela equidade social, cultural e com responsabilidade ambiental. 


\section{Referências}

ABREU, M. A. Evolução Urbana do Rio de Janeiro: Iplanrio. Rio de Janeiro: Jorge Zahar, 1987.

BARBOSA, J. L. A Cidade e o Cinema: espaço e representações. A obra de arte como leitura reveladora do mundo. Niterói: UFF, 2002.

BERQUE, A. De paysage en outre-pays. Le Débat, 65: 4-13, 1991.

BERQUE, A. Paysage, milieu, historie. In: BERQUE, A. Cinq Propositions pour Une Théorie du Paysage. Paris: Editions Champ Vollon, 1994.

BERQUE, A. Les Raisons du Paysage: de la Chine antique aux environnements de synthése. Paris: Hazan, 1995.

BERQUE, A. Paisagem-marca, paisagem-matriz: elementos da problemática para uma geografia cultural. In: CORRÊA, R. L. \& ROSENDAHL, Z. Paisagem, Tempo e Cultura. Rio de Janeiro: Eduerj, 1998.

BOAS, F. A Formação da Antropologia Americana: 1883-1911 - antologia. Rio de Janeiro: Contraponto, Editora UFRJ, 2004.

BOYER, M. C. The City of Collective Memory: its historical imagery and architectural entertainments. Cambridge: Mit Press, 1994.

CASTELLS, M. A Sociedade em Rede. São Paulo: Paz e Terra, 1999.

CHOAY, F. O Urbanismo: utopias e realidades. São Paulo: Pespectiva, 1979.

CLAVAL, P. A geografia cultural: o estado da arte. In: CORRÊA, R. L. \& ROSENDAHL, Z. (Orgs.). Manifestações da Cultura no Espaço. Rio de Janeiro: Eduerj, 1999.

COLLOT, M. Pontos de vista sobre a percepção das paisagens. Boletim de Geografia Teorética, 20(39): 21-32, 1990.

CONAN, M. Génealogie du paysage. In: ROGER, A. (Dir.). La Théorie du Paysage en France (1974-1994). Paris: Editions Champ Vollon, 1995.

CORRÊA, R. L. O Espaço Urbano. 3. ed. São Paulo: Ática, 1995. (Série Princípios).

CORRÊA, R. L. Geografia cultural: uma bibliografia. Espaço e Cultura, 5: 67-71, 1998.

CORRÊA, R. L. \& ROSENDHAL, Z. Apresentando leituras sobre paisagem, tempo e cultura. In: CORRÊA, R. L. \& ROSENDHAL, Z. (Orgs.). Paisagem, Tempo e Cultura. Rio de Janeiro: Eduerj, 1998.

COSGROVE, D. A geografia está em toda parte: cultura e simbolismo nas paisagens humanas. In: CORREEA, R. L. \& ROSENDHAL, Z. (Orgs.). Paisagem, Tempo e Cultura. Rio de Janeiro: Eduerj, 1998a.

COSGROVE, D. E. Em direção a uma geografia cultural radical: problemas da teoria. Espaço e Cultura, 5: 5-29, 1998b.

DEBORD, G. A Sociedade do Espetáculo. Rio de Janeiro: Contraponto, 1997.

DIAMOND, J. Armas, Germes e Aço: os destinos das sociedades humanas. 4. ed. Rio de Janeiro: Record, 2003.

FERNANDES, A. Urbanismo contemporâneo no Brasil: entre o negócio e o direito. In: PINHEIRO MACHADO, D.; COUTINHO, R. \& PEREIRA, M. (Orgs.). Urbanismo em Questão. 1. ed. Rio de Janeiro: Prourb, 2003.

FRIDMAN, F. Donos do Rio em Nome do Rei: uma história fundiária da cidade do Rio de Janeiro. Rio de janeiro: Jorge Zahar, Garamond, 1999.

GRIGG, D. Regiões, modelos e classes. In: CHORLEY, R. \& HAGGETT, P. (Orgs.). Modelos Integrados em Geografia. Rio de Janeiro: Livros Técnicos e Científicos, Edusp, 1974.

HARVEY, D. A Justiça Social e a Cidade. São Paulo: Hucitec, 1980.

KEESING, R. Theories of culture. Annual Review of Anthropology 3: 73-97, 1974. 
KZURE-CERQUERA, H. Rio de Janeiro e Berlim: a representação do espaço público no cinema. In:VAZ, L. F.; ANDRADE, L. da S. \& GUERRA, M. W. (Orgs.). Os Espaços Públicos nas Políticas Urbanas: estudos sobre o Rio de Janeiro e Berlim. Rio de Janeiro: 7 Letras, 2008.

KZURE-CERQUERA, H. Limites e desafios para o urbanismo contemporâneo face às fragmentações, colisões e articulações do espaço da cidade. In: HERBST, H. (Org.). Dez Anos de Arquitetura na Rural: percursos e perspectivas do Departamento de Arquitetura e Urbanismo da Universidade Federal Rural do Rio de Janeiro. Seropédica: Editora da UFRRJ, 2010.

LÉVI-STRAUSS, C. As Estruturas Elementares do Parentesco. Petrópolis: Vozes, 1976.

LÉVI-STRAUSS, C. Totemismo Hoje. São Paulo: Abril, 1985. (Coleção os Pensadores).

LIPOVETSKY, G. Os Tempos Hipermodernos. São Paulo: Barcarolla, 2004.

LUCHIARI, M. T. A (re)significação da paisagem no período contemporâneo. In: ROSENDAHL, Z. \& CORREA, R. L. (Orgs.). Paisagem, Imaginário e Espaço. Rio de Janeiro: Eduerj, 2001.

MALINOWSKI, B. Uma Teoria Científica da Cultura. Rio de Janeiro: Zahar, 1962.

MERCANTE, M. S. A Interconexão entre Saberes, Práticas e Percepções: o mediador entre cultura enatureza, 2006. Disponível em: http://cfh.ufsc.br/ mercante/intercon.htm>. Acesso em: 22 set. 2013.

SAHLINS, M. Cultura e Razão Prática. Rio de Janeiro: Zahar, 1979.

SANTOS, M. Pensando o Espaço do Homem. São Paulo: Hucitec, 1986.

SANTOS, M. Técnica, Espaço, Tempo: globalização e meio técnico-científico informacional. São Paulo: Hucitec, 1994.

SANTOS, M. A Natureza do Espaço: técnica e tempo, razão e emoção. 2. ed. São Paulo: Hucitec, 1996.

SASSEN, S. As Cidades na Economia Mundial. São Paulo: Studio Nobel, 1998.

SAUER, C. O. A morfologia da paisagem. In: CORRÊA, R. L. \& ROSENDAHL, Z. Paisagem, Tempo e Cultura. Rio de Janeiro: Eduerj, 1998.

SCHAMA, S. Paisagem e Memória. São Paulo: Companhia das Letras, 1996.

VAZ, L. F. Modernidade e Moradia. Rio de Janeiro: 7 Letras, 2002.

VAZ, L. F. \& KZURE-CERQUERA, H. Padrões de habitação popular no Rio de Janeiro. In: SCHWEIZER, P. J. (Org.). Planejamento Participativo na Reestruturação Urbana. Rio de Janeiro: 7 Letras, 2000.

VIVEIROS-DE-CASTRO, E. Os pronomes cosmológicos e o perspectivismo ameríndio. Mana, 2(2): 115-144, 1996.

WERNER, D. A ecologia cultural de Julian Steward e seus desdobramentos. Antropologia em Primeira Mão, 4: 1-11, 1995. 


\title{
2 \\ Cidades Saudáveis: ainda um tema relevante?
}

\author{
Marco Akerman • Rosilda Mendes • André Luiz Fischer
}

Z ste capítulo trata do tema cidades saudáveis com base em seus pressupostos e negar a necessidade imperativa de que o campo da promoção da saúde nas cidades esteja em estreita vinculação com múltiplos setores e múltiplos saberes. Entretanto, mesmo que os temas da intersetorialidade e da interdisciplinaridade estejam presentes em artigos, teses e congressos da área, são constantes as reivindicações da ampliação de interlocutores para que não paire a sensação de estarmos falando para nós mesmos sem eficácia suficiente para influenciar as políticas públicas.

A fim de atualizar as perspectivas acerca da temática sobre cidades saudáveis realizou-se um breve levantamento do estado da arte, por meio das publicações indexadas pela Biblioteca Virtual de Saúde (BVS) entre 1986-2010, cotejando-o com a pluralidade de significados que se fazem presentes na leitura de autores, das áreas de ciências sociais, políticas e planejamento urbano, não diretamente filiados ao campo da promoção da saúde, que examinam algumas concepções de cidades e apontam um quadro de desafios a serem enfrentados na contemporaneidade: Hermínia Maricato (2010); Marcelo Lopes de Souza (2010); Mara Veras (2010); Zygmunt Bauman (2009); Ladislau Dowbor (1999); Manuel Castells e Jordi Borja (1996); Octavio Ianni (1996); Italo Calvino (1990); Milton Santos (1985); Raquel Rolnik (1988). 
Há que se destacar que não se tem aqui a pretensão de esgotar as respostas possíveis às questões provenientes do cenário urbano. Trata-se, pois, de escolhas e do reconhecimento de que essas contribuições teóricas expressam diferentes dimensões que podem possibilitar um interessante diálogo com o tema cidades saudáveis.

Não são poucos os esforços de vincular a questão urbana à saúde. Assim, pretende-se aqui, ao tratar da iniciativa/estratégia/agenda de cidades saudáveis, considerá-la como um amplo e complexo repertório favorecedor da análise, reflexão e tomada de decisão. Indaga-se sobre o sentido dessas ações realizadas no intuito de constituir-se como uma agenda urbana inovadora e, assim, organizar-se para superar os inúmeros desafios sociais e políticos, o que propicia o contato com novas e potenciais ideias transformadoras de revalorizar a vida das cidades e produzir saúde. Averiguou-se, nessa direção, se suas respostas ao enfrentamento da complexa realidade das cidades têm de fato um caráter emancipatório e transformador ou se reforçam abordagens integrativas e conservadoras.

Também não são raros os estudos, escritos e reflexões advindos de distintas áreas de conhecimento acerca dos problemas sociais manifestados na cidade, o que evidencia novos e velhos temas como a globalização, a urbanização, a segregação, a desigualdade, a exclusão, a pobreza. Igualmente tem-se formulado a ideia de que as cidades possam ser repensadas para transformar a realidade socioespacial a fim de torná-las um melhor lugar para se viver.

Pretende-se aqui dialogar com algumas dessas perspectivas e percorrer o caminho reflexivo indicado por Italo Calvino quando se refere à cidade de Marósia. Diz ele: "vejo duas cidades: uma do rato, uma da andorinha... ambas mudam com o tempo; mas não muda a relação entre elas: a segunda é a que está para se libertar da primeira" (Calvino, 1990: 140-141).

Por isso, cabe indagar: quais os desafios sociais, políticos e conceituais colocados hoje para as cidades? Que respostas contemporâneas têm sido formuladas? A agenda por cidades saudáveis responde a esses desafios?

Enfrenta-se, dessa maneira, o questionamento do título deste capítulo ao analisar a relevância da iniciativa/estratégia/agenda de cidades saudáveis, não para carimbá-la como relevante ou irrelevante per si, mas para sinalizar sua relevância ou não em sintonizar seus pressupostos e respostas políticas com outras perspectivas disciplinares.

De modo a contribuir para o debate sobre as formas de atuação nas cidades, considera-se, de antemão, que as cidades são espaços da política, e por isso, 
permeados por disputas, conflitos e relações de poder. Mas são também dotados de simbologia, de distintas identidades, de representações, de imaginários e de subjetividades. Essa dupla significação traz inúmeros desafios e parece ser um profícuo horizonte à produção social da saúde, tanto na inclusão de diversos sujeitos locais no estabelecimento de políticas públicas de melhoria das condições de vida e saúde, como na tomada de decisões partilhadas, portanto, mais legítimas.

Como produto da sociedade, a cidade não poderia deixar de expressar a realidade social e econômica na qual está inserida. No entanto, não se trata apenas de considerá-la reflexo do que se passa na sociedade, como local da produção industrial, da troca de mercadorias. As cidades são muito mais: são produzidas e apropriadas sob determinadas relações sociais. "A cidade é objeto e também agente ativo das relações sociais (...). Os espaços urbanos não se constituem meros cenários para a sociedade, pois são parte dela" (Maricato, 2010: 42).

Uma vez dito isso, um primeiro aspecto a ser examinado refere-se à necessária revisão das questões essenciais apontadas nos estudos sobre as cidades. Em seguida, será analisado o estado da arte sobre as cidades saudáveis e o diálogo que a agenda estabelece com múltiplos setores e múltiplos saberes.

\section{Cidades: tensões e mudanças}

Nossas cidades, num certo momento histórico, começaram a se organizar em razão do mercado e dos interesses do capital. A gênese da cidade do capital, tal como definida por Rolnik (1988), vai operar uma reorganização radical das cidades: verifica-se a mercantilização do espaço, a organização da cidade materializa a divisão da sociedade em classes e, finalmente, um poder centralizado e despótico se instala. Essa redefinição do espaço urbano trouxe importantes reflexos para a vida na cidade: espaços de aglomeração e competição, da luta pelo espaço construído em torno das melhores localizações, de inclusão e de exclusão, com zonas de pobreza e riqueza, de segregação, de ambientes poluídos, espaços geradores de agravos e problemas de saúde.

Mais recentemente as cidades passaram também a ter um papel estratégico na competitividade internacional, em tempos de globalização financeira e cultural, o que fez com que o direito à cidade, às raízes e ao território sejam

quase sempre direitos relegados, subordinados ao uso predatório do ambiente construído pelos agentes do urbano: capital e suas frações, Estado, 
restando à classe trabalhadora mover-se pelas determinações desse mercado. Nesse cenário, joga papel primordial a associação entre parcelas do capital imobiliário e do financeiro, moldando as cidades para a competitividade internacional. Progressivamente, as cidades são conformadas como espaços de fluxos, de circulação de mercadorias, de pessoas, numa vasta rede de itinerários, pontos de partida e de chegada, sem oportunidade de fruição ou pausas para a reflexão. (Veras, 2010: 37-38)

O crescimento populacional, a extensão da cidade não legal, o peso da marginalidade social, o déficit de infraestrutura moderna e a fraqueza dos governos locais são ainda questões decisivas que as cidades latino-americanas devem enfrentar (Castells \& Borja, 1996). No caso brasileiro, o processo de urbanização, concomitantemente com a globalização, foi intenso nos últimos cinquenta anos. O percentual total da população que vive nas cidades passou de 45\%, em 1945 (45 milhões), para 84\% em 2010 (160 milhões). As cidades, sobretudo a grande cidade, refletem os espaços globais de privilégio e exclusão, orientando um modelo obsoleto e irracional de ocupação do espaço urbano. O que se assiste na considerável maioria das cidades brasileiras, atualmente, é um quadro de perda da identidade entre as pessoas e o espaço geográfico a que pertencem, além de uma extensa fragmentação e segregação material e socioespacial, iniquidades no acesso à terra urbanizada e à moradia segura e legal, ao saneamento ambiental, aos transportes públicos de qualidade, ao emprego e aos serviços de educação e saúde, estes cada vez mais raros e caros.

O crescimento populacional e a conformação de grandes metrópoles acabaram por gerar outros problemas como o desemprego crônico, as doenças cosmopolitas, os vícios internacionalizados, o crime banalizado e a insegurança institucionalizada. Tais elementos resultaram também, por suscitar, como bem resumiu Milton Santos, sintomas diversos da mesma síndrome, o medo. Há medos urbanos, segundo ele, de toda natureza: "objetivos e subjetivos, individuais e coletivos, ocasionais e permanentes, fundados e infundados. Mas, o medo da pobreza e dos pobres constitui o maior dos medos" (Santos, 1985: 126).

Não é sem razão a ênfase que as políticas sociais das últimas décadas têm dado ao desenvolvimento urbano e às medidas de planejamento e gestão local, sob orientação da descentralização e de novas formas de gestão dos fundos públicos, como instrumentos capazes de enfrentar situações tão adversas. Bauman (2009) chega a sugerir que as cidades contemporâneas são depósitos nos quais se procuram desesperadamente soluções locais para problemas produzidos pela globalização, e "os cidadãos e aqueles que foram eleitos como seus representantes 
estão diante de uma tarefa que não podem nem sonhar em resolver: a tarefa de encontrar soluções locais para contradições globais" (Bauman, 2009: 32). Entretanto, o autor acena com possibilidades de que é "nos lugares que se forma a experiência humana (...). E é nos lugares, e graças aos lugares, que os desejos se desenvolvem, ganham forma, alimentados pela esperança de realizar-se, e também pelo inevitável risco da decepção..." (Bauman, 2009: 35). O fato de as cidades constituírem-se historicamente em um campo de tensões e vistas como espaços de grandes confrontações não significa pensá-las apenas como um lócus de problemas e impermeável às transformações, como se

a culpa fosse dela e não da própria estruturação da sociedade. Se a fragmentação se coloca como um problema, pode também levar a recriação de uma vida coletiva local representativa das condições de vida presentes em cada um dos territórios e lugares. Aqui se coloca a necessidade de tomá-la como o lugar do processo violento de mudança. (Santos, 1985: 124)

Essa visão guarda estreita afinidade com outras concepções que reconhecem as cidades como locais de sobrevivência e de mudança, e que analisam, portanto, as situações do presente e as potencialidades de transformação futura. Tal tendência se expressa nas proposições que indicam o aparecimento da chamada cidade global, que tem seu desenvolvimento e expansão em fins do século XX. Ela se constitui em densas regiões urbanizadas, com forte controle econômico, por meio das quais configura possibilidades do capitalismo global e onde tudo se experimenta, da democracia e tirania, da racionalização e alienação, da cidadania e anomia, onde se afirma a diversidade e também a desigualdade; onde se articula o real e o imaginário (Ianni, 1996).

Manifesta-se também na ideia do surgimento de espaços subnacionais fracionados, onde se redefinem os papéis econômico, social e político das metrópoles e das cidades e reconstituem-se os espaços comunitários desarticulados permitindo também a reconstituição de um ser humano mais integrado com base nos segmentos hoje fragmentados (Dowbor, 1999).

Ou ainda, em proposições que destacam a cidade como ator social e a constituição de espaços simbióticos e simbólicos, em que os primeiros supõem negociações de políticas de desenvolvimento urbano entre os atores sociais que coabitam a cidade, e os segundos atentam para as identidades coletivas, para a diversidade cultural, para os processos que dinamizam as relações, convertendo a cidade num espaço de respostas possíveis aos propósitos econômicos, políticos e culturais de nossa época. Ressaltam-se nessa proposição as novas competências 
e funções do governo das cidades, definidas mediante um marco coerente de mobilização e cooperação dos atores sociais urbanos (Castells \& Borja, 1996).

Também Souza (2010), ao defender mudar a cidade, o faz sob o ângulo autonomista, como uma tarefa a ser assumida por uma coletividade e não inspirada por intelectuais tecnocráticos e imposta pelo Estado. Sobressae-se nessa formulação a ação coletiva e conjunta em torno da articulação entre instituições políticas e sociedade civil. Essa visão supõe que os instrumentos de planejamento e gestão da cidade só adquirem verdadeira importância ao terem sua operacionalização e implementação sendo influenciadas e monitoradas pelos cidadãos. Tal mudança não é, portanto, privilégio do Estado, nem monopólio exclusivo dos especialistas em planejamento e gestão urbanos, mas define-se como uma ação coletiva e conjunta em torno da articulação entre instituições políticas e sociedade civil.

A fim de evitar as polarizações, Bauman (2009) sugere que as cidades contemporâneas são campos de batalha nos quais os poderes locais e os sentidos de identidade se encontram, se confrontam e lutam tentando chegar a uma solução satisfatória para os conflitos. Daí a ambivalência de se viver numa cidade que atrai e afasta, diz o autor:

A desorientadora variedade do ambiente urbano é fonte de medo, em especial entre nós que perderam seus modos de vida habituais e foram jogados num estado de grave incerteza pelos processos desestabilizadores da globalização. Mas esse mesmo brilho caleidoscópico da cena urbana, nunca desprovida de novidades e surpresas, torna difícil resistir a seu poder de sedução. (Bauman, 2009: 47)

Em tal perspectiva as cidades são também laboratórios onde é possível descobrir, desenvolver e experimentar soluções e alternativas aos problemas globais.

O leitor se depara, nessa breve síntese, com as diversas dinâmicas engendradas na cidade, o que o leva a pensar no futuro e no reino da utopia, que revela o ideal de um mundo imaginado. Nesse sentido, cabe a pergunta: que desafios se apresentam? Que implicações podem ser vislumbradas nos processos de intervenção sobre o urbano de forma a produzir saúde de uma ampla perspectiva?

Uma breve análise dos autores selecionados conduz a um possível quadro comum de desafios. E para citar mais uma vez Calvino, há que se reportar a sua conclusão em relação à cidade de Berenice. A verdadeira Berenice se constitui em uma sucessão no tempo de cidades diferentes: "todas as futuras Berenices já estão 
presentes neste instante, contidas uma dentro da outra, apertadas espremidas inseparáveis" (Calvino, 1990: 147).

\section{Para Abrir Diálogo com Outras Perspectivas}

Retoma-se, uma vez mais, que não há como negar a necessidade imperativa de que o campo da promoção da saúde nas cidades esteja em estreita vinculação e diálogo com múltiplos setores e múltiplos saberes, para que possa diminuir a sensação, muitas vezes vocalizada, de que estamos falando para nós mesmos e sem a necessária ampliação de interlocução.

A lógica desse procedimento está ancorada no pressuposto de que para abrir diálogo com outras perspectivas há que se partir, talvez, de algum marco conceitual comum sobre cidade e pactuar um quadro de desafios que tenha algum grau de consenso para que as armas de cada corpo e conhecimento possam ser mutuamente potencializadas.

Para o estudo, utilizou-se como metodologia a busca de informações com as palavras-chave: município saudável, para a língua portuguesa; comunidades saludables, para a língua espanhola e healthy cities para as línguas inglesa, espanhola e portuguesa.

Tendo como base a palavra-chave município saudável foi possível identificar um total de 61 trabalhos entre artigos de periódicos e textos monográficos (teses, manuais, relatórios, experiências etc.), delimitados com base na presença do descritor no título. Como a BVS contava com sua própria metodologia de agregação das buscas e classificação, encontraram-se os seguintes itens, de acordo com a concentração dos principais assuntos: cidade saudável - 54; promoção da saúde 16; qualidade de vida - 9; participação comunitária - 7; ação intersetorial - 5 .

Com a palavra-chave comunidades saludables foram encontrados 84 trabalhos, sendo os principais assuntos delimitados os seguintes: cidade saudável - 65; promoção da saúde - 43; participação comunitária - 15; saúde da população urbana - 13; políticas de saúde - 10; desenvolvimento da comunidade - 8 .

E, finalmente, com a palavra-chave healthy cities nos três idiomas (inglês, espanhol e português) encontrou-se um total de 318 trabalhos, sendo em espanhol 33, em português - 35 e inglês - 238. Healthy cities em espanhol com os principais assuntos: promoção da saúde - 23; saúde da população urbana 8; cidade saudável - 6; política de saúde - 6. Em língua portuguesa: cidade saudável - 25; cidades - 15; promoção da saúde - 15; saúde da população urbana - 
13; qualidade de vida - 8; política de saúde - 6. Os trabalhos em língua inglesa estavam assim delimitados: saúde da população urbana - 129; promoção da saúde - 87; cidade saudável - 64; planejamento de cidades - 37; participação comunitária - 31; avaliação de programas e projetos de saúde - 24; saúde ambiental - 23; saúde pública - 21.

Chama a atenção nessa tipologia da BVS a estreita relação que os autores dos trabalhos estabelecem entre cidades saudáveis e promoção da saúde, sobretudo nos artigos em português e espanhol, o que reforça a máxima sempre vocalizada de que a iniciativa de cidades saudáveis é uma estratégia de promoção da saúde. Entretanto, nos de língua inglesa, aparentemente, os autores inscrevem muito mais suas análises de cidades saudáveis no escopo de saúde urbana e planejamento urbano do que no âmbito da promoção da saúde, o que sugere uma abertura para o diálogo com outras perspectivas e políticas urbanas.

Na Tabela 1, a seguir, indica-se a distinção entre artigos e textos monográficos dentre os itens encontrados nas três línguas, classificando-os em: texto conceitual; texto sobre avaliação; manuais - de implementação ou de avaliação; informe de atividades e relato de experiências. A pesquisa identificou um total de 463 itens, dos quais 137 foram excluídos por estarem repetidos nos três idiomas, tendo sido classificados, então, 326 itens, que se encontram subdivididos entre as categorias definidas.

Com o intuito de executar uma revisão mais detalhada, definiu-se uma nova periodização em relação a esses 326 - de 1997 a 2010 -, obtendo-se como resultado 77 artigos. Destes, após revisados, selecionaram-se 28, especificamente aqueles que indicavam alguma concepção mais abrangente de cidade e indicavam desafios a serem enfrentados pela iniciativa de cidades saudáveis. As referências aos artigos escolhidos estão listadas no final deste capítulo e formam o corpo de autores da

Tabela 1 - Itens de pesquisa sobre cidades saudáveis classificados por língua de origem do texto (artigo ou monografia) e subdivididos em texto conceitual, texto avaliativo, manuais, informes de atividades e relato de experiência

\begin{tabular}{l|l|c|c|c|c|c|c|c}
\hline $\begin{array}{l}\text { Itens de } \\
\text { pesquisa }\end{array}$ & \multicolumn{2}{l|}{ Artigos } & \multicolumn{4}{l}{ Monografias } \\
\hline $\begin{array}{l}\text { Língua de } \\
\text { Origem }\end{array}$ & Conceitual & Avaliação & $\begin{array}{c}\text { Relato de } \\
\text { experiência }\end{array}$ & Manuais & Avaliação & Conceituais & $\begin{array}{c}\text { Informes } \\
\text { de atividade }\end{array}$ & $\begin{array}{c}\text { Relato de } \\
\text { experiência }\end{array}$ \\
\hline Espanhol & 5 & 2 & 2 & 27 & 13 & 4 & 16 & 13 \\
\hline Português & 16 & 1 & 5 & 10 & 7 & 2 & 1 & 26 \\
\hline Inglês & 43 & 10 & 22 & 11 & 5 & 12 & 53 & 20 \\
\hline Total & $\mathbf{6 4}$ & $\mathbf{1 3}$ & $\mathbf{2 9}$ & $\mathbf{4 8}$ & $\mathbf{2 5}$ & $\mathbf{1 8}$ & $\mathbf{7 0}$ & $\mathbf{5 9}$ \\
\hline
\end{tabular}

Fonte: BVS, 1986-2010. 
promoção da saúde que dialoga com o corpo de dez autores que selecionamos do campo das ciências sociais, políticas e do planejamento urbano.

\section{Bases para o Estabelecimento do Diálogo}

Todos em busca da cidade ideal! Ela, de fato, existe? Talvez não, mas o cachorro a idealiza com "um poste por metro quadrado, sem carro e sem risco de morrer"; ${ }^{1}$ para a galinha, a cidade ideal "tem as ruas cheias de minhocas..."; e para a gata, "o ideal seria um prato de tripa fresquinha, sardinha num bonde de lata e alcatra no final da linha". Mas aí surge o teimoso, sábio e estraga-prazeres do jumento, que, prevenido, alerta que "a cidade é uma estranha senhora, que hoje te sorri e amanhã te devora". E segue o coro de crianças dizendo: "o jumento é sabido e que é melhor ficar bem prevenido" e olha, gata, que a tua pelica vai virar uma bela cuíca".

E o coro dos autores com os quais se quer estabelecer diálogo, o que pensam a respeito das cidades?

Em linhas gerais, poderia se dizer que nenhum deles observa a cidade de maneira idealizada como os desejos do cachorro, da gata e da galinha. Nem totalmente se alinham ao coro das crianças de que a cidade é puro risco e perigo para os gatos que nela habitam.

Aparentemente os autores estabelecem uma relação pulsante das múltiplas facetas da cidade, sem perceber a cidade como problema ou como solução, já que: "a cidade é objeto e também agente ativo das relações sociais..." (Maricato, 2010); "há medo e há confiança" (Bauman, 2009); "uma vasta rede de itinerários, pontos de partida e de chegada..." (Veras, 2010); “...de inclusão e de exclusão..." (Rolnik, 1988); um campo privilegiado para "um processo violento de mudança" (Santos, 1985); um espaço onde se "...afirma a diversidade e também a desigualdade, onde se articulam o real e o imaginário" (Ianni, 1996); a possibilidade da "...reconstituição de um ser humano mais integrado a partir de segmentos hoje fragmentados" (Dowbor, 1999); a tensão entre a necessidade de políticas públicas que sejam universais, mas que não descuidem de singularidades culturais (Castells \& Borja, 1996) e que não sejam impostas pelo Estado, mas sim negociadas com a sociedade civil (Souza, 2010). E Calvino (1990) coroa a não polarização maniqueísta, reafirmando a tensão pérpetua de que a cidade não muda para sempre e ressaltando: "vejo duas cidades: uma do rato, uma da andorinha... ambas mudam com o tempo; mas não muda a relação entre elas: a segunda é a que está para se libertar da primeira".

\footnotetext{
${ }^{1}$ Cidade Ideal, música composta por Enriquez, Bardotti e Chico Buarque, do álbum Os Saltimbancos, de Chico Buarque de Holanda.
} 


\section{Diálogo com a Concepção de Cidade e com o Quadro de Desafios}

E os autores da promoção da saúde, que visão têm da cidade, e que quadro de desafios tem sido proposto por eles?

A urbanização, que se intensifica no mundo desenvolvido a partir da década de 1950 e nos países em desenvolvimento nas décadas de 1970 e 1980, parece ser um fator desencadeante para reconectar as preocupações sanitárias com as cidades, qualificando-as como um determinante social da saúde (WHO, 1996; Vlahov et al., 2007; CSDH, 2008).

Os mencionados dez artigos dos autores dos campos das ciências sociais, políticas e do planejamento urbano selecionados neste capítulo trazem um marco conceitual dialético de cidades e de urbanização como ponto de partida e estabelecem desde então um quadro de desafios e de propostas de intervenções no âmbito da organização das estruturas e políticas urbanas.

No entanto os autores do campo da promoção da saúde pesquisados parecem ocupar-se menos de uma concepção de cidade e de urbanização, analisando em seus artigos o quadro de desafios a ser enfrentado. Sim, descrevem a cidade como algo complexo e dinâmico, lugar de convivência e de vida por excelência, e como tal desempenha papel determinante na saúde das pessoas e de seus problemas concretos no território, por exemplo (Westphal, 2000; Lorca et al., 2010). Todavia, sem explicitar o instigante debate da tensão pulsante e permanente entre duas cidades que se digladiam, afirmado de várias maneiras na revisão realizada nas áreas de conhecimento das ciências sociais, políticas e do planejamento urbano.

Entretanto, os autores da promoção da saúde marcam em seus escritos um forte componente de visão estratégica de cidade (Almeida, 1997; Westphal, 1997; Keinert, 1997), inclusive propondo a utilização do PES, ferramenta de Planejamento Estratégico Situacional, na implementação e operação de suas iniciativas de cidades saudáveis (Adriano et al., 2000; Teixeira, 2004).

Tais concepções e modus operandi das iniciativas não são, em si, antagônicas com a possibilidade de se perceber as tensões presentes na cidade. Muito ao contrário, o PES se ocupa da luta de interesses distintos, mas talvez, ao se buscar a imagem-objetivo/visão de cidade que se almeja no futuro, inconscientemente, se negaria que essa tensão dialética permanente iria cessar nesse futuro imaginário, predominando o desejo de que os bons saiam vencedores.

O desafio está em seguir buscando esse futuro melhor, sem se conformar jamais com aquilo que se define como inegociável no campo dos valores e 
propósitos, mas driblando, sempre, a tentação em assumir algumas vezes, de forma maniqueísta, ${ }^{2}$ o futuro versus o presente, a cidade ideal versus a cidade real.

Em relação ao quadro de desafios colocado pelos dois conjuntos de autores há uma feliz coincidência, o que abre uma bela perspectiva de diálogos interdisciplinares e mútua identificação de possibilidades de cooperação em pesquisa e em participação de eventos científicos, o que possivelmente rompe com uma percepção de isolamento de que sempre se está falando para si mesmo.

A grande maioria dos artigos do campo da promoção da saúde revisados abre amplo diálogo com outras disciplinas, setores, agendas e com movimentos sociais ao enunciar, de maneira clara, que as iniciativas de cidades saudáveis visam a ação intersetorial com protagonismo do Estado, participação da sociedade civil e dos movimentos sociais, desenvolvimento social, desenvolvimento sustentável, desenvolvimento urbano, fortalecimento do capital humano e social, atuação sobre os Objetivos de Desenvolvimento do Milênio (ODMs), Agenda 21 etc. (Lorca et al., 2010; Meresman et al., 2010; Barton et al., 2009; Green, 2009; Green et al., 2009; Lawrence \& Fudge, 2009; Geres Valls \& Velazquez Valoria, 2008; Yuasa et al., 2007, OPS, 2006; Comaru \& Westphal, 2004; Málaga \& Restrepo, 2001; Westphal, 1997, 2000; Malik, 1997).

Essa abertura de diálogo do movimento de municípios e cidades saudáveis evidencia-se também ao se constatar a amplitude dos dez princípios enunciados pela Organização Mundial da Saúde (OMS, 1995) para a implementação de iniciativas desse tipo:

- um ambiente físico limpo e seguro;

- um ecossistema estável e sustentável;

- alto suporte social, sem exploração;

- alto grau de participação social;

- necessidades básicas satisfeitas;

- acesso a experiências, recursos, contatos, interações e comunicações;

- economia local diversificada e inovativa;

- orgulho e respeito pela herança biológica e cultural;

- serviços de saúde acessíveis a todos;

- $\quad$ alto nível de saúde.

\footnotetext{
${ }^{2}$ Segundo o dicionário Aurélio: "'Maniqueísmo'. [De Maniqueu + -ismo.] S. m. 1. Filos. Doutrina do persa Mani ou Manes (séc. III), sobre a qual se criou uma seita religiosa que teve adeptos na Índia, China, África, Itália e S. da Espanha, e segundo a qual o Universo foi criado e é dominado por dois princípios antagônicos e irredutíveis: Deus ou o bem absoluto, e o mal absoluto ou o Diabo".
} 
José Luiz Riani Costa (1997), acerca de tais princípios, emite uma significativa declaração, salientando que essa agenda deve ficar aberta ao diálogo com outros setores, disciplinas e agendas, ao afirmar "que apenas nos dois últimos requisitos de uma cidade saudável apareceu algo mais diretamente ligado ao setor saúde. Mas muita gente quando fala em cidade saudável liga muito com serviços de saúde, ou com profissionais de saúde" (Costa, 1997: 69-70). É provável que essa ideia tenha sido reforçada porque a discussão tem sido conduzida pela OMS, pela Opas, pela Secretaria de Saúde e pelo Ministério da Saúde. Na verdade, o grande volume de ações para um projeto de cidade saudável escapa ao sistema de saúde, especialmente aos serviços de saúde. O Projeto Cidade Saudável pressupõe, portanto, um novo projeto de cidade e uma sociedade renovada.

Tomando como referência os pontos sintetizados com base na revisão dos dez autores selecionados e cotejando-a com o leque de proposições feitas no âmbito das iniciativas de cidades saudáveis pelos autores da promoção, pode-se verificar que:

- Ambos os grupos de autores estão preocupados com os espaços de privilégio, exclusão e segregação socioespacial na cidade que orientam um modelo obsoleto, irracional e injusto de ocupação: "a razão de ser mais importante do movimento de municípios saudáveis na América Latina é a diminuição da exclusão social por ser a principal explicação das grandes diferenças em matéria de saúde" (Málaga \& Restrepo, 2001).

- Ambas as perspectivas identificam o déficit de infraestrutura e a fraqueza dos governos locais em preencher tal lacuna. Por isso, há propostas de que a institucionalização do planejamento e gestão das políticas públicas saudáveis possa contribuir para a elevação da capacidade de governo (Lorca et al., 2010; Meresman et al., 2010, Green et al., 2009, Becker et al., 2007; Teixeira, 2004; OPS, 2002; Malik, 1997; Keinert, 1997).

- Ambas se incomodam com a grande fragmentação das políticas públicas e algumas iniciativas de cidades saudáveis operam esforços significativos para integrar saúde no planejamento urbano (Barton et al., 2009; Green, 2009; Green et al., 2009; Lawrence \& Fudge, 2009; Geres Valls \& Velazquez Valoria, 2008; Comaru \& Westphal, 2004).

- Ambas denunciam as iniquidades no acesso à moradia segura, ao saneamento ambiental, ao transporte público de qualidade, ao emprego e aos serviços de educação e saúde, e por isso a promoção da equidade é recomendada como um valor central nas iniciativas de cidades saudáveis (Tsouros, 2009; Yoo et al., 2007; Comaru \& Westphal, 2004). 
- Ambas desejam incisivamente soluções locais (Twiss et al., 2003; Clark, 2000) para problemas produzidos pela globalização (Rupp, 1998) e estabelecem a participação social como elemento-chave na construção dessas soluções (Heritage \& Dóris, 2009; Tsouros, 2009; Kegler et al., 2007; Kegler et al., 2008; Briggs-Marsch \& Warren, 2000).

Chama atenção que dois pontos identificados no quadro de desafios dos autores de referência selecionados - reconhecer o papel estratégico das cidades na competitividade internacional e enfrentar o medo que assola as cidades, com a perda da solidariedade coletiva - não apareçam mencionados na literatura de cidades saudáveis. Portanto, têm sido pouco debatidos entre os ativistas do campo da promoção da saúde.

Para Santos (1996), na era da globalização, os eventos são globalmente solidários, pela sua própria origem. Entretanto, nos lugares de convivência, eventos simples são produzidos e amalgamados e, em sua realização concreta, os eventos são também localmente solidários. As diversas situações do cotidiano territorial são, assim, resultantes do acontecer solidário. "É assim que a integração entre o universal e o individual ganha um novo conteúdo histórico em nosso mundo atual" (Santos, 1996: 107).

Bauman problematiza o medo não apenas como consequência da já propalada insegurança urbana, mas como efeito da mixofobia, o medo de misturar-se.

\footnotetext{
Essa mixofobia não passa da difusa e muito previsível reação a impressionante e exasperadora variedade de tipos humanos e de estilos de vida que se podem encontrar nas ruas da cidade... Uma vez que a multiforme e plurilinguística cultura do ambiente urbano na era da globalização se impõe... as tensões derivadas da 'estrangeiridade' incômoda e desorientadora desse cenário acabarão, provavelmente por favorecer as tendências segregacionistas. (Bauman, 2009: 42)
}

Em realidade, esses temas podem ser tratados como eventos associados e precisam ganhar relevância nas agendas de cidades saudáveis. O recente episódio ocorrido na Noruega, em que 76 pessoas foram assassinadas sob a justificativa de que o país precisava ser preservado da influência estrangeira, e os constantes episódios de homofobia nas metrópoles brasileiras denotam a urgência de se atuar sobre a prevalente mixofobia nas cidades globalizadas. 


\section{O Que Podemos Concluir sobre a Relevância das Cidades Saudáveis?}

Desde os anos 1990, quando surgem os primeiros delineamentos do ideário por cidades saudáveis, implementaram-se muitas iniciativas. Seus aportes iniciais têm sido revistos e reinterpretados com base em várias experiências desenvolvidas em cidades e comunidades. A recuperação empreendida neste capítulo procurou retratar algumas dessas tendências em torno do movimento por cidades saudáveis. Mais relevante ele se tornará quanto maior a capacidade de diálogo e interlocução entre atores, pesquisadores, gestores e governos.

A aposta é de que, para além dos esforços empreendidos sobre avaliação de resultados, ainda há espaços para revisões e incorporações nas formulações acerca da produção da saúde nas cidades.

A dinâmica das cidades parece apontar para a necessidade imperiosa de se traçar novos caminhos éticos para a sociedade. Nesse sentido, a agenda por cidades saudáveis ganha potencialidade ao resgatar valores fundamentais, como democracia, solidariedade, equidade, ética e justiça. Várias das noções incorporadas nesse movimento caracterizam-se por serem polissêmicas e, portanto, ultrapassam os limites de um campo único de conhecimento. Elas também ensejam diversas outras subcategorias de análise, as quais podem contribuir para ampliar a forma de se interpretar e de se propor soluções.

Assim como a relevância da agenda por cidades saudáveis se fortalece com a abertura de diálogo multidisciplinar e multisetorial, ela reivindica, ainda, que cada vez mais se amplie como movimento, e que este, como um software, se abra a contribuições que possam ser incorporadas continuamente a seu construto, desenvolvendo novas versões que futuramente poderiam ser adaptadas a distintos contextos e a novos problemas.

Meresman e colaboradores (2010: 753) relatam um exercício desenvolvido pela Opas com tal objetivo - o de captar contribuições múltiplas para reposicionar a agenda nas Américas - e recomendam o seguinte:

- Faz-se necessário reforçar a identidade de cidades saudáveis abrindo-se caminho para uma segunda geração de conceitos e ferramentas, para a renovação do seu marco lógico e para a atualização de metodologias e abordagens.

- É preciso que a ampliação de cidades saudáveis na política nacional seja vista não como um fim em si mesmo, mas como uma estratégia para se construir caminhos que possam fortalecer a governança urbana. 
- É essencial priorizar mais o foco no planejamento urbano, transporte, assentamentos humanos, habitação, saúde mental, prevenção da violência e em outros fatores que nos estilos de vida individuais.

- É imprescindível o desenvolvimento de redes sociais que acompanhem a difusão dos processos participativos por uma cooperação horizontal e que valorize a singularidade e diversidade de atores e processos.

- É primordial que haja maior integração das ações de saúde com a produção local e a geração de renda, programas habitacionais e iniciativas de inclusão social.

- É de fundamental importância que se fortaleçam e melhorem os processos de implementação de cidades saudáveis, levando-se em conta: a institucionalização da estratégia; a busca da estabilidade de equipes técnicas; a definição de um quadro jurídico-institucional mais preciso no estabelecimento de conselhos de gestão interinstitucional, intersetorial e interdisciplinar; os mecanismos de consulta interinstitucional, com ferramentas mais flexíveis; o permanente estímulo aos desenvolvedores do trabalho colaborativo; o desenvolvimento de coordenação e gestão de competências; e a viabilização de fontes de financiamento integrados.

- É vital a adoção de novas vias de colaboração on-line, a fim de dinamizar novas formas de participação social (desenvolvimento de redes virtuais e ferramentas de governo eletrônico) e de usá-las para melhorar processos de governança por meio de capacitação, empregando-se ferramentas eficazes para a tomada de decisão por parte dos cidadãos.

- Faz-se necessário fortalecer alianças com setores mais dinâmicos: cultural, de juventude, empresarial, acadêmico e de organizações produtivas.

- Torna-se necessária a disponibilidade de uma formação permanente e de uma atualização dirigida aos profissionais envolvidos em cidades saudáveis, com ênfase em novos tópicos (determinantes sociais da saúde, desenvolvimento local, redes cooperativas, avaliação etc.), fornecendo ferramentas específicas que correspondam ao nível de responsabilidade e competência de cada nível de gestão.

- É preciso estimular o espírito investigativo, para se estabelecer uma agenda permanente de pesquisa e para mobilizar as capacidades técnicas existentes. 


\section{Referências}

ADRIANO, J. R. et al. A construção de cidades saudáveis: uma estratégia viável para a melhoria da qualidade de vida? Ciência \& Saúde Coletiva, 5(1): 53-62, 2000.

ALMEIDA, E. S. Cidade/município saudável, a questão estratégica: o compromisso político. Saúde e Sociedade, 6(2): 47-54, 1997.

BARTON, H. et al. Healthy urban planning in European cities. Health Promotion International, 24, supl. 1: 91-99, 2009.

BAUMAN, Z. Confiança e Medo na Cidade. Rio de Janeiro: Zahar, 2009.

BECKER, D. et al. Network of healthy communities of Rio de Janeiro-Brazil. Promotion of Education, 14(2): 101-102, 2007.

BRIGGS-MARSH, J. \&WARREN, J. A park for all the people. Public Health Report, 115(2-3): 253-256, 2000.

CALVINO, I. As Cidades Invisíveis. Trad. Diogo Mainardi. São Paulo: Companhia das Letras, 1990.

CASTELLS, M. E. \& BORJA, J. As cidades como atores políticos. Novos Estudos, 45: 152-166, 1996.

COMMISSION ON SOCIAL DETERMINANTS OF HEALTH (CSDH). Closing the Gap in a Generation: health equity through action on the social determinants of health. Geneva: WHO, 2008.

CLARK, D. K. The city government's role in community health improvement. Public Health Report, 115(2-3): 216-221, 2000.

COMARU, F. A. \&WESTPHAL, M. F. Housing, urban development and health in Latin America: contrasts, inequalities and challenges. Environmental Health, 19(3): 329-343, 2004.

COSTA, J. L. R. Algumas reflexões sobre cidades saudáveis. Saúde e Sociedade, 6(2): 19-30, 1997.

DOWBOR, L. A Reprodução Social:propostas para uma gestão descentralizada. 2. ed. Petrópolis:Vozes, 1999.

GEREZ VALLS, M.D. \&VELAZQUEZ VALORIA, I. The health of cities and their citizens. Gaceta Sanitaria, 22, supl. 1: 71-78, 2008.

GREEN, G. Partnership structures in the WHO European Healthy Cities project. Health Promotion International, 24, supl. 1: 37-44, 2009.

GREEN, G. et al. City health developing planning. Health Promotion International, 24, supl. 1: 72-80, 2009.

HERITAGE, Z. \& DÓRIS, M. Community participation and empowerment in healthy cities. Health Promotion International, 24, supl. 1: 45-55, 2009.

IANNI, O. A Era do Globalismo. Rio de Janeiro: Civilização Brasileira, 1996.

KEGLER, M. C. et al. Skill improvement among coalition members in the California Healthy Cities and Communities Program. Health Education Research, 22(3): 450-457, 2007.

KEGLER, M. C. et al. Strenghtening community leadership. Health Promotion International, 9(2): 170-179, 2008.

KEINERT, T. M. M. Planejamento governamental e políticas públicas: a estratégia 'cidades saudáveis'. Saúde e Sociedade, 6(2): 55-64, 1997.

LAWRENCE, R. J. \& FUDGE, C. Healthy cities in a global and regional context. Health Promotion International, 24, supl. 1: 11-18, 2009.

LORCA, E. et al. Healthy cities: a reference strategy in local public health policies. Gaceta Sanitaria, 24(6): 435-436, 2010.

MÁLAGA, H. \& RESTREPO, H. E. Reflexiones sobre el futuro de municipios saludables en América. In: RESTREPO, H. E. \& MALAGA, H. E. (Eds.). Promoción de la Salud: como construir vida saludable. Bogota: Editorial Médica Internacional, 2001. 
MALIK, A. Cidades saudáveis: estratégias em aberto. Saúde e Sociedade, 6(2): 19-30, 1997.

MARICATO, E. Habitação e Cidade. 7. ed. São Paulo: Atual, 2010.

MERESMAN, S. et al. Contributions for repositioning a regional strategy for Healthy Municipalities, Cities and Communities (HM\&C): results of a pan-american survey. Journal of Urban Health. 87(5): 740-754, 2010.

ORGANIZAÇÃO MUNDIAL DA SAÚDE (OMS). Veinte Pasos para Formular un Proyecto de Ciudades Sanas. Washington: OMS, 1995.

ORGANIZACIÓN PANAMERICANA DE LA SALUD (OPS). Municipios y Comunidades Saludables: guía de los alcaldes para promover calidad de de vida. Washington: Paho, 2002.

ORGANIZACIÓN PANAMERICANA DE LA SALUD (OPS). Hoja de Ruta para Contribuir al Logro de los Objetivos de Desarrollo del Milenio en los Municipios y Comunidades Saludables. Washington: OPS, 2006.

ROLNIK, R. O Que é Cidade. São Paulo: Brasiliense, 1988.

RUPP, G. Towards healthy cities: opportunities for collaboration. Journal of Urban Health, 75(2): 401-406, 1998.

SANTOS, M. O País Distorcido. São Paulo: Publifolha, 1985.

SANTOS, M. A Natureza do Espaço: técnica e tempo, razão e emoção. São Paulo: Hucitec, 1996.

SOUZA, M. L. Mudar a Cidade: uma introdução crítica ao planejamento e à gestão urbanos. 7. ed. Rio de Janeiro: Bertrand Brasil, 2010.

TEIXEIRA, C. F. Formulação e implementação de políticas públicas saudáveis: desafios para o planejamento e gestão das ações de promoção da saúde nas cidades. Saúde e Sociedade, 13(1): 37-46, 2004.

TSOUROS, A. City leadership for health and sustainable development in the World Health Organization European Healthy Cities Network. Health Promotion International, 24, supl. 1: 4-10, 2009.

TWISS, J. et al. Community gardens: lessons learned from California Healthy Cities and Communities. American Journal of Public Health, 93(9): 1.435-1.438, 2003.

VERAS, M. Cidade, vulnerabilidade e território. Revista Ponto-e-Vírgula, 7:32-48, 2010. Disponível em: <www.pucsp.br/ponto-e-virgula/n7/indexn7.htm>. Acesso em: mai. 2014.

VLAHOV, D. et al. Urban as a determinant of health. Journal of Urban Health, 84(1): 16-26 2007.

WESTPHAL, M. Municípios saudáveis: aspectos conceituais. Saúde e Sociedade, 6(2): 9-18, 1997.

WESTPHAL, M. Municípios saudáveis: um compromisso com a qualidade de vida. Ciência \& Saúde Coletiva, (5)1: 39-51, 2000.

WORLD HEALTH ORGANIZATION (WHO). Center for Health Development Urbanization: a global health challenge. Kobe: WHO Center for Health Development, 1996.

YOO, W. S. et al. Introduction of health impact assessment and healthy cities as a tool for tackling health inequality. Journal of Preventive Medicine Public Health, 40(6): 439-446, 2007.

YUASA, M. et al. Emergence model of social and human capital and its application to the Healthy Municipalities project in Northeast Brazil. Health Promotion International, 22(4): 292-298, 2007. 


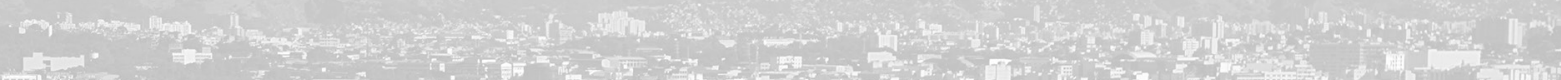
and

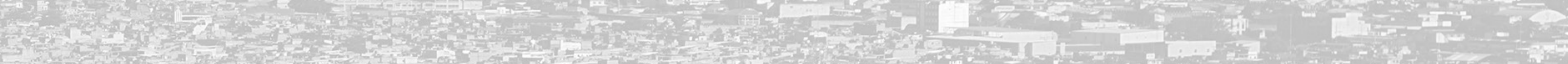

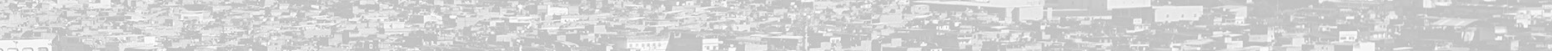

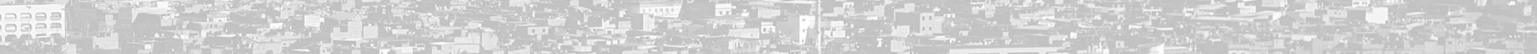

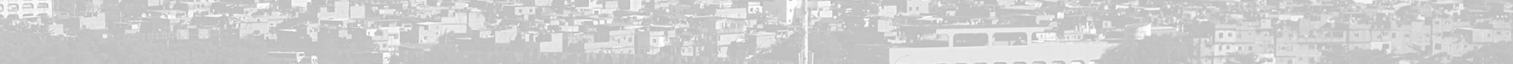

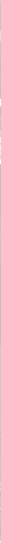




\title{
Favela, Conjuntos Habitacionais, Bairros Populares e outras Formas Urbanas: por uma agenda comum de luta pela cidade
}

\author{
Marcelo Baumann Burgos
}

Gu não é um texto sobre favela, é sobre cidade. Não porque pretenda sustentar
uma posição valorativa de que a favela pertence à cidade, o que, além de óbvio, esconderia justamente o que precisa ser discutido. Tampouco porque intencione negar a especificidade da favela, que também precisa ser discutida. Apesar de ter como foco a favela, este texto versa sobre a cidade exatamente porque pretende contribuir para a urgente tarefa de elaborar uma perspectiva capaz de redefinir a relação entre a favela e os demais espaços populares da cidade.

Sua premissa fundamental é a de que o fim do ciclo da modernização conservadora, formalmente encerrado com a Constituição de 1988, e sociologicamente superado à medida que o direito constitucional realiza seu processo de decantação, desloca o lugar que a favela historicamente ocupou na vida das metrópoles brasileiras, abrindo espaço para uma nova visada que permita pensar a favela como uma forma urbana que não necessariamente precisará desaparecer para que se assegure sua completa inscrição na vida da cidade. Supera-se assim, também, o velho debate remoção versus urbanização, que até hoje ainda estrutura e esteriliza os embates ideológicos sobre a questão da favela.

A noção de modernização conservadora foi amplamente consagrada pela sociologia política produzida entre os anos compreendidos entre 1970 e 1980, para dar conta da natureza do processo de industrialização/urbanização que ocorreu 
com enorme intensidade entre os anos 1940 e $1970 .{ }^{1}$ Uma modernização que, ao mesmo tempo que arrancou o homem brasileiro da submissão e indigência da vida rural em que se encontrava, trazendo-o para as cidades e suas periferias e inserindo-o em formas modernas de relação de produção, o manteve afastado da política e da cidadania, seja por meio da engenharia corporativista, que capturou a energia cívica de sua vida sindical e associativa, seja por meio de mecanismos de controle político do homem urbano, que encontraram nas diferentes formas de segregação urbana uma poderosa aliada - e entre suas formas possivelmente a favela tenha sido sua fórmula mais bem-sucedida. Para tal processo não foi irrelevante a condenação do Partido Comunista à clandestinidade, facilitando o caminho para a conformação de um clientelismo urbano recessivo, sem o qual não se pode compreender a lógica de expansão de grandes cidades como São Paulo e Rio de Janeiro.

O esgotamento do ciclo de modernização conservadora se explica, em parte, pela consolidação dos processos de substituição das importações e das exportações, que permitiu a criação de uma pujante economia industrial; mas também pela superação da ordem autoritária com a instauração da Carta de 1988, que tornou possível, pela primeira vez, a estabilização do país sob uma democracia liberal. Afirmam-se, com isso, os ideais de igualdade e de liberdade como valores perpétuos do novo país que se está a criar.

De fato, a Carta de 1988 fixou "um desenho imaginário de país" (Lessa, 2008: 378), que tem no sistema de direitos fundamentais seu núcleo básico (Cittadino, 1999). Há muitas evidências de que os valores inscritos na Constituição vêm cumprindo seu processo de decantação, modulando os interesses e apetites dos segmentos emergentes. Conforme já afirmado em outra oportunidade,

se é certo que a transição como obra em progresso só encontrará seu termo quando os segmentos populares se apropriarem efetivamente da política, radicalizando sua potencialidade cidadã, é igualmente certo que, caso venham a realizar esse percurso, não poderão mais ignorar os valores democráticos instilados na vida brasileira pela Carta de 88. (Burgos, 2010: 128)

Dessa forma, faz sentido argumentar que a nova ordem jurídica está em conflito aberto com o regime urbano, forjado ao longo do processo de modernização conservadora. ${ }^{2}$ Com base nesse enquadramento do problema, também

\footnotetext{
${ }^{1}$ Para citar algumas das referências clássicas dessa bibliografia, vale lembrar A Revolução Burguesa no Brasil, de Florestan Fernandes (1978); Autoritarismo e Democratização, de Fernando Henrique Cardoso (1975); Liberalismo e Sindicato no Brasil, de Luiz Werneck Vianna (1978); e Cidadania e Justiça, de Wanderley Guilherme dos Santos (1987).

${ }^{2}$ Adota-se aqui a noção de regime urbano apresentada por Luiz Cesar Queiroz Ribeiro (2007: 35), a saber: "as condições e formatos institucionais pelos quais em cada cidade tomou forma o processo de incorporação das camadas populares ao poder urbano comandado
} 
faz sentido indagar sobre os efeitos de tal conflito sobre a favela, que, embora originária do liberalismo econômico da República Velha, se afirmou como eficiente mecanismo de controle político e social dos egressos do processo de desruralização que acompanha a modernização conservadora.

\section{A Perspectiva do Direito à Cidade}

Nesse contexto de decantação de direito constitucional, a noção de direito à cidade assume especial utilidade heurística para se pensar a relação entre a favela e os demais espaços populares.

A $5^{\text {a }}$ edição do Fórum Urbano Mundial do United Nations Human Settlements Programme (UN-Habitat), realizado no Rio de Janeiro, em 2010, teve como tema o direito à cidade. No resumo do Estado das Cidades do Mundo - título do relatório produzido pelo UN-Habitat (2010) - observa-se que

o conceito de direito à cidade tem sido usado de diferentes maneiras em todas as regiões, países e cidades do mundo. Em alguns lugares tem sido usado como um arco teórico e político, focado no cumprimento, empoderamento, participação, autorrealização, autodeterminação e várias formas de proteção dos direitos humanos em nível municipal. Em outros lugares, o conceito tem servido como plataforma para ação, enquanto, em algumas cidades, o conceito está ausente do discurso político: ou não se usa ou não está completamente banido. (UN-Habitat, 2010: 20)

Importante notar que, além de fatores como desigualdades históricas socioeconômicas, miséria absoluta, degradação do meio ambiente e os desastres naturais relacionados com as mudanças climáticas, o relatório destaca que "mecanismos e instituições inclusivos mal-definidos " (UN-Habitat, 2010:21) também impõem limites à luta pelo direito à cidade. ${ }^{3}$

Em suas considerações finais, o documento assevera que "o direito à cidade pode oferecer às autoridades municipais a plataforma de que elas precisam para uma ampla gama de políticas e iniciativas que promovam um entorno urbano inclusivo", sustentando, ainda, que o

pelas elites políticas locais e as forças de acumulação urbana". Para o autor, "a eficácia dos regimes urbanos de cada cidade teve como fundamento a manutenção no plano nacional de um regime político caracterizado fortemente por governos autoritários e ditatoriais que permitiram a instauração de um processo controlado de negociação da incorporação das massas urbanas no sistema político e nos benefícios do crescimento econômico acelerado".

${ }^{3} 0$ documento também aponta "deficiências nos instrumentos que possibilitam entender e antecipar alguns dos fatores que geram mais desigualdades" (por exemplo, a escassez de terra e a concentração da propriedade na mão de alguns poucos; a falta de políticas redistributivas; os mercados habitacionais ineficazes etc.) (UN-Habitat, 2010). 
direito à cidade clama por um tipo holístico, equilibrado e multicultural de desenvolvimento urbano, que deve impregnar todas as áreas das políticas, incluindo o uso, o planejamento, a gestão e a reforma do solo, e deve fazêlo em estreita cooperação com as agências do governo e com a sociedade civil. (UN-Habitat, 2010: 21)

Portanto, ao mesmo tempo que aponta para uma agenda de direitos materiais relacionados à infraestrutura urbana básica e aos direitos sociais, a UN-Habitat também valoriza os aspectos processuais inerentes à luta pela afirmação desses direitos.

O recente protagonismo do direito à cidade no debate público internacional encontra um óbvio precursor no influente livro, originalmente publicado em fins dos anos 1960, de Lefebvre (2006). Nele, o autor faz uma análise crítica do esgotamento da agenda do Welfare State, que apesar de fazer com que "a antiga miséria proletária se atenue e tenda a desaparecer nos grandes países industriais", criou "uma nova miséria, que toca principalmente o proletariado sem poupar outras camadas e classes sociais: a miséria do habitat, a miséria do habitante submetido a uma quotidianeidade organizada (na e pela sociedade burocrática do consumo dirigido)" (Lefebvre, 2006: 142-143). Vale dizer, uma miséria decorrente da expulsão dos segmentos populares da cidade para os conjuntos habitacionais das periferias.

Assim é que, após admitir o avanço proporcionado pela ampliação de direitos sociais - "direitos mal reconhecidos tornam-se pouco a pouco costumeiros antes de se inscreverem nos códigos formalizados" -, entre os quais o direito ao trabalho, educação, saúde, habitação etc., Lefebvre sustenta que uma nova fronteira se impõe com a identificação do direito à cidade, isto é, o direito "à vida urbana, à centralidade renovada, aos locais de encontro e de trocas, aos ritmos de vida e empregos do tempo que permitem o uso pleno e inteiro desses momentos e locais". E adverte que, para a classe operária, "rejeitada dos centros para as periferias, despojada da cidade, expropriada assim dos melhores resultados de sua atividade, esse direito tem um alcance e uma significação particulares" (Lefebvre, 2006: 142-143).

Ao recuperar o argumento de Lefebvre, o objetivo, aqui, não é o de colocar à sombra toda uma agenda de acesso a direitos sociais que está longe de ter sido universalizada nas metrópoles brasileiras, mas chamar a atenção para o fato de que ela sozinha já não é suficiente para assegurar a cidadania dos homens das favelas e periferias. Realmente, é possível afirmar que, pelo menos desde os anos 1980, favelas e periferias viram avançar seu acesso aos direitos sociais, 
incluindo educação, saúde e acesso a bens coletivos como água, energia elétrica e saneamento. Mesmo sem ter assegurado o pleno acesso a tais direitos, é inegável que essa agenda se afirmou politicamente, comprometendo as elites locais e regionais e as lideranças políticas. O que não avançou na mesma proporção foi o direito a ter direitos de seus moradores, isto é, sua condição de cidadão capaz de participar do debate público sobre decisões que interessem ao seu lugar de moradia e à sua cidade, e isso, segundo a perspectiva adotada neste capítulo, pressupõe o acesso à cidade no sentido lefebvreano, ou seja, acesso à centralidade e à diversidade urbanas, às diferentes oportunidades que a cidade oferece, incluindo acesso a instituições políticas e culturais e acesso à justiça.

Um exemplo ilustra bem o que está em questão: bem antes da ocupação militar da Vila Cruzeiro (favela localizada no subúrbio do Rio de Janeiro), ocorrida em fins de 2010, este autor recebeu convite por parte de algumas de suas lideranças para ajudá-los a construir uma reivindicação que revela bem o que está em discussão. Preocupados com o fato de as novas gerações ficarem muito restritas à vida na favela, manifestavam inquietação com a decadência de bairros de seu entorno, como Penha e Olaria, e defendiam a criação de um grande centro cultural no antigo prédio do Cine Olaria. Para eles, assegurar espaços que permitam que seus filhos tenham acesso a centralidades urbanas já é tão importante quanto foi a luta por água e luz em outras épocas.

Dessa perspectiva do direito à cidade, discutir as especificidades da favela em face de outras formas urbanas torna-se menos importante do que voltar a atenção para a construção de parâmetros comuns capazes de contemplar, além da favela, diferentes espaços urbanos como conjuntos habitacionais, loteamentos irregulares e bairros populares, ${ }^{4}$ que passariam a ser entendidos como formas urbanas que se diferenciam menos por uma suposta singularidade morfológica de resto, cada vez mais imprecisa -, e mais pelo grau de acesso à cidade.

Em sua tese de doutorado sobre o Conjunto Habitacional Cidade Alta (localizado no subúrbio do Rio de Janeiro), Mario Brum (2011) demonstra que não apenas o conjunto funcionou como antessala da construção de uma nova favela na região, criada para abrigar parentes egressos de famílias moradoras do conjunto, mas também que o próprio conjunto foi se favelizando, com a ocupação

\footnotetext{
${ }^{4}$ Um esforço nessa direção foi realizado por Marcelo Burgos e Maria Alice Rezende de Carvalho (2011), por meio da construção do Índice de Democratização da Cidade (IDC). Ele contempla três dimensões: a qualidade dos domićlios; o grau de acesso aos serviços urbanos; e os direitos do morador à privacidade e à mobilidade. 0 IDC faz parte de um manual de metodologia para a formulação do Diagnóstico Social Participativo do Programa Morar Carioca, da Prefeitura Municipal do Rio de Janeiro. 0 manual foi encomendado pelo Instituto de Arquitetos do Brasil (IAB), a fim de subsidiar os escritórios de arquitetura responsáveis pela elaboração dos projetos de intervenção urbana do programa.
} 
de áreas coletivas pela construção dos denominados puxadinhos. Além disso, Brum também constata que a indistinção entre a favela e o conjunto habitacional chega a tal ponto que, em dado momento, os moradores do conjunto se dão conta de que a favela vizinha encontra-se mais estruturada que o Conjunto Habitacional, o que leva sua associação de moradores a perceber as vantagens de ser favela, filiando-se durante um período à federação de associação de favelas e não à de bairros.

A perspectiva do direito à cidade permite, afinal, formular uma linha de reflexão capaz de superar o isolamento político e analítico da favela, contribuindo assim para a construção de uma agenda mais universalista de luta pela cidade e pela cidadania. ${ }^{5}$

Para avançar nessa direção será preciso, no entanto, refletir sobre as razões que levaram a favela a ser isolada politicamente e transformada, sobretudo no Rio de Janeiro, em inimiga da cidade.

\section{Sobre o Isolamento Político da Favela}

A hipótese aqui proposta é a de que o isolamento da favela, e sua construção como inimiga da cidade, foi um dos mecanismos de controle social do mundo popular urbano ao longo do processo de modernização conservadora - complementar à engenharia corporativista.

A favela serviu como forma de acesso subalterno dos de baixo às migalhas da modernidade, mas também como biombo entre os demais segmentos populares e a cidade. Isso fica evidenciado quando se acusa a favela e a favelização de responsável pela degradação de bairros populares dos subúrbios do Rio de Janeiro. De fato, por diferentes vias, seja nos principais veículos de comunicação, na política e até em trabalhos acadêmicos, tem sido frequente identificar a favela como uma espécie de inimiga da cidade - acusam-na de desvalorizar os imóveis dos bairros de classe média, de degradar os bairros populares e de descaracterizar e degenerar os conjuntos habitacionais. E mesmo na periferia, basicamente ocupada pela chamada autoconstrução em loteamentos irregulares, a favela é percebida como ameaça, contra a qual se opõem formas defensivas que legitimam

\footnotetext{
${ }^{5}$ Ainda que com variações, tal perspectiva também tem sido defendida por outros autores, entre os quais se destaca Pedro Claudio Cunca Bocayuva (2009: 13). A questão, diz ele, "é a de tornar a periferia 0 centro de uma nova dinâmica que supere os limites da comunidade de identidade, da naturalização do lugar fixo, para uma afirmação de mobilidade e acesso que oriente as políticas de construção e fortalecimento de potencialidades que só podem ser desenvolvidas dentro de um novo olhar sobre a economia e a ecologia social e política da cidade".
} 
a formação de condomínios fechados de baixa renda e, o que é mais comum, a difusão de formas de controle do território pelas chamadas milícias.

Mas a favela também foi convertida em inimiga da cidade em um sentido mais geral: seu crescimento exponencial é tratado como ameaça à paisagem e ao meio ambiente; a favelização, supostamente, afugentaria os negócios, as empresas e o turismo. Por fim, além de corporificar a representação difusa de violência urbana, a favela ameaçaria ainda a moralidade pública, do que seria expressão a sua associação aos chamados funks proibidões, que, segundo se diz, fazem apologia ao uso de drogas e ao sexo irresponsável.

Notável, portanto, que a forma urbana favela, que deixou de ser apenas forma para se converter em representação social desde o início da República Velha, quando se afirmava no país, em especial no Rio de Janeiro, um ideal excludente de cidade - caro à França da Belle Époque, que surge após a repressão aos operários da Comuna de Paris -, se transforma em verdadeira obsessão carioca, deslocando o debate do direito à cidade para uma espécie de luta contra (ou a favor) da favela (Valladares, 2005; Burgos, 1998). Daí se segue, quase que inevitavelmente, uma responsabilização individualizada dos moradores da favela diante do que seria a decadência da cidade, e uma tendência bastante acentuada de criminalização do favelado.

Por seu turno, a vida associativa das favelas, quando consegue sobreviver ao avanço das gangues de traficantes e milicianos ${ }^{6}$ que arrasam sua sociabilidade, tende a adotar uma perspectiva hiperlocalista na sua luta pelo direito à cidade, particularizando de tal maneira sua ação política que, no limite, a própria ideia de cidade desaparece, dando lugar a uma territorialização generalizada que fragmenta a cidade em mil pedaços, cada qual buscando um caminho próprio às fontes de acesso à política, a fim de conquistar bens coletivos de primeira necessidade (Burgos, 2005). ${ }^{7}$

\footnotetext{
${ }^{6}$ Os termos milícia e miliciano foram adotados pela grande mídia do Rio de Janeiro e consagrados pela Comissão Parlamentar de Inquérito das Milícias, instaurada em 2008 pela Assembleia Legislativa do Rio de Janeiro. Tais termos têm sido utilizados para qualificar grupos - em geral compostos por policiais e ex-policiais, bombeiros e ex-bombeiros - que se posicionam como verdadeiros donos do território, impondo regras e normas às favelas que se encontram sob o seu domínio.

${ }^{7}$ A lógica da fragmentação é tão radical que se manifesta até mesmo no interior das favelas. Dados colhidos em pesquisa de campo que, mesmo em comunidades relativamente pequenas e que, para todos os efeitos, pertencem à mesma favela, as fronteiras são sempre lembradas e avivadas por lideranças locais e por moradores. Assim é o caso, por exemplo, das favelas do Cantagalo e do PavãoPavãozinho, em Copacabana, nas quais os moradores do Cantagalo fazem questão de se diferenciar dos do Pavão-Pavãozinho. 0 mesmo se aplica ao Borel e à Casa Branca, localizadas na Tijuca: moradores do Borel têm reclamado que a Casa Branca tem sido privilegiada pelas ações recentes do poder público (Agradece-se, aqui, a contribuição dos pesquisadores Mauro Amoroso e Luiz Fernando Almeida Pereira). Longe de ser especificidade dessas áreas, a lógica fragmentadora recorta o território da esmagadora maioria das favelas.
} 
Assim, se de um lado a questão da favela se reduz à questão da comunidade A ou B, não encontrando via de tradução em uma abordagem mais geral, de outro lado, a favela captura quase completamente a questão urbana, deixando invisíveis e desarticulados os outros espaços urbanos populares, também seduzidos pela prática de acusação à favela. Em suma, ao menos no Rio de Janeiro, a favela - ou melhor, cada favela, e, a rigor, cada pedaço de favela - ocupa quase completamente o espaço da questão urbana, inibindo a formação de uma perspectiva mais universal de luta pelo direito à cidade. Desse modo, moradores de um bairro popular empobrecido como é Olaria, por exemplo, se percebem profundamente distantes dos moradores do Complexo do Alemão - do qual é vizinho - como se houvesse entre eles uma diferença que, no limite, tornasse completamente impossível defenderem uma agenda comum. Ou, para citar outro exemplo, moradores do Conjunto Habitacional da Cidade Alta se sentem totalmente apartados dos das favelas do Cordovil, malgrado reconhecerem sua origem e seus problemas comuns.

Difícil imaginar regime urbano mais afável à lógica conservadora da modernização brasileira. Mas, nesse caso, o efeito sobrevive ao fim de sua causa. Esgotada a modernização conservadora, a lógica da fragmentação segue sendo afável à dominação dos segmentos populares pelo mercado sujo do voto, bem como pelos demais mercados clandestinos - imobiliário e de serviços, incluindo os serviços de segurança.

É verdade também que nas principais metrópoles brasileiras o direito à vida urbana que a cidade propicia assumiu para o mundo popular o status de "bem entre os bens", na conhecida expressão de Lefebvre (2006: 16). E, de fato, na perspectiva de seu uso, é o segmento popular que utiliza o transporte público, a rede pública hospitalar e a escola pública; mas ainda falta ao segmento popular conquistá-la politicamente. E, agora, a forma favela, antes funcional como alternativa possível de acesso à cidade em uma sociedade marcada pela hierarquia, deverá se transformar em um obstáculo, em uma camisa de força que precisará ser superada pelo mundo popular. Em suma, a implosão da favela como categoria da luta urbana se apresenta como o grande desafio político para o movimento de democratização do acesso à cidade.

Trata-se, portanto, de conceber uma nova imaginação de cidade, na qual as formas urbanas deixem de capturar e interditar o debate público relativo ao direito à cidade. Mas, para avançar nesse debate, torna-se necessário levar a sério a suposta singularidade da favela. Disso depende, afinal, a elaboração de novos artefatos conceituais para a superação dos efeitos produzidos pela reificação das formas urbanas. 
Sobre a Singularidade da Favela

Como definir a singularidade da favela? Esta tem sido uma questão recorrente, e diversos esforços têm sido realizados a fim de respondê-la. Pois, se a categoria favela está sobrecarregada com diferentes representações - às vezes positivas, e quase sempre negativas -, seria preciso encontrar uma forma de defini-la que não se deixasse contaminar por essas mesmas representações.

Em 2009, o Observatório de Favelas realizou o seminário "O que é favela, afinal?", e o material com as intervenções dos pesquisadores convidados foi reunido em livro sob o mesmo título. Na síntese das diferentes perspectivas nele apresentadas seus organizadores apontaram as seguintes características como definidoras das favelas:

1 - território caracterizado pela incompletude histórica de políticas e de ações do Estado, e onde faltam garantias de efetivação de direitos sociais; 2 - território onde os investimentos do mercado formal são precários, especialmente o imobiliário, o financeiro e o de serviços;

3 - território onde as edificações são predominantemente caracterizadas pela autoconstrução, não considerando os padrões urbanos normativos do Estado;

4 - território que abriga presença expressiva de negros (pretos e pardos). (Silva et al., 2009: 96-97)

Como não podia deixar de ser, a síntese proposta é bastante abrangente, contemplando diferentes dimensões, nenhuma delas na verdade exclusivas de uma forma urbana específica. Portanto, o resultado do esforço inédito de se reunir um conjunto representativo de especialistas, e de se tentar encontrar um denominador comum entre as diferentes abordagens, só faz reforçar a constatação da impossibilidade de se isolar algum ou alguns aspectos objetivos que efetivamente singularizem a favela.

De fato, qualquer que seja a dimensão que se eleja, sempre se terá que conceder que esta não é uma singularidade da favela. A informalidade do uso do solo ou a relação jurídica com a habitação, a morfologia e a tipologia das construções, ou o perfil socioeconômico de sua população, enfim, nenhuma característica resiste a um teste empírico. Nas grandes cidades brasileiras, boa parte das habitações encontra-se na informalidade; inversamente, nem todas as habitações de favelas estão na informalidade (Pereira da Silva, 2009). Quanto à morfologia urbana, pedaços de conjuntos habitacionais, de loteamentos e até de bairros populares muitas vezes se confundem com espaços considerados como favelas; quanto à 
tipologia da construção então, nem se discute, afinal, as favelas são hoje quase totalmente de alvenaria; com relação ao perfil socioeconômico, não apenas os pobres não vivem exclusivamente nas favelas, como elas próprias apresentam um grau razoável de estratificação socioeconômica.

Entretanto, se a categoria favela não é uma descrição de características objetivas do espaço, e sim um amálgama de representações, então uma forma de fugir da armadilha levantada pelo problema é justamente a de tomar como ponto de partida o próprio domínio das representações. ${ }^{8} \mathrm{O}$ que há de comum, por exemplo, quando alguém utiliza o verbo favelizar? O que se pretende dizer quando se acusa alguém de se comportar como favelado? É possível sustentar que o elemento comum contido no sentido que se empresta ao uso de tais palavras é o da ausência - completa ou parcial - de ordem pública, de uma ordem cujas regras sejam coletivamente compartilhadas e, em última instância, sancionadas pelo Estado.

Como será visto adiante, em uma sociedade baseada no princípio do Estado Democrático de Direito, tais regras somente podem emanar do Direito Constitucional. Nesse sentido, é possível não ser mera coincidência que a difusão do uso da palavra favela, com a polissemia que a caracteriza, tenha ocorrido justamente a partir da instauração da ordem democrática. Quanto mais se afirma o Direito Constitucional como instância fundamental de orientação dos costumes e da moralidade, mais se nota sua ausência. Além disso, palavra favela é forte candidata à condição de termo escolhido pelo senso comum para identificar essa lacuna.

Quanto mais um determinado território popular é regulado por regras construídas e sancionadas por autoridades informais locais, mais ele é caracterizado como favela e mais essa representação informa a conduta dos indivíduos e atores políticos e sociais. Isso é o que faz com que diferentes aglomerados habitacionais populares, como é o caso dos conjuntos habitacionais, possam ser redefinidos como favelas. Desse modo, favelizar e desfavelizar passam a ser verbos que remetem a uma percepção do tipo e do grau de regulação jurídica das dinâmicas urbanas.

Como se sabe, historicamente a favela teve diferentes tipos de donos e mandões, do que é exemplo o chamado dono do relógio; ${ }^{9}$ assim, o tráfico, e mais recentemente

\footnotetext{
${ }^{8}$ Somente dessa forma é possível escapar aos dogmas que, segundo Lícia Valladares (2005: 148 e seguintes), têm sido compartilhados pela maior parte dos pesquisadores sobre favelas, a saber: 0 dogma da especificidade da favela; 0 dogma da favela como o locus da pobreza; e o dogma da unidade da favela.

${ }^{9}$ Conhecido personagem das favelas cariocas, o dono do relógio era, em geral, um morador da localidade que recebia da concessionária de energia elétrica (Light) a prerrogativa de controlar o uso da energia elétrica e seu acesso pelos demais moradores.
} 
a milícia, se distinguem das formas de mando anteriores menos pelo lugar que ocupam, e mais pela extensão do exercício violento de poder sobre o território e sua população. Porém, é bem provável que esses donos do lugar nunca tenham exercido seu domínio sem a ajuda e cumplicidade de outros agentes da vida da cidade - além, evidentemente, da omissão das autoridades públicas. Atuando com os donos do lugar encontram-se: lideranças que muitas vezes se apropriam da associação de moradores e as ditas ONGs locais; políticos e suas máquinas de extração de voto; especuladores imobiliários; e empresários de diferentes ramos de negócios. Todos estes atraídos pela brecha de oportunidade para auferir lucros extraordinários, obtidos graças a mecanismos como informalidade do trabalhador, ausência de impostos, e, para alguns bens e serviços, falta de concorrência. Não é difícil deduzir que, para os donos do lugar e para aqueles que se alimentam da informalidade da favela, a inexistência de ordem pública é muito bem-vinda.

O resultado é que quanto mais a favela se encontra politicamente isolada do restante da cidade, mais a liderança de cada favela se esforça para diferenciá-la das demais, mais sua vida associativa se fragiliza. Assim, se mostra cada vez mais difícil reverter tal situação. É nesse contexto - em que a lógica fragmentada e recessiva de relação da favela com as instituições da cidade se combina com a ação violenta de gangues de traficantes e de milicianos - que a recente experiência de policiamento ostensivo nas favelas do Rio de Janeiro, conhecida como Unidades de Polícia Pacificadora (UPPs), ${ }^{10}$ demonstra ser particularmente importante para a discussão que aqui se coloca.

Para os propósitos deste capítulo, o que interessa não é tanto discutir especificamente essa política pública, mas, sobretudo, chamar a atenção para o fato de que ela acena para uma possibilidade que ainda desafia nossa imaginação, a saber: o fato de que, pela primeira vez desde a redemocratização do país, um razoável número de favelas do Rio de Janeiro poderá viver sem a presença ostensiva de traficantes ou de outras formas de donos do lugar. ${ }^{11}$

Vale lembrar, com Angelina Peralva (2000), que a redemocratização, paradoxalmente, coincide com a explosão da violência urbana nas grandes cidades brasileiras, fenômeno que atinge em cheio as favelas cariocas. Portanto, para a

\footnotetext{
${ }^{10}$ As UPPs fazem parte de uma política promovida desde dezembro de 2008 pelo governo do estado do Rio de Janeiro, cuja finalidade é a ocupação ostensiva e permanente de algumas favelas pela Polícia Militar. Seu objetivo oficial é o de libertar esses territórios do poder exercido por grupos de traficantes armados.

${ }^{11}$ À época da conclusão deste capítulo, um total de 17 favelas da cidade, boa parte localizada nas zonas sul e norte, haviam sido ocupadas pelas UPPs. Sem contar com a Vila Cruzeiro e o Complexo do Alemão, estas já sob o domínio das forças militares. Ao que tudo indicava, naquele momento esse tipo de política pública seria progressivamente estendida a diversas outras favelas da cidade.
} 
discussão aqui proposta, é bastante desafiador pensar nessa coincidência entre o processo de decantação da Constituição de 1988 e a ausência de opressão do tráfico. Quais as prováveis consequências poderia isso trazer para o desejado processo de unificação de moradores de diferentes espaços urbanos em torno da luta pelo direito à cidade? De que modo essa nova e promissora situação poderia repercutir na redução do isolamento da favela? Especular sobre tal questão pressupõe, contudo, que se enfrente a questão de fundo das favelas, relacionada ao problema da ausência de ordem pública. Somente a partir dela é que será possível conjecturar sobre o legado que a experiência das UPPs poderá produzir para a luta pelo direito à cidade.

\section{A Ordem Pública na Favela}

A exclusão do acesso à ordem pública talvez seja a pior das privações que atinge as populações das favelas, uma vez que ela compromete os padrões de sociabilidade ao produzir incerteza quanto ao comportamento da vizinhança; compromete as relações mercantis, expondo sua população à selva da ausência de regulação dos apetites; cerceia seu acesso à política, submetendo-a a máquinas especializadas em atuar como intermediárias entre os territórios populares e o poder público; e, muito especialmente, a deixa indefesa diante do Estado e seu braço armado.

Nos territórios ocupados por gangues de traficantes ou de milicianos a situação é naturalmente mais complexa. Se de um lado a presença de tais grupos armados é fruto de uma história de exclusão desses territórios da ordem pública - vale dizer, do direito à ordem pública -, de outro, tanto o tráfico quanto a milícia passam a ser agentes produtores de padrões próprios de exclusão, os quais acabam por conferir sentido a um senso comum que opera com uma imagem difusa de que as favelas são espaços produtores de violência.

Não por acaso, tem sido uma preocupação central da sociologia e da antropologia da favela separar as condições objetivas do cotidiano desses territórios das representações a seu respeito. A equipe liderada por Luiz Antonio Machado (2008) realizou um importante esforço nessa direção, tendo concluído que a adesão à "...sociabilidade violenta se caracteriza antes como submissão que como subordinação", e que "as populações mais diretamente afetadas [pela sociabilidade violenta] continuam a viver uma vida 'normal', porém à custa de uma enorme atenção e um diuturno esforço adicional destinado a garantir a continuidade das rotinas permanentemente ameaçadas..." (Machado, 2008: 45). 
Daí deduz-se não ser verdade que a convivência com grupos armados que desafiam o monopólio da violência legítima do Estado, ditando e sancionando regras sob seu domínio, produza uma espécie de cultura da violência, que, no limite, forjaria uma subjetividade violenta. E é exatamente pela forte tendência do senso comum de operar com tal percepção que a observação de Machado se torna fundamental. ${ }^{12}$

Disso não se segue que a longa convivência com o tráfico/milícia não tenha aprofundado o fosso entre as favelas e a ordem pública, inibindo sua vida associativa e, com isso, a liberdade civil necessária para a sua participação nos fluxos de produção de opinião e de conversão de demandas e interesses em direitos. Tampouco significa que a crescente inserção no mercado consumidor fenômeno nacional e com incidência recente no mundo popular brasileiro - não tenha favorecido o desenvolvimento de um individualismo menos protegido pela ordem pública, e menos treinado para valorizá-la. Com efeito, sem deixar de reconhecer o enorme esforço feito por muitas lideranças comunitárias de, apesar de tudo, atuar civicamente nos territórios, não seria exagero afirmar que o que mais tem prosperado como contraponto societal à cultura do mercado nos territórios populares são as comunidades religiosas erigidas em torno de igrejas, católica e evangélicas, as quais, por isso mesmo, acabam por exercer papel hipertrofiado na sua sociabilidade, ocupando domínios que deveriam estar a cargo de outras instituições. ${ }^{13}$

Considerando que em uma sociedade democrática, a ordem pública significa regulação com base no Direito e dos direitos, e que estes devem ser elaborados por meio de ampla participação da sociedade, o quadro que se observa nas favelas é que nelas não falta apenas Estado, mas, também, sociedade.

Tem-se plena ciência de que tal observação nada tem de tranquila. Ela remete a um importante debate sobre os efeitos na sociabilidade popular das mudanças em curso na vida brasileira, tendo como base seus dois principais vetores: de um lado, a forte chegada do mercado no mundo popular; de outro, a decantação do direito constitucional. Esses dois fenômenos recentes da vida

\footnotetext{
12 Evidência forte dessa percepção do senso comum foi encontrada em pesquisa com professores do ensino fundamental que trabalham com crianças e adolescentes moradores de favelas. Com base na análise do material-levantado, chegou-se a uma formulação conclusiva: "construída de modo irrefletido, e por isso mesmo com poderoso efeito sobre suas representações [dos professores], a ideia difusa de que existe uma cultura da violência na favela mobiliza, em favor do argumento, a presença objetiva do tráfico, não tanto para explicar a existência dessa mesma cultura, mas para reafirmar suas próprias razões" (Burgos, 2009: 75).

${ }^{13}$ Este autor tem defendido que essa situação torna ainda mais relevante o papel institucional a ser jogado pelas escolas públicas (Burgos, 2008a).
} 
brasileira, e mais a aguda manifestação da sociabilidade violenta nos territórios populares, produziram impactos contraditórios na vida popular, desfigurando a sociabilidade de tipo comunitária que com frequência se atribuía à favela. Ainda que se reconheça a fertilidade desse debate, não se pretende dar prosseguimento a ele aqui, mas tão somente anotar que o direito à ordem pública pressupõe uma sociabilidade capaz de contemplar o individualismo de novo tipo que tem emergido no mundo popular como consequência da agenda de fortalecimento e ampliação dos direitos civis e políticos.

Com base no argumento sustentado neste capítulo seria, no entanto, contraditório pressupor que a fragilidade do direito à ordem pública seja uma singularidade da favela. Ao contrário, entende-se que ela se espraia com maior ou menor intensidade pelas outras formas urbanas, em todas as metrópoles brasileiras, constituindo-se, por isso mesmo, num sério desafio ao processo de afirmação da democracia de 1988: o regime urbano desafia a ordem constitucional.

Quanto à experiência das UPPs, esta faz (uma vez mais) das favelas cariocas uma espécie de laboratório, cujo desfecho interessa à forma pela qual a democracia brasileira conseguirá equacionar o ordenamento constitucional de 1988 com regimes urbanos reacionários, inercialmente legados da modernização conservadora. ${ }^{14} \mathrm{O}$ que está em jogo, afinal, é como fazer para que o Direito e os direitos possam nortear a participação do mundo popular na vida da cidade: no plano da sociabilidade - que atravessa sua família, vizinhança e os espaços coletivos que frequenta -, na sua relação com o mercado e na sua relação com a política.

As UPPs ainda são uma experiência em aberto, a qual pode assumir sentidos diversos daqueles originalmente previstos por seus mentores e gestores. Por um lado, ao atacar o sistema de mando prevalecente nas favelas subjugadas pelo tráfico, as UPPs assumem um caráter emancipador que não pode ser negado. Por outro lado, a adoção de um policiamento de proximidade especial, baseado em uma forte ostensividade, não deixa de denunciar o fracasso de instituições intermediárias capazes de realizar a passagem da vida privada para a vida pública. ${ }^{15}$ E mesmo que venha a emancipar as favelas do jugo do tráfico, isso não garante -

\footnotetext{
${ }^{14}$ Talvez não seja excessivo lembrar aqui a já clássica passagem do pequeno texto escrito por Pierre Bourdieu, intitulado "Efeitos do lugar", em seu livro A Miséria do Mundo: "Uma parte da inércia das estruturas do espaço social resulta do fato de que elas estão inscritas no espaço físico e que não poderiam ser modificadas senão ao preço de um trabalho de transplantação, de uma mudança das coisas e de um desenraizamento ou de uma deportação de pessoas, as quais suporiam transformações sociais extremamente difíceis e custosas" (Bourdieu, 1997: 161).

${ }^{15} \mathrm{~A}$ proporção de policiais por moradores é um bom indicador do grau de ostensividade das UPPs. Em algumas favelas - como, por exemplo, Chapéu Mangueira/Babilônia, situada na zona sul do Rio de Janeiro, chega a ser a de um policial para cada sessenta moradores.
} 
em condições normais, a policialização dos espaços populares costuma ter efeito contrário - a construção de uma vida social mais autônoma e participativa, não assegurando, portanto, o direito à ordem pública.

O grande dilema da experiência das UPPs é o de como fazer com que uma intervenção concebida pelo Estado, sem participação social, seja convertida em ponto de passagem para o fortalecimento da sociedade civil. Nesse cenário, o horizonte desejável é aquele em que o espaço aberto pelas UPPs seja ocupado não apenas pelo Estado, mas também pela sociedade civil. Somente com ela, e com um conjunto de instituições intermediárias, será possível instaurar uma dinâmica capaz de acelerar a transformação do Direito e dos direitos em moralidade. Sem isso, a nova ordem pública não poderá se consolidar, permanecendo como um conjunto de forças externas à sociabilidade. Converter Direito e direitos em moralidade significa fazer deles a única fonte aceitável para nortear o comportamento cotidiano dos indivíduos e dos atores sociais, econômicos e políticos. No fundo, pode-se afirmar que ter direito à ordem pública significa ter direito a conviver com vizinhos e com atores coletivos que se orientem por uma moralidade lastreada pelos valores e regras constitucionais.

A relação entre o direito constitucional e a moralidade é tema de primeira grandeza para pensar o futuro da democracia no Brasil. Apenas para apontar sua extensão, bastaria a lembrança dos conflitos existentes entre o direito constitucional e a moralidade religiosa, especialmente aquela identificada com expressões mais radicais e sectárias do cristianismo, que têm tido grande penetração na vida popular. Não obstante reconhecer sua importância para a sociologia dos territórios populares, não será possível iniciar neste texto tal discussão. Aqui, a abordagem dessa questão será bem mais modesta e focalizada, invocando especificamente o debate a respeito do papel que as chamadas agências de proximidade poderão jogar nesse momento de transição de regimes urbanos ainda mergulhados em uma ordem autoritária para uma ordem pública democrática que, afinal, possa estar fundada em uma moralidade compatível com os valores e regras constitucionais.

\section{Agências de Proximidade e a Construção de uma Nova Ordem Pública}

São precisas as palavras de Bocayuva (2009), quando afirma que

a gestão social pública inovadora quando articulada com as redes de cooperação horizontal entre as populações presentes nos territórios 
podem fortalecer o potencial de transformação endógena presente no espaço local (...) A unificação das ações, a valorização do capital social local, a identificação das interações e redes de comunicação, intercâmbio e informação entre as favelas e o conjunto da cidade exigem uma nova forma de abordagem das políticas públicas territorializadas. (Bocayuva, 2009: 10)

É particularmente importante trazer ao debate experiências que têm por tônica a descentralização da construção de marcos regulatórios da sociabilidade, como no caso da onda de inovação institucional desenvolvida na França com base na ideia de uma justiça de proximidade.

No início dos anos 1990, diante do crescente sentimento de insegurança, associado à ocorrência de uma série de conflitos envolvendo sobretudo jovens pobres, moradores dos subúrbios e periferias de Paris e de outras grandes cidades, o governo francês resolve apostar em inovações institucionais com o objetivo de aproximar o Direito e suas instituições do cotidiano dos moradores das áreas consideradas críticas - les quartiers sensibles -, criando as Maisons de Justice et Droit (MJD). As primeiras MJD são instaladas ainda em 1991, e sete anos depois o governo aprova lei inscrevendo-as no código de organização judiciária francês.

A comparação entre a justiça de proximidade francesa e a polícia de proximidade norte-americana, feita por Anne Wyvekens (2001), traz relevantes elementos para a reflexão. A autora organiza sua comparação constatando que nos anos 1990, tanto na França quanto nos EUA, as irrupções juvenis nas periferias e nos bairros problemáticos despertaram um crescente sentimento de insegurança fortemente associado ao descontrole do espaço urbano, dando ensejo a respostas com objetivos até certo ponto convergentes, mas fundadas em procedimentos diferentes.

Na França, observa Wyvekens, a degradação do espaço urbano é percebida como sintoma do abandono por parte das instituições públicas estatais, percebidas como muito distantes e pouco presentes na vida cotidiana, ao passo que nos EUA a degradação dos espaços públicos remete a uma concepção cara à ecologia urbana. Na França, a ênfase na questão da restauração da sociabilidade conduz a uma aposta na pedagogia do Direito como recurso capaz de restaurar a confiança nas instituições. A MJD é, nesse caso, a criação institucional mais significativa. Já nos EUA, a tônica tem sido a da reforma da polícia, presente tanto na experiência da tolerância zero em Nova York, quanto na do policiamento comunitário desenvolvida em Chicago. O controle sobre o espaço público é seu alvo e a intervenção da polícia é respaldada e amplificada mediante a criação de canais de diálogo com as comunidades. 
No caso dos EUA, portanto, está em jogo a ideia de que a ordenação do espaço urbano fomentaria a regeneração de uma cultura cívica perdida, enquanto o braço coercitivo da polícia exprimiria a vontade da coletividade organizada, reduzindo ou até mesmo eliminando a possibilidade de conflito. Na França, diversamente, a justiça de proximidade remete ao projeto de articulação entre as instituições de socialização, visando a uma construção coletiva e consensuada de regras de convivência. Em suma, se no primeiro caso o recurso à polícia denota que o objetivo central é o de conferir efetividade ao Direito já existente, no segundo a rede de proximidade pretende funcionar como canal de construção coletiva de regras de convívio.

Assim, se em ambos os casos está em jogo o problema da sociabilidade violenta projetada no espaço urbano e se, igualmente em ambos os casos, as soluções buscadas propõem-se a criar novas formas de atuação sobre a vida local, no caso francês percebe-se a ênfase em uma juridificação da sociabilidade tendo por base a articulação entre o Direito e instituições da vida local que atuam na vida cotidiana. Já no modelo norte-americano, aposta-se em uma juridificação de caráter repressivo, sustentada pela articulação entre a polícia e os grupos organizados da localidade contra aqueles que seriam identificados como estranhos à comunidade.

Em linhas gerais, pode-se dizer que, tal como concebida na França, a justiça de proximidade tem por finalidade aproximar o Direito da vida local, abrindo, assim, novos canais de comunicação entre o particularismo da vida local e o universalismo republicano. Trata-se de um dos muitos recursos institucionais que têm sido experimentados perante os efeitos do esvaziamento do Estado welfareano, com a precarização das relações de trabalho e a crescente erosão da legitimidade de instituições sociais, entre as quais especialmente a escola. Como no conhecido argumento de Antoine Garapon, as instâncias produtoras de solidariedade social mergulharam em uma profunda crise, e "o direito convertese na última instância da moral comum em uma sociedade desprovida dela" (Garapon, 1996: 141).

Apesar de apresentar significativas variações em cada localidade - com o que, aliás, denotam sua porosidade diante das especificidades locais -, as MJD oferecem, de acordo com Wyvekens (2001), basicamente dois tipos de serviços, os quais pretendem favorecer o acesso ao Direito e a seus profissionais. São eles:

- administração de conflitos cíveis da vida cotidiana e de pequenos delitos criminais - incluindo os praticados por menores de idade -, por meio do julgamento, da mediação, da conciliação e da composição; 
- assistência jurídica ampliada, que vai desde a simples prestação de informações até a formação de redes voltadas para a difusão de uma pedagogia de direitos e de auxílio às vítimas de violência.

A fim de aprofundar o acesso ao Direito, interessantes iniciativas têm sido desenvolvidas no interior das MJD. Dentre estas encontram-se os ateliês da cidadania - experimentos coletivos que, de acordo com Joëlle Bordet (2001), aproximam dos magistrados e promotores outros profissionais das instituições atuantes na vida local: a polícia, as escolas e os serviços públicos municipais, além de pesquisadores, animadores culturais e lideranças da vida associativa. Dessa mobilização social tem surgido uma série de iniciativas concretas, como a formação de grupos de discussão, a produção de diagnósticos sobre a relação dos jovens com a lei, publicações voltadas para a troca de informações entre os atores locais, entre outras. Na avaliação de Bordet, tais iniciativas teriam resultado em ganhos significativos para a construção de novos consensos e de referências comuns formuladas em torno dos textos jurídicos, "contribuindo fortemente para a reinserção social e profissional dos jovens" (Bordet, 2001: 39).

A justiça de proximidade constitui-se, portanto, em marcante experiência de inovação institucional na civil law tradition, ${ }^{16}$ ao buscar superar o "fosso secular existente entre os profissionais do Direito e os sujeitos de direito" e ao transcender os limites do Direito codificado, apostando na ampliação das vias de construção consensual do Direito, por meio da mediação e da conciliação, e em coletivos cuja base é o Judiciário (Peyrat, 2001: 77).

Quando se pensa na realidade brasileira, é possível sustentar que não faltam instâncias de proximidade em nossa ordem jurídica, política e social (Burgos, 2008b). A começar pela escola pública, que, se fortalecida, pode desempenhar extraordinário papel de aproximação entre o direito e a sociabilidade popular, contribuindo para a tradução do direito em moralidade. As instituições judiciais e processuais, como os juizados especiais, as ações civis públicas e a rede de proximidade criada pelo Estatuto da Criança e do Adolescente são também instâncias que já fazem parte da vida ordinária brasileira, e já produzem um aprendizado institucional. No entanto, ainda se trata de um saber difuso e inarticulado, incapaz de suportar a organização de uma política de proximidade nos moldes do que se vem ensaiando há mais de duas décadas em alguns países da Europa. Mas tais experiências, ainda atomizadas e desenvolvidas por agências

\footnotetext{
${ }^{16}$ Denominação consagrada por estudiosos do direito comparado para distinguir os países cuja cultura jurídica deve aspectos fundamentais de sua tradição ao direito civil romano, em especial sua forma codificada, de países que têm um direito com forte presença da tradição consuetudinária e do uso do precedente, a common law tradition.
} 
que atuam de forma muito focalizada, se melhor articuladas poderão prestar grande serviço no aprofundamento de uma cultura de direitos e da cidadania participativa.

A instalação do Centro Judiciário do Complexo do Alemão e da Penha (inaugurado em 22 de julho de 2011) é uma importante iniciativa nessa direção. Instituído em parceria com o Ministério da Defesa, o governo do estado do Rio de Janeiro, a Defensoria Pública Estadual e os tribunais de Justiça Comum, Eleitoral, Federal e do Trabalho, o projeto oferece, em um mesmo local, acesso da população a todos os ramos do Poder Judiciário. ${ }^{17}$ Candidata-se, assim, a proporcionar uma aproximação dos moradores de toda aquela região com o Direito e os direitos, abrindo caminho para a organização de um ambiente institucional favorável à formação de uma nova ordem pública.

\section{A Luta pela Cidade}

Ao longo deste capítulo, pretendeu-se sustentar que as metrópoles brasileiras, e de modo específico o Rio de Janeiro, ainda estão mergulhadas em um regime urbano construído em um contexto de modernização conservadora, o qual tem resistido e reagido às transformações pelas quais tem passado o país. E um dos efeitos desse regime urbano foi justamente o da fragmentação da questão urbana em lutas particularizadas, homólogas ao que seriam as especificidades de cada forma urbana. Assim é que favelas, loteamentos, conjuntos habitacionais e bairros populares construíram caminhos próprios e excludentes de luta pela cidade, supervalorizando suas diferenças e especificidades, sendo a maior evidência desse processo o isolamento político das favelas.

Paradoxalmente, o protagonismo das favelas capturou a questão urbana, o que contribuiu para desarticular os demais segmentos populares na luta pelo acesso à cidade. Contudo, o próprio avanço da urbanização das favelas, por um lado - conseguido à custa de sua enorme submissão política -, e de outro, a decadência dos conjuntos e bairros populares - resultado de sua baixa capacidade de organização -, tornam cada vez mais parecidas as suas condições objetivas.

\footnotetext{
${ }^{17}$ Consoante com 0 argumento aqui sustentado na solenidade de inauguração do Centro, o ministro da Defesa, Nelson Jobim, afirmou: "A pacificação de uma população não se restringe apenas à atividade policial. Esse é um início de um processo. A introdução da cidadania plena num Estado social passa, seguramente, pela presença do Poder Judiciário. Não um Poder Judiciário de toga e beca, que não dialogava e se enxergava intocável quanto às necessidades do país. Mas de um Poder Judiciário que se põe a serviço da nação". Disponível em: <www.conjur.com.br/2011-jul-22/centro-judiciario-complexo-alemao-inaugurado-rio-janeiro>.
} 
Torna-se plausível, assim, defender a adoção de uma perspectiva comum de direito à cidade que, em vez de operar com as supostas singularidades das formas urbanas, traga para o primeiro plano a agenda comum de luta pela cidade. Todavia, considerando a força da forma favela na nossa imaginação de cidade, é inevitável enfrentar a discussão sobre a sua suposta singularidade. Não há novidade ao se afirmar que nenhuma tentativa de descrever a especificidade da favela com base em características objetivas da forma urbana resiste a um teste empírico, já que nenhuma delas é exclusiva da favela. Consequentemente há a necessidade de se deslocar o foco para o estudo das representações sobre a favela, procurando identificar o que nelas subsiste como elemento comum. Conclui-se, então, que o núcleo duro das representações sobre a favela é a identificação da ausência de ordem pública, que estaria se tornando mais evidente à medida que o direito constitucional se torna mais presente na vida brasileira: quanto maior sua importância, maior a percepção de sua falta. $\mathrm{E}$ assim, a palavra favela assume cada vez mais o significado de denúncia de falta de ordem pública.

Portanto, construir novos nexos entre a favela e as demais formas urbanas com foco na luta pelo direito à cidade implica considerar os desafios intrínsecos aos processos de construção da ordem pública, isto é, de regulação de comportamentos com base no Direito e nos direitos constitucionais. Desafios, vale dizer, inerentes à penetração dos valores e regras constitucionais em territórios ainda prisioneiros do regime urbano construído no contexto da modernização conservadora. Sob esse aspecto a experiência das UPPs demonstra ser particularmente relevante, pois, na medida em que se propõe a libertar localidades subjugadas por grupos paramilitares que têm produzido e sancionado regras, abre espaço para a indagação sobre como tais localidades poderão construir o direito à ordem pública democrática, a uma ordem pública construída com a participação de seus moradores.

Chega-se, assim, a um desafio que não poderá ser vencido apenas com energia societal, reclamando também a formulação de políticas públicas específicas. Daí o interesse de recuperar inovações institucionais como as realizadas na França acerca da ideia de justiça de proximidade. É que facilitar, estimular e criar âncoras institucionais que promovam a aproximação entre o direito e a moralidade nos territórios populares torna-se fundamental para assegurar que a ordem pública possa ser construída sob bases democráticas.

Caso essa dinâmica adquira força e seja progressivamente apropriada pelos segmentos populares da cidade, as fronteiras ainda tão marcadas entre favelas - seja lá o que isso ainda signifique - e as demais formas urbanas poderão ceder 
terreno para uma agenda de luta pelo direito à cidade, capaz de integrar segmentos que ainda hoje se hostilizam. Favorecer tal processo é favorecer um avanço mais sustentável da democracia de 1988, já que os regimes urbanos reacionários são um dos mais importantes enclaves de resistência à generalização do Estado Democrático de Direito que a Constituição instaurou. 


\section{Referências}

BOCAYUVA, P. C. C. Os riscos da comunidade capturada versus a plataforma da "favelania". Otra Economía, III(5), 2009, Unisinos, Brasil. Disponível em: <www.socioeco.org/bdf_fichepublication-870_es.html>. Acesso em: fev. 2014.

BORDET, J. La Justice de proximité: un enjeu réel et symbolique de la vie sociale. Revue Droit et Cultures, 3: 31-41, 2001.

BOURDIEU, P. (Coord.). A Miséria do Mundo. Petrópolis: Vozes, 1997.

BRUM, M. S. I. Cidade Alta: história, memórias e estigma de favela num conjunto habitacional do Rio de Janeiro, 2011. Tese de Doutorado, Niterói: Programa de Pós-Graduação em História Social, Universidade Federal Fluminense.

BURGOS, M. B. Dos Parques Proletários ao Favela-Bairro: as políticas públicas nas favelas do Rio de Janeiro. In: ZALUAR, A. \& ALVITO, M. (Orgs.). Um Século de Favela. Rio de Janeiro: Editora FGV, 1998.

BURGOS, M. B. Cidade, territórios e cidadania. Dados-Revista de Ciências Sociais, 48(1): 189-218, 2005.

BURGOS, M. B. Segregação urbana e institucional: a relação entre as escolas públicas e as favelas. Desigualdade e Diversidade - Revista de Ciências Sociais da PUC-Rio, 2: 81-114, 2008a.

BURGOS, M. B. Políticas de proximidade e sociabilidade violenta: um balanço da experiência brasileira. In: LIMA, R. K. et al. (Orgs.). Reflexões sobre Segurança Pública e Justiça Criminal numa Perspectiva Comparada. Brasília: Secretaria Especial de Direitos Humanos, 2008b.

BURGOS, M. B. Escola e projetos sociais: uma análise do 'efeito-favela'. In: PAIVA, Â. \& BURGOS, M. (Orgs.). A Escola e a Favela. Rio de Janeiro: Editora PUC-Rio, Loyola, 2009.

BURGOS, M. B. A Constituição de 1988 e a transição como obra em progresso. Revista da Emarf, Cadernos Temáticos, 119-128, 2010.

BURGOS, M. B. \& CARVALHO, M. A. R. Manual do diagnóstico social participativo do morar carioca. Rio de Janeiro: Central/PUC-Rio, 2011. (Mimeo.).

CARDOSO, F. H. Autoritarismo e Democratização. 3. ed. Rio de Janeiro: Paz e Terra, 1975.

CITTADINO, G. Pluralismo, Direito e Justiça Distributiva. Rio de Janeiro: Lúmen Júris, 1999.

FERNANDES, F. A Revolução Burguesa no Brasil. Rio de Janeiro: Zahar, 1978.

GARAPON, A. Judiciário e Democracia: o guardião de promessas. Rio de Janeiro: Revan, 1996.

LEFEBVRE, H. Direito à Cidade. São Paulo: Centauro, 2006.

LESSA, R. A Constituição brasileira de 1988 como experimento de filosofia pública: um ensaio. In: OLIVEN, R. G.; RIDENTI, M. \& BRANDÃO, G. M. (Orgs.). A Constituição de 1988 na Vida Brasileira. São Paulo: Anpocs, 2008.

MACHADO, L. A. Violência urbana, sociabilidade violenta e agenda pública. In: MACHADO, L. A. (Org.). Vida Sob Cerco: violência e rotina nas favelas do Rio de Janeiro. Rio de Janeiro: Nova Fronteira, 2008.

PERALVA, A. Violência e Democracia: paradoxo brasileiro. São Paulo: Paz e Terra, 2000.

PEREIRA DA SILVA, M. L. Favela: É geral? É particular? É urbano?. In: SILVA, J. S. et al. (Orgs.). O Que é Favela, Afinal? Rio de Janeiro: Observatório de Favelas, 2009.

PEYRAT, D. Cultiver la faculté de droit. Revue Droit et Cultures, numéro hors série: 57-82, 2001.

RIBEIRO, L.C. Q. Metrópoles, reforma urbana e desenvolvimento nacional. In: RIBEIRO, L.C. Q. \& SANTOS JUNIOR, O. A. (Orgs.). As Metrópoles e a Questão Social Brasileira. Rio de Janeiro: Revan, 2007.

SANTOS, W. G. Cidadania e Justiça: a política social na ordem brasileira. 2. ed. Rio de Janeiro: Campus, 1987.

SILVA, J. S. et al. (Orgs.). O Que é Favela, Afinal? Rio de Janeiro: Observatório de Favelas, 2009. 
UN-HABITAT. Estado das Cidades do Mundo 2010/2011: unindo o mundo dividido. Resumo e principais constatações. Rio de Janeiro: Ipea, 2010.

VALLADARES, L. A Invenção da Favela: do mito de origem a favela.com. Rio de Janeiro: Editora FGV, 2005.

VIANNA, L. W. Liberalismo e Sindicato no Brasil. 2. ed. Rio de Janeiro: Paz e Terra, 1978.

WYVEKENS, A. Proximité et Sécurité: que nous apprend l'Amérique? Revue Droit et Cultures, numéro hors série: 163-179, 2001. 


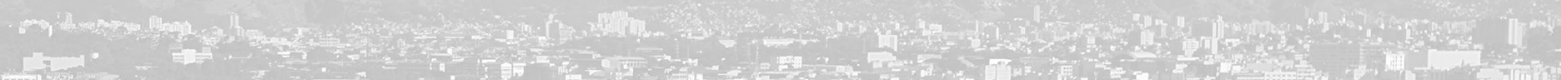
and

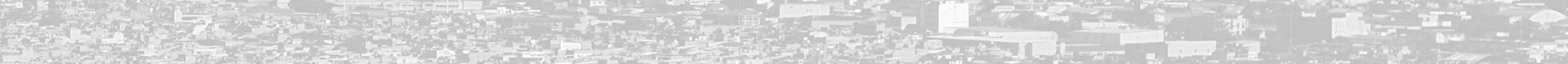

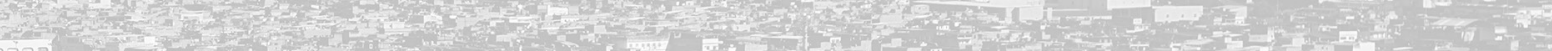

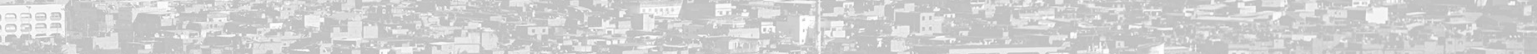

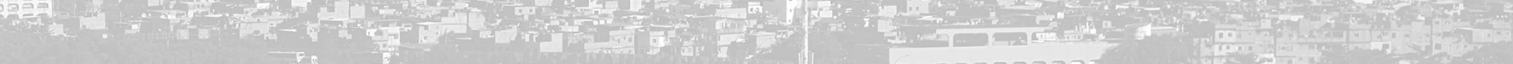

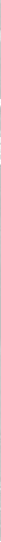




\title{
4 \\ Cidades Saudáveis ou Cidades Justas?
}

\author{
Ana Clara Torres Ribeiro
}

\begin{abstract}
$\mathrm{A}$ s reflexões sobre a temática das cidades saudáveis foram abordadas nos capítulos anteriores sob olhares de distintas origens disciplinares, envolvendo os campos do urbanismo e cultura, da saúde pública em suas diferentes dimensões, além da sociologia e das políticas públicas. Nitidamente entrelaçados com a questão do direito à cidade, tais estudos foram enriquecidos, neste capítulo, pelo pensamento sociológico da professora Ana Clara Torres Ribeiro, vinculado ao campo do planejamento urbano. Com a divulgação das suas concepções, à época ainda em processo de criação, instaurou-se uma inflexão na narrativa desta coletânea, que, no entanto, foi recompensada pela inserção de novos eixos analíticos, direcionados a um complexo debate sobre as grandes cidades contemporâneas. O texto acabado, nos moldes acadêmicos, não pôde acontecer. No entanto, o seu falecimento prematuro não poderia ser razão para suas reflexões serem omitidas.

Assim, este capítulo cumpre dois objetivos essenciais: de homenagear a professora e de explicitar, de maneira não convencional, aspectos do seu pensamento, certamente uma contribuição singular para o tema das cidades saudáveis.

A maneira que se considerou mais adequada para dar conhecimento ao público desta pequena parte do legado da professora foi a publicação de dois textos: aquele escrito como referência para a palestra por ela proferida no Seminário Cidades Saudáveis: desafios e perspectivas e, outro, consubstanciado pela transcrição da própria palestra. Ambos passaram por um processo de revisão
\end{abstract}


técnica, o que resultou na inclusão de subtítulos na palestra transcrita, de notas de rodapé e de referências, em complementação às citações da autora.

Os dois textos se complementam e, juntos, evidenciam sua percepção crítica das ideias contidas na proposta para a mesa Equidade, Participação Social e Sustentabilidade. ${ }^{1} \mathrm{~A}$ ousada análise proporcionada pelo seu olhar desconstruiu a temática proposta - a começar pelo título da mesa - e centrou a atenção nas metas nela previstas. Vale atentar para as suas ideias-síntese a respeito de uma cidade-justa, que seria contraposta à visão de cidade saudável.

O breve comentário ao trabalho de Ana Clara feito por Jorge Campos Valadares, ${ }^{2}$ debatedor da mesma mesa no referido seminário, sublinha aspectos da visão original e humanista dessa pensadora:

Ana Clara, com as agudas e profundas discussões em torno do espaço banal, aquele do cotidiano, advertiu sempre sobre a incompletude dos conceitos, dos modelos, dos módulos, da moda. Trabalhando muito proximamente do professor Milton Santos, e com a noção de território usado, formulou questões sobre a arte de viver a vida, por onde as pessoas vão, com sua criatividade, inventando uma maneira de fazer frente ao infortúnio, aos poderes precários, em um país como o nosso, com toda sorte de dificuldades humanas para imensos setores populacionais, e um país submetido ao que Ana Clara chamou de uma história europeia das cidades e, também, penso eu, ao que seja uma história europeia das urbanidades, da educação.

Ana Clara Torres Ribeiro foi uma pensadora necessária à compreensão do espaço não só da cidade, mas do espaço da vida humana. Sempre nos trouxe um pensamento aberto ao diálogo e uma prática do vamos fazer juntos, fugindo sempre à pretensão de ser modelo. Mestra do convívio, sempre foi disponível ao diálogo e contra saberes herméticos e onipotentes. Sua prática nunca contradisse a sua teoria.

Ana Clara Torres Ribeiro, viva!

As organizadoras

\footnotetext{
${ }^{1}$ Ementa da mesa Equidade, Participação Social e Sustentabilidade: "Nas propostas de cidades saudáveis, a intersetorialidade necessariamente se articula às ações de promoção de saúde e de participação popular e controle social. Na formação das cidades contemporâneas, resultado de um processo histórico, deve-se buscar a equidade e a participação social como ferramentas para uma construção socioambiental sustentável cada vez mais ampla, abrangente e igualitária. Nesse sentido, são eixos fundamentais 0 desenvolvimento de ações intersetoriais voltadas à qualidade de vida que permitam convergir, em um espaço-território singular, políticas públicas como o planejamento urbano, a gestão social, a atenção à saúde, a educca̧ão, a cultura e a qualidade ambiental, dentre outros".

${ }^{2}$ Jorge Valadares foi debatedor na mesa em que Ana Clara participou como palestrante, no Seminário Cidades Saudáveis: perspectivas e desafios - realizado na Fundação Oswaldo Cruz (Fiocruz) no fim de 2010.
} 
Sistemas e Modelos: a construção de paradigmas na reflexão da cidade $^{3}$

\section{Elementos para uma problematização}

Os conceitos, quando externos às circunstâncias da vida e também à percepção dos que deles dependem para a ação, trazem o aprisionamento das ideias, impedindo a compreensão da dupla face da reflexão da transformação social, reconhecida por Henri Lefebvre (1991) - lógica formal/lógica dialética - como movimento do pensamento e pensamento do movimento.

Movimentos que são irrecusáveis pela instabilidade que caracteriza a experiência na (e da) cidade e a grandeza do urbano. Faltam-nos, muitas vezes, palavras para dizer dessa experiência e também conceitos para construir a análise, sobretudo quando a urbanização perde os seus nexos com o desenvolvimento e se transforma num elenco sempre atualizado de problemas e diagnósticos.

Riscos de engessamento da reflexão podem ser reconhecidos, por outro lado, nos consensos. A noção de equidade, que é hoje apresentada como superior à de igualdade, será que não reduz a própria força transformadora da igualdade? A noção de participação, que substitui a práxis e, por fim, a noção de sustentabilidade, que não favorece o reconhecimento de destruições nem do caráter potencialmente insurgente da ação, coexistem em sistemas racionalmente formalizados.

Como disse Gerd Bornheim, os críticos dos sistemas existentes muitas vezes exigem a eficácia sistêmica. Por essa razão, incomodam-se com o que escapa à rotina e à previsão. Com essa atitude mental, recusam o incerto, o tentativo, o parcial e o que pode ser lido como menor ou pequeno. A sustentabilidade é sistêmica, mas se trata de uma qualidade a ser conquistada com relação a qual sistema?

Derivam daí duas consequências. A primeira é o ocultamento da crise do modelo dominante de cidade, que hoje se manifesta como violência e exclusão social, mas que também se manifesta como criatividade e relevantes transformações culturais; e a segunda, o desconhecimento das sistemáticas construídas pela ação social, carregadas de historicidade, de memórias e de formas tentativas de configuração do tecido social e de conquista da autonomia. Desconhece-se, assim, a tenacidade dos vínculos sociais tecidos em espaços e circunstâncias antagônicos.

\footnotetext{
${ }^{3}$ Texto de referência elaborado como texto-guia da palestra proferida por Ana Clara Torres Ribeiro na mesa-redonda Equidade, Participação Social e Sustentabilidade, do Seminário Cidades Saudáveis, organizado pela Fiocruz nos dias 23 e 24 de novembro de 2010.
} 
Entretanto, é justamente a sistematicidade de origem popular que Milton Santos disse que precisaríamos reconhecer, desvendar, fazer crescer e afirmar, abrindo oportunidade para a concepção de futuros alternativos. Um reconhecimento e um desvendamento que, portadores da compreensão da potência da ação coletiva, permitiriam desvendar futuros alternativos.

As resistências ao movimento do pensamento e ao pensamento do movimento são agravadas por metas preestabelecidas. Nessas metas, podem ser reconhecidas tanto a urgência da ação quanto a força de um ordenamento reflexivo preestabelecido e, até certo ponto, rígido. Essa rigidez emerge na citação de modelos que não chegam a orientar efetivamente o desvendamento do real.

O monitoramento de metas, hoje tão ampliado, corresponde a ativismos que substituem a ação social e a reflexão política de largo prazo, criando obstáculos ao diagnóstico ativo da experiência urbana - aquele que é de natureza histórica e dialógica - e, sem dúvida, a formas de participação que estimulem a configuração de coletivos resistentes à programação e à pré-formatação da ação.

Cabe, assim, fazer as seguintes indagações: como e por quais modelos se realiza hoje a reflexão da experiência urbana? Até que ponto os modelos têm deixado de cumprir a sua função científica, que é a de reduzir provisoriamente a complexidade do real para a ela retornar, como a busca do concreto pensado exige? Na ausência desse retorno, como a historicidade pode alterar o modelo, o que deixaria clara a sua função de simples ferramenta?

Essas perguntas se referem a ideários presentes no campo das políticas públicas e no campo dos estudos urbanos, prenhe da influência exercida pelo pensamento formal do urbanismo e do direito e dos modelos que formatam o imaginário.

Antes, o desenvolvimento urbano desejável articulava-se à modernização socioeconômica e à atuação civilizatória do Estado. A urbanização era então compreendida como um fenômeno quase pedagógico, portador de promessas de alcance de ambiciosas metas para o país. Os exemplos superavam, então, o conjunto instrumental das boas práticas e a competitividade que orienta a atual disputa por grandes eventos.

Hoje, no cerne do capitalismo globalizado devorador de commodities, a grande cidade corre o risco de ser reconhecida como uma espécie de novo epicentro do atraso. Afinal, as comunicações transformam os sentidos dos lugares.

No atual período histórico - que também passará, como disse Milton Santos -, retornam as referências ao caos urbano, desacompanhadas dos processos por ele responsáveis. Também se afirmam ideários que aproximam a noção de ordem 
da noção de segurança e da estética clean. Projetam-se, assim, a fragmentação desejada pelos interesses dominantes e a exclusão social.

Na mesma direção, são veiculadas concepções da relação sociedade-natureza que rejeitam o convívio com o outro e as rugosidades do espaço herdado. Com o apoio das novas tecnologias, emerge um cenário marcado pela valorização crescente dos fluxos e da logística territorial; pela formação de uma periferia rica e excludente; e pelo destaque atribuído às cidades médias, portadoras de amenidades, que absorvem funções antes exclusivas das grandes cidades.

Nesse período, o imaginário urbano tem sido nutrido por uma incessante produção cultural que busca moldar o indivíduo e conceber modos de vida, em articulação com desejos, expectativas e ansiedades. Essa produção estimula o abandono do compartilhamento de experiências e a construção de um interclassismo progressista.

Convém, pois, fazer as seguintes indagações: como acontecem, atualmente, os vínculos entre classes médias e classes populares? Qual é o papel desempenhado pelos movimentos culturais na configuração desses vínculos? Quais são os nexos atuais entre movimentos sociais e movimentos culturais?

Em meio à perda de referências para a experiência urbana, observa-se a superficialização das relações sociais, conexa a desafios relacionados à perda de valores e à carência de linguagens efetivamente comuns. Esses processos mergulham suas raízes no próprio tecido social, ultrapassando o Estado e a esfera política.

Nesse contexto, as representações dominantes da cidade e do urbano valorizam os espaços privados e o mercado, mas ultrapassam esses limites quando tais representações são coladas à busca de soluções para a grande cidade, lida agora, quase que exclusivamente, como uma condensação de desafios dramáticos e sufocantes. Uma leitura que corresponde, é claro, aos dados da realidade. Porém, essa leitura também tem servido para legitimar todo tipo de individualismo ou para apoiar saídas especulativas e mercadológicas para os cada vez mais espetacularizados problemas urbanos.

Em tais circunstâncias, constata-se um inesperado convívio entre diferentes ativismos, que se desdobram no espaço urbano herdado e em construção. Entre esses ativismos, estão os que resultam da ação de antigos e novos movimentos sociais e, também, os que resultam de formas de realização das políticas públicas e das corporações.

Essa movimentação do presente possui uma dupla face: de um lado, está a atualização de processos pretéritos, isto é, de determinantes históricos da 
urbanização. De outro lado, está o novo novíssimo, isto é, fenômenos que podem ser reconhecidos como absolutamente novos.

Essas duas ordens de fenômenos convivem no presente, bastando citar, nessa direção, a preservação das hierarquias sociais e das oligarquias e, de outra, os impulsos globais, quais sejam, os processos transescalares da denominada nova economia.

\section{As origens da fala: a ótica de um campo disciplinar}

O olhar que trago para esta mesa é devedor do trabalho de gerações dedicadas à compreensão do fenômeno urbano, respeitosa da sua grandeza, instabilidade e dinâmica. Um fenômeno que, por sua força e escala, sintetiza a capacidade de construção e destruição do capitalismo, constituindo-se no depósito das esperanças e desesperanças que orientaram (e que orientam) projetos de modernização. Um fenômeno que não pode ser apreendido apenas com base em estatísticas ou em representações estáticas da realidade social. Um exemplo dessas características do fenômeno urbano pode ser encontrado na transumância produzida pela modernização, nos anos 1970, do território brasileiro.

A grandeza do urbano também pode ser lembrada através do reconhecimento da Amazônia como região urbana ou da citação da metrópole de São Paulo, na qual, como demonstrou Milton Santos, se condensaram, nas últimas décadas, as consequências sociais e espaciais da urbanização corporativa. Uma condensação que explode como violência, incêndio de favelas, no tempo do deslocamento casa-trabalho, na precariedade dos transportes coletivos, no aumento do número de helicópteros, nas enchentes, nos engarrafamentos e numa irracionalidade que racionalizações, de múltiplas origens, não conseguem controlar.

A efervescência das mercadorias como força propulsora da modernização, desigualmente distribuída no espaço urbano, inscreve-se nas fraturas do espaço banal (Milton Santos) e na surpreendente hibridização de empresas, firmas e instituições sociais. Bancos vendem mercadorias, casas lotéricas exercem funções bancárias, empresas e igrejas se transformam em organizações não governamentais (ONGs) e, em pouco tempo, diferentes tipos de firmas oferecerão serviços de telefonia celular.

Esses processos não se adaptam a diagnósticos singelos. Afinal, no urbano, convivem, tensa e contraditoriamente, necessidades, coletivos ativos e formas de obtenção do lucro. Acontecem contínuas alterações nesses vetores da experiência urbana, como demonstram as carências individuais e coletivas relacionadas 
à habitação, à mobilidade espacial, às influências culturais e à estrutura das famílias. Acontecem também transformações associadas à natureza e às formas de realização da mercadoria, como demonstram o avanço dos produtos financeiros e a transnacionalização da produção imobiliária.

Ante a violência dos processos que formam o fenômeno urbano, intensificada nas últimas décadas, aumenta a desconexão entre urbanização e integração social, expressando a cisão entre economia e sociedade. Com a cisão apagam-se a rede de cidades e a relação campo-cidade como referências centrais do planejamento. Ver, como exemplos, a falta de articulação entre o programa Minha Casa, Minha Vida, os planos diretores urbanos e o projeto do trem-bala ou da represa de Belo Monte.

No presente, aumentam os riscos de desconexão entre investimentos no crescimento econômico e compromissos com a concretização dos direitos urbanos. Perdem-se, assim, referências centrais da pauta humanística, dilacerada em meio à sobrecarga imagética.

O fenômeno urbano apresenta, hoje, quatro faces exemplares: o urbano novo novíssimo da Região Centro-Oeste, relacionado à produção de commodities; a crescente separação entre infraestrutura econômica e infraestrutura de uso social imediato, como exemplifica o sistema de transportes; a colonização da rede urbana pelas novas formas de produção imobiliária e pelas redes de serviços; e a difusão da dinâmica imobiliária em todo o território urbano, como demonstra o dinamismo do mercado imobiliário de favelas. ${ }^{4}$

Em face desse nível de mudança, é impossível valorizar apenas a associação entre democracia e desenvolvimento local, que não dá conta da complexidade contemporânea do fenômeno urbano. A materialidade desse fenômeno exige, de fato, a construção de uma pauta de direitos mínimos que articulem direitos econômicos, espaciais, culturais, sociais e políticos. Duas perguntas se impõem com relação a tal questão: qual é este mínimo? Qual é concretamente a intersetorialidade, traduzida em direitos, que pode garantir a saúde em contextos urbano-metropolitanos?

Sem a concepção e a defesa de ao menos o direito mínimo, continuará se repetindo a desigual modernização do território brasileiro, mais uma vez demonstrada pela diferença do acesso ao saneamento básico e à internet. Mudam as necessidades, a administração pública e as formas de obtenção do lucro e permanece a precariedade das condições urbanas de vida. Continuam pouco

${ }^{4}$ Ver Abramo (1997, 2003a, 2003b). 
tocados, portanto, os processos que vinculam urbanização e pobreza (consultar o livro Pobreza Urbana, de Milton Santos e, também, Espoliação Urbana, de Lúcio Kowarick). ${ }^{5}$

No presente, as abstrações - alimentadas pelo direito, pelo urbanismo e por modelos econômicos - esgotam-se sob a pressão da abstração maior, emanada da hegemonia do capital financeiro e cognitivo e das múltiplas configurações da exclusão (do anonimato ao extermínio). Diante de abstrações há a necessidade de articular crescimento econômico e urbanização através da visualização e da projeção de uma cidade justa, de desenvolver uma leitura sistêmica dos recursos disponíveis (e a conquistar) para o alcance dessa cidade, de forma a ampliar a pressão social sobre os órgãos de governo (hoje, apenas a ação dominante manipula os sistemas instáveis - ver Pablo González Casanova em As Novas Ciências e as Humanidades $-{ }^{6}$ de controlar os impulsos globais que fragmentam a experiência urbana, os investimentos públicos e as redes sociais; e de controlar a força desenraizadora do capital financeiro, exigindo nexos entre investimentos e integração social.

\section{Proposições preliminares: sujeito corporificado, direitos urbanos e} teoria socialmente necessária

Direitos precisam ser conectados à materialidade urbana. Uma resposta a essa necessidade pode ser encontrada na valorização do sujeito corporificado, isto é, sujeito de direitos. ${ }^{7}$ Afinal, o corpo é um referente seguro tanto para a materialização individual de direitos como para a sua generalização. Ele constituise num mediador entre o individual e o humano genérico, podendo orientar a evolução econômica socialmente justa, já que é um sustento insubstituível da empatia e da solidariedade.

O corpo - incluindo a sua força reprodutiva e mobilidade - configura um norte da pauta humanística, por sustentar nexos entre direitos urbanos e direitos humanos. Essas possibilidades ficam claras quando se reflete sobre os vínculos entre o corpo individual e o corpo coletivo, constituído pelo espaço urbano, pela cidade. Uma reflexão que estimula a descoberta de teorias do envolvimento. ${ }^{8}$

\footnotetext{
${ }^{5}$ Ver Santos (1978) e Kowarick (1979).

${ }^{6}$ Ver Casanova (2006).

${ }^{7}$ Ver Ribeiro (2000). Trata-se de artigo em que a autora desenvolve o conceito de sujeito corporificado.

${ }^{8}$ Dentre muitas referências sobre o tema envolvimento, assinalamos comentário no XV Ciclo de Estudos sobre o Imaginário, realizado em outubro de 2008, em Recife. Imaginário do envolvimento/desenvolvimento: "Gilbert Durand coloca, a respeito do 'trajeto antropológico', que a tensão entre dois polos é responsável por qualquer dinâmica sociocultural. Envolvimento e desenvolvimento são
} 
Os princípios que regem a teoria socialmente necessária ${ }^{9}$ consideram indispensável evitar que a leitura censitária da população conduza isoladamente a concepção dos direitos urbanos, e julgam necessário articular direitos e experiência urbana, como, por exemplo, inviolabilidade do domicílio, direito à terra ocupada, ao reconhecimento do estado de necessidade, do direito de ir e vir e ao usufruto da cidade.

Boa parte do pensamento do urbano tem sido submetida à pressão do sucesso da economia brasileira. Reduz-se, assim, a percepção dos vínculos entre esse sucesso e a crise societária, uma vez que o consenso tende a submeter o futuro apenas ao monitoramento do presente.

Minha participação nesta mesa constitui-se na mediação ativa (dinâmica e política) entre dois objetivos: equidade e sustentabilidade. Com relação às exigências dessa mediação, convém não esquecer o seguinte adágio popular, citado por Maria Del Pilar Barreto González em trabalho final do curso virtual "A experiência urbana da América Latina" (Clacso, 2008/2009): "eu participo, tu participas, nós participamos, eles decidem".

A respeito das metas do conhecimento, destaco os seguintes tópicos:

1 - Valorização das especificidades locais

Esta valorização, como sabemos, depende do conhecimento dos lugares. Nessa direção, confunde-se frequentemente a ótica do local com a ótica do lugar, impedindo a análise da sedimentação da experiência urbana e da configuração dos vínculos sociais. No impedimento à reflexão dos lugares, devem ser recordados a idealização do lugar e do cotidiano, a incidência de impulsos globais, a distância entre forças econômicas internas e externas e o predomínio da lógica da localização, ou seja, de cima para baixo, do maior para o menor.

Essa observação corresponde ao reconhecimento do urbano como uma construção histórica transescalar complexa, na qual o ator do lugar sofre a pressão exercida por atores (projetos, interesses) que se manifestam em escalas mais amplas. Há, portanto, níveis e graus de dependência dos lugares diferentes e instáveis, que limitam a autonomia e a singularidade.

aqui considerados como polos entre os quais estão incluídas as dimensões da vivência que dizem respeito a diversos campos: o político, principalmente, mas também o da consciência de cada um quanto às suas responsabilidades sociais, tais como, questões éticas, morais e inclusão/exclusão social. Não se trata pois de estabelecer mais uma dicotomia, mas de perceber estas dimensões como polaridades dinâmicas". Disponível em: <http://evouriques.wordpress.com/2008/06/06/mesa-do-netccon-sobre-comunicacao-e-imaginariodo-envolvimento-e-aprovada-pelo-congresso-internacional-imaginario-do-envolvimento-desenvolvimento-ufpe >. Acesso: 18 jun. 2014.

${ }^{9}$ Ver Ribeiro (2005). 


\section{2 - Diagnóstico sociourbano sanitário}

Os diagnósticos têm sido padronizados, o que dificulta justamente a compreensão das singularidades dos lugares. Com o predomínio do olhar que valoriza o local sobre o olhar que valoriza o lugar, a homogeneização se impõe sobre as singularidades. Os lugares têm sido transformados em nichos ou alvos de uma ação que é, cada vez mais, de teor estratégico. O insistente acionamento do território é muito mais indicativo desse predomínio do que da valorização dos lugares.

Em geral, esquece-se que o território admite, pelo menos, duas leituras fundamentais: uma leitura vertical, que corresponde aos desígnios dos atores que se confrontam e afirmam no cerne de campos de poder mais amplos; e uma leitura horizontal, relacional e vivencial, que corresponde à construção social dos lugares.

Portanto, seria correto dizer que o território não é uma referência sem riscos. Não se trata de uma referência neutra e nem tampouco sempre benigna. Se hoje se multiplicam as lutas sociais por recursos territorializados, também é verdade que o território não pode substituir nem o sujeito e nem a política como centros reflexivos de um projeto que vise ao alcance de uma cidade mais justa e igualitária.

3 - Reconhecimento da cidade como campo de forças: contradições, oposições e tensões

Com relação a essa meta, talvez seja interessante lembrar que a noção de campo também implica limite e regras de entrada. Assim, nem todo habitante encontra-se incluído num efetivo campo de forças no sentido político do termo, ou seja, em sentido ativo. Por outro lado, no que concerne à disputa de capital econômico, a distância entre o volume de recursos internos e externos pode levar à dissolução de campos historicamente configurados, gerando confrontos entre antigos atores pela presença no novo campo configurado pelos atores de campos mais abrangentes. Nessa direção, seria importante articular, analiticamente, campo e escala.

\section{4 - Empowerment comunitário}

Essa meta pressupõe a existência de um sujeito coletivo, a comunidade. Um sujeito de existência duvidosa, na medida em que se construiria com base apenas na habitação, na territorialidade, e engolfaria uma grande diversidade de experiências e identidades. Nesse sentido, a noção de comunidade, em contextos urbano-metropolitanos, pode conduzir a uma leitura autoritária da experiência 
urbana, quando corresponda à imposição de uma falsa homogeneidade e, até mesmo, de uma identidade coletiva inexistente.

Voltando ao início da exposição, registramos que a reflexão do urbano lida com diferentes e contraditórios níveis de abstração e com modelos e ideários de diferentes origens, que nem sempre se combinam e nem, muito menos, orientam a ação planejada e planejadora que termina por ser realizada.

\section{Palestra ${ }^{10}$}

- É um prazer estar aqui, mas essa participação foi para mim um desafio. Preocupame muito estabelecer o diálogo com aqueles que me convidam porque significa um sentido de copresença. Essa busca de sentido, busca de conexão, é necessária, mas não está isenta de equívocos da minha parte, pois, na medida em que é uma interação efêmera, não é efetivamente experienciada. Enfim, se eu tiver cometido uma série de equívocos para com os meus pressupostos dialógicos, peço desde já desculpas por isso, é por que não entendi muito bem o convite e criei enredos de outra maneira.

Vocês sabem que os sociólogos são militantes do cinismo. Nós somos cínicos profissionais. Por vezes, nos veem como uma espécie de intelectuais abstratos, mas prefiro substituir essa imagem por outra - a de militantes do cinismo ou de cínicos militantes. Vindo para cá, comecei a ver o estado em que se encontra a cidade, as ameaças à saúde mais imediatas que nos cercam, também detectadas ao ouvir e ler relatos de notícias. Faço, há dez anos, um trabalho de sistematização de notícias em periódicos, organizado num banco de dados no Lastro $^{11}$ e, pelas análises das notícias veiculadas nesses periódicos, as situações observadas poderiam se radicalizar. Em alguns lugares, porém, o que acontece não é uma radicalização. O que acontece diariamente é um transbordamento para as grandes vias da cidade que incluem os bairros de classe média e média alta. É o que acontece para um grande segmento da cidade do Rio de Janeiro e isso ocorre também em outras cidades brasileiras e em outras cidades do mundo. Basta recordar a Cidade do México e algumas cidades italianas.

A violência não nos é particular. Talvez fosse bom se fosse assim, porque só nós sofreríamos e o resto do mundo estaria um pouco mais feliz. Porém, não é isso que acontece, há uma difusão fortíssima da violência. Também não podemos dizer que seja algo completamente novo. Afinal de contas, a violência caracteriza a formação social

\footnotetext{
${ }^{10}$ Transcrição da palestra proferida por Ana Clara Torres Ribeiro na mesa-redonda "Equidade, Participação Social e Sustentabilidade" do Seminário Cidades Saudáveis, organizado pela Fiocruz nos dias 23 e 24 de novembro de 2010.

${ }^{11}$ Laboratório da Conjuntura Social: tecnologia e território, do Instituto de Pesquisa e Planejamento Urbano e Regional, da Universidade Federal do Rio de Janeiro (Ippur/UFRJ), então coordenado pela professora Ana Clara.
} 
brasileira e está muito longe das metáforas da gentileza. Muito ao contrário, trata-se de uma formação brutal, e essa formação brutal continua se desdobrando no presente.

Em face dos eventos que nos cercam, agora na sua radicalidade mais visível, eu me lembrei de Marx, quando ele diz que, por vezes, os fatos ultrapassam as palavras. Na verdade, acho que os fatos ultrapassam as palavras numerosas vezes, e, se ultrapassam as palavras, ultrapassam os conceitos. Também pensei em outro autor importante, Henri Lefebvre, para dizer sobre o papel da dialética na compreensão do capitalismo, para dizer o quanto é importante ter um pensamento orientado pela dialética e o quanto também é importante acompanhar pelo pensamento o movimento do mundo, isto é, o devir, o devir histórico. Existe uma dialeticidade fundante que é o movimento do pensamento, ou seja, temos que fazer mover o nosso pensamento e o pensamento do próprio movimento. $O$ que acontece hoje com relação ao urbano, ou às grandes cidades, já vem sendo anunciado desde os anos 1970, ou início dos anos 1980. Esse anúncio está relacionado à perda de nexos entre o urbano, entre a incidência da urbanização e o desenvolvimento econômico e social.

Nós experimentamos, na nova base técnica da própria vida coletiva, uma crescente perda de nexos entre a urbanização e a grande concentração urbana ou, digamos, entre a concentração de diferentes no espaço mais ou menos delimitado e a compreensão do que seja o desenvolvimento econômico e social. Muito ao contrário, o que se registra cada vez mais é um desencanto com relação à cidade, sobretudo com relação à grande cidade, que vai perdendo seus nexos propositivos com a política e, também, seus nexos propositivos com a civilidade ou até com aquilo que the é próprio, que seria a urbanidade.

A cidade perde encanto, perde encantamento, perde a força da circularização, perde a característica que the é muito forte desde a industrialização, sobretudo na virada do século XIX para o século XX. Ou seja, a sedução da cidade. Se imaginarmos o que as grandes cidades representaram como foco sedutor para a criação das grandes ideias, para as ideias políticas, para o desvendamento do próprio eu, para a construção da subjetividade, para, enfim, a explosão da criação, o que temos hoje como leitura da cidade, e isso também tem algum rebatimento para o nosso país, é uma perda monumental.

\section{Sobre o título da mesa-redonda: Equidade, Participação Social e Sustentabilidade}

É nesta circunstância do presente ou com essa consciência, ainda que tentativa, do presente, que, de alguma maneira, eu observei o título da mesa. Fiz isso porque sou obsessiva e queria um elo para a minha reflexão. Por isso, então, fui reificar o título da mesa. Sei que todo título é arbitrário, mas, mesmo assim, fui ler o título e a ementa 
da mesa, detalhadamente. Assim, vi três ideias fortes: equidade, participação $e$ sustentabilidade. Eu tenho cismas com palavras, mas isso faz parte da tal militância cínica ou do tal cinismo militante. Comecei a torcer meu cérebro para absorver esses três conceitos, mas pensando que eles não combinam entre si. Mas vamos falar de equidade. Atualmente, as pessoas dizem que não se trata de igualdade, que igualdade achata as diferenças, que tem de ser equidade. Já me ensinaram suficientemente bem toda essa nova lição de bom mocismo verbal. Já aprendi, mas desconfio que, muitas vezes, a equidade enfraquece a luta pela igualdade. Desculpem-me. Trata-se de uma percepção, não de uma certeza, mas não é uma percepção muito ingênua porque não sou ingênua.

O segundo termo é participação, que, muitas vezes, na minha opinião, substitui a práxis e, por fim, temos a noção de sustentabilidade. Em relação a esta última, é preciso saber o que precisa ser sustentado, principalmente quando se trata da cidade. A grande cidade não pode ser recortada feito um sistema para ser sustentado, exatamente porque depende completamente de nexos extraordinariamente amplos e instáveis. Lembro-me de uma pesquisa do IBGE, em que se mostravam os mapas das cidades com seus nexos, em termos de trazer mercadoria e vender mercadoria, de vir pessoas em busca de serviços, de lançar pessoas pelo mundo. Os nexos das informações eram fantásticos e tínhamos um mapa extraordinário em termos de vínculos. O que nós estamos sustentando? O que nós estamos recortando para ser sustentado, efetivamente, é isso aqui? É esse conjunto de relações ou é o quê, exatamente?

É preciso saber o que é para ser sustentado, principalmente quando está referido à experiência urbana metropolitana. Ao trazer essa questão de sustentabilidade-que é uma leitura sistêmica do sistema, ou de algum sistema, ou de algum aspecto sistemático-, lembrei-me do filósofo Gerd Bornheim. Em tom de brincadeira, num seminário que organizamos nos anos 1990, ele me disse que considerava a classe média muito engraçada por criticar o sistema sendo completamente dependente dele no cotidiano. Ele lembrou alguns exemplos de reclamações da classe média relativos ao funcionamento insatisfatório dos transportes públicos, da telefonia. Lembro que Bornheim ${ }^{12}$ não chegou a enfrentar o tempo pleno da informática doméstica. Hoje sim, as pessoas ficam irritadíssimas porque o sistema não está funcionando do jeito como deveria, como se a vida delas e a da humanidade inteira dependessem pura e exclusivamente daquilo.

Contudo, a sistematização - ou a sistematicidade, ou ainda, a adesão ao sistema constitui um conjunto de fenômenos com crescente incidência, daí talvez a adesão a determinados termos e metas como a da sustentabilidade. O problema é que a meta da sustentabilidade tem o poder de esconder algumas coisas a respeito dos vínculos que

\footnotetext{
${ }^{12} 0$ filósofo, que faleceu em 2002, não chegou a vivenciar plenamente as mudanças das tecnologias da informação.
} 
transcendem às cidades. As cidades são seres dependentes, que sugam, que selecionam recursos para sua sobrevivência (basta ver para onde vai a energia de Belo Monte ${ }^{13}$ ), caso contrário, não sobrevivem. A grande cidade é um ser altamente dependente e, ao mesmo tempo, autoritário, um ser coletivo extremamente difícil de ser apreendido e perigoso. A grande cidade, a grande metrópole é isso, mas muitas vezes não temos isso, pensamos numa única escala, essa escala do imediato, e, muito menos, não percebemos o lançar de uma grande metrópole voraz sobre recursos que são amplíssimos, enormes.

Essa estruturação de sistematicidades extremamente complexa, em realidade, corresponde ao que é efetivamente a sobrevivência de uma metrópole que suga mais-valia em territórios muito distantes e sobrevive, inclusive, através da tributação. Isso é escondido, muitas vezes, através de uma noção de sustentabilidade.

Sobre a relação sustentabilidade-modelo de cidade e a ementa da mesa

Convivemos com uma noção de sustentabilidade, imediatamente aceita no que concerne a alguns fenômenos políticos fundamentais, que esconde, exatamente por essa aceitação imediata, a crise do modelo dominante de cidades. Basta ver o que se observa não só em Nova Iorque, mas também em São Paulo, no Rio de Janeiro. Hoje, o modelo de cidade cuja gênese é, sobretudo, europeia no nosso caso, tem dentro de si uma americanização muito forte também, pela adoção do modelo rodoviarista. Esse modelo dominante de cidade rodoviarista está em crise, está se esgotando, e, ao se esgotar, arrasta uma quantidade de irracionalidades que são sistêmicas. Estas sim, as irracionalidades, são sistêmicas.

De outro lado, muitíssimas vezes, também se desconhece que, por trás de um anseio imediato da sustentabilidade, há sistemáticas construídas pela própria ação da sociedade, que busca sobreviver em meio à crise do modelo dominante de cidade. Sobrevive criando sistematicidades. Trata-se de uma imensa ação coletiva popular que permite a sobrevivência dentro desses sistemas macro, abertos. É uma sistematicidade popular que garante, de alguma maneira, a sobrevivência da maioria, e que escapa, em grande parte, à ação do Estado, não correspondendo diretamente à sua ação, mas que está dentro do tecido da própria sociedade. Milton Santos, esse geógrafo tão conhecido, no livro Por Uma Outra Globalização, dizia que nós deveríamos entender essa outra sistematicidade, a popular, que de alguma maneira pode gerar ideários para futuros alternativos. Não é possível que nós aqui tenhamos futuro possível apenas numa cidade

\footnotetext{
${ }^{13}$ A usina hidrelétrica de Belo Monte está sendo construída no rio Xingu, no estado do Pará. 0 projeto dessa central elétrica foi duramente criticado por ambientalistas brasileiros e internacionais, além de comunidades indígenas, 0 que levou a sucessivas reduções do escopo original. Ainda assim, será a terceira maior hidrelétrica do mundo.
} 
global que vai ser brutalmente excludente, não é possível que consigamos projetar apenas isso ou aceitar esse futuro como o único possível.

Além de considerar o título da mesa, cujos termos me ajudaram, de alguma forma, a tentar estabelecer um diálogo, observei também na ementa que havia um elenco considerável de metas preestabelecidas e que essas metas, por serem numerosas, trazem um risco de impedir o desvelamento da força da ação da própria sociedade. Afinal, podemos não enxergar muito bem o que é efetivamente uma ação tentativa e diária da própria sociedade. Trata-se de nexos que se constroem no cotidiano e que, de alguma forma, garantem a sobrevivência de muitíssimos, mesmo que nós não consigamos perceber muito bem como isso acontece. Porém, se pararmos para escutar em qualquer esquina, vamos compreender como ocorre.

Outro ponto que me parece importante também vem da ementa, mas não dessa ementa específica, e sim de uma quantidade imensa de ementas de editais de outros programas, de outros projetos, dos quais também participo. Observa-se aí uma rápida colocação de modelos. Existe sempre um modelo no meio dessa confusão imensa que estou tentando descrever aqui da crise da cidade historicamente configurada, do modelo tradicional de cidade. No meio dessa crise, vemos uma grande quantidade de modelos sendo veiculada. Isso soa estranho porque, diante da "aceleração contemporânea", ${ }^{14}$ como modelar com essa facilidade? Na verdade, isso seria, em princípio, contraditório ou mesmo impossível.

O que estamos entendendo por modelos hoje? Qual é a função dos modelos hoje? O que de fato eles significam? Comecei a fazer essas indagações e, além de constatar a existência do modelo da cidade saudável, identifiquei modelos da cidade criativa, da cidade educativa... Ou seja, há vários outros modelos, sem contar os modelos de gestão democrática, gestão transparente, gestão isso, gestão aquilo. Está certo, não sou eu que vou ficar jogando pedras naquilo que pode nos ajudar a pensar, mas, de qualquer forma, acho que não é impertinente o conjunto de perguntas que vou formular a seguir.

As primeiras perguntas seriam as seguintes: como se realiza hoje a reflexão da experiência urbana? Por quais modelos se realiza essa reflexão? Quantos são esses modelos? Quais são os seus termos? Qual é o seu funcionamento lógico? - Não estou dizendo histórico, estou dizendo lógico.

As segundas perguntas seriam as seguintes: até que ponto os modelos têm deixado de cumprir a sua função científica para ter uma função política? Qual é a função

\footnotetext{
${ }^{14}$ Expressão de Milton Santos, utilizada originalmente em seu livro intitulado Técnica Espaço Tempo (Santos, 1994). Foi incluída aqui para explicitar a ideia da professora Ana Clara sobre a dificuldade de se propor modelos de cidade num contexto de mudanças, que instaurou, conforme suas palavras, a "crise da cidade historicamente configurada".
} 
científica dos modelos? Que nós saibamos, os modelos tinham uma função histórica, científica, de reduzir provisoriamente a complexidade do real para depois retornar à complexidade. O problema é que às vezes nós simplificamos, mas não retornamos ao complexo. Isso acontece porque, de um modo geral, os projetos, em razão do tempo em que são elaborados, não permitem que se recupere a complexidade, e isso está se reproduzindo seguidamente.

As terceiras perguntas abordariam o seguinte ponto: na ausência desse retorno para a complexidade, como a historicidade e a experiência social podem alterar o modelo? Isso deixaria clara a sua função de simples ferramenta. Afinal de contas, o modelo é apenas uma ferramenta ou o modelo é um ideário? Se for um ideário, já é outra coisa, já virou projeto. O modelo é um ideário ou uma ferramenta?

Essas são perguntas pertinentes no campo das políticas públicas e também pertinentes no campo dos estudos urbanos. Todavia, no campo dos estudos urbanos, que é onde eu efetivamente trabalho, e sobretudo com base na sociologia, nesses campos nós temos, sem dúvida, um predomínio da forma sobre o conteúdo, o que é característico do modelo. O modelo destaca a forma sobre o conteúdo, mas, naturalmente, os conteúdos retirados dessa forma devem retornar para pressionar a forma. Se não retornam, nós sabemos que a forma se lança acima dos conteúdos e isso naturalmente tem o perigo de cristalizar o movimento do pensamento.

\section{Sobre o pensamento formal e o pensamento dialético}

E é por isso que o movimento do pensamento se traduz no pensamento formalista e jamais no dialético. Em meio às dificuldades em que vivemos, o pensamento formalista traz certo conforto. Ficamos mais tranquilos, mas esse conforto pode ser passageiro, porque logo depois os fatos contrariam o modelo e, efetivamente, aquilo que idealizamos acaba não acontecendo. Isso significa dizer que, de alguma maneira, estamos às voltas com circunstâncias bastante adversas para os estudos urbanos e metropolitanos. Estamos trabalhando com modelos que podem não corresponder ao lançamento de novos ideários que deveriam estar relacionados, de alguma maneira, à crítica das teorias da modernização e do desenvolvimento ou com a invenção de outras teorias que fossem, também, projetos políticos. Na ausência disso, um megaobjeto, um megacoletivo que não se projeta, constitui, em si mesmo, riscos societários extraordinários.

Observo isso com enorme preocupação porque me parece que estamos lidando com grandes dificuldades. Não se trata apenas de um projeto de pesquisa singular. É uma questão da sociedade brasileira, que tem enorme dificuldade para ultrapassar o pensamento instrumental, mesmo o operacional simples, para entrar no pensamento da complexidade e na projeção, para projetar o que estamos vivendo na contemporaneidade 
e as suas consequências. O que vivemos hoje - todos nós, evidentemente, sabemos - éo impacto de tudo isso nas sociedades periféricas, se bem que o Brasil é muito orgulhoso da sua atual posição no mundo (tenho minhas dúvidas a esse respeito, mas não vou discutir isso). O que se observa é esse capitalismo globalizado, financeiro e cognitivo, característico do atual período histórico, e a posição periférica do Brasil continua trazendo consequências bastante dramáticas.

De um lado, temos o controle de capital financeiro stricto sensu, que altera a realidade urbana de uma forma brutal. Basta ver a quantidade de famílias devedoras que temos hoje no Brasil, basta ver a crise da juventude já devedora do cartão de crédito, basta ver a política de endividamento dos velhos através das suas aposentadorias. Podemos chamar tudo isso de subordinação ao capital financeiro transnacional. De outro lado, temos o capitalismo cognitivo que, na verdade, muito mais nos satura de informação do que favorece a cognição, o conhecimento. Essa nossa situação faz com que acabemos por aderir a alguns diagnósticos muito singelos da experiência urbana, que correspondem mais a certo alarmismo, a certo terrorismo, do que efetivamente a uma orientação da ação coletiva.

\section{Sobre política urbana e segurança - caos e cosmos}

O que acontece é que as referências ao caos urbano retornam. O que acontece, também, é que os ideários de remoção da pobreza também retornam e que a rejeição do excluído vem aumentando. Vem aumentando, também, a adesão a uma política urbana que quer se traduzir, de qualquer forma, numa política de segurança, como se a segurança fosse a síntese de todas as políticas. Isso dentro de um constructo que projeta a ideia de caos, mas só que se trata de um caos que não tem cosmos, de um caos que se desenha à medida que alguém fale. E como não há cosmos, o que temos, efetivamente, é uma fragmentação que se faz diariamente, sobretudo se pensarmos nos grandes projetos de intervenção urbana, nas intervenções do Estado e nas grandes intervenções do capital privado, cada vez mais espetaculares. É como se não fosse possível colocar o saneamento no lugar e, ao mesmo tempo, criar um equipamento espetacular. Isso é impressionante, mas é essa a substituição efetiva da ação socialmente necessária por uma intervenção egoica dos governantes. Desculpem, não devia dizer isso, mas é isso que efetivamente acontece, é isso que estamos vendo. Para que tudo isso? Acho que isso mostra que a saída que está sendo apresentada para nós é característica da sociedade do espetáculo. Como disse Guy Debord, até o caos tem cara de espetáculo ${ }^{15}$ tem que ter fogo, tem que ter explosão, tem que ter bomba, tem que ter isso, tem que ter aquilo, porque se não tiver tudo isso não é bom o suficiente e não convence ninguém

${ }^{15}$ A menção por ela referida, aqui, consta do livro A Sociedade do Espetáculo, de Guy Debord (1997). 
que estamos no meio do caos. Precisávamos chegar a tudo isso? Temos isso na ação de governo, na ação dos traficantes, na ação de tudo que é lado. É uma espetacularização do caos e da ação que, de alguma maneira, resiste ao caos. Estamos convencidos que vivemos numa sociedade cinematográfica, que pouca diferença tem daquilo que vemos na televisão, que pouca diferença tem em relação à guerra do Golfo, à guerra do Iraque ou de qualquer outra parecida.

É justamente esse mar de imagens, de ideias, que nos dificulta a realização de uma análise fria, que deve ser fria, dos fenômenos sociais e dos espaciais. Dessa forma, torna-se difícil introduzir-se a possibilidade de formulação de outro imaginário, porque o nosso imaginário está contaminado por essa leitura dominante do caos, por um cosmos que parece que só vai poder existir naquilo que a cidade-espetáculo oferece. O cosmo tem que ser da sociedade-espetáculo: são ofertas dos cartões de crédito, ofertas dos spas, dos grandes hotéis, ofertas das mulheres lindas, das celebridades, das casas etc. E essa história de gente rica e bonita? Isso, para mim, é uma categoria estranhíssima. É essa gente bonita que configura o cosmos; ressalta-se o que elas fazem no seu cotidiano, as cirurgias plásticas feitas por elas etc. Provavelmente, sou eu que tenho preconceito. Mas, o que é relevante nesses exemplos é que nós ficamos com o espetáculo da desgraça, da violência, do caos, e com um cosmos que é de pouquíssimos.

O futuro é desenhado para pouquíssima gente e a adesão social a essa imagem da pouquíssima gente se dá por algo surpreendentemente simples, mediante o recurso à Mega-Sena. O prêmio da Mega-Sena cresce, crescem as filas para comprar um bilhete. Quanto mais alto o prêmio, mais crescem as filas, mais a televisão faz propaganda no meio do Jornal Nacional e essa situação vai num crescendo. Mas, quinhentos mil não é muito dinheiro? Eu queria ter quinhentos mil reais! Não resolve a vida da maioria? As pessoas, porém, são levadas a não se contentar com isso. Tem que ser muito mais, tem que ser 20, 25, 30 milhões. Para quê? Ninguém é centopeia, não vai dar para colocar tanto sapato, nem para morar em tantas casas. Apesar de ser absolutamente irracional, isso faz parte da celebração do sucesso, da celebração de um cosmos para poucos, que, de alguma maneira, serve de contrapartida ao caos como única leitura da experiência urbana. Esse caos que serve de desculpa para que não se tente mais nenhum interclassismo progressista, para que não se participe de nenhum movimento social, para que não se faça mais nada em termos da busca de uma conexão forte e produtiva com os conviventes, ou seja, com os copresentes. 


\section{Sobre o privilégio da esfera privada em relação à pública}

Essa ideação, na verdade, corresponde também à maneira como nós atribuímos o privilégio da esfera privada em relação à pública, isto é, do mercado em relação às instituições sociais e políticas. É isso que corresponde ao mundo corporativo. Milton Santos é autor de um livro muito bem construído, chamado São Paulo: metrópole corporativa e fragmentada. ${ }^{16}$ De fato, podemos dizer que as grandes cidades brasileiras revelam semelhanças com essa reflexão sobre São Paulo. A TV está sempre mostrando imagens dessa cidade. É difícil entender como as pessoas conseguem viver com tanto engarrafamento. Por que entupiram as cidades brasileiras com tantos carros? Não estou dizendo que as pessoas não devem ter carro; eu adoro que as pessoas tenham carro, mas os carros têm de circular. Se não circulam, o trânsito engarrafa; se o trânsito engarrafa, a poluição aumenta ainda mais. O que significa essa história? Ela corresponde, é claro, ao mundo corporativo e a uma visão de metrópole, de grande cidade, onde teremos, de um lado, como projeção, centros urbanos extremamente excludentes, dominados pelo mercado financeiro especulativo e pelas ideias da criação e, de outro lado, segregações bastante grandes, outra realidade tecida, no máximo, pela criação de outras centralidades que mantêm os menos afortunados o mais longe possível desse centro.

São Paulo é a segunda metrópole do mundo no que concerne ao número de helicópteros, situação que a prefeitura não controla. Vocês bem podem imaginar o risco que é uma quantidade imensa de helicópteros circulando sobre a cidade. Além disso, verificamos aquela intervenção absolutamente imprópria, que é a ampliação do aeroporto de Congonhas. Depois do acidente da TAM, ${ }^{17}$ também não gerou nada, não houve nenhuma consequência. Nós temos, de um lado, essa margem de risco corporativo e das grandes elites colocadas sobre a totalidade das cidades de uma forma, eu diria, absolutamente chocante, para usar um termo educado. E de outro lado, temos o crescimento da população que anda a pé. Ninguém vai me fazer crer que é possível andar de bicicleta naquela trama gigantesca que é a metrópole de São Paulo. Isso é totalmente impossível. Ninguém vai, de jeito nenhum, sair pela ciclovia. Isso nos configura realmente o patamar de racionalidades simultâneas, e eu não sei se as pessoas pretendem defender a sistematicidade para essa coisa. É isso que nós queremos que se reproduza sistematicamente? É para isso que nós defendemos a sistematização? É nessa direção que nós vamos defender a sustentabilidade? É isso que nós queremos sustentar?

\footnotetext{
${ }^{16}$ Trata-se da obra Metrópole Corporativa Fragmentada: o caso de São Paulo. Ver Santos (1990).

${ }^{17}$ Conhecido acidente aéreo ocorrido em 17 de julho de 2007, durante o pouso no Aeroporto Internacional de Congonhas, cidade de São Paulo. Não houve sobreviventes. Com a perda das 187 pessoas que estavam no avião e, ainda, com outras 12 mortes no solo, esse acidente aéreo foi um dos piores já ocorridos na América Latina.
} 
Tudo isso é muito complicado, mas pode ser indicado por um conjunto de fatos que a imprensa está sempre noticiando. Um exemplo são as enchentes: São Paulo e Rio de Janeiro mostraram bem o que isso significa. Temos, também, os engarrafamentos cada vez mais fortes e, ainda, os incêndios em favelas. Observamos um número crescente de incêndios em favelas de São Paulo, mas ninguém sabe quem põe, quem tira ou se é uma combustão espontânea ou, ainda, se é um acidente. Dispomos de um conjunto de fatos, fatos que eu não estou inventando porque estão lá, todos os dias, na imprensa e aparecendo com muito destaque. Sustentar esse tipo de situação não promete muito, não nos garante que possamos superar essa equação perversa com a qual convivemos atualmente.

\section{Sobre a exacerbação das celebridades, o modelo dinâmico da cidade justa, ${ }^{18}$ cidadania e saúde}

Até agora, me detive nesses conceitos que revelam a historicidade da nossa experiência urbana, tentando contrariar alguns discursos eufóricos e tentando, talvez, corresponder ao que nós sabemos. Sabemos porque vivemos, porque estamos por aí, porque estamos vendo as coisas, porque estamos conversando no meio da rua. Eu, pelo menos, adoro conversar no meio da rua para saber das coisas. A situação que observamos por aí dificilmente admite uma tradução em metas. As metas não são simples de serem discernidas, na verdade são bem difíceis de serem definidas. Fiquei imaginando quais seriam os desafios atuais para que pudéssemos ordenar, de alguma maneira, a superação dessa equação espetacular da exacerbação das celebridades, para escaparmos de tudo que é maravilha, do Rio Maravilha, Porto Maravilha etc. Escapar um pouco da espetacularização e tentar ver de outra maneira. Mas, afinal de contas, podemos lançar o modelo. Isso não é tão difícil assim, quer dizer, modelo como projeto mais ou menos simples.

Pensei, então, que podemos ter um modelo de cidade justa - vou tentar cidade justa. Como seria essa cidade justa? Jamais poderia ser um modelo estático; teria que ser altamente dinâmico, altamente móvel, pensando, sobretudo, que os sistemas são instáveis, abertos. Nós vamos modelar qualquer coisa, vamos modelar uma coisa instável que abre, que se mexe, vamos buscar outras formas de reflexão e, certamente, também seria necessário pensar alguns mínimos para essa cidade justa. Então, o que seria o mínimo? Andei fazendo umas provocações: o que é o mínimo com relação à política habitacional? É uma casa bem equipada? É o quê, para o indivíduo, para o cidadão? Não estou me referindo à família. O que seria para o cidadão? O que seria

${ }^{18}$ Ver Ribeiro e Poggiese (2008), sobre documento intitulado Declaración de Buenos Aires: por una ciudad justa, assinado por 28 pesquisadores. 
o mínimo para um rapaz que chega aos 18 anos, para uma moça que chega aos 21? O que é o mínimo para essa criatura dizer que está exercendo sua cidadania? É viver num quarto? É o quê?

Fiquei imaginando o que poderíamos pensar para várias outras áreas setoriais $e$ juntar isso tudo na reflexão da saúde, porque saúde não é só saneamento. Suponho que o saneamento seja, mais do que qualquer outra coisa, absolutamente fundamental, mas, de qualquer maneira, há outros pontos essenciais, como transporte etc. Qual o mínimo para fazer a articulação desses vários setores na direção do que poderia ser, talvez, a modelagem de uma cidade justa? Pode ser uma modelagem pequenina, experimental, aproveitando a expertise generalizada nessa direção das boas práticas para fazer uma pequenininha, sem muita complicação: uma cidade justa. O que poderíamos pretender seria a realização dessa ideia num município pequeno, de tal maneira que pudéssemos imaginar esta cidade justa operando com metas relacionadas a vários serviços conectados. É claro que sempre foi o desejo de todos nós uma articulação intersetorial, que levasse realmente a uma garantia de cidadania. Como é que isso pode acontecer dentro de uma estrutura urbana específica, com um sistema de propriedades específico, onde os recursos orçamentários realmente estejam disponíveis e nós pudéssemos enxergar isso bastante bem e de uma maneira projetiva? Eu creio que isso pode nos ajudar a exercitar o modelo da cidade justa, sabendo que a realidade urbana jamais é monoescalar, que ela é necessariamente transescalar. Há sempre uma transescalaridade espaço-temporal e temos que entender que é uma configuração basicamente instável, que jamais será um sistema completamente fechado. Devemos entender isso e trabalhar em direção a esse objetivo, que poderia ser o modelo de uma cidade justa. Eu gostei dessa ideia.

\section{Sobre as quatro metas da ementa}

Por que não posso dizer que a minha ideia teria essa característica e que ela seria assim? Tenho uma natureza insistente. Observando as metas que estavam na ementa, verifiquei que eram muitas. É uma proposta altamente trabalhosa, pensei que eram demais, que a minha cabeça não ia dar conta de abranger outras e, por isso, decidi examinar quatro delas. A primeira dizia respeito à valorização das especificidades locais: dependendo dos modelos, estes não combinam com a valorização das especificidades locais, é verdade. Algo que nos parece estranho, também, recentemente colocado na ideação dos estudos urbanos, é privilegiar o desenvolvimento local como se ele fosse intrinsecamente superior e mais democrático. Isso tem sido afirmado recorrentemente, esse tipo de leitura é feito com frequência, não sei muito bem por que, mas é isso que acontece. Posso até fazer força para acreditar, mas essa visão não resiste a uma observação mais atenta. 
Nesse fim de semana, num debate que tivemos na Maré, ${ }^{19}$ vi acontecer uma confusão entre local e lugar, ${ }^{20}$ como se o local fosse igual ao lugar, como se local e lugar fossem a mesma coisa. Muitas vezes, o discurso está valorizando o local dizendo que está trabalhando com o lugar, mas não está trabalhando com o lugar, e sim com metas que se localizam ali. Isso é o local, não é o lugar! Muitas vezes, trabalhamos com as duas coisas. Não estou dizendo que vocês estão fazendo isso ou aquilo, só estou dizendo que corre o risco de acontecer e é muito comum que aconteça.

O segundo ponto é o diagnóstico sociourbano. Urbano é necessariamente sócio, não tem salvação! Na contemporaneidade, apresenta-se o diagnóstico sociourbano. Contudo, em face da pressão de que estamos recebendo algo em termos de veiculação de modelos e, também, por reconhecer que local e lugar não são a mesma coisa, realmente me preocupa essa junção do sociourbano. O sócio muitas vezes se transforma num nicho e o urbano num território.

Outra observação: fico muito preocupada com o que considero um excesso de referência ao território como sinônimo de urbano. O urbano não deve ser reduzido ao território. É como se o termo território fosse progressista. Acho isso engraçadíssimo. Como assim? O território está substituindo o sujeito da ação? O território é mais importante que o sujeito? O sujeito não pode ficar em qualquer território e não pode querer sair do território? Ele tem que ficar lá? É democrático destinar o sujeito a um único território? Dependendo do território, isso é muito cruel.

Para terminar, vou me deter em dois pontos. O primeiro é a referência ao empowerment. Pertenço a uma geração que tem muita dificuldade em lidar com essa ideia de empoderamento. Vamos discutir com seriedade. Pode-se ajudar na manifestação do desejo, do anseio, da conquista da autonomia, de alguns valores. Mas, empoderamento, o poder em si mesmo? Fala-se muito em empoderamento, que, para mim, ou não é nada ou pode ser algo terrível. Não se trata do poder pelo poder, mas tem de se levar em conta os conteúdos que correspondam a determinados projetos qualificados. Essa percepção é ainda mais complicada quando é associada à ideia de comunidade, porque não existe comunidade. Do ponto de vista daqueles que acreditam nesses termos, o que acabei de falar é absolutamente radical e improcedente.

Reafirmo, aqui, que não existe comunidade. A insistência neste termo não expressa uma verdade. É como você empurrar o jovem para dentro de um espaço e dizer que

\footnotetext{
${ }^{19} \mathrm{~A}$ professora Ana Clara referia-se a um debate ocorrido no Corpocidade 2: debates em estética urbana, evento realizado nos dias 21 e 22 de novembro de 2010 no Colégio Brasileiro de Altos Estudos, da UFRJ, Rio de Janeiro. Algumas atividades desse encontro foram realizadas na área do Complexo da Maré, bairro da zona norte do Rio onde se concentra a população de cerca de 16 favelas espalhadas por cerca de 800 mil metros quadrados.
}

${ }^{20}$ A respeito da distinção entre local e lugar, ver Ribeiro (2009). 
naquele espaço é tudo mais ou menos legal, que as pessoas são todas iguais ou muito parecidas e que partilham o mesmo cosmo de valores. Será que é mesmo uma comunidade? Claro que é politicamente correto substituir favela por comunidade, mas isso também destrói a memória das lutas sociais ou, pelo menos, colabora para a destruição das lutas das favelas no Rio de Janeiro. Comunidade já é uma coisa complicadíssima e empoderamento de comunidade mais ainda, porque a comunidade não é um sujeito social. Eu escrevi um texto ${ }^{21}$ no qual investigava a ideia de comunidade, e sofri para escrevê-lo. Essa ideia é importante na área social; há muita referência à comunidade no serviço social. Eu queria encontrar, de qualquer forma, uma alternativa a essa ideia sem ficar implicando com ela. Sei que não cabe, sei que, voltando atrás, o sociólogo é um cínico militante, mas não queria insistir muito nisso...

Fui procurar saber e descobri comuna e não comunidade. A comuna tem uma ancestralidade. A comuna era o lugar onde ficavam os judeus na rede urbana, onde ficavam também os de origem muçulmana - era o lugar dos excluídos. Sim, é outra ideação. Não estou dizendo que temos de adotar comuna, que seria melhor para esse tipo de discurso de comunidade. Não é nada disso. Mas tenho a esperança de que podemos acionar esse adverso, escapando um pouco das recorrências discursivas, até mesmo para exercitarmos o nosso humor e brincar com a vida.

Foi isso que eu consegui pensar e espero ter trazido a questão das cidades. Mas, afinal, quem a trouxe aqui não fui eu, foram todos os outros que falaram antes de mim nesta mesa. Eu vim depois. Para trocar ideias. Obrigada.

\footnotetext{
${ }^{21}$ A referência a esse texto, que aborda, especificamente, os termos comunidade comuna, não foi localizada. No entanto, identificou-se outro, em que Ribeiro se refere a tais termos de maneira genérica e aciona o pensamento de Milton Santos, ao refletir sobre a articulação do "sujeito social e suas circunstâncias" e a"possibilidade de valorização da força societária das territorialidades populares, que" (...) "não se deixam aprisionar nos limites formalmente reconhecidos das denominadas comunidades". Ver Ribeiro (2013: 28). Identificou-se, ainda, outro texto em que Ana Clara Ribeiro e Amélia Rosa Teixeira problematizam os termos comunidade e sociedade. Ver Ribeiro e Teixeira (1982).
} 


\section{Referências}

ABRAMO, P. Mercado imobiliário na favela: características e impactos do Programa Favela-bairro. Relatório Parcial. Convênio Finep/PCRJ/Ippur-UFRJ. Rio de Janeiro, 1997.

ABRAMO, P. A teoria econômica da favela. In: ABRAMO, P. (Org.). A Cidade da Informalidade: o desafio das cidades latino-americanas. Rio de Janeiro: Sette Letras, $2003 a$.

ABRAMO, P. Mobilidade Residencial na Cidade do Rio de Janeiro. Rio de Janeiro: Prefeitura da Cidade do Rio de Janeiro. Secretaria Municipal de Urbanismo. Instituto Municipal de Urbanismo Pereira Passos, 2003b. (IPP/Prefeitura da Cidade do Rio de Janeiro - Ippur/Universidade Federal do Rio de Janeiro)

CASANOVA, P. G. As Novas Ciências e as Humanidades: da academia à política. São Paulo: Boitempo, 2006.

DEBORD, G. A Sociedade do Espetáculo. Tradução brasileira: Estela dos Santos Abreu. Rio de Janeiro: Contraponto, 1997.

KOWARICK, L. A Espoliação Urbana. Rio de Janeiro: Paz e Terra, 1979.

LEFEBVRE, H. Lógica Formal/Lógica Dialética. Rio de Janeiro: Civilização Brasileira, 1991.

RIBEIRO, A. C. T. Sujeito corporificado e bioética: caminhos da democracia. Revista Brasileira de Educação Médica, 24(1): 82-86, 2000.

RIBEIRO, A.C.T.Território usado e humanismo concreto: o mercado socialmente necessário. In: SILVA, C. A. et al. (Orgs.). Formas em Crise: utopias necessárias. Rio de Janeiro: Arquimedes Edições, 2005.

RIBEIRO, A. C. T. Cartografia da Ação Social: região latino-americana e novo desenvolvimento urbano. Encarte 'Cadernos da América Latina'. Le Monde Diplomatique Brasil. São Paulo, jul., 2009.

RIBEIRO, A. C. T. Aceleração e fragmentação: o trabalho na grande cidade periférica. In: RIBEIRO, A.C.T. Por uma Sociologia do Presente: ação, técnica e espaço. v. 4. Rio de Janeiro: Letra Capital, 2013.

RIBEIRO, A. C. T. \& POGGIESE, H. A. Declaração de Buenos Aires. Cadernos Ippur/UFRJ, 22(2), 2008.

RIBEIRO, A. C. T. \& TEIXEIRA, A. R. Comunidade - uma nova ideologia urbana ou uma nova ideologia política? In: ENCONTRO NACIONAL DE ESTUDOS RURAIS E URBANOS, set. 1982, São Paulo. Cadernos Ippur - série de textos para discussões internas... Rio de Janeiro: Ippur/UFRJ, 1982. n. 7.

SANTOS, M. Pobreza Urbana. São Paulo, Recife: Hucitec, UFPE, CNPV, 1978.

SANTOS, M. Metrópole Corporativa Fragmentada: o caso de São Paulo. São Paulo: Nobel/Secretaria de Estado de Cultura, 1990.

SANTOS, M. Técnica Espaço Tempo: globalização e meio técnico-científico informacional. São Paulo: Hucitec, 1994. 


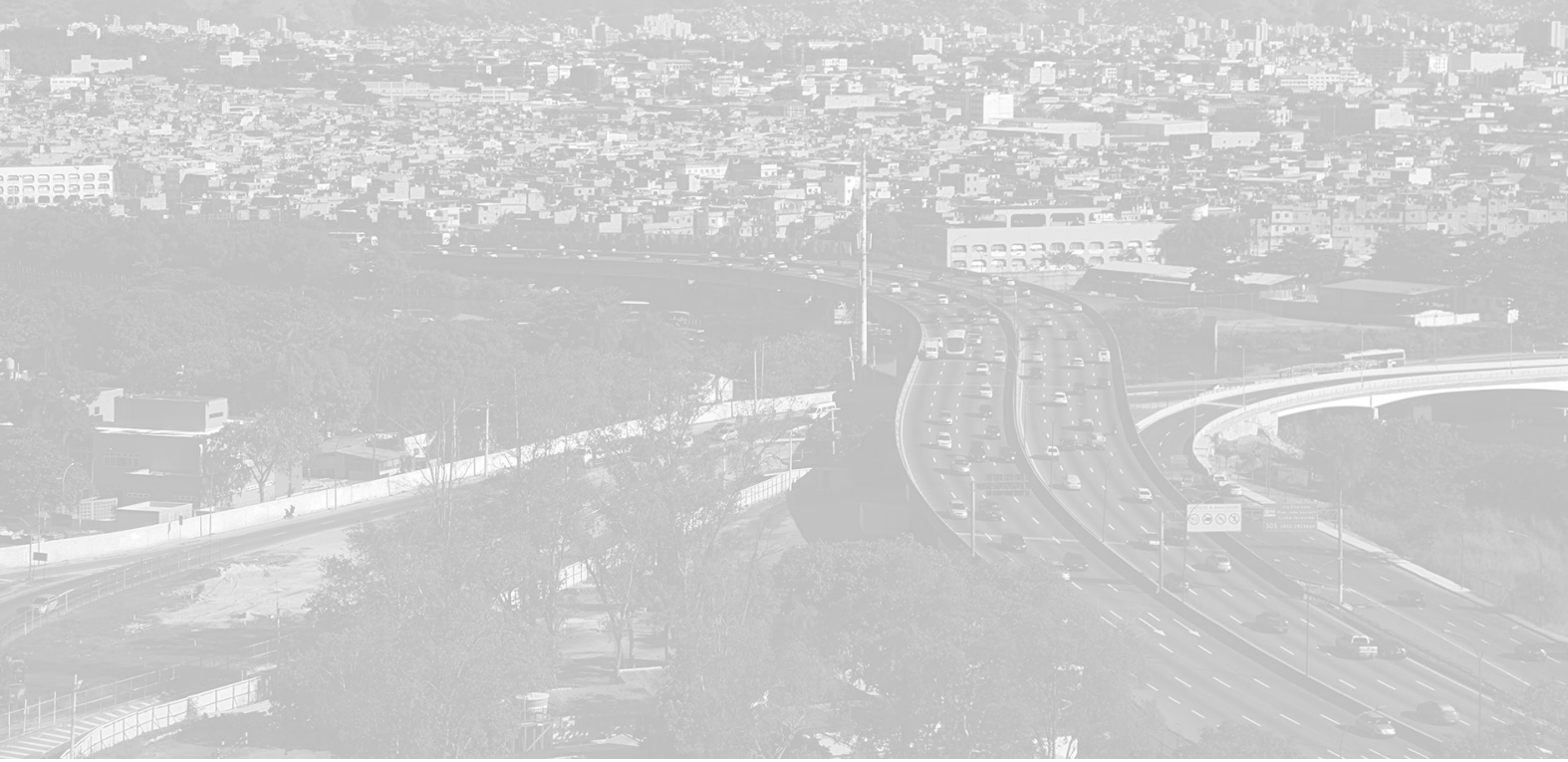




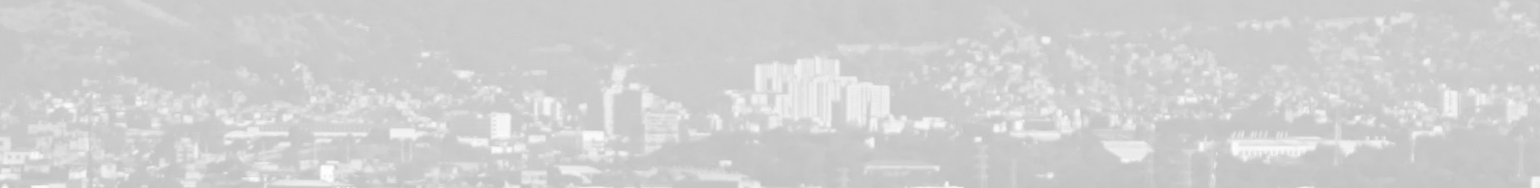

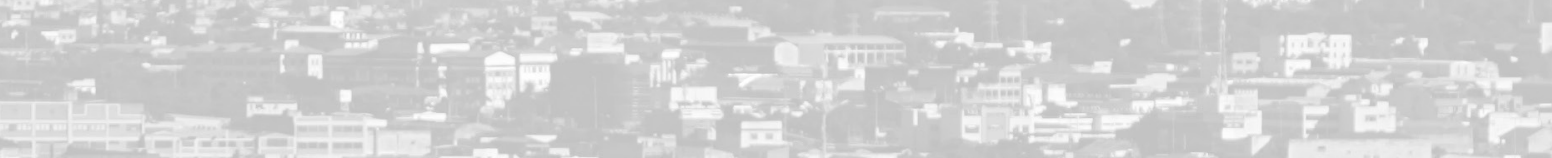

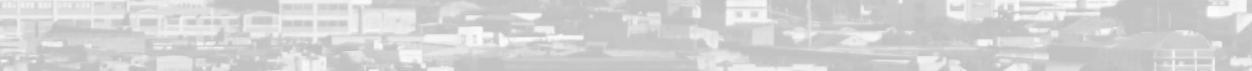

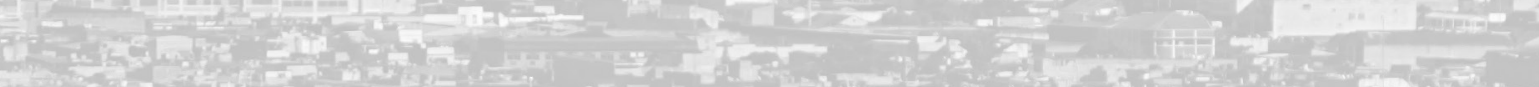

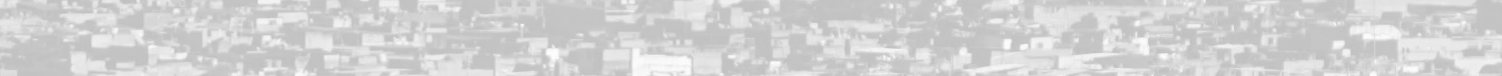

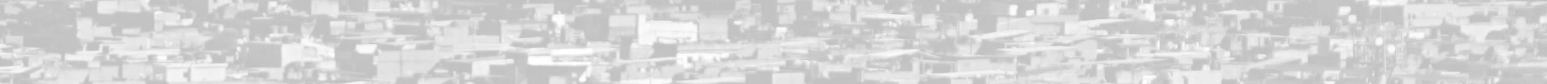

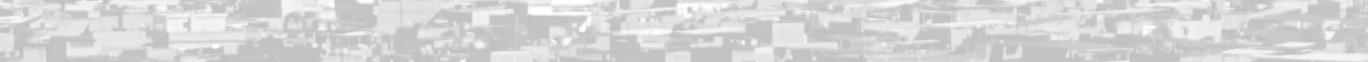

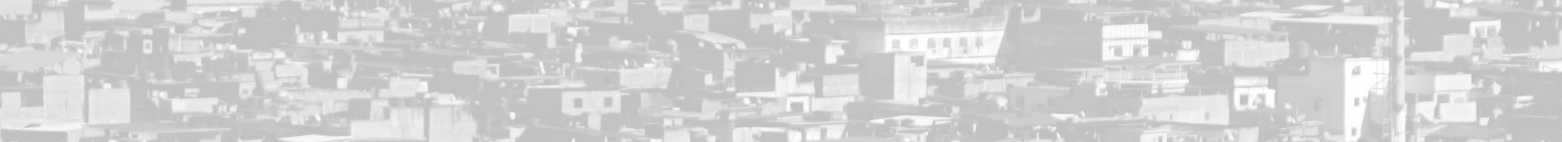

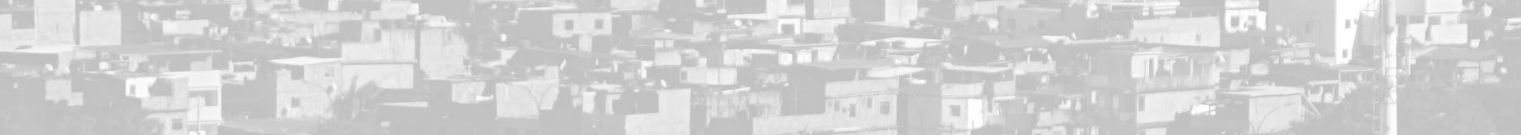

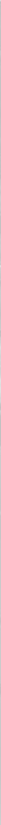


PARTE II SEIS PROJETOS PARA UMA CIDADE SAUDÁVEL 


\title{
Manaus: uma análise ecossistêmica por meio de indicadores de sustentabilidade ambiental e de saúde*
}

\author{
Leandro Luiz Giatti • Carlos Machado de Freitas • Sylvain J. M. Desmoulière \\ Marcilio S. Medeiros • Mírcia B. Costa e Silva • Antonio Levino da S. Neto
}

\begin{abstract}
cidade de Manaus, capital do estado do Amazonas, tem sido considerada um importante polo na Região Pan-Amazônica (Becker \& Stenner, 2008), por seu intenso crescimento econômico e demográfico, com ocorrência de profundas e rápidas mudanças ambientais. O processo exerce forte pressão sobre os sistemas naturais de floresta tropical, em especial, a partir da década de 1970, em que se observa uma intensificação da motricidade induzida por um processo de fluidez do território nacional (Santos, 2009) e rápida industrialização promovida pela Zona Franca de Manaus (Geo Manaus, 2002).
\end{abstract}

Como fatores portadores de futuro para essa capital, têm-se: as condições e tendências dos processos de desenvolvimento vigentes na Amazônia Legal, com intensos impactos ambientais, desigualdades e prejuízos à qualidade de vida dos habitantes (Freitas \& Giatti, 2010); a continuidade de políticas de incentivos fiscais de apoio à industrialização e ao crescimento econômico inerente (Pereira, 2005); o desenvolvimento de infraestrutura sul-americana que transforma a Amazônia de periferia para posição central na porção continental (Théry, 2005); e a escolha dessa capital como uma das sedes da Copa do Mundo de futebol de 2014.

\footnotetext{
* Texto adaptado da síntese preliminar"Manaus: uma análise ecossistêmica através de indicadores de sustentabilidade ambiental e de saúde", que serviu como subsídio ao Seminário Indicadores de Sustentabilidade Ambiental e de Saúde na Cidade de Manaus, realizado nos dias 27 e 28 de junho de 2011, em Manaus. Tanto a síntese preliminar como o seminário foram resultados da pesquisa "Abordagem ecossistêmica para o desenvolvimento de indicadores e cenários de sustentabilidade ambiental e de saúde na cidade de Manaus/AM", desenvolvida com financiamento das Vice-Presidências de Pesquisa e de Serviços de Referência e Meio Ambiente da Fundação Oswaldo Cruz - Edital 01/2007 "Cidades Saudáveis: saúde, ambiente e desenvolvimento".
} 
Neste capítulo, tendo por base uma abordagem ecossistêmica, procurou-se compreender como o desenvolvimento urbano de Manaus afeta os serviços dos ecossistemas e as condições de bem-estar e saúde da população valendo-se desenvolvimento de um conjunto de indicadores de sustentabilidade ambiental e de saúde. Tal análise tem como objetivo subsidiar propostas de ações que possam vir a integrar a agenda pública na gestão urbana e ambiental de Manaus, as quais, futuramente, favoreçam a promoção da saúde.

\section{Concepção Teórica e Metodologia para Análise das Condições e Tendências da Situação Socioambiental e de Saúde}

O Millennium Ecosystem Assessment (MEA, 2005) revela que, apesar de logros em indicadores como esperança de vida ao nascer e mortalidade infantil, o planeta tem enfrentado um processo de profunda degradação dos ecossistemas, especialmente nos últimos cinquenta anos, em situações tais como: extensas e rápidas mudanças para atendimento de crescentes demandas das sociedades; uso insustentável e degradação de recursos naturais em nível global; evidências de mudanças não lineares capazes de incidir severamente sobre bem-estar e saúde; e maiores consequências negativas sobre populações pobres.

Como proposta de estudos integrados necessários para compreender as mudanças holísticas nos ecossistemas, adotou-se as abordagens ecossistêmicas, que pressupõem: reunião de informações diversas, as quais possibilitem demonstrar as interfaces entre bens e serviços, equilibrando-se com as metas ambientais, políticas, sociais e econômicas; formulação de políticas públicas amplas e instituições mais efetivas para implementá-las; participação do público na gestão, particularmente a das comunidades locais. Com essa finalidade, optou-se especificamente pela Abordagem Ecossistêmica em Saúde (AES) (Freitas, 2009), como subsídio para a compreensão das condições atuais e tendências históricas de mudanças nos ecossistemas e seus serviços na cidade de Manaus, bem como das consequências para o bem-estar e a saúde das populações, além da busca de respostas integradas com diversos outros setores e atores, sejam estes locais, regionais e mesmo nacionais.

Atendendo premissas da Teoria dos Sistemas Complexos, no que diz respeito à hierarquia entre os diferentes níveis de organização socioambiental e à dinâmica desses níveis em face de diferentes escalas (espaciais e temporais), a AES tem como base de investigação: o pluralismo metodológico, capaz de reunir, tratar e analisar dados e informações diversas; a ampla participação social; o foco em observações 
de campo que permitam o olhar e o auscultar da realidade local; e a promoção da cooperação e aprendizagem social. Desse modo, houve a possibilidade de se constituir narrativas de tendências e possíveis futuros ou cenários na interface entre os processos que moldam as situações socioambientais, as condições de vida e a situação de saúde das populações.

Tal abordagem deve resultar na proposição de estratégias de monitoramento para a gestão de diversas políticas públicas (Waltner-Toews, 2001; Kay et al., 1999).

Como orientação essencial, adotou-se como principal meta dos processos de desenvolvimento econômico e urbano a melhoria das condições de vida e situação de saúde das populações, que deveria pautar-se por princípios de sustentabilidade ambiental e equidade social como norteadores de análise e busca de soluções. Assume-se que a sustentabilidade deve estar fundamentada no princípio ético de equidade em relação às gerações presentes e futuras, tanto em relação aos determinantes das condições de vida e situação de saúde (emprego, renda, desigualdades e condições de vida), como aos ambientais (manutenção dos serviços dos ecossistemas que servem de suporte à vida). Diante desse horizonte, quanto maiores as iniquidades sociais, mais os distintos grupos populacionais da cidade de Manaus se tornam vulneráveis.

Tais mudanças e impactos aqui tratados apresentam-se como forças motrizes e pressões e integram uma complexa cadeia de efeitos diretos e indiretos, mediados (em escala temporal de semanas/meses e escala espacial local/regional) e modulados (amplas mudanças com base em origens sutis e/ou indiretas, possuindo escala temporal de anos ou décadas e espacial que pode variar do regional ao nacional). Os elementos dessa cadeia de efeitos combinam-se e se sobrepõem simultaneamente, em diferentes níveis de organização socioambiental e escalas espaciais/temporais, bem como envolvem múltiplos determinantes sociais e ambientais, podendo, inclusive, resultar em propriedades emergentes ou rupturas nos sistemas socioambientais, como grandes mudanças ambientais globais, dentre elas as climáticas, exigindo longo prazo para adaptações sociais e no curto prazo atingindo milhões ou bilhões de pessoas em escala global (MEA, 2005).

Dois estudos relativamente recentes demonstram essa complexidade dos determinantes sociais e ambientais e sua cadeia de efeitos. O primeiro, realizado por Prüss-Üstün e Corvalán (2006), revela que os fatores de ordem ambiental contribuem fortemente para os quadros globais de morbimortalidade, estimando que $24 \%$ da carga total de doenças e $23 \%$ de todos os óbitos podem ser fortemente atribuíveis a fatores ambientais. No mesmo estudo é ressaltado também como essa carga ambiental de doenças se expressa de modo desigual em várias porções do 
planeta. Nos países em desenvolvimento, por exemplo, prevalecem importantes doenças de elevada carga ambiental, como as diarreicas, nas quais os fatores ambientais respondem por até $94 \%$ da causalidade. No segundo estudo, dos mesmos autores, assinala-se que o desenvolvimento econômico não resulta em uma redução linear da carga ambiental de doenças, uma vez que países com PIB per capita similar ao do Brasil podem ter uma variação na ordem de duas vezes e meia a mais impactos em termos de saúde ambiental (Prüss-Üstün, Bonjour \& Corvalán, 2008).

Nesse contexto, determinados grupos populacionais podem sofrer exposições muito mais severas quando submetidos à sobreposição de distintos padrões de riscos ambientais (Smith \& Ezzati, 2005; Franco Netto et al., 2009).

\section{A Complexidade nos Sistemas Socioambientais e de Saúde}

Buscou-se compreender os sistemas socioambientais complexos na condição de sistemas abertos, envolvendo diferentes níveis de organização socioambiental e com capacidade de auto-organização em torno de atratores, dinâmicos e adaptativos. Considerou-se como atratores as situações e eventos, que podem se constituir por meio de estímulos positivos ou negativos, cuja dinâmica por eles condicionada impulsiona uma auto-organização em consequência de processos circulares de retroalimentação (feedbacks) e adaptações contínuas. Na condição de níveis de organização socioambiental temos as escalas espaciais e temporais, em que prevalecem estruturas hierárquicas livres com relações de reciprocidade que podem ocorrer dentro de um mesmo nível ou entre distintos níveis de organização socioambiental (Kay et al., 1999; Waltner-Toews, 2001).

Tais atratores tornam os sistemas propensos a determinados tipos de organização hegemônica, além de serem múltiplos e nem sempre seguirem um padrão de complementaridade e cooperação, mas, ocasionalmente, de competição e contradição. Podem incidir na emergência de novos estados e situações, fragmentações, surpresas e mesmo catástrofes também possíveis. A análise da complexidade inerente aos sistemas socioambientais tem como objetivo identificar os atratores e pontos críticos de instabilidade ou vulnerabilidade que podem resultar na emergência espontânea de novos padrões e estruturas de relações, bem como de novas formas de organização (social e ambiental). Essa abordagem requer tratar o sistema socioambiental dialeticamente, sendo chave o conceito de contradição e permitindo integrar o aparentemente paradoxal conceito de “destruição criativa" na estrutura geral (Kay et al., 1999; Funtowicz \& Ravetz, 1994). 
Desse modo, não basta identificar perturbações lineares na estabilidade dinâmica (como surtos de doenças ou aumento de morbimortalidade) e tratálas com intervenções pontuais. Necessita-se investigar e agir sobre sinais que apontam para novas formas de organização em torno de atratores e propriedades emergentes que podem resultar em alterações radicais e efeitos severos sobre a saúde, bem-estar e condições de vida (Waltner-Toews, 2001; Kay et al., 1999).

Como parte fundamental de uma AES, este texto trata de definir a situaçãoproblema relacionada ao sistema socioambiental, às condições de vida e à situação de saúde com base em dados e indicadores amplamente produzidos e publicados por distintas fontes, tais como Instituto Brasileiro de Geografia e Estatística (IBGE), o Departamento de Informática do Sistema Único de Saúde/MS (Datasus), as Secretarias de Estado de políticas públicas (do Amazonas e de Manaus) e a Superintendência da Zona Franca de Manaus (Suframa), dentre outras.

Do ponto de vista operacional, analisou-se uma ampla cadeia de causas e consequências por meio do modelo Força Motriz-Pressão-Situação-ExposiçãoEfeito-Ação (FPSEEA), proposto pela Organização Mundial da Saúde (OMS) (Corvalán, Briggs \& Kjellström, 2000). A principal vantagem deste sobre outros modelos de indicadores é considerar, de modo mais destacado, as exposições ambientais dos humanos em diferentes situações ambientais, assim como seus consequentes efeitos sobre a situação saúde. A aplicação desse modelo possibilita o estabelecimento de ligações causais entre os fatos, permitindo vislumbrar que os efeitos sobre as situações de saúde das populações resultam de um amplo processo histórico e socioambiental, de modo que é impossível compreendê-los dissociados de seus determinantes sociais e ambientais, exigindo ações em todos os níveis.

\section{Aplicação e Análise da Matriz FPSEEA para Manaus}

Forças motrizes socioeconômicas e pressões ambientais

O estado do Amazonas, em termos espaciais, é a maior unidade da federação. Tem área de 1.601 .920 km² e divide-se em 62 municípios. Componente da Região Norte do país e da macrorregião Amazônia Legal, encontra-se delimitada por nove estados onde ocorre o bioma amazônico, a saber: Acre, Amapá, Amazonas, Pará, Rondônia, Roraima, Tocantins, Mato Grosso, Maranhão. A respeito dos remanescentes de vegetação nativa, o estado do Amazonas ainda apresenta uma das melhores condições de conservação, onde apenas 2,4\% de sua cobertura original de floresta foi desmatada até o ano de 2012. A capital Manaus estende-se sobre uma área $11.474 \mathrm{~km}^{2}(0,73 \%$ da área do estado) e um desmatamento 
total acumulado até 2012 de $1.249 \mathrm{~km}^{2}$, equivalente a 10,9\% da área municipal (Inpe, 2014). Oliveira e Costa (2007) afirmam que a área urbanizada de Manaus corresponde a $4 \%$ da área do município. Geograficamente, a cidade localiza-se sobre um baixo planalto que se desenvolve na barranca da margem esquerda do rio Negro - nas imediações da confluência do rio Solimões - e também nas proximidades da foz do rio Tarumã com o rio Negro (Geo Manaus, 2002).

Historicamente, desde o período do extrativismo, Manaus tem grande importância por sua localização estratégica, com acesso por uma extensa rede hidroviária, dispondo de conexões internas pelo estado e também externas ao país. Desde a década de 1970 predomina, em Manaus, o crescimento da industrialização promovida pela Zona Franca, reforçando o papel dessa cidade na condição de liderança macrorregional (Becker \& Stenner, 2008).

Milton Santos (2009) assinala que a chegada do processo de industrialização a Manaus também é determinada por um processo técnico-científico que possibilitou a fluidez do espaço, ampliando o poder de ocupação territorial promovido pelo Estado, com base na grande mobilidade de fatores de produção, trabalho, produtos, mercadorias e capital.

Apesar da importância indiscutível de Manaus em toda a extensa Região Amazônica, sua rede urbana, distribuída por 72 municípios, compreende 1,7\% em relação à população nacional, apresentando baixa intensidade de relacionamento com outras cidades. Manaus é bastante prejudicada por sua precária conexão com eixos rodoviários (Sathler, Monte-Mór \& Carvalho, 2009). Em contraponto a essas fragilidades, há no contexto internacional, desde o ano 2000, um amplo projeto multilateral e multissetorial denominado Iniciativa de Integração da Infraestrutura Regional Sul-americana (Iirsa). Esta iniciativa almeja aumentar a fluidez do território da América do Sul por meio de eixos de integração e desenvolvimento, transformando a Amazônia em área privilegiada em termos de fluxos (Théry, 2005). Tal iniciativa certamente incide em significativo aporte à já privilegiada posição estratégica de Manaus, embora haja indicativos de negligência a questões ambientais e urbanas inerentes a esse processo (Vitte, 2009).

Manaus concentra cerca de metade da população do estado e aproximadamente $80 \%$ de seu produto interno bruto - PIB (Freitas \& Giatti, 2010). Seu crescimento populacional pode ser observado no Gráfico 1, com nítida e intensa progressão a partir da década de 1970, com 99,5\% de sua população atualmente concentrada na área urbana (IBGE, 2011). A respeito disso, no período de 1950 a 2000 a taxa de urbanização no Brasil saltou de $36,1 \%$ para $81,2 \%$ e, comparativamente, no estado do Amazonas cresceu de 26,8\% para 74,8\% (IBGE, 2000). 
Gráfico 1 - População residente em Manaus de 1872 a 2010

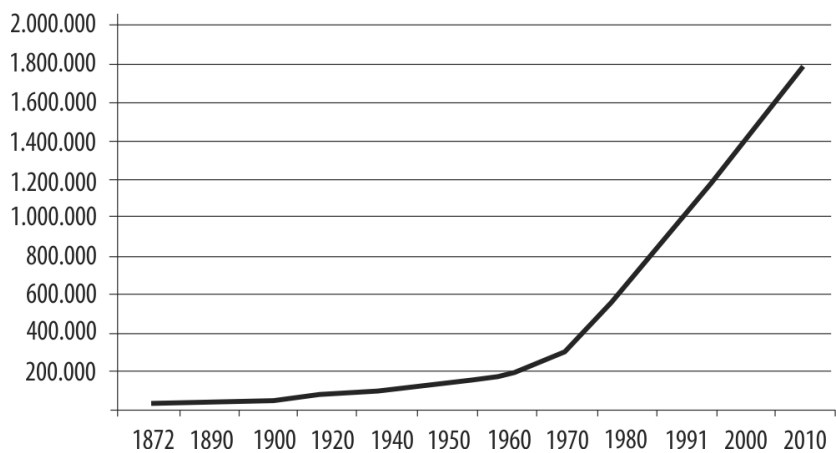

Fontes: Recenseamento do Brasil 1872-1920. Rio de Janeiro: Diretoria Geral de Estatística, [1872]-1930; Censos demográficos 1940-2010.

Obs: Exceto os dados do censo demográfico 2010, todos os demais foram obtidos diretamente com a Unidade Estadual do Amazonas do IBGE.

Os municípios da Região Amazônica, de modo geral, têm apresentado grande variação populacional, principalmente por migrações. Assim, Manaus destaca-se com uma das maiores mudanças em termos de crescimento populacional para municípios brasileiros entre 2000 e 2007 (Théry, 2008). Segundo Sathler, MonteMór e Carvalho (2009: 22), "Na Amazônia, a integração econômico-espacial provida pela globalização não foi suficiente para reduzir significativamente as distâncias entre as pequenas cidades e os demais níveis hierárquicos das redes urbanas", o que faz com que Manaus, na condição de cidade globalizada, exerça grande força atrativa para a migração.

O PIB de Manaus é bastante expressivo, ocupando, em 2011, o sexto maior dentre os municípios do país. Com crescimento marcante entre os anos de 2002 (IBGE, 2007) e 2011 (186\%), totalizou neste último ano R\$ 51 bilhões. O PIB per capita nessa capital atingiu R\$27.845,00 em 2011, ao passo que o PIB per capita do estado do Amazonas chegou a R\$ 18.244,00 no mesmo ano (IBGE, 2013). Em 2011 o PIB de Manaus representou 2,6 vezes o PIB de Belém (no Pará), segunda maior cidade da Amazônia brasileira (IBGE, 2013).

Apesar disso, indicadores de distribuição de renda em Manaus têm demonstrado permanência e recrudescimento de desigualdades. Como exemplo, pode-se mencionar o percentual de pobres, ${ }^{1}$ que aumentou de 23,6\%, em 1991, para $35,2 \%$ em 2000. De acordo com dados do censo demográfico de 2010, o percentual de pessoas abaixo da linha da pobreza em Manaus foi de 35,5\%

\footnotetext{
${ }^{1}$ Pessoas com renda domiciliar per capita mensal inferior a $\mathrm{R} \$$ 61,90, sendo 20100 ano de valor de referência.
} 
(Pnud, 2012). A renda domiciliar per capita mensal de Manaus, mesmo sendo a maior dentre os municípios amazonenses, apresentou queda de $\mathrm{R} \$ 276,90$, em 1991, para R $\$ 262,40 \mathrm{em} \mathrm{2000.}{ }^{2} \mathrm{Em} 2010$, a o rendimento nominal mensal per capita em Manaus teve média de R\$641,00 e mediana de R\$334,00 (IBGE, 2011). Nesse sentido, se por um lado observamos a elevação da renda, por outro, temos indícios da prevalência de grandes desigualdades. Assim, temos a razão entre a renda dos $10 \%$ mais ricos e dos $40 \%$ mais pobres, que evoluiu de $18,8 \%$ em 1991 para 30,8\% em 2000 (Ipea, 2010).

Na motricidade do processo econômico, o Polo Industrial de Manaus (PIM), cujo admirável crescimento pode ser verificado no Gráfico 2, contava, em 2008, com 550 fábricas, gerando 113.837 empregos diretos e cerca de 400 mil indiretos (Suframa, 2010). Por sua vez, é importante ressaltar a suscetibilidade conjuntural do faturamento do PIM sobre dois aspectos: primeiro em relação à vulnerabilidade econômica externa, como a crise do governo Collor - em 1991 e a crise cambial - em 1997. E ainda, com a crise econômica de 2008-2009, o montante de faturamento do PIM declinou aproximadamente 7\% (Amazonas, 2010); segundo, com relação à troca e fluxo de mercadorias e insumos. O PIM exporta pouco (principalmente para o Mercosul) - sendo o maior escoamento de sua produção para o mercado nacional -, ao passo que importa muitos insumos tecnológicos, especialmente de países asiáticos (Suframa, 2008).

Na análise de Pereira (2005), a Zona Franca é um modelo de pouca relação com as potencialidades da região, que defende interesses exógenos com aquisição de mão de obra barata e significativos favores fiscais e governamentais. Nesse sentido, "A ZFM contorna a rede de trocas tradicional substituindo-a por uma dependência em investimento externo por firmas estrangeiras e multinacionais..." (Browder \& Godfrey, 2006: 160).

O rápido crescimento econômico e populacional de Manaus vem induzindo pressões como o aumento do consumo de energia elétrica, gerada principalmente em termoelétricas. Entre 1999 e 2008, eleva-se em 59,2\% o crescimento do valor bruto fornecido, assim como o fornecimento per capita, que se apresenta igualmente crescente, apesar do crescimento populacional, apresentando uma relação de elevação de padrão de consumo. ${ }^{3}$ Assinala-se que no período de 1999 a 2008 o número de consumidores de energia elétrica em Manaus subiu 35,2\%, elevando-se de 324.276 para 438.536 ligações (Amazonas, 2010).

\footnotetext{
${ }^{2}$ Unidade de valor monetário em reais, sendo 20000 ano de valor de referência.

${ }^{3}$ Informações cedidas pela Manaus Energia, em referência a 2008 e série histórica.
} 
Gráfico 2 - Evolução do faturamento do PIM, total e subsetores de 1988 a 2007 em bilhões de dólares

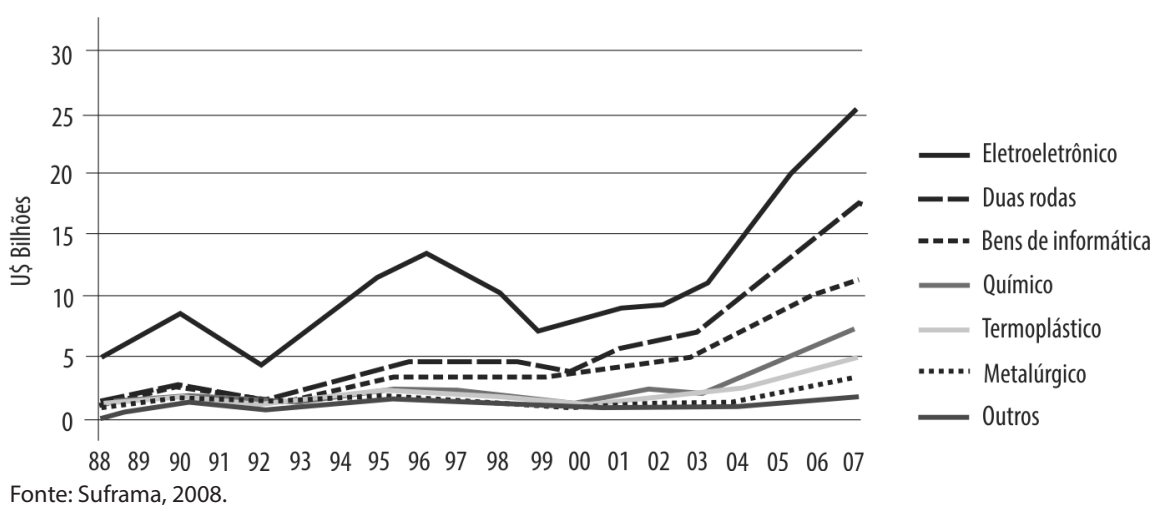

A frota de veículos em Manaus cresceu 178,5\% entre 1995 e 2008. Calculando-se a relação da frota de veículos pela população, verifica-se a elevação de $62,5 \%$ do coeficiente no período, atingindo-se o índice de um veículo para cada quatro habitantes. Todavia, de acordo com o censo demográfico de 2010 (Ipea, 2010), o percentual de pessoas que viviam em domicílios com carro disponível para locomoção em Manaus atingiu 21,5\%.

As desigualdades associadas à ocupação espacial são exibidas na Figura 1, com a distribuição de categorias de renda e a delimitação dos cursos hídricos de Manaus, concentrando a pobreza nas periferias distantes e nas áreas de influência dos igarapés, mesmo nas partes mais centrais da cidade. Essa segregação ocorre historicamente naquela capital. Porém, com a rápida industrialização, tal segregação vem-se acelerando e reproduzindo condições de precária infraestrutura e equipamentos (Oliveira \& Schor, 2008), caracterizando assim um processo de urbanização corporativa (Santos, 2009).

\section{Situação e exposição}

Considera-se que essa capital é um ecossistema urbano complexo, cuja dinâmica acarreta efeitos sobre a saúde. Dessa forma, há de se avaliar a atual (e provavelmente também a futura) vulnerabilidade dos grupos populacionais e a resiliência - capacidade de adaptação das coletividades humanas. Os atratores que incidem sob o urbano sobrepõem-se ao ecossistema natural, não sendo possível distinguir o natural do antrópico, o que faz com que se organizem diferentes

\footnotetext{
${ }^{4}$ Informação cedida diretamente pelo Detran do estado do Amazonas, em referência ao ano 2009.
} 


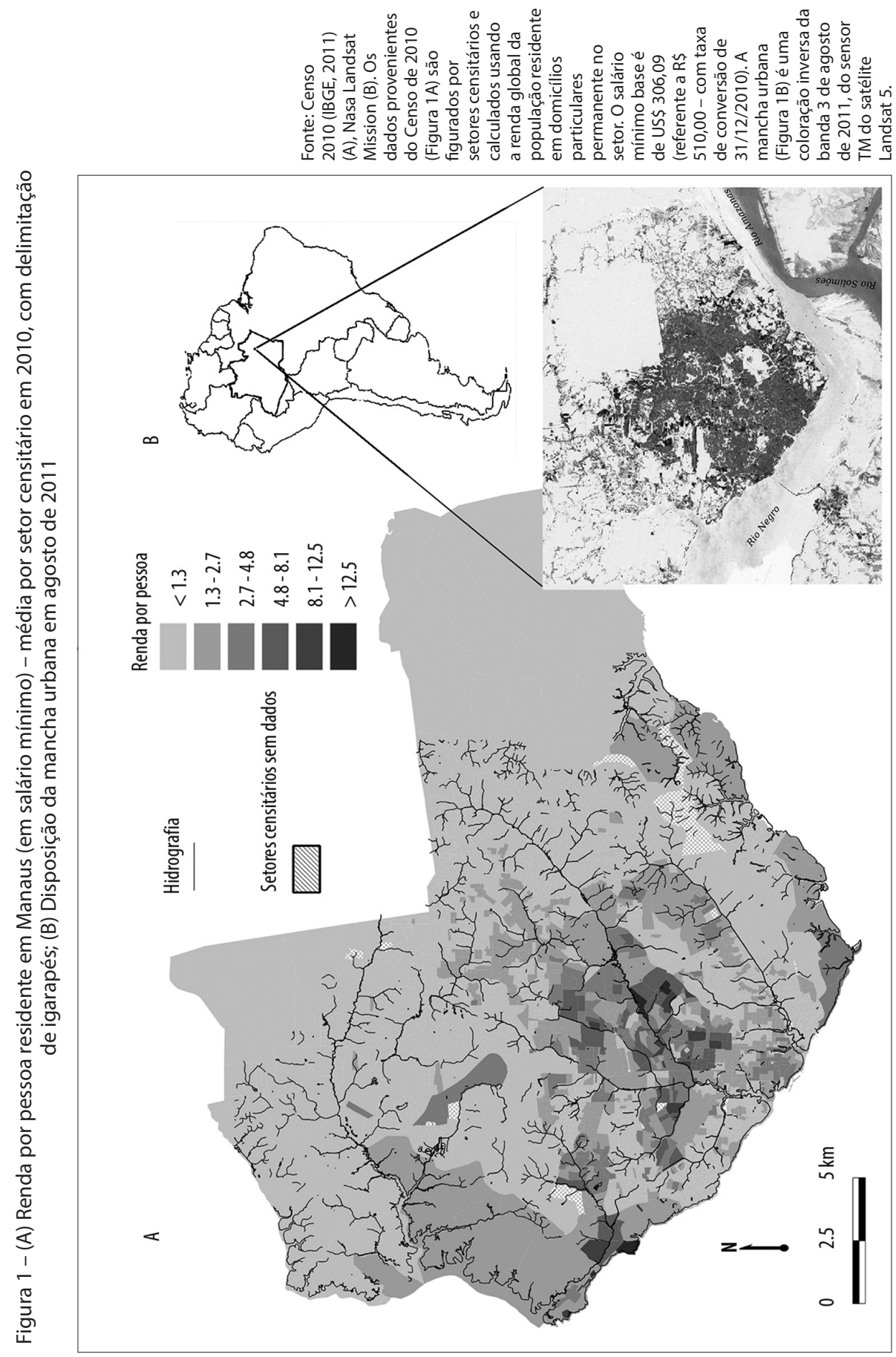


padrões de situações e exposições ambientais, com seus respectivos impactos nos serviços dos ecossistemas e riscos à saúde humana.

A dinâmica urbana do uso do solo se faz intensa, conduzindo a ocupação para periferias distantes, como, aliás, historicamente também para as áreas de influência dos igarapés e do sistema hídrico. A ocupação de áreas distantes ocorreu por projetos estaduais ou municipais de construção de complexos residenciais populares (Nova Cidade, Cidade Nova e outros), materializando uma cidade espraiada com inúmeros vazios, destruindo a cobertura vegetal natural, privando a população de serviços essenciais e reproduzindo sérios problemas viários.

Em se tratando de esgotamento sanitário, o percentual de domicílios com instalação sanitária ligada à rede geral de esgotos (e/ou águas pluviais) era de 32,5\% em 2000, apontando, por um lado, um sério déficit relacionado a tal setor (Ipea, 2010). Por outro lado, de acordo com dados de 2008 da Pesquisa Nacional de Saneamento Básico, Manaus conta com 418.657 domicílios abastecidos por água de rede pública, ao passo que são apenas 29.768 (7,1\% do total com abastecimento de água) os esgotados por rede coletora de esgotos sanitários (IBGE, 2010).

O percentual de domicílios atendidos por abastecimento de água encanada proveniente de rede geral apresenta crescimento desde 1970 até 1991 (atingindo 79\%) e ligeira queda no ano de 2000 (74\%), totalizando, nesse ano, 243.296 domicílios (Ipea, 2010).

Um plano de ação da Companhia Águas do Amazonas ${ }^{5}$ - concessionária de saneamento no município - descreve o sistema de abastecimento de água da cidade. Ele é composto por adutoras que fornecem água tratada captada no rio Negro, além de soluções alternativas como a distribuição de água proveniente de poços profundos no meio urbano. Tal sistema mantinha, em 2007, aproximadamente 600 mil pessoas com abastecimento precário e 250 mil pessoas sem abastecimento público de água. Permanecem as maiores dificuldades de abastecimento nas zonas norte e leste da cidade, predominantemente. Vale salientar que essas áreas comportavam, à época, quase metade dos domicílios (44,2\%), e foram tornando-se as localidades da cidade que mais cresceram entre 1991 e 2000 (Oliveira \& Costa, 2007; FJP, 2011). Em análise de dados do censo demográfico de 2000 é possível verificar a prevalência do abastecimento de domicílios por água de poços ou nascentes em Manaus, mesmo em áreas atendidas por rede pública de abastecimento (IBGE, 2000).

\footnotetext{
${ }^{5}$ Documento obtido da companhia em 2009.
} 
Nessa capital o percentual de pessoas que vivia em domicílios atendidos por coleta de resíduos sólidos era de 78\% em 1991, tendo evoluído para 91\% em 2000 (Ipea, 2010). Em 2007, de acordo com o Sistema Nacional de Informações sobre Saneamento (SNIS), a taxa de cobertura da coleta de resíduos sólidos foi de 100\% para o município de Manaus (Brasil, 2009).

Em um panorama comparativo entre dados de saneamento dos censos demográficos de 2000 e 2010, evidenciou-se que em Manaus o percentual de domicílios considerados adequados caiu, no período em questão, de 56,3\% para 50,3\%. Cabe ressaltar que a categoria considerada adequada diz respeito à disponibilidade simultânea de abastecimento de água por rede geral, esgotamento sanitário por rede geral ou fossa séptica e lixo coletado direta ou indiretamente (IBGE, 2011). O fato de a destinação de esgotos para fossa séptica ser contemplada na categoria, certamente permite a inclusão de muitos domicílios na mesma, apesar de, como já apresentado, haver baixa cobertura de domicílios por esgotamentos via rede coletora, solução que seria mais adequada para essa grande Manaus.

A coleta de resíduos sólidos urbanos em Manaus em 2007 foi de 1.975 t/dia, com produção per capita de 1,20 kg/hab/dia (Abrelpe, 2007). Em 2009 registra-se a coleta de $2.168 \mathrm{t} /$ dia nessa capital, com produção per capita de 1,25 kg/hab/dia. Para o Brasil, projeta-se uma produção per capita de resíduos sólidos urbanos da ordem de 1,25 kg/hab/dia, com variações. A produção de resíduos per capita em Manaus se destaca por ser o maior encontrado na região da Amazônia Legal, com tendência de se aproximar do valor de outras capitais brasileiras com elevada produção de resíduos (Abrelpe, 2009). Os resíduos sólidos urbanos coletados nessa capital são encaminhados para um aterro de resíduos sólidos urbanos controlado, iniciado em 1986, situado na zona norte da cidade, no km 19 da rodovia AM-010. Este recebe aproximadamente 900 mil toneladas por ano $(875.892 \mathrm{em} 2002 \mathrm{e}$ 883.676 em 2007) na forma de resíduos domiciliares e públicos, de serviços de saúde, entulho e resíduos de podas e outros. A coleta seletiva $(0,1 \%$ do total em 2002 e $0,2 \%$ em 2007), apesar de ter duplicado, permanece com cifra muito baixa (Brasil, 2004, 2009).

Entre 1971 e 1986, existia em Manaus um depósito de lixo desprovido de critérios técnicos de proteção ambiental. Situava-se na área hoje ocupada pelo bairro periférico Novo Israel, zona norte da cidade, local onde entre 2007 e 2008 água contaminada, inclusive por metais pesados, era captada em poços e consumida pela população local. Isso, apesar do reconhecimento do problema ambiental (Giatti et al., 2010). 
Analisando a inserção de Manaus nos sistemas naturais, especificamente quanto ao sistema hídrico, a cidade está localizada entre dois grandes rios e inúmeros igarapés, abrangendo quatro bacias hidrográficas tributárias do rio Negro. No interior da cidade situam-se integralmente duas bacias - dos igarapés São Raimundo e Educandos - e partes das bacias do igarapé Tarumã-Açu e do rio Puraquequara. A complexa rede hidrográfica da cidade, composta por inúmeros afluentes dos cursos principais apresenta uma série de problemas, como águas poluídas - sobretudo por esgotos domésticos -, alagamentos de áreas ocupadas, riscos de desabamentos e inundações por cheias fluviais (Geo Manaus, 2002).

O igarapé Tarumã-Açu, que corta a cidade pela sua zona oeste e deságua no rio Negro, nas proximidades do bairro Ponta Negra, constitui um importante local de lazer e para atividades de recreação, inclusive de contato primário com a água. Ele tem sofrido um processo de contaminação tanto por esgotos domésticos como pelo fato de ter em sua bacia de drenagem a localização do aterro controlado da rodovia AM-010 (Santos et al., 2006), acarretando contaminação por metais pesados em níveis superiores aos estabelecidos pela resolução Conama n. 357/2005 (Santana \& Barroncas, 2007).

Ressalta-se ainda que a "cidade cresce de costas para os rios, aterra seus igarapés ou deixa-os como veias abertas a drenar esgotos" (Oliveira \& Schor, 2008: 59). Isso também consumou um modelo de urbanização que agride intensamente os recursos hídricos e suas áreas de influência, como por aterramentos que desde o passado ocorriam sob uma lógica de supressão de áreas sujeitas a ares corrompidos (Valle \& Oliveira, 2003).

Uma intervenção de grandes proporções nos igarapés foi feita por meio do Programa Social e Ambiental dos Igarapés de Manaus (Prosamim), realizado com financiamento do Banco Interamericano de Desenvolvimento (BID). Tal programa deve ser mencionado como ação de resgate do espaço dos igarapés no meio urbano, embora estejam bastante oprimidos pelo traçado que a cidade constituiu. Todavia, um grande esforço ainda se faz necessário para se tratar das causas da poluição dos igarapés por esgotos, pois só então poder-se-á considerar as áreas beneficiadas como ambientes favoráveis à saúde.

Os igarapés, chavascais e nascentes, por sua importância sistêmica e sua contribuição no provimento de serviços de ecossistemas e suporte à vida (MEA, 2005), são fundamentais no ciclo da água, drenagem, manutenção da biota, interação com sistemas terrestres, influência no microclima, interação com rios e bacia hidrográfica, entre outros. Sob a necessidade de se manejar essas áreas por sua capacidade como sistemas de suporte à vida, sua gestão deve ser realizada 
em torno das trocas e fluxos com sistemas antrópico e natural. Assim, há que se assinalar que a preservação e a não ocupação irregular desses sistemas hídricos tem grande relevância:

- para a drenagem urbana e para a prevenção de enchentes, inundações e desastres associados;

- para a minimização do efeito que produz calor urbano, podendo interferir positivamente mediante a constituição de ilhas de calor;

- por ter a possibilidade de oferecer áreas verdes para usufruto dos habitantes, revertendo em ambientes favoráveis à saúde e favorecendo práticas saudáveis - promoção da saúde;

- por ter a possibilidade de fortalecimento da identidade singular da cidade, com suas características de interação com os sistemas naturais.

Quanto à cobertura vegetal no espaço urbano de Manaus, um estudo realizado tomando por base um sensoriamento remoto, entre 1986 e 2004 (Nogueira, Sanson \& Pessoa, 2007), mostra como a partir do franco crescimento urbano de Manaus decorre um processo de desmatamento que, de modo predatório, ocupa as bordas e os espaços intraurbanos. Durante ocupação, a área urbana da capital perdeu $65 \%$ de sua cobertura vegetal, tendo sido suprimida aproximadamente 20\% da cobertura em apenas 18 anos.

Com a grande extensão do município e a ocupação de apenas uma pequena fração de sua área, é no ambiente urbano, profundamente modificado, que as consequências da depleção do verde vêm interferir no bem-estar humano de grande parte da população.

Com relação à arborização urbana, há carência de dados ou indicadores para Manaus, mas a cidade tem apresentado padrão de arborização em quintais, o que pode ser verificado em uma ocupação planejada e consolidada como a do bairro Cidade Nova, na zona norte de Manaus. Por sua vez, ocupações mais recentes e também planejadas, como a do bairro Nova Cidade, carecem substancialmente de arborização. Tal fator, muitas vezes, acaba por criar ambientes bastante inóspitos como os dos conjuntos residenciais populares desse mesmo bairro, os quais não contam com áreas verdes e são constituídos por casas que oferecem pouco conforto térmico. ${ }^{6}$

Também se ressaltam outros problemas decorrentes da precária urbanização de Manaus: inadequação dos instrumentos de planejamento e controle; insuficiência

${ }^{6}$ Informação obtida da Secretaria Municipal de Meio Ambiente (Semma/Manaus) por ocasião de apresentação no seminário Impacto das Mudanças Climáticas sobre Manaus e Bacia do Rio Negro, ocorrido em Manaus em 2008. 
e desarticulação da malha viária; descaracterização ou substituição de edificações de interesse histórico e cultural: intensificação da atividade imobiliária; e deficiência da infraestrutura urbana e dos serviços e equipamentos sociais básicos (Geo Manaus, 2002). Em termos de expansão urbana, os conjuntos habitacionais e as ocupações espontâneas constituíram os mais recentes (três últimas décadas) vetores, reproduzindo contradições entre ricos e pobres no contexto da moradia (Oliveira \& Costa, 2007).

Na tentativa de qualificar e quantificar aspectos de habitação, o conceito de déficit habitacional básico, segundo a Fundação João Pinheiro (FJP, 2011), corresponde ao somatório das habitações que registraram ou foram caracterizadas no último censo demográfico como coabitação familiar, domicílios improvisados e domicílios rústicos. Assim, o déficit habitacional urbano de Manaus é estimado em 105.044 unidades habitacionais, correspondente a 69\% do déficit do estado do Amazonas. O componente que mais pesa negativamente para esse indicador é o de coabitação familiar, representando 52\% do total do déficit (FJP, 2011).

Com relação à poluição atmosférica, não há ainda em Manaus uma rede de monitoramento. Contudo, verifica-se que sua pluma de dispersão de poluentes pode ser observada por cerca de $100 \mathrm{~km}$ de distância sobre suas imediações, onde prevalecem áreas de florestas nativas (Kuhn et al., 2010). Recentemente, usinas mais modernas e menos poluentes movidas a gás natural têm substituído antigas usinas a óleo combustível nessa capital (Geo Manaus, 2002). Por conta disso, deve haver preocupação com o aumento da frota de veículos e a consequente poluição atmosférica no meio urbano.

\section{Efeitos}

Para um estudo da situação de saúde de Manaus, considerando agravos de elevada carga de fatores ambientais (Prüss-Üstün \& Corvalán, 2006), é importante que se reflita inicialmente sobre o processo de transição demográfica e epidemiológica. Nesse sentido, uma relevante medida é a que diz respeito ao índice de envelhecimento, representado pelo número de pessoas com 60 ou mais anos de idade para cada cem habitantes com menos de 15 anos (Ripsa, 2008). Entre 1991 e 2008 esse índice evoluiu no país, passando de 21,0 para 37,9, ao passo que em Manaus, no mesmo período, passou de 10,8 para 17,4 (Datasus, 2014).

A taxa de fecundidade total brasileira, entre 1991 e 2011, caiu de 2,73 para 1,78 filhos por mulher (queda de 0,95 filhos por mulher), enquanto no estado do Amazonas, no mesmo período, caiu de 4,07 para 2,55 filhos por mulher, representando uma queda de 1,52 filhos por mulher (Datasus, 2014). 
A expectativa de vida ao nascer em 2008, para a população brasileira, foi de 73 anos, enquanto para a população do Amazonas foi de 71,8 anos.

A redução da mortalidade infantil em Manaus já assinala um desempenho melhor que o nacional, baixando de 48,8 óbitos de menores de 5 anos por mil nascidos vivos, em 1996, para 16,5 em 2010, o que demonstra a tendência ao cumprimento do Objetivo de Desenvolvimento do Milênio, cuja meta a ser atingida por Manaus em 2015 é de 16,2 óbitos de crianças menores de 5 anos para cada mil nascidos vivos (Pnud, 2012).

De modo geral, a capital do Amazonas ainda conta com uma população bastante jovem, mas que experimenta um processo tardio de envelhecimento, sobretudo se comparado à realidade do país (Figuras $2 \mathrm{a}$ e $2 \mathrm{~b}$ ). A confrontação entre as pirâmides etárias de Manaus, relacionadas aos dados dos censos de 2000 e 2010, aponta para um início de estreitamento na base em 2010, sendo a faixa etária dos 14 anos a mais numerosa, o que permite inferir sobre a ocorrência de grande e constante migração de jovens para essa capital.

Essa transição demográfica, acompanhada pela substituição dos índices de morbimortalidade por doenças infecciosas e parasitárias para doenças crônico-

Figura 2a - Pirâmides etárias de Manaus e do Brasil, 2010

MANAUS

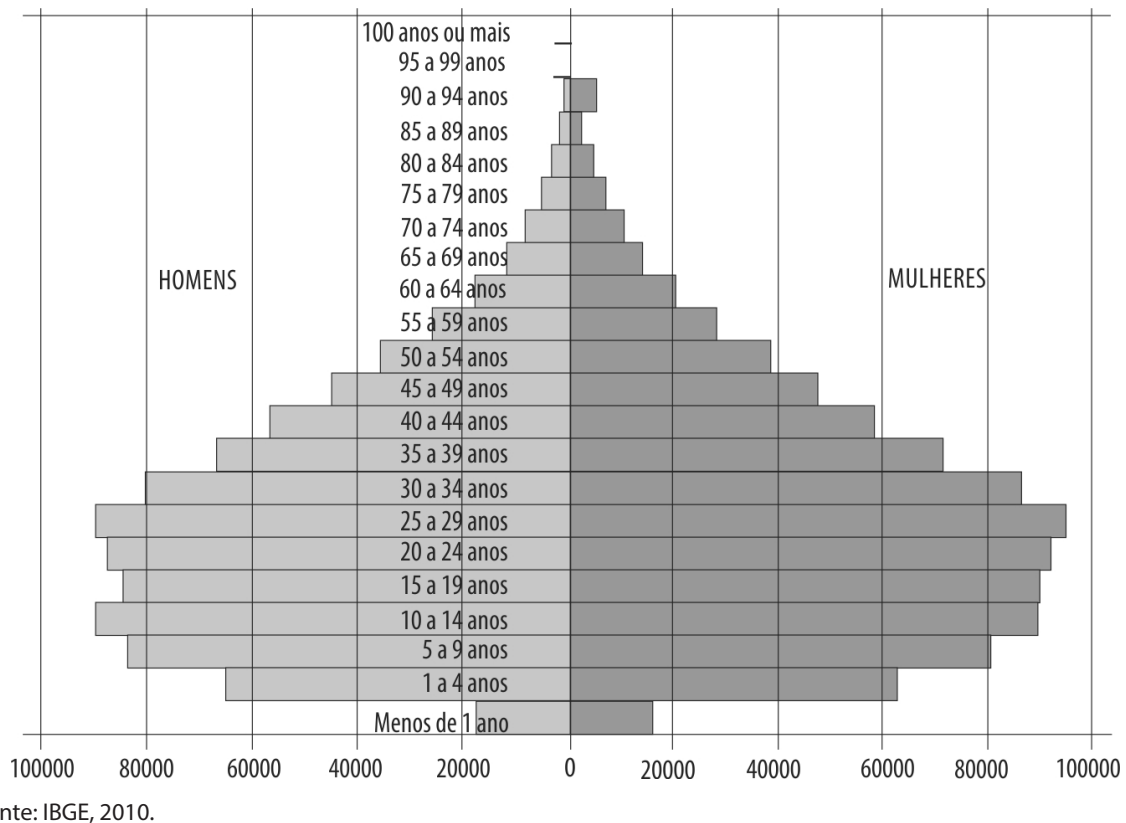


degenerativas, tem-se reproduzido com certas singularidades nos países em desenvolvimento. No Brasil, por exemplo, temos a persistência de algumas doenças infecciosas associadas à pobreza e a precárias condições sanitárias, ao passo que temos o crescimento das doenças associadas ao processo de urbanização, industrialização e da expansão das fronteiras agrícolas (Barreto \& Carmo, 2007).

Figura 2b - Pirâmides etárias de Manaus e do Brasil, 2010

BRASIL

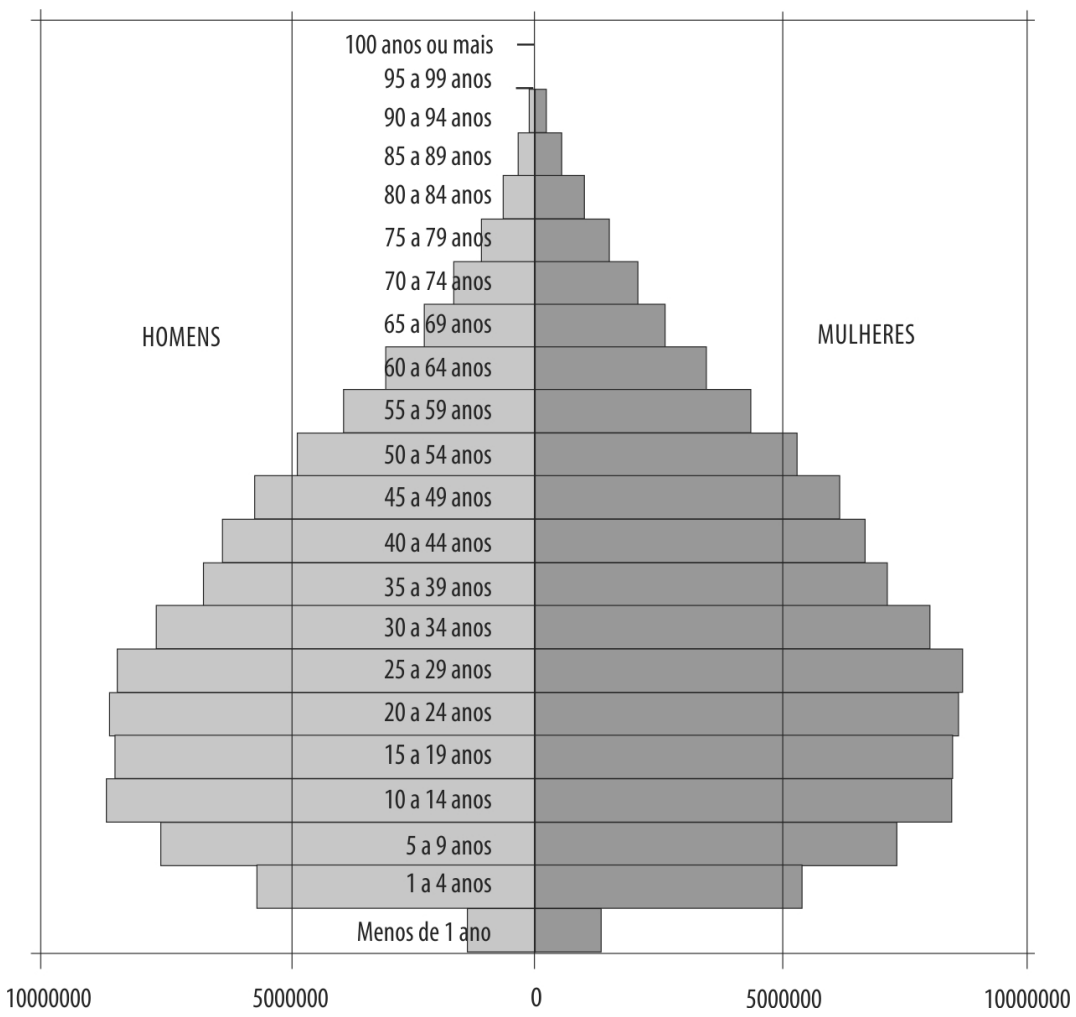

Fonte: IBGE, 2010.

Um estudo realizado por Smith e Ezzati (2005), sobre Carga Global de Doenças, aborda criticamente a clássica descrição de transição epidemiológica. Nessa análise demonstram que, com base na lógica do desenvolvimento econômico e social, ocorre uma transição da relevância de distintas categorias de riscos ambientais, classificados por abrangências: do domicílio (déficit de saneamento ambiental, precárias moradias, subnutrição); da comunidade (desenvolvimento desregulado associado à urbanização e à industrialização, exposições ocupacionais, expansão de fronteiras agrícolas e poluição ambiental); e de escala 
global (crise da insustentabilidade ambiental, expressa nas mudanças climáticas e suas consequências).

Como a carga total de doenças decai em países desenvolvidos, também os fatores de risco ambientais declinam em todas as categorias. Dentre os países em desenvolvimento, frequentemente estes mantêm grande importância em termos de riscos ambientais, e mediante as desigualdades intrarregionais, podem ter a configuração em que determinadas parcelas da população (como os moradores de favelas) sofram a sobreposição dos três grupos de padrões de riscos, conforme observam Franco Netto e colaboradores (2009).

Dadas as peculiaridades de ser uma cidade na floresta de um país em desenvolvimento, a cidade de Manaus merece ser analisada de modo a atender suas peculiaridades e desigualdades, buscando-se assim compreender os impactos à saúde oriundos de seus dos problemas socioambientais. Assim, chamamos atenção para as situações de vulnerabilidade descritas nas seções anteriores, como no caso da distribuição espacial da pobreza, o precário saneamento, a proximidade com os igarapés poluídos, a periferia distante e seu contato com a floresta e, por fim, a sobreposição com os riscos modernos, como o crescimento da frota de veículos e a poluição atmosférica, as ilhas de calor urbano, os acidentes de tráfego, exposições ocupacionais e outros.

Observando tendências recentes na proporção das mais representativas causas de morbidade hospitalar em Manaus (Gráfico 3), é possível perceber que as doenças infecciosas e parasitárias (DIP) vêm apresentando períodos com crescimento e situações de queda, porém, mantendo-se constantemente como um grupo relevante na proporção como causa de morbidade. Considerando o nível de abrangência dos riscos ambientais na classificação proposta por Smith e Ezzati (2005), as DIP podem estar predominantemente relacionadas aos riscos do domicílio e da comunidade, refletindo também precárias condições socioeconômicas e da atenção básica à saúde da criança, combinadas com fatores ambientais que favorecem a ocorrência de infecções respiratórias, como umidade em moradias precárias. Outros dois grupos de agravos relevantes em termos de morbidade crescente são doenças do aparelho circulatório e neoplasias, expressando um grupo de riscos ambientais que reflete o intenso processo de urbanização e industrialização, com abrangência que afeta diferentes comunidades.

Em termos de mortalidade (Gráfico 4), as infecciosas e parasitárias têm papel menos importante em proporção, mas ainda não apresentam tendência de decréscimo. Uma expressiva redução da proporção das DIP na mortalidade 
em Manaus ocorreu em um período anterior a 1996, tendo em vista que em 1985 esse grupo representou 18,5\% e em 1995 caiu para 5,5\% do total de óbitos notificados na capital. Tal declínio tão rápido da mortalidade por doenças infecciosas e parasitárias representou uma importante mudança no padrão de mortalidade no município (Santos \& Moura, 2000). Por sua vez, para o período apresentado no Gráfico 4, o crescimento da proporção de neoplasias é verificável para mortalidade em Manaus, do mesmo modo como vem crescendo a proporção para mortalidade por causas externas e por doenças do aparelho circulatório. Para esse último grupo, em acordo com uma tendência nacional de se tornar o mais importante em termos de mortalidade (Barreto \& Carmo, 2007).

\section{Gráfico 3 - Proporção (\%) de principais causas de morbidade hospitalar (capítulo CID-10)} por residência em Manaus - 1998 a 2013

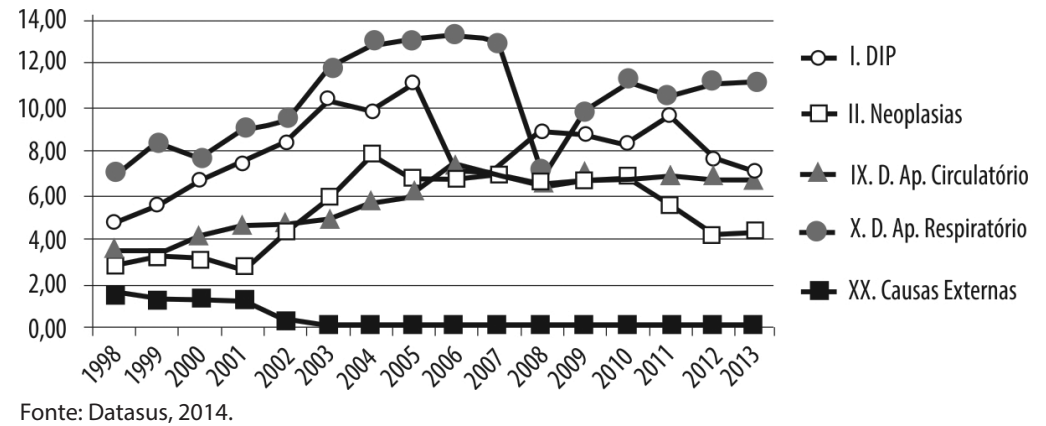

Gráfico 4 - Proporção (\%) de principais causas de óbitos (capítulo CID-10) por residência em Manaus - 1996 a 2012

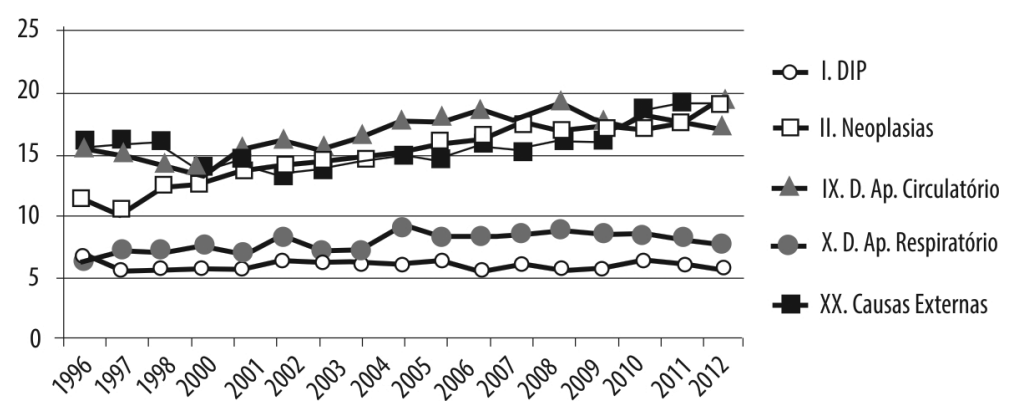

Fonte: Datasus, 2014.

Para causas externas, diferentemente do padrão da morbidade, a mortalidade proporcional para essa categoria é bastante significativa, o que leva a inferir sobre a gravidade/letalidade dos respectivos agravos. Entre 1985 e 1995, a proporção de mortes por causas externas em Manaus cresceu 10,6\%. 
Em termos das proporções de principais causas para morbidade e mortalidade, para menores de 5 anos de idade - faixa etária mais suscetível a riscos ambientais do domicílio e da comunidade -, podemos ter uma importante indicação por dois importantes grupos de causas: as DIP e as doenças do aparelho respiratório. Ambos os grupos se situam como de grande importância em termos de morbidade e de menor importância em termos de mortalidade em menores de 5 anos (Datasus, 2014). Isso leva a considerar que, de um lado, o sistema de atenção à saúde tem dado respostas no tratamento dessas morbidades, tendo evitado mortes. Todavia, a exposição aos fatores de risco e o acometimento, tanto por doenças infecciosas e parasitárias como por doenças do aparelho respiratório, prevalecem interferindo intensamente na saúde e na qualidade de vida da população jovem.

Especificamente as doenças diarreicas agudas (DDA) e as infecções respiratórias agudas (IRA), na condição de mortalidade proporcional dentre menores de 5 anos (Gráfico 5), temos a seguinte descrição: no caso das IRA, apesar de algumas oscilações, a proporção relacionada a essa causa se mantém razoavelmente constante. Para DDA, há uma queda substancial a partir de 1990, com nítida tendência de redução, que pode ser atribuída à ampliação da atenção primária em saúde, especialmente ao considerar o pouco progresso em termos de saneamento, particularmente de rede e tratamento de esgotos domésticos.

Gráfico 5 - Mortalidade proporcional (\%) por DDA e IRA em menores de 5 anos. Manaus - 1990-2011

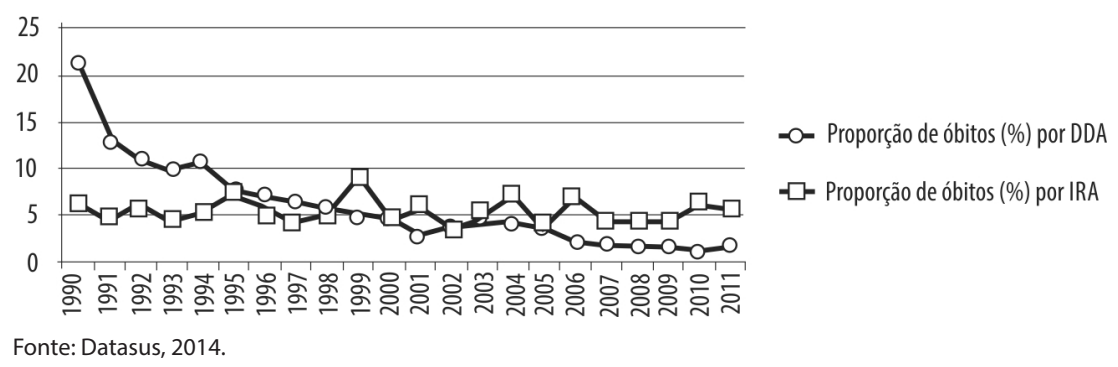

\section{Anos potenciais de vida perdidos na população de Manaus}

As mortes atribuíveis a fatores de risco ambientais na cidade de Manaus foram estimadas por meio do indicador Anos Potenciais de Vida Perdidos (APVP) pela esperança de vida ao nascer de cada indivíduo, conforme proposto por Romeder e McWhinnie apud Silva (1984). Como causas básicas de mortes definidas abordadas nesta análise, consideram-se as enfermidades 
fortemente atribuíveis a fatores ambientais sugeridas por Prüss-Üstün e Corvalán (2006), em que cada causa tem sua respectiva carga de causalidade atribuída a fatores ambientais.

A análise comparativa do número absoluto dos APVP na cidade de Manaus, entre os anos de 2000 e 2007, registra redução na ordem de $9 \%$ do total: em 2000 foram 216.829 APVP, acumulando coeficiente de 154,16 por mil habitantes; e em 2007 foram 197.087 APVP, acumulando coeficiente de 143,5 por mil habitantes. O sexo masculino representa maioria (60\% e $61 \%$, respectivamente) e a razão entre os sexos foi de 1,6 e 1,7, respectivamente (Dias, Medeiros \& GuerreiroHurtado, 2010).

As doenças infecciosas e parasitárias, as causas maternas, as causas perinatais e as deficiências nutricionais que representam o Grupo 1 da supracitada classificação da OMS, em 2000, representam 41\% dos APVP. Em 2007, são as doenças crônico-degenerativas, do Grupo 2, responsáveis por quase a metade do número dos APVP (44\%), o que caracteriza uma nítida mudança do padrão da mortalidade na cidade de Manaus.

As causas externas - Grupo 3 - apresentaram uma variação positiva de 5\% no número absoluto dos APVP na análise comparativa entre os dois anos da análise. Contudo, registrou uma redução no coeficiente: em 2000 foram 36,80/ mil habitantes; e em 2007 baixaram para 31,35/mil habitantes. Nesse grupo de causas de mortes, a razão entre o sexo masculino e feminino foi de 14,5 e 15,1, respectivamente, o que demonstra a maior vulnerabilidade masculina perante a violência urbana na cidade de Manaus. Dentre as enfermidades fortemente atribuíveis a fatores ambientais no contexto social, econômico e ambiental, quatro delas mantiveram-se na mesma posição em número absoluto de anos de mortes prematuras na comparação, conforme destaca a Tabela 1: violência; doenças cardiovasculares; acidentes de trânsito; e infecções das vias aéreas inferiores. As doenças diarreicas, que representavam a quinta posição na classificação (postos) em 2000, recuaram e em 2007 ocuparam a décima posição. A quinta posição, nesse último ano, foi ocupada pelas neoplasias da traqueia, brônquio e pulmão.

As doenças e agravos fortemente atribuíveis a fatores ambientais que apresentaram crescimento entre os dois anos analisados foram: asma (132\%); hepatite B (63\%); mal de Parkinson (60\%); e uso de drogas e álcool (54\%); DPOC (45\%); câncer de traqueia, brônquios e pulmões (26\%); malária (17\%); doenças cardiovasculares (17\%); e acidentes de trânsito (6\%). Por sua vez, as doenças diarreicas e as tuberculoses apresentaram um padrão inverso, ou seja, decréscimo de $75 \%$ e $42 \%$, respectivamente. 
Conclui-se que os coeficientes dos APVP estimados para Manaus, em 2000 e em 2007, foram superiores aos registrados no Projeto Carga de Doença, em 1998, para a Região Norte - 97,00/mil habitantes - e para o Brasil - 111,00/mil habitantes (Gadelha et al., 2000).

Apesar do incremento de mortes prematuras por doenças crônicas e degenerativas, típicas dos países desenvolvidos que completaram a transição epidemiológica, as doenças infecciosas e parasitárias, as causas maternas, as causas perinatais e as deficiências nutricionais ainda são responsáveis por cerca de um terço de anos potenciais de vida perdidos na cidade. Apresentaram, inclusive, percentuais superiores ao registrado na Região Norte, assim como também para todo o país em 1998 (38\% e 27\%).

Tabela 1 - Distribuição proporcional e ordenamento de doenças e agravos fortemente atribuíveis a fatores ambientais. Manaus - 2000 e 2007

\begin{tabular}{|c|c|c|c|c|c|c|c|c|c|}
\hline \multirow{2}{*}{ Doenças e agravos } & \multicolumn{4}{|l|}{$\begin{array}{l}2000 \\
\text { APVP }\end{array}$} & \multicolumn{4}{|l|}{$\begin{array}{l}2007 \\
\text { APVP }\end{array}$} & \multirow{2}{*}{ Variação } \\
\hline & Posto & $\mathrm{N}$ & $/ 100$ & $\begin{array}{l}\text { /mil } \\
\text { hab. }\end{array}$ & Posto & $\mathbf{N}$ & $/ 100$ & $\begin{array}{l}\text { /mil } \\
\text { hab. }\end{array}$ & \\
\hline Todas as causas & & 216829 & 100 & 154,24 & & 197087 & 100 & 113,79 & -9 \\
\hline GRUPO 1 & - & 89593 & 41 & 63,73 & - & 51451 & 26 & 29,71 & -43 \\
\hline 1. Tuberculose & 6 & 2411 & 1 & 1,71 & 9 & 1400 & 1 & 0,81 & -42 \\
\hline 4. Doenças Diarreicas & 5 & 5323 & 2 & 3,79 & 10 & 1321 & 1 & 0,76 & -75 \\
\hline Hepatite B & 11 & 646 & 0 & 0,46 & 11 & 1053 & 1 & 0,61 & 63 \\
\hline Hepatite C & 16 & 0 & 0 & 0,00 & 16 & 74 & 0 & 0,04 & 0 \\
\hline 8. Malária & 14 & 246 & 0 & 0,17 & 15 & 287 & 0 & 0,17 & 17 \\
\hline 11. Dengue & 17 & 0 & 0 & 0,00 & 14 & 319 & 0 & 0,18 & 0 \\
\hline $\begin{array}{l}\text { 1. Infec. das Vias } \\
\text { Aéreas Inf. }\end{array}$ & 4 & 8077 & 4 & 5,74 & 4 & 6775 & 3 & 3,91 & -16 \\
\hline 1. Desnutrição & 7 & 2202 & 1 & 1,57 & 7 & 1619 & 1 & 0,93 & -27 \\
\hline GRUPO 2 & - & 72053 & 33 & 51,25 & - & 86953 & 44 & 50,20 & 21 \\
\hline $\begin{array}{l}\text { 7. Câncer traq., bronq. } \\
\text { e pulm. }\end{array}$ & 8 & 2066 & 1 & 1,47 & 5 & 2601 & 1 & 1,50 & 26 \\
\hline $\begin{array}{l}\text { 5. Uso de drogas } \\
\text { ilícitas e álcool }\end{array}$ & 12 & 579 & 0 & 0,41 & 12 & 892 & 0 & 0,51 & 54 \\
\hline 7. Mal de Parkinson & 15 & 17 & 0 & 0,01 & 17 & 27 & 0 & 0,02 & 60 \\
\hline $\begin{array}{l}\text { G. Doenças } \\
\text { cardiovasculares }\end{array}$ & 2 & 17552 & 8 & 12,49 & 2 & 20467 & 10 & 11,82 & 17 \\
\hline 1.DPOC & 10 & 1406 & 1 & 1,00 & 6 & 2041 & 1 & 1,18 & 45 \\
\hline 2. Asma & 13 & 342 & 0 & 0,24 & 13 & 793 & 0 & 0,46 & 132 \\
\hline GRUPO 3 & - & 51735 & 24 & 36,80 & - & 54296 & 28 & 31,35 & 5 \\
\hline $\begin{array}{l}\text { 1. Acidentes de } \\
\text { trânsito }\end{array}$ & 3 & 11998 & 6 & 8,53 & 3 & 12676 & 6 & 7,32 & 6 \\
\hline 3. Quedas & 9 & 2001 & 1 & 1,42 & 8 & 1552 & 1 & 0,90 & -22 \\
\hline $\begin{array}{l}\text { 2. Violência } \\
\text { (agressões) }\end{array}$ & 1 & 24218 & 11 & 17,23 & 1 & 29125 & 15 & 16,82 & 20 \\
\hline
\end{tabular}

Fonte: Datasus, 2014. 
Prüss-Üstün e Corvalán (2006) pressupõem que 40\% das mortes por violência e acidentes de trânsito, por exemplo, derivam de políticas e práticas de uso e ocupação do solo, desenho urbano inapropriado, estrutura urbana e adensamento demográfico, vias inadequadas e mal sinalizadas, ocasionando maior proximidade das residências em relação às vias de circulação de veículos automotores de médio e grande porte. Dentre as mortes por doenças cardiovasculares, estima-se que 16\% são originadas pelo estresse ocupacional, poluição atmosférica e exposição ambiental a chumbo e tabaco. As mortes por infecções das vias aéreas inferiores estão associadas à poluição em ambientes fechados - como uso de combustíveis sólidos - e a outros fatores domésticos - como as dimensões e características da habitação -, sendo responsáveis por 25\% do total, enquanto as neoplasias de traqueia, brônquio e pulmão devem-se a exposições ocupacionais (9\%), poluição atmosférica (5\%) e exposição à fumaça de cigarro em ambientes fechados (1\%). Vale salientar que todas são causas de morte evitáveis por meio de medidas socioambientais, algumas de baixo custo, e alto impacto na redução e controle das mesmas (Dias, Medeiros \& Guerreiro-Hurtado, 2010).

Outras doenças e indicadores relevantes na dinâmica de saúde e ambiente em Manaus

No Gráfico 6 é possível observar uma evolução recente da incidência da dengue, com um significativa elevação em 2001, seguida de redução e elevado pico em 2011. Manaus sofreu a primeira epidemia dessa doença em 1998, que desde então passou a ter grande importância local. Na cidade, a infestação e distribuição do vetor são homogêneas em distintos bairros, facilitando a ocorrência de epidemias (Ríos-Velásquez et al., 2007).

A malária, que ocorre de forma endêmica na Amazônia Legal, com média de 500 mil casos por ano, se mantém como sendo de grande importância na condição de morbidade nessa mesma metrópole. Após uma redução na noti-

Gráfico 6 - Taxa de incidência de dengue (casos/100 mil hab.) em Manaus - 1999-2012

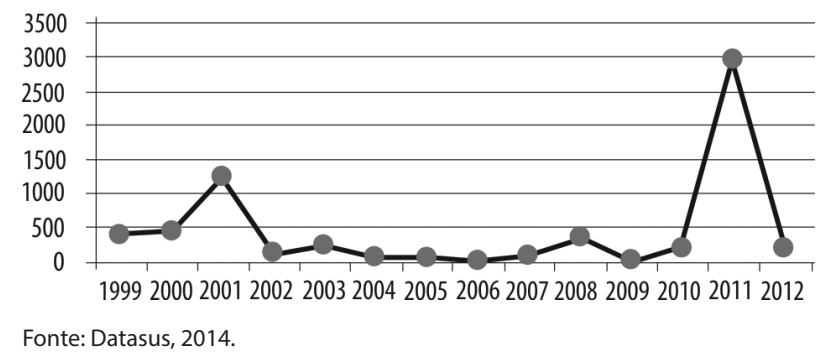


ficação de casos, constatada entre 2000 e 2002, segue-se uma nova tendência de aumento de casos entre 2003 e 2005 e, após 2006, novo decréscimo (Silva, 2010). Segundo dados do Datasus/Sivep Malária, em 2007 ocorreram em Manaus 40.403 casos da doença; 19.711 casos em 2008; 16.423 casos em 2009; e 15.635 casos em 2010. Nesse mesmo ano, o índice parasitário anual por malária foi de 11,99 casos por mil habitantes.

Apesar da tendência à redução, em Manaus a malária tem se constituído por significativas oscilações, chegando a picos muito preocupantes. Tal fato indica dificuldades no alcance das metas em torno da prevenção e assistência à saúde, além de incipiente esforço intersetorial que não consegue lidar com a motricidade da doença. Esta é inerente ao processo de ocupação populacional desordenada das áreas periféricas da cidade, onde ocorrem importantes fatores relacionados à proliferação do vetor e da disseminação da doença. Presume-se que a necessária mudança de enfoque no controle da malária passa, impreterivelmente, pela mobilização e participação social na construção de um novo modelo de controle. Nesse sentido, e na falta de direcionamento pelos documentos de referência do Programa Nacional de Controle Integrado da Malária (PNCM), do Ministério da Saúde, o conceito de rede social coloca-se como um significativo referencial para um controle ecossistêmico da malária em Manaus, como afirma Silva (2010).

No Gráfico 7 pode-se verificar como também a leishmaniose tegumentar americana (LTA) continua a ter grande importância em Manaus, apesar da tendência ao declínio. A doença, nessa cidade, está intensamente circunscrita às margens da zona urbana e áreas rurais. Surtos da doença ocorrem quando se instalam populações modificando ambientes naturais. Posteriormente prevalecem casos esporádicos, inclusive em cães (Guerra et al., 2007).

No Gráfico 8 estão agrupadas algumas causas de mortalidade por doenças crônicas que podem ser compreendidas como de amplo significado em um contexto

Gráfico 7 - Taxa de incidência de LTA (casos/100 mil hab.) em Manaus - 2001-2012

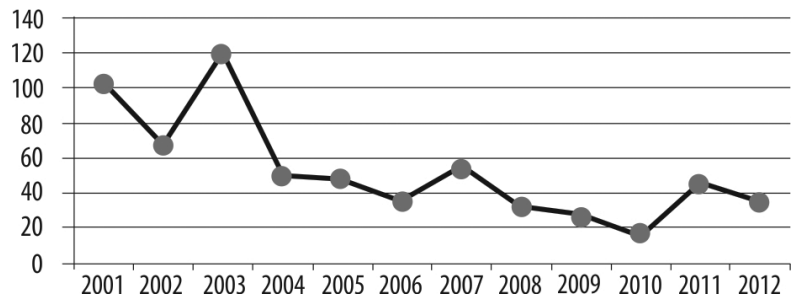

Fonte: Datasus, 2014. 
de mudanças socioambientais e de transição epidemiológica. Comparando-se essas às do Gráfico 4 - de mortalidade proporcional por principais causas -, verifica-se, primeiramente, que em ambos é bastante nítida a tendência de aumento da mortalidade por neoplasias. Por sua vez, tendo em vista que as taxas de mortalidade específica por doenças do aparelho circulatório e causas externas vêm caindo (Gráfico 8), estas últimas ainda têm prevalecido como relevantes mediante a mortalidade proporcional por diversas causas (Gráfico 4). Tal situação pode estar sendo corroborada por uma redução da taxa de mortalidade geral, em concordância com o que se espera para o processo de envelhecimento da população. De fato, a taxa bruta de mortalidade para o estado do Amazonas em 1991 foi de 5,9/mil habitantes, ao passo que em 2011 foi de 4,6/mil habitantes (Datasus, 2014).

Como já comentado quanto à importância da mortalidade por causas externas, desagregou-se esse grupo em dois de seus principais componentes no Gráfico 9, quais sejam: taxa de mortalidade por acidentes de transporte - que tem diminuído; e taxa de homicídios - que apresenta oscilação entre 1990 até 2004, para a partir de 2005 apresentar clara tendência de crescimento (Datasus, 2014).

O crescimento das taxas de homicídios em Manaus acompanha tendência das regiões metropolitanas brasileiras. Em 1980, a taxa de mortalidade por homicídios em Manaus foi de 20 por 100 mil habitantes, atingindo 32,4 por 100 mil habitantes em 2000. Em termos do tipo de ocorrência, observa-se uma proporcional redução no número de homicídios por armas de fogo em relação aos causados por arma branca. Outra questão de destaque quanto a homicídios nessa capital é a desigual distribuição espacial das ocorrências, nos quais apenas as zonas leste e sul da cidade concentraram 60\% dos óbitos por tal causa no ano 2000 (Nascimento \& Teixeira, 2006).

Para Barreto e Carmo (2007), dentre as principais causas de óbito e internações no Brasil estão as doenças crônico-degenerativas, os acidentes e as diversas

Gráfico 8 - Taxas de mortalidade específica por doenças do aparelho circulatório, causas externas e neoplasias malígnas (óbitos/100 mil hab.) em Manaus - 1990-2011

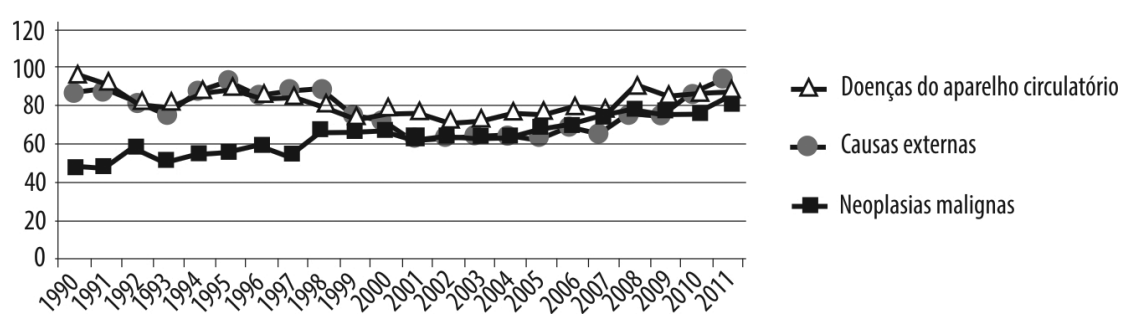


formas de violência. Todavia, os autores assinalam relevantes desigualdades regionais no país quanto a esse padrão, destacando entre outros fatores: a pobreza, a inadequada infraestrutura urbana, as alterações do meio ambiente, o desmatamento, a ampliação de fronteiras agrícolas, os processos migratórios e as grandes obras de infraestrutura.

\section{Gráfico 9 - Taxas de mortalidade específicas por componentes de causas externas (óbitos por 100 mil hab.) em Manaus - 1990-2011}

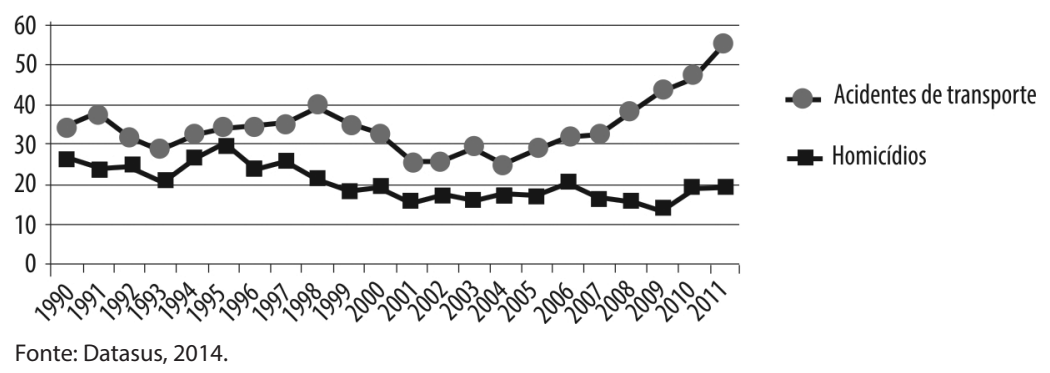

Em 2011 a taxa de mortalidade por acidentes de transporte foi de 22,5 para o Brasil, 14,5 para o Amazonas e 19,6 por 100 mil habitantes para Manaus. Para a taxa de mortalidade por homicídios no mesmo ano, o Brasil atingiu 27,4, o estado do Amazonas 36,5 e Manaus figurou com 56,1 por 100 mil habitantes, demonstrando o quanto as violências são causas importantes nessa capital (Datasus, 2014). Freitas e Giatti (2010), discutindo indicadores de homicídios na Amazônia Legal, destacam a importância dessa causa de mortalidade na região de modo geral, por ter relação com distintos fenômenos como o processo de ocupação de terras. Para o caso específico de Manaus, há que se ressaltar as grandes desigualdades sociais, a segregação espacial dos desfavorecidos e, ainda, o processo de rápido crescimento populacional e de expansão urbana conflituosa.

\section{Para Concluir}

O estudo das condições e tendências para questões de sustentabilidade ambiental e de saúde em Manaus permitiu identificar uma intensa dinâmica demográfica e econômica, com forte expressão no modelo de industrialização, agindo na motricidade de rápidas e significativas mudanças ambientais. Essa análise possibilita que se verifique que o processo econômico predominante nessa cidade globalizada possa ser entendido como um importante atrator. Este, por sua vez, age na retroalimentação e na auto-organização de um sistema orientado para crescer demograficamente, consumindo espaço e recursos naturais de modo 
acelerado (urbanização espraiada) e também gerando, mantendo e agravando situações precárias no quadro sanitário local. Isso acarreta sérias dificuldades para que as políticas públicas consigam atender com equidade as crescentes demandas por serviços, infraestrutura, atenção à saúde, entre outras. Essa dinâmica também se agrava mediante as diferenças que Manaus apresenta em comparação com o restante de sua região, sustentando uma constante atração migratória.

Se, de um lado, o sistema industrial encontra condições necessárias para se desenvolver e se perpetuar, por outro, o mesmo não acontece com o que diz respeito às dimensões social e ambiental de Manaus. Isso pode ser verificado no recrudescimento de desigualdades sociais e na exacerbação da histórica relação insustentável do urbano sobre os sistemas naturais preexistentes.

A análise da situação de saúde (Castellanos, 2004), na condição de efeito dos processos socioambientais em curso, denotou que apesar de estar ocorrendo aumento de expectativa de vida ao nascer e envelhecimento da população de Manaus, permanece incidindo, principalmente sobre os mais pobres, a sobreposição de fatores ambientais nos três grupos identificados por Smith e Ezzati (2005), tal como no nível do domicílio para o caso das doenças relacionadas ao precário saneamento, ou no nível da comunidade como na elevação de mortalidade para doenças crônicas e causas externas, bem como no nível global para os riscos de inundações ou deslizamentos, por exemplo.

Assim, considerando as inter-relações em uma ampla cadeia de causas e consequências, que se estende desde as forças motrizes - como no caso da industrialização, do crescimento econômico e das migrações -, espera-se que essa leitura sistêmica possa contribuir com opções estratégicas e condizentes com a complexidade dos processos determinantes da situação de saúde dessa grande e peculiar cidade. Nesse contexto, vale assinalar a necessidade de intervenções que possibilitem desencadear reações sistêmicas, como estímulos positivos que estimulem atratores capazes de promover retroalimentação e reorganização em distintos elementos da cadeia de ordem social e ambiental, contribuindo assim para o estabelecimento de ciclos virtuosos de promoção da saúde. 


\section{Referências}

AMAZONAS (Estado). Sistema de Informações Governamentais do Amazonas - E-SIGA. Disponível em: <www2.e-siga.am.gov.br/portal/page/portal/esiga2009>. Acesso em: 21 jul. 2010.

ASSOCIAÇÃO BRASILEIRA DE EMPRESAS DE LIMPEZA PÚBLICA E RESÍDUOS ESPECIAIS (ABRELPE). Panorama dos Resíduos Sólidos no Brasil -2007. São Paulo: Abrelpe, 2007.

ASSOCIAÇÃO BRASILEIRA DE EMPRESAS DE LIMPEZA PÚBLICA E RESÍDUOS ESPECIAIS (ABRELPE). Panorama dos Resíduos Sólidos no Brasil - 2009. São Paulo: Abrelpe, 2009.

BARRETO, M. L. \& CARMO, E. H. Padrões de adoecimento e de morte da população brasileira: os renovados desafios para o Sistema Único de Saúde. Ciência \& Saúde Coletiva, 12, supl.: 1.7791.790, 2007.

BECKER, B. K. \& STENNER, C. Um Futuro para a Amazônia. São Paulo: Oficina de Textos, 2008.

BRASIL. Ministério das Cidades. Programa de Modernização do Setor Saneamento Sistema Nacional de Informações sobre Saneamento: diagnóstico da gestão e manejo de resíduos sólidos urbanos - 2002. Brasília: Ministério das Cidades, SNSA-Ipea, 2004.

BRASIL. Ministério das Cidades. Sistema Nacional de Informações sobre Saneamento: diagnóstico do manejo de resíduos sólidos urbanos - 2007. Brasília: Ministério das Cidades, SNSA, 2009.

BROWDER, J. O. \& GODFREY, B. J. Cidades da Floresta: urbanização, desenvolvimento e globalização na Amazônia Brasileira. 1. ed. Manaus: Ufam, 2006.

CASTELLANOS, P. L. Análisis de situación de salud de poblaciones. In: MARTINÉS-NAVARRO, E. T. et al. Vigilância Epidemiológica. Madrid: McGraw-Hill, Interamericana, 2004.

CORVALÁN, C.; BRIGGS, D. \& KJELLSTRÖM, T. The need for information: environmental health indicators. In: CORVALÁN, C.; BRIGGS, D. \& ZIELHUIS, G. (Eds.). Decision-making in Environmental Health: from evidence to action. London: E \& FN Spon, World Health Organization, 2000.

DEPARTAMENTO DE INFORMÁTICA DO SUS (DATASUS). Informações de saúde. Disponível em: < $<w w w$. datasus.gov.br>. Acesso em: 28 ago. 2014.

DIAS, K. P. B.; MEDEIROS, M. S. \& GUERRERO-HURTADO, C. Anos potenciais de vida perdidos atribuíveis a fatores ambientais na cidade de Manaus, Amazonas, Brasil. In: JORNADA INICIAÇÃO CIENTÍFICA DO PIBIC/ILMD/CNPq/FAPEAM, 7, 2010, Manaus. Anais... Manaus, 2010.

FRANCO NETTO, G. et al. Impactos socioambientais na situação de saúde da populaçao brasileira: Estudo de indicadores relacionados ao saneamento ambiental inadequado. Tempus - Acta de Saúde Coletiva, 3(4): 53-71, 2009.

FREITAS, C. M. (Org.). Enfoques Ecossistêmicos em Saúde: perspectivas para sua adoção no Brasil e em países da América Latina. Brasília: Organização Pan-Americana da Saúde, Fundação Oswaldo Cruz, 2009. (Série Saúde Ambiental, 2).

FREITAS, C. M. \& GIATTI, L. L. Sustentabilidade Ambiental e de Saúde na Amazônia Legal, Brasil: uma análise através de indicadores. Brasília: Organização Pan-Americana da Saúde, 2010. (Série Saúde Ambiental, 4).

FUNDAÇÃO JOÃO PINHEIRO (FJP). Déficit Habitacional Municipal no Brasil 2010. Belo Horizonte: FJP, 2011.

FUNTOWICZ, S. \& RAVETZ, J. R. Emergent complex systems. Futures, 26(6): 568-582, 1994.

GADELHA, A. M. J.et al. Projeto carga de doença. Relatório Técnico. Rio de Janeiro: Fundação Oswaldo Cruz, 2002. Relatório.

GEO MANAUS. Projeto GEO Cidades: relatório ambiental urbano integrado - informe GEO. Manaus / Supervisão: Ana Lúcia Nadalutti La Rovere, Samyra Crespo; Coordenação: Rui Velloso. Rio de Janeiro: Consórcio Parceria 21, 2002.

GIATTI, L. L. et al. Exposição à água contaminada: percepções e práticas em um bairro de Manaus / Estado do Amazonas, Brasil. Revista Panamericana de Salud Pública, 28(5): 337-343, 2010. 
GUERRA, J. A. O. et al. Estudo de dois anos com animais reservatórios em área de ocorrência de leishmaniose tegumentar americana humana em bairro de urbanização antiga na cidade de Manaus-AM, Brasil. Acta Amazônica, 37(1): 33-38, 2007.

INSTITUTO BRASILEIRO DE GEOGRAFIA E ESTATÍ́STICA (IBGE). Censo 2000. Rio de Janeiro: IBGE, 2000.

INSTITUTO BRASILEIRO DE GEOGRAFIA E ESTATÍSTICA (IBGE). Produto Interno Bruto dos Municípios 2002 - 2005. Rio de Janeiro: IBGE, 2007.

INSTITUTO BRASILEIRO DE GEOGRAFIA E ESTATíSTICA (IBGE). Pesquisa Nacional de Saneamento Básico - PNSB. IBGE, 2010. Disponível em: <www.sidra.ibge.gov.br>. Acesso em: 30 nov. 2010.

INSTITUTO BRASILEIRO DE GEOGRAFIA E ESTATÍSTICA (IBGE). Indicadores sociais municipais. Uma análise dos resultados do universo do Censo Demográfico 2011. Disponível em: <www.ibge. gov.br/home/estatistica/populacao/censo2010/indicadores_sociais_municipais/indicadores_ sociais_municipais.pdf>. Acesso em: 10 jan. 2012.

INSTITUTO BRASILEIRO DE GEOGRAFIA E ESTATÍSTICA (IBGE). Contas Regionais do Brasil 2011. Rio de Janeiro: IBGE, 2013.

INSTITUTO DE PESQUISA ECONÔMICA APLICADA (IPEA). Base de dados. Disponível em: <www. ipeadata.gov.br>. Acesso em: 22 jul. 2010.

INSTITUTO NACIONAL DE PESQUISAS ESPACIAIS (INPE). Projeto PRODES - Monitoramento da Floresta Amazônica Brasileira por Satélite. Disponível em: <www.dpi.inpe.br/prodesdigital/ prodesmunicipal.php>. Acesso em: 08 ago. 2014.

KAY, J. J. et al. An ecosystem approach for sustainability: addressing the challenge of complexity. Futures, 31: 721-742, 1999.

$\mathrm{KUHN}$, U. et al. Impact of Manaus city on the Amazon green ocean atmosphere: ozone production, precursor sensitivity and aerosol load. Atmospheric Chemistry and Physics Discussions, 10: 13.091-13.178, 2010.

MILLENNIUM ECOSYSTEM ASSESSMENT (MEA). Ecosystems and Human Being: synthesis. Washington: Island Press, 2005.

NASCIMENTO, G. \& TEIXEIRA, P. Análise da mortalidade por homicídios no município de Manaus segundo sua evolução histórica e fatores sócio-econômicos, institucionais e espaciais de determinação. In: ENCONTRO NACIONAL DE ESTUDOS POPULACIONAIS DA ABEP, XIV, 2006, Caxambu. Anais... Caxambu, 2006.

NOGUEIRA, A. C. F.; SANSON, F.\& PESSOA, K. A expansão urbana e demográfica da cidade de Manaus e seus impactos ambientais. In: SIMPÓSIO BRASILEIRO DE SENSORIAMENTO REMOTO, XIII, 2007, Florianópolis. Anais... Florianópolis: Inpe, 2007.

OLIVEIRA, J. A. \& COSTA, D. P. A análise da moradia em Manaus (AM) como estratégia de compreender a cidade. Revista Electrônica de Geografia y Ciências Sociales, 245(30), 2007.

OLIVEIRA, J. A. \& SCHOR, T. Manaus: transformações e permanências, do forte à metrópole regional. In: CASTRO, E. (Org.). Cidades na Floresta. São Paulo: Annablume, 2008.

PEREIRA, D. Amazônia (In)sustentável -Zona Franca de Manaus: estudo e análise. 2. ed. Manaus: Valer, 2005.

PROGRAMA DAS NAÇÕES UNIDAS PARA O DESENVOLVIMENTO (PNUD). Portal ODM. Disponível em: <www.portalodm.com.br>. Acesso em: 10 jan. 2012.

PRÜSS-ÜSTÜN, A. \& CORVALÁN, C. Preventing Disease Through Healthy Environments: towards an estimate of the environmental burden of disease. Geneva: World Health Organization, 2006.

PRÜSS-ÜSTÜN, A.; BONJOUR, S. \& CORVALÁN, C. The impact of the environment on health by country: a meta-synthesis. Environmental Health, 7: 1-10, 2008.

REDE INTERAGENCIAL DE INFORMAÇÕES PARA A SAÚDE (RIPSA). Indicadores Básicos para a Saúde no Brasil: conceitos e aplicações. Brasília: Organização Pan-Americana da Saúde, 2008. 
RÍOS-VELÁSQUES, C. M. et al. Distribution of dengue vectors in neighbourhoods with diferente urbanization types of Manaus, state of Amazonas, Brazil. Memórias do Instituto Oswaldo Cruz, 102(5): 617-623, 2007.

SANTANA, G. P. \& BARRONCAS, P. S. R. Estudo de metais pesados (Co, Cu, $\mathrm{Fe}, \mathrm{Cr}, \mathrm{Ni}, \mathrm{Mn}, \mathrm{Pb}$ e $\mathrm{Zn}$ ) na Bacia do Tarumã-Açu Manaus - (AM). Acta Amazônica, 37(1): 111-118, 2007.

SANTOS, C. A. \& MOURA, H. A. A mortalidade por causas externas no município de Manaus. In: ENCONTRO NACIONAL DE ESTUDOS POPULACIONAIS DA ABEP, XII, Caxambu. Anais... Caxambu, 2000. v. 1.

SANTOS, I. N. et al. Influência de um Aterro Sanitário e de Efluentes Domésticos nas Águas Superficiais do rio Tarumã e Afluentes - AM. Acta Amazônica, 36(2): 229-236, 2006.

SANTOS, M. A Urbanização Brasileira. São Paulo: Edusp, 2009.

SATHLER, D.; MONTE-MÓR, R. L. \& CARVALHO, J. A. M. As redes para além dos rios: urbanização e desequilíbrios na Amazônia brasileira. Nova Economia, 19(1): 11-39, 2009.

SECRETARIA DE ESTADO DE PLANEJAMENTO E DESENVOLVIMENTO ECONÔMICO. GOVERNO DO ESTADO DO AMAZONAS (SEPLAN). Produto Interno Bruto Municipal Amazonas 2002 - 2007. Manaus: Seplan, 2009. Disponível em: <www.seplan.am.gov.br>. Acesso em: 17 jul. 2010.

SILVA, M. B. C. Avaliação do Controle da Malária em Manaus/AM: perspectivas para uma abordagem ecossistêmica, 2010. Tese de Doutorado, Recife: Centro de Pesquisas Aggeu Magalhães, Fundação Oswaldo Cruz em consórcio com o Instituto de Pesquisas Leônidas e Maria Deane (ILMD/Fiocruz).

SILVA, M. G. C. Anos potenciais de vida perdidos segundo causas, em Fortaleza (Brasil), 1978-80. Revista de Saúde Pública, 18(2): 108-121, 1984.

SMITH, K. R. \& EZZATI, M. How environmental health risks change with development: the epidemiologic and environmental risk transitions revisited. Annual Review Environmental Resources, 30: 291-333, 2005.

SUPERINTENDÊNCIA DA ZONA FRANCA DE MANAUS (SUFRAMA). Indicadores de Desempenho do Polo Industrial de Manaus 2003 - 2008. Manaus: Suframa, 2008.

SUPERINTENDÊNCIA DA ZONA FRANCA DE MANAUS (SUFRAMA). Investimentos. Disponível em: <www.suframa.gov.br/investimentos/index.cfm>. Acesso em: 20 jul. 2010.

THÉRY, H. Situações da Amazônia no Brasil e no continente. Estudos Avançados, 19(53): 37-49, 2005.

THÉRY, H. A população brasileira em 2007. Confins (Online), 2, 2008. Disponível em: <http://confins. revues.org/993>.

VALLE, A. S. \& OLIVEIRA, J. A. A Cidade de Manaus: análise da produção do espaço urbano a partir dos igarapés. In: OLIVEIRA, J. A.; ALECRIM, J. D. \& GASNIER, T. R. (Orgs.). Cidade de Manaus: visões interdisciplinares. Manaus: Edua, 2003.

VITTE, C. C. S. Desenvolvimento, planejamento territorial e integração nacional: os antecedentes, a gênese e a consolidação da Iniciativa de Integração da Infra-estrutura Regional Sul-Americana - IIRSA. In: ARAGÓN, L. E. \& OLIVEIRA, J. A. (Orgs.). Amazônia no Cenário Sul-americano. Manaus: Edua, 2009.

WALTNER-TOEWS, D. An ecosystem approach to health and its applications to tropical and emerging diseases. Cadernos de Saúde Pública, 17, supl.: 7-36, 2001. 


\title{
6
}

\section{Cidade Saudável e Direito à Cidade: outro mundo possível em Itaboraí}

\author{
Carla Moura P. Lima $\cdot$ Eduardo Stotz \\ Gil Sevalho • Jorge A. de Castro • Rossana Silva Souza
}

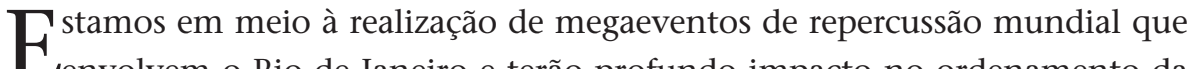
Cenvolvem o Rio de Janeiro e terão profundo impacto no ordenamento da vida dos habitantes da cidade e de sua região metropolitana, redesenhando os mapas urbanos do ponto de vista das infraestruturas de trânsito, comunicação, informação, habitação, saneamento, emprego e, obviamente, da distribuição da renda. A Copa do Mundo, promovida pela Federação Internacional de Futebol Associado (Fifa), e os próximos Jogos Olímpicos de 2016 são entendidos como oportunidades de investimento de capital, vistos como eventos capazes, inclusive, de redimir a cidade de seus problemas sociais estruturais.

Obras como a do Arco Metropolitano do Rio de Janeiro e investimentos industriais como o do Complexo Petroquímico do Estado do Rio de Janeiro (Comperj), com menor visibilidade nos meios de comunicação de massa, terão, contudo, um impacto mais amplo, significativo e duradouro na vida dos cidadãos dessa região que hoje aglomera cerca de 15 municípios e uma população de mais de dez milhões de pessoas.

O Comperj é apresentado pelo consórcio empresarial Petrobras-Braskem, pelo governo do estado do Rio de Janeiro e pela mídia, em geral, como "uma oportunidade de desenvolvimento", em resposta a um processo histórico de esvaziamento econômico. Tal esvaziamento é difusamente sentido pela população 
da região, que assiste de longe à implantação do Complexo, sem vivenciar e sem se dar conta das consequências que dele podem advir (Moysés, 2010).

Algumas questões devem, então, ser colocadas: Como a população afetada pelo projeto industrial percebe as transformações em marcha? Quais as expectativas formuladas no interior desse processo? Que visões de futuro são construídas?

Eis as questões que este capítulo, adaptado de um estudo baseado em resultados de pesquisa ${ }^{1}$ realizada em Itaboraí entre 2007 e 2011, pretende responder. O objetivo é apresentar as avaliações sobre as necessidades e expectativas sociais da população itaboraiense consideradas mais relevantes pelos participantes de fóruns de Ouvidoria Coletiva (OC) realizados em 2008, no município de Itaboraí. E também a identificação mais particular de avaliações feitas em 2010 numa área circunscrita desse município - o distrito de Itambi -, quando se aplicou a técnica da Matriz de Indicadores para Avaliação de Pós-Ocupação, proposta pelo Programa Habitar Brasil/Banco Interamericano de Desenvolvimento (BID-HBB) por meio do Ministério das Cidades.

\section{Direito à Cidade}

Adotou-se uma definição de cidades saudáveis desenvolvida criticamente nas formulações apresentadas por Márcia Faria Westphal, uma das pioneiras nesse campo de estudos.

Cidades ou municípios saudáveis constituem designações de uma estratégia de promoção da saúde fundamentada em ações de caráter coletivo, orientadas para promover e fomentar processos favoráveis ao bem-estar e opor-se àqueles que o colocam em risco (Westphal, 1997). O termo estratégia, apropriado da arte militar para o âmbito da política pública utilizado nessa definição, remete à ideia de plano de ação e de forças sociais capazes de implementá-lo. Não por acaso o planejamento estratégico e o protagonismo da sociedade civil são apresentados como instrumentos para a operacionalização de tal estratégia.

Assim, a proposta de cidades saudáveis é concebida como uma estratégia de longo prazo, compreensível nos termos de um projeto e de um movimento pensados para experimentar a gestão democrática e participativa dos problemas das cidades (Westphal, 1997).

\footnotetext{
${ }^{1}$ Projeto Cidades Saudáveis: Saúde, Inovação Tecnológica e Desenvolvimento Urbano na Área de Implantaçãa do Complexo Petroquímico de Itaboraí - RJ. Foi aprovado em 2007 nos termos do Programa de Desenvolvimento e Inovação Tecnológica em Saúde Pública (PDTSP), tendo sido concluído em 2011 - Vigilância Civil da Saúde na Atenção Básica: uma proposta de Ouvidoria Coletiva (2008-2011).
} 
Contudo, a proposta de plano de governo "estabelecido com as instituições representativas da sociedade como um todo, todas as classes sociais, todos os setores da sociedade e em parceria com os setores do governo" (Westphal, 1997: 14) idealiza a sociedade e deixa de identificar os conflitos de interesses, inclusive de classes, capazes de bloquear o bem-estar para todos. Em consequência, o planejamento governamental não é neutro em matéria de interesses sociais e não comporta necessariamente todas as classes sociais.

Uma tentativa de superação desse limite aparece noutro estudo, formulado em coautoria, no qual se procura dar conta da consistência teórica dos estudos sobre determinantes sociais da saúde e, consequentemente, da política formulada para modificá-los. Admitindo-se que "pensar em determinação social da saúde implica em uma reflexão sobre a saúde enquanto objeto das ciências sociais", Zioni e Wesphal (2007: 28) retomam as disputas paradigmáticas desse campo de saber científico, pautadas na disjuntiva entre estrutura e ação, e as diferentes alternativas surgidas em fins do século XX, para assumir a perspectiva de uma "sociologia da experiência" (Dubet, 1994).

A assunção dessa abordagem permite, como assinalado por Zioni e Westphal,

identificar os conflitos e os projetos que se encontram em disputa, a posição dos sujeitos envolvidos, as representações e as experiências envolvidas na definição dos problemas vividos, a participação dos atores e sujeitos na elaboração das propostas de enfrentamento. (Zioni \& Westphal, 2007: 32)

O entendimento dos conflitos, no entanto, requer necessariamente o estudo das estruturas, seja na forma de cenário ou de situação abrangente, ou ainda, das condições dadas da ação dos homens ao qual se refere Karl Marx na obra O 18 Brumário de Luís Bonaparte. É necessário remeter-se, portanto, à ideia de totalidade social ou de totalização, ao se considerar a sociedade moderna como um processo histórico e, à medida que se examinam aspectos particulares desse processo considera-se uma totalização sempre parcial. Essa é a abordagem prevalente nos estudos de sociologia urbana, a qual considera as desigualdades econômicas, as políticas públicas, os conflitos sociais, a violência e os direitos sociais e outras tantas reflexões apropriadas ao entendimento dos espaços urbanos, "verdadeiro palco de fatos sociais indutores de problemáticas sociológicas contemporâneas" (Barreira, 2010: 149).

Importa advertir, no entanto, sobre as limitações do urbano como um campo urbanístico porquanto esteja: sujeito às injunções e demandas de agentes situados em outras esferas do mundo social, quer dizer, em relação a campos mais autônomos e estruturados (Martins, 2006). 
A ideia de campo, apropriada de Pierre Bourdieu por Jeová Dias Martins em sua tese de doutoramento, serve para descortinar os polos em torno dos quais tendem a se agrupar, idealmente, as forças sociais atuantes na cidade - a saber, a cidade mercado e o direito à cidade -, sem que isso signifique a precedência de um polo sobre o outro ou que essa definição venha a exaurir os sentidos das práticas urbanas. Campo urbanístico designa uma determinada composição "de agentes e instituições que reivindicam para si o monopólio da definição legítima do dever-ser da metrópole" ainda que, como adverte o autor, tal monopólio não seja necessariamente realizável (Martins, 2006: 40).

A cidade como espaço do valor de troca predomina sobre a cidade como espaço do valor de uso, pois esse predomínio responde à lógica do sistema econômico no qual está inserida. Tanto mais equivalente à imposição, quanto menor a capacidade de resistência dos grupos sociais mais vulneráveis. O resultado pode ser a desterritorialização, como é o caso das comunidades que moram nos arredores da Área de Proteção Ambiental (APA) de Guapimirim, a exemplo dos coletores de caranguejos do bairro de Itambi, em Itaboraí, limítrofe com a APA.

Para isso, o Comperj estabeleceu o Programa de Remanejamento e Monitoramento da População Deslocada. É a contrapartida social "dos pré-requisitos que os gestores do Estado se apoiam: visão em curto prazo, interesses globais sobrepondo-se aos interesses locais, racionalidade estritamente técnico-científica." (Moysés, 2010: 8).

Ao se contrapor ao modelo de desenvolvimento hegemônico, Moysés (2010) traz a contribuição de Celso Furtado na obra Cultura e Desenvolvimento em Época de Crise. A apropriação do pensamento do grande cientista social parece perder a correlação entre desenvolvimento capitalista e luta social implícita na seguinte passagem do Prefácio daquela obra:

Como escapar da armadilha da 'racionalidade econômica' que, entre nós, opera inexoravelmente no sentido de favorecer aqueles que controlam o poder? A resposta é simples: modificando as bases sociais de sustentação desse poder. Vale dizer: assegurando uma participação efetiva no processo político dos segmentos sociais vitimados pela referida racionalidade econômica. Nenhum avanço real é exequível sem desenvolvimento político, sem democratização substantiva, sem a presença organizada na esfera política de amplos segmentos da sociedade civil, particularmente da massa trabalhadora. Nosso real atraso é político e não econômico. (Furtado, 1984: 12)

A participação institucionalizada tem sido apresentada como alternativa à fragmentação de interesses vigente na sociedade, sem se apresentar de fato 
como uma forma de democracia participativa. Em geral, a participação tem um caráter setorial e de cunho consultivo. As audiências públicas, nas quais estudos são apresentados e discutidos, não encaminham nenhum mecanismo para a participação no processo decisório. Por isso assumem o papel de uma abertura à sociedade civil meramente formal. Superar essa limitação é um desafio para pesquisas de caráter participativo.

Uma reflexão sobre o conceito de vulnerabilidade social parece necessária para apreender contextos urbanos em processos de transformação acelerada, como vem acontecendo em Itaboraí.

Lucio Kowarick (2009) chama atenção para a construção histórica do conceito de vulnerabilidade no contexto do pensamento científico-social e político norte-americano, que passou de conotação progressista estruturada na década de 1960 para uma concepção conservadora na qual a culpabilização dos indivíduos e populações em situações de fragilidade social é explícita. É nessa perspectiva que ganha sentido a ideia de subclasse, como um conjunto de desajustados que preferem viver à custa de programas sociais a inserirem-se na economia de mercado. Salienta criticamente o autor que, mesclada a certas concessões de cunho liberal que não alteraram a tônica da concepção, foi uma interpretação mais amortecida dos ideais conservadores que triunfou e se sustenta ainda na discussão sobre culpar ou não os pobres urbanos por seus infortúnios.

Compreenda-se que um aspecto fundamental da questão da vulnerabilidade está no afastamento do Estado, sob a orientação neoliberal, de suas responsabilidades sociais.

Transpondo sua reflexão para os ambientes urbanos brasileiros, Kowarick (2009) enfatiza que orientar a análise da vulnerabilidade, considerando-se exclusivamente a ideia de exclusão social, dificulta o reconhecimento de que nas cidades de hoje existem formas extremamente precárias de inclusão que não podem ser desconsideradas. É nessa direção que o autor constrói seu pensamento e suas investigações unindo uma vulnerabilidade socioeconômica, referente à falta de garantias de trabalho, saúde e saneamento, educação, moradia e estrutura urbana e à vulnerabilidade civil, concernente a insegurança, falta de proteção e exposição à violência.

Na prática, em termos de ações, essa fundamentação teórica significa a tomada de posição em favor do desenvolvimento de práticas construídas em comum com a população local; no caso da presente reflexão, de metodologias participativas no campo da educação e saúde. Metodologias estas que, entre outros 
resultados, possam contribuir para a democratização das políticas públicas, para o fortalecimento das organizações populares e para a melhoria da qualidade dos serviços públicos de saúde oferecidos às populações que vivem em contextos de pobreza.

Caso contrário, os sentidos continuarão a escapar aos pesquisadores científicos, principalmente dos campos da educação e da saúde, dependentes de um conhecimento produzido sobre as classes populares baseado exclusivamente na ideia da sociedade e da política como representação. A incapacidade relativa de fazer uma investigação científica na perspectiva popular foi denominada por Victor Valla, em releitura de José de Souza Martins, de crise de compreensão (Valla, 1995). Para superá-la ainda é necessário estudar a realidade com metodologias capazes de incorporar o modo como as pessoas das classes populares elaboram seu conhecimento do mundo, com toda a ambiguidade implicada pela situação de opressão e medo em que se encontram cotidianamente (Lima \& Stotz, 2010).

\section{Uma Caracterização de Itaboraí}

De acordo com o Tribunal de Contas do Estado do Rio de Janeiro (2007), Itaboraí pertence à Região Metropolitana, que também abrange os municípios do Rio de Janeiro, Belford Roxo, Duque de Caxias, Guapimirim, Japeri, Magé, Mesquita, Nilópolis, Niterói, Nova Iguaçu, Paracambi, Queimados, São Gonçalo, São João de Meriti, Seropédica e Tanguá.

Limita-se ao norte com Cachoeira de Macacu e Guapimirim, ao sul com Maricá, a leste com Tanguá e a oeste com São Gonçalo e baía de Guanabara. Itaboraí tem uma área total de 439,3 km², correspondentes a 9,2\% da área da Região Metropolitana. O município é cortado pelo leito da Estrada de Ferro Leopoldina, fator que condicionou sua ocupação.

A escolha de Itaboraí para instalação do Comperj decorre das vantagens geográficas e logísticas do município: de acordo com o Relatório de Impacto Ambiental (Petrobras/Concremat, 2007), está situado a 103 km do porto de Itaguaí e dos terminais de ilhas d'Água e Redonda (30 km). É atendido por rodovias e ferrovias, além das sinergias com a Refinaria de Duque de Caxias (Reduc) (50km), com as plantas petroquímicas das empresas RioPolímerose da Suzano $(50 \mathrm{~km})$ e com o Centro de Pesquisas e Desenvolvimento Leopoldo Américo Miguez de Mello - Cenpes $(38 \mathrm{~km})$. A ligação rodoviária entre o Comperj e o porto de Itaguaí será viabilizada com o Arco Metropolitano do Rio de Janeiro, eixo viário com 145 km de extensão (obra em andamento). 
O Comperj faz parte do Programa de Aceleração do Crescimento (PAC) do governo federal, anunciado em 2007 e formalizado em 31 de março de 2008. É fruto da parceria da Petrobras com o Grupo Ultra e o Banco Nacional de Desenvolvimento Econômico e Social - BNDES (Bienestein et al., 2009). Trata-se do maior investimento da Petrobras, estimado num total de oito bilhões de dólares. Com a entrada da Brasken na sociedade com a Petrobras, formalizada em março de 2011, o planejamento do Comperj sofreu uma brusca mudança: da fabricação de produtos plásticos passou para a de combustíveis, sobretudo a de querosene de aviação, "de olho nos grandes eventos esportivos de 2014 e 2016" (Simpep, 2011). Está localizado no distrito de Porto das Caixas, município de Itaboraí, nos limites com Cachoeiras de Macacu e Guapimirim. Encontra-se em construção em um terreno com extensão de $45 \mathrm{~km}^{2}$, com a área industrial ocupando $26 \%$ do território. Na Figura 1 é possível localizar o Comperj, indicado na área norte do município.

Figura 1 - Itaboraí: divisão distrital

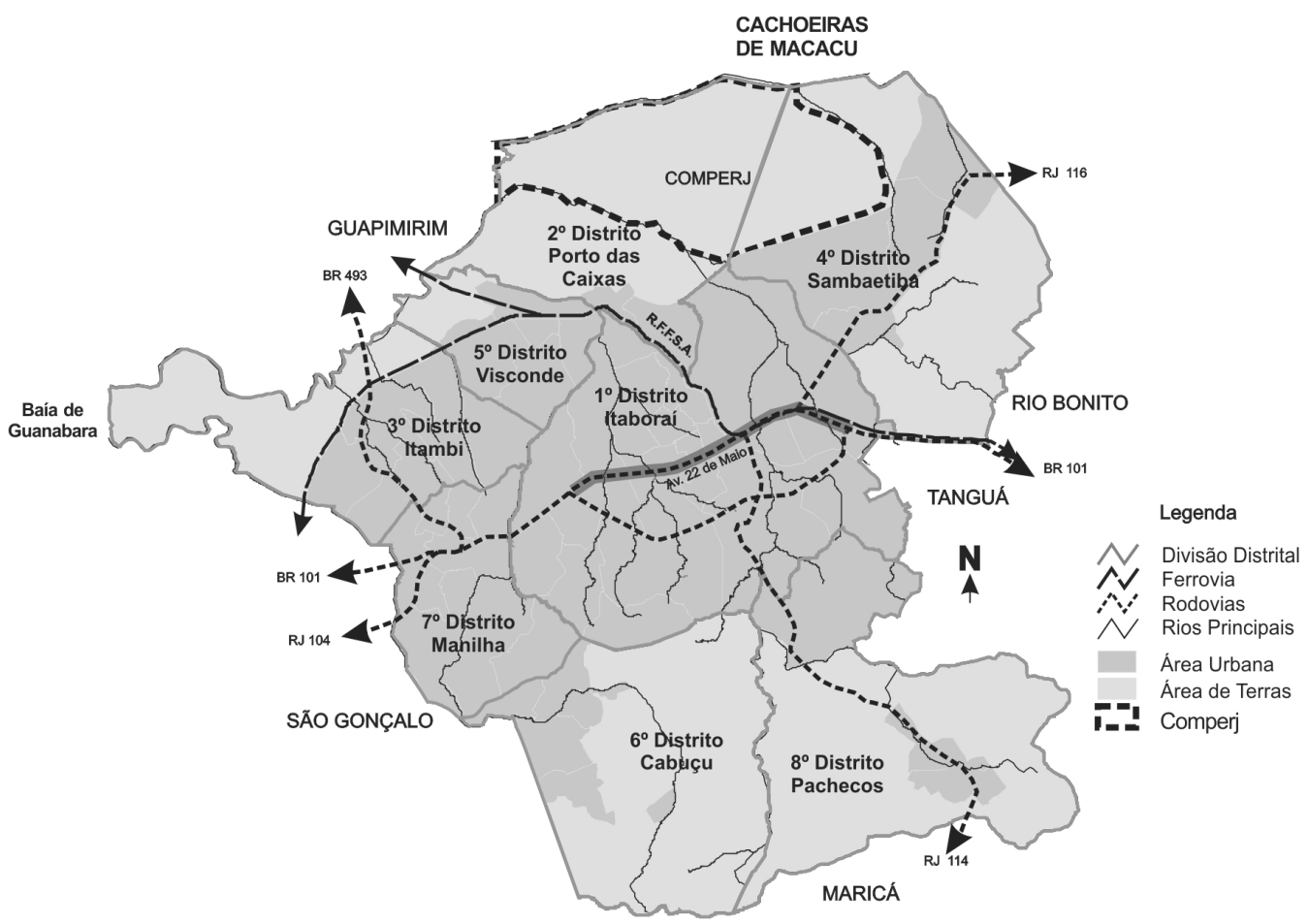

Ilustração: Rossana Souza.

Fonte: Secretaria de Planejamento da Prefeitura Municipal de Itaboraí (Seplan/PMI). 
A estimativa para a população do município de Itaboraí em 2010 era de 218.008 habitantes, segundo o IBGE (2010). É uma população que pode ser considerada jovem, com 84,88\% dos seus habitantes com idade até 49 anos (Toledo \& Sabroza, 2009).

A população feminina corresponde a 50,56\% da população total, sendo que $66 \%$ do total de mulheres se encontram em idade fértil (10 a 49 anos). A taxa de crescimento anual estimada, correspondente ao período de 2000 a 2007, foi de $2,4 \%$.

Itaboraí pode ser classificada como uma cidade média inserida em Região Metropolitana. Sua história recente evidencia o esvaziamento econômico da baixada litorânea, da qual fazia parte até fins dos anos 1960. Com a erradicação dos laranjais, tornou-se uma cidade-dormitório de uma população que trabalha em São Gonçalo, Niterói e no Rio de Janeiro.

Economista especializada no estudo da economia fluminense, Ângela Moulin S. Penalva Santos observa que o desenvolvimento econômico e social municipal passa pela capacidade de arcar com os custos da descentralização das políticas públicas porque, apesar da competência tributária própria definida pela Constituição Federal de 1988, os municípios têm sofrido reveses no tocante à autonomia, com a edição de quatro dezenas de emendas constitucionais. Apenas 223 dos 5.600 municípios brasileiros tinham, no entanto, população superior a cem mil habitantes, sendo assim capazes de "sustentar uma economia local que resulte em carga fiscal municipal com alguma expressão" no âmbito das políticas públicas (Penalva Santos, 2004: 2).

As cidades na classe de tamanho populacional acima de cem mil e até um milhão de habitantes são consideradas cidades médias. A propósito da evolução das finanças públicas destas, é importante situá-las dentro ou fora de regiões metropolitanas, de modo a entender sua dinâmica de crescimento. Itaboraí é classificada como cidade média, em razão de sua população de 218.090 habitantes em 2010, conforme censo do IBGE.

Para efeito do estudo realizado no intuito de entender as consequências do projeto Comperj sobre a vida, trabalho e saúde da população de Itaboraí e sua região, acredita-se ser importante classificá-la nos termos do Consórcio Intermunicipal de Desenvolvimento da Região Leste Fluminense (Conleste).

O Conleste foi constituído por 11 municípios da área de abrangência do Comperj logo após o anúncio da localização do projeto industrial feito pela Petrobras, com o objetivo de promover o desenvolvimento local equilibrado por 
meio de planejamento e execução de ações coordenadas. Fazem parte do Conleste os municípios de Itaboraí, São Gonçalo, Cachoeiras de Macacu, Casimiro de Abreu, Guapimirim, Niterói, Magé, Maricá, Rio Bonito, Silva Jardim e Tanguá.

Para situar a capacidade do município de Itaboraí - e dos demais incluídos no Conleste - de sustentar e impulsionar, mediante recursos fiscais, a economia local, destacaram-se alguns indicadores, como população, renda per capita, receitas correntes e outros. Foge aos propósitos do estudo procurar entender o processo econômico e político e a dinâmica do gasto público local. Serão salientados apenas alguns indicadores, como forma de aproximação da realidade examinada.

Com base nos dados disponibilizados pelo IBGE, pode-se observar na Tabela 1 qual o perfil das finanças municipais de Itaboraí e demais municípios do Conleste.

Para análise das finanças públicas municipais lançou-se mão das receitas correntes e não das receitas orçamentárias realizadas, pois o que interessou foram aquelas que, oriundas de arrecadação própria (tributária, das contribuições, patrimonial, agropecuária, de serviços, industrial e outras) e de transferências intergovernamentais, permitam avaliar a autonomia para cobrir as despesas orçamentárias destinadas à manutenção das atividades governamentais, sejam constitucionalmente definidas ou não.

Na Tabela 1, o item "Receitas próprias" inclui as receitas tributárias, patrimonial, de capital etc.

Das receitas orçamentárias oriundas de transferências intergovernamentais, as federais contemplam alguns fundos, como o de Manutenção e Desenvolvimento da Educação Básica e de Valorização dos Profissionais da Educação (Fundeb), do Fundo Nacional de Saúde e do Fundo de Participação dos Municípios (FPM), composto de 22,5\% da arrecadação do Imposto de Renda (IR) e do Imposto sobre Produtos Industrializados (IPI) que, contudo, é destacado na fonte do IBGE Cidades@. A importância deste aumenta com o tamanho populacional e a pobreza do município, sendo uma transferência redistributivista (Penalva Santos, 2004). Quanto às transferências estaduais, a mais importante é, sem dúvida, o Imposto sobre Circulação de Mercadorias e Serviços (ICMS), o qual é transferido conforme o peso da atividade econômica do município, sendo por isso considerado uma "quase-receita".

Ao destacar a correlação entre população, PIB per capita e receitas, tem-se que observar que alguns dos municípios incluídos no Conleste, como Cachoeiras de Macacu, Casimiro de Abreu, Guapimirim e Silva Jardim, já recebem royalties da Petrobras, nos termos da lei n. 9.478, de 6 de agosto de 1997. Como se pode 
perceber na Tabela 1, esses valores distorcem o PIB per capita e o desempenho nas finanças públicas do conjunto do Conleste.

\begin{tabular}{|c|c|c|c|c|c|c|c|c|c|c|c|}
\hline$\therefore \circ$ & $\stackrel{m}{i}$ & $\overline{\mathcal{Y}}$ & $\begin{array}{l}\circ \\
\stackrel{0}{m}\end{array}$ & $\hat{\approx}$ & $\begin{array}{l}\infty \\
\stackrel{\infty}{\circ}\end{array}$ & $\underset{m}{\stackrel{\sim}{m}}$ & $\bar{m}$ & $\frac{0}{\dot{m}}$ & $\begin{array}{l}0 \\
0 \\
0\end{array}$ & ' & \\
\hline 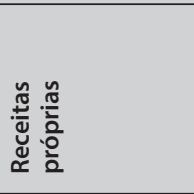 & 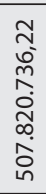 & 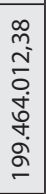 & 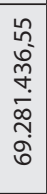 & 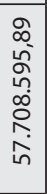 & 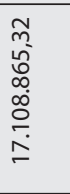 & 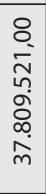 & 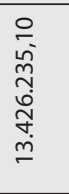 & 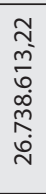 & 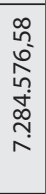 & ' & \\
\hline$\delta^{\circ}$ & $\stackrel{\text { mे }}{-}$ & $\infty^{\circ}$ & $\begin{array}{l}\infty \\
\stackrel{\infty}{ \pm}\end{array}$ & $\underset{\sigma}{ }$ & $\stackrel{\infty}{i_{n}^{\prime}}$ & $\stackrel{\overbrace{}}{\stackrel{2}{-}}$ & $\stackrel{\underset{\sim}{\sim}}{\sim}$ & $\hat{\sigma}$ & $\bar{i}$ & ' & ' \\
\hline 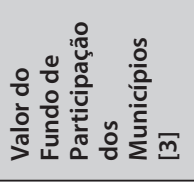 & $\begin{array}{l}\infty \\
\infty \\
\stackrel{\infty}{1} \\
\infty \\
\infty \\
\infty \\
\stackrel{n}{n} \\
\stackrel{m}{m}\end{array}$ & 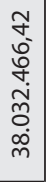 & 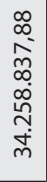 & 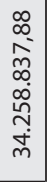 & 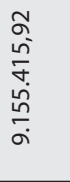 & 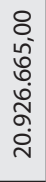 & 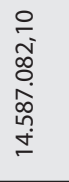 & $\begin{array}{l}\bar{\Sigma} \\
\overline{0} \\
0 \\
0 \\
\infty \\
m \\
m \\
\dot{v}\end{array}$ & 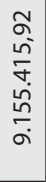 & 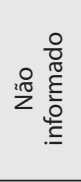 & \\
\hline व & $\stackrel{m}{\sigma}$ & $\begin{array}{l}\text { ஸे } \\
\text { ஸे }\end{array}$ & $\begin{array}{l}\stackrel{\infty}{\circ} \\
\stackrel{-}{-}\end{array}$ & $\stackrel{\stackrel{\omega n}{n}}{\stackrel{n}{n}}$ & 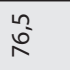 & $\begin{array}{l}0 \\
\infty \\
\infty\end{array}$ & $\stackrel{m}{i}$ & $\stackrel{\text { ñ }}{\text { in }}$ & $\stackrel{+}{\stackrel{ \pm}{N}}$ & ' & ' \\
\hline 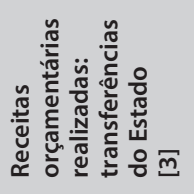 & 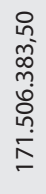 & 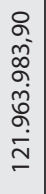 & 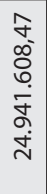 & 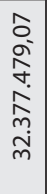 & 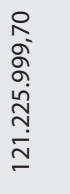 & 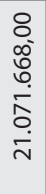 & 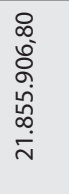 & $\begin{array}{l}0 \\
m \\
\infty \\
\infty \\
m \\
0 \\
o \\
o \\
\stackrel{0}{0}\end{array}$ & 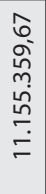 & : & 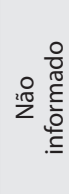 \\
\hline$\circ$ & $\stackrel{1 n}{\sigma}$ & $\bar{d}$ & $\stackrel{m}{\mathfrak{f}^{\prime}}$ & ma & 옴 & $\frac{0}{m}$ & $\frac{n n}{i n}$ & $\stackrel{\infty}{m}$ & 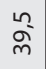 & ' & \\
\hline 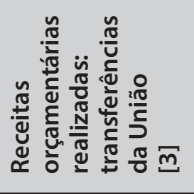 & 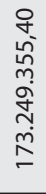 & 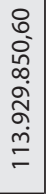 & 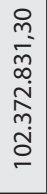 & 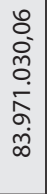 & 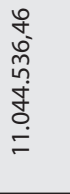 & 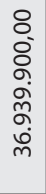 & 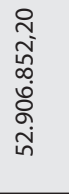 & 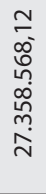 & 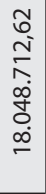 & 날 & 날 \\
\hline 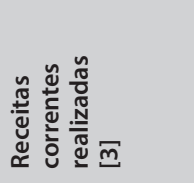 & 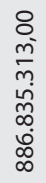 & 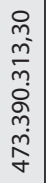 & 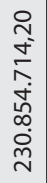 & 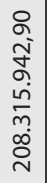 & 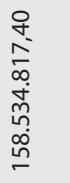 & 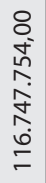 & 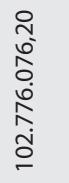 & $\begin{array}{l}\bar{\infty} \\
\bar{\delta} \\
0 \\
0 \\
\frac{1}{0} \\
\infty\end{array}$ & $\begin{array}{l}\stackrel{9}{1} \\
\dot{f} \\
\delta \\
\dot{J} \\
b \\
\dot{f} \\
\dot{f}\end{array}$ & 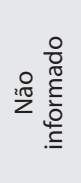 & 2: \\
\hline 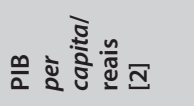 & $\underset{\substack{m \\
\infty}}{\stackrel{m}{\infty}}$ & 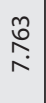 & 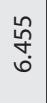 & $\begin{array}{l}\text { ָे } \\
\text { bे }\end{array}$ & $\begin{array}{l}\text { ñ } \\
o \\
\dot{y}\end{array}$ & ڤે & 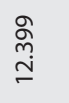 & $\begin{array}{l}\frac{n}{m} \\
\stackrel{n}{N}\end{array}$ & $\begin{array}{l}\frac{9}{1} \\
\hat{b}\end{array}$ & 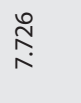 & $\begin{array}{l}n \\
\hat{\alpha} \\
\infty \\
0 \\
0\end{array}$ \\
\hline 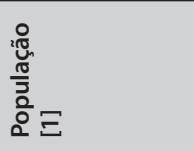 & 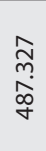 & $\begin{array}{l}\bar{\delta} \\
\text { ळ. } \\
\text { ूे }\end{array}$ & 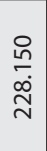 & 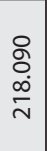 & $\underset{\substack{m \\
m}}{\stackrel{m}{m}}$ & $\begin{array}{l}\frac{a}{n} \\
\stackrel{n}{\simeq} \\
\simeq\end{array}$ & $\begin{array}{l}\stackrel{P}{n} \\
\mathfrak{m} \\
\text { in }\end{array}$ & $\begin{array}{l}\stackrel{0}{\infty} \\
\text { in } \\
\text { in }\end{array}$ & $\begin{array}{c}\bar{m} \\
\stackrel{\circ}{\dot{m}}\end{array}$ & 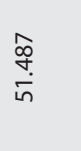 & $\begin{array}{l}\stackrel{\circ}{0} \\
\stackrel{n}{N}\end{array}$ \\
\hline$\frac{. \frac{0}{2}}{\frac{0}{\frac{0}{5}}}$ & 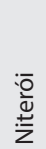 & 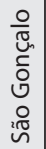 & $\begin{array}{l}\mathscr{U} \\
\stackrel{\pi}{\Sigma} \\
\sum^{\pi}\end{array}$ & $\begin{array}{l}-\overline{0} \\
\overline{0} \\
\frac{0}{0} \\
\text { I0 }\end{array}$ & 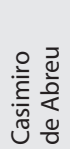 & $\frac{\sqrt[\pi]{\frac{\pi}{2}}}{\frac{\pi}{\pi}^{\frac{\pi}{2}}}$ & 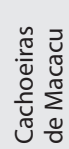 & $\begin{array}{l}\stackrel{0}{\frac{\pi}{c}} \\
\frac{0}{0} \\
.0 \\
. \frac{0}{x}\end{array}$ & 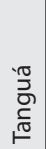 & 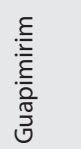 & $\begin{array}{l}\frac{E}{\overline{0}} \\
\frac{\sqrt{0}}{\sqrt{0}} \\
\frac{0}{\bar{n}}\end{array}$ \\
\hline
\end{tabular}


Então, qual a imagem de Itaboraí que tais dados permitem construir? Em que pese a defasagem dos anos da informação $(2006,2007)$, verifica-se que se trata de um município com baixo PIB per capita, forte dependência da transferência do governo federal e baixa participação do ICMS no conjunto das receitas correntes. Em outros termos, aponta para uma cidade média de renda baixa, com uma população predominantemente pobre.

$\mathrm{Na}$ relação dos municípios com maior incidência de pobreza objetiva e subjetiva elaborada pelo IBGE na Tabela 2, Itaboraí aparece em terceiro lugar, embora o nível de desigualdade de renda aferida pelo índice de Gini seja, ao lado do de Tanguá, mais baixo que o de Niterói.

Tabela 2 - Pobreza e desigualdade nos municípios do Conleste, 2003

\begin{tabular}{l|l|l|l|l|l}
\hline Municípios & População & $\begin{array}{l}\text { PIB per } \\
\text { capita/reais }\end{array}$ & $\begin{array}{l}\text { Incidência da } \\
\text { pobreza (\%) }\end{array}$ & $\begin{array}{l}\text { Incidência } \\
\text { da pobreza } \\
\text { subjetiva (\%) }\end{array}$ & Índice de Gini \\
\hline Tanguá & 30.731 & $6.740,00$ & 68,12 & 47,40 & 0,39 \\
\hline Magé & 228.150 & $6.455,00$ & 64,02 & 40,59 & 0,41 \\
\hline Itaboraí & 218.090 & $6.923,00$ & 59,43 & 34,28 & 0,39 \\
\hline Silva Jardim & 21.360 & $6.855,00$ & 52,09 & 50,54 & 0,42 \\
\hline Guapimirim & 51.487 & $7.726,00$ & 46,21 & 30,52 & 0,42 \\
\hline $\begin{array}{l}\text { Cachoeiras de } \\
\text { Macacu }\end{array}$ & 54.370 & $12.399,00$ & 41,50 & 37,66 & 0,45 \\
\hline São Gonçalo & 999.901 & $7.763,00$ & 39,86 & 18,23 & 0,41 \\
\hline Maricá & 127.519 & $7.997,00$ & 38,72 & 21,06 & 0,44 \\
\hline Rio Bonito & 55.586 & $20.315,00$ & 21,52 & 20,97 & 0,46 \\
\hline Casimiro de Abreu & 35.373 & $44.932,00$ & 16,92 & 14,06 & 0,41 \\
\hline Niterói & 487.327 & $18.713,00$ & 12,47 & 4,54 & 0,46 \\
\hline
\end{tabular}

Fonte: Elaborada com base nos dados do IBGE Cidades@, relativos ao Mapa da pobreza e desigualdade nos municípios - 2003.

Apenas os três últimos municípios estavam classificados abaixo do indicador de pobreza do Brasil, estimado em 33,90\%. Em termos de incidência de pobreza subjetiva, apenas cinco estavam abaixo do indicador de 28,07\%.

A história política recente de Itaboraí influencia diretamente as condições de vida e saúde da população.

Até 2003 a maioria dos serviços públicos de saúde eram terceirizados, como consultas e exames. Tal situação se reverteu nos anos de mandato do 
prefeito Cosme José Salles, até fins de 2008. Exemplos das modificações foram a estruturação do Programa Saúde da Família do município e a incorporação da categoria de agente comunitário de saúde ao quadro de servidores públicos do município.

Em 2008, ano no qual a experiência em Ouvidoria Coletiva foi introduzida como uma possibilidade para o trabalho na atenção básica do município, havia uma Secretaria Municipal de Saúde estruturada cujas ações serviam de referência para outras cidades. Esse cenário de êxito permitiu que a gestão dessa secretaria aceitasse os desafios propostos pelo subprojeto Ouvidoria Coletiva e, por sua vez, propusesse a ampliação da proposta original do projeto.

\section{Ouvidoria Coletiva: uma proposta de participação e diálogo}

Como afirmado anteriormente, a inclusão das organizações civis de caráter popular na formulação, implementação e avaliação de políticas públicas é um imperativo quando se trata de dar conta de problemas tão complexos como os impactos de um megaprojeto de desenvolvimento industrial do tipo do Comperj, num contexto de acentuada desigualdade social como é o caso de Itaboraí. Contudo, viabilizar essa participação é sempre um desafio.

A elaboração de novas metodologias em educação e saúde pode contribuir para a constituição de uma sociedade composta por cidadãos dotados de ferramentas para pensar seus problemas e encontrar soluções (Alves, 2003).

A metodologia de Ouvidoria Coletiva encaminhada no âmbito da pesquisa assinalada deve esse nome à ideia, elaborada por Victor Valla em 2003, de ampliar a concepção das ouvidorias tradicionais, na medida em que a escuta excede o âmbito dos serviços públicos de saúde. Isso porque não se restringe a avaliar o atendimento oferecido e sim pretende obter mais informações sobre as condições de vida das comunidades com base na percepção de participantes representativos da situação investigada. Nesse sentido, se constitui numa ouvidoria autônoma, não vinculada a um órgão público específico e, portanto, não responsável pelo serviço de atendimento ao consumidor.

A metodologia da Ouvidoria Coletiva é entendida como um processo de educação e saúde, a saber, como uma prática social baseada no diálogo e no intercâmbio entre os saberes científico e popular (Briceño-León, 1996), capazes de favorecer a compreensão do processo do sofrimento e das formas de se lidar com ele. A Ouvidoria Coletiva contribui para a construção compartilhada dos 
conhecimentos em saúde (Carvalho, Acioli \& Stotz, 2001): uma de suas finalidades consiste numa aproximação maior entre os atendimentos nos serviços públicos de saúde e a resolução das queixas dos usuários.

A orientação dos serviços de saúde em busca da identificação e inclusão das necessidades de segmentos socialmente vulneráveis pode ser favorecida pela metodologia da Ouvidoria Coletiva.

A metodologia envolve a realização de diálogos por meio da organização de encontros, denominados fóruns, nos quais os grupos são constituídos geralmente em torno de centros de saúde. Cada grupo conta com dez participantes em média, sendo eles: profissionais da saúde, em especial agentes comunitários de saúde; líderes religiosos locais, de várias denominações; representantes de instituições comunitárias; e outros convidados identificados como relevantes por cada grupo.

A importância de se ter representantes das diferentes denominações religiosas se justifica pela crescente busca das classes populares a essas instituições, tanto pelas queixas de problemas físicos quanto em relação ao sofrimento psíquico.

As instituições religiosas são identificadas como provedoras de auxílios para um segmento social geralmente invisível, constituído pelos que vivem em situação de pobreza absoluta ou miseráveis. Como já mencionado, discussões acerca das condições de vida dos mais pobres entre os pobres costumam ser excluídas de instâncias de participação social, uma vez que eles não dispõem dos recursos mínimos para o cumprimento das exigências governamentais necessárias ao acesso aos programas de transferência direta de renda, como o programa Bolsa Família. Assim, só lhes resta pedir socorro nas instituições religiosas que, em geral, promovem práticas de caridade e de solidariedade sem maiores exigências.

O processo de implantação da metodologia da Ouvidoria Coletiva em Itaboraí iniciou-se em meados de 2008, com a capacitação dos profissionais da saúde para o trabalho junto das equipes de Estratégia Saúde da Família (ESF) do município.

A decisão dos gestores da Secretaria Municipal de Itaboraí em oferecer tal capacitação se deve à compreensão sobre a necessidade de o serviço público de saúde se preparar, nesse município, para as mudanças nas condições de vida da população em virtude das profundas transformações na cidade iniciadas em 2008, com a implantação do Comperj.

Alguns efeitos nas condições de vida da população admitidos pelos gestores de saúde decorriam da previsão de pressão demográfica (22 mil trabalhadores diretos no pico das obras, além daqueles em busca de emprego); do aumento dos índices de comportamentos antissociais; de ocupação irregular de áreas urbanas 
com acentuação de carências sociais e de aumento do tráfego local e regional, assinalados como aspectos negativos do aumento da oferta de emprego e da arrecadação tributárias dos municípios (EIA, 2007).

Itaboraí destacava-se, em 2008, por ser a cidade de mais de 200 mil habitantes com maior cobertura em ESF do estado do Rio de Janeiro: a saber, 76,23\%. Nesse sentido, Itaboraí ocupa uma dianteira que se distancia muito da cobertura de ESF em outros municípios próximos como São Gonçalo com 36,47\% e Niterói com 25, 34 \% (Stotz, 2011).

O município dispunha de 44 equipes de ESF alocadas em 36 unidades de saúde (TCE, 2007), além de um Conselho Municipal de Saúde que contava com a participação ativa de diversas lideranças comunitárias do município.

A capacitação em Ouvidoria Coletiva envolveu 480 participantes, entre profissionais da saúde da atenção básica e lideranças comunitárias. Foi compreendida pelos gestores como uma estratégia de aprofundamento do diálogo entre os profissionais da saúde e outros sujeitos envolvidos na vida comunitária nas localidades em torno das Unidades Básicas de Saúde (UBS) da cidade.

A utilização da metodologia em Itaboraí requereu diversas modificações decorrentes da construção coletiva iniciada durante a capacitação dos profissionais da saúde. Teve como base os contextos das localidades e dos participantes. Os aspectos fundamentais da Ouvidoria Coletiva foram, porém, preservados.

Uma das modificações na metodologia foi a eliminação da agenda prévia: os temas a serem discutidos desde os primeiros fóruns foram sugeridos pelos próprios participantes e selecionados por ordem de prioridade.

\section{Vulnerabilidade Social: chave de leitura para entender os desafios}

Conforme se observa no Gráfico 1, realizaram-se 27 fóruns de Ouvidoria Coletiva até fins de 2008, estando entre os temas mais discutidos: saneamento básico; alcoolismo; o bairro; o SUS; violência; educação; saúde do idoso; dengue; fome; a Estratégia Saúde da Família; transporte; desnutrição; drogas; adolescência (gravidez e dificuldades) e lazer.

No gráfico fica demonstrado que os temas mais discutidos nos fóruns foram dois: educação e gravidez na adolescência. Ambos relacionam-se diretamente com a implantação do Comperj na região. 
Gráfico 1 - Primeiros fóruns - Itaboraí: temas discutidos

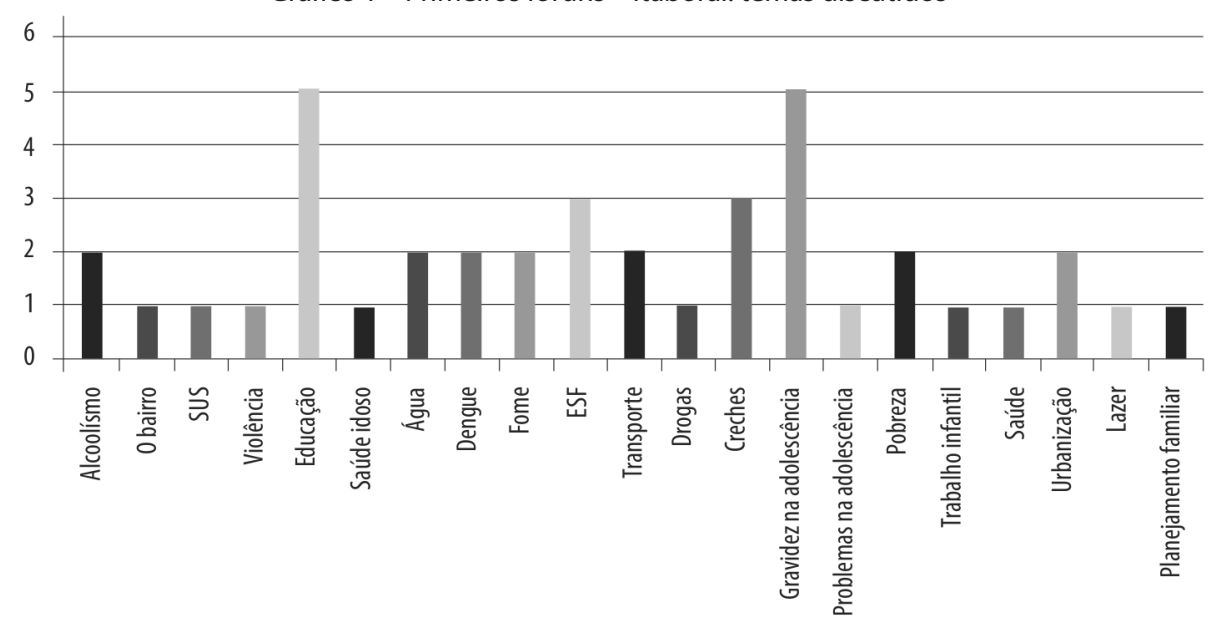

O tema educação, escolhido por vários fóruns, revela a percepção de que a maioria da população tem baixo grau de escolaridade, a maioria contando apenas com o nível de ensino fundamental. Com isso, os participantes de vários fóruns identificaram a necessidade de elevar o nível de escolaridade com a finalidade de promover o acesso aos cursos profissionalizantes.

$\mathrm{Na}$ época em que aconteceram os primeiros fóruns, havia a crença de que milhares de vagas de emprego seriam oferecidas à população local. E que seriam incorporados a esse mercado os trabalhadores que tivessem cursos profissionalizantes na área industrial e de petróleo. Assim, a ênfase na educação pode ser entendida como expressão do medo de perderem o trem da história. As mulheres, por sua vez, foram identificadas como as que mais necessitavam de tais vagas. Por isso, o tema educação inclui a percepção da necessidade da abertura de creches públicas nos bairros populares.

Em 2010 os profissionais da saúde revelaram, durante grupos focais realizados em diferentes unidades de saúde, que as almejadas vagas não apareceram e que a população empobrecida não demonstrava mais tanta esperança na geração de empregos com a criação do Comperj.

Segundo o IBGE (2010), há uma distinção de pobreza também pela falta de oportunidades e poder. Quanto maior a vulnerabilidade de grupos sociais, tanto maior a probabilidade de ser agravada tal situação. Somente o "crescimento econômico não será suficiente se os pobres não forem capazes de usufruir seus benefícios por falta de treinamento, saúde ou acesso à infraestrutura básica" (IBGE, 2010: 1). 
A percepção acerca dos limites da educação no âmbito do município corresponde aos dados encontrados. Apesar de o recenseamento feito pelo IBGE em 2000 ter considerado que 86,8\% da população do município era alfabetizada, no acesso ao ensino formal identificaram-se distorções idade-série elevadas à medida que se avançava nos níveis escolares. Entre alunos do ensino fundamental, 33,3\% estavam com idade superior à recomendada, chegando tal defasagem a 40,7\% entre os que alcançavam o ensino médio.

Em 2011 Itaboraí encontrava-se na 2.976ª posição entre os 5.565 municípios brasileiros, quando avaliados os alunos que cursavam os primeiros anos escolares. E na $3.629^{a}$ posição, no caso daqueles que cursavam os anos finais. Quando analisada sua posição entre os 92 municípios de seu estado, o município encontrava-se na $52^{\mathrm{a}}$ posição nos anos iniciais e na $71^{\mathrm{a}}$, nos anos finais (Portal ODM, 2011).

O tema gravidez na adolescência foi outro que mereceu destaque nos fóruns de OC. A percepção do aumento do número de casos já configurava uma preocupação importante, agravada pelo receio de que a chegada de grande quantidade de homens para trabalhar na construção das instalações do Comperj pudesse acentuar ainda mais a situação.

Tal preocupação justifica-se. Segundo Rosélia Piquet (2007), os resultados de estudos acerca dos impactos locais e regionais de indústrias de petróleo têm mostrado impressões desfavoráveis em relação às consequências geradas para as regiões e populações. A realidade apresenta-se diversa do que previram os planos que deram origem aos empreendimentos.

No que tange à gravidez na adolescência, em países onde o desemprego é crônico e grande parte da população se aloca em subempregos, o "local do empreendimento passa a caracterizar-se por uma estrutura atípica, com elevado coeficiente de homens jovens" (Piquet, 2007: 19). A autora também aponta como consequências o aparecimento de processos sociais problemáticos que eram desconhecidos nas localidades afetadas, como favelização, prostituição e criminalidade.

A gravidez na adolescência é identificada como um problema crítico com elevado índice nas comunidades. Os profissionais da saúde constataram um impasse: se por um lado muitas famílias não querem que seus filhos participem de palestras sobre qualquer tema relacionado a sexo nas escolas e nas unidades de saúde, por outro, não conseguem segurar seus filhos e filhas e as meninas acabam engravidando. 
Nos discursos dos profissionais são percebidas diversas causas para a questão, como: iniciação sexual precoce; falta de informação e diálogo intrafamiliar, visão da atividade sexual como meio de inserção social; falta de compreensão dos pais e dos parentes.

As percepções das consequências da gravidez na adolescência, observadas pelos profissionais na convivência com as adolescentes grávidas citadas, foram: o afastamento dos jovens da escola e a interrupção das interações sociais geradas pela gravidez. Ou seja, grávidas cada vez mais novas que acabam delegando as responsabilidades maternas para as avós ou outras pessoas próximas.

Uma informação coletada durante o processo de observação participante junto das equipes e comunidades de Itaboraí foi a alta incidência de adolescentes engravidadas por padrastos, pais, vizinhos ou algum parente próximo. Tal situação é tratada com extrema delicadeza pelos profissionais da saúde, em especial pelos agentes comunitários, que tentam intermediar conciliações no intuito de que essa adolescente possa aderir ao programa de pré-natal o mais rapidamente possível, pois não são raros os casos considerados de alto risco.

Apesar de a educação ter sido apontada como a principal solução para o problema da gravidez na adolescência, esta não pode ser resumida à escolarização nos termos de garantia de vagas às jovens. Implica também um processo de ressocialização, uma vez que remete ao desafio de enfrentar a violência doméstica nas famílias mais pobres.

\section{Fóruns no Distrito de Itambi: indicadores de vulnerabilidade}

Um dos procedimentos metodológicos utilizados na pesquisa foi o da Avaliação com Foco na Pós-Ocupação. O Ministério das Cidades emprega essa matriz para avaliar os projetos financiados pelo Programa Habitar Brasil/Banco Interamericano de Desenvolvimento (BID-HBB), destinados à população que vive em territórios classificados pelo IBGE como áreas subnormais. A matriz tem sido usada para projetos em favelas. Mais uma inovação da pesquisa é a utilização dessa matriz em áreas não favelizadas, como o distrito de Itambi.

Os dados constantes nos discursos de lideranças da região, captados no terceiro módulo de Capacitação em Ouvidoria Coletiva, foram organizados em quadros contendo indicadores de vulnerabilidade de acordo com a citada matriz.

O distrito de Itambi foi usado como caso de referência para a aplicação do procedimento, por ter sido identificado como o de maior vulnerabilidade em relação aos demais distritos de Itaboraí (Figura 2). 
Figura 2 - 3ํDistrito - Itambi e as Unidades Básicas de Saúde

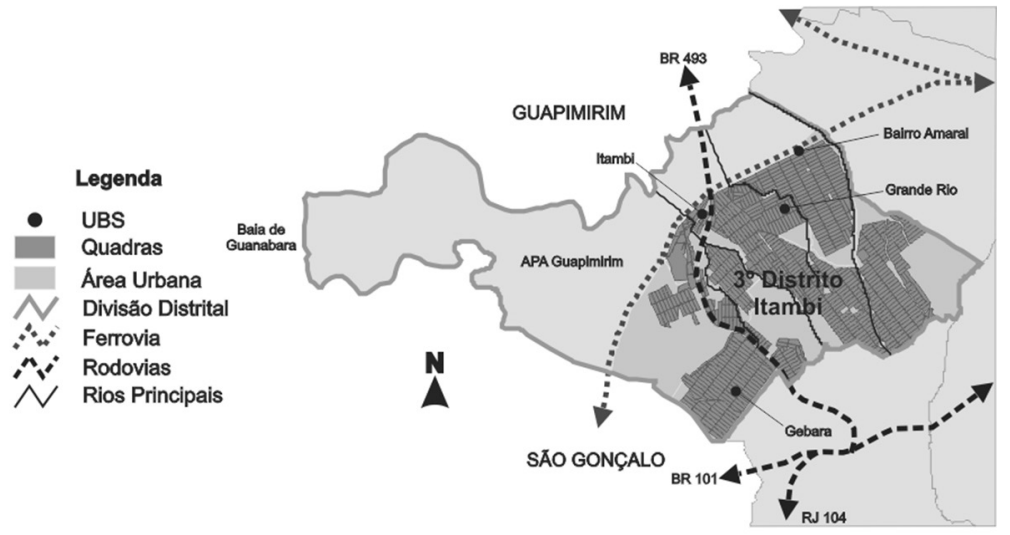

Ilustração: Rossana Souza.

Fonte: Secretaria de Planejamento da Prefeitura Municipal de Itaboraí (Seplan/PMI).

Sobre as questões relacionadas à moradia e inserção urbana, os Fóruns Grande Rio e Gebara trouxeram algumas percepções apresentadas no Quadro 1.

Quadro 1 - Percepções dos problemas nos fóruns: moradia e inserção urbana

\begin{tabular}{|l|l|}
\hline \multicolumn{2}{|l|}{ Infraestrutura básica } \\
\hline Fórum Grande Rio & $\begin{array}{l}\text { discute (...) a falta de saneamento básico(...) por que (...) as crianças costumam } \\
\text { brincar em valas a céu aberto e apresentam frequentemente doenças. O outro } \\
\text { ponto citado foi quanto a (...) falta de abastecimento regular de água na } \\
\text { unidade de saúde. }\end{array}$ \\
\hline Mobilidade Urbana & menciona a dificuldade de transporte para os doentes. \\
\hline Fórum Grande Rio & traz o problema dos horários das vans. \\
\hline Fórum Gebara & \multicolumn{2}{|l}{} \\
\hline Qualidade Ambiental & queixa-se de muito lixo nas ruas (por falta de uma caçamba). \\
\hline Fórum Gebara &
\end{tabular}

Sobre as questões relativas à inclusão social, todos os Fóruns - Grande Rio, Gebara e Bairro Amaral - trouxeram percepções, conforme ilustra o Quadro 2.

As características físicas do distrito de Itambi são extremamente precárias, com diversas áreas de ocupação irregular habitadas por pessoas sob as piores condições de vida, nas quais identificamos passivos ambientais que poluem, desfiguram e degradam fisicamente a região. 
Quadro 2 - Percepções dos problemas nos fóruns: serviços sociais públicos e participação

\begin{tabular}{|l|l|}
\hline \multicolumn{2}{|l|}{ Acesso aos Serviços Sociais Públicos ligados a Educação } \\
\hline $\begin{array}{l}\text { Fórum } \\
\text { Grande Rio }\end{array}$ & $\begin{array}{l}\text { relaciona a falta de oferta de creches (...) à dificuldade da aquisição de } \\
\text { renda pelas mães. Ainda discute a falta de vagas em todos os segmentos, } \\
\text { principalmente na educação infantil. }\end{array}$ \\
\hline Acesso aos Serviços Sociais Públicos ligados à Saúde \\
\hline $\begin{array}{l}\text { Fórum } \\
\text { Grande Rio }\end{array}$ & \begin{tabular}{l} 
queixa-se da falta de atendimento odontológico na unidade de saúde. \\
\hline Acesso aos Serviços Sociais Públicos ligados à Assistência Social
\end{tabular} \\
\hline Fórum Grande Rio & $\begin{array}{l}\text { traz a questão do aumento de gravidez na adolescência e do consumo de } \\
\text { drogas lícitas e ilícitas. }\end{array}$ \\
\hline $\begin{array}{l}\text { Fórum } \\
\text { Bairro Amaral }\end{array}$ & $\begin{array}{l}\text { também traz a questão da gravidez na adolescência, acrescentando o } \\
\text { afastamento da escola e a falta de informação e diálogo. Entende a atividade } \\
\text { sexual como meio de inserção social. }\end{array}$ \\
\hline Acesso aos Serviços Sociais Públicos ligados à Comunicação \\
\hline $\begin{array}{l}\text { Fórum } \\
\text { Grande Rio }\end{array}$ & $\begin{array}{l}\text { queixa-se da falta de um telefone público. } \\
\text { pórum } \\
\text { Grande Rio }\end{array}$ \\
\hline A Cidadania e Participação a realização mais rápida de exames quando há apadrinhamento \\
\hline
\end{tabular}

\section{Considerações Finais}

A cidade-dormitório de Itaboraí tenderá, num futuro imediato, a sofrer uma profunda transformação. É provável que se mantenha ainda na função de cidadedormitório, dada a limitação estrutural do tipo de empreendimento como o Comperj em relação à real capacidade de gerar empregos estáveis (Piquet, 2007). As obras de infraestrutura, instalação de equipamentos urbanos e a construção da planta industrial já representam atração para grande número de trabalhadores que chegam ao local, vindos de fora do município. As edificações de shoppings centers e de conjuntos habitacionais, a especulação imobiliária e o aumento populacional súbito, sequer captado no recenseamento demográfico de 2010, são algumas evidências da antecipação das mudanças que tornam o espectro de Macaé mais plausível como imagem de futuro para a região (O Globo, 02/09/2011; Fórum Comperj, 2011).

Provavelmente a massa de riqueza gerada, direta e indiretamente, pelo Comperj, tenderá a reduzir a pobreza, mas, em contrapartida, poderá acentuar a desigualdade social, invertendo os indicadores anteriormente assinalados (ver Tabela 2). 
Os temores e as esperanças quanto a esse futuro foram manifestados pelos agentes comunitários e demais profissionais da saúde nos fóruns da Ouvidoria Coletiva em Itaboraí durante o ano de 2008, tendo sido confirmados nos grupos focais de avaliação dessa experiência em 2010-2011. Nesse sentido, a educação como valor socialmente partilhado, ancorado na ideia de mobilidade social, permite entender a convergência entre medo e esperança mostrada pela população trabalhadora de Itaboraí.

No compasso de espera do futuro imediato, a prefeitura do município tem de lidar tanto com a escassez de recursos próprios - fortemente dependente de transferências intergovernamentais carimbadas como despesas obrigatórias -, quanto com o tempo político das disputas que dificultam ou paralisam a administração. Uma questão importante é saber quando e como a transferência da cota-parte do imposto sobre circulação de mercadorias, advindo da operação industrial do Comperj, produzirá o efeito-renda alardeado em favor do empreendimento. Enquanto isso, a brutal demanda de insumos pelo Comperj pode ser uma oportunidade para Itaboraí conquistar pelo menos uma melhoria real no saneamento básico, exigindo-se o tratamento e o controle dos efluentes industriais.

A formação das pessoas nas diferentes profissões e habilidades - privadas e públicas -, percebida por todos como uma necessidade, pode tornar-se um fato, conquistando prioridade na agenda governamental municipal. As parcerias com instituições públicas abrem um dos caminhos para tal formação. Nesse sentido, há que se assinalar a importância do Mestrado Profissional em Vigilância da Saúde da Região Leste do Rio de Janeiro, criado pela Escola Nacional de Saúde Pública Sergio Arouca, da Fundação Oswaldo Cruz (Ensp/Fiocruz). Trata-se da qualificação pós-graduada de gestores e técnicos nos temas e questões de política pública relevantes para a região, que converge ensino, pesquisa e desenvolvimento social.

Não resta dúvida que a variável fundamental do desenvolvimento econômico socialmente mais justo, como assinalou Celso Furtado em sua obra Cultura e Desenvolvimento em Época de Crise (Furtado, 1984), é a participação política da população, ampla e diversificada.

Pode-se então reconhecer a relevância das formas de participação popular que, à semelhança da Ouvidoria Coletiva, permitem instaurar processos nos quais a experiência e o saber dos diferentes grupos da população, expressos pelas lideranças civis e religiosas, alcancem e façam jus à esperança de um mundo melhor para os itaboraienses. 
Queremos aqui expressar nossa sincera homenagem a Rossana Silva Souza, que participou ativamente na concepção deste capítulo e que infelizmente já não está entre nós. 


\section{Referências}

ALVES, R. Por uma Educação Romântica. 4. ed. Campinas: Papirus, 2003.

BARREIRA, I. A. F. Cidade, atores e processos sociais: o legado sociológico de Lúcio Kowarick. Revista Brasileira de Ciências Sociais, 25(72): 149-159, 2010.

BIENESTEIN, R. et al. O Leste Fluminense e o Comperj: atores, consensos e conflitos. In: ENCONTRO DA ASSOCIAÇÃO NACIONAL DE PÓS-GRADUAÇÃO E PESQUISA EM PLANEJAMENTO URBANO E REGIONAL, XIII, 25-29 maio 2009, Florianópolis.

BRICEÑO-LEÓN, R. Siete tesis sobre la educación sanitaria para la participación comunitaria. Cadernos de Saúde Pública, 12(1): 7-30, 1996.

CARVALHO, M. A. P.; ACIOLI, S. \& STOTZ, E. N. O processo de construção compartilhada do conhecimento uma experiência de investigação científica do ponto de vista popular. In: VASCONCELOS, E. M. A Saúde nas Palavras e nos Gestos: reflexões da Rede Educação Popular e Saúde. São Paulo: Hucitec, 2001.

DUBET, F. Sociologia da Experiência. Lisboa: Instituto Piaget, 1994.

EIA - ESTUDO DE IMPACTO AMBIENTAL - COMPERJ. Apresentação. Concremat Engenharia, 2007. Disponível em: <www.observatoriodopresal.com.br/wp-content/uploads/2011/08/ Apresentação-EIA-EM-TODOS-OS-VOLUMES.pdf>. Acesso em: 28 ago. 2014.

FORUM COMPERJ. Secretários da região metropolitana do Rio discutem impactos do Comperj, 16 fev. 2011.

FURTADO, C. Cultura e Desenvolvimento em Época de Crise. Rio de Janeiro: Paz e Terra, 1984.

INSTITUTO BRASILEIRO DE GEOGRAFIA E ESTATÍSTICA (IBGE). Mapa da pobreza e desigualdade nos municípios - Brasil -2003, 2010. Disponível em: <www.ibge.gov.br>. Acesso em: 17 nov. 2010.

KOWARICK, L. Escritos Urbanos. São Paulo: Editora 34, 2009.

LIMA, C. M. P.\&STOTZ, E. N. Religiosidade popular na perspectiva da Educação Popular em Saúde: um estudo sobre pesquisas empíricas. Revista Eletrônica de Comunicação, Informação \& Inovação em Saúde, 4(3): 81-93, 2010. Disponível em: <http://www.reciis.icict.fiocruz.br/index.php/reciis/ article/view/388> Acesso em: 18 ago. 2014.

MARTINS, J. D. As Regras da Metrópole: campo urbanístico e ordem social na região metropolitana de São Paulo, 2006. Tese de Doutorado em Sociologia, Brasília: Universidade de Brasília.

MOYSÉS, Y. S. O Comperj: modelo de desenvolvimento hegemônico e contradições no espaço local (Itaboraí, Rio de Janeiro). Revista Geografar, 5(1): 1-24, 2010.

O GLOBO. Com obras do Comperj, Itaboraí sofre 'boom' imobiliário e enfrenta os males da migração. O Globo, Rio de Janeiro, 09 jan. 2011. Disponível em: <http://oglobo.globo.com/ economia/com-obras-do-comperj-itaborai-sofre-boom-imobiliario-enfrenta-os-males-damigracao-2840022>. Acesso em: 30 ago. 2014.

PENALVA SANTOS, A. M. Descentralização e autonomia financeira municipal: a perspectiva das cidades médias. Indicadores Econốmicos FEE, 32(3): 101-126, 2004.

PIQUET, R. Indústria do petróleo e dinâmica regional: reflexões teórico-metodológicas. In: PIQUET, R. \& SERRA, R. (Orgs.). Petróleo e Região no Brasil: o desafio da abundância. Rio de Janeiro: Garamond, 2007.

PORTAL ODM - Acompanhamento Brasileiro dos Objetivos de Desenvolvimento do Milênio ITABORAÍ RJ Relatórios Dinâmicos: Itaboraí, Rio de Janeiro, 2011. Disponível em: <www. relatoriosdinamicos.com.br/portalodm/2-educacao-basica-de-qualidade-para-todos/ BRA003033029/itaborai---rj>. Acesso em: 30 ago. 2014.

RELATÓRIO Final da pesquisa Vigilância Civil da Saúde na Atenção Básica: uma proposta de Ouvidoria Coletiva (2008-2011). Rio de Janeiro, Escola Nacional de Saúde Pública Sergio Arouca/Fiocruz, 2011. 
SINDICATO DA INDÚSTRIA DE MATERIAL PLÁSTICO DO PARANÁ (SIMPEP). Boletim Eletrônico Semanal, 61: Brasken vai participar do Comperj, 01 de abril de 2011. Disponível em <http://simpep. com.br/wp/wp-content/uploads/2011/04/Boletim-Simpep-61.pdf> Acesso em:30 ago. 2014.

TRIBUNAL DE CONTAS DO ESTADO DO RIO DE JANEIRO (TCE). Estudo Socioeconômico Itaboraí. Secretaria-Geral de Planejamento, 2007. Disponível em: <www.setrerj.com.br/pdfs/dados_ itaborai.pdf $>$. Acesso em: 20 out. 2008.

TOLEDO, L. \& SABROZA, P. Acompanhamento analítico da evolução de doenças e agravos segundo parâmetros epidemiológicos pré-estabelecidos. Plano de monitoramento sanitário do processo de implantação do Comperj. Relatório técnico: executivo de mobilização-etapa 1 da implantação do plano. Rio de Janeiro, 28 jan. 2009.

VALLA, V. V. Participação popular e informação numa conjuntura de nova ordem mundial. In: MARTíNEZ, F. J. M. \& SILVA, L. R. (Comps.). La Medicina al Final del Milênio. Guadalajara: Universidad de Guadalajara, 1995.

STOTZ, E. N. Vigilância Civil da Saúde na Atenção Básica: uma proposta de ouvidoria coletiva (2008-2011). Relatório final. Rio de Janeiro: Ensp/Fiocruz, 2011

WESTPHAL, M. F. Municípios saudáveis: aspectos conceituais. Saúde e Sociedade, 6(2): 9-18, 1997.

ZIMERMAN, D. Classificação geral dos grupos. In: ZIMERMAN, D. \& OSÓRIO, L. C. (Orgs.). Como Trabalhamos com Grupos. Porto Alegre: Artes Médicas, 1997.

ZIONI, F. \& WESTPHAL, M. F. O enfoque dos determinantes sociais de saúde sob o ponto de vista da teoria social. Saúde e Sociedade, 16(3): 26-34, 2007. 


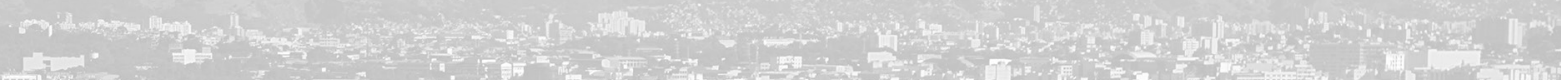
and

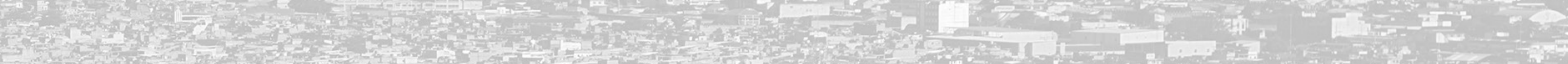

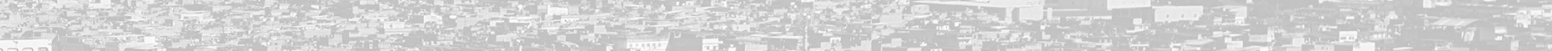

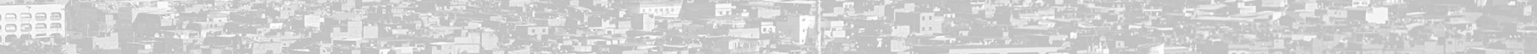

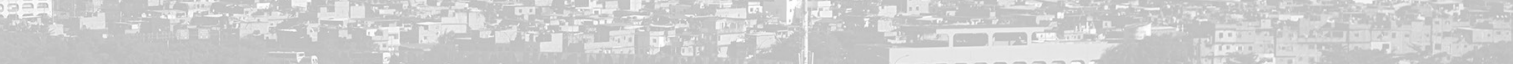

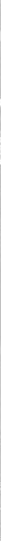




\title{
Em Busca da Qualidade de Vida: metodologia e indicadores para intervenções socioespaciais
}

\author{
Carmen Beatriz Silveira $\cdot$ Simone Cynamon Cohen \\ Bárbara Pellegrini • Monica Dias de Souza • Ana Beatriz Melo Oliveira
}

Cada lugar é, à sua maneira, o mundo. (...) Mas, também, cada lugar, irrecusavelmente imerso numa comunhão com o mundo, torna-se exponencialmente diferente dos demais.

Milton Santos

Ste capítulo apresenta as ideias norteadoras e algumas ações do projeto Uma
Proposta de Hábitat Saudável em Comunidade Vizinha ao Campus Fiocruz da Mata Atlântica, realizado entre 2008 e 2010, por intermédio do Programa de Desenvolvimento do Campus Fiocruz da Mata Atlântica (PDCFMA) em parceria com a Escola Nacional de Saúde Pública Sergio Arouca (Ensp). ${ }^{1}$ Consistiu em uma investigação em Curicica1, uma de sete comunidades da antiga Colônia Juliano Moreira (CJM), localizada no bairro de Jacarepaguá, no Rio de Janeiro, e integrante do Programa de Aceleração do Crescimento (PAC-Colônia).

A experiência respaldou-se no conceito ampliado de saúde, que transcende o entendimento de saúde como ausência de doenças e afirma a relação desta com o acesso às condições essenciais para assegurar a qualidade de vida. Trata-se, desse modo, de compreender a saúde como "uma importante dimensão da qualidade

\footnotetext{
${ }^{1} 0$ projeto foi desenvolvido sob a coordenação geral de Simone Cynamon Cohen, a coordenação executiva e de pesquisa urbanística de Carmen B. Silveira e a coordenação de pesquisa social de Gisélia Potengy.
} 
de vida" (OMS, Carta de Ottawa, 1986: 1-2). Tal compreensão se entrelaça - e muitas vezes se confunde - com o conceito de qualidade de vida. Constituem, ambas, concepções polissêmicas que englobam as diversas dimensões da existência das sociedades humanas. Pode-se entender qualidade de vida como a "capacidade de uma comunidade de desfrutar de uma vida média longa de forma saudável, ou seja, 'viver muito' e 'viver bem'" (Keinert \& Karruz apud Vitte \& Keinert, 2009). Se for adotado o ponto de vista do Grupo de Qualidade de Vida da divisão de Saúde Mental da Organização Mundial da Saúde, qualidade de vida é "a percepção do indivíduo de sua posição na vida, no contexto da cultura e sistema de valores nos quais ele vive e em relação aos seus objetivos, expectativas, padrões e preocupações"(The Whoqol Group, 1994). A primeira abordagem alude a uma visão objetiva das condições de vida de uma determinada comunidade, enquanto a segunda remete a uma percepção subjetiva dos indivíduos referida às diferentes sociedades em que vivem.

Essas concepções carecem de aprofundamento, sobretudo ao se analisar as sociedades moderno-contemporâneas como sociedades complexas, conforme o antropólogo Gilberto Velho. Desse modo, acentua-se a problemática a ser examinada, por verificar-se, em tais sociedades, "uma tendência de constituição de identidades a partir de um jogo intenso e dinâmico de papéis sociais, que se associam a experiências e a níveis de realidade diversificados, quando não conflituosos e contraditórios" (Velho, 1999: 8).

Em razão das restrições concernentes à materialização de um projeto que buscava viabilizar instrumentos destinados a políticas públicas em contextos socioespaciais desiguais e fragmentados, as ações propostas ficariam distantes do aprofundamento requerido ao considerarem-se as abordagens acima esboçadas. Assim, também, a sua relação com as condições de saúde nos assentamentos urbanos irregulares. Sob tais condições, procurou-se ampliar e complementar o escopo de atuação da gestão do Sistema Único de Saúde (SUS), por meio de algumas reflexões e ações que se revelaram necessárias à investigação desenvolvida. Com esse intuito, deu-se relevo ao estudo da habitação saudável como condição essencial à qualidade de vida, compreendida no contexto do direito à cidade, e, nesse sentido, identificada com o movimento nacional pela moradia digna, ${ }^{2}$ indispensável à ampliação dos propósitos do SUS. ${ }^{3}$

\footnotetext{
${ }^{2}$ Ver, a respeito, o documento "A luta por moradia e pelo Direito à Cidade". Disponível em: <www.moradiadigna.org.br/moradiadigna/ v1/index2.asp? $\mathrm{p}=19 \& \mathrm{\& id}=70>$. Acesso em: 31 mar. 2010.

${ }^{3}$ Cabe destacar a lei n. 11.124/2005, que institui o Fundo Nacional de Habitação de Interesse Social (FNHIS). 0 art. $4^{\circ}$ (alínea c do inciso I)
dessa lei considera a"moradia digna como direito e vetor de inclusão social".
} 
Nessa perspectiva, a reflexão ora exposta fundamenta-se em três premissas básicas. Inicialmente, sublinha a assertiva de que a saúde é condicionada por um amplo conjunto de fatores e é construída individualmente, mas também e de forma especial - coletivamente. Portanto, não prescinde da ampliação da solidariedade, tendo em vista a complexidade das sociedades humanas. A segunda, por extensão da primeira, ressalta que o objetivo comum de buscar uma compreensão dos distintos aspectos que afetam, condicionam ou determinam a saúde não é assegurado somente pelo setor saúde e depende, para ser alcançado, do trabalho articulado de um conjunto de atores sociais, com base em ações intersetoriais e transdisciplinares e, por suposto, na participação social. Finalmente, assinala que as ações em saúde, nessa concepção ampla, devem se adequar às necessidades dos diferentes lugares sem deixar de compreender as diferenças relativas às dimensões sociais, culturais e econômicas, conforme se preconiza na Carta de Ottawa (OMS, 1986: 2) ${ }^{4}$ e em diversas políticas públicas e investigações contemporâneas que reconhecem a diversidade de ângulos analíticos passíveis de apreciação no que concerne à elucidação das condições de vida.

Cabe frisar que tais premissas devem ser compreendidas tanto por sua complexidade relativa à implementação de projetos e ações vis-à-vis as observações anteriores, quanto pelo exame das possíveis dificuldades adicionais geralmente associadas à gestão urbana em seu sentido amplo, em razão das disputas entre posturas políticas distintas muitas vezes presentes nas políticas públicas.

Os objetivos principais que fundamentaram o estudo e a intervenção do projeto e que sintetizam a proposta anteriormente delineada, em traços gerais, consubstanciaram-se nos seguintes pontos:

- desenvolver, avaliar e sistematizar metodologia transdisciplinar e participativa para intervenção em assentamentos urbanos irregulares, visando à promoção da qualidade de vida dos moradores da comunidade-alvo e à sua apropriação em projetos semelhantes;

- desenvolver indicadores de vulnerabilidade física e social como instrumento de identificação das condições de habitação e saúde, passível de ser utilizado em políticas públicas;

- contribuir para a difusão do conceito e da prática da promoção da saúde, pelos beneficiários diretos - moradores e pesquisadores-e, de forma indireta, pelos gestores públicos, abarcando portanto a intersetorialidade dos atores sociais envolvidos.

${ }^{4}$ Relacionada à Primeira Conferência Internacional de Promoção da Saúde. 
Em razão da complexidade do projeto aqui analisado, para o escopo deste capítulo, optou-se por enfocar a abordagem metodológica e o desenvolvimento de indicadores de vulnerabilidade física de maneira mais aprofundada que os indicadores de vulnerabilidade social. Considera-se que o foco aqui selecionado examina aspectos significativos para contribuir na elaboração de políticas públicas. $^{5}$

\section{Cidades Saudáveis no Contexto da Promoção da Saúde: urbanização capitalista e saúde nas grandes cidades}

O movimento de cidade saudável iniciado na década de 1970, com base em reflexões sobre uma concepção ampla de saúde, desenvolveu-se na década seguinte e teve como marco a Primeira Conferência Internacional sobre Promoção da Saúde realizada em Ottawa, Canadá, em 1986. O processo expandiu-se para algumas cidades europeias e, posteriormente, na década de 1990, abarcou algumas cidades da América Latina com apoio da Organização Pan-Americana da Saúde/ Organização Mundial da Saúde (Opas/OMS). Entre outras dimensões, buscou responder à crise das condições de saúde, compreendida como um dos problemas da urbanização crescente. Assim, o processo saúde-doença uma vez mais foi pensado sob a lógica do habitar e do hábitat, incluindo formas de intervir na cidade para a promoção de uma pressuposta melhoria da qualidade de vida e, portanto, da saúde coletiva.

Desencadeado nas últimas décadas do século XX, esse movimento tem sido relacionado à crise das cidades que engendrou o movimento sanitário, a partir de meados do século XIX, nos países europeus. Malgrado as diferenças entre contextos, no intuito de auxiliar na compreensão da problemática atual que envolve as grandes cidades dos países centrais e se manifesta também nos países emergentes, como o Brasil, procura-se evidenciar algumas questões cruciais sobre o processo de urbanização daquele período.

Com a expansão do modo de produção capitalista na sua fase industrial, verificou-se um aumento populacional sem precedentes em algumas cidades europeias, graças "à diminuição da taxa de mortalidade que, pela primeira vez, se afasta decididamente da de natalidade" e à mudança na distribuição de habitantes - êxodo rural-urbano - "provocada pelas primeiras transformações

\footnotetext{
${ }^{5}$ Outra análise dos indicadores de vulnerabilidade física e social voltará a atenção para a relação entre a forma das habitações e 0 conteúdo social das famílias que nelas residem. Do cruzamento entre aspectos referidos aos dois grupos de indicadores, problematizados nas oficinas com os moradores e na mesa intersetorial, buscar-se-á compreender com mais profundidade essa relação socioespacial.
} 
organizativas e acentuada pelas inovações técnicas" (Benevolo, 1994: 15-16). Instaurou-se uma crise nessas cidades, nas quais o tecido urbano tornou-se congestionado e o ambiente construído passou a revelar numerosos problemas quanto à densidade de ocupação, poluição atmosférica e dos rios, distribuição dos equipamentos e funções urbanas, e no que diz respeito à circulação intraurbana. As contradições da industrialização acarretaram prejuízo à qualidade de vida urbana e se expressaram nitidamente em três aspectos: as condições precárias das habitações, sobretudo as construções populares; as condições sanitárias deficitárias causadoras de epidemias que atingiram grande parte das cidades; e as condições de trabalho desumanas impostas nas fábricas, as quais desencadearam fortes movimentos populares (Benevolo, 1976; Howard, 1996).

Com o propósito de superar essa situação formaram-se duas vertentes principais de atuação nas grandes cidades: uma que negava qualquer possibilidade de solução nas estruturas espaciais existentes e propunha a criação de novas cidades; outra que desenvolvia a sua ação por meios administrativos e normativos, numa tentativa de superar as contradições (Benevolo, 1976, 1994).

A primeira baseava-se fundamentalmente nas concepções dos socialistas utópicos, ou utopistas sociais, oriundas do final do século XVIII e das primeiras décadas do século XIX. Essa visão propunha modelos de cidade com base em desenho de um espaço físico novo, fundamentado numa organização social também nova. Tratava-se de idealizações de cidade que negavam as estruturas então existentes, abstraindo a complexidade socioespacial que as produzia. Fracassaram as primeiras aplicações práticas desses modelos alternativos de cidadeseveramente questionados pelos socialistas científicos, particularmente Karl Marx e Friedrich Engels, no Manifesto do Partido Comunista, de 1848 (Marx \& Engels, s/d: 73; Benevolo, 1976). Posteriormente, foram retomadas pelo poder público, a partir da segunda metade do século XIX, então despolitizadas e transformadas em propostas de cidades fundamentalmente técnicas (Choay, 1979).

Desse modo, algumas de suas concepções foram concretizadas, com resultados parciais e duração restrita. No entanto, assinala-se a apropriação de algumas de suas ideias, como a "'unidade de habitação' com um número limitado de habitantes, as instalações centralizadas, os pátios, a rue intérieure, a circulação de viaturas no andar térreo - com certas soluções de arquitetura moderna" (Benevolo, 1994: 94). Evidencia-se, ainda, a emergência do último representante dos socialistas utópicos, o inglês Ebenezer Howard, no fim do século XIX, que desenvolveu a proposta de cidade-jardim, com numerosos desdobramentos e aplicações práticas. Cabe realçar que Howard sofrera influência das... 
ideias do Movimento Sanitário e propostas de pensadores que queriam reverter a miséria das comunidades, recomendando que as cidades mantivessem o ar limpo, o transporte público eficiente, construíssem hospitais e instituições para idosos e doentes mentais, proibissem o álcool e o tabaco, e adotassem medidas de saúde no trabalho. (Gentille apud Pelicioni, 2000: 22)

A segunda vertente, vinculada à ação do Estado, abarcava a legislação urbanística moderna, que se desenvolveu, sobretudo, entre 1830 e 1850. Estabeleceram-se normas de ocupação urbana que ordenavam o uso do solo e permitiam intervenções urbanísticas mais drásticas, chamadas reformas urbanas. Tratava-se de obras públicas que procuravam solucionar os problemas da cidade mediante destruição e reconstrução dos espaços.

As leis da urbanística moderna foram instauradas na Inglaterra a partir da reforma da Constituição inglesa, em 1832, quando se buscou institucionalizar as intervenções nas estruturas urbanas bastante modificadas pelo processo industrial, notadamente com perda significativa de sua urbanidade. Ressalta-se o fato de, em 1835, serem instituídas as administrações municipais eletivas, em substituição às antigas instituições feudais. Destaca-se, ainda, o surgimento das leis sanitárias pela necessidade de remediar os males da cidade industrial, no mesmo período, entre 1830 e 1850. Reiterando, eram os técnicos e os higienistas, que naquele período dominavam a organização das cidades, os proponentes dos "primeiros instrumentos urbanísticos modernos": as leis sanitárias (Howard, 1996: 25).

Conquanto seja a Inglaterra a precursora, foi na França que se instituiu a mais antiga lei urbanística que, em 1850, propiciou as primeiras intervenções urbanas drásticas. ${ }^{6}$ Amplamente conhecidas, constituem importante atuação pública no espaço físico de Paris, transformando o sistema viário do centro e do subúrbio, entre outras providências, numa cidade que já passava de um milhão de habitantes. ${ }^{7}$ No Brasil houve vários exemplos, mas a primeira grande reforma urbana, conhecida como haussmanização, foi executada no Rio de Janeiro entre 1902 e 1906, com a denominação Reforma Passos.

Apesar de constituírem-se em formas de atuação aparentemente distintas, pode-se constatar que ambas (as propostas de cidades novas e de leis e intervenções

\footnotetext{
${ }^{6}$ Trata-se das obras executadas pelo barão Georges Haussmann, entre 1853 e 1869, então prefeito de Paris.

7 Em seu conjunto, tais obras foram muito complexas, cabendo enfatizar que se tornaram exemplos para desdobramentos posteriores tanto em outras cidades francesas quanto em grandes cidades européias: Bruxelas, entre 1867 e 1871; Barcelona, em 1859; Estocolmo, em 1866; Viena, em 1876; e outras. 0 modelo também foi apropriado na América Latina: na cidade do México, em 1860, em Buenos Aires, entre outras.
} 
urbanas aplicadas às estruturas espaciais existentes) provêm de concepções de cidade semelhantes, respaldadas, em síntese, na ideia de um espaço urbano ordenado, equilibrado, e que deveria assimilar as conquistas técnicas decorrentes da industrialização. Tal ideia tem sido recorrente desde a origem das disciplinas que estudam as cidades como um objeto global na primeira década do século XX, quando surgem na Inglaterra, na França e nos Estados Unidos, algumas escolas de pensamento sobre as cidades. As disciplinas instituem a denominada "ciência urbana" que, desde o seu início, vincula-se a uma atuação prática, o "planejamento urbano" (Topalov, 1991: 29-30).

Para compreender, ao menos parcialmente, a instauração nas últimas décadas de políticas públicas referidas à promoção da saúde - que envolvem o equacionamento dos problemas urbanos relacionados à qualidade de vida remete-se à proposta de cidade-jardim, que tem sido mencionada pela proximidade de suas premissas com as propostas de cidades saudáveis e sustentáveis. Maria Cecília Focesi Pelicioni sinaliza que a concepção de Howard passou por algumas modificações e incorporou processos mais democráticos, incluindo consulta e participação popular. Desse modo, foi reconstruída e apropriada "como estratégia de nível local no movimento de Promoção da Saúde (...) no Canadá, como o nome de 'Cidade Saudável', no começo da década de 1970 (...)” (Strozzi \& Giacomini apud Pelicioni, 2000: 22). ${ }^{8}$

Não essencialmente relacionados a esse movimento, no Brasil, a partir da década de 1950, realizaram-se projetos inspirados na concepção de cidadejardim: "a terra barata começa a ser retalhada em novos 'jardins', parentes já muito distantes dos originais ingleses" (Santos, 1988: 43). A aguda observação de Carlos Nelson Ferreira dos Santos pode ser apropriada para diversos outros exemplos de implementação da proposta de cidade-jardim em cidades brasileiras, ${ }^{9}$ em que se verificaram apropriações de forma, independentes do conteúdo social preconizado por Howard, adaptadas aos nossos processos de ocupação urbana pelo mercado imobiliário.

Finalmente, sintetizam-se alguns aspectos que podem contribuir para a abordagem que se afigura significativa neste capítulo. Assim, alude-se aos pensamentos sobre as representações de cidade saudável, conceito baseado na visão ampliada de saúde que aponta para a qualidade de vida urbana e, especialmente, para a força de permanência das ideias higienistas que perpassaram os projetos

\footnotetext{
${ }^{8}$ Ver, a respeito, Liza (2003).

${ }^{9}$ Ver, a respeito, Howard (1996).
} 
urbanísticos. Nesse contexto, evidenciam-se as configurações urbanas referidas a padrões específicos e necessários de salubridade, relacionando-os a um ethos urbano globalizado. Tratar as cidades como adoecidas constituiria uma maneira de identificar meios, planos, estratégias e métodos para torná-las saudáveis. No Brasil, tal compreensão adquire um aditivo de vulto, em razão da imensa desigualdade, cristalizada socioespacialmente com seus efeitos contraditórios: déficits de habitação, especulação imobiliária, carência de equipamentos públicos e de infraestrutura.

Nessa direção, remete-se ao direito à cidade, narrativa recorrente nos meios acadêmicos e nos movimentos sociais. Haveria um quadro rígido de entendimento acerca da cidade saudável impreterivelmente demarcado em bases de propriedades de significação em que se consideram os imperativos da insalubridade social? Nesse cenário, sob que paradigmas se deve pensar a cidade saudável? Que políticas públicas poderiam ser formuladas? Nas ideias do projeto aqui exposto, sublinha-se a proposta de abordagem metodológica e a produção de indicadores como um dos caminhos que poderiam contribuir na busca de um hábitat humano necessário e desejável.

\section{Os Caminhos da Pesquisa: a proposta metodológica}

A noção de promoção da saúde que respaldou a concepção do projeto tem sido relevante no contexto da "renovação do pensamento sanitário contemporâneo buscando contrapor-se ao modelo biomédico, hospitalocêntrico e curativo que domina (...) desde o século XIX" e por atentar, de alguma forma, para a abordagem dos determinantes sociais no processo saúde-doença, ao preconizar ações derivadas de articulação intersetorial, por meio de visão interdisciplinar e de participação social (Rabello, 2010: 80). Conforme as premissas expostas no início deste capítulo, contudo, procurou-se adotar uma visão transdisciplinar, que busca uma compreensão mais complexa que aquela da interdisciplinaridade.

Interessante salientar, na noção de promoção da saúde, o enfoque no cotidiano das populações e nos condicionantes da qualidade de vida, incluindo aspectos sociais, culturais, econômicos, educacionais, habitacionais e ambientais, de modo geral, o que conforma um campo de saúde pública com uma concepção de saúde positiva. Nessa direção, na metodologia implementada no projeto, valorizaram-se os conceitos de memória, habitação e hábitat saudável, bem como de cidade saudável e de direito à cidade, pressupondo que tal reflexão pode contribuir para fundamentar propostas de intervenção em assentamentos urbanos irregulares. 
Considerou-se a relação da habitabilidade e de cidade saudável com o direito à cidade, no sentido do direito à vida plena, conforme Henri Lefebvre ([1968]2001: 117): "O direito à cidade [...] só pode ser formulado como direito à vida urbana, transformada, renovada". Acionaram-se, igualmente, as ideias do autor no que concerne à compreensão da cidade no contexto do seu modo de produção, articuladas às potencialidades presentes no pensamento sobre o direito à cidade que deveriam conduzir à transformação espacial necessária no processo de urbanização. Em suas palavras:

O direito à cidade se manifesta como forma superior dos direitos: direito à liberdade, à individualização na socialização, ao hábitat e ao habitar. $\mathrm{O}$ direito à obra (à atividade participante) e o direito à apropriação (bem distinto do direito à propriedade) estão implicados no direito à cidade. (Lefebvre, 2001: 135)

Com esse propósito, enfatizou-se a ideia de apropriação associada à participação social efetiva, por suposto, incorporada transversalmente aos enfoques disciplinares adotados e explicitados a seguir. Sumariando, a metodologia desenvolvida adotou abordagem socioespacial e antropológica nas seguintes dimensões: arquitetônica e urbanística; de saúde ambiental; simbólica, histórica e cultural; econômica, demográfica e educativa. Os procedimentos metodológicos desencadearam-se por meio de pesquisas quantitativa e qualitativa que propiciaram a produção de indicadores de vulnerabilidade física e social referidos às moradias da comunidade investigada. Tais indicadores foram problematizados em seis oficinas de educação socioespacial para o hábitat saudável, mediante um processo participativo e em uma mesa intersetorial, que consistiu de um encontro com representantes do poder público e dos moradores para debate e reavaliação da proposta.

A Figura 1, a seguir, sintetiza as dimensões essenciais da abordagem metodológica para o desenvolvimento dos indicadores de vulnerabilidade física e social nas habitações de tais assentamentos urbanos.

A proposta metodológica apresentada na Figura 1 se desenvolveu estruturada em cinco etapas subdivididas em 21 atividades, conforme a Figura 2.

Ressalta-se que a essencialidade contida nos requisitos do projeto considerou as recomendações existentes no conjunto legal em vigor, especialmente nas áreas da saúde (lei n. 8.080/90 e lei n. 8.142/90), habitação/urbanismo (lei n. 11.888/08) e assistência social (lei n. 8.742/93 e Norma Operacional Básica do Sistema Único de Assistência Social - Nob-Suas/05, alterada em 2012). 
Figura 1 - Esquema da proposta metodológica do projeto

\section{Abordagem socioespacial e antropológica}
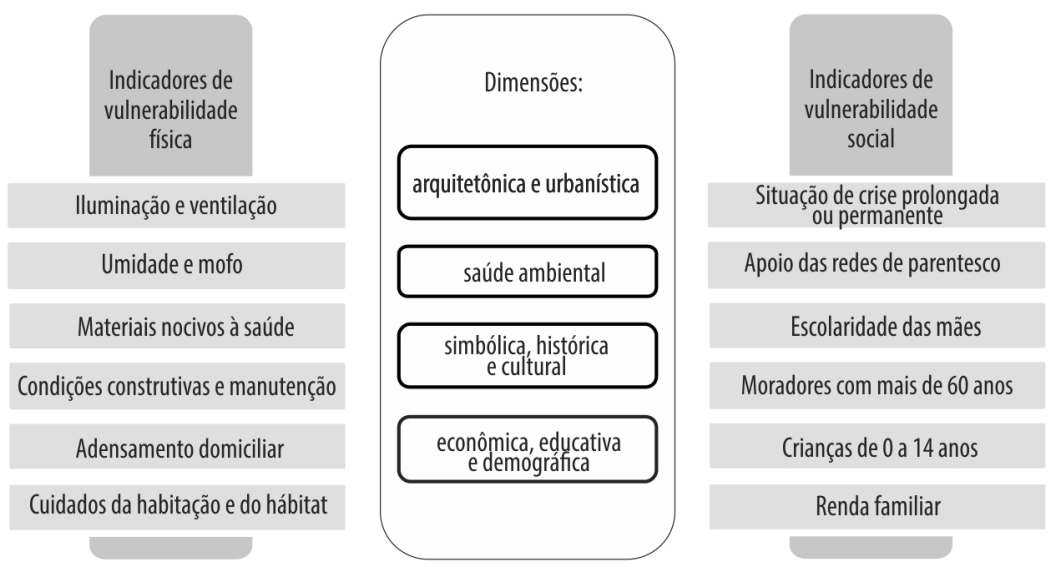

De forma a complementar essa exposição da metodologia praticada, expõe-se, a seguir, os procedimentos adotados e sintetizam-se mais algumas concepções essenciais para o desenvolvimento do projeto.

Para a estruturação da equipe identificou-se a necessidade da conjugação de saberes específicos de diferentes áreas do conhecimento - ponto central no modelo de trabalho preconizado. A equipe de trabalho foi formada por profissionais e estagiários de origens disciplinares distintas envolvendo os campos da habitação e urbanismo, da assistência social, cultural e da saúde. Desde a fase da elaboração do questionário até o formato final utilizado e durante todo o projeto, a presença de diferentes visões permitiu uma compreensão ampla do objeto de estudo: as equipes que realizaram o trabalho de campo da pesquisa foram compostas por duplas de arquitetos e cientistas sociais, além de um supervisor de campo que se responsabilizava pela parte operacional, pelo cumprimento de todas as etapas da entrevista e pelo controle da qualidade da informação.

Conforme assinalado ainda no início deste capítulo, a escolha da comunidade se deu entre sete localizadas na área da antiga Colônia Juliano Moreira (CJM). Curicica1 situa-se no bairro de Jacarepaguá, XVI Região Administrativa (RA) da cidade do Rio de Janeiro. Por ser alvo do Programa de Aceleração do Crescimento (PAC) em curso naquela área, o PAC-Colônia, o investimento do projeto poderia contribuir para a melhoria das condições de habitação e do hábitat considerando-se 
Figura 2 - Atividades desenvolvidas nas cinco etapas do projeto

ETAPA 1 - REVISÃO BIBLIOGRÁFICA E RELATÓRIO DE DADOS SECUNDÁRIOS

1 - Levantamento de referências sobre o tema: complementação do estudo proposto;

2 - Levantamento de dados secundários da AP4, XVI RA e comunidades do PAC-Colônia

3 - Relatório sobre dados secundários: base documental para a pesquisa

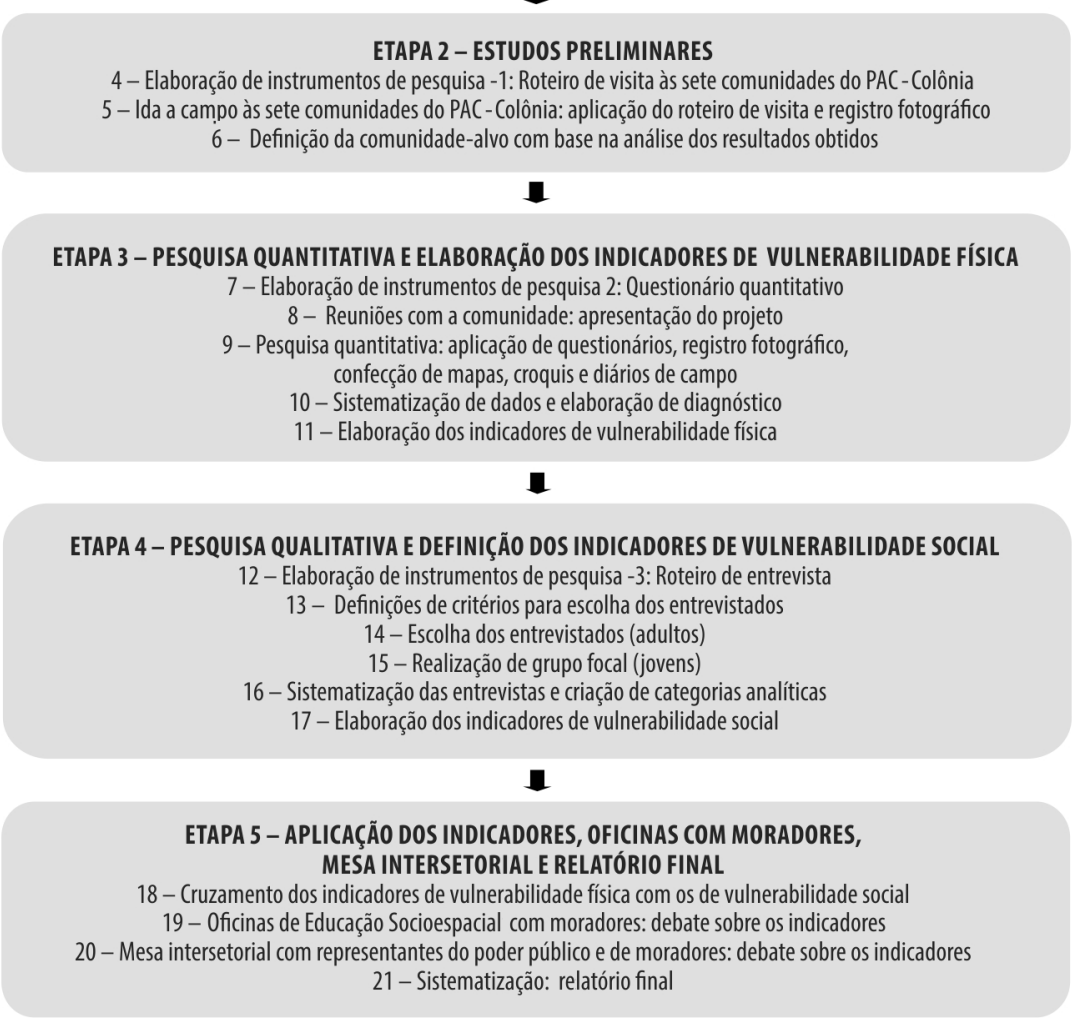

as intervenções urbanísticas previstas pelo município. Tratou-se de uma experiência em pequena escala, em um universo possível de ser investigado, considerando os recursos disponibilizados para a pesquisa, as condições de moradia analisadas no levantamento e a equipe alocada no projeto.

A escolha de Curicica $1^{10}$ justificou-se, também, com base na observação de algumas de suas características quando comparada às outras seis comunidades

\footnotetext{
${ }^{10}$ Grosso modo, a comunidade delimita-se, geograficamente, com o campus Fiocruz da Mata Atlântica (CFMA) ao norte e a oeste, 0 Centro de Referência Professor Hélio Fraga (CRPHF) a leste e a estrada de Curicica ao sul. 0 acesso até o local é feito por tal estrada, que margeia a parte frontal da ocupação.
} 


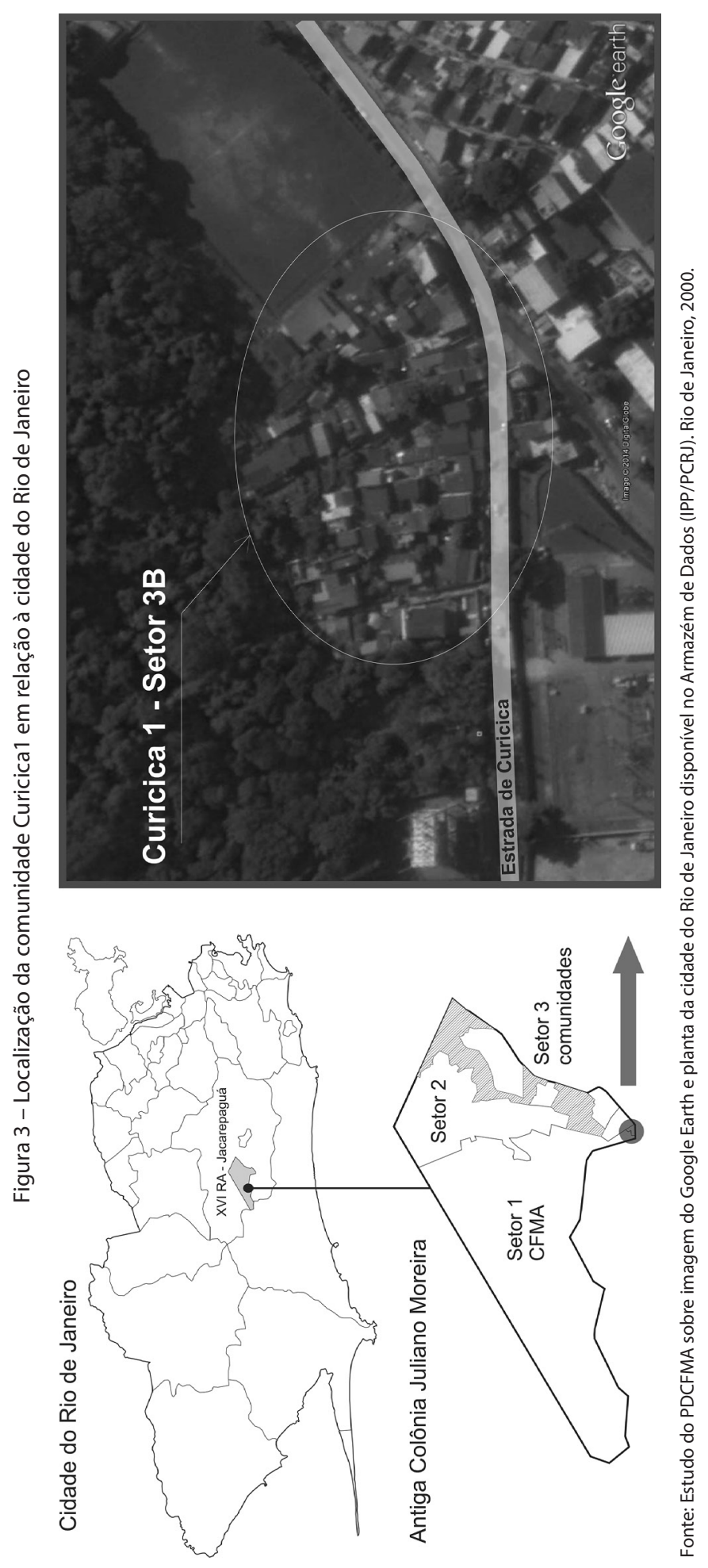


vizinhas ao CFMA: tratava-se da menor (contava com menos de trezentos moradores) e mais antiga (com aproximadamente 60 anos de existência), condições que favoreciam a amplitude e o aprimoramento do estudo diagnóstico. O grau de enraizamento da comunidade em seu território, as redes sociais baseadas em relações de parentesco e de grupos religiosos que valorizavam a ocupação daquela área e fortalecem o sentido de pertencimento foi outro fator preponderante na escolha. Em adição, o trabalho em Curicica1 seria facilitado pela influência não ostensiva da milícia ${ }^{11}$ (é comum tal presença na região).

Também influenciou a cobertura da comunidade pela Estratégia de Saúde da Família (ESF) e pela política de vigilância da exclusão social que tem os Centros de Referência da Assistência Social (Cras) como núcleo de articulação da rede social. A operação do ESF e do Cras na comunidade, somadas à atuação pontual da Secretaria Municipal de Habitação (SMH) em função do PAC-Colônia, permitiu almejar - como um desdobramento possível do projeto - a difusão do conhecimento produzido para as equipes de saúde, assistência social e habitação, fato que representaria uma inovação no campo das políticas públicas (Cynamon et al., 2004).

Diante da dificuldade de obtenção de dados desagregados sobre as condições gerais de vida da população e de suas moradias nas áreas a serem urbanizadas pelo PAC-Colônia e, em particular, da comunidade de Curicica1 - conquanto haja informações nos cadastros das ESF e dos Cras - estabeleceu-se como primeiro passo a realização de um diagnóstico da comunidade, por intermédio de uma pesquisa quantitativa.

Com esse intuito, elaborou-se um questionário com perguntas estruturadas e semiestruturadas para ser aplicado, preferencialmente, à pessoa responsável pelo domicílio, ou pelo cônjuge. ${ }^{12}$ As questões, selecionadas, buscavam dar conta de parte substancial das características socioespaciais da comunidade e tinham como objetivo conhecer as relações prováveis das condições de habitabilidade das moradias - construtivas, de salubridade e de manutenção -, com os aspectos econômicos, demográficos, educativos e de saúde. Nessa perspectiva, os questionários aplicados no projeto abordaram questões que vão desde a composição familiar e sua situação socioeconômica até as características

\footnotetext{
${ }^{11}$ Os autores se referem aos esquadrões de extermínio, organizações paramilitares organizadas em milícias particulares que controlam regiões da cidade. Ressalve-se que a legislação brasileira ainda carece de definição específica para as expressões suprarreferidas apesar dos textos do art. 288-A do Código Penal e da lei 12.694/2012.

${ }^{12}$ As duplas de pesquisadores foram autorizadas a contatar outros membros da família, como último recurso.
} 
da edificação e seu entorno. Definiu-se que cada entrevistador elaboraria diário de campo para complementar as informações coletadas com a aplicação do questionário e que seria feito o croqui de cada residência visitada para auxiliar a avaliação dos aspectos pertinentes à salubridade das mesmas, como as condições de iluminação, de ventilação, umidade, entre outras.

Inicialmente, procedeu-se à divisão da comunidade em sete setores identificados em planta (Figura 4). O critério adotado para tal divisão foi a organização espacial da comunidade formada por agrupamentos de lotes com acessos comuns. Essa setorização, viabilizou a organização do segundo momento da pesquisa: o levantamento de campo, realizado por seis duplas de pesquisadores, como já mencionado, formadas por arquitetos e cientistas sociais. A intenção era abranger todo o universo estudado. Para tanto, foram feitas várias visitas a campo, até que a maior parte do contingente populacional tivesse sido encontrada em casa e o questionário aplicado a um número de moradores significativamente representativo da comunidade em foco.

Deu-se início ao trabalho de campo com um encontro com os moradores para exposição do projeto, debate e apresentação dos entrevistadores que começariam a transitar pela comunidade. Tal contato permitiu estabelecer relações de confiança entre pesquisadores e moradores e possibilitou uma aproximação e compreensão de aspectos relevantes da comunidade, além de facilitar os retornos e as conversas complementares para esclarecimentos.

Instruídas a realizar a entrevista em um clima de conversa, de preferência com o pesquisador sentado, em todos os casos as duplas de pesquisadores obtiveram acesso ao interior das residências. Durante todo o trabalho de campo, realizaramse registros fotográficos e os moradores, quando solicitados, disponibilizaram seus acervos particulares de fotos e documentos. A aplicação do questionário atingiu moradores de 68 domicílios e, em 63,2\% dos casos, as entrevistas se efetivaram com uma única visita ao domicílio, em sua maioria feitas nas condições almejadas.

Em vista de a estratégia conjugar a percepção de campos disciplinares distintos, enquanto o especialista em ciências sociais iniciava a conversa e as questões de cunho social, demográfico e econômico, o arquiteto tratava dos aspectos da edificação e do seu uso - por meio de observação direta e das perguntas estruturadas no questionário. Tal profissional também era encarregado de elaborar o croqui da habitação visando à identificação gráfica das condições internas de habitabilidade, como umidade, ventilação e outras. Com o objetivo de manter a qualidade da informação, estabeleceu-se a rotina de controle dos questionários aplicados no retorno do campo. Essa operação foi fundamental para buscar-se 


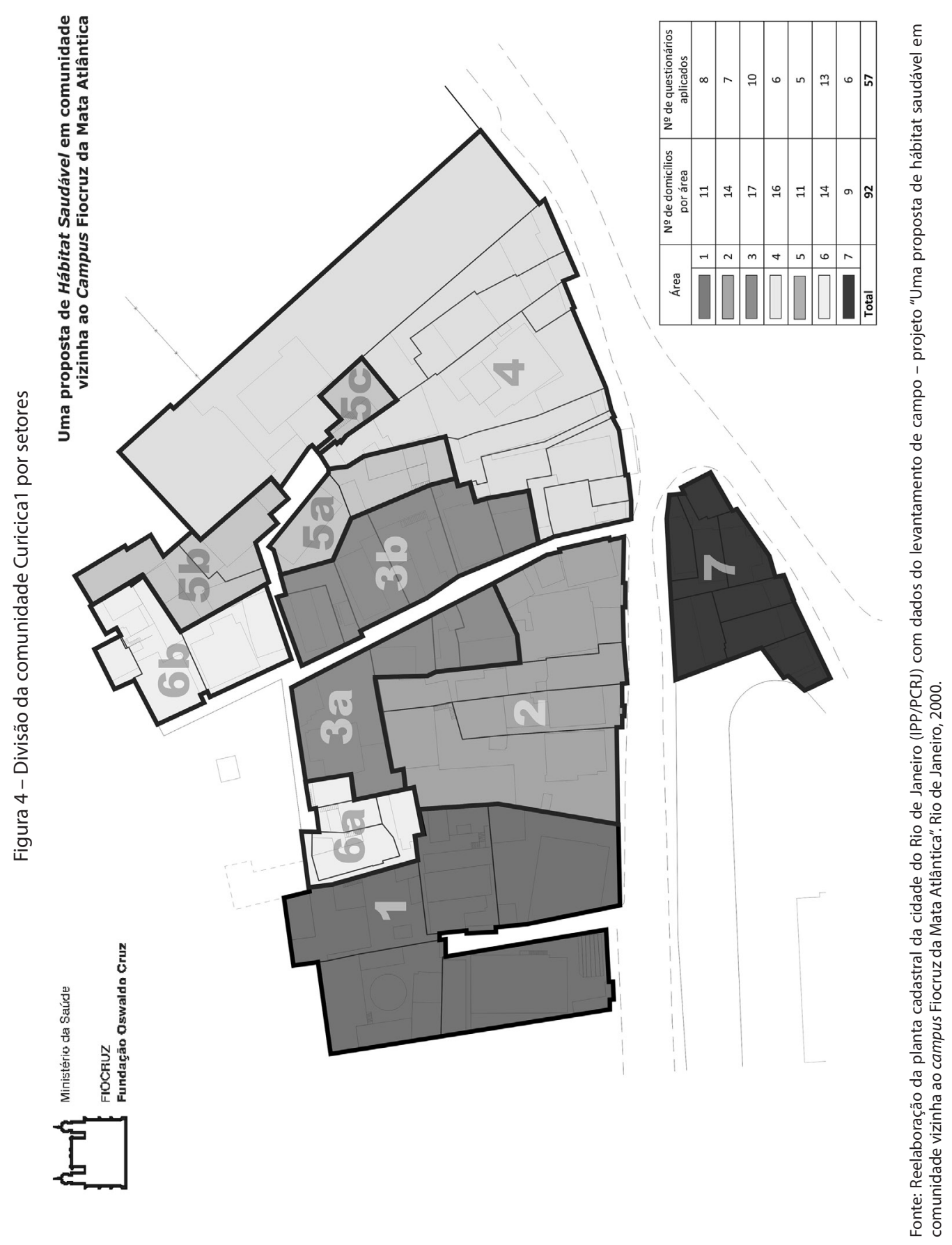


uma compatibilização entre as diferentes compreensões sobre algumas respostas e os respectivos registros pelos entrevistadores. O diálogo permanente entre os membros da equipe foi essencial a uma compreensão a respeito das perguntas e à busca de uma homogeneização no preenchimento das respostas. Constatavam-se, assim, as dificuldades, mas, também, a riqueza do trabalho transdisciplinar no entendimento diferenciado de certas questões.

Todos os dados obtidos ${ }^{13}$ passariam por uma análise crítica da equipe de trabalho, no intuito de esclarecer dúvidas no preenchimento do questionário e atingir-se uma homogeneidade nas informações coletadas para viabilizar a sua codificação e posterior digitalização em um banco de dados. O levantamento de campo também permitiria a correção da delimitação dos lotes (ao todo, 49) e dos limites das edificações contidos na planta cadastral fornecida pela prefeitura da cidade. O mapa da comunidade foi, assim, redesenhado para evidenciar a divisão real dos lotes e a definição do número de domicílios existentes (identificados pela existência de fogões, equipamento essencial da moradia, caracterizando o espaço da cozinha).

No terceiro momento da pesquisa, analisaram-se os dados extraídos das respostas obtidas na aplicação do questionário e relacionados às características físicas do domicílio (aspectos relevantes para avaliação dos níveis de vulnerabilidade e salubridade das edificações) e os croquis das edificações, complementados com observações sobre as condições de moradia. Buscava-se identificar: as tipologias arquitetônicas segundo o número de cômodos; os tipos de materiais empregados na construção; e as condições de conforto no interior da moradia, incluindo a relação entre o número de moradores e o número de compartimentos utilizados como dormitórios.

A prática de redação de diários de campo permitiu o registro de acontecimentos cotidianos no campo, desde o momento em que os pesquisadores entravam na comunidade - como eram recebidos e outras observações significativas -, até a volta ao escritório. Esse instrumento revelava, necessariamente, o olhar de cada pesquisador, diferenciado pelo viés de sua especialidade e de sua subjetividade. Mostrou-se particularmente rico na troca de impressões entre os componentes da equipe sobre aspectos importantes da comunidade não contemplados pelo questionário, servindo para sincronizar e aprofundar o conhecimento sobre o território em estudo.

\footnotetext{
${ }^{13}$ Excetuando-se seis casas não ocupadas, não fizeram parte da pesquisa apenas 18 dos 92 domicílios (79\% daquelas ocupadas no período), seja pela ausência dos moradores, não encontrados nas diversas visitas realizadas, ou pela recusa dos mesmos em participar da pesquisa.
} 
Por meio da análise das perguntas abertas, observação e elaboração de diários de campo, constatou-se, no quarto momento, a importância dos aspectos relacionados à higiene dos domicílios e à presença de animais domésticos e silvestres. Foram identificados alguns hábitos que poderiam estar relacionados ao surgimento de doenças e, nas edificações, problemas quanto ao estado de conservação que poderiam oferecer riscos a seus moradores. Após a análise das informações incluídas no banco de dados da pesquisa verificou-se a necessidade de levantar, de forma sistematizada, alguns aspectos considerados imprescindíveis à compreensão das condições construtivas e de manutenção da moradia e que integram o panteão de temas significativos da promoção da saúde.

Careciam de identificação mais precisa variáveis que influenciam a saúde humana registradas de forma qualitativa. Por esse motivo, um questionário complementar, composto de perguntas fechadas, foi aplicado no quinto momento. Como alguns moradores não foram encontrados, no total atingiu-se 57 domicílios (66\% do total dos ocupados), resultado que ainda permitiu a obtenção de um conjunto significativo de respostas. Todos os dados foram codificados e incluídos em um banco de dados. ${ }^{14}$ Em seguida, procedeu-se ao cruzamento das variáveis consideradas relevantes e realizou-se a análise.

No Gráfico 1 são demonstrados os quantitativos de domicílios da base de análise do diagnóstico e dos indicadores de vulnerabilidade social (68) e da base de análise dos indicadores de vulnerabilidade física (57).

Posteriormente, buscar-se-ia construir indicadores que viessem a permitir a análise do perfil do universo estudado em relação aos valores neles implícitos. Todos esses procedimentos foram executados e constituíram um corpo de informações consistentes que permitiu a complementação do diagnóstico realizado. Cabe assinalar que as dimensões simbólica, histórica e cultural perpassam o conjunto das questões tratadas e foram abordadas, mais especificamente, seja nas perguntas do questionário relativas a essas dimensões seja nas atividades posteriores, relativas à pesquisa qualitativa e às oficinas de habitação saudável, explicitadas adiante.

A pesquisa qualitativa foi realizada por meio de entrevistas que seguiram um roteiro pré-definido, com perguntas abertas que visavam à compreensão de questões referentes aos seguintes aspectos: identificação do grupo doméstico do entrevistado; origem e trajetória social; informações referentes à família;

${ }^{14}$ No aplicativo Statistical Package for the Social Sciences (SPSS). 
Gráfico 1 - Número de domicílios em Curicica1 e universo pesquisado, 2009 e 2010

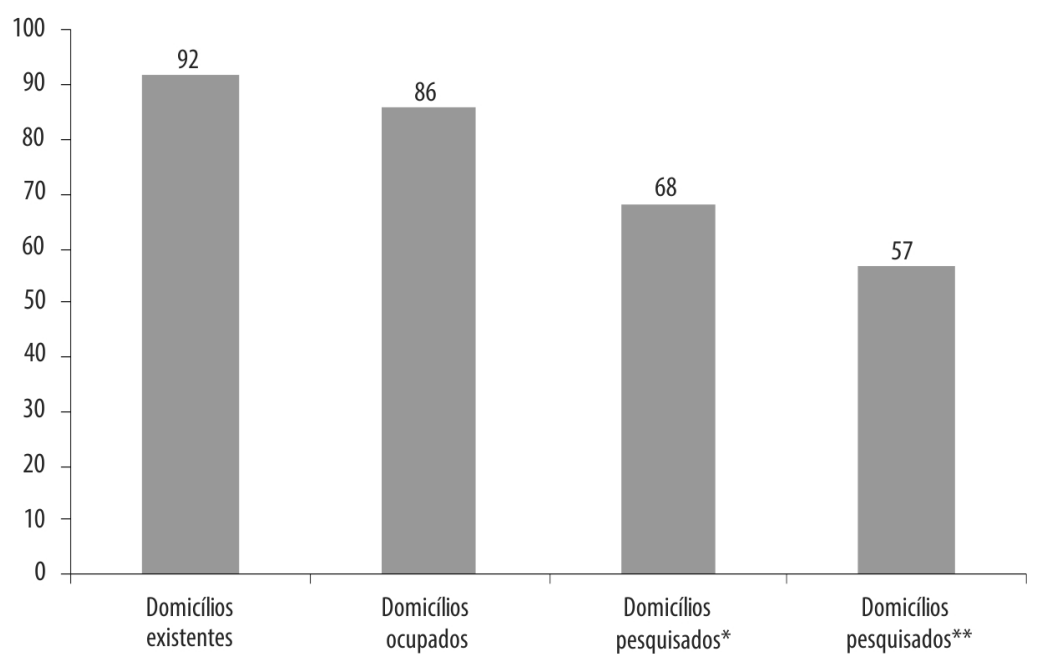

Fonte: levantamento de campo - projeto “Uma proposta de hábitat saudável em comunidade vizinha ao campus Fiocruz da Mata Atlântica".

* Base de análise do diagnóstico e dos Indicadores de Vulnerabilidade Social.

** Base de análise dos Indicadores de Vulnerabilidade Física.

informações sobre as condições de moradia atual; história local com foco principal no processo de ocupação da área e nas mudanças ambientais e sociais observadas; histórico de estudo; inserção no trabalho; redes de sociabilidade; adultismo, racismo, sexismo e outros sistemas de diferenciações; repertório cultural, lazer, tempo livre e uso da cidade, cidadania; vulnerabilidades, obstáculos e violências, planos para o futuro.

Inicialmente foram identificadas e mapeadas as pessoas-chave da comunidade: lideranças informais, líderes religiosos, de esporte, de ações culturais e de outros grupos, de forma a incluir moradores mais idosos e mais antigos, bem como os mais recentes. As entrevistas foram realizadas durante dois encontros com o entrevistado. Essa estratégia destinava-se a proporcionar a percepção do contexto a ser analisado em dois momentos distintos, além de conhecer outras pessoas da casa e da vizinhança. A orientação foi para que as entrevistas fossem realizadas em lugar tranquilo, sempre que possível. Além disso, propôs-se que os pesquisadores mantivessem a escuta atenta a todas as demandas para avaliação da possibilidade de atendê-las. A critério do entrevistador, em caso de perceber que o contexto não era favorável (entrevistado apressado, muita interrupção, entre outras razões), poderia optar por retornar em outra oportunidade. 
Com o consentimento dos entrevistados, gravaram-se os encontros. Ao final da pesquisa todas as gravações foram transcritas e sistematizadas por categorias definidas com base no roteiro de entrevista, procedendo-se posteriormente à análise qualitativa do material coletado. Em complementação às atividades anteriores, idealizou-se um grupo focal, efetivado com jovens, considerando-se que a dinâmica contribuiria para compreender os efeitos da solidariedade das redes sociais locais e os conflitos e preconceitos atuantes na comunidade.

\section{Sobre os indicadores de vulnerabilidade física e social ${ }^{15}$}

A adoção de metodologia transdisciplinar e participativa para auxiliar na intervenção em ambientes construídos e, mais especificamente, em assentamentos urbanos irregulares, pressupõe a utilização de indicadores de vulnerabilidade física e social referidos às diferentes dimensões das moradias e aos moradores desses assentamentos. As pesquisas quantitativa e qualitativa foram formatadas, desenvolvidas e implementadas, de modo a permitir que seus resultados viabilizassem a construção de instrumentos que pudessem fornecer dados sobre o entrelaçamento de fatores que identificassem a qualidade da habitação, concebida como espaço promotor de saúde.

Nessa direção, os indicadores de vulnerabilidade física desenvolvidos no âmbito do projeto constituíram ferramenta significativa para a identificação das características que interferem diretamente na saúde dos moradores e propiciaram o mapeamento de medidas necessárias à obtenção de um hábitat saudável. A investigação das questões que interferem na construção de um espaço arquitetural salubre examinou os critérios do Comitê de Higiene e Habitação da Associação Pan-Americana da Saúde Pública (Apha) para condições classificadas inadequadas a uma moradia, como: abastecimento de água contaminada; suprimento de água fora da casa; instalação sanitária (toalete) de uso coletivo fora de casa, entre outras (Azevedo Netto \& Botelho, 1991), também consideradas para a definição das variáveis que vieram a compor tais indicadores.

Assim, o desenvolvimento de indicadores de vulnerabilidade física proporcionou a identificação dos fatores de risco e do grau de vulnerabilidade das habitações e do hábitat na comunidade investigada. Tais indicadores podem constituir um componente metodológico para posterior aplicação em programas de políticas públicas.

\footnotetext{
${ }^{15}$ Além das referências citadas neste item, ressalta-se o documento de Cavallieri e Lopes (2008) que aborda o Índice de Desenvolvimento Social (IDS) e que forneceu subsídios para os indicadores desenvolvidos nesse projeto.
} 
No que concerne aos indicadores de vulnerabilidade social identificados e selecionados de acordo com o contexto que envolve o projeto, remete-se ao estudo clássico de Paulo de Martino Januzzi, segundo o qual um indicador social constitui:

uma medida em geral quantitativa dotada de significado social substantivo, usado para substituir, quantificar ou operacionalizar um conceito social abstrato, de interesse teórico (para pesquisa acadêmica) ou programático (para formulação de políticas) (Januzzi, 2006: 15)

Interessante salientar a relação dos indicadores com os territórios aos quais se referem. Mediante as palavras do mesmo autor, trata-se de "um recurso metodológico, empiricamente referido, que informa algo sobre um aspecto da realidade social" e também diz respeito a resultados e metas a serem alcançadas, pois "em uma perspectiva programática, o 'indicador social' é um instrumento operacional para monitoramento da realidade social, para fins de formulação e reformulação de políticas públicas" (Januzzi, 2006: 15). Para fundamentar a construção de indicadores sociais, apoiou-se, ainda, em concepção que examina os riscos socioambientais que as habitações urbanas precárias ou vulneráveis poderiam apresentar para a saúde de seus habitantes, mediante um enfoque complexo do conceito de risco (Rojas et al., 2008).

\section{Sobre a participação social e as oficinas com os moradores}

A participação dos indivíduos residentes no território foi premissa básica da metodologia durante todo o período de realização do projeto. Não somente por ser um direito constitucional adquirido e largamente referido na legislação ordinária e complementar, mas com vistas à ampliação da participação cívica e pró-ativa no planejamento, no acompanhamento e na avaliação de políticas e programas (relação consciente do cidadão para com o Estado) assim como à emancipação humana (Marx, 2010: 54) - considerando que "o dever do Estado não exclui o das pessoas, da família, das empresas e da sociedade" (Brasil, 1990a). A premissa está apoiada no conjunto legal que prevê, na saúde, a "participação da comunidade" (Brasil, 1990a) - princípio fundamental viabilizado com a criação dos conselhos de saúde de caráter "permanente e deliberativo" (Brasil, 1990b) e de "formação paritária com o restante dos segmentos" (Brasil, 1990b) representados. Fundamenta-se, também, nas normas legais do campo da assistência social, que determinam como diretriz para a organização da assistência a "participação da população, por meio de organizações representativas, na formulação das políticas e no controle das ações em todos os níveis" - sendo a participação da comunidade definida em 
normativas do Ministério do Desenvolvimento Social (MDS) como um processo pedagógico de construção de cidadania e um direito do cidadão (Brasil, 1993).

No caso das intervenções de urbanização, reforça a valorização da participação social a recomendação para a seleção dos beneficiários dos serviços de assistência técnica para construção e reforma de moradias, que deve ser feita "por meio de sistemas de atendimento implantados por órgãos colegiados municipais com composição paritária entre representantes do poder público e da sociedade civil" (Brasil, 2008).

As questões identificadas como prioritárias para os moradores da comunidade foram problematizadas em seis oficinas temáticas. Batizadas de Oficinas de Educação Socioespacial para um Hábitat Saudável, tiveram os objetivos (sintetizados) de: apresentar os dados relativos às pesquisas finalizadas e debater a respeito dos temas referidos às condições de habitabilidade consubstanciados nos indicadores de vulnerabilidade física, para o seu aprimoramento e consolidação preliminar; sensibilizar e estimular a percepção do espaço vivido, fundamentado em aspectos da história e memória destilada nas entrevistas e nos diversos contatos informais com os moradores; observar a qualidade desse espaço e os lugares preferidos de vivência no interior das moradias e aqueles relacionados à sociabilidade na comunidade, com base na percepção dos próprios moradores.

Por meio da adoção de uma abordagem socioespacial e ambiental, quatro eixos temáticos nortearam o trabalho: reconhecimento do espaço vivido; autoconhecimento e saber local; habitação e hábitat saudável na busca da qualidade de vida; e construção da cidadania na busca da "afirmação de sujeitos que, individual e coletivamente, lutem por direitos e por sua garantia" (Ribeiro, 2000: 83). Pretendeu-se revisitar os indicadores desenvolvidos em diálogos com os moradores, com a utilização de diversas dinâmicas subsidiadas na proposta de educação popular (Mano \& Prado, 2010) que privilegia o processo coletivo numa relação dialógica - mediante a problematização de concepções de lugar, memória, cotidiano e de habitação saudável nas representações coletivas. Num ambiente em que a escuta do outro foi valorizada, evidenciou-se a desenvoltura dos moradores que se manifestaram com liberdade, tecendo considerações sobre os dados apresentados, expondo suas sugestões e revelando aspectos significativos dos fatos e situações comentados no decorrer desses eventos.

Respaldadas na participação ativa para a resolução de problemas enfrentados pelos residentes na área do projeto, as oficinas com os moradores constituíram instrumento potencial de qualificação e de construção de conhecimento. 
Revelaram-se como ambientes privilegiados para produção de resultados efetivos, tendo em vista a construção progressiva de territórios saudáveis.

\section{Sobre o trabalho intersetorial e transdisciplinar e sobre a mesa intersetorial}

A metodologia também foi fundamentada nos pressupostos de ação integrada dos entes federativos, unidade na concepção, articulação no planejamento e consequente realização de políticas públicas articuladas para "enfrentar e superar a pobreza, as desigualdades sociais, econômicas e as disparidades regionais e locais existentes no país" (Brasil, 2005), vastamente citados na legislação brasileira.

As referências à intersetorialidade e à transdisciplinaridade estão respaldadas no artigo 23 da Constituição Federal de 1988 que, ao estabelecer as competências comuns da União, dos estados, do Distrito Federal e dos municípios, incluiu, entre outros aspectos, cuidar da saúde, proteger o meio ambiente, proporcionar os meios de acesso à cultura, à educação e à ciência, bem como promover programas de construção de moradia e melhoria das condições habitacionais e de saneamento básico. A "organização dos serviços públicos de modo a evitar a duplicidade de meios para fins idênticos" e a "integração em nível executivo das ações de saúde, meio ambiente e saneamento básico", igualmente, são princípios da organização do SUS que fortalecem o argumento (Brasil, 1990a).

As normativas do Ministério das Cidades, tal e qual, fazem referência à necessidade dos entes federados promoverem "parcerias para o atendimento das necessidades das famílias e para a implantação das políticas sociais públicas na área de intervenção, contribuindo para o acesso das famílias a serviços de educação, saúde, esporte, lazer, cultura, assistência social, segurança alimentar e segurança pública" (Brasil, 2007).

Ressalta-se ainda, no campo da assistência social, o atendimento às necessidades básicas dos cidadãos, a ser garantido por meio de "um conjunto integrado de ações de iniciativa pública e da sociedade" (Brasil, 1993) e desenvolvido "de forma integrada às políticas setoriais, visando ao enfrentamento da pobreza" (Brasil, 2008). No âmbito da política habitacional, o planejamento e a implementação das ações de prestação de assistência técnica pública e gratuita para o projeto e a construção de habitações de interesse social para as famílias de baixa renda são previstos para serem realizados pelos municípios, os estados e o Distrito Federal, com base no apoio financeiro da União (Brasil, 2008), "de forma coordenada e sistêmica, a fim de evitar sobreposições e otimizar resultados" (Brasil, 2008). 
A premissa da intersetorialidade também é considerada na legislação em relação à influência de diferentes fatores sobre a condição de saúde individual e coletiva: o art. $3^{\circ}$ da lei n. 8.080/1990 (Brasil, 1990a) reflete a concepção resumida no princípio constitucional do "atendimento integral, com prioridade para as atividades preventivas, sem prejuízo dos serviços assistenciais" (Brasil, 1988). Buscando meios para garantir a integração de políticas, a legislação determinou que fossem criadas, no Conselho Nacional de Saúde, comissões intersetoriais "integradas pelos Ministérios e órgãos competentes..." (Brasil, 1990a) para articular políticas e programas de interesse da saúde cuja execução não seja do SUS.

O quadro legal vigente preconiza a articulação da gestão entre os três entes federativos e entre as unidades administrativas de uma mesma esfera de governo tanto no planejamento quanto no financiamento e na realização das ações, como essenciais para a transformação das cidades, em direção à concepção de cidades saudáveis. Entretanto, no cotidiano dos serviços, conquanto já sejam percebidos esforços para a ampliação da interlocução entre setores da administração pública com vistas à integração, a gestão ainda é "predominantemente verticalizada, setorial e dicotômica... [e constitui]... um entrave ao desenvolvimento urbano sustentável e à melhoria da qualidade de vida nas cidades", "... apesar de existir uma estreita relação entre condições de salubridade do ambiente e mecanismos de determinação do processo saúde-doença", como verificou Evania Galindo (2004: 16) em estudo sobre a política de saneamento e de saúde na cidade de Recife.

No intuito de se desenvolver um trabalho orientado por ações intersetoriais, além dos diversos contatos com diferentes órgãos públicos ao longo do projeto, realizou-se uma reunião que contou com representantes dos moradores da comunidade investigada, do poder público municipal e do projeto Arquitetos de Família. ${ }^{16} \mathrm{O}$ encontro, chamado de mesa intersetorial, almejou debater a proposta de indicadores de vulnerabilidade física e social, bem como compartilhar com órgãos da administração pública e representantes de outros projetos que expressem similitudes com o trabalho desenvolvido. Buscou-se, desse modo, estabelecer um diálogo com base na troca de informações e também avaliar as possibilidades de utilização desses indicadores em políticas públicas destinadas à melhoria da qualidade de vida e saúde em assentamentos urbanos irregulares. As contribuições resultantes do debate realizado foram incorporadas ao relatório final do projeto, tornando-se parte constitutiva das propostas nele consubstanciadas.

\footnotetext{
${ }^{16}$ Destinado a prestar assistência técnica para melhorias habitacionais e promoção de espaços protetores da vida, saudáveis e sustentáveis, assim como a qualificar profissionais para a prestação dos atendimentos. Foi promovido pelo Instituto Vital Brazil em parceria com a 0NG Soluções Urbanas, em Niterói, Rio de Janeiro.
} 


\section{Desenvolvimento de Indicadores}

Conforme se assinalou no item "Os caminhos da pesquisa", para a investigação proposta, indicadores constituem instrumentos operacionais que apontam ações necessárias em determinados territórios, por meio da identificação de dados essenciais à qualidade de vida. Destinam-se a fornecer um conjunto de informações a respeito de carências, incertezas, dificuldades ou instabilidades socioespaciais, culturais e econômicas que permitam avaliar e propor intervenções que contribuam para mudanças nas condições essenciais de habitabilidade e de saúde. Nesse sentido, embora em geral configurem informações objetivas, tais instrumentos devem ser acompanhados de análises qualitativas que possam ampliar a compreensão do universo investigado e comprovar (ou não) os valores a eles atribuídos.

Cabe destacar alguns aspectos relevantes que constituíram a base da construção dos indicadores, seja por apropriação e respectiva adaptação de indicadores já consagrados na literatura e nas pesquisas e intervenções urbanas contemporâneas, seja pela criação de novos, mediante associação de variáveis identificadas como prioritárias em investigações destinadas a romper com o quadro atual de carências dos moradores e de suas moradias. Assim, buscou-se compreender de maneira abrangente os aspectos sociais das famílias e as características físicas das edificações, o que possibilitou correlacionar esses dados com a qualidade de vida local. Focaliza-se aqui, de acordo com o exposto no início deste capítulo, o desenvolvimento de indicadores de vulnerabilidade física.

\section{Indicadores de vulnerabilidade física}

A habitação saudável, conforme o conceito utilizado pela Opas (2009) e aqui adotado, deve ser apreendida como a relação que se estabelece entre moradia, saúde, ambiente, seus fatores sociais, técnicos e a análise de saneamento. Deve ainda ser compreendida em seu contexto mais amplo, incorporando também a escola, os espaços destinados às manifestações religiosas e o local de trabalho, assim como todos os lugares de interação social. Tal concepção destina-se ao enfrentamento de fatores de risco por meio do entendimento das dimensões tecnológica e sociológica, sendo a primeira relativa aos aspectos construtivos e de manutenção da moradia, e a segunda aos aspectos simbólicos e funcionais dessa habitação, considerando os seus significados para a sociedade (Cohen et al., 2008).

As moradias dos assentamentos urbanos irregulares muitas vezes não apresentam condições de habitabilidade desejáveis, seja pela precariedade dos 
materiais utilizados em sua construção e dificuldades em sua manutenção, pela ausência de ventilação e iluminação adequadas, seja pela exiguidade de seus compartimentos ou pelas deficiências de saneamento. Tais assentamentos, que em diversos casos abrigam habitações de interesse social construídas em Áreas de Especial Interesse Social (Aeis), revelam aspectos de uma urbanização que cristaliza a desigualdade socioeconômica e cultural e acentua a perda da qualidade de vida urbana com impacto significativo na saúde pública.

As condições habitacionais anteriormente esboçadas distam das diretrizes da Constituição Federal de 1988 que, no seu artigo 182, preconiza o "pleno desenvolvimento das funções sociais da cidade" e ressalta a função social da propriedade urbana. "Sob tal princípio, o conceito de Interesse Social é constitucionalmente incorporado às políticas habitacionais para os setores de população de baixa renda." (Larcher, 2005: 10). Para tanto, faz-se necessário que as ações do poder público municipal identifiquem meios de privilegiar ações que induzam a garantia da qualidade de vida e a saúde dos seus habitantes com foco prioritário nas habitações de interesse social.

Nessa perspectiva, a moradia deve ser pensada como um condicionante da saúde e de "consolidação do desenvolvimento social" (Cohen et al., 2007: 192), assim como ambiente que condiciona o alcance da melhoria na qualidade de vida. Dessa maneira, a produção de indicadores de vulnerabilidade da habitação em assentamentos urbanos irregulares contribui para o entendimento da realidade socioespacial cristalizada no território e pode sinalizar alguns pontos de contato importantes entre a chamada cidade legal e a cidade real. Essa abordagem se justifica pela premência de uma compreensão a respeito dos processos de ocupação urbana e de criação de metodologias para implementação de políticas públicas inclusivas, com fundamentação técnica aprimorada para contextos urbanos desiguais e fragmentados.

Desse modo, tais indicadores podem ser vistos como ferramenta significativa para a identificação das características que interferem diretamente na saúde dos moradores e propiciam o mapeamento de medidas necessárias à obtenção de um hábitat saudável. Trata-se de instrumentos consistentes para o diagnóstico de áreas de habitação de interesse social e para o desenvolvimento da metodologia proposta no projeto, destinada à elaboração de políticas públicas. Os indicadores de vulnerabilidade física das habitações apresentados neste capítulo constituem resultado, em sua maior parte, de análise do trabalho de campo e que é, portanto, produto desenvolvido com base no trabalho empírico associado às referências consultadas. 
O processo de construção desses indicadores, base para o diagnóstico das condições de habitabilidade das moradias, fundamentou-se na pesquisa quantitativa, nos croquis arquitetônicos e nos registros fotográficos. Posteriormente, os dados relacionados às características físicas do domicílio, extraídos das respostas obtidas na aplicação do questionário e os croquis das edificações, complementados com observações sobre as condições de moradia, foram analisados nos seguintes aspectos: as tipologias arquitetônicas segundo o número de cômodos, os tipos de materiais empregados na construção e as condições de conforto no interior da moradia, incluindo a relação entre o número de moradores e o número de quartos (ou compartimentos utilizados como quartos). Trata-se de aspectos relevantes para a obtenção de informações relativas aos níveis de vulnerabilidade e salubridade das edificações.

Os problemas identificados como mais representativos no levantamento de campo estão relacionados, em sua maior parte, ao elevado percentual (aproximadamente 65\%) de domicílios que têm sua iluminação e ventilação comprometidas pela presença de obstruções nas janelas, que podem gerar aumento de temperatura e alto grau de umidade no interior na edificação.

As informações foram aplicadas ao banco de dados do projeto para análise, seleção e definição das variáveis mais apropriadas para compor os grupos de indicadores que apontam os tipos de vulnerabilidade física da habitação: iluminação e ventilação; adensamento domiciliar; umidade e mofo; materiais construtivos nocivos à saúde; condições construtivas e manutenção e cuidados com a habitação e o hábitat. O Quadro 1, a seguir, sintetiza as características dos indicadores produzidos e/ou selecionados pela equipe do projeto.

\section{Síntese analítica dos indicadores}

Quadro 1 - Características dos indicadores produzidos e/ou selecionados

\begin{tabular}{|l|l|l|l|l|}
\hline INDICADORES & VARIÁVEIS & PESO & CONSEQUÊNCIAS & DOENÇAS \\
\hline $\begin{array}{l}\text { Iluminação e } \\
\text { ventilação } \\
\text { Indicador 1 }\end{array}$ & $\begin{array}{l}\text { Ausência ou insuficiência de janelas/ } \\
\text { vãos voltados para áreas abertas em } \\
\text { um ou mais cômodos }\end{array}$ & 2 & $\begin{array}{l}\text { Luz solar direta } \\
\text { insuficiente }\end{array}$ & $\begin{array}{l}\text { Carência de } \\
\text { vitamina D }\end{array}$ \\
\cline { 2 - 5 } & $\begin{array}{l}\text { Presença de elementos que obstruem } \\
\text { a entrada de iluminação e ventilação } \\
\text { no domicílio }\end{array}$ & 2 & $\begin{array}{l}\text { Circulação do ar } \\
\text { insuficiente. Elevação } \\
\text { térmica no domicílio. } \\
\text { Necessidade de } \\
\text { fonte de energia não } \\
\text { renovável. }\end{array}$ & $\begin{array}{l}\text { Tuberculose; } \\
\text { bronquite; } \\
\text { pneumonia; } \\
\text { asma; alergias. }\end{array}$ \\
\hline $\begin{array}{l}\text { Adensamento } \\
\text { domiciliar } \\
\text { Indicador 2 }\end{array}$ & \begin{tabular}{l} 
No de moradores no domicílio \\
\cline { 2 - 5 } \\
No de cômodos utilizados como
\end{tabular} & 1 & 1 & \\
\hline
\end{tabular}


Quadro 1 (cont.) - Características dos indicadores produzidos e/ou selecionados

\begin{tabular}{|c|c|c|c|c|}
\hline INDICADORES & VARIÁVEIS & PESO & CONSEQUÊNCIAS & DOENÇAS \\
\hline \multirow{7}{*}{$\begin{array}{l}\text { Umidade } \\
\text { e } \\
\text { mofo } \\
\text { Indicador } 3\end{array}$} & $\begin{array}{l}\text { Ausência de revestimentos no piso do } \\
\text { banheiro }\end{array}$ & 1 & \multirow{7}{*}{$\begin{array}{l}\text { Aumento nas } \\
\text { condições de umidade } \\
\text { no domicílio. } \\
\text { Surgimento de mofo/ } \\
\text { fungo/ bactéria/ } \\
\text { vírus/ ácaros. } \\
\text { Possibilidade de } \\
\text { proliferação de } \\
\text { vetores do ciclo } \\
\text { de transmissão de } \\
\text { doenças. }\end{array}$} & \multirow{7}{*}{$\begin{array}{l}\text { Leishmaniose; } \\
\text { doença de } \\
\text { Chagas; } \\
\text { malária; febre } \\
\text { amarela. }\end{array}$} \\
\hline & $\begin{array}{l}\text { Revestimentos inadequados no piso } \\
\text { do banheiro }\end{array}$ & 1 & & \\
\hline & $\begin{array}{l}\text { Revestimento inadequado na parede } \\
\text { do box do banheiro ou nas paredes } \\
\text { próximas ao chuveiro }\end{array}$ & 1 & & \\
\hline & $\begin{array}{l}\text { Laje não impermeabilizada exposta } \\
\text { às intempéries }\end{array}$ & 2 & & \\
\hline & Presença de infiltração ascendente & 2 & & \\
\hline & Presença de infiltração descendente & 2 & & \\
\hline & $\begin{array}{l}\text { Existência de lacuna de fechamento } \\
\text { entre a parede e a cobertura }\end{array}$ & 1 & & \\
\hline \multirow{3}{*}{$\begin{array}{l}\text { Materiais } \\
\text { nocivos } \\
\text { à saúde } \\
\text { Indicador } 4\end{array}$} & $\begin{array}{l}\text { Existência de telhados em } \\
\text { fibrocimento (amianto) em } \\
\text { edificações com laje ou forro }\end{array}$ & 2 & \multirow{3}{*}{$\begin{array}{l}\text { Inalação e/ } \\
\text { ou absorção } \\
\text { de substâncias } \\
\text { prejudiciais à saúde } \\
\text { por parte dos } \\
\text { moradores }\end{array}$} & \multirow{3}{*}{$\begin{array}{l}\text { asbestose; } \\
\text { câncer de } \\
\text { pulmão, do } \\
\text { trato digestivo, } \\
\text { laringe } \\
\text { e ovário; } \\
\text { mesotelioma }\end{array}$} \\
\hline & $\begin{array}{l}\text { Existência de telhados em } \\
\text { fibrocimento (amianto) em } \\
\text { edificações sem laje ou forro }\end{array}$ & 2 & & \\
\hline & $\begin{array}{l}\text { Existência de caixa d'água em } \\
\text { fibrocimento (amianto) }\end{array}$ & 2 & & \\
\hline \multirow{8}{*}{$\begin{array}{l}\text { Condições } \\
\text { construtivas e } \\
\text { manutenção } \\
\text { Indicador } 5\end{array}$} & $\begin{array}{l}\text { Ausência de revestimento nas } \\
\text { paredes internas do domicílio }\end{array}$ & 1 & \multirow{8}{*}{$\begin{array}{l}\text { Risco de curto circuito. } \\
\text { Falta d'água } \\
\text { por ausência } \\
\text { de reservatório. } \\
\text { Possibilidade de } \\
\text { proliferação de } \\
\text { vetores do ciclo } \\
\text { de transmissão de } \\
\text { doenças. }\end{array}$} & \multirow[t]{8}{*}{$\begin{array}{l}\text { Dengue; } \\
\text { leishmaniose }\end{array}$} \\
\hline & $\begin{array}{l}\text { Ausência de revestimentos nas } \\
\text { paredes externas do domicílio }\end{array}$ & 1 & & \\
\hline & $\begin{array}{l}\text { Ausência de revestimentos no piso } \\
\text { dos cômodos secos (como sala e } \\
\text { quartos) }\end{array}$ & 1 & & \\
\hline & $\begin{array}{l}\text { Revestimento em condições } \\
\text { inadequadas no piso dos cômodos } \\
\text { secos }\end{array}$ & 1 & & \\
\hline & $\begin{array}{l}\text { Presença de fissuras/trincas na } \\
\text { edificação }\end{array}$ & 1 & & \\
\hline & $\begin{array}{l}\text { Instalação elétrica inadequada } \\
\text { (fiação aparente, junto ao forro ou } \\
\text { diretamente abaixo da cobertura, } \\
\text { ausência de conduíte) }\end{array}$ & 2 & & \\
\hline & Ausência de caixa d'água & 1 & & \\
\hline & $\begin{array}{l}\text { Caixa d'água sem vedação e/ou } \\
\text { manutenção }\end{array}$ & 1 & & \\
\hline
\end{tabular}


Quadro 1 (cont.) - Características dos indicadores produzidos e/ou selecionados

\begin{tabular}{|c|c|c|c|c|}
\hline INDICADORES & VARIÁVEIS & PESO & CONSEQUÊNCIAS & DOENÇAS \\
\hline \multirow{7}{*}{$\begin{array}{l}\text { Cuidados com } \\
\text { a habitação e } \\
\text { o hábitat } \\
\text { Indicador } 6\end{array}$} & Consumo de água não tratada & \multirow[t]{7}{*}{-} & \multirow{7}{*}{$\begin{array}{l}\text { Possibilidade de } \\
\text { contrair doenças; } \\
\text { Proliferação de insetos; } \\
\text { Solo infectado com } \\
\text { agentes infecciosos. }\end{array}$} & \multirow{7}{*}{$\begin{array}{l}\text { Diarreia, } \\
\text { escabiose, } \\
\text { pediculose, } \\
\text { conjuntivite } \\
\text { bacteriana; } \\
\text { tracoma, } \\
\text { alergias, } \\
\text { toxoplasmose, } \\
\text { entre outras. }\end{array}$} \\
\hline & $\begin{array}{l}\text { Consumo de água diretamente da } \\
\text { torneira }\end{array}$ & & & \\
\hline & $\begin{array}{l}\text { Lixo domiciliar guardado em } \\
\text { recipiente aberto }\end{array}$ & & & \\
\hline & $\begin{array}{l}\text { Presença de animais domésticos no } \\
\text { domicílio }\end{array}$ & & & \\
\hline & $\begin{array}{l}\text { Presença de animais silvestres } \\
\text { (invasores) }\end{array}$ & & & \\
\hline & $\begin{array}{l}\text { Fogão próximo à passagem de } \\
\text { pessoas }\end{array}$ & & & \\
\hline & $\begin{array}{l}\text { Botijão de gás em local que ofereça } \\
\text { riscos }\end{array}$ & & & \\
\hline
\end{tabular}

Para classificar os domicílios quanto à sua vulnerabilidade física, cada uma das variáveis foi analisada a fim de estabelecer uma ponderação, considerando o nível de possibilidade de interferência na saúde dos moradores. Assim, foram atribuídos os pesos 1 ou 2 às variáveis. O peso 2 indica que a variável tem grande relevância e por isso não precisa estar associada a outra para demonstrar a condição de vulnerabilidade física com relação ao indicador correspondente. No caso da variável com peso 1, se estiver associada a uma ou mais de mesmo peso, já se confirma vulnerabilidade. As variáveis do indicador "Cuidados com a habitação e o hábitat" não foram ponderadas porque estão relacionadas a hábitos e informações que podem ser tratados com orientação e ações educativas (exemplo: oficinas de arte-educação, em propostas de educação popular que preconizem a participação).

Dessa forma, classificaram-se os domicílios de acordo com os problemas identificados em cada um dos cinco indicadores cujas variáveis foram ponderadas, mediante a sua classificação em quatro faixas de vulnerabilidade física, criadas para expressar diferentes níveis de salubridade:

- Faixa 1, correspondendo às habitações que apresentaram de zero a um indicador de vulnerabilidade física;

- Faixa 2, às habitações que revelaram a presença de dois ou três indicadores;

- Faixa 3, para os casos de presença de quatro indicadores;

- Faixa 4, para as situações com os cinco indicadores presentes. 
Nessa perspectiva, as habitações da comunidade de Curicica1 tiveram suas vulnerabilidades físicas evidenciadas nos Gráficos 2 e 3. O primeiro aponta os percentuais constatados por tipo de indicador. A análise desse gráfico expressa alguns aspectos comuns presentes na maioria dos domicílios, ou seja, com exceção do indicador de adensamento domiciliar, que no momento da pesquisa não se configurava como um problema expressivo nessa comunidade, os demais demonstram a elevada fragilidade das situações construtivas e de uso das edificações que abrigam os domicílios investigados.

O Gráfico 3 demonstra uma concentração de grande parte dos domicílios analisados nas faixas 2 e 3 , portanto revela que a maioria dos domicílios apresenta sérios problemas de salubridade. O resultado da análise dos indicadores evidencia, assim, a necessidade de equacionamento da vulnerabilidade identificada para se assegurar condições de habitabilidade e, por conseguinte, das condições fundamentais para a almejada moradia digna, indispensável à qualidade de vida.

Gráfico 2 - Indicadores de vulnerabilidade física das habitações. Curicica1 - 2009/2010 (\%)

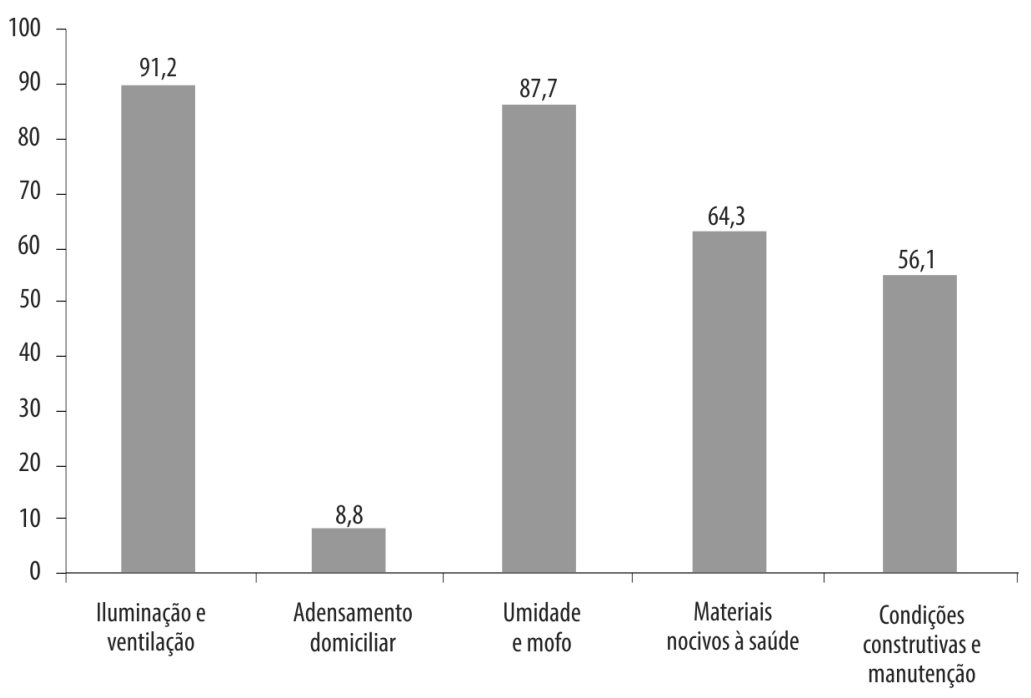

Fonte: Levantamento de campo do projeto. 
Gráfico 3 - Classificação dos domicílios por faixa de insalubridade. Curicica1 - 2009/2010 (\%)

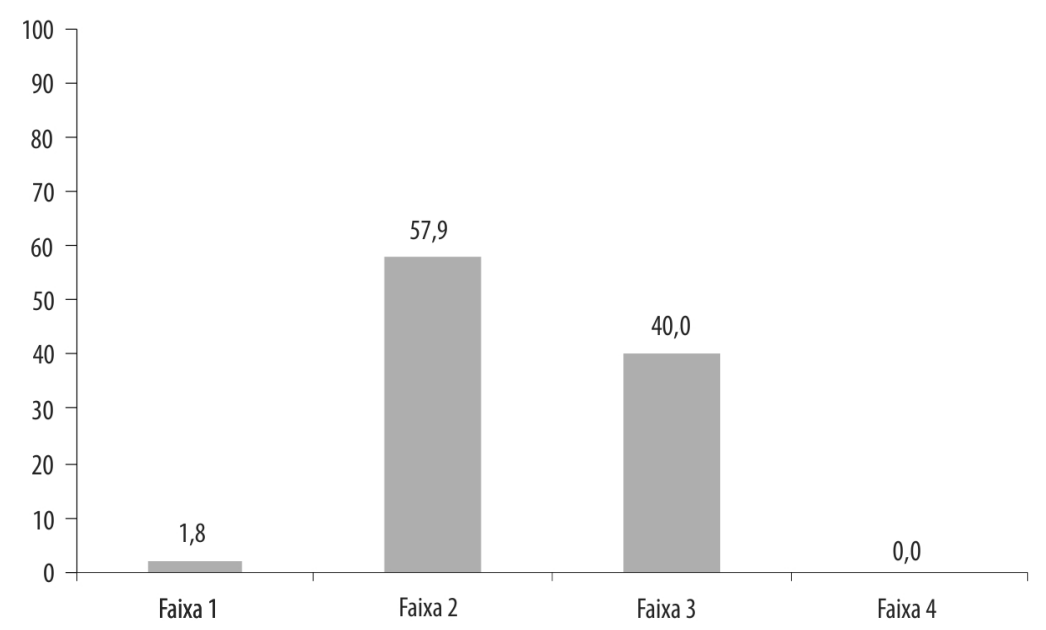

Fonte: Levantamento de campo do projeto.

\section{A Qualidade de Vida no Contexto da Desigualdade}

A marca da modernização brasileira se expressa, notadamente, na desigualdade que se faz presente no processo de urbanização. Portanto, diz respeito à segregação socioespacial e às formas de ocupação dos espaços encontrados para a produção de moradia popular. Compreende, ainda, as estratégias utilizadas para a construção das moradias e a precariedade de serviços disponibilizados, que tendem a perpetuar a lógica da segregação dos grupos sociais.

A opção por estratégias e mecanismos de pesquisa que favorecessem a aproximação de diferentes especialistas - como sociólogos, antropólogos, educadores, urbanistas, arquitetos - no projeto examinado, dispunha-se a promover uma compreensão ampla do espaço investigado, considerado como ambiente historicamente construído por seus moradores. Nesse sentido, a convivência no decorrer do projeto permitiu o desenvolvimento de uma percepção a respeito da história de vida desses moradores e trouxe a compreensão sobre as trajetórias que poderiam ser classificadas como estados ou situações de vulnerabilidade socioespacial.

Assim, estima-se que a metodologia para intervenção socioespacial em assentamentos urbanos irregulares, exposta neste capítulo, pode ser examinada e 
apropriada em investigações e projetos semelhantes que tenham como propósito alcançar o direito à cidade e à cidadania, particularmente no que concerne à qualidade de vida. Compreende-se que os resultados obtidos podem fornecer subsídios para outras reflexões e ações em benefício dos planejamentos e programas destinados à intervenção nas cidades, mais especificamente em suas áreas periféricas.

Consideraram-se, na promoção de moradia saudável, aspectos sociais que incidem, em menor ou maior grau, sobre seu estado físico, como as relações de redes de familiaridade e vizinhança, menos oportunidade de emprego (formal ou informal), menos oportunidade de profissionalização, difícil acesso ao lazer, dentre outros. Esses fatos, somados ainda à exposição a riscos (enchentes e desmoronamentos) e/ou violência (marginal ou policial), constituem uma lista quase interminável de fatores que podem ser considerados como agentes sociais produtores dos espaços construídos. Tais aspectos e suas variantes podem vir a ser considerados como parte das dimensões da cidade, em especial das localidades pouco providas de ações do poder público.

Os resultados das pesquisas quantitativa e qualitativa foram discutidos com os moradores e representantes do poder público municipal, interlocutores privilegiados para a análise e reavaliação do projeto, na busca de uma consolidação do processo participativo e de uma construção compartilhada de conhecimento. Tendo em vista os objetivos propostos no projeto, o desenvolvimento de indicadores constituiu um passo inicial para contribuir na elaboração de uma metodologia transdisciplinar que auxiliasse no diagnóstico de problemas comumente encontrados nos assentamentos urbanos irregulares.

A valorização da concepção de promoção da saúde, fundamentada na noção da saúde condicionada por múltiplos fatores - na atenção primária ambiental, no conceito de habitação saudável e no direito à cidade -, deverá ser alcançada com a realização de novas pesquisas e intervenções. Estas deverão atribuir importância aos estudos empíricos que identifiquem as especificidades de cada assentamento investigado, numa perspectiva participativa. Considera-se que o conhecimento almejado e, ao menos parcialmente conseguido, analisado à luz do conceito de habitação saudável aqui adotado, poderá constituir uma visão abrangente que inclua os referenciais mencionados anteriormente e que possa ser apropriada para a construção de cidades mais justas e igualitárias.

Destacam-se, além disso, como resultados da investigação, as reformas de cinco casas, empreendidas por moradores que participaram ativamente do projeto, 
incluídas a concepção de habitação saudável como condição essencial de qualidade de vida e saúde. Tais iniciativas permitem inferir que o projeto teve uma parcela de contribuição na transformação socioespacial de Curicica1 por meio da compreensão das concepções orientadoras, sobretudo quanto à apropriação popular dos indicadores de vulnerabilidade física das habitações. Sublinha-se, também, a constatação de uma demanda crescente, entre os moradores, de assessoria técnica para reformas em mais de dez casas, como resultado da implementação do projeto e debate participativo dos seus produtos. Nesse processo, evidencia-se o inextricável desdobramento do projeto, como ação fundamental para aprofundar a compreensão dos indicadores de vulnerabilidade social, necessariamente entrelaçados aos anteriores, numa perspectiva de equacionamento das relações socioespaciais em sua totalidade.

De outro ponto de vista, por meio da articulação dos conceitos de história, memória, habitação e hábitat saudável, território saudável e direito à cidade, valorizou-se o processo coletivo fundamentado na escuta atenta e no diálogo com os atores envolvidos. Desse modo, delinearam-se subsídios significativos para políticas públicas.

Um aspecto ideológico que a metodologia implementada suscitou diz respeito ao entendimento que ainda se tem sobre a cidade que, historicamente, tem sido concebida como espaço que necessita ser cuidado tal qual um paciente adoecido, conforme mencionou-se no item "Cidades saudáveis no contexto da promoção da saúde". Essa ideia remonta à visão higienista - no Rio de Janeiro, nitidamente representada em documentos e ações do poder público a partir da segunda metade do século XIX até as primeiras décadas do século XX (Rio de Janeiro, 1977).

Da constatação da força de permanência dessa visão deriva a pergunta: a política pública reifica a ideia de cidade saudável? Afinal, quanto à forma, como se pensa a cidade? De que maneira a cidade é gerida? A sociedade participa de sua construção e manutenção? Sabe-se que, em assentamentos urbanos irregulares, muitas vezes, a cidade é produzida pelos próprios moradores - os urbanistas do seu próprio espaço. Assim, pergunta-se: que políticas são pensadas para esses lugares e de que maneira são implementadas?

Compreende-se que a nossa sociedade produz e reproduz cidades desiguais e fragmentadas, em que se materializam espaços da riqueza e espaços da pobreza social e espacial. Tal compreensão engendra as reflexões aqui contidas, resultantes de uma investigação que, de modo crítico e fundamentado na realidade socioespacial estudada, buscaram - evitando a sobreposição do saber, mas compartilhando e combinando conhecimento e saberes - desenvolver um 
pensamento sobre os lugares da cidade, em especial, direcionando-se aos diferentes aspectos da habitação e do hábitat que considerem as formas produzidas pelos habitantes.

Cabe acrescentar que a realização de obras públicas em áreas complexas, como os assentamentos urbanos irregulares, requer intervenções distintas e profundas, tendo em vista os níveis de precariedade das condições de habitabilidade e as demandas sociais acumuladas por anos de invisibilidade. Por décadas, tais assentamentos foram desconsiderados como partes constituintes da cidade, que tem se desenvolvido de forma fragmentada.

Para além do acompanhamento do destino dos investimentos públicos e outras iniciativas destinadas à proteção da saúde, procurou-se superar aspectos da dicotomia tecnologia-sociedade, buscando integrar questões técnicas, socioculturais, econômicas e políticas no intuito de contribuir para a promoção da saúde em territórios vulnerabilizados. A metodologia do projeto e os produtos apresentados neste capítulo poderiam ser analisados como um instrumento de interesse social em direção às políticas públicas indispensáveis para a construção de cidades democráticas. Embora muitas vezes consagradas por lei, tais políticas ainda carecem de posturas mais abrangentes no caminho da transformação socioespacial. Por fim, destaca-se a relação moradia/habitabilidade/qualidade de vida/sustentabilidade como um dos pressupostos que fundamentam a promoção da saúde e, portanto, a cidade saudável ou, pelo menos, mais igualitária. 


\section{Referências}

ANDRADE, L. M. S. O conceito de Cidades-Jardins: uma adaptação para as cidades sustentáveis. Arquitextos, 2003. Disponível em: <www.vitruvius.com.br/revistas/read/ arquitextos/04.042/637>. Acesso em: 30 abr. 2011.

AZEVEDO NETTO, J. M. \& BOTELHO, M. H. C. Manual de Saneamento de Cidades e Edificações. São Paulo: Pini, 1991.

BENEVOLO, L. História da Arquitetura Moderna. São Paulo: Perspectiva, 1976.

BENEVOLO, L. As Origens da Urbanística Moderna. Lisboa: Editorial Presença, 1994.

BRASIL. Presidência da República. Constituição Federal da República Federativa do Brasil de 1988. Disponível em: <www.planalto.gov.br/ccivil_03/constituicao/constituicao.htm >. Acesso em: 19 mar. 2010.

BRASIL. Presidência da República. Lei n. 8.080 de 19 set. 1990. Dispõe sobre as condições para a promoção, proteção e recuperação da saúde, a organização e o funcionamento dos serviços correspondentes e dá outras providências. Diário Oficial da União, Brasília, 1990a. Disponível em: http://www.planalto.gov.br/ccivil_03/Leis/L8080.htm. Acesso em 8 set. 2014.

BRASIL. Presidência da República. Lei n. 8.142 de 28 dez. 1990. Dispõe sobre a participação da comunidade na gestão do Sistema Único de Saúde (SUS) e sobre as transferências intergovernamentais de recursos financeiros na área da saúde e dá outras providências. Diário Oficial da União, Brasília, 1990b. Disponível em: <www.planalto.gov.br/ccivil_03/Leis/L8142. htm>. Acesso em: 19 mar. 2010.

BRASIL. Presidência da República. Lei n. 8.742 de 07 dez. 1993. Dispõe sobre a organização da Assistência Social e dá outras providências. Disponível em: <www.planalto.gov.br/ccivil_03/ Leis/L8742.htm>. Acesso em: 19 mar. 2010.

BRASIL. Ministério do Desenvolvimento Social e Combate à Fome. Norma Operacional Básica do Sistema Único de Assistência Social NOB/SUAS Brasília, 2005. Disponível em: http://www. google.com.br/url?sa=t\&rct=j\&q=\&esrc=s\&frm=1\&source=web\&cd=1\&ved=0CB8QFjAA\&url= http\%3A\%2F\%2Fwww.mds.gov.br\%2Fassistenciasocial\%2Farquivo\%2Fnorma-operacionalbasica-do-suas.pdf\&ei=0AQPVJW7HbOQsQSiqYJY\&usg=AFQjCNGI2Km6W6t8lyLj4YOs6NArd3mYA\&bvm = bv.74649129,d.cWc. Acesso: 15 ago. 2014.

BRASIL. Ministério das Cidades, Secretaria Nacional de Habitação. Manual de Instruções Específicas para Desenvolvimento de Trabalho Social em Intervenções de Urbanização de Assentamentos Precários - Programa: Urbanização Regularização e Integração de Assentamentos Precários - Ação: Apoio à Melhoria das Condições de Habitabilidade de Assentamentos Precários. Ministério das Cidades, 2007. Disponível em: http://www.google. com.br/url?sa=t\&rct=j\&q=\&esrc=s\&frm=1\&source=web\&cd=1\&ved=0CB0QFjAA\&url=http $\%$

3A\%2F\%2Fwww.sst.sc.gov.br\%2Farquivos\%2Fid_submenu\%2F234\%2Finstrucoes_especificas _para_desenvolvimento_de_trabalho_social.pdf\&ei=ugYPVO-2POyasQTXioH4Cw\&usg=AF QjCNGFMN9IX6F19eyrY6̈iJfxHgUQdHLg Acesso em: 15 ago 2014.

BRASIL. Presidência da República. Lei n. 11.888 de 24 dez. 2008. Assegura às famílias de baixa renda assistência técnica pública e gratuita para o projeto e a construção de habitação de interesse social e altera a Lei n. 11.124, de 16 jun. 2005. Disponível em: <www.planalto.gov. br/ccivil_03/_Ato2007-2010/2008/Lei/L11888.htm>. Acesso em: 19 mar. 2010.

CAVALLIERI, F. \& LOPES, G. Índice de Desenvolvimento Social - Comparando as realidades microurbanas da cidade do Rio de Janeiro. Rio de Janeiro, 2008. 14 p. (Coleção Estudos Cariocas). Disponível em: http://www.armazemdedados.rio.rj.gov.br/arquivos/2394_\%C3\%ADndice\%20 de\%20desenvolvimento\%20social_ids.PDF. Acesso em 20 de Outubro de 2010.

CHOAY, F. O Urbanismo. Utopias e Realidades. Uma Antologia. São Paulo: Perspectiva, 1994.

CYNAMON, S. E. et al. Rede Brasileira de Habitação Saudável: habitação saudável como estratégia sinérgica da saúde da família no Brasil. Revista Panamericana de Salud Pública, 1:103-116, 2004. 
COHEN, S. C. et al. Habitação saudável e ambientes favoráveis à saúde como estratégia de promoção da saúde. Ciência \& Saúde Coletiva, 12(1): 191-198, 2007.

COHEN, S. C. et al. A qualidade da água na habitação como componente essencial para melhor qualidade de vida: um estudo de gestão do sistema hídrico intra e peri-domiciliar no loteamento de Parque Morada Anchieta. Cadernos - Centro Universitário São Camilo, 1: 120$142,2008$.

GALINDO, E. F. A intersetorialidade como Requisito para Construção de uma Cidade Saudável: política de Saneamento e de Saúde no Recife (gestão 2001-2004) - Estudo de Caso, 2004. Dissertação de Mestrado em Desenvolvimento Urbano, Recife: Universidade Federal de Pernambuco.

HOWARD, E. Cidades-Jardins de Amanhã. São Paulo: Hucitec, 1996.

JANNUZZI, P. M. Indicadores Sociais no Brasil: conceitos, fontes de dados e aplicações. 3. ed. Campinas: Alínea, 2006.

LARCHER, J. V. M. Diretrizes Visando a Melhoria de Projetos e Soluções Construtivas na Expansão de Habitações de Interesse Social, 2005. Dissertação de Mestrado em Construção Civil, Curitiba: Universidade Federal do Paraná.

LEFEBVRE, H. O Direito à Cidade [1968]. São Paulo: Centauro, 2001.

LEFEBVRE, H. Lógica Formal / Lógica Dialética. Rio de janeiro: Civilização Brasileira, 1991.

LIZA, M. S. A. O conceito de Cidades-Jardins: uma adaptação para as cidades sustentáveis. Arquitextos, São Paulo, 04.042, Vitruvius, nov. 2003. Disponível em: <http://www.vitruvius.com.br/revistas/ $\mathrm{read} /$ arquitextos/04.042/637>. Acesso em: 30 de abril de 2012

MANO, M. A. M. \& PRADO, E. V.P. Vivências de Educação Popularna Atenção Primária à Saúde: a realidade e a utopia. São Carlos: EdUFSCAR, 2010.

MARX, K. Sobre a questão judaica. São Paulo: Boitempo, 2010.

MARX, K.\&ENGELS, F. Manifiesto del Partido Comunista. Moscou: Ediciones en Lenguas Extranjeras, s.d.

ORGANIZAÇÃO MUNDIAL DA SAÚDE (OMS). Carta de Otawa, 1986. Disponível em: <www.opas.org. br/promocao/uploadArq/Ottawa.pdf>. Acesso em: 14 out. 2009.

ORGANIZAÇÃO PAN-AMERICANA DA SAÚDE (OPAS). Municípios / cidades saudáveis. Disponível em: <www.opas.org.br/coletiva/temas.cfm?id=28\&area=Conceito >. Acesso em: 17 ago. 2009.

PELICIONI, M. C. F. Educação em Saúde e Educação Ambiental: estratégias de construção da escola promotora da saúde, 2000. Livre Docência, São Paulo: Faculdade de Saúde Pública, Universidade de São Paulo.

RABELLO, L. S. Promoção da Saúde: a construção social de um conceito em perspectiva comparada. Rio de Janeiro: Editora Fiocruz, 2010.

RIBEIRO, A. C. Sujeito corporificado e bioética: caminhos da democracia. Revista Brasileira de Educação Médica, 24(1): 82-86, 2000.

RIO DE JANEIRO. Prefeitura. OLIVEIRA REIS, J. Relatório da Comissão de Melhoramentos da Cidade do Rio de Janeiro. In: O Rio de Janeiro e seus Prefeitos: evolução urbanística da cidade. Rio de Janeiro: Editora Lidador, 1977.

ROJAS, M. C. et al. Repensando de manera holística el riesgo de la vivienda urbana precaria para la salud: un análisis desde el enfoque de la vulnerabilidad sociodemográfica. Salud Colectiva, 4(2): 187-201, 2008.

SANTOS, C. N. F. dos. A Cidade como um Jogo de Cartas. Niterói: Eduff; São Paulo: Projeto Editores, 1988.

SANTOS, M. Espaço e Método. São Paulo: Nobel, 1985.

SANTOS, M. O lugar e o cotidiano. In: SANTOS, B. S. \& MENEZES, M. P. (Org.). Epistemologias do Sul. São Paulo: Cortez, 2010. 
THE WHOQOL GROUP. Development of the WHOQOL: rationale and current status. Monograph on Quality of Life Assessment: cross-cultural issues. International Journal of Mental Health, 23(3): 24-56, 1994.

TOPALOV, C. Os saberes sobre a cidade: tempos de crise? Espaço e Debates, 11(34): 28-38, 1991.

VELHO, G. Projeto e Metamorfose: antropologia das sociedades complexas. Rio de Janeiro: Jorge Zahar, 1999.

VITTE, C. C. S. \& KEINERT, T. M. M. Qualidade de Vida: planejamento e gestão urbana. Rio de Janeiro: Bertrand Brasil, 2009. 


\title{
8
}

\section{Análise da Implementação de Ações Intersetoriais: desafios e alternativas metodológicas}

\author{
Rosana Magalhães • Célia Leitão Ramos • Regina Bodstein • Fábio Peres \\ Luciene Burlandy $\cdot$ Ângela V. Coelho $\cdot$ Milena N. Ferreira \\ Monica de Castro M. Senna • Carlos dos Santos Silva • Lívia Cardoso Gomes
}

Clógicos da avaliação de ações intersetoriais. Nossa pesquisa, realizada entre os anos de 2008 e 2010 na região de Manguinhos, zona norte do município do Rio de Janeiro, envolveu a análise de documentos normativos dos programas Bolsa Família (Brasil, 2010) e Estratégia Saúde da Família (Brasil, 1998), além de entrevistas em profundidade com coordenadores, gestores e profissionais. A principal finalidade foi desenvolver uma ferramenta metodológica para a análise da implementação de ações intersetoriais e sistematização de informações relevantes para a tomada de decisão no campo da promoção da saúde. Como analisam Denis Allard, Bilodeau e Gendron (2008), o uso de matrizes no desenho avaliativo de programas sociais contribui para a hierarquização e sistematização de informações e favorece a discussão coletiva sobre como e por que os programas tendem a alcançar os efeitos pretendidos. Assim, a perspectiva é compartilhar essa experiência e ampliar o debate sobre a avaliação da implementação de ações intersetoriais com gestores, técnicos e demais atores-chave e, dessa maneira, estimular novas agendas de pesquisa e reflexões sobre a área.

\section{Desafio da Intersetorialidade}

Desde o fim dos anos 1970, o debate em torno da promoção da saúde e da redução das desigualdades sociais têm trazido novas perspectivas para o desenho de 
políticas, programas e intervenções na área (Salazar \& Anderson, 2008). O reconhecimento do papel e da responsabilidade dos governos locais sobre os determinantes econômicos, sociais e ambientais da saúde forjaram novos consensos em torno da importância do planejamento urbano, da gestão social e do desenvolvimento de ações intersetoriais sustentáveis convergindo em um espaçoterritório delimitado. A perspectiva das cidades saudáveis, construída tendo como base pressupostos e marcos reflexivos do campo da promoção da saúde, tem contribuído para o desenho de novas estratégias de intervenção em vários países. Nessa trajetória, questões mais amplas como a pobreza, a violência ou o perfil associativo local passaram a integrar a agenda da saúde na medida em que repercutem, impactam ou mesmo conformam o perfil sanitário da população. Com isso as iniciativas e programas tendem a se tornar mais dinâmicos e complexos, incorporando múltiplos parceiros, atores e contextos. O consenso é de que nenhuma organização agindo isoladamente pode agregar recursos, conhecimento, redes de apoio e confiança necessários para a melhoria das condições de saúde e bem-estar da população. A partir daí, profissionais e pesquisadores na área veem-se engajados na construção de alianças, mecanismos de cooperação e novas arenas de concertação. Nesse chamado redesenho do espaço sociossanitário a intersetorialidade emerge como uma estratégia prioritária para conferir novos contornos ao padrão tradicionalmente fragmentado das intervenções, garantir a convergência de práticas e saberes e, ainda, promover a integração entre recursos gerenciais, financeiros e humanos.

No entanto, existem várias barreiras para a implementação de ações conjuntas. Além das diferenças profundas no que se refere à capacidade institucional das organizações e setores, as assimetrias e desigualdades de poder entre agências estatais, setor privado e associações civis podem dificultar a implementação de parcerias. Outra barreira importante é o foco em objetivos imediatos ou de curto prazo. Ainda que tais parcerias sejam bem-sucedidas, ações intersetoriais envolvem a criação de laços de confiança que demandam tempo e continuidade. Além disso, as ações intersetoriais tendem a envolver investimentos diferenciados, de acordo com cada realidade local. Diante da complexa cadeia de negociações e compromissos que sustenta a ação intersetorial, é preciso identificar quais incentivos são prioritários. Na verdade, construir parcerias, condições para o diálogo e caminhos para cooperação a fim de gerar novos padrões de governança devem ser considerados resultados a serem alcançados, mas também estratégias para alcançar mudanças efetivas. Nesse aspecto, processos e resultados encontramse imbricados e atravessados pelas múltiplas influências de cada contexto. 
Assim, como verificar em que medida as ações intersetoriais estão sendo satisfatoriamente implementadas? Como identificar os principais obstáculos para a ação intersetorial? O que contribui para a intersetorialidade? O que inviabiliza a cooperação? Como perceber nexos significativos entre ações intersetoriais e maior efetividade dos programas no campo da promoção da saúde?

Para responder a tais questões é fundamental avançar no desenho de novas ferramentas metodológicas e estratégias avaliativas. Como analisam François Champagne e colaboradores (2009), a avaliação de intervenções complexas impõe abordagens conceituais e metodológicas capazes de promover o diálogo interdisciplinar. Para Huey-Tsyh Chen (1990), é importante ampliar a reflexão sobre a natureza dos programas buscando articular objetivos, processos de implementação e resultados. Com esse deslocamento, torna-se possível avaliar se o fracasso do programa resulta de falhas na implementação ou de inconsistências na teoria entendida aqui como o conjunto de concepções, princípios e proposições que explicam e orientam cada atividade ou componente da intervenção. Como ressaltam Leonard Rutman e George Mowbray (1983), programas expressam convicções sobre como alcançar mudanças. Compreender como tais ideias são implementadas e quais seus impactos tornam-se as principais tarefas para o avaliador. Esse esforço deve ser combinado com a percepção de deslocamentos e efeitos não previstos, favorecendo o uso de estratégias para contornar limites e obstáculos.

De acordo com Carol Weiss (1998), as teorias que orientam os programas não são necessariamente corretas ou consensuais, ao contrário, podem revelar ambiguidades, contradições e efeitos perversos. No desenho avaliativo do programa, porém, tais questões devem ser privilegiadas. Além disso, para a autora é preciso explorar o processo de tradução dos objetivos em atividades na dinâmica operacional da intervenção. Frequentemente existem discrepâncias entre o que foi previsto no desenho original do programa e os incentivos, interesses e valores dos atores envolvidos na implementação das ações. Ao privilegiar a base teórica do programa e sua relação com o contexto, é possível analisar inconsistências na formulação dos objetivos e/ou no desenho da implementação. Essa aproximação com os elementos cognitivos, sociais e culturais que podem estar sendo mobilizados no desenvolvimento das ações permite compreender como os efeitos são alcançados, quais as consequências não previstas e como se sustentam os modelos causais adotados. 


\section{A Abordagem Metodológica}

Como dito anteriormente, as ações intersetoriais envolvem complexas redes de parcerias e, em geral, estão imersas em contextos marcados pela diversidade de interesses e demandas. Partindo dessas constatações, o principal desafio da pesquisa foi desenvolver uma ferramenta metodológica capaz de incorporar tanto a teoria do programa e a teoria de implementação, como também as referências adotadas pelos atores envolvidos e os deslocamentos e adaptações realizadas no curso das atividades. Nessa direção, buscou-se sistematizar as teorias dos programas e respectivas teorias de implementação mediante a leitura de instrumentos normativos e documentos oficiais.

Para a pesquisa de campo, realizada entre 2008 e 2009 e aprovada no Comitê de Ética da Escola Nacional de Saúde Pública Sergio Arouca (Ensp/Fiocruz), desenvolveram-se roteiros semiestruturados dirigidos a 23 coordenadores dos programas, gestores locais, membros das equipes e profissionais envolvidos com o processo de implementação das ações intersetoriais previstas nos programas Bolsa Família e Estratégia Saúde da Família, em Manguinhos. Os roteiros foram organizados de acordo com os seguintes tópicos temáticos: percepções sobre a ação intersetorial; processo de implementação; resistências e mecanismos de adesão no curso das ações (e não apenas ao final dos programas) e identificação de mudanças de direção (positivas ou negativas). O objetivo era acompanhar os "programas em ação", ou seja, identificar a rede de atores e de arranjos institucionais concretos presentes no curso da implementação. Desse ponto de vista, mais do que descrever o conjunto de atividades e recursos utilizados para o alcance dos objetivos de cada programa, a ênfase maior foi dada à análise das relações entre atividades, recursos, atores e o contexto local.

Se a análise dos documentos e instrumentos normativos permitiu identificar modelos causais adotados nos respectivos programas, a realização de entrevistas em profundidade favoreceu a aproximação com as percepções, interesses e motivações dos profissionais envolvidos. Assim, a perspectiva foi articular duas dimensões que interagem permanentemente no curso dos programas: uma associada aos modelos lógicos e componentes estruturais das intervenções e outra ligada aos sentidos e significados atribuídos pelos atores no cotidiano das ações. 
As Teorias dos Programas Bolsa Família e Estratégia Saúde da Família

O Programa Bolsa Família busca garantir benefícios monetários para indivíduos ou famílias definidas como pobres e extremamente pobres, tendo por base critério de renda. No entanto, o pressuposto é que apenas a transferência de renda não reduz a pobreza de maneira sustentável. Com isso, medidas de curto e longo prazo voltadas à melhoria da educação e acesso a serviços básicos de saúde devem ser combinadas à transferência do recurso monetário. Condicionalidades, definidas como contrapartidas sociais, devem ser cumpridas pelo núcleo familiar para que seja mantido o auxílio financeiro. A execução das ações deve ser descentralizada e conjugar as diversas instâncias federativas. A intersetorialidade, assim como a participação comunitária e o controle social, são aspectos ressaltados na estrutura do programa.

Já no âmbito da Estratégia Saúde da Família, a territorialização e a vinculação comunitária das equipes de saúde - as quais incluem médicos, enfermeiras, odontólogos e agentes comunitários - são apontadas como estratégias para a reorientação do modelo assistencial. Embora a intersetorialidade não possa ser considerada um eixo estruturante do desenho original do programa, está presente na teoria de implementação na medida em que as ações de saúde devem responder às múltiplas demandas das famílias em cada contexto. Por exemplo, demandas como o acesso ao saneamento básico, ao transporte ou à habitação são incorporadas à agenda de saúde dos profissionais das equipes da Estratégia Saúde da Família.

A articulação entre os programas Bolsa Família e Saúde da Família no nível local previstas na teoria, sobretudo no processo de acompanhamento das contrapartidas sociais e condicionalidades pelas equipes da ESF, é vista como estratégia-chave para mais efetividade das ações no território.

\section{Intersetorialidade: teoria e prática}

Embora a intersetorialidade tenha se tornado um conceito inescapável nos campos da promoção da saúde e do desenvolvimento social, sua operacionalização é difícil. Nem sempre estão evidenciados os papéis e responsabilidades de cada parceiro ou setor. Além disso, construir processos de pactuação e colaboração envolve tempo, esforço e, na maioria das vezes, novos investimentos. Além disso, algumas informações e dados coletados sobre os programas podem 
suscitar reações negativas, constrangimentos ou mesmo representar ameaças aos profissionais envolvidos. Conhecendo de antemão tais barreiras, qual é o propósito da avaliação de ações intersetoriais? Após concluir o processo avaliativo, quais serão os avanços possíveis? De que forma os resultados poderão orientar mudanças substantivas no desenvolvimento dos programas?

Para equacionar tais dilemas, as estratégias avaliativas devem ser legitimadas mediante a discussão coletiva de pontos fortes e fracos. Se a perspectiva é utilizar os resultados da avaliação para a tomada de decisão, tal objetivo deve ser pactuado desde o início. Evidências de ações intersetoriais bem-sucedidas ou de fragilidades na condução das atividades devem ser reinterpretadas, de maneira contínua, pelos gestores, técnicos e profissionais. É preciso lembrar que os bancos de dados não falam por si mesmos. Neste sentido, a matriz organizada em dimensões e níveis considerados prioritários na dinâmica intersetorial pode contribuir para alimentar a cultura avaliativa local na medida em que as informações e dados produzidos no cotidiano sejam permanentemente articulados, debatidos e reincorporados aos processos decisórios.

Com base nessa perspectiva, apontou-se as seguintes dimensões avaliativas para o desenho da matriz: teoria do programa; processo de implementação local; reflexividade avaliativa; concepção de intersetorialidade; contexto da ação intersetorial e organização da relação entre os atores. É essencial ressaltar que a matriz pode e deve ser adaptada perante os objetivos da avaliação e às singularidades locais. Nesse exercício de adaptação é oportuno conciliar pontos de vista e avançar na combinação de diferentes técnicas como a observação local, a aplicação de questionários ou o desenvolvimento de grupos focais. No âmbito da pesquisa, as dimensões foram organizadas conforme se observa na Figura 1, a seguir.

Cada dimensão incluiu aspectos e informações específicas. Na dimensão Teoria do Programa e Mecanismos de Ação foram privilegiados dados que permitissem a compreensão do modelo lógico dos programas. Ao destinar recursos, definir os objetivos, conceber como a mudança pretendida será alcançada ou estabelecer cargos de gerência e coordenação, o desenho do programa reflete a institucionalização formal no caso dos programas pesquisados e, portanto, o que lhe atribui legitimidade e consistência. Dessa forma, o conjunto de informações sistematizadas nessa dimensão subsidiou a construção e a análise da teoria dos programas Bolsa Família e Estratégia Saúde da Família. No exemplo seguinte (Quadro 1) são apresentadas questões avaliativas presentes nessa dimensão e respectivas fontes de informação. 
Figura 1 - Dimensões da matriz avaliativa de ações intersetoriais

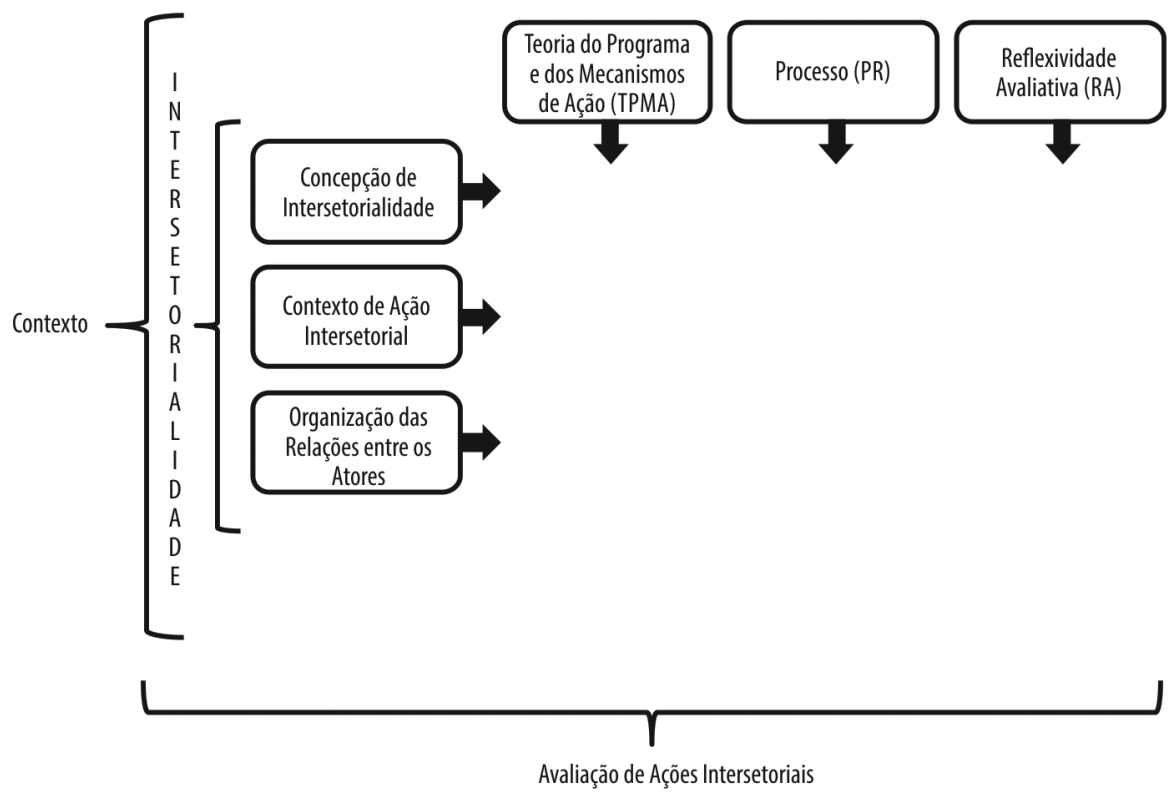

Quadro 1 - Dimensão Teoria do Programa

\begin{tabular}{|l|l|}
\hline Questões avaliativas & Fontes de informação \\
\hline $\begin{array}{l}\text { Quais são os objetivos do programa? } \\
\text { Quais são os principais recursos mobilizados pelo programa? } \\
\begin{array}{l}\text { Quais são as capacidades institucionais exigidas para a ação } \\
\text { intersetorial? }\end{array}\end{array}$ & $\begin{array}{l}\text { Análise de portarias, normas e } \\
\text { dispositivos legais dos programas. }\end{array}$ \\
\hline
\end{tabular}

Na dimensão Processo, exposta no Quadro 2, a preocupação central foi entender como o programa está sendo implementado e como são desenvolvidas as atividades previstas.

Quadro 2 - Dimensão Processo

\begin{tabular}{|c|c|}
\hline Questões avaliativas & Fontes de informação \\
\hline $\begin{array}{l}\text { Exemplo: Considerando o que estava previsto no programa, como } \\
\text { estão sendo desenvolvidas as atividades previstas? } \\
\text { Ocorreram mudanças ou adaptações? Quais foram as alternativas } \\
\text { adotadas? Foram incorporados novos atores? Quais? }\end{array}$ & $\begin{array}{l}\text { Entrevistas semiestruturadas } \\
\text { Observação direta } \\
\text { Análise documental (pautas, } \\
\text { relatórios, comunicados, atas de } \\
\text { reunião etc.) }\end{array}$ \\
\hline
\end{tabular}

Na dimensão Reflexividade Avaliativa, exibida no Quadro 3, a preocupação foi captar os pontos fracos e pontos fortes dos programas selecionados. Buscou-se identificar os fatores que favorecem ou impedem a utilização das estratégias e mecanismos previstos na teoria do programa, oferecendo feedback e suporte ao 
processo de tomada de decisão, além de sistematizar aprendizados, adaptações e inovações no decorrer da implementação das iniciativas.

Quadro 3 - Dimensão Reflexividade Avaliativa

\begin{tabular}{|l|l|}
\hline Questões avaliativas & Fontes de informação \\
\hline $\begin{array}{l}\text { Exemplo: Considerando o contexto e o processo de implementação, } \\
\text { a teoria do programa é consistente? }\end{array}$ & $\begin{array}{l}\text { Análise das relações entre as } \\
\text { subdimensões }\end{array}$ \\
$\begin{array}{l}\text { As mudanças contribuíram para a sustentabilidade das ações } \\
\text { intersetoriais no âmbito dos programas? }\end{array}$ & $\begin{array}{l}\text { Entrevistas e grupos focais } \\
\text { (gestores, técnicos, profissionais }\end{array}$ \\
& e usuários) \\
& Observação direta \\
& Análise documental (pautas, \\
& relatórios etc.) \\
\hline
\end{tabular}

Na dimensão Concepção da Intersetorialidade (Quadro 4), o objetivo foi caracterizar como a intersetorialidade é apreendida e, também, o grau de centralidade no desenho e implementação do programa. Apesar de a intersetorialidade ter se tornado uma diretriz recorrente nos programas e iniciativas no campo da promoção da saúde, seu significado pode ser distinto em cada iniciativa. É razoável supor que a falta de clareza ou concepções conflitantes sobre a ação intersetorial impactam negativamente o alcance dos objetivos previstos.

Quadro 4 - Dimensão Concepção de Intersetorialidade

\begin{tabular}{|l|l|}
\hline Questões avaliativas & Fontes de informação \\
\hline Exemplo: Como a ação intersetorial contribui para a mudança da & Entrevistas semiestruturadas \\
situação-problema? & Observação direta \\
& $\begin{array}{l}\text { Análise documental (relatórios, } \\
\text { atas de reunião, portarias, normas }\end{array}$ \\
\hline
\end{tabular}

Na dimensão Contexto da Ação Intersetorial (Quadro 5), a aproximação com a realidade local permitiu compreender quando e como os mecanismos utilizados podem ser associados aos resultados pretendidos, considerando as especificidades do contexto.

Quadro 5 - Dimensão Contexto da Ação Intersetorial

\begin{tabular}{|l|l|}
\hline Questões avaliativas & Fontes de informação \\
\hline Exemplo: Quais são os aspectos locais e fatores contextuais que & Entrevistas semiestruturadas \\
tendem a favorecer ou dificultar a ação intersetorial? & Observação direta \\
& $\begin{array}{l}\text { Análise documental (pautas, } \\
\text { relatórios, comunicados, atas de }\end{array}$ \\
\hline
\end{tabular}


A dimensão Organização das Relações entre os Atores (Quadro 6) buscou explorar papéis e atribuições, mecanismos de participação social e contornos da dinâmica decisória, além das estratégias para a promoção de mais adesão e apoio entre os atores envolvidos.

Quadro 6 - Dimensão Organização das Relações entre os Atores

\begin{tabular}{|l|l|}
\hline Questões avaliativas & Fontes de informação \\
\hline Exemplo: Quais são os papéis e as atribuições de cada ator na ação & Entrevistas semiestruturadas \\
intersetorial? & Observação direta \\
Existem canais permanentes para favorecer o diálogo entre os & Análise documental (relatórios, \\
gestores, profissionais e atores relevantes? & atas de reunião, portarias, normas \\
Como são resolvidas as controvérsias e conflitos? & e dispositivos legais) \\
\hline
\end{tabular}

Em linhas gerais, cada dimensão da matriz permite caracterizar a relação entre atores e recursos, favorecendo a aproximação com a dinâmica da implementação dos programas e ações intersetoriais no contexto local. Pontos positivos e fragilidades são identificados no desenho lógico dos programas e no fluxo cotidiano das atividades, permitindo uma maior reflexão sobre as alternativas adotadas, escolhas e mecanismos de responsabilização dos atores locais. A análise relacional das dimensões, dispostas em colunas e linhas, geram subdimensões, como pode ser visto na Figura 2.

Figura 2 - Matriz avaliativa de ações intersetoriais

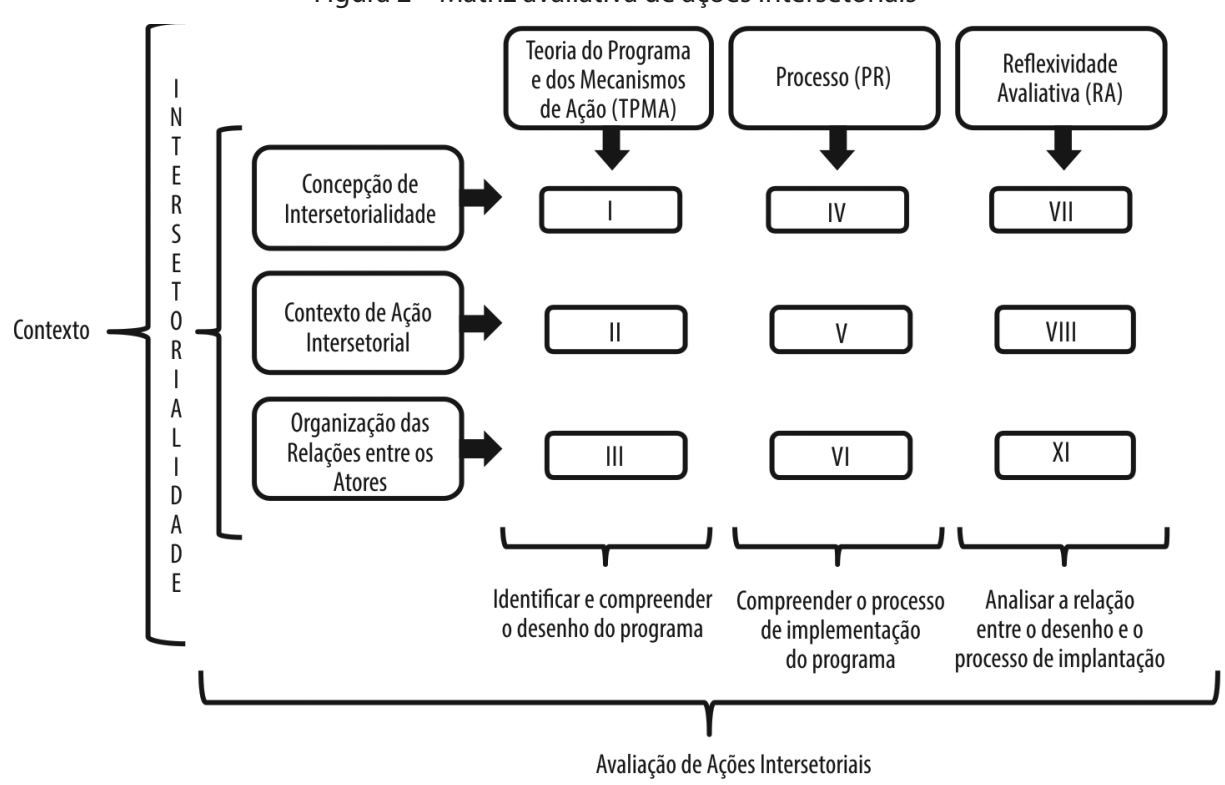


Cada subdimensão foi estruturada tendo por base questões avaliativas, favorecendo a compreensão das especificidades locais, como pode ser observado nos Quadros 7 a 15.

Quadro 7 - Concepção da Intersetorialidade na Teoria do Programa

\begin{tabular}{|l|l|l|}
\hline Subdimensão & Pontos de referência & Questões avaliativas \\
\hline $\begin{array}{l}\text { (I) Concepção da } \\
\text { Intersetorialidade na } \\
\text { Teoria do Programa }\end{array}$ & $\begin{array}{l}\text { 1.1. A presença e a centralidade da } \\
\text { intersetorialidade no programa }\end{array}$ & $\begin{array}{l}\text { - Como é afirmado o princípio da } \\
\text { intersetorialidade para o programa? } \\
\text { - O programa identifica a ação } \\
\text { intersetorial como estratégia } \\
\text { fundamental para o alcance dos } \\
\text { objetivos do programa? Como? }\end{array}$ \\
\cline { 2 - 3 } & $\begin{array}{l}\text { 1.2. Situação-problema que a ação } \\
\text { intersetorial busca resolver }\end{array}$ & $\begin{array}{l}\text { - Qual(is) o(s)problema(s) que o } \\
\text { programa procura resolver através da } \\
\text { ação intersetorial? }\end{array}$ \\
\cline { 2 - 3 } & $\begin{array}{l}\text {-Como a ação intersetorial contribui } \\
\text { para a mudança prevista no programa? }\end{array}$ \\
\cline { 2 - 3 } & 1.3. Atores previstos & $\begin{array}{l}\text { - As ações previstas no programa } \\
\text { envolvem quais setores, áreas e níveis? }\end{array}$ \\
\hline
\end{tabular}

Quadro 8 - Contexto da Ação Intersetorial na Teoria do Programa

\begin{tabular}{|l|l|l|}
\hline Subdimensão & Pontos de referência & Questões avaliativas \\
\hline $\begin{array}{l}\text { (II) Contexto da Ação } \\
\begin{array}{l}\text { Intersetorial na Teoria } \\
\text { do Programa }\end{array}\end{array}$ & $\begin{array}{l}\text { 2.1. Adequação ao contexto como } \\
\text { algo previsto no desenho lógico do } \\
\text { programa }\end{array}$ & $\begin{array}{l}\text { • A teoria do programa prevê adequação } \\
\text { ao contexto? }\end{array}$ \\
\hline
\end{tabular}

Quadro 9 - Organização e Dinâmica da Relação entre Atores na Teoria do Programa

\begin{tabular}{|c|c|c|}
\hline Subdimensão & Pontos de referência & Questões avaliativas \\
\hline \multirow[t]{4}{*}{$\begin{array}{l}\text { (III) Organização e } \\
\text { Dinâmica da Relação } \\
\text { entre os Atores na } \\
\text { Teoria do Programa }\end{array}$} & $\begin{array}{l}\text { 3.1. Definição de atribuições de } \\
\text { cada ator }\end{array}$ & $\begin{array}{l}\text { - Como o programa prevê a organização } \\
\text { das relações entre os atores e das } \\
\text { parcerias? } \\
\text { - Quais são as atribuições de cada } \\
\text { parceiro definidas no programa? }\end{array}$ \\
\hline & 3.2. Definição da participação social & $\begin{array}{l}\text { - Quais os mecanismos de participação } \\
\text { social previstos na ação intersetorial? } \\
\text { - Quem está previsto a participar? }\end{array}$ \\
\hline & 3.3. Previsão de novas parcerias & $\begin{array}{l}\text { - O programa prevê a possibilidade } \\
\text { de novas parcerias ao longo da } \\
\text { implementação? }\end{array}$ \\
\hline & $\begin{array}{l}\text { 3.4. Definição de mecanismos para } \\
\text { aproximação de setores e/ou níveis }\end{array}$ & $\begin{array}{l}\text { - Quais os mecanismos institucionais } \\
\text { previstos no âmbito do programa } \\
\text { para aproximar os setores e/ou níveis } \\
\text { (e.g. comissões intersetoriais, grupos } \\
\text { de trabalho, espaços institucionais } \\
\text { intersetoriais)? }\end{array}$ \\
\hline
\end{tabular}


Quadro 9 (cont.) - Organização e Dinâmica da Relação entre Atores na Teoria do Programa

\begin{tabular}{|l|l|l|}
\hline Subdimensão & Pontos de referência & Questões avaliativas \\
\hline $\begin{array}{l}\text { (III) Organização e } \\
\begin{array}{l}\text { Dinâmica da Relação } \\
\text { entre os Atores na } \\
\text { Teoria do Programa }\end{array}\end{array}$ & $\begin{array}{l}\text { 3.5. Definição de espaços de } \\
\text { concertação entre os parceiros }\end{array}$ & $\begin{array}{l}\text { • O programa prevê a existência } \\
\text { de espaços de concertação entre } \\
\text { os parceiros (espaços decisórios } \\
\text { intersetoriais etc.) } \\
\text { • Quem faz parte desses espaços } \\
\text { decisórios? }\end{array}$ \\
\cline { 2 - 3 } & $\begin{array}{l}\text { 3.6. Compartilhamento de } \\
\text { informações }\end{array}$ & $\begin{array}{l}\text { • O programa prevê o } \\
\text { compartilhamento de informações } \\
\text { (banco de dados unificado e meios de } \\
\text { divulgação)? }\end{array}$ \\
\cline { 2 - 3 } & $\begin{array}{l}\text { 3.7. Estratégias previstas para } \\
\text { promover adesão e apoio dos } \\
\text { parceiros e a sustentabilidade da } \\
\text { ação intersetorial }\end{array}$ & $\begin{array}{l}\text { • Quais as estratégias previstas } \\
\text { para promover adesão e apoio dos } \\
\text { parceiros e a sustentabilidade da ação } \\
\text { intersetorial? } \\
\text { • As atribuições de cada setor previstas } \\
\text { no programa colocam exigências } \\
\text { concretas de gestão que podem } \\
\text { favorecer (facilitar) o diálogo? }\end{array}$ \\
\hline
\end{tabular}

Quadro 10 - Concepção da Intersetorialidade no Processo de Implementação

\begin{tabular}{|l|l|l|}
\hline Subdimensão & Pontos de referência & Questões avaliativas \\
\hline $\begin{array}{l}\text { (IV) Concepção de } \\
\text { Intersetorialidade } \\
\text { no Processo de } \\
\text { Implementação }\end{array}$ & $\begin{array}{l}\text { 4.1 Mudanças na composição das } \\
\text { equipes }\end{array}$ & $\begin{array}{l}\text { • Houve alguma mudança em relação } \\
\text { aos atores previstos? Quais as principais } \\
\text { motivações para as mudanças } \\
\text { adotadas? }\end{array}$ \\
\cline { 2 - 3 } & $\begin{array}{l}\text { 4.2. Importância do } \\
\text { compartilhamento de interesses, } \\
\text { valores e objetivos no que se refere } \\
\text { à ação intersetorial }\end{array}$ & $\begin{array}{l}\text { • Para os atores-chave, qual a } \\
\text { importância da intersetorialidade para a } \\
\text { realização dos objetivos do programa? } \\
\text { • Os atores-chave compartilham } \\
\text { interesses, valores e objetivos em } \\
\text { relação à ação intersetorial? }\end{array}$ \\
\hline
\end{tabular}

Quadro 11 - Contexto da Ação Intersetorial no Processo de Implementação

\begin{tabular}{|l|l|l|}
\hline Subdimensão & Pontos de referência & Questões avaliativas \\
\hline $\begin{array}{l}\text { (V) Contexto da } \\
\text { Ação Intersetorial } \\
\text { no Processo de } \\
\text { Implementação }\end{array}$ & $\begin{array}{l}\text { 5.1. Mudanças na ação intersetorial } \\
\text { em função do contexto (local ou } \\
\text { político-institucional) }\end{array}$ & $\begin{array}{l}\text { • Como os atores avaliam a ação } \\
\text { intersetorial no contexto local? } \\
\text { • O que mudou no processo de } \\
\text { implementação intersetorial? Quais as } \\
\text { principais influências do contexto local } \\
\text { para a adoção de novas alternativas de } \\
\text { ação? }\end{array}$ \\
\hline
\end{tabular}


Quadro 12 - Organização e Dinâmica da Relação entre Atores no Processo de Implementação

\begin{tabular}{|c|c|c|}
\hline Subdimensões & Pontos de referência & Questões avaliativas \\
\hline \multirow[t]{8}{*}{$\begin{array}{l}\text { (VI) Organização e } \\
\text { Dinâmica da Relação } \\
\text { entre os Atores } \\
\text { no Processo de } \\
\text { Implementação }\end{array}$} & $\begin{array}{l}\text { 6.1. Atribuições de cada ator e } \\
\text { mudanças nas parcerias }\end{array}$ & $\begin{array}{l}\text { - Como são organizadas as relações } \\
\text { entre os parceiros (setores e níveis de } \\
\text { colaboração)? } \\
\text { - Foram estabelecidas novas parcerias e } \\
\text { incorporados novos atores? } \\
\text { - Quais são as atribuições de cada } \\
\text { parceiro? } \\
\text { - Como são definidas as atividades e } \\
\text { atribuições de cada parceiro? Quais as } \\
\text { principais mudanças adotadas? }\end{array}$ \\
\hline & $\begin{array}{l}\text { 6.2. Concepções dos atores sobre } \\
\text { seu papel na sustentabilidade da } \\
\text { ação intersetorial }\end{array}$ & $\begin{array}{l}\text { - Qual a concepção dos atores sobre seu } \\
\text { papel no processo de implementação } \\
\text { das ações intersetoriais? }\end{array}$ \\
\hline & $\begin{array}{l}\text { 6.3. Existência de atividades de } \\
\text { capacitação }\end{array}$ & $\begin{array}{l}\text { • Existe capacitação para o } \\
\text { desenvolvimento das ações } \\
\text { intersetoriais? Quem participa? } \\
\text { - Como as estratégias de capacitação } \\
\text { são desenvolvidas no contexto local? }\end{array}$ \\
\hline & 6.4. Participação social & $\begin{array}{l}\text { - Quais o(s) mecanismo(s) de } \\
\text { participação existentes no contexto } \\
\text { local? } \\
\text { - Quem participa e quais são as } \\
\text { principais motivações e incentivos? }\end{array}$ \\
\hline & $\begin{array}{l}\text { 6.5. Mecanismos de aproximação } \\
\text { entre setores e/ou níveis }\end{array}$ & $\begin{array}{l}\text { - Quais os mecanismos institucionais } \\
\text { utilizados para aproximar os setores e/ } \\
\text { ou níveis? } \\
\text { - Quem participa desses espaços de } \\
\text { concertação e diálogo? }\end{array}$ \\
\hline & $\begin{array}{l}\text { 6.6. Espaços de concertação entre } \\
\text { os parceiros }\end{array}$ & $\begin{array}{l}\text { - Quem participa dos espaços } \\
\text { decisórios? } \\
\text { - Quais foram as principais decisões } \\
\text { tomadas a partir de pactos entre } \\
\text { setores? } \\
\text { - Como os setores desenvolvem } \\
\text { estratégias para solução dos conflitos? }\end{array}$ \\
\hline & $\begin{array}{l}\text { 6.7. Compartilhamento de } \\
\text { informações }\end{array}$ & $\begin{array}{l}\text { - Há compartilhamento de informações } \\
\text { (banco de dados unificado, meios de } \\
\text { divulgação, atas periódicas)? Como é } \\
\text { realizada a análise e sistematização das } \\
\text { informações? }\end{array}$ \\
\hline & $\begin{array}{l}\text { 6.8. Adesão e apoio dos parceiros } \\
\text { e a sustentabilidade da ação } \\
\text { intersetorial }\end{array}$ & $\begin{array}{l}\text { - Quais são as principais estratégias } \\
\text { utilizadas para promover adesão e } \\
\text { apoio dos parceiros? } \\
\text { - Quais as principais motivações para } \\
\text { a participação dos atores na dinâmica } \\
\text { intersetorial? }\end{array}$ \\
\hline
\end{tabular}


Quadro 13 - Concepção da Intersetorialidade na Reflexividade Avaliativa

\begin{tabular}{|l|l|l|}
\hline Subdimensão & Pontos de referência & Questões avaliativas \\
\hline $\begin{array}{l}\text { (VII) Concepção da } \\
\text { Intersetorialidade } \\
\text { na Reflexividade } \\
\text { Avaliativa }\end{array}$ & $\begin{array}{l}\text { 7.1. Avaliação da adequação e do } \\
\text { grau de compartilhamento de } \\
\text { interessses, valores e objetivos em } \\
\text { relação à ação intersetorial }\end{array}$ & $\begin{array}{l}\text { • A ação intersetorial adotada é } \\
\text { adequada à mudança almejada pelo } \\
\text { programa? Como a ação intersetorial } \\
\text { contribui para a mudança proposta? } \\
\text { - Como os objetivos e interesses dos } \\
\text { atores envolvidos afetam as ações } \\
\text { intersetoriais? }\end{array}$ \\
\cline { 2 - 3 } & $\begin{array}{l}\text { 7.2. Repercussões da ação } \\
\text { intersetorial no que se refere à } \\
\text { dinâmica dos atores envolvidos }\end{array}$ & $\begin{array}{l}\text { - Considerando o que estava previsto } \\
\text { quais são as repercussões (positivas e } \\
\text { negativas) para as ações intersetoriais? } \\
\text { - Como os resultados obtidos } \\
\text { influenciam as expectativas dos } \\
\text { atores-chave em relação às ações } \\
\text { intersetoriais? }\end{array}$ \\
\hline
\end{tabular}

Quadro 14 - Contexto da Ação Intersetorial na Reflexividade Avaliativa

\begin{tabular}{|c|c|c|}
\hline Subdimensão & Pontos de referência & Questões avaliativas \\
\hline $\begin{array}{l}\text { (VIII) Contexto da } \\
\text { Ação Intersetorial } \\
\text { na Reflexividade } \\
\text { Avaliativa }\end{array}$ & $\begin{array}{l}\text { 8.1. Repercussões das mudanças } \\
\text { na ação intersetorial em função } \\
\text { do contexto (local ou político- } \\
\text { institucional) }\end{array}$ & $\begin{array}{l}\text { - Quais foram os fatores contextuais } \\
\text { que favoreceram e que dificultaram a } \\
\text { implementação das ações intersetoriais? } \\
\text { - Como esses fatores afetaram a } \\
\text { implementação do programa? } \\
\text { - Quais estratégias utilizadas para } \\
\text { neutralizar os fatores contextuais } \\
\text { negativos e potencializar os fatores } \\
\text { positivos? }\end{array}$ \\
\hline
\end{tabular}

Quadro 15 - Organização e Dinâmica da Relação entre Atores na Reflexividade Avaliativa

\begin{tabular}{|c|c|c|}
\hline Subdimensões & Pontos de referência & Questões avaliativas \\
\hline $\begin{array}{l}\text { (IX) Organização e } \\
\text { Dinâmica da Relação } \\
\text { entre os Atores } \\
\text { na Reflexividade } \\
\text { Avaliativa }\end{array}$ & $\begin{array}{l}\text { 9.1. Relações entre os parceiros e a } \\
\text { ação intersetorial }\end{array}$ & $\begin{array}{l}\text { - Como as relações entre os parceiros } \\
\text { afetam as ações intersetoriais? } \\
\text { - Quais são as repercussões (positivas e/ } \\
\text { ou negativas) das mudanças em relação } \\
\text { às parcerias previstas e às atribuições de } \\
\text { cada parceiro para a dinâmica das ações } \\
\text { intersetoriais? } \\
\text { - Em relação à participação social, quais } \\
\text { são os principais obstáculos? } \\
\text { • Em relação aos mecanismos } \\
\text { institucionais para aproximar os } \\
\text { setores e/ou níveis, como as mudanças } \\
\text { afetam as ações intersetoriais? Quais } \\
\text { são os principais obstáculos para a } \\
\text { aproximação dos setores e/ou níveis? Os } \\
\text { mecanismos utilizados para aproximar } \\
\text { os setores foram bem-sucedidos? Por } \\
\text { quê? }\end{array}$ \\
\hline
\end{tabular}


Quadro 15 (cont.) - Organização e Dinâmica da Relação entre Atores na Reflexividade Avaliativa

\begin{tabular}{|l|l|l|}
\hline Subdimensões & Pontos de referência & Questões avaliativas \\
\hline $\begin{array}{l}\text { (IX) Organização e } \\
\text { Dinâmica da Relação } \\
\text { entre os Atores } \\
\text { na Reflexividade } \\
\text { Avaliativa }\end{array}$ & $\begin{array}{l}\text { 9.1. Relações entre os parceiros e a } \\
\text { ação intersetorial }\end{array}$ & $\begin{array}{l}\text { • Em relação aos espaços de diálogo, } \\
\text { como as mudanças afetam a relação } \\
\text { entre os atores? Quais são os principais } \\
\text { obstáculos para o funcionamento } \\
\text { desses espaços? } \\
\text { • Como o fluxo de informações afeta a } \\
\text { ação intersetorial? } \\
\text { • Os incentivos para a adesão são } \\
\text { adequados? De que forma as estratégias } \\
\text { adotadas afetaram a relação entre os } \\
\text { atores? }\end{array}$ \\
\cline { 3 - 4 } & 9.2. Lições aprendidas & $\begin{array}{l}\text { - Quais são as lições aprendidas? } \\
\text { • Quais estratégias têm sido utilizadas } \\
\text { para neutralizar os fatores negativos e } \\
\text { potencializar os fatores positivos? } \\
\text { • O que poderia ser transformado para } \\
\text { garantir maior sustentabilidade das } \\
\text { ações intersetoriais? }\end{array}$ \\
\hline
\end{tabular}

\section{Discussão}

Um dos maiores desafios metodológicos para a avaliação de intervenções complexas no campo da promoção da saúde é estender o alcance das lições apreendidas em um dado contexto local sem perder seu significado e coerência. Para enfrentar esse dilema, ferramentas e estratégias avaliativas devem buscar reconstruir o processo de implementação dos programas e intervenções e descobrir o quanto existe de adaptação e de fidelidade ao desenho original em cada realidade (Patton, 2008). Também é importante reconhecer e discriminar quais são os componentes do programa que tendem a revelar maior dependência do contexto local de implementação (Potvin, Haddad \& Frohlich, 2001). Essa tarefa não é trivial. Além das próprias comunidades e grupos de interesse, instituições e arenas decisórias aparentemente estáveis também são reconformadas ou podem reagir a circunstâncias específicas de maneira não prevista. No entanto, a avaliação de possíveis discrepâncias em relação ao desenho original das intervenções e seus efeitos nos diferentes cenários institucionais e sociais pode contribuir efetivamente para orientar decisões sobre a expansão ou continuidade das ações de promoção da saúde e desenvolvimento social. Mas, para avançar nesse caminho é preciso confrontar os componentes teóricos dos programas os quais sustentam a plausibilidade dos resultados esperados - com os padrões concretos de interação entre instituições, recursos e atores no cotidiano local. Como aponta Peter Dahler-Larsen (2001), a relevância do estudo da teoria do 
programa no processo avaliativo reside na possibilidade de captar sua relação com o contexto.

A construção de acordos e a negociação sobre as alternativas a serem adotadas para a implementação de ações intersetoriais deve ser permanentemente valorizada. Nesse aspecto, é importante garantir mais conhecimento sobre os limites e possibilidades de cada iniciativa. Em algumas experiências os focos em territórios ou em grupos específicos - mulheres ou jovens, por exemplo -, ou ainda em problemáticas específicas como violência ou desemprego, favorecem o diálogo entre diferentes instituições, setores, especialistas, técnicos e comunidades. Porém, nesse caso é importante compreender como permanecem ou são resolvidas possíveis superposições hierárquicas ou, ainda, de que maneira aprendizados e experiências anteriores influenciam a percepção sobre a natureza das ações intersetoriais. Por exemplo, a questão da alimentação saudável nas escolas implica desenvolvimento de ações conjuntas envolvendo o comércio local, professores, famílias, agentes da saúde, a fim de ampliar os efeitos positivos a longo prazo. O trabalho intersetorial tendo por base um problema ou questão em um espaço social definido deve buscar garantir maior afinidade entre gestores, profissionais, famílias e múltiplos atores. Ações intersetoriais envolvem colaboração vertical e horizontal. A aproximação entre instituições estatais e privadas pode favorecer um circuito virtuoso capaz de mobilizar redes de recursos, práticas e saberes.

No entanto, poucas vezes os gestores e agentes implementadores têm clareza sobre o desenho lógico dos programas ou a consistência entre as atividades e a natureza das metas previstas. Além disso, frequentemente antes que a intervenção avance em rotinas, atribuições e papéis definidos, conflitos em torno da alocação de recursos ou do fluxo de informações, por exemplo, podem emergir dificultando o fortalecimento de laços de confiança necessários para uma agenda comum. Nos programas e ações intersetoriais é razoável supor que desacordos e controvérsias tendem a crescer na mesma proporção em que avança a complexidade das parcerias e alianças exigidas.

Nesse sentido, matrizes são ferramentas que contribuem para analisar e reorientar o processo de hierarquização e sistematização de informações. O intrumento, associado às demais estratégias avaliativas, apóia a investigação sobre como e por que as ações alcançam os efeitos pretendidos. Assim, considera-se que a matriz avaliativa, construída considerando as múltiplas fontes de informação e pesquisa qualitativa com atores locais, é um roteiro útil para captar os contornos das ações intersetoriais no campo da promoção da saúde. No entanto, a validade 
e a consistência interna da matriz apresentada neste capítulo estão vinculadas à sua aplicação e adaptação em cada realidade.

\section{Considerações Finais}

A intersetorialidade pode ser entendida como uma articulação estratégica para a convergência e integração de recursos gerenciais, financeiros e humanos com o objetivo de dar novos contornos ao padrão tradicionalmente fragmentado das intervenções públicas. Essa natureza complexa das ações intersetoriais apoiadas necessariamente em laços de confiança, canais de colaboração e negociação permanente envolve conflitos de interesse, incertezas e controvérsias em relação às possíveis mudanças no processo decisório. Assim, a intersetorialidade é um alvo e ao mesmo tempo um desafio.

Considerando a análise das teorias e dos processos de implementação local de programas voltados à ampliação da atenção básica, promoção da saúde e redução da pobreza, desenvolvemos uma matriz com questões que julgamos plausíveis diante da dinâmica e complexidade das ações intersetoriais locais. A ferramenta proposta aqui não é suficiente para a avaliação dos resultados finais das intervenções. No entanto, a matriz contribui para reconhecer os limites para a integração vertical e horizontal das ações, a relevância da perspectiva intersetorial para os atores-chave e os obstáculos a serem enfrentados no curso das iniciativas, estimulando a apropriação coletiva de informações relevantes, a revisão de estratégias e mudanças incrementais. 


\section{Referências}

ALLARD, D.; BILODEAU, A. \& GENDRON, S. Figurative Thinking and models; tools for participatory evaluation. In: POTVIN, L. \& McQUEEN, D. Health Promotion Evaluation Practices in the Americas: values and research. New York: Springer, 2008.

BRASIL. Ministério da Saúde. Saúde da Família: uma estratégia para a reorientação do modelo assistencial. Brasília: Ministério da Saúde, 1998.

BRASIL. Ministério do Desenvolvimento Social e Combate à Fome. Secretaria Nacional de Renda e Cidadania. Análise da pesquisa sobre gestão descentralizada, Programa Bolsa Família. Disponível em: <www.mds.gov.br/bolsa familia/manuaisepublicações>. Acesso em: 28 dez. 2010.

CHAMPAGNE, F.et al. L'évaluation dans le domaine de la santé: concepts et methods. In: BROUSSELLE, A. et al. Lévaluation: concepts et methods. Montréal: Les Presses de l'Université de Montreal, 2009.

CHEN, T. H. Theory-driven Evaluations. London: Sage, 1990.

DAHLER-LARSEN, P. From programme theory to constructivism. Evaluation, 7(3): 331-349, 2001.

PATTON, M. Q. Utilization-focused Evaluation. 4. ed. London: Sage, 2008.

POTVIN, L.; HADDAD, S. \& FROHLICH, K. L. Beyond process \& outcome evaluation: a comprehensive approach for evaluating health promotion programmes. In: ROOTMAN, I. et al. (Eds.). Evaluation in Health Promotion: principles \& perspective. Copenhagen: WHO Regional Publications, 2001. (European Series, 92)

RUTMAN, L. \& MOWBRAY, G. Understanding Programa Evaluation. London: Sage, 1983.

SALAZAR, L. \& ANDERSON, M. L. Health promotion in the Americas: divergent and common ground. In: POTVIN, L. \& McQUEEN, D. Health Promotion Evaluation Practices in the Americas: values and research. New York: Springer, 2008.

WEISS, C. Evaluation. New Jersey: Prentice Hall, 1998. 


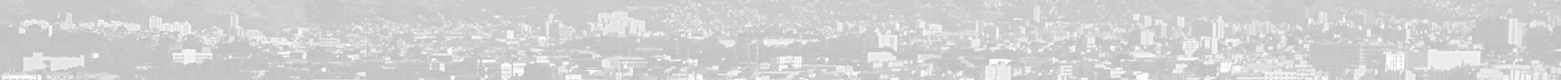
and

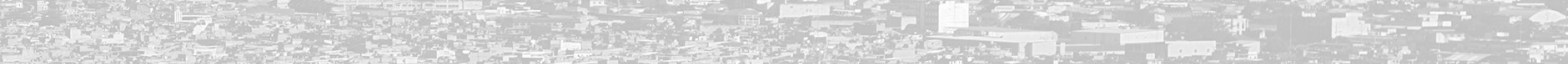

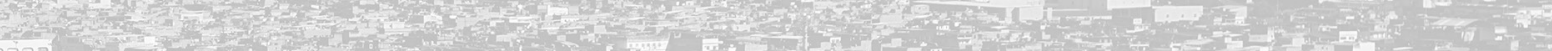

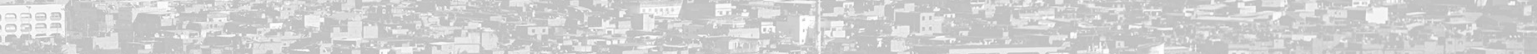

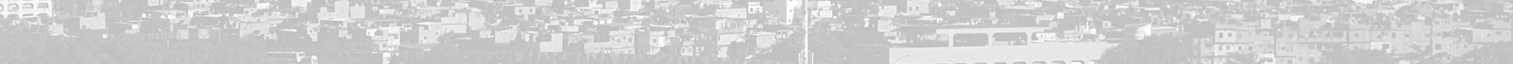

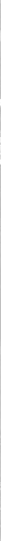




\title{
9
}

\section{Políticas Públicas Urbanas para uma Cidade Saudável: 100 anos de história em Manguinhos}

\author{
Renato Gama-Rosa Costa • Tania Maria Fernandes \\ Letícia de Luna Freire $\cdot$ Monica Dias de Souza $\cdot$ Maria das Mercês Navarro
}

F ste capítulo apresenta algumas reflexões do Projeto Manguinhos - Diagnóstico saúde, desenvolvido pela Casa de Oswaldo Cruz, da Fundação Oswaldo Cruz (COC/Fiocruz). O texto procura apontar as principais ideias encaminhadas por seus componentes, tendo por base a interdisciplinaridade que envolveu o projeto, mediante o olhar das diversas áreas às quais os profissionais envolvidos se vinculam - arquitetura e urbanismo, história, antropologia, sociologia e educação.

O objetivo da proposta se traduz na convicção de que a produção de conhecimento é um requisito básico para a implantação de metodologias, processos e tecnologias sociais capazes de subsidiar a formulação e a execução eficiente e democrática de políticas públicas. A equipe entende que o esforço de implantação do modelo de cidade saudável implica a admissão e compreensão das especificidades locais nas suas multifacetadas dimensões. A afirmação de padrões ideais de promoção de um estilo de vida saudável pressupõe compreender os conceitos de saúde e de qualidade de vida associados às singularidades socioculturais resultantes de processos históricos, nas quais são construídas as formas de coexistência entre as populações urbanas.

Dessa compreensão resultou a proposta de se acompanhar as ações do Programa de Aceleração do Crescimento (PAC) em Manguinhos, cuja implantação 
coincidiu com o início do projeto de pesquisa, buscando um diálogo fecundo com o estudo anteriormente realizado sobre o processo de formação desse território (Fernandes \& Costa, 2009). O projeto teve como propósito acompanhar em tempo real a implantação de uma política pública urbana. Numa perspectiva antropológica, que pressupõe a tentativa de se construir uma relação de simetria, de interlocução consentida, realizou-se trabalho de campo em duas localidades de Manguinhos, com observação direta e participante além da realização de entrevistas, a fim de se apreender a implantação do PAC pela ótica dos moradores da região, diretamente afetados.

Como desdobramento do projeto, alguns dados subsidiaram a criação de um jogo didático, intitulado Unidos para produzir um lugar saudável, que passou a compor o acervo do Museu da Vida, da Casa de Oswaldo Cruz, e que tem sido utilizado no desenvolvimento de ações educativas junto de estudantes das escolas públicas existentes no entorno do campus da Fiocruz, em especial as situadas em Manguinhos.

Com base nos resultados do projeto, este capítulo busca produzir uma reflexão sobre características necessárias para políticas públicas urbanas na perspectiva de que estas não considerem as favelas como tumores a serem extirpados do corpo da cidade e, sim, como parte integrante dela. O foco na saúde e na melhoria da qualidade de vida perpassa várias ações que propõem fortalecer a integração em processos de intervenção direta sobre o território. ${ }^{1}$

A ideia de cidade saudável é hoje, ao mesmo tempo, conceito e instrumento, a ser incorporado no planejamento urbano, ${ }^{2}$ que se relaciona às propostas de elaboração de uma política de promoção à saúde, tendo como foco a qualidade de vida diante do crescimento das cidades e seus eventuais danos. Situa-se numa perspectiva de intersetorialidade, de modo que a promoção à saúde se torne uma referência estratégica para ações no conjunto de políticas públicas, com vistas a ampliar a oferta de serviços para além do campo da assistência. ${ }^{3}$

\footnotetext{
${ }^{1}$ Considera-se aqui 0 conceito de território, com base no pensamento de Milton Santos. Para 0 autor, 0 território se configura como principal instância da sociedade, capaz de revelar mediações e contradições, quando observado para além do espaço físico, com incorporação de seus atores, suas competitividades, seus interesses, seus conflitos e negociações em virtude de uma regulação unificadora ou de uma fragmentação social e geográfica (Seabra, Carvalho \& Leite, 2006).

20 movimento de promoção de cidades saudáveis constitui uma iniciativa da Organização Mundial da Saúde (OMS) para 0 desenvolvimento das condições de saúde e qualidade de vida urbanas, que resultaria de uma estratégia de planejamento urbano, sistemático, contínuo e intersetorial.
}

${ }^{3}$ Ver Keinert (1997). 
Algumas Reflexões sobre as Contribuições para o Tema Cidade Saudável

Preocupado com o crescimento das cidades em consequência de transformações acumuladas desde a revolução industrial, que ocasionaram profundas mudanças no meio urbano europeu, um grupo de urbanistas, atuantes na passagem do século XIX para o XX, formulou teorias sobre a cidade e sua população. Antes dos urbanistas e arquitetos, outros estudiosos se dedicaram aos temas relacionados ao espaço urbano, como médicos, historiadores, sociólogos, antropólogos e filósofos, tanto em estudos reflexivos, como participantes na elaboração de projetos voltados para a constituição e as transformações do espaço das cidades.

Uma das possíveis leituras que se pode fazer das origens desse processo, diz respeito à análise de Michel Foucault (2002), que aponta o protagonismo dos médicos nesse processo, em meados do século XVIII, como responsáveis pelo desenvolvimento, na França, da medicina urbana como uma das etapas da formação da medicina social. Segundo o filósofo, o primeiro objetivo da medicina urbana era a "análise das regiões de amontoamento, de confusão e de perigo no espaço urbano" (Foucault, 2002: 90). A medicina urbana agia, em primeiro lugar, na identificação dos locais onde proliferavam a sujeira e a doença, como os cemitérios e os matadouros, e em seguida, no controle da circulação de ar e água nas cidades. Em segundo lugar, em busca de um ar mais saudável para a população, abriam-se ruas, derrubavam-se morros e, às vezes, dizimavam-se bairros inteiros. Em terceiro lugar, atuava na distribuição da água e dos dejetos, com um domínio mais absoluto do subsolo. Foucault chama atenção para o fato de que, nesse momento, o mais importante não era o controle da circulação de indivíduos, mas sim "das coisas ou dos elementos, essencialmente a água e o ar" (Foucault, 2002: 90).

Os urbanistas se valeriam desses antecedentes, em que pese seus discursos, nos quais os termos médicos davam o tom. Era familiar aos primeiros urbanistas franceses, como Eugéne Hènard, a associação simbólica aos termos médicos com a justificativa de intervenção nas cidades por estas estarem doentes (Hènard, 1982).

O arquiteto catalão Ildefons Cerda, por exemplo, um dos primeiros estudiosos das cidades e responsável pelo termo urbanismo, comparava a cidade a uma máquina complexa e os males que a atingiam a vermes que corroíam as vísceras da humanidade. Utilizava a metáfora do corpo para compreender a cidade. O tratamento dispensado seria similar. Para solucionar os males urbanos, tornando-o um organismo sadio, propunha extirpar a doença. Dentre as medidas cabíveis, 
sugeria a urbanização, pensada, nesse contexto, como aparato científico (Cerdà apud Sica, 1981). Outro importante urbanista, Le Corbusier, afirmava em 1924: "pode-se dizer que toda a imprensa noticiou e, quase diariamente; realmente o urbanismo fazia que falassem dele, pois Paris estava doente, muito doente" (Corbusier, [1925]2000: 239).

Para Françoise Choay (1996), o urbanismo pode ser entendido como uma disciplina nova, uma ciência de concepção das cidades. Como tal, reúne, grosso modo, duas correntes de teorias: uma dita progressista, que visa ao progresso e à produtividade, e outra culturalista, centrada em objetivos humanistas. Essas duas correntes ditam o debate em torno da concepção das cidades, mas Choay reconhece que elas têm em comum a análise crítica à cidade existente e a elaboração de um modelo de cidade que busca o contrário - uma cidade que poderia ser construída e reproduzida ex nihilo (Choay, 1996). O urbanismo pode ser incorporado como despretensão científica, e estaria relacionado, mais modestamente, a controlar e a organizar o fluxo demográfico nas cidades, sem a perspectiva de interferir de forma mais ampla na sociedade. Sua origem estaria ligada aos planos regularizadores das grandes obras urbanas de um Haussmann em Paris, por exemplo.

Nesse sentido, valer-se-á das discussões desses urbanistas e estudiosos do tema para tentar analisar os projetos e as ações empreendidas em Manguinhos em quase um século de história.

\section{Projetos Urbanos para Manguinhos, de 1910 a 2010}

No início do século XX, Manguinhos se configurava como uma área de subúrbio da cidade do Rio de Janeiro com difícil acesso e constituída por manguezal (Benchimol et al., 1988). Começou a ser habitada, sobretudo, por meio da ocupação dos terrenos, que foram, em parte, vendidos e alugados ilegalmente. Os programas de remoção aplicados às favelas de várias áreas da cidade, os quais marcaram as décadas de 1940 a 1970, intensificaram a ocupação da área, pois além de apresentar terrenos vazios, localizava-se próxima ao centro da cidade, contando com importantes vias de acesso, como a Estrada de Ferro Leopoldina, a rua Leopoldo Bulhões, a avenida Brasil e a avenida Suburbana (atual Dom Hélder Câmara). Entre os projetos urbanos e habitacionais elaborados para a região, destaca-se o aterramento de parte da área de mangue, a retificação dos rios, a construção de alguns conjuntos habitacionais, além de obras esparsas e de 
pequeno vulto direcionadas, em geral, para o saneamento básico. Historicamente, ao menos cinco projetos urbanos foram delineados para a área de Manguinhos, especificamente.

Recentemente, a região tem recebido recursos por intermédio do PAC, que aliado a medidas econômicas, apresenta como proposta norteadora a modernização da infraestrutura urbana e a possibilidade de expansão dos investimentos privados em áreas de carência de investimento urbano e baixo poder aquisitivo da população.

O primeiro projeto urbano do século XX foi desenvolvido a partir de 1910, no âmbito do Ministério de Viação e Obras Públicas. Previa o saneamento e a urbanização para toda a região compreendida entre o litoral da baía do Rio de Janeiro e a serra dos Órgãos. Este foi interrompido, em 1916, em virtude da Primeira Grande Guerra, por ser a empresa responsável de origem alemã. Foi retomado em 1922 pela empresa brasileira de capital privado denominada Empresa de Melhoramentos da Baixada Fluminense, que incluiu a urbanização da área de Manguinhos. ${ }^{4}$

Em 1927, foram formuladas duas outras propostas que acenavam para a implantação de um bairro industrial em Manguinhos, compreendido como um espaço estratégico para o crescimento industrial da cidade. Uma, de responsabilidade de Donat-Alfred Agache, constava do Plano de Melhoramentos para o Rio de Janeiro, e a outra incorporava as propostas de urbanização, já formuladas pela Empresa de Melhoramentos. Os dois planos destacavam o crescimento das favelas e propunham a construção de vilas operárias, incluindo a área de Manguinhos para implantação destas vilas, além da construção de vias de acesso à cidade, o que gerou opiniões divergentes por tratar-se de uma 'intervenção' ampla para a região. O engenheiro sanitário Saturnino Britto, por exemplo, em 1944, escrevia que:

\begin{abstract}
grande parte do terreno vai ser obtida por aterro; morros que existem serão escavados até onde o preço do serviço seja compensador, salvando-se desta violência à natureza o morro onde se ergue o Instituto Oswaldo Cruz ou de Manguinhos, onde no projeto antigo(...) e no substituto(...) por feliz ideia formar-se-á um parque (Brito, 1944: 258).
\end{abstract}

A opinião de Britto (1944) ressalta que o projeto, talvez, representasse para a região uma intervenção de excessivas proporções, que mesmo trazendo nos

\footnotetext{
${ }^{4}$ Uma extensa documentação acerca desse projeto pode ser encontrada no Fundo Ministro Francisco Sá, Arquivo Histórico do Museu da República. Ver também Fernandes e Costa (2009).
} 
discursos em sua defesa uma ideia de progresso, sacrificaria muito a morfologia local, formada por pântanos e manguezais. Britto analisa ainda outros projetos apresentados em concorrência pública: um da própria Empresa de Melhoramentos; um de Jerônimo Alencar Lima (dono da empresa, mas que apresentou a proposta como engenheiro civil autônomo); um de Aristides Figueiredo; e um de Jorge Macedo Vieira.

As propostas para a bacia de Manguinhos resultaram no aterramento do litoral e na retificação dos rios, seguindo os trabalhos iniciados em 1922, sem acompanhar, no entanto, o desenho urbano elaborado, pela Empresa de Melhoramentos, por Agache, ou seguir a proposta de constituição de um bairro industrial com residências populares. Em 1932, ocorreu a rescisão do contrato da Empresa de Melhoramentos da Baixada Fluminense com o governo federal.

A abertura da avenida Brasil, entre 1939 e 1947, que compunha um dos planos urbanos a que nos referimos antes e cuja influência foi grande no adensamento dessa região, tinha como justificativa não apenas facilitar a ligação da então capital federal às demais cidades do país e permitir o acesso ao norte da cidade, mas objetivava ainda beneficiar a população dos subúrbios.

Estavam igualmente presentes nos projetos de remodelação da cidade as noções de progresso e de melhoria para as populações que viviam ao longo de seu percurso, como se observa na reportagem do Correio da Manhã que apontava que "os mangues que tanto prejudicam (...) vão desaparecer, beneficiando consideravelmente as populações que se aglomeram por todo subúrbio da Leopoldina" (Correio da Manhã, 11/04/1941 apud Costa, 2006; Fernandes \& Costa, 2009). Entretanto, tratava-se de um rasgo no tecido da área, mesmo que a justificativa para sua construção, apresentada no álbum lançado durante as obras da via, chamasse atenção para seu traçado, descrito como magnífico, e ressaltasse que este valorizaria e embelezaria a região. O documento destaca ainda que os lugares poluídos ou insalubres, maltratados e abandonados, como eram apresentados tais espaços, seriam "transformados em recantos belíssimos e habitados" (Costa, 2006: 235; Fernandes \& Costa, 2009).

Em 1943, na gestão do prefeito Henrique Dodsworth (1937-1945), outro projeto frustrado foi formulado para a região dos subúrbios, incluindo Manguinhos - o Parkway Faria Timbó, elaborado como parte do Plano da Cidade do Rio de Janeiro. Em seu texto, os autores apresentavam como preocupação viabilizar a ocupação ordenada de toda a área percorrida pelo rio Faria Timbó, salvaguardando "os interesses dos futuros moradores da região, proporcionando o 
saneamento, moradia higiênica, a recreação, a economia de tempo no transporte pelo acesso fácil" (Reis apud Fernandes \& Costa,_2009: 85). Acrescentava, ainda, que a proposta se voltava para a tentativa de "transformar [aquela área], pelo paisagismo, num dos mais atraentes subúrbios cariocas, desde que orientadas por um plano de conjunto, e obedecido na expansão natural do uso, o aproveitamento racional dos terrenos" (Reis apud Fernandes \& Costa, 2009: 85). Alguns anos mais tarde, em publicação denominada O Urbanismo no Rio de Janeiro, Szilard e Reis defendiam que "a execução do plano [dotaria] a cidade de um dos mais belos e acessíveis parques ajardinados" (Szilard \& Reis apud Fernandes \& Costa, 2009: 85). Embora seu discurso propusesse "uma zona digna de figurar entre as melhores urbanizadas" (Reis apud Fernandes \& Costa, 2009: 86), sabe-se que, assim como o projeto anterior, esse plano também não se concretizou em relação à proposta original, tendo Manguinhos se transformado em uma das regiões mais poluídas e com menor Índice de Desenvolvimento Humano (IDH) do Rio de Janeiro.

Com base em Françoise Choay, tais projetos, no qual se inclui o PAC, estariam entre a linha culturalista - que preserva os aspectos humanistas - e a linha progressista - direcionada ao progresso e à produtividade. Poderiam ser, ainda, projetos situados entre o urbanismo tábula rasa, numa crítica à cidade existente, e o urbanismo despretensioso, voltada apenas para a ordenação de fluxos. Essa indefinição se refletiu nas ações ocorridas em Manguinhos, deixando os moradores das comunidades incertos em relação a seu futuro.

\section{$\mathrm{O}$ PAC em Manguinhos}

No início de 2007, em 22 de janeiro, o governo federal anunciou a implantação do PAC, como proposta de aplicação de investimento público em diversos eixos tidos como fundamentais ao desenvolvimento do país: infraestrutura; estímulo ao crédito e ao financiamento; melhora do ambiente de investimento; desoneração e administração tributária; medidas fiscais de longo prazo; consistência fiscal (Brasil, 2007a).

De forma geral, o discurso governamental ressalta a "necessidade de acelerar, de forma sustentável, o crescimento do investimento global da economia" (Brasil, 2007a: 1). Para tanto, pauta-se na análise de que a política econômica do primeiro mandato do presidente Luiz Inácio Lula da Silva tenha estabilizado a economia, gerando com isso as bases para um crescimento com distribuição de renda. A apresentação do PAC apostava que o desafio para os anos 2007-2010 seria crescer de forma acelerada e sustentável, aproveitando o momento histórico 
de grande potencial de expansão da economia brasileira, que apontava para o "crescimento do PIB e do emprego, intensificando ainda mais a inclusão social e a melhoria na distribuição de renda do País" (Brasil, 2007a: 2).

A área de investimento em infraestrutura fica subdividida em três linhas específicas: logística (rodovias, ferrovias, portos, aeroportos e hidrovias); energia (geração e transmissão de energia elétrica, petróleo, gás natural e combustíveis renováveis); social e urbano (saneamento, habitação, transporte urbano, luz para todos e recursos hídricos). Assinalando que os investimentos em infraestrutura são fundamentais para "superar os gargalos da economia e estimular o aumento da produtividade e a diminuição das desigualdades regionais e sociais", o governo federal aponta como prioritário impulsionar a "eficiência produtiva dos principais setores da economia, a modernização tecnológica, acelerar áreas já em expansão e ativar áreas deprimidas, aumentar a competitividade e integrar o Brasil com o Brasil, com seus vizinhos e com o mundo" (Brasil, 2007a: 15).

Nesse espectro, o PAC Social e Urbano - a urbanização integrada de favelas -, mais conhecido como PAC Favelas, ganha destaque em várias regiões do país. No Rio de Janeiro, em específico, as maiores intervenções (em termos de ações urbanísticas e recursos alocados) ocorreram no Complexo do Alemão, no Complexo de Manguinhos e na Rocinha, por intermédio da parceria entre os governos, federal, estadual municipal.

O PAC Favelas segue as diretrizes do Programa de Urbanização, Regularização e Integração de Assentamentos Precários do Ministério das Cidades, cujas intervenções propostas "têm como objetivo precípuo a implantação de ações necessárias à regularização fundiária, segurança, salubridade e habitabilidade de população localizada em área inadequada à moradia, visando a sua permanência ou realocação, por intermédio da execução de ações integradas de habitação, saneamento e inclusão social" (Brasil, 2008: 3). O chamado Trabalho Social ${ }^{5}$ seria outro elemento de destaque do PAC Favelas, sendo sua realização condição necessária para o repasse dos recursos.

Por que Manguinhos foi incluído no PAC? Para tal indagação existem, pelo menos, três caminhos explicativos.

Segundo a versão repetida diversas vezes por integrantes do governo do estado do Rio de Janeiro, em diferentes encontros e audiências públicas, a escolha da

\footnotetext{
${ }^{5} 0$ trabalho social na urbanização de assentamentos precários ou de favelas deve garantir condições para 0 exercício da participação comunitária e para a elevação da qualidade de vida das famílias residentes na área do projeto. Se expressa e se desenvolve por meio de um conjunto de ações e atividades que buscam promover a mobilização e organização das comunidades, a educação sanitária e ambiental e a implantação de atividades voltadas para a geração de trabalho e renda (Brasil, 2007b).
} 
localidade teria ocorrido durante um sobrevoo de helicóptero sobre a cidade. Na ocasião, o presidente Luiz Inácio Lula da Silva (2003-2007) teria indagado ao governador Sérgio Cabral Filho que área era aquela sobre a qual sobrevoavam. Alarmado pela miséria e precárias condições de vida observadas, ouviu que se tratava do Complexo de Manguinhos. O presidente Lula teria então afirmado que se prontificava em implantar ali um dos projetos do PAC.

Contrapondo a primeira explicação, lideranças locais garantem que a destinação de recursos do PAC para Manguinhos foi resultado das lutas históricas travadas pelos moradores e apontam como evento-chave um debate sobre o diagnóstico socioambiental da região ocorrido em dezembro de 2006, na Escola Nacional de Saúde Pública Sergio Arouca (Ensp/Fiocruz). Nessa ocasião, com a presença do coordenador da Unidade Gestora de Projetos da Secretaria Nacional de Saneamento Ambiental, do Ministério das Cidades, foi firmado compromisso de destinação de recursos das secretarias de Saneamento e Habitação desse ministério para Manguinhos. Portanto, afirmam certas lideranças que já havia um compromisso do governo antes mesmo do lançamento do PAC, em janeiro de 2007, e do anúncio oficial da destinação de recursos a Manguinhos, em março daquele ano.

E por fim, a terceira versão foi elaborada no trabalho de campo com técnicos da Caixa Econômica Federal, gestora dos recursos, ao arquiteto e urbanista Jorge Mario Jáuregui, que desenvolveu o Plano de Desenvolvimento Urbanístico do Complexo de Manguinhos, e a técnicos da Empresa de Obras Públicas (Emop). Segundo esses, a explicação mais plausível para a destinação dos recursos não foi o sobrevoo do presidente e do governador nem a reunião de lideranças com técnicos do Ministério das Cidades. Afirmam que a exigência de respostas rápidas para o anúncio imediato dos projetos do PAC levou à escolha de localidades que já tinham projetos, anteprojetos ou, no caso de Manguinhos, ao menos relatório de diagnóstico que apontava para algumas possibilidades de modificação no território. Assim, a escolha deve-se, segundo esta última versão, a aspectos técnicos, ainda que sobrepujados por decisões políticas.

O referido relatório de diagnóstico foi elaborado pelo consórcio PAA Agrar, coordenado por Jáuregui, entre julho de 2004 e junho de 2005. O objetivo era elaborar um Plano de Desenvolvimento Urbanístico do Complexo de Manguinhos (PDU Manguinhos) que abordasse questões relativas a urbanismo, legislação, aspectos fundiários, transportes, socioeconomia, aspectos artísticos culturais, sistemas de infraestrutura e meio ambiente. Logo no primeiro aspecto, o consórcio 
fez questão de diferenciar seu projeto da proposta do Programa Favela-Bairro ${ }^{6}$ no que concerne ao tempo e à delimitação do espaço a sofrer intervenção. Para o consórcio, seu projeto seria mais abrangente em ambos os aspectos, ultrapassando os dois anos de obras do primeiro programa e gerando melhorias para regiões além das áreas contempladas, além de não depender de uma única fonte de verbas. Nesse último aspecto, o Plano procurava evidenciar que os recursos viriam do setor público, num esforço conjunto entre as três esferas de poder. O PDU apontava, também, para a discussão conceitual que envolve a relação entre Cidade Formal e Cidade Informal, acompanhando o mesmo discurso expresso no programa anterior, no qual o objetivo indicado era integrar áreas da cidade.

O fato de ser mais abrangente colocava ao consórcio o desafio de se trabalhar com a grande escala da cidade. No caso de Manguinhos, isso envolvia, também, o entorno imediato do bairro, que fora delimitado em 1985, e os eixos viários como a Linha Amarela, a avenida Brasil e a avenida dos Democráticos, além da linha férrea - administrada pela SuperVia -, chamando atenção para o fato de Manguinhos ter sido considerada uma "área residencial localizada em uma encruzilhada circulatória de ordem metropolitana" (Plano de Desenvolvimento Urbanístico..., 2005: 5). Segundo a justificativa do documento:

Esta área tem como núcleo de atenção o conjunto de comunidades de Manguinhos e suas relações com um entorno ampliado. Assim, o termo Complexo de Manguinhos passou a significar o conjunto formado pelas comunidades de Manguinhos e sua sociedade civil, das áreas formais e subnormais localizadas em seu entorno e com as quais mantém intrínseca relação na origem dos problemas urbanísticos identificados. (Plano de Desenvolvimento Urbanístico..., 2005: 5)

Dessa forma, o diagnóstico procurou apontar as escalas de intervenção. Uma no âmbito da "especificidade social local", sua posição em relação ao sistema urbano e as "especiais condições ambientais" (Plano de Desenvolvimento Urbanístico..., 2005: 5). Tais itens tiveram a intenção, assim, de servir de justificativa para as intervenções a serem propostas para Manguinhos, que procurariam acabar com os obstáculos físicos que separariam as comunidades, como a elevação da linha férrea, por exemplo, que se tornaria a marca principal

\footnotetext{
${ }^{6} 0$ Programa Favela-Bairro foi encaminhado pelo prefeito César Maia, em 1993, como uma das proposições formuladas pelo Grupo Executivo de Assentamentos Populares (Geap) e foi concretizado pela então criada Secretaria Municipal de Habitação. Foram alocados vultosos recursos em obras urbanas baseado no acordo estabelecido com o Banco Interamericano de Desenvolvimento (BID) em duas etapas: a primeira em dezembro de 1995 e a segunda, em maio de 2000. Esse órgão, inclusive, o considerou "projeto estrela", premiando-0 como o"Projeto do Ano de 1998" (Burgos, 2006; Magalhães, 2002).
} 
(e mais polêmica) do projeto, criando as já famosas versões cariocas das ramblas da cidade de Barcelona. ${ }^{7}$ As características de infraestrutura da região apontaram para a carência de serviços de drenagem, esgotamento sanitário e áreas de lazer, problemas de deslocamento e mobilidade urbana e alto nível de degradação ambiental. Um diagnóstico cuidadoso, cujo projeto que se seguiu se mostrava ambicioso, sem dúvida, procurando, a seu modo, responder ao planejamento urbano de forma ampliada.

O projeto básico para Manguinhos desenvolveu-se ao longo de 2007. A licitação referente ao custo e responsabilidade pelas obras efetuou-se ainda em dezembro do mesmo ano, sendo as obras de intervenção iniciadas em abril de 2008.

A especificidade do estudo, em busca da compreensão do processo de implantação de uma política pública ainda em vigor, requereu a aplicação de uma metodologia de coleta e produção de fontes que incluía depoimentos orais, ${ }^{8}$ iconografia e anotações de observação de campo, além de documentos produzidos pelas instâncias governamentais e textos analíticos. A observação in loco foi fundamental, por exemplo, para a análise das formas de negociação entre os representantes governamentais e lideranças comunitárias. É preciso aqui pontuar que as próprias condições de pesquisa configuram-se como variável complexa do processo.

Por meio do trabalho de campo, foi possível observar interações e relações interpessoais (nas quais se inclui a relação entre pesquisadores e moradores) que só criam sentido como registro de práticas em uma contextualização específica. O exercício de enxergar seres humanos complexos nas relações, providos de experiências, que se colocam aqui nas disputas políticas, permite estabelecer observação específica do contexto (Foote-Whyte, 2005). A contextualização refere-se, também, às práticas de moradores, lideranças locais, técnicos de instituições governamentais e líderes políticos, que podem levar a posições de cunho clientelista ou a posicionamentos mais radicais de universalização do acesso a serviços urbanos. Tais relações, por vezes, recorrem à memória histórica, seja das lutas por moradia e direitos urbanos, seja pelas alianças políticas entre determinados grupos, também históricas, como pode ser percebido no

\footnotetext{
${ }^{7}$ Por conta dessa proposta, o projeto tem ganhado destaque nos projetos urbanos contemporâneos, a ponto de ser convidado a integrar exposiçōes no Museum of Modern Art (MoMA) de Nova York e no Festival Europalia, de Antuérpia, Bélgica, que tratam de projetos que buscam soluções para populações carentes, conforme matéria do jornal 0 Globo em 24 de outubro de 2010 ("PAC de Manguinhos..., 2010).

${ }^{8}$ Os depoimentos orais aqui indicados estão pautados na antropologia que permite 0 uso das falas escutadas em campo e inscritas nos diários, e a descrição dos fatos observados, como fontes de análise no decorrer do texto.
} 
pensamento do geógrafo Roncayolo (1997). Este reconhece o urbanismo como originado de um conflito político, como um campo de forças de lutas e práticas sociais permanentes, na construção da cidade contemporânea.

Em acordo com os objetivos do projeto, o trabalho de campo viria a se constituir um recurso metodológico capaz de permitir a observação e descrição do processo da intervenção urbana no exato momento que estava sendo colocada em prática, ou seja, momento no qual os atores estavam em ação (Latour, 2000). A realização do trabalho de campo permitiria ainda adensar a produção de conhecimentos necessários para subsidiar futuramente a avaliação de políticas públicas semelhantes àquelas que têm sido empreendidas pelo PAC em Manguinhos. Afinal, interessava, sobretudo, a valorização do entendimento daquela realidade pelo indivíduo que nela vivia. Procurou-se registrar suas insatisfações, angústias, tristezas, preocupações, opiniões, projetos, alegrias e outros entendimentos e sentimentos que vivenciavam naquele momento específico.

\section{O PAC Manguinhos sob o Olhar de seus Moradores}

Tendo por base a construção de conhecimento sobre o programa e o contexto no qual o mesmo seria implantado, optou-se pelo estudo de duas localidades entre as comunidades de Manguinhos que tivessem perfis distintos, tanto em relação à história e tempo de ocupação quanto às ações previstas pelo PACManguinhos, a saber: CHP2 e Embratel. A primeira delas surgiu em 1951, como um Centro de Habitação Provisória (CHP), construído para abrigar moradores de favelas removidas da cidade e, naquele momento, recebia obras de urbanização executadas pela Prefeitura do Rio de Janeiro. A segunda foi criada em 2005 em decorrência da ocupação de instalações abandonadas da Empresa Brasileira de Telecomunicações (Embratel), na avenida Leopoldo Bulhões. Apresentava, no âmbito do PAC, previsão de ser totalmente removida para, em seu lugar, ser construído pelo governo do estado um grande conjunto habitacional popular, o que ocorreu em 2010.

Diferentemente do CHP2, onde as ações do PAC buscavam melhorar as condições de vida da população no próprio local de moradia, na Embratel essas ações teriam o efeito de abolir a própria existência da favela. Dada a possibilidade de se etnografar in loco esse processo radical de transformação de Embratel, priorizou-se nesta localidade maior investimento de tempo da pesquisa de campo, que teve a duração total de oito meses. Por tais condições, no CHP2 o trabalho 
de campo realizado foi mais pontual, com duração de três meses, mas capaz de revelar um importante contraponto às intervenções do PAC na Embratel. É com base nessa relação de contraste, mais do que propriamente de comparação, que se deu o exercício de relativização e sob a qual devem ser lidos os dados aqui apresentados.

É importante, de antemão, frisar que, na prática, o processo de intervenção do PAC não se deu de forma linear, com uma etapa sendo realizada sucessivamente após outra, mesmo na favela de Embratel, onde estava prevista a realocação de todos os seus moradores. A forma de apresentação a seguir, tal como idealizada pelos propositores do projeto, representa a estrutura formal das ações previstas na localidade, isto é, das etapas pelas quais cada morador deveria, necessariamente, percorrer até a remoção de sua moradia e o posterior retorno à área como condômino de um dos apartamentos dos conjuntos habitacionais a serem construídos na região.

De forma geral, a primeira etapa prevista desse processo era aquela em que o projeto governamental para a região seria divulgado, por meio de diversos meios de comunicação, para a sociedade como um todo e para os moradores diretamente atingidos pelas obras. A segunda etapa seria constituída pela realização do censo residencial e comercial pela equipe contratada pela organização não governamental (ONG) para realizar o chamado trabalho social. O censo residencial tinha como objetivo traçar o perfil das moradias e de seus habitantes, identificando, por exemplo, as características físicas de cada benfeitoria, o nome do seu proprietário e o número de seus residentes, a fim de subsidiar as etapas seguintes.

À proporção que as informações do censo fossem consolidadas, o corpo técnico do consórcio responsável pelas obras na localidade daria início à etapa de medição e avaliação de todos os imóveis existentes, tanto residenciais quanto comerciais. Nessa etapa, estes seriam qualificados em termos de sua estrutura física e material e, como forma de controlar o processo, seriam imediatamente identificados na fachada com um número sequencial correspondente à sua localização na área atingida. Além de estabelecer o perfil das construções existentes, a avaliação subsidiaria, posteriormente, a definição de seu valor indenizatório. Como bem observou uma moradora da travessa Vai e Vem, na Embratel, diante da visita dos técnicos à sua residência: "Quando vêm pra medir é porque vão demolir".

O morador do imóvel a ser desapropriado (todas as residências da Embratel e apenas algumas do CHP2) deveria optar por uma das três modalidades indicadas: aluguel social, compra assistida ou indenização em dinheiro. Certamente, a 
possibilidade de permanecer residindo no imóvel ou na localidade não compunha o leque de opções oferecidas. O chamado aluguel social configura-se uma quantia paga mensalmente aos moradores que optassem por residir, posteriormente, em um dos apartamentos dos conjuntos a serem construídos em Manguinhos, como forma de lhes garantir moradia até a conclusão das obras. Já a compra assistida consistia em uma indenização paga em uma única parcela aos moradores que desejassem obter de imediato outro imóvel, tanto nos arredores de Manguinhos, como em outros bairros ou cidades. Uma última alternativa oferecida aos moradores era o pagamento direto da indenização em dinheiro, cujo valor também se baseava na avaliação técnica do bem a ser demolido. Em atenção ao perfil da população da Embratel, grande parte migrante da Região Nordeste do país, essa modalidade indenizatória destinava-se a atender, sobretudo, aqueles que desejavam retornar à sua cidade de origem.

Por fim, o processo de intervenção do PAC na localidade seria concluído com a realocação dos moradores que optaram, no momento da remoção, pelo aluguel social com vistas a se tornarem condôminos dos dois conjuntos habitacionais construídos nos arredores. Com isso, no caso da Embratel, os antigos invasores se transformariam definitivamente em proprietários. Em razão dos vários interesses em torno das negociações para a distribuição das moradias, o Condomínio Embratel acabou se transformando em um grande foco de irregularidades, que no início de 2012 se encontrava sob investigação, a qual envolvia lideranças locais e do tráfico de drogas (Araújo, 2012).

Em fevereiro de 2007, o PAC foi anunciado publicamente pelo governo federal em diversos meios de comunicação de massa, sendo o processo de licitação das obras de urbanização de favelas da região de Manguinhos iniciado após sete meses. Apesar dos comentários informais, o detalhamento do projeto não foi oficialmente apresentado aos moradores em reuniões e assembleias públicas, conforme evidenciam os diversos documentos produzidos pelo Fórum Social de Manguinhos ao longo desse período, sendo constantes na pauta de reivindicações a falta e a imprecisão de informações sobre as ações do PAC na região. Os representantes das localidades que participavam do Fórum - geralmente presidentes das Associações de Moradores - costumavam ser os mais bem informados, sobretudo a partir do momento em que constituíram um Comitê de Acompanhamento do PAC em Manguinhos, permanecendo os moradores excluídos dos círculos de informações.

De modo geral, o PAC representava para os moradores, notadamente na localidade Embratel, a possibilidade de "deixar de viver numa favela", entendendo 
esta como um "lugar sem endereço", portanto, desprovido de serviços públicos de saúde, educação, lazer, urbanização e saneamento básico. Deixar de viver na favela era viver também sem o incômodo causado pelo movimento do tráfico de drogas, sem o comércio e a violência que este acarreta. Ao longo do processo, de maneira geral, as expectativas dos moradores mantiveram-se positivas, sem que deixassem de criticar as diversas falhas e deficiências por eles percebidas. Constataram-se algumas frustrações no setor da participação popular, pois não se sentiam ouvidos em suas demandas e, especialmente, em relação à permanência do tráfico no local.

Sobre a etapa de remoção dos moradores e a demolição dos imóveis, diversas outras questões puderam ainda ser identificadas no trabalho de campo. Para os que contavam com melhores condições habitacionais, a remoção era menos desejada do que para aqueles que viviam em condições mais precárias, que depositavam no PAC a possibilidade de adquirirem uma moradia mais digna. Ambos, porém, tinham em comum algumas críticas quanto à maneira como se deram as remoções. Tais críticas baseavam-se principalmente no fato de as demolições dos imóveis terem ocorrido de forma irregular, conforme iam sendo liberados pelos moradores, o que ocasionou diversos problemas aos que ainda permaneciam residindo na localidade.

Muitos desses problemas colocavam em risco a saúde da população, como a grande quantidade de poeira e escombro resultante das demolições, que, muitas vezes, permaneciam por semanas no local, atraindo um número cada vez maior de roedores. Como disse, indignada, uma moradora: "o pessoal acha que só porque a gente mora em comunidade que a gente tem que se habituar com sujeira". Foram ouvidas inúmeras queixas sobre mordidas de roedores, afastando do local, antecipadamente, muitas famílias que passaram a procurar abrigo na casa de seus familiares, sobretudo para proteger as crianças. Isso gerava um problema à parte, pois havia a necessidade de estar presente no local para acompanhar o processo do recebimento da indenização e posterior retirada dos pertences pessoais. Houve, ainda, os que tiveram seus pertences encaminhados para um depósito público.

Outros problemas afetavam os moradores, do ponto de vista da segurança física e social. Um exemplo era a presença e circulação pelas ruas de máquinas e tratores utilizados pelos operários do consórcio para demolir as construções de alvenaria, sem seguir normas técnicas de segurança, as quais preveem o isolamento da área. Reprovando esse tipo de atuação, um morador chegou a afirmar que isso só acontecia por ser obra pública em favela: "Tá errado a gente morar junto com máquinas. Se fosse área particular, a obra estava paralisada". 
Além disso, as frequentes interrupções do fornecimento de água e energia elétrica atrapalhavam a rotina doméstica, chegando a danificar eletrodomésticos necessários até mesmo ao funcionamento de algumas barracas, que garantiam a sobrevivência de muitos moradores. Como no caso de seu Antônio, que, com a perda de sua geladeira e freezer, deixou de trabalhar vendendo bebidas em sua barraca na avenida Leonel Brizola, assim como cocos nas ruas da Leopoldina. Aguardando a entrega do pagamento (indenização ou aluguel social) e com eletrodomésticos danificados, ficavam numa situação de paralisia social, "sem poder trabalhar nem sair". Se as obras na localidade já haviam expulsado grande parte dos consumidores dos pequenos comércios - os próprios moradores e os usuários de drogas que circulavam pelo local, por exemplo -, o longo tempo de espera pelo pagamento agravava ainda mais a situação financeira de algumas famílias. Ademais, a progressiva desertificação da localidade, com a demolição de um número cada vez maior de residências e a falta de iluminação pública deixavam os moradores vulneráveis a todo tipo de risco, conferindo à Embratel, à noite, um aspecto de cidade fantasma.

Mesmo com todos os problemas apontados anteriormente, os moradores avaliavam as obras do PAC na localidade como importantes para a população, especialmente para os mais pobres. Em geral, consideravam que as ações do PAC produziriam mudanças positivas na saúde, na educação e no lazer da população, sendo tais expectativas calcadas, sobretudo, na construção de edificações específicas voltadas para esses tipos de funções, como a Escola Estadual Luiz Carlos da Vila, a Unidade de Pronto Atendimento (UPA) e o Complexo Esportivo. Em relação à saúde, alguns moradores apontaram ainda a importância da ampliação do acesso à água e a construção de redes de esgoto sanitário. Já em relação à cultura, poucos souberam dizer se o PAC geraria mudanças, uma vez que desconheciam projetos ou edificações previstas para serem construídas na área.

Entre os ex-moradores da Embratel, posteriormente localizados e já instalados num dos conjuntos habitacionais, predominava o sentimento de satisfação, especialmente entre os mais pobres, os primeiros a se mudarem para a nova moradia. Dulcinéia, por exemplo, que antes morava num barraco de madeira e se mudou para um apartamento do bloco 5 no início de janeiro, afirmou que "Para quem não tinha quase nada, isso aqui está muito bom". Para Maria da Penha, que se mudou para o conjunto no dia seguinte ao de Dulcinéia, a alegria podia ser percebida na organização quase completa do apartamento e nos investimentos que a família estava fazendo com a aquisição de novos móveis e aparelhos domésticos. Entretanto, a moradora já identificava alguns problemas 
na infraestrutura do imóvel, como a existência de poucas tomadas elétricas e a luz fraca, o que lhe impossibilitaria de utilizar o forno micro-ondas recentemente presenteado pelo marido. Apesar disso, o apartamento lhe representava um luxo nunca antes imaginado: "Estou num palácio. Eu me sinto a Rainha da Inglaterra!", acrescentou ela.

Ainda que implicitamente houvesse, no projeto do PAC, a crença de que as condições materiais do novo hábitat poderiam homogeneizar grupos que eram diferentes antes da instalação no conjunto, a discrição de Dulcinéia em exibir seu apartamento quase vazio, o entusiasmo de Maria ao expor os pertences comprados especialmente para mobiliar e decorar a nova moradia e, ainda, a mudança protelada dos que acreditavam estar em melhores condições antes da remoção, apontam o quão complexa poderia significar a convivência de diferentes grupos de moradores no mesmo conjunto habitacional.

As obras do PAC no CHP2, por sua vez, objetivavam fornecer infraestrutura básica à localidade mediante sistema de água, esgoto e drenagem; pavimentação de ruas; creche; iluminação pública; coleta de lixo e outros benefícios. Estavam, no entanto, previstas desapropriações de 51 unidades para a construção da creche, cinco unidades para a abertura de via de acesso (rua Maravilha) e 91 unidades para a construção de uma via non aedificandi ${ }^{9}$ (urbanização sobre a adutora que corta a localidade). No CHP2, as obras de infraestrutura urbana foram executadas pela Prefeitura do Rio, ao passo que o censo, por entrevistadores selecionados na comunidade, entre os meses de junho de 2008 e março de 2009. Houve inúmeras críticas por parte dos moradores em relação à forma como se deu o censo, pois, para eles, não ficava nítida a finalidade da consulta.

As obras se iniciaram sem que os moradores de fato tivessem a real compreensão sobre quais seriam as intervenções que ocorreriam no lugar. Alguns moradores comentaram que houve sugestões, por parte da equipe do Trabalho Social, para que fossem eleitos representantes dos moradores por ruas. Por diferentes motivos, não houve uma ampla adesão a essa proposta, ficando a cargo da Associação de Moradores grande parte das negociações, merecendo um mapeamento dos limites dos espaços e das formas de atuação de moradores e lideranças de áreas favelizadas para maior compreensão do processo.

A presença dos órgãos públicos na localidade, especialmente da prefeitura, trouxe aos moradores do CHP2 expectativas sobre as mudanças que lá ocorreriam, ao mesmo tempo que promovia tensões em razão da ausência de informações. Tal

\footnotetext{
${ }^{9}$ Zona onde é proibido qualquer tipo de construção.
} 
ausência causou o aumento não só das incertezas sobre o que de fato aconteceria na área, mas das expectativas com as transformações desejadas para o lugar em que viviam. As conturbadas incertezas e desencontros de informações relatadas também estavam presentes na localidade Embratel e serve de ilustração e evidência de um mesmo procedimento de planejamento e gestão ocorrido em Manguinhos.

As dúvidas e o sentimento de angústia em relação às obras podem ser detectados, por exemplo, na fala de dona Maria, que pensava em fazer uma reforma no terceiro pavimento de sua residência. Porém, a incerteza em relação ao tipo de obra que seria feita pelo PAC, juntamente com a apreensão vivida com a possibilidade de ser removida do local, fez com que adiasse ao máximo o investimento em sua casa. Segundo ela, tal situação demorou meses para se resolver. O marido ali, "segurando o dinheiro" e suportando o medo de perder todo o investimento feito até então. Tinha medo de ter que ser removida, pois sabia que o valor pago como indenização pelo poder público não era compatível com o gasto feito até então na moradia da família. Assim como boa parte das políticas de intervenção urbana nas favelas - mesmo aquelas que apresentam como justificativa promover a sua integração à cidade, como no caso do Programa Favela-Bairro -, o PAC suscitava nos moradores de Manguinhos o antigo fantasma da remoção, experiência que já fora vivenciada pelos primeiros moradores do CHP2, oriundos das favelas da Catacumba, praia do Pinto e Esqueleto, entre outras.

Mediante a pesquisa, constatou-se que grande parte dos moradores tomou conhecimento das obras do PAC por intermédio dos meios de comunicação de massa, como rádio e televisão. A informação, porém, chegava de forma generalizada - "viriam obras" - sem especificar de que tipo seria e em que localidade propriamente de Manguinhos elas ocorreriam. Alguns moradores indicaram ter conhecimento das obras por outdoors e boatos na localidade.

Nesse momento inicial, alegria, descrença e expectativas de mudança eram sentimentos que se misturavam. Enquanto alguns depositavam no PAC a esperança de resolver os problemas mais críticos da localidade, como as inundações e a falta de saneamento básico, outros se mostravam bastante apreensivos e mesmo descrentes, tendo em vista o fato de que muitas obras públicas costumam não ser concluídas. Outros acreditavam que haveria uma completa transformação no lugar. Esperavam que as intervenções repercutissem a ponto de trazer, como consequência, inclusive o fim do tráfico de drogas e a violência na região. No entanto, vários moradores se mostraram desapontados com o andamento da obra, avaliada como "vagarosa", que "não resolvia o problema", mas "causava 
outros", atribuindo a ela até mesmo a percepção do aumento da violência. $\mathrm{Na}$ área prevista para haver remoções, era constante a reclamação dos moradores sobre a falta de informações, uma vez que de fato não sabiam o que aconteceria com eles. Mas, de modo geral, assim como para os moradores da Embratel, como para os da CHP2, o PAC significava coisa boa, melhoria. Desse modo, parece que quase sempre as melhorias desejadas pela comunidade giravam em torno do sonho de ter uma moradia digna. Uma que abrangesse o seu entorno, ou seja, o seu hábitat e não somente a habitação, pois como mencionado por uma das entrevistadas, "não adianta ter uma casa boa e, ao sair, ver crianças usando crack".

Quando da elaboração deste capítulo, divulgou-se pela grande imprensa a prisão de uma das lideranças do condomínio Embratel, por negociação ilícita das moradias e associação ao tráfico de drogas (Araújo, 2012). A morosidade e a falta de lisura permitem, sem dúvida, a instalação de uma dinâmica em que o morador comum é colocado no centro de interesses e negociações das quais ele, o principal interessado, é alijado do processo.

A construção de análises como estas, cujos acontecimentos estão ligados ao tempo presente ainda em processo, apresenta problemáticas específicas como a aqui apontada. Julga-se que a divulgação de tais acontecimentos, que grande parte dos moradores já tinha conhecimento, produzirá efeitos no cotidiano e na forma de morar, caso esse processo e suas relações sejam de fato expostas, o que não poderá ser analisado ainda no âmbito desta publicação.

\section{O Trabalho Colaborativo na Produção Social da Saúde em Manguinhos}

A voz dos moradores de Manguinhos traz, para esta reflexão, elementos indispensáveis para a análise que vislumbra a saúde como resultante de um processo de produção social. Uma participação efetiva, sistematizada e contínua da população local nas decisões sobre o PAC, desde a sua concepção, certamente ampliaria os efeitos positivos dessa política pública na produção de um lugar saudável, tendo em vista que os moradores são os principais pontos de impacto dos problemas socioambientais no que diz respeito à sua própria saúde.

O trabalho de produção social da saúde é altamente complexo e perpassa a construção de ações e culturas que contribuem para a mudança na dinâmica societária geradora de lugares insalubres, como é o caso de Manguinhos. As ações realizadas com tal objetivo podem ter ampliados os seus impactos sociais com base na utilização de uma metodologia de trabalho cooperativo que seja 
responsável pela "criação de uma força produtiva nova, a saber, a força coletiva" (Marx, 2006: 379).

Assim, destaca-se a importância no trabalho entre a Fiocruz e as comunidades de Manguinhos, da aplicação de metodologias cooperativas para maximização do efeito na produção social da saúde, com participação efetiva das comunidades residentes no território. Tal participação contribui para a emancipação (Loureiro, 2007) das pessoas e para a consolidação da cidadania plena e do exercício do uso dos direitos adquiridos, como o direito à cidade, à habitação, à educação, dentre outros garantidos pela Constituição brasileira.

É no contexto desse trabalho cooperativo entre a Fiocruz e as comunidades de seu entorno que se desenvolveu um projeto com as escolas municipais do local, sob a responsabilidade da Casa de Oswaldo Cruz, que produziu o jogo Unidos para produzir um lugar saudável. ${ }^{10}$

$\mathrm{O}$ jogo oferece acesso a conhecimentos e estratégias educativas que podem subsidiar ações educacionais que se destinam a provocar a participação e organização social capaz de produzir um lugar saudável. Coerente com essa finalidade, não existe competição entre os jogadores, todos jogam unidos contra o tempo. Ao longo de meia hora o grupo precisa conseguir, coletivamente, vencer os desafios propostos conquistando o direito de virar as peças de um painel do lado negativo (que retrata uma realidade insalubre) para o lado positivo (que representa um lugar saudável). Um grupo vence quando consegue, no tempo estipulado, virar todas as peças do painel do lado negativo para o positivo. Desse modo, para atingir o objetivo, o grupo estará trabalhando cooperativamente numa competição apenas contra o tempo. Portanto, o jogo simula a situação de uma luta real que vivemos contra o tempo para a superação dos problemas socioambientais da realidade. Em sua elaboração utilizaram-se conteúdos gerados pela pesquisa de campo em relação às ações do PAC e também pelo estudo histórico sobre Manguinhos executado anteriormente por integrantes do projeto, além de narrativas de crianças e adolescentes - moradores de Manguinhos - que estudam em escolas municipais e participam de um trabalho cooperativo tendo por base uma ação desenvolvida pelo Museu da Vida/COC/Fiocruz.

\footnotetext{
${ }^{10}$ Jogo cuja versão parte de um outro, denominado Unidos para construir um mundo melhor, criado durante 0 ano de 1998 em trabalho colaborativo que envolveu principalmente um grupo de seis estudantes do último ano do Ensino Fundamental (14 a 16 anos) da Escola Municipal Orsina da Fonseca, juntamente com professores dessa mesma escola. Já foi publicado duas vezes em diferentes projetos. São acompanhados por livreto que apresenta a história da produção do jogo, para socializar a metodologia utilizada e possibilitar que outros jogos sejam produzidos, tomando-0 como exemplo, além de apresentar uma proposta de utilização do jogo em açōes educativas.
} 
O jogo Unidos para produzir um lugar saudável se constitui, sobretudo, uma tecnologia social que contribui para popularizar conhecimentos produzidos pela equipe da COC e por outros pesquisadores da Fiocruz. É composto por cartas de seis cores, cuja proposta é provocar nos jogadores a discussão sobre os problemas socioambientais mais significativos para a saúde na região, identificando as causas, consequências e possíveis soluções destes. Ele trata, portanto, de uma história que inclui a realização do PAC em Manguinhos. Eis um exemplo de questão extraída do relatório da presente pesquisa, o qual foi incluído numa das cartas do jogo:

Muitos problemas colocavam em risco a saúde da população, como a grande quantidade de poeira e entulho resultante das demolições [do PAC], que muitas vezes ficavam por semanas no local, atraindo um número cada vez maior de roedores. Como disse, indignada, uma moradora: 'o pessoal acha que só porque a gente mora em comunidade que a gente tem que se habituar com sujeira (...)'. Pensando no que está escrito acima, qual é a primeira imagem que vem à cabeça de vocês? (Registrem a resposta na Ficha do jogo).

Ao responder a pergunta e registrá-la na ficha, o grupo conquista o direito de virar o lado de uma das peças do painel - do lado negativo para o positivo. Respondidas as perguntas, vai surgindo a imagem do planeta Terra em cores, com o desenho de mãos se cumprimentando, em alusão a uma vida harmoniosa e saudável para todos. O participante vê-se como parte do processo e corresponsável pelas mudanças que ocorrem. No momento em que as mudanças são intensas, cria-se a oportunidade de refletir sobre o vivido.

Esse jogo está sendo utilizado em oficinas educativas de escolas municipais que participam de um trabalho cooperativo com a Fiocruz em Manguinhos e adjacências. Ele faz parte de um livro que oferece ao professor uma fundamentação teórico-metodológica para a ação-reflexão desenvolvida com os estudantes. ${ }^{11}$ A ideia é a de que os professores, estudantes e demais grupos interessados realizem estudos com os quais possam produzir novas cartas para que esse prossiga num processo de constante construção. Assim, os conteúdos podem ser renovados considerando as ações educacionais desenvolvidas pelos museus, escolas, unidades de saúde, associações de moradores, conselhos de saúde, entre outros, ajudando a induzir a participação e organização social capazes de produzir saúde em Manguinhos, na cidade e no mundo.

\footnotetext{
${ }^{11}$ Intitulado 0 Trabalho Cooperativo no Jogo da Produção Social da Saúde, esse livro compõe um kit do qual faz parte também um outro - História de Pessoas e Lugares: memórias das comunidades de Manguinhos (Fernandes \& Costa, 2009) -, além de vídeos sobre Manguinhos e outros materiais a serem disponibilizados pelo Projeto Cidades Saudáveis.
} 


\section{Para Concluir}

Construir esse trabalho foi um desafio para todos da equipe, no melhor sentido da colaboração destacada por Paulo Freire. Uma tarefa que envolveu pesquisadores, entrevistados e moradores. Participar desse processo revela o quanto ainda há de ser feito para que os habitantes de Manguinhos tenham amplo acesso a seus direitos, como saúde e educação.

A interdisciplinaridade foi uma característica do projeto desde a etapa da organização da equipe, como já mencionado. O desafio era tornar tal proposta passível de ser aplicada em outros locais, além de proporcionar a construção de conhecimento próprio tomando-a como princípio. O desafio não se encerra aqui. Considera-se a necessidade de outras pesquisas que possam desenvolver metodologias que envolvam políticas públicas urbanas que considerem a promoção da saúde dos habitantes como necessidade básica. Como demonstrado, o setor social, responsável pela gestão dos empreendimentos junto dos moradores, deve, a priori, considerar as demandas locais de modo que estas possam verdadeiramente produzir as transformações almejadas, tanto no campo urbanístico como na efetivação dos direitos adquiridos.

A história do tempo presente se tornou uma ferramenta de fundamental importância, incorporando seu método de investigação à pesquisa de campo antropológica para compreender o processo em curso. A construção de reflexões sobre tal processo permite considerar que uma metodologia, para avaliar e promover políticas públicas de urbanização, deve valorizar modelos de trabalhos colaborativos/participativos que contemplem vários elementos, como: levantamento/identificação de fontes produzidas historicamente sobre as políticas públicas locais; identificação dos problemas/dificuldades existentes e/ou produzidos pelas políticas públicas em ação; conhecimento e reconhecimento do espaço vivido e do espaço pensado; identificação das demandas locais e pactuação entre interesses comuns no cotidiano das obras.

As tramas deste processo têm contribuição de diferentes campos de conhecimento, produzisse um registro do processo e, simultaneamente, desse início a uma proposta metodológica. Espera-se que este estudo possa contribuir como fonte de promoção de integração, cidadania e saúde, tanto por meio do registro etnográfico das discussões sobre o PAC nos distintos fóruns existentes, nas trocas com os moradores, assim como na elaboração de material educativo, reflexivo e acadêmico. 
Este foi um esforço conjunto também para que fosse valorizada a história da população local, que construiu seu lugar de moradia, sendo os primeiros planejadores e urbanistas do lugar. Buscou-se analisar o processo e cooperar para que a vida dos moradores que o construíram não se reduza a uma tábula rasa. O PAC chegou, mudou parte de Manguinhos, mas ainda há muitas áreas em situações de precariedade. As idiossincrasias dos processos sócio-históricos não são irrelevantes, ao contrário, fornecem preciosos indícios sobre o social, os grupos humanos e os modos como vivem. Estudar tais processos é fundamental para a construção de conhecimentos que possam contribuir para a transformação dessa realidade.

Espera-se que tudo isso possa estimular outros estudos sobre as favelas e novas formas de ação educativa em saúde - como a que foi proposta no jogo Unidos para construir um lugar saudável -, assim como seja capaz de estimular e subsidiar processos de promoção e produção social da saúde em Manguinhos e em outros territórios similares.

Cabe aqui ressaltar a colaboração de Cláudia Peçanha da Trindade na produção das análises sobre o Programa de Aceleração do Crescimento em Manguinhos durante o período em que atuou como pesquisadora associada ao projeto, entre 2007 e 2010. 


\section{Referências}

ARAÚJO, V. Líder da favela do Mandela preso por negociar apartamentos do PAC: lista de beneficiários no esquema incluía parentes de traficantes. O Globo. Rio de Janeiro, 2a edição, 21 jan. 2012.

BENCHIMOL, J. L. et al. Manguinhos: um retrato de corpo inteiro. Rio de Janeiro: Casa de Oswaldo Cruz, Fundação Oswaldo Cruz, 1988.

BRASIL. Programa de aceleração do crescimento. Material para a imprensa. Brasília, jan. 2007a. (Mimeo.)

BRASIL. Ministério das Cidades. Instruções específicas para desenvolvimento de trabalho social em intervenções de urbanização de assentamentos precários (2007-2010), 2007b.

BRASIL. Ministério das Cidades. Manual de instruções para aprovação e execução dos programas e ações do Ministério das Cidades inseridos no Programa de Aceleração do Crescimento - PAC. Brasília, 2008.

BRITTO, F. S. Obras Completas. Pareceres. V. XVI. Rio de Janeiro: Imprensa Nacional, 1944.

BURGOS, M. B. Dos parques proletários ao Favela-Bairro: as políticas públicas nas favelas do Rio de Janeiro. In: ZALUAR, A. \& ALVITO, M. (Orgs.). Um Século de Favela. 4. ed. Rio de Janeiro: Editora FGV, 2006.

CHOAY, F. Destinos da Cidade Europeia: séculos XIX e XX. Revista de Urbanismo e Arquitetura, 6: 8-21, 1996.

CORBUSIER, L. Urbanismo[1925]. São Paulo: Martins Fontes, 2000.

COSTA, R. G. R. Entre Avenida e Rodovia: a história da Avenida Brasil (1906-1954), 2006. Tese de Doutorado, Rio de Janeiro, Universidade Federal do Rio de Janeiro.

COSTA, R. G. et al. (Coord.). Manguinhos: diagnóstico histórico-urbano-sanitário. Subsídios para políticas públicas sustentáveis em saúde (Relatório Final). Edital Cidades Saudáveis. Rio de Janeiro, 2010.

FERNANDES, T. M. \& COSTA, R. G. Histórias de Pessoas e Lugares: memórias das comunidades de Manguinhos. Rio de Janeiro: Editora Fiocruz, 2009.

FOOTE-WHYTE, W. Sociedade de Esquina [1943]. Rio de Janeiro: Zahar, 2005.

FOUCAULT, M. Microfisica do Poder. Roberto Machado (Org.). 17. ed. Rio de Janeiro: Edições Graal, 2002.

FREIRE, L. L. \& SOUZA, M. D. de. Trocando o pneu com o carro andando: uma etnografia do processo de intervenção do Programa de Aceleração do Crescimento (PAC) no Complexo de Manguinhos. Relatório final da pesquisa de campo para o projeto Manguinhos - diagnóstico histórico-urbanosanitário. Subsídios para políticas públicas sustentáveis em saúde. Edital Cidades Saudáveis do Programa de Desenvolvimento Tecnológico em Saúde Pública da Fundação Oswaldo Cruz. Rio de Janeiro, abr. 2010. (Mimeo.)

HÉNARD, E. Etudes Sur le Transformations de Paris. Paris: Editions L'Equerre, 1982. (Edição fac-símile).

KEINERT, T. M. Planejamento governamental e políticas públicas: a estratégia 'cidades saudáveis'. Saúde e Sociedade, 6(2): 55-64, 1997.

LATOUR, B. Ciência em Ação: como seguir cientistas e engenheiros sociedade afora. São Paulo: Unesp, 2000.

LOUREIRO, C. F. B. Emancipação. In: FERRARO JÚNIOR, L. A. (Org.). Encontros e Caminhos: formação de educadoras(es) ambientais e coletivos educadores. 1. ed. v. 2. Brasília: Ministério do Meio Ambiente, 2007.

MAGALHÃES, S. Sobre a Cidade: habitação e democracia no Rio de Janeiro. São Paulo: Pro Editores, 2002.

MARX, K. O Capital. v. 1. Rio de Janeiro: Civilização Brasileira, 2006.

PAC DE MANGUINHOS ganha exposição no MoMA. O Globo. Rio de Janeiro, 24 out. 2010. 
PLANO DE DESENVOLVIMENTO URBANÍSTICO DO COMPLEXO DE MANGUINHOS. Relatório de diagnóstico. Rio de Janeiro: Consórcio PAA Agrar, jun. 2005.

RONCAYOLO, M. La Ville et ses Territoires. Paris: Gallimard, 1997.

SEABRA, O; CARVALHO, M. \& LEITE, J. C. Território e Sociedade. Entrevista com Milton Santos. São Paulo: Fundação Perseu Abramo, 2006.

SICA, P. Antologia di Urbanistica: dal settecento a oggi. Roma: Laterza, 1981. 


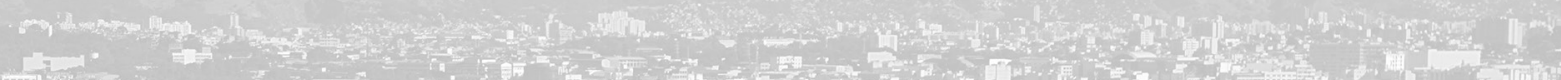
and

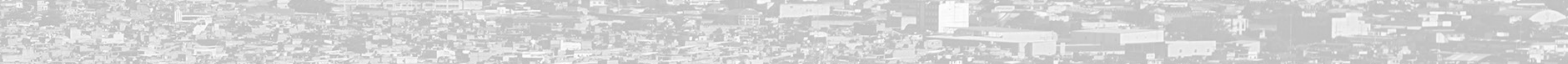

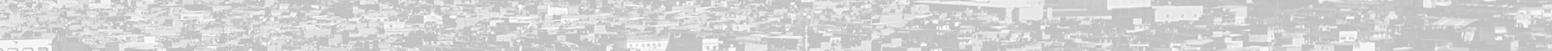

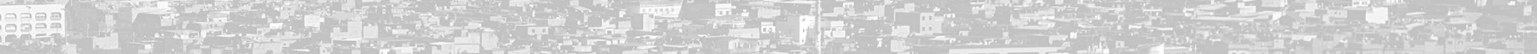

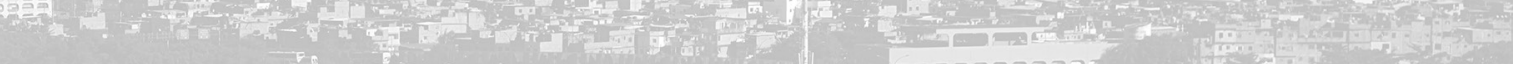

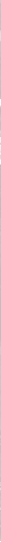




\section{0}

\section{Cidades Saudáveis e Promoção da Saúde Emancipatória: reinvenção cotidiana do (re)conhecimento nos territórios vulneráveis}

O LTM e a Proposição de uma Promoção da Saúde Emancipatória

T ste capítulo discute limites e potencialidades para a construção de cidades ¿saudáveis na perspectiva de uma promoção da saúde emancipatória, e resulta de práticas e reflexões no âmbito do Laboratório Territorial de Manguinhos (LTM). Trata-se de um projeto de extensão desenvolvido por pesquisadores de diversos setores e áreas de conhecimento da Fundação Oswaldo Cruz (Fiocruz), em conjunto com moradores de Manguinhos que fazem parte da comunidade ampliada de pesquisa-ação (CAP). O LTM tem como desafio central contribuir com as bases conceituais e metodológicas para a constituição do que denominamos uma promoção da saúde (PS) emancipatória no âmbito territorial. Seu objetivo último é discutir problemas socioambientais e sanitários do lugar com o propósito de transformar as políticas públicas e práticas institucionais considerando os interesses legítimos e necessidades das populações que vivem no território.

Entende-se uma promoção da saúde emancipatória como

um processo dinâmico de mediações e constituição de campos relacionais, cognitivos e éticos, entre sujeitos individuais e coletivos para solidariamente estabelecerem mecanismos de compartilhamento dos recursos disponíveis na sociedade. Uma promoção da saúde repensada enquanto processo dialético voltado à produção de conhecimentos e práticas que favoreçam 
a constituição de espaços de conquistas de liberdade, de redução de vulnerabilidades socioambientais e de exercício dos direitos humanos fundamentais através do que Paulo Freire denomina de inéditos viáveis. (Porto \& Pivetta, 2009: 220)

Um aspecto importante para uma PS emancipatória refere-se à produção compartilhada de conhecimento, entendida como dinâmicas de mediação entre os conhecimentos científicos e os saberes populares e contextualizados presentes no cotidiano das populações em seus lugares de vida. Tendo por base autores da comunicação em saúde, como Inesita Araújo (2006), pode-se compreender que a promoção da saúde emancipatória procura constituir ciclos comunicativos, ou seja, ciclos que permitam a produção, a circulação e a apropriação dos conhecimentos e informações por parte das comunidades, prioritariamente, mas também de profissionais da saúde, instituições públicas, organizações não governamentais (ONGs) e grupos de pesquisa que atuam em territórios como Manguinhos. Tais ciclos pretendem contribuir na construção de sentidos sociais sobre um dado território, lugar, acontecimento, e da vida das pessoas e dos seus lugares.

Nesse sentido, a proposta de ler e investir no território como um laboratório também encerra um significado político e epistemológico: significa romper com a ideia da ciência e do laboratório científico como um castelo impenetrável ao cidadão comum cujo objetivo principal é conhecer para dominar e prever, e nem sempre transformar a realidade em favor da vida e da justiça social. Significa também romper com as barreiras cognitivas e sociais que isolam o mundo científico das pessoas, por intermédio de um trabalho de tradução que aproxime, de forma solidária, as linguagens e os objetivos de pesquisadores e moradores. A presença da Fiocruz, instituição científica de excelência no cenário internacional, num território marcado por vulnerabilidades socioambientais e elevado déficit democrático, faz da necessidade de repensarmos a prática científica junto com as populações e suas demandas um imperativo categórico.

Esse caminho se constitui, de um ponto de vista próprio, num caminho concreto para que se integre a agenda da promoção da saúde com as raízes da saúde coletiva e os compromissos históricos do movimento sanitário e do Sistema Único de Saúde (SUS) na busca de uma sociedade socialmente justa, além de se incorporar a dimensão da sustentabilidade ambiental, inevitável na agenda contemporânea de todas as sociedades.

São tarefas importantes para isso:

- superar a ênfase nas dimensões individuais e comportamentais que marcam uma visão de promoção de saúde normativa e descontextualizada, pautada 
nas mudanças de estilos de vida e no controle das pessoas, em vez de sua emancipação;

- a dimensão da singularidade humana deve estar vinculada com a construção da liberdade e dos direitos, em conexão com os determinantes socioambientais e suas condições nos territórios e na sociedade como foco da mudança;

- essa perspectiva é uma precondição para que se possa trabalhar no florescimento de sujeitos coletivos e redes sociais, no âmbito das comunidades e suas inter-relações com movimentos sociais mais amplos de transformação na sociedade como um todo. Tais movimentos podem envolver questões e lutas políticas de saúde, de cidadania e direitos humanos, direito à moradia, temas ambientais e de justiça ambiental, articulados a manifestações culturais as mais diversas que contextualizem e forneçam sentido à vida das pessoas do lugar;

- incorporação do conceito de território, em articulação com o de comunidade, na análise dos determinantes socioambientais e dos processos saúde-doença, bem como nas ações de promoção a serem construídas (Porto \& Pivetta, 2009).

Um dos elementos mais desafiadores para a proposta aqui apresentada é a construção de linguagens e práticas que permitam o diálogo entre o mundo técnico-científico e o espaço popular e cotidiano das pessoas e comunidades, as quais dispõem de saberes legítimos acerca dos contextos, valores e culturas nos quais as propostas de promoção da saúde deveriam florescer.

O capítulo, após uma discussão sobre o território de Manguinhos no contexto da formação histórica das cidades brasileiras, apresenta os pressupostos, desafios e alguns resultados e produtos de pesquisas realizadas pelo LTM na análise dos problemas e potencialidades do território. Dentre eles destaca-se o processo de reconstituição da história de formação das diversas comunidades, a análise dos determinantes e condicionantes do processo saúde-doença, questões socioambientais recorrentes como as enchentes e a poluição, e políticas públicas como o Programa de Aceleração do Crescimento (PAC). O desafio é como ultrapassar os limites da produção de conhecimentos de forma que se faça dialogar referenciais técnico-científicos de várias áreas, incluindo as ciências sociais, ambientais e de saúde coletiva, com o saber local e popular dos que vivem e trabalham em Manguinhos. Uma estratégia para tal fim é a incorporação de linguagens audiovisuais, artísticas e lúdicas como forma de abordar temáticas mais complexas, superando discursos argumentativos distanciados das pessoas do lugar. 


\section{A Formação das Cidades Brasileiras: fragmentação, exclusão e injustiça ambiental}

O movimento de cidades saudáveis ocupa destaque no mundo nas décadas de 1980 e 1990, na Europa e no Canadá, como proposta da Organização Mundial da Saúde (OMS) para enfrentamento dos problemas da saúde urbana. Caracteriza-se pela articulação entre os setores público, privado e a sociedade civil no desenvolvimento de projetos interinstitucionais e intersetoriais, em diversos âmbitos das políticas públicas, sendo direcionado à melhoria das condições de vida e saúde da população urbana.

No Brasil, as iniciativas de comunidades, territórios ou municípios saudáveis ganharam alguma projeção principalmente no início do século XXI, pretendendo alterar o quadro de desigualdades sociais e inequidades em saúde em contextos de pobreza e ausência de direitos, na garantia tanto do acesso a bens e serviços como da ampliação da participação nos processos decisórios em políticas públicas. Reconhecendo a saúde como expressão de qualidade de vida, uma cidade saudável implica gerar processos participativos, sociais e institucionais e, sobretudo, pactuar intervenções públicas com o propósito de melhorar a vida de todos os cidadãos (Westphal, 2000). Apesar da importância dessas iniciativas geradas a partir do setor saúde, no contexto de grandes desigualdades e injustiças na distribuição dos benefícios e dos ônus do modelo de desenvolvimento, como é o caso do Brasil, a ideia de cidade saudável deve ser revisitada à luz das contradições percebidas no processo de conquista de saúde para todos nos últimos anos após a promulgação da Constituição de 1988 quando se manteve o padrão de produção de iniquidades.

As inequidades em saúde podem ser compreendidas tanto como diferenças injustas e evitáveis nos perfis de saúde da população que mantêm correlação com as desigualdades de acesso à educação e renda, condições ambientais e fatores macroeconômicos, como a diferenças biológicas, étnicas ou comportamentais. Essas diferenças nos perfis de saúde entre homens e mulheres, entre regiões e comunidades ou entre negros e brancos, por exemplo, vêm se reproduzindo há muito tempo no Brasil, mesmo com os recursos científicos e tecnológicos já existentes, e por isso são consideradas sistemáticas, evitáveis e desnecessárias. Portanto, devem ser enfrentadas por políticas de saúde, mas também pelos demais setores das políticas públicas e da sociedade civil. O compromisso radical com os pilares da promoção da saúde - a participação da população e a intersetorialidade é uma das estratégias fundamentais para a superação das desigualdades sociais e o alcance da equidade. 
O conceito de cidade saudável, assim, extrapola o acesso a serviços de saúde de qualidade ou a uma vaga noção de ambiente saudável ou de desenvolvimento sustentável. Ele está associado, em uma concepção própria, ao exercício pleno dos direitos de cidadania dos habitantes de uma nação, e tais direitos se articulam com o direito à saúde e incluem os direitos humanos, de liberdade de expressão, de organização política e acesso a ambientes saudáveis. Em tal perspectiva, as cidades brasileiras e latino-americanas têm ainda um longo percurso para alcançar esse status.

A formação das cidades brasileiras ao longo do século XX, com sua fragmentação, desigualdade socioambiental e padrão centro-periferias, está diretamente relacionada a um modelo de desenvolvimento econômico excludente e altamente concentrador (Rolnik, 2008; Ribeiro, 1997 e 2000; Lago, 2000). Excludente porque privou as faixas de menor renda de condições básicas de urbanidade e de inserção efetiva na cidade; e altamente concentrador, na medida em que 60\% da população urbana vive hoje em 224 municípios com mais de cem mil habitantes, e 94 municípios pertencem a aglomerados urbanos e regiões metropolitanas com mais de um milhão de habitantes. Também no nível intraurbano há fragmentação, em que convivem na mesma cidade, como no Rio de Janeiro, no mesmo bairro, áreas ditas "de mercado", reguladas por um vasto sistema de normas, leis e contratos, enquanto para as maiorias sobram os espaços precários das periferias, das áreas de risco, como as encostas íngremes e as várzeas inundáveis. A cidade fora da cidade, como refere Raquel Rolnik (2008), é destituída dos direitos fundamentais de cidadania e caracterizada - de forma estigmatizante - pela ausência, "pelo que ela não é ou pelo que ela não tem", como água, esgoto, luz, coleta de lixo, arruamento, lei, ordem e moral (Souza e Silva, 2007: 211). Além das ausências de infraestruturas, equipamentos e serviços que caracterizem a urbanidade e a cidadania, também frequentemente estão ausentes dos mapas e cadastros de prefeituras, são inexistentes nos registros de propriedade dos cartórios, bem como nos registros das concessionárias de serviços públicos (Rolnik, 2008).

A saúde pública no espaço das favelas se insere nesse complexo ciclo vicioso: o ambiente é frequentemente caracterizado pela falta de saneamento básico, de condições precárias de moradia e transporte, pela poluição e enchentes. Todos esses riscos ambientais geram múltiplos problemas de saúde, os quais, em conjunto com os demais problemas relacionados à pobreza e às desigualdades de acesso à educação e alimentação, restringem fortemente os mecanismos de assistência à saúde centrados no modelo médico-assistencial. E para tornar o 
quadro ainda mais complicado, novas territorialidades perversas foram geradas nas últimas décadas em consequência da ausência do Estado e do crescimento de vários comércios ilícitos - em especial o das drogas, ironicamente alimentado pelos consumidores da cidade formal.

A divisão do espaço geográfico por meio da conformação dos territórios ricos e salubres isolados das periferias pobres e insalubres, sem infraestrutura básica de serviços, perigosas e próximas aos lixões e fábricas poluentes, são chamados por autores da justiça ambiental, como Robert Bullard (1994), de zonas de sacrifício. O movimento por justiça ambiental nos territórios urbanos vem se espalhando no mundo e reflete a articulação entre um ambientalismo popular no contexto da ecologia política urbana e a luta por direitos humanos. Reflete também as diferentes formas de combate à discriminação e ao racismo.

No Brasil, os movimentos por justiça ambiental (ver <www.justicaambiental. org.br $>$ e <www.conflitoambiental.icict.fiocruz.br $>$ ) encontram-se ainda mobilizados, em sua maioria, por movimentos de resistência nos campos e florestas advindos de populações rurais e tradicionais, como indígenas, quilombolas e ribeirinhos, que lutam contra os impactos da expansão capitalista por recursos naturais presentes em setores como agronegócio, mineração, siderurgia e construção de hidrelétricas. Porém, nos últimos anos, as favelas passaram a ser discutidas como uma questão de (in) justiça ambiental. Um marco foi a realização no Rio de Janeiro do primeiro Seminário Direito à Moradia e Justiça Ambiental, ${ }^{1}$ em outubro de 2007. Uma das motivações do evento foi o debate recorrente, na mídia, responsabilizando a população das favelas pelo desmatamento das encostas e áreas de preservação. Além de confundir a opinião pública, tais discursos representam uma ameaça à garantia de direitos, reforçando a discriminação contra os moradores das favelas e, muitas vezes, encontram-se vinculados ao favorecimento da especulação imobiliária na cidade.

Entender as favelas do ponto de vista da ecologia política e da justiça ambiental significa compreender esses espaços como resultado histórico marcado por discriminações, racismo, baixos salários, falta de ofertas de políticas urbanas e de habitação para as classes populares. As lógicas de ocupação que marcaram a história das favelas no Rio de Janeiro - e em diversas cidades do país e da América Latina -, normalmente desembocam em condições socioambientais

\footnotetext{
${ }^{1}$ Idealizado para articular o debate sobre justiça ambiental às lutas por moradia digna em territórios urbanos - com foco nas favelas, 0 evento foi organizado pelo Instituto Brasileiro de Análises Sociais e Econômicas (Ibase), pela Rede Brasileira de Justiça Ambiental (RBJA) e pela Frente Estadual Contra a Remoção de Favelas e pela Moradia Digna. Mais detalhes em <www.justicaambiental.org. br/_justicaambiental/pagina.php?id=1768>.
} 
com múltiplas situações de risco. Algumas se agravam diante das chuvas e da precariedade das habitações, como os desmoronamentos nos morros e as enchentes; outras, pela falta de saneamento e infraestrutura (esgoto, coleta de lixo, rede de águas pluviais). Outro fator agravante é a proximidade de vias férreas e de grandes vias de rodagem, ou ainda de fábricas poluentes. Todas essas condições produzem múltiplas situações de risco, conformando as zonas de sacrifício, ou seja, os territórios da discriminação que concentram situações de injustiças ambientais. $^{2}$

Os territórios da segregação e discriminação são também territórios da exclusão, do vazio de direitos e da ausência do Estado e de políticas públicas consistentes. Mas são, principalmente, do ponto de vista de uma abordagem da PS emancipatória, vistos como um território vazio de memória que forneça os sentidos de pertencimento e as bases sociais, culturais, políticas e cognitivas constituintes dos sujeitos coletivos e movimentos sociais. Reconstruir a história do lugar com os moradores, a história vivida e contada por todos, é uma forma de se contrapor ao discurso excludente e segregador. Esse vivenciar coletivo da história do lugar se opõe, como assinala Milton Santos (2000), às fabulações de um mundo imaginário. Tal mundo é também possibilitado pelas ciências a serviço da ideologia dominante, que escamoteia as desigualdades sociais e homogeneíza os lugares, como se iguais fossem e não contivessem suas diversidades e seus potenciais criativos, essenciais à transformação da sociedade e à produção de outra história humana.

As histórias desses territórios permanecem sistemática e deliberadamente ocultas, invisíveis à sociedade e ao Estado, cujas políticas públicas atendem aos interesses das elites. Trata-se, na visão de Boaventura de Souza Santos (2001), de uma epistemologia da cegueira que "exclui, ignora, silencia, elimina e condena à não existência epistêmica tudo o que não é susceptível de ser incluído nos limites de um conhecimento que tem como objectivo conhecer para dominar e prever" (apud Nunes 2007: 49). Quando não esquecidos, os moradores das favelas são tratados ora com estigma, ora como simples alvos de filantropia mantenedora do status quo, e ainda de barganha eleitoral.

Esse aspecto foi bem explorado por Adriana Facina ${ }^{3}$ (2009). Em sua análise sobre como as favelas vêm sendo representadas na cinematografia brasileira, ela aponta

\footnotetext{
${ }^{2}$ Para conhecer o texto que analisa o território de Manguinhos como marcado por situações de injustiça ambiental - disponibilizado no referido seminário -, acessar: <www.justicaambiental.org.br/_justicaambiental/pagina.php?id=1767> .
}

${ }^{3}$ Professora de história e coordenadora do Observatório da Indústria Cultural da Universidade Federal Fluminense (UFF). 
para as consequências desse vazio de respeito pela história e pela vida das pessoas, na lógica presente, na formulação e implementação das políticas públicas:

O que se percebe, sobretudo, é uma super-representação da questão da violência, que tem como contrapartida uma desumanização radical daquelas pessoas que habitam este espaço de forma real, de forma concreta e não na ficção. O que interessa olhar pra favela é esse olhar da violência, da miséria, da ausência. Então, nesse sentido uma intervenção como o PAC vem atuar em cima de qual território? De um território de faltas, de um território de ausências, num território que não tem saúde, onde não tem educação, onde as pessoas não sabem como morar, não sabem como viver em um prédio, não sabem se comportar em sociedade; então qualquer coisa na verdade é um lucro, qualquer melhoria é uma coisa que vai tirar alguém que não tem nada pra uma situação que se tem alguma coisa.

Nesse sentido, Manguinhos é mais que um espaço singular. Sua história é também, de muitas formas, a história das populações que vivem nos territórios periféricos da exclusão no Rio de Janeiro e em tantas outras cidades do Brasil, país que em pleno século XXI ainda permanece com enormes desigualdades sociais.

\section{O Território de Manguinhos, no Rio de Janeiro}

A fragmentação e as desigualdades na cidade do Rio de Janeiro são visíveis àqueles que circulam por seus bairros e favelas. Dois grandes fenômenos ocorrem na cidade: a dualização centro-periferia dentro de um mesmo bairro-região e a fragmentação socioespacial ou, mais adequadamente, socioterritorial, decorrentes da desindustrialização regressiva da região e da globalização da economia. Existe ainda uma fragmentação que é simbólica:

(...) produzida por um variado e ainda multiforme conjunto de representações sociais do espaço metropolitano que cria ruptura entre territórios (...) passam crescentemente a ter o papel de estigmatizadores e diabolizadores dos pobres, na medida em que se busca enunciá-los como o lugar e a origem da chamada violência urbana (Ribeiro, 1997: 66-67).

As violências e os discursos oficiais que orientam as políticas públicas promovem uma nova dualidade: lugares seguros versus lugares violentos, fragmentando ainda mais as precárias cidades brasileiras, gerando enclaves "fora do controle estatal": as favelas e periferias e os "lugares seguros", pela autossegregação das elites e classes médias, autorizados e legitimados pelo Estado, em que todos são territórios de exceção, privatizados por diferentes grupos de poder e no limite de seus poderes (Rolnik, 2008). Enclaves que, para Luciana Corrêa do Lago (2000), 
no Rio de Janeiro, configuram um processo de guetificação em que, de um lado, estão as favelas - os guetos cariocas - e, de outro, os condomínios fechados, shoppings - elites.

O território-bairro de Manguinhos tem cerca de 35 mil moradores em 15 comunidades, marcadas por elevada vulnerabilidade socioambiental, violência e restrições de circulação, informação e organização de espaços coletivos. Refletindo sobre qual a principal questão colocada pelos moradores para discutir saúde, ambiente e políticas públicas, Gleide Guimarães e Consuelo Nascimento, duas moradoras-pesquisadoras que participam do LTM, afirmaram:

(...) são as incertezas. Incertezas que resultam da falta de informações e agem sobre a vida das pessoas, provocando desestímulo e um eterno sentimento de provisoriedade. Vai mudar, mas não dão certeza. Vai demorar, de repente muda de uma hora para a outra. No natal é natural fazer reformas, melhorias, mas ninguém faz. Ninguém tem nenhum controle sobre as mudanças nos seus lugares de moradia, nas suas vidas.

Como um território em disputa, Manguinhos vive a eterna busca de sua vocação e de suas funções na cidade: ao longo de sua história passou de lixão a bairro industrial e área de transição para alocação de removidos. Uma dimensão importante da injustiça ambiental em Manguinhos são as remoções de fora para dentro e de dentro para fora. As de fora para dentro ocorreram principalmente nos anos 1950 e 1960, quando foram assentados em caráter provisório grande contingente de populações de favelas da zona sul, nesse território de riscos, nessa autêntica zona de sacrifício - área de lixão, o Retiro Saudoso, antiga região de mangue, localizada à margem de rios e canais, atravessada por uma potente rede de alta tensão, pela adutora da Companhia Estadual de Águas e Esgotos (Cedae) e por grandes vias, tais como a via férrea, avenidas Brasil, dos Democráticos, Dom Hélder Câmara (antiga Suburbana) e Leopoldo Bulhões. Para completar, em Manguinhos se encontra, ainda, uma refinaria de petróleo a Refinaria de Manguinhos. As remoções de dentro para fora, que existiram e continuam presentes em momentos de crise, como enchentes ou incêndios, ou por obras estruturais como o atual PAC, consistem em deslocar moradores para áreas distantes, longe do emprego, transportes precários etc. sem considerar suas demandas (Fernandes \& Costa, 2009).

Aqui, retoma-se a questão das incertezas, agora na afirmação do sociólogo Zigmunt Bauman:

(...) a ilegibilidade do espaço, as incertezas e o poder estão intrinsecamente associadas. A manipulação da incerteza é a essência e o desafio primário na 
luta pelo poder e influência dentro de toda totalidade estruturada, que aplicada à gestão dos territórios implica na sua própria alienação. (Bauman, 1999: 40)

Ou nas palavras de Gleide Guimarães, uma das moradoras de Manguinhos e pesquisadora do LTM: "Só vai dar certo se o cidadão se envolver. O cidadão só vai se envolver se tiver certeza que vai participar do fazer acontecer. O território não é e talvez não seja nunca 'apropriado' por ninguém - nem o Estado, nem os moradores, nem o poder marginal investe ou investirá".

\section{A Produção Compartilhada de Conhecimentos: estratégias, limites e potencialidades}

As lógicas de elaboração e implementação de políticas públicas tendo como base o planejamento centralizado das cidades, usualmente buscam sustentar projetos políticos alheios às vocações da cidade, dos lugares e de seus habitantes. Na maioria das vezes tais políticas não se constituem num processo que permita a confrontação dos diferentes interesses em jogo e que este não seja construído por atalhos. Os atalhos e as pressas, justificadas em nome da urgência, acabam por justificar o descuidado, a provisoriedade, a não participação, a alienação.

Os atalhos, frequentemente, levam a outros lugares que não os projetados, abreviam as reflexões, são determinados por uma urgência que não nos faz conhecer e apreciar o território que atravessamos. $\mathrm{O}$ atalho, o pai do desastre planejado, com a desculpa de se fazer primeiro, determina um distanciamento, uma negação à participação, um esgarçamento do tecido que deveria trazer junto os habitantes na determinação das suas próprias vidas, do estar juntos não por constrangimento, mas por consciência. (apud Pivetta, 2002: 266)

Ao contrário, diante da complexidade dos problemas socioambientais, deveria se pensar num território como Manguinhos como um laboratório de todos moradores, governantes, pesquisadores -, resgatando o espaço da ciência como espaço público que dialogue e incorpore solidariamente as necessidades das pessoas e da sociedade na forma de analisar e intervir na realidade. Pleiteia-se uma formulação de políticas públicas que não seja só informada pela ciência, mas também pelos saberes e valores dos habitantes do lugar, pelos valores éticos da sustentabilidade, de formas de desenvolvimento que recusem injustiças intoleráveis, e em conjunto tais critérios e práticas permitam estabelecer uma ética das prioridades. 
Os problemas socioambientais e de saúde no território exigem não apenas o saber o que, dentro dos paradigmas técnicos científicos, mas incluem o saber como, juntamente com amplas e complexas questões de ambiente, societárias e éticas. Por isso se faz necessário, para a garantia da qualidade de políticas públicas, programas e projetos, ampliar a contribuição tanto de outros cientistas e especialistas como de representantes de interesses sociais como defendem Silvio Funtowicz e Jerome Ravetz (1992). Essa é a justificativa fundamental para a criação de comunidades ampliadas de produção de conhecimentos e práticas.

Quando os problemas não têm soluções claras, são complexos ou ambíguos em si, as técnicas quantitativas - aparentemente objetivas - dão abertura à crítica metodológica, e essa é uma das razões que envolvem o porquê de os debates não poderem ficar restritos aos especialistas acadêmicos ou funcionários públicos. O conhecimento das condições locais não somente deveria dar formato ao problema, mas também determinar os dados sólidos e relevantes, contextualizando-os e dando sentido a eles (Funtowicz \& Ravetz, 1992).

Ao enfrentar a complexidade dos problemas socioambientais de um território como Manguinhos, é necessário radicalizar as avaliações críticas sobre os discursos e programas não só de promoção de saúde, mas da prática científica e das políticas públicas em geral, que acabam por reproduzir conhecimentos e práticas de forma descontextualizada e burocrática, sem efetivamente trabalhar junto com as populações. Partindo do campo da saúde coletiva, as preocupações e intenções aqui demonstradas apontam para a superação de uma forma especializada e fragmentada de se fazer ciência, a qual coloca cientistas aparentemente objetivos e neutros - eventualmente até os das ciências sociais e humanas - de uma forma afastada ou mesmo acima das populações e das pessoas objetos de suas investigações. O desafio, portanto, é o de construir uma prática de produção de conhecimentos sensível e cidadã, solidária e compartilhada, antenada com o mundo das necessidades e possibilidades partindo-se de cenários por vezes tão cruéis, mas acima de tudo humanos.

Tal postura encontra seus fundamentos na pedagogia da ação dialógica e humanizadora de Paulo Freire e seu princípio da solidariedade, bem como nas abordagens sociológicas contemporâneas baseadas na análise contextual. Uma PS emancipatória, assim, tem como tarefa central a criação de processos relacionais, dialógicos e políticos que possibilitem a emergência de novas práticas humanizantes e democráticas. Tais práticas devem influenciar e redirecionar políticas públicas que simultaneamente reduzam vulnerabilidades 
socioambientais e ampliem os direitos humanos e a cidadania das populações excluídas (Porto \& Pivetta, 2009).

A noção de construção compartilhada de conhecimento é tomada aqui de Regina Marteleto e Víctor Valla como sendo

um conceito e, ao mesmo tempo, um caminho metodológico nascido da busca por um novo paradigma teórico-epistemológico para se compreender e se efetivar a relação entre acadêmicos, intelectuais, técnicos e representantes do poder público com a população (...) não resultará em amálgama, mas em composições contraditórias e provisórias entre o conhecimento teórico, histórico, técnico e o conhecimento popular (...) Produzindo um terceiro conhecimento, 'um conhecimento que não é sinônimo de ciência, mas sim fruto de diversos modos de produção do saber'. (Marteleto \& Valla, 2003: 14-16)

Configura-se, portanto, segundo Santos (2006), como um trabalho de tradução que permite criar inteligibilidade entre diferentes linguagens e situações, possibilitando aos diferentes grupos sociais interferir e transformar solidariamente uma realidade desfavorável.

Produzir de forma compartilhada conhecimento e informação sobre Manguinhos, nas práticas do LTM, significa tomar esse território como objeto de aprendizagem, não apenas dos pesquisadores, mas também dos moradores que nele vivem. É fazer do território o laboratório de todos, para a transformação pela ação coletiva. Assumindo o "bairro como novo lugar de luta pela identidade dos grupos populares", como destaca Martín-Barbero (2004: 113), na complexidade de seus processos, com suas tantas vozes, se pode contribuir para a promoção de mecanismos e mediações que proporcionem uma comunicação participativa. Uma comunicação referenciada em Paulo Freire, "ligada mais à liberação da fala, da atividade e da criatividade popular que à potência ou o tipo de mídia utilizada", desfazendo da ilusão que o alternativo é o meio em si (Martín-Barbero, 2004: 119).

De outra forma sublinha ainda Facina (2009) sobre a tarefa da pesquisa social em possibilitar a veiculação de outras vozes, daquelas que são caladas pelos veículos de comunicação de massa e de reprodução dos estigmas e discriminações que a sociedade produz em relação às populações de favelas e periferias:

Porque também tem isso: fala que é autorizada e fala que não é autorizada. Um filme como Tropa de Elite pode mostrar as coisas que são colocadas, agora um funk que fala da realidade que é vista nas favelas é chamado de proibidão. Então a gente tem que começar a pensar nessas divisões, nesses olhares e se colocar contra isso das formas possíveis, não só criticando, mas também produzindo visões alternativas. 
Um componente metodológico na forma de se operacionalizar a construção compartilhada de conhecimento e informação se deu por meio da formação do que se denomina uma Comunidade Ampliada de Pesquisa-Ação (CAP), inspirados em Funtowicz e Ravetz $(1992,1994)$. A CAP é formada por servidores da Fiocruz, das várias áreas do conhecimento que integram o campo da saúde coletiva e por moradores de Manguinhos, que juntos desenvolvem trabalhos de pesquisa-ação no LTM.

\section{Tradução e Linguagens para a Produção-Circulação-Apropriação de Conhecimento e Informação}

O trabalho realizado no LTM parte da perspectiva do compartilhamento de saberes e práticas na construção de outra realidade para Manguinhos, na colaboração para a constituição de cidadãos autônomos e emancipados, na mediação entre os conhecimentos científicos e o saber popular, como

a possibilidade de a população lançar seus mundos no nosso mundo. Lançar mundos cotidianos, coloridos, imprevisíveis, sonoros, polifônicos, no mundo monocórdio, preto e branco, previsível, repetitivo, restritivo das organizações que fazem e implantam políticas públicas em saúde... (Brandão, Araújo \& Cardoso, 2002: 1)

O propósito central é constituir ciclos comunicativos, que contribuam para a construção de sentidos sociais considerando questões e problemas concretos que se expressam sobre um dado território, lugar, acontecimento e na vida das pessoas, entendendo a mediação como "a propriedade exercida pelo elemento que possibilita a conversão da realidade em outra" (Araújo, 2002: 259).

O projeto ético que nos inspira é a construção de uma nova forma de produzir sentidos, conhecimentos e argumentações na sociedade, de modo a combater a exclusão, promover a saúde e a democracia. Exclusão, aqui, é entendida como impossibilidade de fazer circular seus próprios sentidos. A mobilização tem o propósito de criar processos em que os vários sentidos circulantes possam conviver e se confrontar de maneira mais equivalente, propiciando dinâmicas de transformação que atendam às necessidades e potencialidades de satisfação das pessoas, comunidades e da sociedade como um todo (Brandão, Araújo \& Cardoso 2002).

O ciclo de comunicação compreende a produção-circulação-apropriação do conhecimento e da informação (Araújo, 2006). A produção, tradicionalmente, se inscreve no domínio das disciplinas e técnicas para a geração de dados, 
conhecimento e informação no âmbito das instituições, as quais usualmente não dispõem de instrumentos e métodos para ouvir outras vozes que não as de seus profissionais especialistas. Aqui, o desafio é ampliar seu escopo no sentido de uma produção compartilhada.

A circulação se dá no domínio das mídias e tecnologias de comunicação e informação. É ela que "confere existência aos produtos simbólicos, que os tiram do âmbito privado e os tornam de fato públicos" (Araújo \& Cardoso, 2007: 75). O desafio consiste em disputar com as mídias e formas de comunicação existentes os espaços e conteúdos de circulação, incorporando a criatividade e a cultura local como estratégia também de produção de conhecimento e informação.

A apropriação, por fim, fecha o ciclo da comunicação. Ela é o "lugar que define se a comunicação se realiza ou não e que sentidos finalmente dela resultarão" (Araújo \& Cardoso, 2007: 75). É o espaço do domínio do direito e da cidadania, do âmbito da educação, da formação da consciência e dos princípios pedagógicos que norteiam os fluxos, formas e canais de comunicação que são estabelecidos. O desafio aqui consiste na transformação de objetos em sujeitos, na busca ativa de conhecimentos que promova a cidadania, na realização de direitos, no fim mesmo da democracia, e por extensão, na disputa por modelos de sociedade, culminando numa dialética de confrontação e compromissos táticos possíveis.

Um desafio central de todo esse processo é o de natureza metodológica, mas também epistemológica e ética: a construção compartilhada de conhecimentos por uma comunidade ampliada de pesquisa-ação se faz, nas palavras de Marize Cunha ${ }^{4}$ num caminho de pedras, em que a autonomia do pesquisador passa pela autonomia do morador-pesquisador e vice-versa. Metodologia, estratégia e tática se mesclam e se confundem o tempo todo, já que inclusive os ritmos e tempos não são os mesmos entre pesquisadores e moradores e suas realidades.

A matéria-prima para esse caminhar nas pedras, seguindo a tendência atual de uma ciência crítica que reconhece a complexidade e os avanços do pensamento sistêmico, tem por base o debruçar sobre situações e problemas. Essas situaçõesproblema buscam ser compreendidas dentro das dinâmicas dos territórios vivenciadas pelas populações, em diálogo (e confronto) com informações, análises e conhecimentos científicos levantados por instituições no processo de pesquisa. Ao fornecer focos e condições objetivas, tais situações ou problemas permitem o aflorar de perspectivas, de relações e compromissos entre as pessoas (pesquisadores

\footnotetext{
${ }^{4}$ Pesquisadora do Departamento de Endemias da Escola Nacional de Saúde Pública e da equipe do LTM.
} 
engajados e pesquisadores-moradores) e os vários sujeitos do território na produção de agendas de trabalho, revistas periodicamente de acordo com a evolução do grupo e das dinâmicas dos territórios.

Dentre os vários focos já trabalhados pode-se citar os temas da história oral das comunidades de Manguinhos e problemas como a violência, a ocorrência de enchentes, a presença da refinaria de petróleo e, mais recentemente, a principal política pública já implementada na área - o chamado PAC Manguinhos.

Utilizando recursos pouco convencionais da análise social em diálogo com a comunicação audiovisual, a fotografia, a arte-educação e as tecnologias de informação e comunicação na apropriação dos conteúdos da pesquisa, o processo tem demonstrado que se está na direção do que foi proposto - um caminho virtuoso no diálogo entre a ciência e a cidadania (Cadernos LTM, 2009).

\section{Algumas Experiências no Uso de Linguagens Audiovisuais e Lúdicas para o $(R e)$ Conhecimento do Território}

O LTM vem, ao longo dos últimos anos, desenvolvendo uma série de experiências na construção compartilhada de conhecimentos e de ciclos de comunicação em torno de problemas concretos do território. A questão da linguagem se destaca como possibilidade de pensar a produção de conhecimento e a comunicação de outra forma, mais sensível, ampla e participativa. Portanto, a busca da inserção da arte e da linguagem lúdica no trabalho realizado é entendida como uma forma de mediar e traduzir as possíveis relações entre o conhecimento que é sistematizado pela comunidade científica e os conhecimentos que são vivenciados nas comunidades do entorno da Fiocruz. Muitos desafios se apresentam quando a arte é inserida num processo de troca de conhecimentos, na qual se busca a mediação entre o que se quer aprender sobre uma determinada realidade ao reapresentar para os que nela vivem questões já colocadas em suas vidas. Para o LTM, a arte não é, como na visão da popularização da ciência, uma simples ferramenta para divulgar e fazer entender verdades científicas, mas sim uma importante instância na qual, considerando as diversas percepções dos moradores de Manguinhos sobre o território onde vivem, estes se reconheçam como sujeitos de sua história e não como objeto a ser estudado.

Dentre as pesquisas e produtos recentes que buscam incorporar novas linguagens e processos de produção compartilhada de conhecimentos, destaca-se: o site <www.conhecendomanguinhos.fiocruz.br>; livro, documentário e cordel sobre a história das comunidades; jogos eletrônicos e presenciais tipo role playing 
game (RPG) - sobre temas de saúde e ambiente no território; documentários e relato fotográfico do PAC Manguinhos. Esse conjunto de materiais constitui o que denominamos caixa de ferramentas, kit ou mala do LTM e está disponível para o uso de todos os interessados. A seguir, são apresentados alguns desses materiais.

\section{O desenvolvimento do site <www.conhecendomanguinhos.fiocruz.br>}

O site <www.conhecendomanguinhos.fiocruz.br> reúne conhecimentos e informações produzidas pelo projeto em torno dos temas: História de Pessoas e Lugares, Território e Cidadania e Saúde, Ambiente \& Desenvolvimento. É a principal ferramenta disponibilizada ao público em geral, para concretizar os objetivos do LTM de

construir uma promoção da saúde que integre ciência e cidadania, invista na formação de sujeitos coletivos e redes sociais, resgate a memória coletiva das comunidades, sistematize conhecimentos sobre o lugar e acompanhe, de forma crítica e propositiva, políticas públicas relevantes para a população de Manguinhos, construindo assim um modelo solidário de conhecer e interagir nos territórios em que vivemos. (trecho retirado do site do LTM)

Seu processo de construção envolveu todos os pesquisadores do LTM na sistematização dos conteúdos, durante o ano de 2007 até meados de 2008, e contou com a realização de três oficinas de validação com: a equipe do LTM; pesquisadores da Fiocruz e de outras instituições de Manguinhos; e com ex-alunos do Programa de Vocação Científica da Escola Politécnica Joaquim Venâncio (Provoc/Fiocruz) e seus familiares.

O site é uma ferramenta didático-pedagógica que deve ir além de um repositório multimídia de informações, sendo também um espaço de interação, estímulo à reflexão e construção compartilhada de conhecimento. A abordagem pedagógica do site inclui a dimensão da interatividade em dois momentos: a interatividade no processo e a interatividade no produto. A interatividade no processo ocorre na participação efetiva de moradores, alunos, pesquisadores, dentre outros atores sociais, no processo de construção e estruturação do site, de forma que ele represente um conhecimento sistematizado, mas que não esteja desvinculado da vida cotidiana dos futuros usuários prioritários do site.

Já a interatividade no produto se concretiza na implementação de ferramentas que permitam a interação entre os usuários-navegantes e a inclusão de conteúdo por parte desses mesmos usuários, porém com uma estruturação predeterminada no desenvolvimento do site. A abordagem pedagógica também busca despertar as pessoas que usam o site, em especial os jovens, para questões do contexto 
social onde eles se inserem, e, em paralelo, fugir da fetichização tecnológica, estimulando a compreensão de que a tecnologia utilizada é um meio que não deve ser valorizado por si só, e sim uma ferramenta para se alcançar objetivos socialmente relevantes.

O processo de construção do site contou com a participação de jovens bolsistas do Programa de Vocação Científica para o Desenvolvimento Local Integrado e Sustentável (Provoc/Dlis), da Fiocruz, alunos do ensino médio que estudam em escolas públicas da região, desde sua fase inicial de concepção, contextualizando suas necessidades e demandas por intermédio de uma produção compartilhada de conhecimento voltada à transformação de sua realidade e do próprio território. A intenção é que as tecnologias da informação e comunicação (TIC) amplifiquem a voz dos moradores por meio da interatividade tendo como base o site, e façam a interface com os demais membros da sociedade para o acúmulo de capital social dessa comunidade. Um aspecto relevante do uso da internet é o seu crescente uso por classes populares e movimentos sociais em processos de democratização da informação e divulgação de lutas locais (Maia, 2007).

Um dos principais desafios colocados desde seu lançamento, em setembro de 2008, é implementar estratégias de circulação e apropriação do conteúdo disponibilizado no site e, ao mesmo tempo, continuar a produção de novos conteúdos considerando os novos e diversos subprojetos. Desafio este que se constitui no próprio processo de avaliação/validação continuado do site como ferramenta mediadora da comunicação.

\section{Histórias de pessoas e lugares de Manguinhos}

As histórias de Manguinhos estão sistematizadas no documentário Manguinhos: histórias de pessoas e lugares, no cordel Manguinhos em Prosa e Verso e no livro Histórias de Pessoas e Lugares: memórias das comunidades de Manguinhos, publicado em 2009 pela Editora Fiocruz.

A reconstituição das histórias do lugar tem importância central para a promoção da saúde emancipatória que se pretende construir, tendo a compreensão da história como um sistema de críticas, conceito que Tania Maria Fernandes e Renato da Gama-Rosa apresentam em seu livro (Fernandes \& Costa, 2009).

É fundamental, como ensina Marilena Chaui, conhecer a história e não confundi-la com destino, mas perceber a historicidade da construção de um processo de desenvolvimento humano, do território e da sociedade. Entender que não existe um ponto predeterminado, fixo, idêntico e perfeito que se 
deva alcançar, mas que a vida é um processo historicamente construído - é transformação e criação. A história, como passado vivido, é o espelho retrovisor que situa o cidadão no presente para que pense um futuro emancipador e não como negação do presente (Chaui, 2006). Resgatar as histórias dos moradores da região, fazendo um paralelo com as histórias de construção do bairro, tem sido de fundamental importância para a comunidade ampliada de pesquisa do LTM, e em especial para os moradores de Manguinhos. Estes estão tendo a oportunidade de entender os diversos fatores que resultaram numa região rica em problemas socioambientais, bem como o que levou a população local a escolher tal lugar para morar e nele permanecer.

As histórias de pessoas e de lugares das comunidades de Manguinhos compõem o tema do livro de autoria dos pesquisadores Tania Maria Fernandes e Renato da Gama-Rosa. A publicação visita cem anos de ocupação urbana com base em abordagens da história, da memória e do urbanismo. Analisa ainda o processo de ocupação dessa área, em especial das moradias populares, que se iniciou nos primeiros anos do século XX, tendo ocorrido mediante iniciativas individuais e de grupos, ou de políticas públicas pontuais e desarticuladas com a cidade como um todo. Para tal estudo assumiu-se, como questão central, problemáticas urbanísticas, ambientais e sociais historicamente vinculadas a áreas de grande exclusão social e violência urbana, como é o caso de Manguinhos. O trabalho ressalta, principalmente, as particularidades relacionadas aos processos de instalação, algumas provisórias, outras definitivas, próprias dessas comunidades, tanto oriundas de políticas habitacionais como de invasões. A abordagem não se limita à constatação da pobreza e da exclusão social, e sim em perceber a ação governamental, o processo de ocupação e algumas das possíveis formas de identificação dos moradores com seu espaço e sua história.

Os resultados dessa pesquisa estão sendo divulgados para a comunidade por meio de parcerias com instituições públicas como as escolas públicas do entorno, associações de moradores e ONG locais. Outras linguagens, além da acadêmica divulgada pelo livro, também foram desenvolvidas com a finalidade de ampliar o ciclo de comunicação sobre o tema da história, como o documentário Manguinhos, Histórias de Pessoas e Lugares, dirigido por Fabiana Melo Sousa; e a publicação de um cordel denominado Um Cordel para Manguinhos, escrito por Gleide Guimarães (ambas, pesquisadoras do LTM e moradoras de Manguinhos).

A publicação do cordel carrega o nome da equipe criadora e valoriza a realização do projeto LTM, de seus apoiadores e divulga parte da pesquisa realizada sobre a história de Manguinhos. No LTM, considera-se fundamental o incentivo 
da participação coletiva em todos os trabalhos realizados. No entanto, também há entendimento sobre a importância do reconhecimento dos esforços individuais que carregam em si suas habilidades específicas e suas histórias pessoais, para que os trabalhos realizados não sejam frutos de uma massa sem nome e sem identidade, mas de um coletivo plural no qual se busca a todo momento a troca de experiências e de saberes.

Lendo o cordel, o morador de Manguinhos tem a possibilidade de identificar alguns momentos das histórias das comunidades e neles reconhecer instantes de suas vidas pessoais, ou ainda tomar conhecimento de outras histórias relacionadas à cidade do Rio de Janeiro.

Pesquisando sobre as histórias de Manguinhos, pode-se perceber que existem dificuldades em encontrar registros históricos da região, em que quase tudo o que se noticia são os aspectos negativos das comunidades, como a violência. Na pesquisa desenvolvida pelo projeto, observou-se que existem muitos problemas nas comunidades, porém que há também manifestações culturais importantes que determinaram momentos históricos na região, como a fundação da Escola de Samba Unidos de Manguinhos, em 23 de abril de 1964, as festas juninas locais e os grupos de dança De Quina prá Cuia de Salão e Vai e Vem. Em 2005, por exemplo, realizou-se o ato Caminho da Paz, com Garantias de Direitos, um evento promovido pelo movimento social de Manguinhos em que a rua Leopoldo Bulhões foi fechada para um dia de atividades culturais.

Não é objetivo do LTM a construção de um olhar romântico sobre a história de Manguinhos, um lugar onde há situação de miséria e abandono. Mas, e isso sempre se reaprende no trabalho com as populações e os habitantes do lugar, ao lado da miséria humana convive a beleza e a dignidade das pessoas que resistem e fazem florescer a vida nas condições mais difíceis. Conhecer as histórias do bairro onde se mora pode ser o início de um processo de valorização de seu lugar para a formação de sua identidade, resgatando os sentidos da própria vida na localidade onde se vive. Isso só é possível levando-se em conta não apenas os atuais problemas, quando estes incomodam aos que usam a região como passagem em rodovias públicas ou como objeto de estudo, mas também as histórias de pessoas que nasceram e morreram na região e ajudaram assim a construir parte da história do Rio de Janeiro.

Dessa forma, o estereótipo da favela como um berço da marginalidade e das mazelas da cidade é contestado por seus moradores a partir do momento que conhecem tanto as origens de seu bairro como a de seus problemas. Essa é a concretização de um dos objetivos buscados, o de compartilhar com Manguinhos 
as pesquisas desenvolvidas, acreditando na capacidade de transformação de uma população conhecedora de sua história, para que ela mesma possa escrever seu futuro.

Futuro este que fica em aberto ao final do cordel produzido, quando o PAC Manguinhos traz, com suas propostas de grandes obras, mais um momento de esperança para a população da região: “... muito há para acontecer/ tem o PAC com as promessas de mudanças/ tem esperança no ar /daremos então mais um tempo/ e voltaremos a contar...".

Para a continuidade das trocas de experiências, distribuiu-se o cordel nas escolas públicas locais pelo projeto Tecendo Redes, do Museu da Vida da Fiocruz, além de ter sido entregue a algumas comunidades de Manguinhos pela equipe do Canteiro Social do PAC, da Prefeitura do Rio de Janeiro.

Projetos audiovisuais para o acompanhamento do PAC: documentário e fotografia como linguagens do cotidiano

O acompanhamento do PAC é um dos temas que o Laboratório Territorial de Manguinhos prioriza desde meados de 2007, cuja importância se expressa em três dimensões:

- a potencialidade das suas promessas para a transformação do território e melhoria na qualidade de vida dos moradores de Manguinhos;

- a crescente organização dos movimentos sociais locais e sua mobilização para ampliar a participação e influência nos destinos das ações previstas no programa;

- a possibilidade de acompanhamento de uma política pública desde o lançamento até a produção de resultados e impactos sobre o território.

Nesse sentido, estão sendo desenvolvidas atividades que têm como objetivo primordial a realização do mapeamento e análise dos efeitos das obras do PAC sobre as condições do território. ${ }^{5}$

Por meio de ambos os produtos, os documentários e o relato fotográfico, se faz o registro das obras e dos processos de interlocução entre os atores do Programa procurando a identificação, análise e avaliação de elementos presentes no cotidiano do lugar que possam se constituir em indicadores de transformação da qualidade de vida. Foram pensados como instrumentos para que as populações,

\footnotetext{
${ }^{5}$ Projeto Território, Políticas Públicas e Promoção da Saúde. Análise dos Efeitos Potenciais do PAC para a Redução de Riscos Ambientais e Vulnerabilidades em Manguinhos, Rio de Janeiro, que contou com o apoio da Coordenação Geral de Vigilância Ambiental (CGVAM), da Secretaria de Vigilância em Saúde do Ministério da Saúde, por intermédio de convênio com a Fiocruz.
} 
em particular aquelas em vulnerabilidade social, possam expressar suas necessidades e serem protagonistas de suas próprias histórias. O exercício do direito à informação, ao acesso equitativo e justo aos benefícios do Programa e à proteção aos mais vulneráveis, com abertura de espaços de participação e diálogo entre poder público e comunidades, seriam bons indicadores de sustentabilidade dos investimentos e de resultados mais efetivos em relação à promoção da saúde e às melhorias nas condições ambientais e de vida em Manguinhos. O processo de leitura das imagens, os fatos relatados pelos pesquisadores moradores, as informações coletadas nos documentos oficiais, depoimentos de moradores e as discussões presentes no Fórum Social de Manguinhos compuseram a leitura do processo e dos resultados do PAC sobre as vulnerabilidades socioambientais de Manguinhos.

A conclusão, de caráter processual, contrapõe os avanços com as mazelas que se reproduzem na implementação de políticas públicas, como o desrespeito para com alguns moradores obrigados, num curto espaço de tempo a saírem de suas casas para a execução das obras, sendo compelidos a morar em meio insalubre junto de entulhos das casas vizinhas já demolidas e a presença de ratos e escorpiões. Trazer à tona as vozes ocultas desses moradores, vítimas de injustiças ambientais, é um dos objetivos do trabalho que se vem realizando.

\section{O desenvolvimento de jogos interativos e de RPG}

Os jogos interativos e os role-playing games, também conhecidos como RPG, consistem na elaboração de jogos criados e produzidos por jovens sobre temas relevantes da realidade de Manguinhos. Trata-se de incorporar uma tecnologia computacional e de informação de caráter lúdico que possa atrair jovens e pessoas em contato com computadores para fins de aprendizado e reflexão em torno de problemas e interesses relacionados ao território. Envolveu inicialmente uma parceria com a organização Moleque de Ideias, especializada no trabalho de informática para crianças e jovens.

Em seu primeiro estágio, selecionou-se um programa para criação de jogos simples em duas dimensões: o Stagecast, ${ }^{6}$ pela sua capacidade de, num período curto de formação, propiciar o desenvolvimento de jogos nos quais os jovens poderiam exercitar sua criatividade e habilidades de pensamento à medida que aprendiam conceitos avançados de programação. Durante 2008 e 2009 realizaramse vários encontros quinzenais com duração aproximada de três horas, com a

${ }^{6}$ Stagecast Creator - trata-se de um aplicativo de fácil aprendizagem utilizado para iniciar crianças e jovens na arte de programar jogos eletrônicos interativos. 
finalidade de que os jovens e pesquisadores dominassem a ferramenta e passassem a criar livremente vários jogos. A escolha dos temas foi diversa, incluindo jogos tradicionais (jogo da memória e jogo da velha), jogos de perseguição (peixes e tubarões, carteiros e cachorros) até outros assuntos de interesse como dengue, gestão de recursos naturais e, claro, futebol. Essa oportunidade de criar jogos livres também permitiu que os participantes conhecessem melhor as diferentes facetas dos jogos, como ferramentas gráficas, uso de som, simulação e movimentação.

É importante ressaltar que, ao desenvolver jogos, vários objetivos iniciais foram perseguidos: um aprendizado dos jovens do projeto com relação à tecnologia computacional de desenvolvimento de jogos (que implica certa capacidade de programação criativa); o desenvolvimento do trabalho coletivo em equipe, já que os jogos foram previstos para serem desenvolvidos por equipes; e o aprofundamento dos temas específicos de interesse para a saúde pública e a população de Manguinhos, incorporando discussões mais abrangentes sobre os determinantes sociais e as políticas públicas que se encontram por detrás dos problemas analisados.

Foram produzidos sete jogos nessa fase inicial de aprendizado. Tais jogos tiveram uma finalidade mais didática voltada ao domínio do software, bem como da integração da equipe na proposta do LTM. O exemplo mais relevante nessa fase foi o jogo da memória, desenvolvido para incluir fotos de Manguinhos, servindo como fonte de inspiração lúdica para que o jogador conheça (e reconheça) áreas do bairro, com suas histórias e características.

Um significativo problema ocorrido ao final dessa primeira fase foi a desistência de participação do projeto por parte de jovens do Provoc/Dlis e da ONG local denominada Casa Viva. Tal abandono decorreu em razão de diversos motivos, tais como vestibular, gravidez e participação em curso técnico de tempo integral. Isso reflete o fato de se trabalhar com jovens adolescentes em fase ainda muito dinâmica de suas vidas.

$\mathrm{Na}$ segunda fase do trabalho, avaliou-se como perspectiva de continuidade a realização de jogos em torno de dois temas relevantes: tuberculose e dengue. O projeto que mais avançou foi o de tuberculose, demandado pelo Centro de Saúde Escola Germano Sinval Faria, vinculado à Escola Nacional de Saúde Pública Sergio Arouca (CSEGSF/Ensp).

Diante da desmotivação dos jovens moradores que permaneceram no projeto com os limites de programação do Stagecast, assim como a crítica de uma das jovens moradoras associadas ao uso exclusivo de plataformas livres, houve 
um redirecionamento da proposta, que abandonou a realização de um jogo eletrônico de computador para direcionar seu foco para jogos presenciais tipo RPG, aproveitando a larga experiência de um dos moradores participantes do grupo com essa modalidade de jogo. Assim, ao longo de 2010 e início de 2011 os jogos foram desenvolvidos na forma de RPG, tomando como material os relatos e atas das diversas reuniões que envolveram a constituição de uma comunidade ampliada de produção compartilhada de conhecimentos sobre o tema tuberculose. A constituição do grupo contou com membros do Centro de Saúde Escola, profissionais do Programa Saúde da Família (PSF) local, dois moradores usuários do SUS que já contraíram tuberculose anteriormente, a equipe dos jogos do LTM, além dos pesquisadores José Wellington e Marize Cunha, que atuam com educação popular e saúde.

O desafio principal para a elaboração posterior do jogo RPG denominado A Tosse Misteriosa foi traduzir a rica discussão sobre o problema da tuberculose em geral e no território de Manguinhos, presente no relatório final das oficinas realizadas com a referida comunidade ampliada de produção compartilhada, em uma linguagem e roteiro que estimulassem a curiosidade de jovens sobre o assunto. Normalmente os discursos e linguagens sobre problemas de saúde específicos como a tuberculose tendem a assumir uma forma técnica que pode afastar as pessoas leigas e, nesse caso, os jovens, por intermédio de uma linguagem muito distante daquela que habitualmente utilizamos. O jogo foi finalizado e faz parte da caixa de ferramentas Maleta de Trabalho do LTM: reconhecendo Manguinhos, juntamente com os outros materiais político-pedagógicos sobre o território (Zancan et al., s.d.).

\section{Mangue Manguinhos Manguezal}

A produção do slideshow Mangue Manguinhos Manguezal deu continuidade às discussões sobre a área temática saúde, ambiente e desenvolvimento, no tema específico Cenários Ambientais: Ontem, Hoje. E Amanhã?, que foi um dos assuntos geradores do site do LTM na Internet. Por meio dele, pretendeu-se repensar a ecologia urbana de forma articulada com questões sociais e ecológicas mais amplas, relacionando tópicos como saúde de ecossistemas, saneamento básico, cidadania e justiça - entendendo o Manguezal em seu contexto histórico -, para pensarmos o presente e o futuro de Manguinhos, já que esse é um bairro construído basicamente sobre um manguezal aterrado em meados do século XX.

Ao fazer uma visita à Área de Proteção Ambiental (APA) de Guapimirim em julho de 2008, várias descobertas e insights foram gerados pela comunidade 
ampliada de pesquisa-ação. A ida à APA simbolicamente representou uma viagem pelo túnel do tempo, já que uma paisagem que se apresentava como o que Manguinhos foi, em termos naturais, cerca de dois, três ou mais séculos atrás. Outra descoberta foi se deparar com a beleza natural do mangue relativamente protegido a apenas alguns quilômetros do Rio de Janeiro, perceber que a baía de Guanabara, tão degradada, ainda apresenta paisagens e ecossistemas repletos de vida e beleza. Além disso, pôde-se aprender mais sobre o papel do manguezal no ciclo da vida aquática e animal, incluindo belos pássaros que vivem e se reproduzem na região. Também se encontrou a presença de comunidades de pescadores artesanais que ainda vivem, com dificuldades decorrentes da poluição da baía de Guanabara, dos frutos da pesca de caranguejos e peixes. Ao confrontar toda essa vivência com a paisagem de Manguinhos, puderam-se perceber os contrastes e perplexidades, mas também as esperanças e possibilidades de vislumbrar Manguinhos em seu presente e futuro com outros olhos.

Após a visita, decidiu-se usar múltiplas linguagens na construção de um slideshow que permitisse captar a vastidão de sentimentos e ideias experimentadas. Para isso, o projeto visou captar tais experiências por meio de atividades coletivas de reflexão e arte-criação integrando diferentes linguagens discursivas, visuais e sonoras. A metodologia adotada para a construção do slideshow envolveu as seguintes atividades: visita à APA de Guapimirim em fins de julho de 2008; produção individual de textos sobre as impressões da visita; ampliação do acervo fotográfico de Manguinhos e região adjacente, em especial a zona de (ex) manguezal existente às margens dos rios Faria Timbó e Jacaré, do canal do Cunha, do complexo da Maré, das ilhas do Fundão e do Governador; pré-seleção das fotos de Manguinhos e região, bem como da APA de Guapimirim (foram pré-selecionadas oitenta fotos para a oficina, dentre cerca de oitocentas tiradas durante a visita); levantamento de material bibliográfico sobre mangues e seu significado ecossistêmico; preparação e realização de oficina de sensibilização e produção coletiva de material (troca de experiências, palavras-chaves, textos e ideias para o roteiro) voltada ao slideshow; e, por fim, a formação de equipe de criação e produção final do slideshow.

A oficina de sensibilização e produção coletiva de material se inspirou em elementos da arte-educação e da escrita criativa para organizar as atividades. A primeira atividade da oficina foi uma proposta de relaxamento corporal por meio de técnicas de respiração e integração corpo-mente. Em seguida apresentaram-se grupos de fotos divididas em duas etapas: (a) fotos da APA de Guapimirim, retratando as belezas naturais do lugar; (b) fotos de Manguinhos e 
região, revelando contrastes com as primeiras. Na primeira parte solicitou-se aos participantes que escrevessem palavras-chave relacionadas às fotos apresentadas, seguida da construção de frases. Posteriormente, três grupos foram formados, os quais fizeram a seleção ou recriação de frases e textos considerando as frases produzidas individualmente.

Na segunda parte, após a visualização em silêncio das fotos, formaram-se outros três grupos (diferentes da primeira etapa). Foram entregues mandalas aos participantes e se pediu para, uma vez mais, escreverem palavras-chave em cada folha. Depois, solicitou-se que a escrita das frases fosse feita coletivamente nos grupos. Ao fim de ambas as etapas cada grupo compartilhou com os demais os textos produzidos e selecionados, incluindo formas criativas de apresentação, como um jogral feito na primeira parte. Ao fim da oficina selecionou-se um grupo de voluntários para produzir a versão final do slideshow, tendo por base as frases e reflexões produzidas na oficina. Também foram recolhidas todas as folhas, com a finalidade de servir de modelo para o trabalho desse mesmo grupo.

Além do slideshow produzido, o processo de preparação do mesmo fortaleceu a introdução de metodologias coletivas de trabalho criativo que permitiram aumentar as formas de comunicação dentro da comunidade ampliada de pesquisa-ação. A junção de formas discursivas e reflexivas com métodos de arte-educação, como o desenho, a fotografia e a escrita criativa/poética, são ferramentas promissoras para a construção compartilhada de conhecimentos proposta pelo LTM. Ao longo da oficina foi possível levantar múltiplos significados acerca das paisagens confrontadas, além de vivências singulares e coletivas, revelando os vários contrastes entre belezas e limites, entre vida e sobrevivência, entre integração e restrição, entre realidade e sonho, entre dignidade, justiça e violência. Água, lama, ar e vida apresentaram-se em suas múltiplas dimensões, possibilitando retratar de forma direta, por meio de uma linguagem metafórica ou poética, bem como do uso de imagens, os vários e impactantes significados de confrontar realidades tão díspares e tão fortemente conectadas pela proximidade histórica e espacial.

A criação do slideshow levantou a ideia de, futuramente, poder-se realizar um projeto que aproxime os dois territórios e suas populações (Manguinhos e APA Manguezal da baía de Guanabara) em torno da justiça ambiental e da construção de ambientes saudáveis. Tal projeto permitiria, caso seja levado adiante, criar uma experiência de integração entre realidades urbanas e a preservação de ecossistemas próximos de importância estratégica em termos de qualidade ambiental da região, no caso, a baía de Guanabara. 
Para realizar o slideshow, foram de grande importância os estudos anteriores sobre o estuário de Manguinhos, centrados principalmente na produção do pesquisador da Fiocruz Lejeune de Oliveira. Especialista em hidrologia, ele realizou relevantes estudos sobre a poluição na baía de Guanabara desde os anos 1930 até os anos 1970. Tais estudos contribuíram, junto com a visita à APA de Guapimirim e ao longo da preparação do slideshow, com o levantamento de uma série de questões interessantes que podem ser expressas nas seguintes perguntas: O que é mais vivo e mais antigo na paisagem de um mangue? O que resiste ao tempo e sobrevive, sendo um dos últimos remanescentes, mesmo no estado mais degradado, que se adaptou e continua povoando a paisagem? Muitas vezes a vida que permanece sofre pela opacidade, chegando a ser imperceptível nos cenários examinados, pois se tem sempre a preocupação de fazer levantamentos sobre as espécies que desapareceram, fruto do progresso desordenado e dos golpes desferidos contra a natureza. Mas perceber o que resiste e ainda emana vida e beleza proporciona força para compreender a natureza e prosseguir em busca de outras paisagens no lugar.

\section{O personagem Mangarça}

Concebeu-se Mangarça, um personagem que habita o mangue e aparece como arauto de uma realidade social. Simultaneamente, ele surge como uma forma de resistência e de adequação ao ambiente do mangue. Sua concepção conta com o suporte criativo, unido ao talento, de Viviane Nonato, uma das jovens moradoras e artistas de Manguinhos que atua no LTM. Com uma proposta essencialmente lúdica e estética, ele se apresenta com a potencialidade de um porta-voz e de um meio de conhecimento e informação. Objetivando a aproximação, o efeito instantâneo de comunicação, leveza e facilidade de leitura, bem como a possibilidade de acesso às várias faixas etárias, pensamos em produzir tiras que tenham como base ativa o poder de síntese para relatar um fato, um acontecimento e, em um segundo momento, partindo-se delas, desenvolver argumentos para uma proposta de história em quadrinhos (HQ).

As HQs podem futuramente funcionar, assim como os jogos lúdicos, como uma interação entre emissor e receptor, facilitada por esse meio de comunicação que utiliza recursos linguísticos específicos, humor e uma narrativa que se aproxima muito da oralidade, do tom informal, para informar e conscientizar, objetivando uma construção cidadã e humanística. Enfim, o Mangarça é um tipo de ferrramenta para a ampliação dos círculos comunicativos, uma ideia que parte dos talentos locais e que se pretende operar mais à frente dos trabalhos, por meio de conversas e interações com moradores e outros parceiros. 


\section{Para Finalizar}

Conforme discutido neste capítulo, uma questão central para a construção de cidades saudáveis, que também precisam ser democráticas, é romper com certa forma de planejamento centralizado e tecnocrático das cidades pelo Estado. Isso leva à perda da identidade e do reconhecimento do lugar pelas pessoas, ao mesmo tempo que fragiliza os laços de responsabilidade. A gestão democrática, segundo Luiz Cesar de Queiroz Ribeiro e Orlando Alves Santos Júnior (2011: 5), será alcançada se rompermos com "as lógicas particularistas que esquartejam a cidade em vários centros de decisão que funcionam segundo os interesses que comandam cada uma delas", quais sejam: o clientelismo urbano, o patrimonialismo urbano, o corporativismo urbano e o empresariamento urbano. São práticas que privatizam o poder local, que resultam na instalação e permanência de ilegalidades, ou ainda de legalidades ilegítimas, que produzem e reproduzem muitos donos de pedaços da cidade, que instalam práticas pouco republicanas nas instâncias de decisões democráticas legalmente estabelecidas, entre outras práticas perversas de gestão da cidade.

Novos padrões de sociabilidade serão possíveis colocando-se como centro da agenda da reforma urbana, fundamentada nos princípios do direito à cidade, a preocupação em estabelecer mediações e mecanismos que propiciem a coesão social baseada na solidariedade, na construção de identidades e na representação de interesses coletivos (Ribeiro \& Santos Júnior, 2011). Mas, apesar dos vários problemas, há razões para se ter esperanças. Alguns caminhos vêm sendo construídos pelos movimentos sociais, pela academia, ONGs e governos comprometidos com a superação das desigualdades socioeconômicas e com a construção da cidadania neste país.

Do ponto de vista da saúde coletiva, da promoção da saúde e da própria ciência, os desafios apontados ao longo do capítulo demandam e impulsionam novas concepções e práticas que visam à redução dos problemas e vulnerabilidades socioambientais, em estreita articulação com a construção da democracia e da cidadania, como por exemplo: novas formas de se produzir conhecimento e novos modos de se construir e implementar políticas públicas. Avanços epistemológicos e metodológicos têm ocorrido em diversas áreas do conhecimento, inclusive na saúde coletiva, tendo como base a incorporação da teoria da complexidade e das abordagens sistêmicas, ecossistêmicas e ecossociais, que se articulam às perspectivas participativas de produção compartilhada de conhecimentos. 
Nesse sentido, tendo como referenciais a promoção da saúde emancipatória e a justiça ambiental, pode-se acreditar que os trabalhos realizados no LTM oferecem potenciais caminhos para o fortalecimento do poder local e da cidadania da população de Manguinhos, assim como também para outras comunidades e territórios em contextos semelhantes.

Considerando a participação e a intersetorialidade, referenciais fundantes da ideia de cidades saudáveis e da promoção da saúde, é possível perceber como ainda são frágeis os avanços da cidadania e da sustentabilidade socioambiental em várias periferias das cidades que concentram as zonas de sacrifício. Isso, ainda que levando-se em conta os consideráveis avanços no Brasil nos últimos anos, como o ganho efetivo das políticas públicas em áreas socialmente vulneráveis e conquistas materiais na infraestrutura, além de certo aumento de renda direta ou via programas como o Bolsa Família.

Avalia-se então que, em relação a Manguinhos, existem dois pontos significativos para que esses avanços se traduzam em real transformação: o primeiro diz respeito à intensificação das ações dentro do território de maneira que permita a difusão, incorporação e releitura dos problemas. Isso inclui uma articulação maior com movimentos sociais, instituições e entidades atuantes no local, como escolas, ONGs comunitárias, associações, além das potencialidades da biblioteca e do serviço social, estes últimos instalados com as obras do PAC em Manguinhos. O segundo desafio se refere ao trabalho de diálogo de Manguinhos com redes e movimentos sociais mais amplos, os quais permitam articular lutas e movimentos locais com processos mais coletivos diante do PAC e outras políticas públicas urbanas. Articulando, por exemplo, experiências e visões do PAC com outros lugares que passam por processos semelhantes, como a Rocinha e o Complexo do Alemão, ambos também no Rio de Janeiro.

A Comunidade Ampliada de Pesquisa-Ação do LTM tem grandes potencialidades, mas também constrangimentos para o alcance de seus objetivos. De maneira geral, de um lado as instituições e seus pesquisadores podem estabelecer vínculos e mecanismos para infundir outras formas de capital ao capital social existente nas comunidades circunvizinhas, mas também podem oferecer espaços e contextos que bloqueiam ou burocratizam as iniciativas comunitárias. De outro, as assimetrias entre os atores do processo - econômicas, cognitivas, culturais, de identidade, dentre outras - estão associadas ao capital social, cultural e econômico dos sujeitos desse mesmo processo, e podem levar a potencializar ou a restringir as mudanças mais estruturais, necessárias às transformações da qualidade de vida das populações mais vulneráveis (Wakfield \& Poland, 2005). 
Assim, pôde-se identificar no trabalho de construção compartilhada de conhecimento três naturezas de dificuldades: socioespacial, uso do tempo e institucional. Os constrangimentos socioespaciais resultam da ainda presente violência do tráfico de drogas ilícitas e do aparato de segurança do Estado, que impedem a livre circulação de moradores e dos pesquisadores e profissionais nos territórios de exclusão, não somente no sentido físico de mobilidade, do ir e vir, mas também na circulação de ideias que possibilitem produzir temores de retaliação por parte dos agentes da violência.

Com relação ao uso do tempo, de um lado tem-se os moradores em situação de escravos das necessidades, que limita suas disponibilidades para a participação em projetos, programas e reflexões como as aqui propostas. De outro, os pesquisadores em situação de escravos da burocracia e das prioridades institucionais, em particular ante as demandas por um produtivismo acadêmico alienado que desconsidera ou desvaloriza atividades de extensão como o LTM, e, também, ante a eterna busca de financiamento para seus projetos, o que é agravado pela dificuldade de incorporar moradores da comunidade como bolsistas por não se enquadrarem nos critérios acadêmicos de financiamento.

As limitações institucionais são ainda sentidas pela reprodução de hierarquias de poder e estranhamentos de classe, em que alguns setores ou grupos veem os moradores de uma comunidade favelada sob a perspectiva da filantropia e da tutela, não lhes conferindo lugar de saber, mas sim de informantes ou ratinhos de laboratório, conforme frequentemente os próprios moradores se referem ante os grupos acadêmicos que os interpelam. Tal questão mais uma vez se coloca diante do modelo hegemônico de prática científica e da necessidade de refundarmos as bases das instituições, caso se almeje caminhar na construção de sociedades solidárias e democráticas.

Outro problema também se refere a como possíveis alianças entre diferentes grupos e organizações podem ser dificultadas pela disputa de recursos e pretensos monopólios políticos de canalização das vozes do lugar, o que põe a questão do poder local e suas articulações com diferentes organizações e projetos políticos como aspectos a serem considerados numa proposta como a do LTM. Diante disso, nosso posicionamento tem sido o de buscar engendrar esforços, processos de produção de conhecimento e produtos - como documentários e o portal na Internet - como potenciais instrumentos de mediação entre as múltiplas e legítimas iniciativas locais e as necessidades das pessoas que vivem no lugar, com e apesar dos vários poderes em disputa. 


\section{Referências}

ARAÚJO, I. Mercado Simbólico: interlocução, luta, poder - um modelo de comunicação para políticas públicas, 2002. Tese de Doutorado, Rio de Janeiro: Escola de Comunicação, Universidade Federal do Rio de Janeiro.

ARAÚJO, I. Materiais Educativos e Produção de Sentidos Sociais na Intervenção Social. In: MONTEIRO, S. \& VARGAS, E. (Orgs.). Educação, Comunicação e Tecnologia: interfaces com o campo da saúde. Rio de Janeiro: Editora Fiocruz, 2006.

ARAÚJO, I. S. \& CARDOSO, J. M. Comunicação e Saúde. Rio de Janeiro: Editora Fiocruz, 2007.

BAUMAN, Z. Globalização: as consequências humanas. Rio de Janeiro: Jorge Zahar, 1999.

BRANDÃO, A. P.; ARAÚJO, I. \& CARDOSO, J. M. Redes discursivas em movimento: avaliação de estratégias de comunicação na saúde. In: GT POLÍTICAS E ESTRATÉGIAS DE COMUNICAÇÃO, ENCONTRO DA COMPÓS, XI, 5-8 jun. 2002, Rio de Janeiro.

BULLARD R. Dumping in Dixie: race, class and environmental quality. Boulder: Westview Press, 1994.

CADERNOS LTM. Seminário de Avaliação 2008. Impresso, 1, jun. 2009.

CHAUI, M. Cultura e Democracia: o discurso competente e outras falas. 11. ed. São Paulo: Cortez, 2006.

FACINA, A. As Políticas Públicas, a Cidade e a Cidadania: o PAC Manguinhos em Foco. Intervenção no Centro de Estudos da Ensp, dia 23/09/2009. Disponível no documentário PAC Manguinhos: Promessa, Desconfiança e Esperança, produzido pelo LTM em DVD.

FERNANDES, T. M. \& COSTA, R. G. R. Histórias de Pessoas e Lugares: memórias das comunidades de Manguinhos. Rio de Janeiro: Editora Fiocruz, 2009.

FUNTOWICZ, S. \& RAVETZ, J. R. Three types of risk assessment and the emergence of post-normal science. In: KRIMSKY, S. \& GOLDING, D. (Eds.). Social Theories of Risk. London, Westport: Praeger, 1992.

FUNTOWICZ, S. \& RAVETZ, J. R. Emergent complex systems. Futures, 26(6): 568-582, 1994.

LAGO, L. C. Desigualdades e Segregação na Metrópole: o Rio de Janeiro em tempo de crise. Rio de Janeiro: Revan/Fase, 2000.

MAIA, R. C. M. Redes cívicas e internet: efeitos democráticos do associativismo. Logos 27: Mídia e Democracia, 14(2): 43-62, 2007.

MARTELETO, R. \& VALLA, F. Informação e educação popular - o conhecimento social no campo da saúde. Perspectivas em Ciência da Informação, n. especial: 8-21, 2003.

MARTÍN-BARBERO, J. Ofício de Cartógrafo: travessias latino-americanas da comunicação na cultura. São Paulo: Edições Loyola, 2004. (Coleção Comunicação Contemporânea, 3)

NUNES, J. A. Governação, Conhecimentos e Participação Pública. Coimbra: Centro de Estudos Sociais, Universidade de Coimbra, 2007.

PIVETTA, F. Laboratório territorial como instância para a promoção da saúde: contribuição para as discussões acerca do Programa DLIS Manguinhos. In: ZANCAN, L. \& BODSTEIN, R. (Eds.). Promoção da Saúde como Caminho para o Desenvolvimento Local: a experiência em Manguinhos -RJ. Rio de Janeiro: Abrasco, Fiocruz, 2002. (Saúde Movimento, 5).

PORTO, M. F. S \& PIVETTA, F. Por uma promoção da saúde emancipatória em territórios urbanos vulneráveis. In: CZERESNIA, D. \& FREITAS, C. M. (Orgs.). Promoção da Saúde: conceitos, reflexões, tendências. Rio de Janeiro Editora Fiocruz, 2009.

RIBEIRO, L. C. Q. Transformações da estrutura sócio-espacial: segmentação e polarização na região metropolitana do Rio De Janeiro. In: Rio 97: o mercado de trabalho no Rio de Janeiro. Rio de Janeiro: Prefeitura do Rio de Janeiro/Secretaria Municipal do Trabalho, 1997.

RIBEIRO, L. C. Q. O Futuro das Metrópoles: desigualdades socioespaciais e governabilidade. Rio de Janeiro: Revan/Fase, 2000. 
RIBEIRO, L. C. Q. \& SANTOS JUNIOR, O. A. Desafios da questão urbana. Le Monde Diplomatique Brasil. São Paulo, p.4-5, abr. 2011.

ROLNIK, R. A lógica da desordem. Le Monde Diplomatique Brasil. São Paulo, p.10-11, ago. 2008.

SANTOS, B. S. A Crítica da Razão Indolente: contra o desperdício da experiência. São Paulo: Cortez, 2001.

SANTOS, B. S. A Gramática do Tempo: por uma nova cultura política. São Paulo: Editora Cortez, 2006.

SANTOS, M. Por uma Outra Globalização: do pensamento único à consciência universal. São Paulo: Record, 2000.

SOUZA E SILVA, J.Um espaço em busca de seu lugar: as favelas para além dos estereótipos. In: Território, Territórios: ensaios sobre o ordenamento territorial. 3.ed. Rio de Janeiro: Lamparina, 2007.

WAKFIELD, S. E. L. \& POLAND, B. Family, friend and foe? Critical reflections on the relevance and role of social capital in health promotion and community development. Social Science \& Medicine, 60: 2.819-2.832, 2005.

WESTPHAL, M. F. O movimento cidades/municípios saudáveis: um compromisso com a qualidade de vida. Ciência \& Saúde Coletiva, 5(1): 39-51, 2000.

ZANCAN et al. Dispositivos de comunicação para a promoção da saúde: reflexões metodológicas a partir do processo de compartilhamento da maleta de trabalho'reconhecendo Manguinhos'. Interface - Comunicação, Saúde, Educação, s.d. [aceito para publicação] 


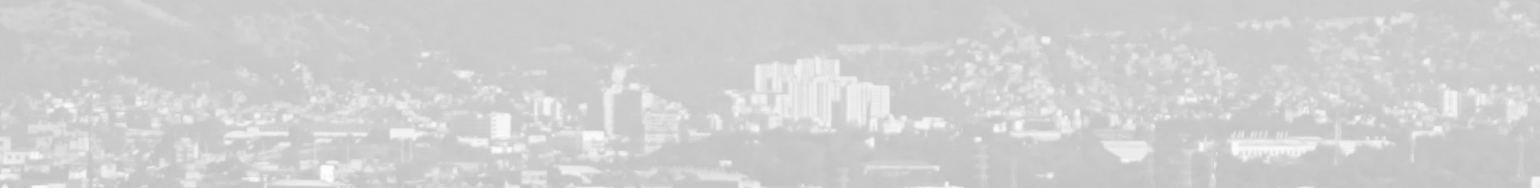

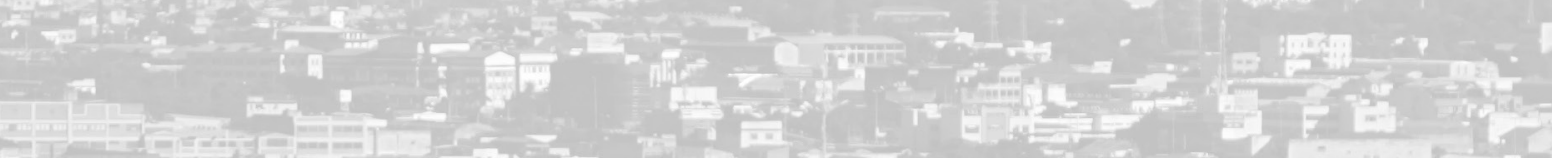

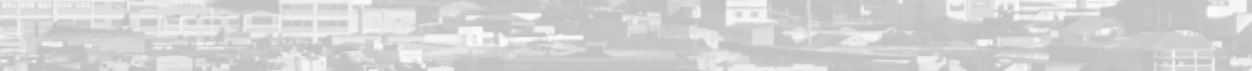

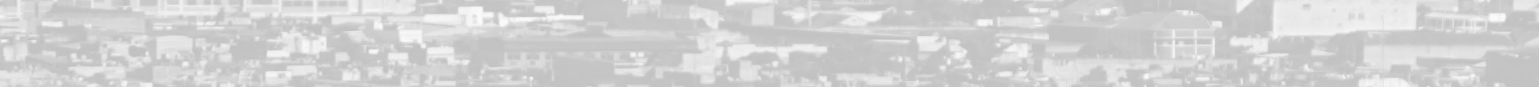

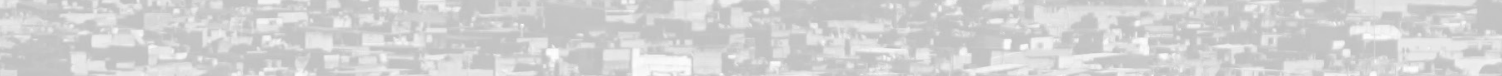

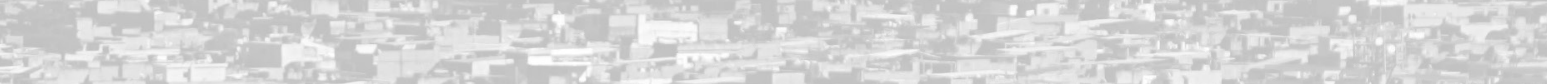

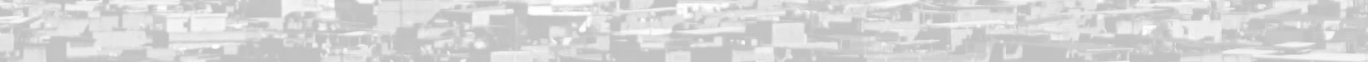

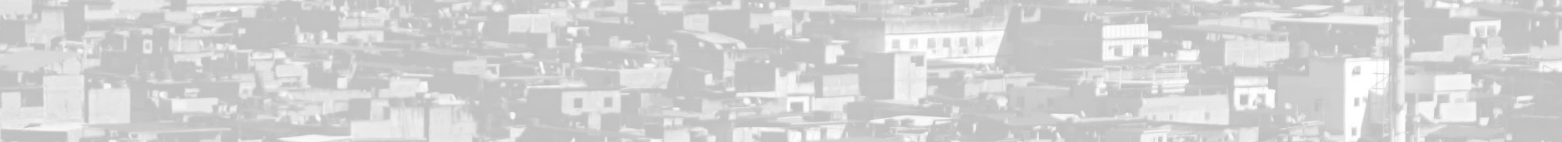

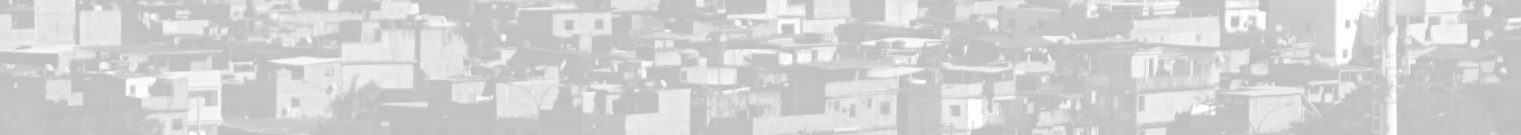

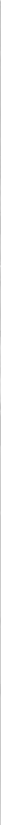




\section{APÊNDICE}

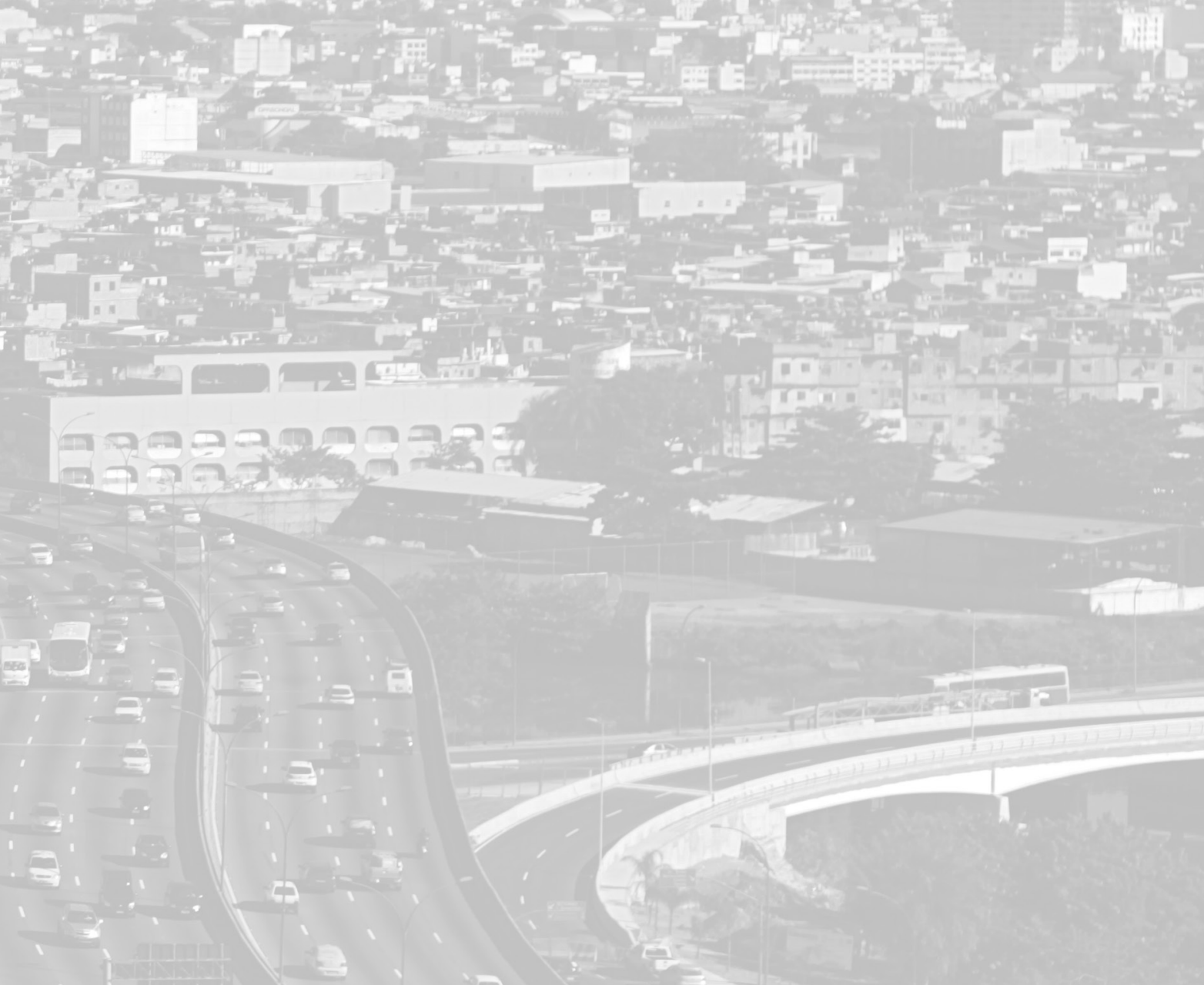




\title{
Notas sobre Iniciativas e Redes Brasileiras de Comunidades, Municípios e Cidades Saudáveis e Sustentáveis: modelos, estratégias, resultados e parceiros
}

\author{
Guilherme Franco Netto • Rogério Fenner • Cícero Dedice de Góes Junior
}

F ste texto foi elaborado conjuntamente com os parceiros das Redes e Iniciativas no Brasil. Tem por finalidade apresentar tanto um panorama das ações de promoção da saúde relacionadas ao eixo "Desenvolvimento Sustentável" da Política Nacional de Promoção da Saúde (PNPS), quanto de expor as estratégias, os principais produtos, resultados e parcerias das redes e iniciativas no estímulo à troca de informações e experiências. Promove, assim, a integração, a colaboração e a cooperação não só entre elas, mas também com os demais setores públicos e privados, sejam eles institucionais, governamentais, empresariais ou sociais.

O Levantamento evidencia as ações de promoção da saúde dentro de uma perspectiva nacional, estimulando assim a integração entre as redes e as iniciativas e os órgãos governamentais, além de facilitar a compreensão das ações e atividades comuns. O texto também ressalta a necessidade de formação de recursos humanos e a definição de metas e indicadores que facilitem a avaliação efetiva das ações de promoção da saúde, especialmente aquelas implementadas pela estratégia Municípios Saudáveis.

A promoção da saúde está presente em praticamente todos os capítulos da Agenda 21 Global, principal documento resultante da Conferência das Nações Unidas sobre Meio Ambiente e Desenvolvimento (Cnumad). O tema é 
especialmente abordado no capítulo 6, no qual se discute a proteção e a promoção da saúde humana (Brasil, 1992). ${ }^{1}$

Em 2007, a Organização Mundial da Saúde (OMS) elaborou o primeiro relatório com estimativas sobre a incidência de doenças associadas aos ambientes não saudáveis e inadequados (13 milhões de óbitos ocorrem anualmente, no mundo, em decorrência dessas condições). Dentre as principais áreas de intervenção identificadas pela OMS, encontram-se as que se referem à busca de solução para os problemas na qualidade da água e no saneamento, os quais foram também mencionados no relatório supracitado da Comissão Especial constituída pelo Conselho de Defesa dos Direitos da Pessoa Humana.

Diante desses problemas, organizações e organismos multilaterais têm despendido esforços para detectar as realidades e os problemas das cidades e compreender, de forma mais ampla, as dinâmicas que se estabelecem internamente nesses espaços, assim como as interações destes com seu entorno. Organismos como o Banco Mundial, ${ }^{2}$ o Programa Hábitat das Nações Unidas, ${ }^{3}$ o Programa das Nações Unidas Sobre o Meio Ambiente (Pnuma), ${ }^{4}$ a Organização Pan-Americana da Saúde, vinculada à Organização Mundial da Saúde (Opas/ OMS), ${ }^{5}$ a Fundação Europeia ${ }^{6}$ e países como o Canadá, ${ }^{7}$ dentre outros, têm desenvolvido esforços no sentido de aprofundar a compreensão sobre os ambientes urbanos e metropolitanos.

A Portaria n. 687, de 30 de março de 2006, aprovou a Política Nacional de Promoção da Saúde (PNPS), a qual estabelece que a promoção deva ser entendida

\footnotetext{
${ }^{1}$ Disponível em: <www.mma.gov.br/responsabilidade-socioambiental/agenda-21/agenda-21-global>. Acesso em: 16 out. 2014.

${ }^{2}$ Compilando dados do Observatório das Nações Unidas (1998), da empresa Earth Observing System - E0S (2003) e do banco de dados Taylor, e publicando indicadores sobre 412 cidades de 134 países, no estudo "Cidades num Mundo Globalizado (2006)".

${ }^{3}$ Organizando indicadores urbanos, do enfoque em moradia (1991) a outras questões urbanas (1996-2001). Atualmente voltado aos Objetivos de Desenvolvimento do Milênio das Nações Unidas, em parceria com governos locais e metropolitanos.

${ }^{4}$ A Agenda 21, apresentada durante a Conferência das Nações Unidas sobre o Meio Ambiente e o Desenvolvimento (Cnumad, Rio de Janeiro, junho de 1992) e aprovada por todos os países presentes à Rio 92, propiciou a criação da Comissão de Desenvolvimento Sustentável (CDS), vinculada ao Conselho Econômico e Social das Nações Unidas (Ecosoc).

${ }^{5}$ A Opas/OMS desenvolve o Projeto Municípios e Comunidades Saudáveis (Cidades Saudáveis) desde 1992. Atualmente coleta 32 indicadores de saúde em uma variedade de cidades. Nesse projeto, 0 que se pretende é facilitar os mecanismos para que as pessoas possam melhorar suas condições de vida. A estratégia utilizada enfoca a união entre autoridades locais e membros da comunidade, além do estabelecimento e fortalecimento de parcerias.

${ }^{6}$ No continente europeu existem várias iniciativas em curso. Em 2003, a Fundação Europeia (European Foundation) propôs Indicadores Urbanos Europeus no Projeto de Indicadores Comuns Europeus.

${ }^{7} 0$ Canadá tem apresentado o maior número de iniciativas relacionadas a indicadores urbanos, envolvendo várias cidades e atores governamentais e não governamentais. A Federação das Municipalidades Canadenses (FMC) tem ampla experiência em desenvolver indicadores urbanos. Desde 1996, a FMC conduz o projeto Meios de Relatar a Qualidade de Vida (MRQV), para vinte comunidades canadenses (que representam mais de 50\% da população do país). Atualmente, 72 indicadores são coletados de 12 fontes (Banco Mundial - Vancouver - 2006).
} 
em um sentido mais amplo, não apenas no combate às doenças, mas também no delineamento de políticas para dentro do setor saúde. Dessa forma, a promoção da saúde deve ser um mecanismo de fortalecimento e implantação de uma política transversal, integrada e intersetorial, compondo redes de compromisso e corresponsabilidade quanto à qualidade de vida e à saúde da população em que todos participem na proteção e no cuidado com a vida (Brasil, 2006).

A promoção integra políticas e ações da saúde nos diferentes setores - nos níveis global, nacionais e locais - e compromete-se com o enfrentamento dos determinantes sociais e ambientais da saúde, nos termos da Declaração do Rio sobre os Determinantes Sociais da Saúde, endossada por todos os Estadosmembros da OMS na Assembleia Mundial da Saúde de 2012.

A saúde é um direito de todos e deve ser tratada em caráter universal, equitativo e integral para a plena realização do potencial da vida humana, profundamente condicionada pelos modos de produção e consumo mediados por determinantes sociais, econômicos e ambientais, sobre os quais se pode atuar de forma integrada e intersetorial. A saúde, como qualidade de vida e bem-estar, deve estar relacionada ao modo de viver das pessoas, assim como à sua relação com o meio ambiente e os fatores e processos relativos ao desenvolvimento.

Os modelos de Comunidades, Municípios e Cidades Saudáveis e Sustentáveis, que busca, entre seus objetivos, a promoção da saúde, devem ser construídos de forma específica em cada comunidade, município ou cidade, não sendo possível a aplicação direta de modelos já existentes de outras localidades. Tais modelos são estruturados e adaptados em razão das variáveis e indicadores locais que devem ser redefinidos ou recombinados com indicadores que já estejam disponíveis em virtude da complexidade dos sistemas urbanos e rurais.

É possível induzir os implementadores de programas e projetos de cidades, municípios e comunidades saudáveis para que fomentem a cooperação com as instâncias políticas locais, de saúde, de meio ambiente e de planejamento, utilizando seus resultados na formação e elaboração dos instrumentos políticos por meio dos fóruns de discussão.

A maneira como se está vivendo nas cidades afeta a saúde e o meio ambiente. Os programas de municípios saudáveis encorajam um debate dinâmico entre seus participantes para informá-los sobre o tema, explorando abordagens interativas, identificando interesses comuns, novos direcionamentos e oportunidades de colaboração. Para tal, são necessárias informações sobre situações de risco existentes locais e as características especiais do ambiente da região, os quais interferem no padrão de saúde das populações. 
As cidades e municípios passam por transformações continuamente, da mesma forma que se alteram suas relações com o ambiente externo. A compreensão dos fenômenos envolvendo os aglomerados urbanos e rurais necessita de diagnósticos acurados para capturar os aspectos ambientais, sociais e econômicos, entre outros, e as relações estabelecidas entre esses aspectos. O crescimento dos conglomerados aumenta o poder político e decisório dos municípios no contexto regional, nacional e internacional. E as relações entre cidades ganham o espaço dos acordos internacionais, como nos programas de controle do aquecimento global, em que o papel destas adquire relevância nas propostas voltadas para a sustentabilidade e a qualidade de vida das sociedades.

Os indicadores de saúde pública, socioeconômicos e ambientais fazem parte do rol de indicadores para medir a sustentabilidade e a qualidade de vida. Eles estão sendo aprimorados por meio de um trabalho conjunto dos diversos setores das comunidades envolvidas com o Plano de Municípios Saudáveis de cada município. Tais indicadores devem proporcionar discussões sobre como, por que e quais são as utilidades da coleta desses dados, na busca de soluções e intervenções que minimizem as iniquidades em saúde, promovendo mais qualidade de vida e da própria saúde para as populações dos municípios brasileiros.

Um estudo realizado em 2000 analisou a gênese do movimento Municípios Saudáveis no Brasil (Mendes, 2000), tendo revelado as principais características de sua implementação. As iniciativas de municípios saudáveis no Brasil foram motivadas sobretudo pela discussão de formação de redes estaduais e pela realização de eventos que tentavam estimular o desenvolvimento de projetos nos municípios. A pesquisa indica que as primeiras experiências foram frágeis, do ponto de vista da participação social e, principalmente, não avançaram em termos de desenvolver um novo modo de gestão municipal - integrada, participativa e intersetorial -, na medida em que se restringiram ao setor saúde ou foram lideradas por ele (Mendes, 2000). O estudo também permitiu verificar que a participação social apresentou progressos e retrocessos, conforme a capacidade de ação e reação dos grupos envolvidos.

Diferentemente de alguns países da América Latina, do Canadá ou Europa, o Brasil não dispõe de um órgão único ou instituição que aglutine as experiências de municípios saudáveis. No fim dos anos 1990, algumas universidades e instituições iniciaram o debate de formação de uma Rede Brasileira de Municípios Saudáveis como uma estratégia que possibilitasse ampliar esse movimento no país. Nos anos 2000 e 2001 o Ministério da Saúde, juntamente com o Conselho Nacional 
de Secretários Municipais de Saúde (Conasems) e a Opas/Brasil, articulou esforços para iniciar a formação da Rede Brasileira de Municípios Saudáveis.

As entidades que participam das redes e iniciativas de cidades, municípios e comunidades saudáveis e sustentáveis no Brasil tentam se articular para estabelecer uma rede brasileira. O Ministério da Saúde, respaldado por um movimento social legítimo, decidiu incentivar essa articulação para potencializar as ações existentes e disseminá-las mais facilmente pelo território nacional. A consumação dessa articulação representa um desafio para ampliar e fortalecer o movimento de integração de agendas de promoção da saúde e desenvolvimento sustentável no país.

A dimensão do país, o número expressivo de experiências em andamento com objetivos comuns, bem como a diversidade regional, acabaram por fortalecer as Redes e Iniciativas Regionais que se desenvolvem em todo o país com o apoio das instituições de ensino e pesquisa, das organizações governamentais e de outros parceiros. As iniciativas e as redes de Municípios Saudáveis são essenciais à promoção da intersetorialidade e da integração das ações e políticas públicas que levam a uma melhor qualidade de vida da população, à erradicação da miséria, à redução das iniquidades socioeconômicas e à compreensão da complexidade dos ecossistemas urbano e rural. Estas iniciativas/redes são também importantes para a compreensão das inter-relações dos fatores geográficos, ambientais, políticos e socioeconômicos.

\section{Redes e Iniciativas de Cidades, Municípios, Comunidades} Saudáveis e Sustentáveis

Existem cinco Redes de Cidades/Municípios/Comunidades Saudáveis e Sustentáveis no Brasil, as quais atuam pelo movimento de cidades saudáveis em municípios de pequeno, médio e grande porte. São elas: (1) a Rede de Municípios Potencialmente Saudáveis (RMPS) (SP, RJ, PR, MG e AM), Unicamp; (2) a Rede Pernambucana de Municípios Saudáveis (RPMS) (PE), UFPE/Nusp e Condepe/ Fidem; (3) a Rede de Ambientes Saudáveis de Curitiba (Rasc) (PR), PUC/PR; (4) a Rede de Comunidades Saudáveis (RCS) (RJ), Cedaps; (5) a Rede Brasileira de Habitação Saudável (RBHS), Fiocruz/Rede Amazônica de Habitação Saudável (Rahs) (PA), Unama.

Também existem 16 iniciativas ou projetos brasileiros que atuam com abordagem de Territórios Saudáveis, servindo de base para ações estratégicas da gestão local e para o desenvolvimento de políticas públicas nacionais de 
promoção da saúde. São elas: (1) Projeto Ambientes Verdes e Saudáveis na Cidade de São Paulo (PAVS) (SP), SMS de São Paulo e USP/Cepedoc; (2) Capela em Ação São Paulo (SP), SMS de São Paulo e USP/Cepedoc; (3) Projeto Natal: Cidade Saudável (RN), SMS de Natal; (4) Projetos Vigilância Ambiental na Biorregião do Araripe e Cariri Saudável (CE), Fundação Araripe; (5) Rostos, Vozes e Lugares (RVL), Guarulhos, Fortaleza, Olinda, Rio Branco e Teresina, Opas, USP/Cepedoc e SMS das cidades citadas; (6) Projeto Saúde Urbana (Urban Heart), Guarulhos, Olinda e Belo Horizonte, SMS das cidades citadas, USP/Cepedoc, UFPE/Nusp e UFMG/Osubh; (7) Observatório de Saúde Urbana de Belo Horizonte (Osubh) (MG), UFMG; (8) Efetividade da Intersetorialidade: em busca de um Distrito Sanitário Saudável e Sustentável em Goiânia (GO), UFG; (9) Projeto Viva a Vida (MS); (10) Projeto Planaltina Saudável (DF); (11) Programa Jogo de Cintura (DF); (12) Laboratório Territorial de Manguinhos - LTM (RJ)/Fiocruz; (13) Projeto Desenvolvimento Sustentável e Promoção da Saúde: implantação da agenda cidades saudáveis integrada à Agenda 21 nas comunidades tradicionais e áreas protegidas do mosaico da Bocaina, (RJ)/Fiocruz; (14) Projeto Itaboraí Saudável (RJ), Fiocruz; (15) Práticas e Saberes no Desenvolvimento Sustentável e na Promoção da Saúde em Terreiros de Candomblé do Município de São Francisco do Conde (BA), Fiocruz; (16) Programa Metrópoles Saudáveis (PMS), São Paulo (SP), Proam.

As redes de municípios saudáveis objetivam colaborar com a construção de políticas saudáveis, integradas, participativas e articuladas, considerando as peculiaridades das diferentes áreas geográficas e dos grupos populacionais envolvidos nas questões públicas de um determinado município. Também buscam estratégia de desenvolvimento das localidades alicerçada na intersetorialidade, na participação popular, no enfrentamento dos determinantes e condicionantes sociais de saúde e na sustentabilidade ambiental.

\section{Rede de Municípios Potencialmente Saudáveis (RMPS) - Unicamp}

A RMPS foi criada em 2003 e adota como base norteadora do processo a perspectiva da promoção da saúde. Seus principais objetivos são o de capacitar a administração municipal para o desenvolvimento de um projeto único de governo - envolvendo diferentes setores da cidade e a comunidade - e o de aproximar a academia da administração pública local e as comunidades para a construção de políticas públicas que promovam a vida.

O processo metodológico de trabalho da RMPS para tecer a saúde se desenvolve a partir da assinatura do Termo de Adesão pelo prefeito municipal e da organização do Comitê Local da RMPS, seguindo-se o mapeamento dos 
desejos da administração pública e da população, o mapeamento dos projetos em desenvolvimento no município e a construção da Matriz de Sistematização. $\mathrm{O}$ que se quer? O que se tem a esse respeito? O que se quer com isso? O que se deseja mudar? A seleção das prioridades coletivas, a colocação em prática das ideias e soluções, a fim de se atender às prioridades e, por fim, a elaboração de ações que possibilitem novas políticas públicas saudáveis.

O movimento da RMPS tem facilitado concretamente a interação e articulação entre projetos e pessoas, possibilitando pactos entre universidades, governos locais, comunidades, para que se alcance coletivamente a qualidade de vida. Viabiliza a soma de esforços para a reflexão, planejamento e prática de um local onde as pessoas possam viver felizes. A RMPS pauta participação social, intersetorialidade, interdisciplinaridade e parcerias como ferramentas fundamentais para o desenvolvimento urbano saudável. A Rede liga-se em parceria com o Laboratório de Investigações Urbanas (Labinur) da Faculdade de Engenharia Civil, Arquitetura e Urbanismo/Universidade Estadual de Campinas (Unicamp), ${ }^{8}$ com a Faculdade de Jaguariúna; com a Opas/OMS, prefeituras, organizações e sociedade civil.

Rede Pernambucana de Municípios Saudáveis (RPMS) - UFPE/Nusp e Condepe/Fidem

A RPMS <www.municipiossaudaveis.pe.gov.br> originou-se do Projeto Municípios Saudáveis no Nordeste do Brasil, e inicialmente envolvia cinco municípios do agreste central de Pernambuco: Barra de Guabiraba, Bonito, Camocim de São Félix, Sairé e São Joaquim do Monte. O projeto, interinstitucional, foi fruto de um convênio entre a Universidade Federal de Pernambuco (UFPE) por meio do Núcleo de Saúde Pública e Desenvolvimento Social (Nusp) e a Secretaria de Planejamento do Governo do Estado de Pernambuco -, por intermédio da Agência Condepe/Fidem e a Agência de Cooperação Internacional do Japão (Jica), entre os anos de 2003 a 2008.

A estratégia de trabalho consistiu na formação de uma equipe técnica dos órgãos conveniados, que apoiaram as equipes municipais e a população. Supervisores e facilitadores locais foram capacitados. A metodologia utilizada foi denominada Método Bambu e tem uma perspectiva participativa que objetiva a definição de prioridades locais, além do aumento de potencialidades e do capital social, visando à cooperação intersetorial entre a população, os municípios e o governo do estado.

${ }^{8}$ Disponível em: < www.redemunicipiosps.org.br>. 
O foco da Rede pernambucana é a promoção da saúde, que busca a realização de ações de prevenção da violência e a promoção da cultura de paz. A prática de atividade física, alimentação e hábitos saudáveis também referendam a proposta de cidades saudáveis, igualmente apontada pelas Cartas das Conferências Internacionais - desde a de Ottawa -, e tem ainda o apoio do Departamento de Saúde Ambiental e Saúde do Trabalhador, do Ministério da Saúde (DSAST/ MS). Para fortalecimento e divulgação da promoção da saúde em Pernambuco e das ações de Municípios Saudáveis criou-se, em 2007, a Rede Pernambucana de Municípios Saudáveis, estruturada mediante parcerias entre universidade, governo estadual, governos municipais e sociedade civil, contando ainda com a cooperação internacional do governo japonês.

Vinte e dois municípios que integram a RPMS são monitorados pelo Nusp/ UFPE, que os capacitam para o ingresso na Rede, já tendo qualificado mais de mil e quatrocentos técnicos municipais. A Agência Condepe/Fidem atua na mobilização comunitária e no desenvolvimento de tecnologias sociais específicas e, ainda, em sua difusão e fortalecimento, o que proporciona capacitações destinadas à sustentabilidade e à geração de renda dos grupos municipais, além da elaboração dos Planos Diretores Participativos Saudáveis.

Além das instituições citadas, a RPMS mantém parcerias também com a Opas, Associação Brasileira de Saúde Coletiva (Abrasco), UFRPE, Serviço Brasileiro de Apoio às Micro e Pequenas Empresas (Sebrae), Conselho Nacional de Desenvolvimento Científico e Tecnológico (CNPq) e várias empresas e escolas.

\section{Rede Ambientes Saudáveis de Curitiba (Rasc) - PUC/PR}

Em 2003 foi criada a Rasc, no Paraná. Caracteriza-se como uma estratégia intersetorial de promoção da saúde e de fortalecimento da gestão pública. Envolve secretarias e órgãos governamentais vinculados à prefeitura, universidades e instituições de ensino superior, empresas, escolas e organizações sociais, cuja gestão está sob encargo da Secretaria Municipal de Saúde. A Rede já mobilizou mais de duzentas instituições na cidade e atua diretamente com lideranças, agentes mobilizadores locais e promotores de ações intersetoriais nas instituições. A Rasc tem propiciado a construção de metodologias de mobilização, diagnóstico situacional, desenvolvimento de capacidades, gestão de conhecimentos e potencialidades locais, além de estratégias de sistematização e avaliação de processos e resultados. ${ }^{9}$

\footnotetext{
${ }^{9}$ Disponível em : <ambientesaudavel.wordpress.com/rede-de-ambientes-saudaveis>.
} 
Rede de Comunidades Saudáveis (RCS) - Cedaps

O Centro de Promoção da Saúde (Cedaps) é uma organização não governamental criada em 1993. Suas ações são desenvolvidas em rede, potencializando a troca de experiências, atividades conjuntas de incidência política e comunicação, o que aumenta, dessa forma, o poder político para obter mais recursos e influenciar políticas públicas. A equipe multidisciplinar envolvida utiliza a metodologia participativa Construção Compartilhada de Soluções Locais, que funciona como auxiliar na formulação, desenvolvimento e avaliação de ações para mobilização dos territórios populares. O Cedaps fomenta e assessora a Rede de Comunidades Saudáveis (RCS) do Rio de Janeiro, composta por 151 organizações comunitária sediadas em favelas e periferias da região metropolitana. Sua organização, dinâmica e objetivos materializam os fundamentos preconizados pelo campo da promoção da saúde e geram a base social necessária para a ampliação da participação da comunidade na formulação e gestão de políticas públicas saudáveis.

A RCS é uma iniciativa da sociedade civil, baseada na cooperação técnica entre pares. Além do Rio de Janeiro, a RCS encontra-se na Bahia - em cooperação com o Gapa/Bahia - e apresenta iniciativas de organização no mesmo formato nos estados de Minas Gerais e Goiás. Ela é regida por uma Carta de Princípios formulada e declarada, pelos territórios populares (materialização de iniquidades na cidade), ao governo e à sociedade de forma geral. ${ }^{10}$

\section{Rede Brasileira de Habitação Saudável (RBHS) - Fiocruz e Rede}

Amazônica de Habitação Saudável (Rahs) - Unama

A RBHS foi criada no ano de 2002 e faz parte da Red Interamericana de Vivienda Saludable, que abrange ao todo 12 países e tem por finalidade tornar saudável qualquer ambiente construído. Sua atuação fundamenta-se em enfoques sociológico e técnico de enfrentamento dos fatores de risco e uma adequada promoção da saúde. Tal enfrentamento dá-se em relação à localização físico-geográfica-ambiental, à construção, à habilitação, à adaptação, ao gerenciamento, ao uso e à manutenção do ambiente construído e de seu entorno. O principal desafio dos projetos é a consolidação da intervenção sobre os fatores determinantes da saúde no espaço construído.

A RBHS é uma ferramenta para a operacionalização da Política Nacional de Promoção da Saúde, no âmbito da habitação. Sua estratégia se baseia no

\footnotetext{
${ }^{10}$ Disponível em: <www.cedaps.org.br $>$.
} 
enfoque intersetorial e multidisciplinar, na participação comunitária e na aliança em rede. Seu propósito é identificar, avaliar e manejar a questão da habitação saudável na esfera local. Para tanto, desenvolve um plano de atividades baseado na construção de capacidades, no desenvolvimento de projetos e pesquisas e na realização de serviços técnico-científicos. Também é objetivo da RBHS desenvolver metodologias de ensino, investigação-ação e procedimentos para implementação da vigilância epidemiológica e ambiental em saúde.

A Rede Amazônica da Habitação Saudável (Rahs) foi criada em 2003, sendo parte integrante da RBHS e interligada à Red Interamericana de Vivienda Saludable. Tem por objetivo orientar a sociedade e o estado sobre os processos de melhoria das condições de vida em relação às habitações. A metodologia adotada é uma adaptação à de Hanlon para a realidade amazônica. A Rahs, em conjunto com a RBHS, atua nas seguintes linhas de pesquisa: habitação e saúde; promoção da saúde; saneamento e saúde ambiental; e gestão ambiental e saúde. Utiliza a metodologia de pesquisa-ação, centrando suas investigações nos determinantes socioambientais da saúde e nos fatores de risco e de vulnerabilidade no ambiente construído e em seu entorno, articulando-se com a Estratégia Saúde da Família.

As linhas de pesquisa em que trabalha servem para minimizar os impactos das mudanças climáticas, em busca da salubridade e sustentabilidade ambiental por intermédio de pesquisa primária e do diagnóstico de contaminação e impactos ambientais nos recursos hídricos, solo e na atmosfera, com metodologia participativa. ${ }^{11}$

Alguns projetos se articulam às redes de municípios, cidades e territórios saudáveis existentes. Os projetos, como as redes, objetivam fortalecer a gestão intersetorial, tendo como fundamento a promoção da saúde, a conservação ambiental, a participação da sociedade civil e a integração das políticas sociais, econômicas e ambientais.

Projeto Ambientes Verdes e Saudáveis: construindo políticas públicas integradas - Pavs, Cepedoc/SMS-SP

Este projeto foi instituído em 2005, por iniciativa da Secretaria Municipal do Verde e Meio Ambiente (SMVMA), em articulação com o Programa das Nações Unidas para o Meio Ambiente (Pnuma). Contou com recursos da Prefeitura do Município de São Paulo (PMSP), Banco Interamericano de Desenvolvimento (BID), Ministério da Saúde e Pnuma.

\footnotetext{
${ }^{11}$ Disponível em: <www.ensp.fiocruz.br/rbhs/index.htm>.
} 
Além dos objetivos estruturais, o projeto buscou a capacitação dos agentes comunitários de saúde (ACS), agentes de proteção social (APS) e agentes de controle de zoonoses. Para se alcançar tais objetivos, contou-se com ativa participação das Secretarias Municipais do Verde e Meio Ambiente, Assistência e Desenvolvimento Social e Secretaria Municipal de Saúde, com suas instituições parceiras da Estratégia Saúde da Família.

Realizaram-se diversas oficinas regionais de planejamento, envolvendo mais de trezentos profissionais, nas quais se definiram: abordagem pedagógica, conteúdos, materiais educativos, formas de comunicação e processo de avaliação. Daí resultou o Plano de Capacitação e a formalização dos acordos assinados com todas as instituições envolvidas diretamente em sua execução. A capacitação desenvolveu-se em 108 salas de aula distribuídas em todas as regiões da cidade, com carga horária de 128 horas, tendo sido capacitados, num período de dois semestres, mais de cinco mil agentes comunitários de saúde e agentes de proteção social. Outro resultado do projeto foi o de fortalecer tecnicamente os processos de gestão das políticas públicas ambientais no município de São Paulo, notadamente no que diz respeito ao aprimoramento dos sistemas de informação e à qualificação dos gestores das políticas públicas de saúde e meio ambiente, conduzindo-os para a formulação e implementação de uma agenda de ações intersetoriais e interinstitucionais voltadas à redução dos riscos ambientais que ameaçam a saúde da população paulistana.

Como principais parceiros destacaram-se o Iclei: Governos Locais para Sustentabilidade - políticas públicas na área de compras sustentáveis e do clima; Fundação Oswaldo Cruz (Fiocruz) - metodologia de estudo do território e de priorização de problemas de meio ambiente e saúde; Instituto Brasileiro de Estudos e Apoio Comunitário (Ibeac) - comunicação interna e externa do Projeto; Faculdade Latino-Americana de Ciências Sociais (Flacso) - apoio à coordenação geral e administrativa do projeto; Centro de Estudos, Pesquisa e Documentação em Cidades Saudáveis/Faculdade de Saúde Pública da Universidade de São Paulo (Cepedoc/FSP-USP) - avaliação e retroalimentação do projeto; Instituto Sociombiental (ISA) - estudos e propostas para a proteção, conservação e recuperação das bacias hidrográficas dos mananciais que abastecem o município de São Paulo, estudos e propostas de gestão dos parques urbanos.

A estruturação do projeto possibilitou a criação da equipe de coordenação, composta por dois técnicos de nível central e 49 gestores ambientais, sendo seis regionais e 43 locais. Além disso, permitiu uma proposta inovadora, trazendo novos atores para a rede básica: são 170 agentes de promoção ambiental (APA) 
que contribuem para ampliar e consolidar a atuação intersetorial e a participação social nas áreas de abrangência das equipes da Saúde da Família. Em articulação com 12 instituições parceiras da SMS na Estratégia Saúde da Família, o programa desenvolve um contínuo processo de capacitação dos ACS e dos APA, para apropriação e reconhecimento social e ambiental do território. A gestão atual de 1.049 projetos socioambientais, produtos desse novo e complexo olhar sobre o território, engloba os seguintes eixos temáticos, descritos no Quadro 1.

Quadro 1 - Eixos temáticos dos projetos

\begin{tabular}{|c|l|}
\hline No de projetos & Eixo Temático \\
\hline 27 & Arborização \\
\hline 126 & Hortas / Alimentação Saudável \\
\hline 232 & Educação Ambiental e Cultura de Paz \\
\hline 329 & Gerenciamento de Resíduos Sólidos \\
\hline 146 & A3P (Agenda Ambiental na Administração Pública) \\
\hline 13 & Constituição de Espaços de Convivência \\
\hline 36 & Infraestrutura / Revitalização de espaços públicos \\
\hline 22 & Geração de renda \\
\hline 80 & Educomunicação \\
\hline 6 & Área de Mananciais \\
\hline 32 & $\begin{array}{l}\text { Convívio saudável com os animais e prevenção às } \\
\text { Zoonoses }\end{array}$ \\
\hline
\end{tabular}

Fonte: Adaptado de <www.prefeitura.sp.gov.br/cidade/secretarias/saude/ atencao_basica/pavs/index.php?p=25407 >.

Capela em Ação - Cepedoc/Subprefeitura de Capela do Socorro, de São Paulo

Este projeto foi desenvolvido na subprefeitura da Capela do Socorro, no período de março de 2005 a março de 2006, para responder de forma organizada às demandas da população, por meio da gestão integrada das ações municipais mediante estímulo à mobilização e à participação dos diversos atores presentes no território.

Para sistematizar a realização desse projeto, subdiviu-se a área total em dez territórios menores denominados microrregiões. Estas foram abordadas de forma sequencial, seguindo-se um cronograma preestabelecido. Cada período de intervenções concentradas era precedido por reuniões de planejamento e finalizado com reuniões de avaliação/prestação de contas. 
O Projeto Capela em Ação estava baseado em dois eixos principais de trabalho, que atuavam de maneira sinérgica e complementar. O primeiro eixo resolutivo - correspondeu às ações de zeladoria da cidade, tais como limpeza de praças, terrenos e córregos, poda de árvores, corte de mato, tapa-buraco, limpeza de bueiro e boca de lobo, limpeza e conservação de galerias, construção de escadarias de acesso, construção de calçadas, ações de fiscalização, indicação de pontos para iluminação pública, pavimentação, manutenção das unidades escolares e de saúde, entre outras.

As necessidades de intervenção na microrregião eram detectadas nas reuniões de planejamento com a comunidade, nas reuniões intersetoriais (com os dirigentes dos equipamentos e serviços públicos) e nas solicitações acumuladas nos Serviços de Atendimento ao Cidadão (SAC). Após análise das possibilidades de execução, as respostas ocorriam no período de concentração (três a quatro semanas) ou entravam no planejamento de médio e longo prazo. Após o período de execução dos serviços, realizavam-se reuniões de avaliação (uma com a comunidade e outra com os representantes institucionais), contando com a presença do subprefeito e da equipe de coordenação dos setores envolvidos.

Tomando por base a energia gerada com a resolução das demandas e estabelecida uma relação de confiança entre a população e os gestores locais, acumulam-se condições para o desenvolvimento do segundo eixo - o propositivo-, que envolve adesão voluntária e percepção coletiva.

Esse segundo eixo era definido como programa das cinco sementes, quais sejam: (1) Semente da Vida - discute o tema arborização. É realizado nas escolas, creches, unidades de saúde e demais espaços coletivos, com posterior plantio de árvores pelos pais, em associação ao nascimento e ao crescimento dos filhos. Além de promover a arborização, as ações procuram despertar o sentimento de cuidar, de estabelecer vínculos com a cidade; (2) Semente do Conhecimento - utiliza o livro como instrumento de reflexão e debate, visando à implantação de clubes do livro com alunos, professores e jovens da comunidade, a fim de dinamizar o uso da biblioteca escolar e o estímulo à leitura; (3) Semente da Arte - investe na certeza de que todo homem é capaz de produzir arte, de que é um artista em potencial. Busca identificar e fomentar o surgimento de talentos artísticos locais: grupos de dança, teatro, música e outros; (4) Semente da Cidade Limpa e Meio Ambienteenvolve o trabalho de discussão sobre a cidade. Executa a recuperação física de áreas degradadas, com a retirada de lixo e entulho, e busca a posterior implantação de praças e áreas de lazer; (5) Semente da Cidadania e Cultura da Paz - incentiva a discussão e reflexão sobre a questão da violência e busca o estabelecimento de 
relações com os atores locais para resolver os conflitos por meio do diálogo, com abordagem de novos valores e conceitos de felicidade.

\section{Projeto Natal Cidade Saudável - Cepedoc/SMS-Natal, RN}

Natal Cidade Saudável é uma estratégia que, por meio de ações intersetoriais, busca equacionar e dar solução a problemas e situações de uma comunidade em um período de tempo satisfatório e a custos compatíveis com a realidade e as disponibilidades municipais. O projeto adota, por um lado, um conceito territorial de progressão bairro a bairro; de outro, prevê ações pontuais e de largo impacto, destinadas à cidade como um todo.

A proposta considera inicialmente seis linhas de ação: proteção à saúde; segurança pública; educação para qualificação da comunidade; ação comunitária; estímulo a atividade física; conexão saúde \& turismo com geração de renda (cerca de $60 \%$ do PIB municipal provém de atividades do setor turismo).

\section{Projetos Vigilância Ambiental na Biorregião do Araripe e Cariri Saudável - Araripe}

A Fundação para o Desenvolvimento Sustentável do Araripe (Fundação Araripe $)^{12}$ está presente, em parceria com o Ministério da Saúde, junto às prefeituras da região para o fortalecimento das unidades de saúde pública/ ambiental e à preparação de iniciativas maiores na gestão das cidades a caminho dos municípios saudáveis. A adesão dos municípios à estratégia Cidades, Municípios, Territórios Saudáveis requer a mobilização e o engajamento de toda a sociedade. Assim, o compromisso de trabalhar é feito em dois níveis:

- por meio de ações de identificação de formação e de desenvolvimento das lideranças e de suas mobilizações progressivas, das quais estão envolvidas as instituições da sociedade civil e a população dos seis municípios, em seu conjunto;

- a promoção de coordenações e convergências no plano das ações, mediante o envolvimento das instituições da área pública, seus agentes e seus responsáveis.

\footnotetext{
${ }^{12}$ A fundação, como Organização da Sociedade Civil de Interesse Público (Oscip), está localizada no sul do Ceará. Tem como missão a condução de atividades voltadas para a preservação do meio ambiente e de seus recursos naturais, assim como a promoção do desenvolvimento biorregional - sob os aspectos econômicos, sociais, políticos, culturais e ecológicos -, para chegar à erradicação da pobreza e à incorporação das massas rurais e urbanas do Nordeste aos benefícios do desenvolvimento no contexto das mudanças climáticas do semiárido. Trata-se da geração de conhecimentos, mediante estudos e pesquisas; da divulgação e da troca de experiências; da formação de líderes comunitários e da incorporação no patrimônio cultural da população dos ensinamentos da pesquisa, notadamente em termos de políticas públicas e do pleno exercício da cidadania no seio das diversas camadas sociais.
} 
A implantação do projeto deu-se por meio de um processo realizado com base na formação de um Conselho de Reflexão, de um grupo piloto e de um campo permanente de pesquisa e de ações, vistas como contribuições para chegar às mudanças necessárias à construção de municípios saudáveis. O ponto de partida foi a implantação do trabalho em seis municípios: Araripe, Barbalha, Jardim, Juazeiro do Norte e Nova Olinda, todos do Cariri cearense, com características como modelo para os demais municípios da região.

A Fundação Araripe também contribuiu para a elaboração/adoção de modelos de vigilância à saúde em diversas áreas do Nordeste: no Cariri cearense (Araripe, Crato, Jardim e Juazeiro do Norte) e no Polo Gesseiro de Pernambuco (Trindade), por intermédio de convênio com o Ministério da Saúde (n. 1.482/2002 e n. 4.854/2005), permitindo mobilizar atenções, adotar modelos de vigilância e avançar na gestão integrada da saúde e do ambiente. ${ }^{13}$

\section{Rostos, Vozes e Lugares (RVL)}

A iniciativa RVL foi lançada no 47ํㅡ Conselho Diretor da Opas em setembro de 2006, em sua sede em Washington D.C., Estados Unidos. Desde então, diferentes países latino-americanos, por intermédio dos ministérios da Saúde e dos escritórios da Opas nos países, têm identificado municípios vulneráveis, onde, além da liderança local, existe um processo de organização comunitária, o que torna possível a realização da iniciativa.

Rostos, Vozes e Lugares trabalha com apoio, vontade política, trabalho em equipe e comprometimento dos líderes das comunidades, assim como com a participação de todos os membros da comunidade, para promover a análise da situação de saúde no nível local pautada pela discussão sobre os Objetivos de Desenvolvimento do Milênio (ODM). O projeto tem como finalidade criar estratégias locais para o enfrentamento das iniquidades e melhoria das condições de vida. Envolve ainda a discussão sobre os determinantes sociais da saúde para reduzir as vulnerabilidades e minimizar as desigualdades, mediante o envolvimento das comunidades em seu próprio processo de desenvolvimento. No Brasil, a iniciativa é coordenada pela Representação da Opas e conta com a participação da SVS/MS, Cepedoc/USP e prefeituras municipais de Fortaleza, Guarulhos, Olinda, Rio Branco, Palmas, Sobral e São Francisco do Conde.

\footnotetext{
${ }^{13}$ Disponível em: <www.fundacaoararipe.org.br $>$.
} 


\section{Projeto Saúde Urbana (Urban Heart)}

O Urban Health Equity Assessment and Response Tool (Urban Heart) é um instrumento de avaliação e resposta de equidade em saúde urbana. Proposto pela Opas/OMS, foi adaptado para o município de Guarulhos, sendo desenvolvido e aplicado até o ano de 2008 e atendido aos seguintes objetivos do projeto: acompanhar indicadores selecionados para os cinco domínios propostos (saúde, infraestrutura urbana, econômico, desenvolvimento social e governança); reconhecer os determinantes sociais de saúde para definir intervenções prioritárias, para a promoção de ação intersetorial na busca da equidade em saúde; participação e mobilização das comunidades para o entendimento e análise das iniquidades em saúde da cidade.

O projeto envolve quatro regiões e 16 distritos de saúde, com mudanças também nas áreas de abrangência das unidades básicas de saúde.

\section{Observatório de Saúde Urbana de Belo Horizonte (Osubh)}

Fundado em 2002, o Osubh resulta de uma parceria entre a Universidade Federal de Minas Gerais (UFMG) e a Prefeitura de Belo Horizonte (PBH). Tem o intuito de promover estudos que tenham como foco a saúde urbana. Destacam-se como atuais pilares para os estudos nessa área: o adensamento de populações; o papel do ambiente físico e social como modelador da saúde das pessoas e a necessidade de aferir os fenômenos, tendo como objeto a aquisição de conhecimento profundo sobre a saúde urbana por meio da pesquisa científica, nos níveis individual e comunitário, para compreender as condições sociais e ambientais da vida urbana, de modo a permitir a implementação de estratégias específicas de intervenção e de políticas públicas, utilizando abordagens contemporâneas. A intenção desses esforços combinados é fornecer uma base empírica para determinar quais as intervenções de saúde urbana podem funcionar melhor em contextos específicos.

Sob tais aspectos é que são definidas as estratégias de atuação do Osubh, visando, sobretudo, a capacitação de pesquisadores para o desenvolvimento de estudos sobre a saúde da população que vive em grandes centros urbanos, notadamente em áreas de intensa urbanização, associadas às desigualdades intraurbanas.

O Osubh realiza uma ampla gama de estudos voltados para a promoção da saúde e o combate às iniquidades, contendo abordagens inovadoras de investigação concentradas nos problemas de saúde presentes na sociedade atual. 
Enfocam os determinantes de doenças crônicas, incluindo atividades físicas e hábitos alimentares; o uso indevido de drogas, incluindo álcool, tabaco e outras; o papel dos determinantes sociais da saúde e de várias doenças infecciosas no contexto urbano.

\section{Efetividade da Intersetorialidade: em busca de um distrito sanitário saudável e sustentável em Goiânia (GO)}

O projeto busca dar sustentabilidade a uma parceria ensino-serviço-comunidade iniciada em 1998 entre a Universidade Federal de Goiás (UFG), a Secretaria Municipal de Saúde de Goiânia (SMS) e diversos grupos organizados da sociedade civil do Distrito Sanitário Leste (DSL)/SMS, no município de Goiânia. Implementou-se o Projeto Ações Intersetoriais para a Saúde (Aips), que vigorou no período de 2007 a 2010. Este teve por objetivo aumentar a capacidade local em produzir e manter melhorias socioambientais que contribuam para a promoção da saúde. O projeto utiliza abordagem participativa na construção da saúde ambiental, com o envolvimento do setor público e da comunidade em torno dos problemas levantados. Preconiza a inclusão de parcerias no trabalho, com ênfase na intersetorialidade, ou seja, atuando em diferentes níveis, porém de forma integrada. ${ }^{14}$

Além disso, o projeto passou a reconhecer princípios, valores e estratégias da promoção da saúde, o que contribui para a superação da visão biologicista de saúde, até então, predominante. Tal parceria estimulou a realização de ações intersetoriais e de promoção da saúde no âmbito da SMS, como a inclusão dessas ações, agora pontuadas, na ficha de produtividade dos ACS do município. Disseminou-se conhecimento para a comunidade científica, com destaque para a importância atribuída à exposição de conceitos e o acesso a ferramentas como manuais e folders que norteiem o processo de tomada de decisão, práticas e educação permanente de gestores e trabalhadores, aqui entendendo a tradução do conhecimento como "síntese, disseminação, troca e aplicação eticamente sadia do conhecimento para melhorar a saúde" (Straus, Tetroe \& Graham, 2009).

O estabelecimento de um Comitê Local, com representantes dos diversos setores e segmentos envolvidos na ação, possibilitou a construção de competências, nivelamento conceitual e empoderamento do grupo no papel de propositor e realizador de ações intersetoriais.

\footnotetext{
${ }^{14}$ Disponível em: <www.who.int/social_determinants/resources/health_equity_isa_2008_en.pdf>.
} 


\section{Projeto Viva a Vida (Mato Grosso do Sul)}

A consolidação do SUS, sobretudo a descentralização das ações de saúde para estados e municípios, culminou em 2003 com o Pacto pela Saúde. Ele trouxe mais visibilidade ao SUS, qualificou sua gestão e, principalmente, reafirmou os compromissos pela vida. Mato Grosso do Sul celebrou esse Pacto em março de 2007, tendo sido o primeiro estado brasileiro a contar com a adesão de $100 \%$ de seus municípios. Foram assinados os Termos de Compromisso da Gestão Municipal e da Gestão Estadual, aprovados pelos Conselhos Municipais e Estadual de Saúde, os quais monitoram o cumprimento dos diversos compromissos firmados entre os gestores, entre os quais a implantação da política de promoção da saúde.

O projeto da SES/MS dialoga com as iniciativas similares de municípios saudáveis no estado, mediante a adoção de políticas públicas integradas, inclusivas, inovadoras e voltadas para o desenvolvimento sustentável. Também busca soluções inovadoras para a melhoria da qualidade de vida da população: reduzir as iniquidades, conscientizar para uma visão ampla do conceito e das práticas de saúde e ampliar as condições de acesso da população a bens e serviços essenciais.

São municípios prioritários aqueles cujo Índice de Desenvolvimento Humano (IDH) esteja acima da 50 $0^{\mathrm{a}}$ posição: Aral Moreira (54 $4^{\mathrm{a}}$; Sete Quedas $\left(58^{\mathrm{a}}\right)$; Coronel Sapucaia $\left(62^{\mathrm{a}}\right)$; Itaquiraí $\left(65^{\mathrm{a}}\right)$; Juti $\left(67^{\mathrm{a}}\right)$; Eldorado $\left(68^{\mathrm{a}}\right)$; Antônio João $\left(72^{\mathrm{a}}\right)$; Paranhos (75); Tacuru (76 ) e Japorã $\left(78^{\mathrm{a}}\right)$. Municípios com ações de suporte regional: Ponta Porã e Naviraí. Municípios vizinhos cujas ações contribuirão para o fortalecimento regional: Iguatemi, Mundo Novo, Amambaí e Laguna Caarapã.

\section{Projeto Planaltina Saudável (DF)}

No Distrito Federal, o Plano Distrital de Promoção da Saúde (PPS) foi elaborado com base na Política Nacional de Promoção da Saúde (PNPS), tendo sido aprovado pelo Conselho de Saúde do Distrito Federal em 23 de março de 2007. O foco inicial concentrou-se na implementação do Plano de Promoção da Saúde (PPS) nas Regionais de Saúde. Em 2010, 80\% destas regionais elaboraram seus PPS. Decidiu-se pela implementação do PPS em um projeto-piloto com o intuito de se criar um território saudável.

Esse projeto-piloto teve como base teórica iniciativas como as do Movimento Cidades Saudáveis, vinculado à Organização Mundial da Saúde, e a de Municípios Saudáveis, vinculado ao Ministério da Saúde. Teve o intuito de motivar gestores 
locais e sociedade civil a desenvolverem estratégias, em diversos setores das políticas públicas, para a implementação de projetos interinstitucionais e intersetoriais que consideraram os problemas e as possibilidades locais para a realização de projetos sociais, visando realizar ações de melhoria das condições de vida e saúde da população e, portanto, de sua qualidade de vida.

Para tal projeto selecionou-se uma Região Administrativa (RA) que apresentasse rede de serviços de saúde em funcionamento e uma extensa área rural com 100\% de cobertura de Equipes de Saúde da Família, mas com elevados índices de desigualdade social, violência e pobreza. Por contemplar essas características, Planaltina foi a RA escolhida. Além disso, destacou-se pela realização de projetos com participação comunitária, tanto das instituições como da população em geral. O projeto articula os diversos atores intra e intersetoriais envolvidos nas ações de Promoção da Saúde, implementa as Práticas Integrativas de Saúde (PIS) e atividades físicas. Promove atividades educativas de prevenção de acidentes de trânsito e de saúde dos trabalhadores, amplia e fortalece a rede de prevenção da violência, do uso abusivo de álcool e outras drogas, e da promoção da saúde e estímulo à cultura da paz. Incentiva ainda ações de vigilância, prevenção e atenção relacionadas à violência familiar, de uso de tabaco, alimentação segura, e reorienta as práticas de saúde de modo a permitir a interação e humanização em saúde, meio ambiente e desenvolvimento sustentável.

Elaborou-se um planejamento, por meio da metodologia de construção de um Modelo Lógico, com participação de vários representantes da Regional de Saúde de Planaltina. Assim, em 2011 organizaram-se reuniões intersetoriais e oficinas para a elaboração de Planos de Ação contando com representantes da comunidade, conselho de saúde e das instituições locais parceiras. Esses planos foram acompanhados e avaliados por equipe da coordenação do PPS local e regional.

\section{Programa Jogo de Cintura (DF)}

Este programa é uma proposta de promoção da saúde por meio da mudança de hábitos alimentares e da prática de atividade física por adultos. Executado por equipes de Atenção Básica (Estratégia Saúde da Família), tem como objetivo geral contribuir para mudanças comportamentais sustentáveis no estilo de vida, com ênfase no incremento da prática de atividade física, favorecendo a redução de fatores de risco para as doenças crônicas não transmissíveis (DCNT) em população adulta. Tem como meta, também, incentivar o aumento do consumo de frutas e hortaliças, o desenvolvimento do conhecimento sobre a importância da atividade 
física, o estímulo para que esta seja feita ao menos por trinta minutos diários durante cinco dias na semana, além da incorporação da promoção da saúde nas ações da ESF em São Sebastião.

Para o alcance de tais objetivos formou-se um grupo técnico-gerencial, composto por representantes da Atenção em Saúde e da Vigilância em Saúde da Secretaria de Estado de Saúde do DF. E também um grupo científico de referência, composto por pesquisadores da Universidade de Brasília, da Universidade Católica de Brasília e da Embrapa Hortaliças, com a finalidade de oferecer suporte às equipes do ESF. O programa foi implantado na $1^{a}$ RA do DF, São Sebastião. Foram capacitados profissionais de seis equipes da ESF, responsáveis pela cobertura de aproximadamente 24 mil pessoas. Mediante a capacitação, as equipes (médicos, enfermeiros, técnicos de enfermagem e agentes comunitários de saúde) mostraram-se aptas a conquistar a adesão de moradores ao projeto durante visitas domiciliares. Isso, por meio da exposição da proposta do programa e a realização de cadastro, de avaliação de estado de saúde, da realização de encontros mensais abordando temas relacionados à alimentação saudável, práticas de atividade física, apoio psicológico, formação social não violenta e fortalecimento do controle social, além de formação de grupos de caminhada.

\section{Laboratório Territorial de Manguinhos (LTM) - Fiocruz}

O LTM é um projeto de pesquisa-ação e propõe uma promoção da saúde (PS) que integre ciência e cidadania na construção de um modelo solidário de conhecer e interagir nos territórios em que vivemos, com base em um diálogo multidisciplinar e polifônico, em torno das vulnerabilidades socioambientais de Manguinhos, Rio de Janeiro. Desde 2003, desenvolve pesquisas e produz materiais para reflexão sobre temas relativos às vulnerabilidades socioambientais de Manguinhos, como as enchentes, por exemplo, assim como dos processos de mudança, em especial os impactos mais imediatos da implementação do Programa de Aceleração do Crescimento (PAC), com obras de infraestrutura, habitação e equipamentos sociais no conjunto de favelas de Manguinhos.

O caminho metodológico do LTM é orientado por três concepções centrais: o ciclo da comunicação, a produção compartilhada do conhecimento e a noção de tradução. Estas fundamentam nossas estratégias de operacionalização, quais sejam: a formação de comunidades ampliadas de pesquisa-ação envolvendo pesquisadores, profissionais da saúde e moradores; a produção de conhecimento e informação através linguagens audiovisuais, informáticas e artísticas, apropriadas aos processos de gestão integrada do território e ampliação da cidadania. 
Dentre as experiências recentes que buscam incorporar novas linguagens e processos de produção compartilhada de conhecimentos, destacam-se: análises do PAC Manguinhos por meio de um registro fotográfico - PAC Manguinhos, um Relato Fotográfico - e dois documentários - PAC Manguinhos: o futuro a Deus pertence? e PAC Manguinhos: promessa, desconfiança, esperança; histórias de Manguinhos sistematizadas no documentário Manguinhos: histórias de pessoas e lugares, no cordel Manguinhos em Prosa e Verso e no livro Histórias de Pessoas e Lugares: memórias das comunidades de Manguinhos, publicado pela Editora Fiocruz (Fernandes \& Costa, 2009); o site <www.conhecendomanguinhos.fiocruz. br> oferece o acervo virtual organizador do conhecimento e da informação, além de uma ferramenta para interação e aprendizagem; jogos interativos que contextualizam os problemas e potencialidades de Manguinhos, por meio da linguagem - como RPG e outros jogos virtuais - sobre temas relevantes de saúde: tuberculose, meio ambiente e seus determinantes, por exemplo o slideshow Mangue, Manguinhos, Manguezal, uma análise dos ecossistemas locais comparando Manguinhos - um bairro construído sobre um manguezal aterrado, completamente degradado - com a APA de Guapimirim (RJ), uma área de manguezal preservada.

Projeto Desenvolvimento Sustentável e Promoção da Saúde:

implantação da Agenda Cidades Saudáveis integrada à Agenda 21 nas comunidades tradicionais e áreas protegidas do mosaico da Bocaina Fiocruz

O projeto propõe-se a implantar uma agenda territorializada integrada à agenda das comunidades tradicionais de Áreas Protegidas do Mosaico da Bocaina no contexto da Agenda 21 local, utilizando tecnologias sociais e participativas e abordagem integradora dos princípios e categorias do Desenvolvimento Sustentável e da Promoção da Saúde. Os territórios iniciais de atuação do projeto são duas comunidades caiçaras: Pouso da Cajaíba e Praia do Sono, selecionados pelos representantes das 24 comunidades tradicionais (12 Caiçaras, sete indígenas e cinco quilombolas) de municípios dos estados do Rio de Janeiro e de São Paulo, abrangendo seis Unidades de Conservação dentre as 15 que compõem o Mosaico.

É uma pesquisa-ação que objetiva contribuir para a promoção da qualidade de vida, por meio da construção e implantação coletiva de agenda estratégica local (Comunidade Saudável); e também para a promoção da sustentabilidade econômica solidária, incorporando-se às iniciativas em curso no Mosaico, voltadas para o turismo como arranjo produtivo preferencial. 
Utiliza a abordagem ecossistêmica associada à abordagem comunicativa do planejamento estratégico-situacional, apoiando a incorporação de territórios excluídos à cidadania, porém buscando evitar sua captura pela racionalidade dominante, estimulando a transformação do modelo de produção para uma economia e uma sociedade mais solidária e equânime.

Projeto Cidades Saudáveis: saúde, inovação tecnológica e desenvolvimento urbano na área de implantação do complexo petroquímico de Itaboraí (Comperj) - Rio de Janeiro, Fiocruz

O projeto, aprovado nos termos do Programa de Desenvolvimento e Inovação Tecnológica em Saúde Pública (PDTSP), desenvolveu-se entre 2007 e 2011 no âmbito do Departamento de Endemias Samuel Pessoa, vinculado à Escola Nacional de Saúde Pública Sergio Arouca, da Fundação Oswaldo Cruz (Densp/ Ensp/Fiocruz). Contemplou a realização de dois subprojetos: a) Vigilância Civil da Saúde na Atenção Básica: uma proposta de ouvidoria coletiva; e b) Levantamento das Condições de Crescimento da Infraestrutura Urbana e Regional e seu Impacto sobre o Desenvolvimento da Saúde Regional.

Esses subprojetos estabeleceram objetivos que buscaram fazer um levantamento dos principais processos e fatos potencialmente produtores de vulnerabilidades à saúde das populações, na área de abrangência do Complexo Petroquímico de Itaboraí. Considerando-se as tecnologias existentes, investigar as tecnologias a serem utilizadas no decorrer da implantação de dispositivos de transição urbana e ambiental para a identificação de processos inovadores, no âmbito da vigilância da saúde ambiental. E contribuir, por meio de parcerias com as empresas e instituições envolvidas, para a implantação do Complexo.

O subprojeto Vigilância Civil da Saúde na Atenção Básica: uma proposta da Ouvidoria Coletiva promoveu a capacitação dos profissionais da Estratégia Saúde da Família de Itaboraí, tendo construído uma metodologia de construção partilhada de conhecimento em saúde no nível local. Os resultados foram incluídos na publicação Por uma Itaboraí Saudável, organizada por Carla Moura Lima e lançado em 2011 pela Escola Nacional de Saúde Pública Sergio Arouca/ Fiocruz.

O subprojeto Levantamento das Condições de Crescimento da Infraestrutura Urbana e Regional e seu Impacto sobre o Desenvolvimento da Saúde Regional propiciou a utilização da Matriz Avaliativa de Pós-Ocupação, até então utilizada em áreas favelizadas, com a incorporação das informações oriundas dos fóruns de ouvidoria coletiva realizados em um distrito do município de Itaboraí. 
Os resultados do projeto superaram o nível propriamente acadêmico, na medida em que representam uma inovação tecnológica, em âmbito social, da formação permanente dos profissionais de saúde da ESF, da reestruturação da gestão das unidades básicas de saúde e da relação destas com atores sociais locais diversos. Além disso, inaugurou uma nova relação entre a academia, os serviços públicos, o nível da gestão municipal e a população organizada, na direção da democratização da política pública, em termos de formulação, planejamento, gestão, avaliação e controle social.

Práticas e Saberes no Desenvolvimento Sustentável e na Promoção da Saúde em Terreiros de Candomblé - Município de São Francisco do Conde (BA) - Fiocruz

O Projeto Práticas e Saberes no Desenvolvimento Sustentável e na Promoção da Saúde em Terreiros de Candomblé, desenvolvido no município de São Francisco do Conde, Bahia, é de autoria dos pesquisadores Ana Cristina de Souza Mandarino e Estélio Gomberg, da Universidade Federal da Bahia (Ufba), e de Edmundo Gallo (Fiocruz). Foi aprovado no edital Pró-Saúde I, da Fundação de Amparo à Pesquisa do Estado da Bahia (Fapesb), e teve como intuito implantar a Agenda Cidades Saudáveis integrada à Agenda das Comunidades Tradicionais e Áreas Protegidas no município em questão, sob a perspectiva do desenvolvimento sustentável e da promoção da saúde, assim como apreender o papel e o significado dos terreiros de candomblé neste e, além disso, se estes de fato atuam como agências sociais na promoção da equidade da saúde da população negra por meio da articulação de diversas racionalidades terapêuticas.

A intenção foi utilizar tecnologias sociais participativas e uma abordagem ecossistêmica para integrar a gestão ambiental a uma compreensão holística da saúde humana, considerando os importantes fatores sociais, econômicos e culturais inerentes a um ecossistema (Feola \& Bazzani, 2002).

O projeto foi apresentado com enfoque na abordagem ecossistêmica, baseado nos conceitos de desenvolvimento sustentável e promoção da saúde, sendo tais temas abordados a partir das práticas e dos saberes realizados nos terreiros. Buscou-se problematizá-los e, quando aplicável, identificar soluções que permitissem sua continuidade, preservando, porém, o ambiente. Por exemplo, substituindo-se objetos utilizados nas oferendas aos orixás por materiais degradáveis - como tecido -, uma vez que os materiais originais permanecem no meio ambiente. No mesmo sentido, destacou-se a necessidade de reaproveitamento do resíduo da vela (parafina), utilizada em larga escala nas atividades 
dos terreiros de candomblé, o que pode gerar fonte de renda. A confecção de roupa específica para os rituais também foi identificada como oportunidade para geração de renda, assim como a horta comunitária e a cozinha industrial, além de fornecerem subsídios para as atividades.

O resultado do plano pode ser observado no Quadro 2, a seguir.

Quadro 2 - Matriz de desafios e estratégias

\begin{tabular}{|c|c|}
\hline Desafios & Estratégia \\
\hline \multirow{2}{*}{$\begin{array}{l}\text { Descarte inadequado das } \\
\text { oferendas a exemplo dos } \\
\text { balaios, vidros, resíduo das } \\
\text { velas queimadas }\end{array}$} & Diagnosticar a situação de descarte de resíduos no meio ambiente \\
\hline & Identificar e utilizar materiais alternativos \\
\hline \multirow[t]{2}{*}{$\begin{array}{l}\text { Contaminação da água por } \\
\text { efluentes domésticos }\end{array}$} & $\begin{array}{l}\text { Diagnosticar a situação de saneamento nas proximidades da cozinha } \\
\text { industrial }\end{array}$ \\
\hline & Avaliar a qualidade da água \\
\hline \multirow[t]{4}{*}{$\begin{array}{l}\text { Baixa oferta de emprego e } \\
\text { renda }\end{array}$} & $\begin{array}{l}\text { Articular e organizar as associações para confeccionar a vestimenta } \\
\text { utilizada nos cultos }\end{array}$ \\
\hline & Reaproveitar o resíduo da vela queimada para produzir novas \\
\hline & Mapear as plantas utilizadas nos tratamentos \\
\hline & Implementar projetos de horta comunitária \\
\hline
\end{tabular}

\section{Programa Metrópoles Saudáveis (PMS-SP, Proam)}

Este programa visa construir informações entre a sociedade e os setores governamentais acerca da capacidade de suporte para as grandes cidades e suas relações com a saúde humana e ambiental, em busca de uma sociedade saudável. Está direcionado a promover a consciência e a capacidade de reação social ante os riscos ambientais, contribuindo para que as pessoas possam melhorar suas condições de vida e cidadania.

Alinhado ao Objetivo de Desenvolvimento do Milênio de garantir a sustentabilidade ambiental, o PMS tem promovido debates sobre as realidades de São Paulo, Buenos Aires e Cidade do México. Os resultados esperados do programa possibilitaram o domínio do conhecimento por parte das comunidades envolvidas e dos riscos ambientais a que estão submetidas, subsidiando a proposição de políticas estratégicas legitimadas socialmente. Nessa perspectiva, o programa propõe o estabelecimento de indicadores que mensurem os determinantes dos riscos ambientais e suas dinâmicas, a capacidade de suporte das metrópoles e as interações entre sociedade e governo, a fim de constituir uma plataforma de gestão. 
Os objetivos específicos estão divididos em etapas. A primeira é objeto desse projeto e consiste em: sistematizar conceitos com relação às metrópoles, saúde ambiental e sustentabilidade, preservando, na medida do possível, a originalidade dos conceitos já consagrados cientificamente e internalizados pelas organizações; identificar parâmetros e aspectos referentes à saúde e à sustentabilidade dos ambientes metropolitanos, extraídos dos processos inerentes a esses espaços; levantar parâmetros para indicadores de democracia e governança ambiental.

O projeto poderá ter como possibilidade de continuidade a realização de estudo piloto para validação dos indicadores e dos mecanismos de produção e utilização dos dados, com participação de provedores e usuários da informação, além de teste das formas de divulgação e apropriação por parte da sociedade.

\section{Para finalizar}

As cidades brasileiras, assim como as outras pertencentes à América Latina, enfrentam, no início do século XXI, dificuldades advindas de fatores que influenciam nas condições de vida e saúde das populações. Entre eles pode-se citar: a crescente urbanização; falta de infraestrutura; baixos níveis de investimentos nos municípios de pequeno porte e zona rural, acrescido do peso da desigualdade social e o déficit de infraestrutura.

Tal situação se consolida a partir da segunda metade do século XX no Brasil, que deixa de ter características rurais para se tornar predominantemente urbano. Os dados nacionais revelam que o período de inversão de residência da população se dá entre 1940 e 1980, quando a taxa de urbanização salta de 26,35\% para 68,86\% (Santos, 1996). Os dados do ano 2000 demonstram que 136 milhões de pessoas, representando $80 \%$ do total da população, vivem em áreas urbanas. Segundo as projeções indicam, em 2030 aproximadamente 83\% do total da população estará concentrada em áreas urbanas.

A urbanização está inserida num contexto macroeconômico, além do demográfico, o qual envolve uma combinação de fatores sociais, econômicos e políticos que afetam decisivamente a saúde da população brasileira. A infraestrutura local dos municípios tem se tornado insuficiente pela sobrecarga resultante do aumento da demanda por serviços de saúde, saneamento, segurança pública, educação, habitação, alimentação, tratamento e coleta do lixo, entre outros (WHO, 2008).

A descentralização administrativa da saúde, instituída pela lei n. 8.080/90, estabeleceu novas instâncias de decisão, facilitando as práticas de controle social 
e de democratização da gestão e contribuindo para a construção de uma nova cultura política. Nesse contexto, iniciativas governamentais, como a elaboração participativa de alguns Planos Diretores Municipais e outras agendas de desenvolvimento local, têm ocorrido com ampla participação de representantes do setor saúde (Motta \& Westphal, 1998).

A Portaria n. 687 de 30 de março de 2006 (Brasil, 2006) aprovou a Política Nacional de Promoção da Saúde (PNPS), colocando-a como um mecanismo de fortalecimento e implantação de uma política transversal, integrada e intersetorial. Uma das linhas estratégicas da política é o Desenvolvimento Sustentável, relacionado às iniciativas de Cidades Saudáveis, que pressupõe a potencialização de uma forma mais ampla de gestão que permita intervir de maneira mais eficaz e eficiente nos determinantes sociais da saúde. Nesse sentido, o Departamento de Vigilância em Saúde Ambiental e Saúde do Trabalhador da Secretaria de Vigilância em Saúde (SVS), articulado com o Departamento de Análise de Situação em Saúde do Ministério de Saúde (Dasis/MS), no contexto da linha estratégica Desenvolvimento Sustentável da PNPS, desenvolvem seus esforços em apoio às diferentes iniciativas, difundindo experiências bem-sucedidas.

As redes e iniciativas de Comunidades, Municípios e Cidades Saudáveis e Sustentáveis devem ser consideradas de fundamental importância para a implementação da Estratégia Cidades Saudáveis, dentro da perspectiva do eixo Desenvolvimento Sustentável da PNPS, por meio de ações intersetoriais prioritárias identificadas nessa oportunidade. Fica assim evidente no texto deste Apêndice a necessidade de um-mecanismo nacional de articulação intersetorial, além de uma efetiva participação social que conte com representações da sociedade civil e dos movimentos sociais. O comprometimento multisetorial e entre as três esferas de gestão do SUS deve ser especialmente debatido e aplicado dentro da perspectiva da saúde como centro comum dos três eixos da Conferência das Nações Unidas sobre o Desenvolvimento Sustentável - ocorrida em junho de 2012 -, também conhecida como Rio+20.

As Redes/Iniciativas podem promover a inter-relação das ações dos diferentes setores, organizar as atividades numa estrutura funcional intersetorial de maneira a facilitar e agilizar a atuação dos atores nos diferentes setores, respondendo às demandas de forma mais articulada tanto interna quanto externamente. Essa instância nacional de articulação e interlocução entre representantes governamentais, não governamentais, academia e organismos internacionais destinar-se-ia a fomentar e fortalecer a PNPS, numa ação de mobilização para o desenvolvimento de políticas públicas associadas ao ideário de cidades, 
municípios e comunidades saudáveis e sustentáveis. Teria ainda o papel de aglutinar as redes/iniciativas de cidades, municípios e comunidades saudáveis e sustentáveis, em prol do fortalecimento da PNPS. Assim, a constituição dessa instância, estruturada em bases de ação solidária e integrada, como mecanismo de fortalecimento de uma política transversal, integrada e intersetorial, é essencial para a mobilização e reforço das redes e iniciativas de cidades, municípios e comunidades que objetivam o desenvolvimento sustentável e a melhoria da qualidade de vida e saúde e estaria especificamente voltada à promoção da articulação e da intersetorialidade das diversas redes/iniciativas.

Além disso, essa instância teria uma atribuição essencial na promoção e fomentação de projetos de intervenção e/ou pesquisa. Ela age como um catalisador nos processos de implementação e elaboração de políticas públicas, dinamizando o processo de gestão da promoção da saúde especialmente num contexto de desenvolvimento sustentável integrando os demais eixos da PNPS. Existe a necessidade de propor um sistema de monitoramento e avaliação das ações das Redes/Iniciativas de Cidades, Municípios e Comunidades Saudáveis e Sustentáveis que utilize o modelo de avaliação participativa, tendo em vista que se almeja o envolvimento cada vez maior dos participantes nas decisões. Isso para que todos se sintam gradativamente mais corresponsáveis pelas ações realizadas, pelos sucessos e fracassos, em um ambiente de diálogo permanente entre os principais agentes institucionais que atuam na área da Promoção da Saúde e nas redes/iniciativas de Cidades, Municípios e Comunidades Saudáveis e Sustentáveis.

Na Oficina de Desenvolvimento Sustentável realizada em Belo Horizonte em outubro de 2011, antecedendo a $10^{\text {a }}$ Conferência Internacional de Saúde Urbana, ratificou-se a recomendação da $1^{\text {a }}$ Reunião da Câmara Técnica de Desenvolvimento Sustentável do Comitê Gestor da PNPS relacionada à elaboração de um termo de referência para a publicação de um edital para monitoramento e avaliação da efetividade das ações de Promoção da Saúde vinculadas ao eixo do desenvolvimento sustentável da PNPS (Indicadores). O estabelecimento de uma instância nacional que una as Redes/Iniciativas fica condicionado ao desenvolvimento de indicadores para mensurar a efetividade das ações de promoção da saúde e das estratégias implementadas pelas iniciativas e redes.

Registre-se aqui uma homenagem a Rogério Fenner, cuja participação foi de extrema relevância para a elaboração deste texto. 


\section{Referências}

FEOLA, G. \& BAZZANI, R. (Eds.). Desafíos y Estrategias para la Implementación de un Enfoque Ecossistémico para la Salud Humana en los Países em Desarrollo: reflexiones a propósito de las consultas regionales. Montevideo: CIID, 2002. Disponível em: <https://idl-bnc.idrc.ca/dspace/ handle/10625/27531>. Acesso em: 17/10/2014.

FERNANDES, T. M. \& COSTA, R. G. Histórias de Pessoas e Lugares: memórias das comunidades de Manguinhos. Rio de Janeiro: Editora Fiocruz, 2009.

MENDES, R. Cidades Saudáveis no Brasil e os Processos Participativos: os casos de Jundiaí e Maceió, 2000. Tese de Doutorado. São Paulo: Faculdade de Saúde Pública, Universidade de São Paulo.

MOTTA, R. M. M. \& WESTPHAL, M. F. Partipación de la población en el establecimineto y la dirección de políticas públicas saludables. In:WORLD CONFERENCE OFTHE INTERNATIONAL UNION FOR HEALTH PROMOTION AND EDUCATION, XVI, San Juan de Porto Rico, 1998.

SANTOS, M. A Natureza do Espaço: técnica e tempo, razão e emoção. São Paulo: Hucitec, 1996.

STRAUS, S. E.; TETROE, J. \& GRAHAM, I. D. (Eds.). Knowledge Translation in Health Care: moving from evidence to practice. England: West Sussex: Blackwell, 2009.

WORLD HEALTH ORGANIZATION (WHO). Health Equity Through Intersectoral Action: An Analysis of 18 Country Case Studies. Her Majesty the Queen in Right of Canada, represented by the Minister of Health, 2008. Copyright World Health Organization (WHO), 2008. Disponível em: <www.who. int/social_determinants/resources/health_equity_isa_2008_en.pdf $>$. Acesso em: 17 out. 2014. 


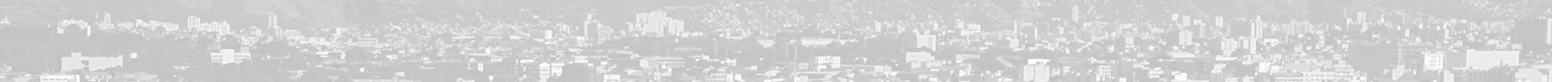

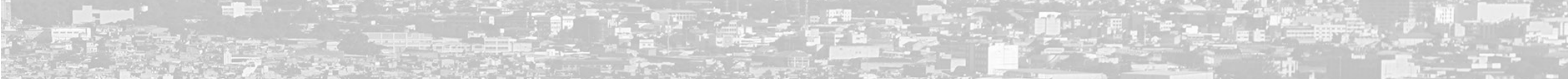
P.

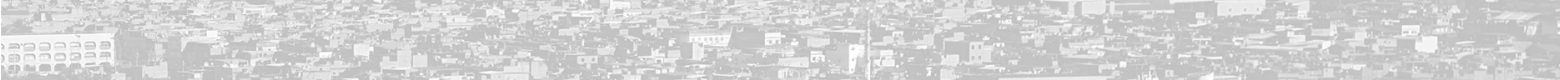

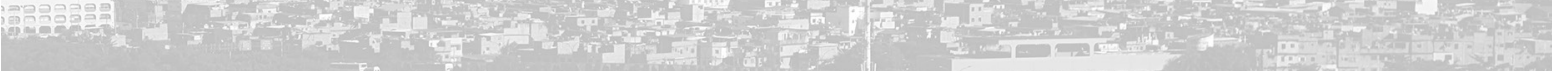

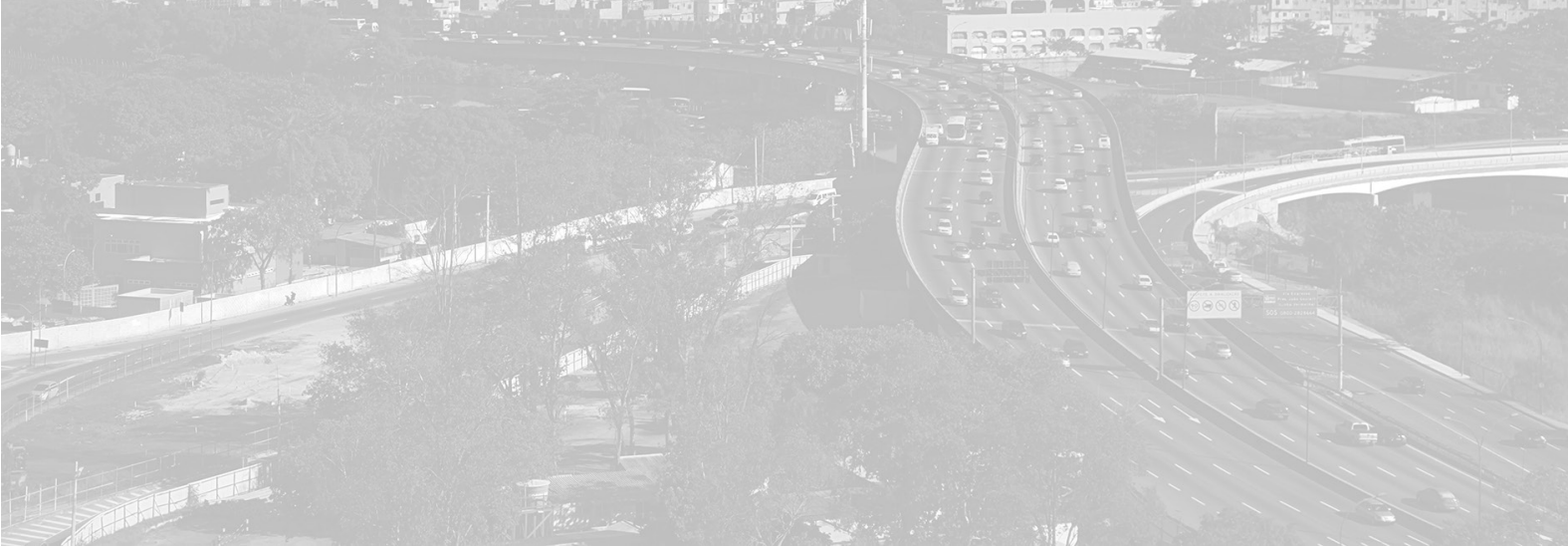


Formato: $16 \times 23 \mathrm{~cm}$

Tipologia: Stone Serif, Myriad e Rockwell (miolo/capa)

Papel: Pólen Bold 70g/m2 (miolo)

Cartão Supremo $250 \mathrm{~g} / \mathrm{m} 2$ (capa)

CTP, Impressão e acabamento: Imos Gráfica e Editora Ltda.

Rio de Janeiro, dezembro de 2014.

Não encontrando nossos títulos em livrarias,

contactar a Editora Fiocruz:

Av. Brasil, 4036 - térreo - Manguinhos

21040-361 - Rio de Janeiro - RJ

Telefones: (21) 3882-9039 e 3882-9041

Telefax: (21) 3882-9006

editora@fiocruz.br

www.fiocruz.br/editora 